\title{
ESTUDOS SOBRE GÊNERO
}
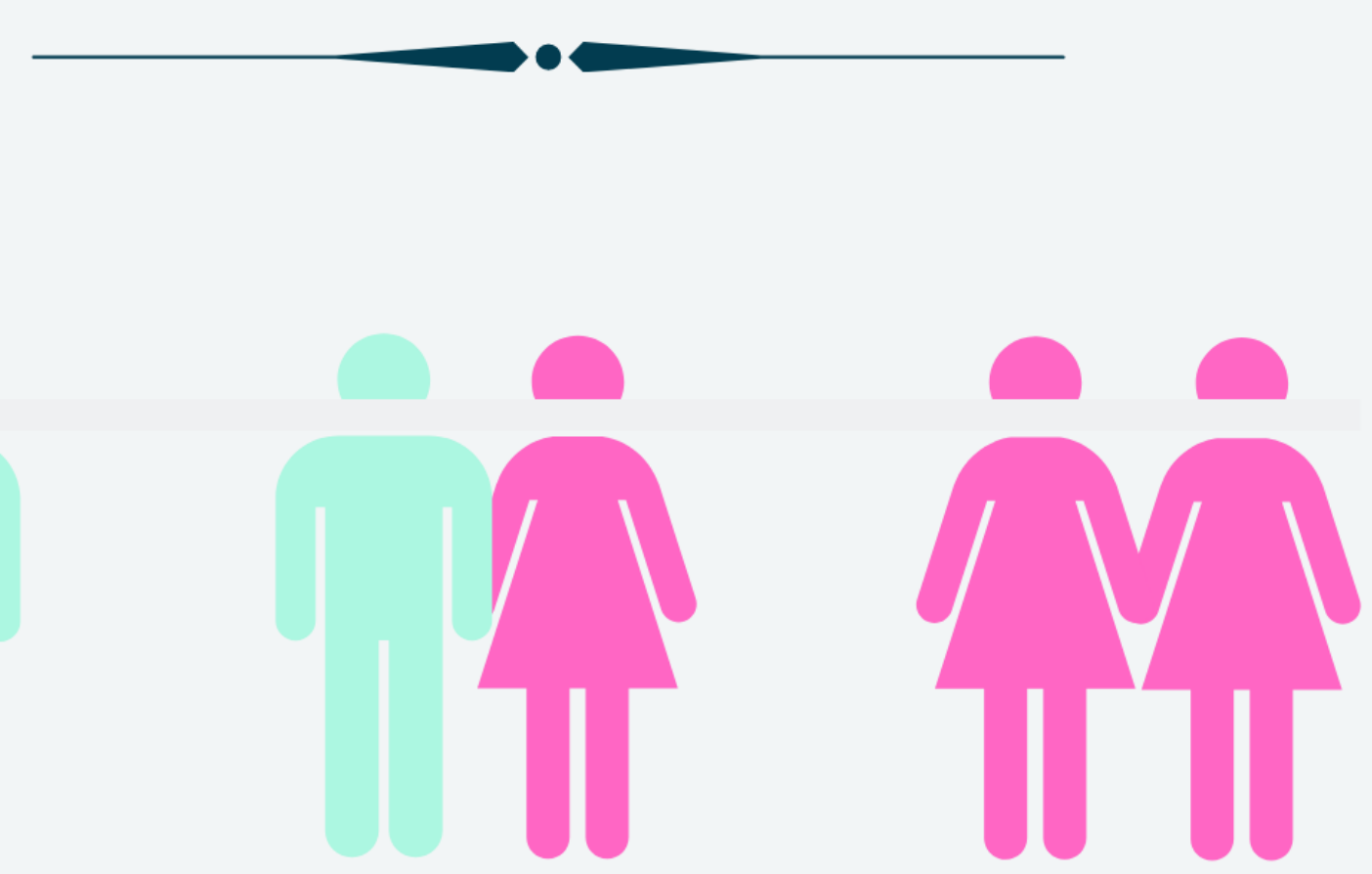

VOLUME 1

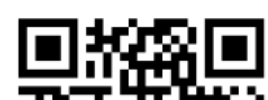

yts:

Norys:

回社些

Editora Poisson 
Editora Poisson

(organizadora)

\section{Estudos sobre Gênero - Volume 1}

1a Edição

Belo Horizonte

Poisson

2020 


\section{Editor Chefe: Dr. Darly Fernando Andrade}

\section{Conselho Editorial}

Dr. Antônio Artur de Souza - Universidade Federal de Minas Gerais

Ms. Davilson Eduardo Andrade

Dra. Elizângela de Jesus Oliveira - Universidade Federal do Amazonas

Msc. Fabiane dos Santos

Dr. José Eduardo Ferreira Lopes - Universidade Federal de Uberlândia

Dr. Otaviano Francisco Neves - Pontifícia Universidade Católica de Minas Gerais

Dr. Luiz Cláudio de Lima - Universidade FUMEC

Dr. Nelson Ferreira Filho - Faculdades Kennedy

Ms. Valdiney Alves de Oliveira - Universidade Federal de Uberlândia

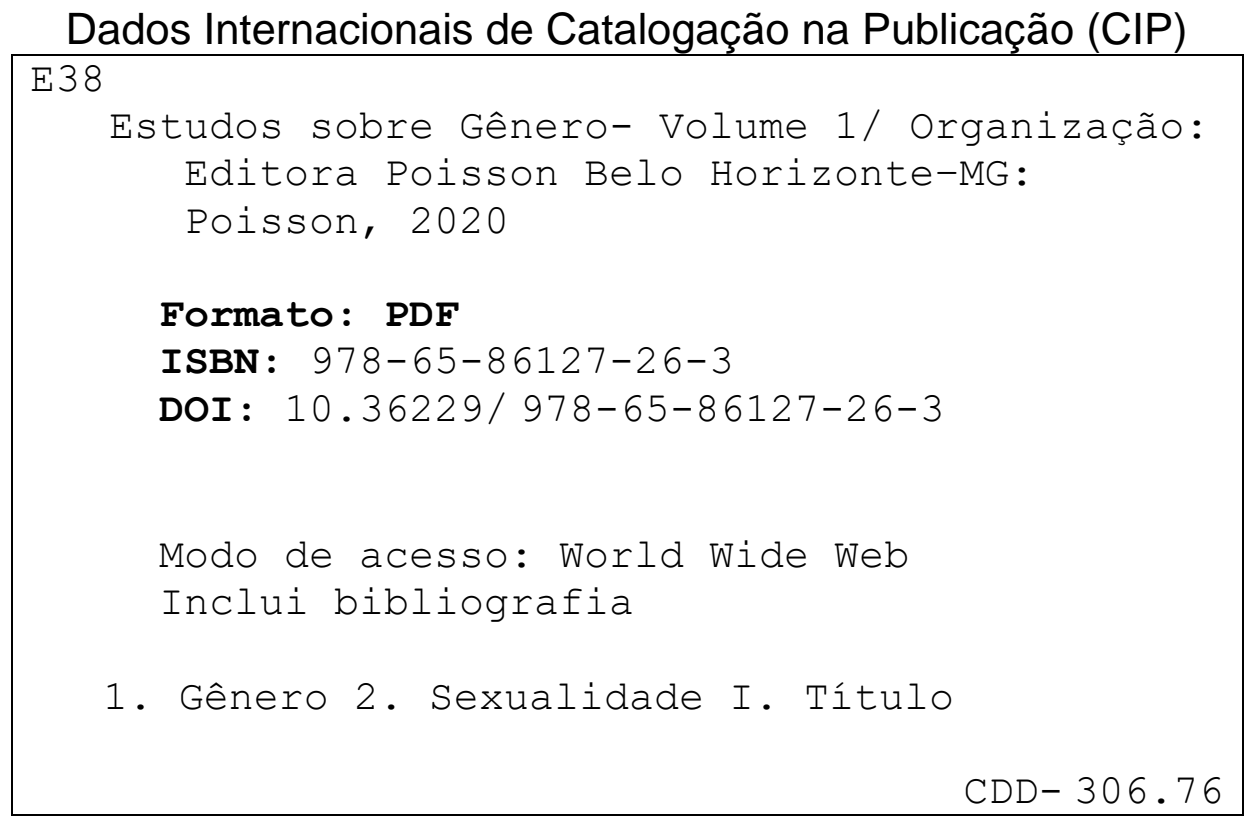

O conteúdo dos artigos e seus dados em sua forma, correção e confiabilidade são de responsabilidade exclusiva dos seus respectivos autores

$\underline{\text { www.poisson.com.br }}$

contato@poisson.com.br 


\section{SUMÁRIO}

Capítulo 1: A biologização do machismo no livro 0 remorso de Baltazar Serapião .8

Mylla Maggi Vieira da Costa, Joseval dos Reis Miranda

DOI: $10.36229 / 978-65-86127-26-3 . C A P .01$

Capítulo 2: Contação de história e gênero: Personagens adolescentes em questão?.....15 Ellen Borges Tenorio Galdino, Adélia Augusta Souto de Oliveira, Paula Orchiucci Miura, Luciana de Araújo Vieira

DOI: $10.36229 / 978-65-86127-26-3 . C A P .02$

Capítulo 3: A escrita da subalterna: Invisibilidade da mulher negra em A paixão segundo G.H. de Clarice Lispector 22

Ludmilla Carvalho Fonseca

DOI: $10.36229 / 978-65-86127-26-3 . C A P .03$

Capítulo 4: Feminismo negro, feminicídio e a violência de gênero contra as mulheres. .35

Angela Carla de Farias, Lina Maria Brandão Aras

DOI: $10.36229 / 978-65-86127-26-3 . C A P .04$

Capítulo 5: Uma noite no clube da Luluzinha: relato de experiencia sobre violência e gênero no Ocupa Minc/PI.

Luciana de Lima Lopes Leite

DOI: $10.36229 / 978-65-86127-26-3 . C A P .05$

Capítulo 6: Violência sexual e relações de poder: 0 que pensam estudantes do interior da Paraíba?

Jaqueline Moreira de Souza, Benícia Brenda Barbosa da Silva, Kasandra Campos de Oliveira, Laysa Maria Barauna Lima, Lúcia Temóteo

DOI: $10.36229 / 978-65-86127-26-3 . C A P .06$

Capítulo 7: A possibilidade de re(nascer): 0 caso das mulheres gestantes em uma unidade prisional em Minas Gerais.

Juliana de Ávila Ferreira, Cleide da Conceição Solano, Kátia Luciana Gonçalves Xavier, Raquel Quirino

DOI: $10.36229 / 978-65-86127-26-3 . C A P .07$ 


\section{SUMÁRIO}

Capítulo 8: A inserção do gênero feminino na condução de motocicleta no Município de Maceió-AL e a relação com a acidentalidade 70

Jessica Yolanda Figueiredo de Barros, Karine da Silva Santos

DOI: 10.36229/978-65-86127-26-3.CAP.08

Capítulo 9: Uma reflexão sobre a ausência de lésbicas e mulheres bissexuais em festas LGBTIAQ+ na cidade de Recife. .80

Fernanda de Carvalho Azevedo Mello

DOI: $10.36229 / 978-65-86127-26-3 . C A P .09$

Capítulo 10: "Espelhos da noite": Identidades vestidas pelo controle social. .89

Rose Cláudia Oliveira de Andrade, Maria de Fátima Araújo Di Gregorio

DOI: $10.36229 / 978-65-86127-26-3 . C A P .10$

Capítulo 11: Reflexões sobre organização lésbica na Bahia em tempos de ditadura..104 Zuleide Paiva da Silva

DOI: $10.36229 / 978-65-86127-26-3 . C A P .11$

Capítulo 12: 0 direito fundamental à não identificação do gênero no registro de nascimento. 111

Mariana de Barros e Silva Pinheiro, Giorge Andre Lando

DOI: 10.36229/978-65-86127-26-3.CAP.12

Capítulo 13: A dificuldade qualificada de ser pessoa digna em Salvador, Bahia: Usurpação de direitos fundamentais de travestis e transexuais em situação de rua......117

Fábio Periandro de Almeida Hirsch, Iarlis Neves Brandão

DOI: $10.36229 / 978-65-86127-26-3 . C A P .13$

Capítulo 14: A visibilidade transgênero no Instagram. 124

Lucíola Carla Correia da Silva

DOI: $10.36229 / 978-65-86127-26-3 . C A P .14$

Capítulo 15: Relato de experiência do Projeto de Extensão "Babado, gritaria e confusão: focus para a saúde da população LGBT" 132

Pâmela Tays de Holanda Silva, Matheus dos Santos Carvalho, Jaqueline Paulino Gomes, Jéssica Gabriele Burity da Costa, Patrícia Maria de Brito França, Amanda Oliveira Bernardino Cavalcanti de Albuquerque

DOI: $10.36229 / 978-65-86127-26-3 . C A P .15$ 


\section{SUMÁRIO}

Capítulo 16: Diversidade sexual e LGBTQfobia: Desconstruindo o preconceito na academia 139

Anderson Alexandre de Araújo Sá, Kasandra Campos de Oliveira, Laysa Maria Barauna Lima, Lúcia Maria Temóteo

DOI: 10.36229/978-65-86127-26-3.CAP.16

Capítulo 17: Análises das médias de variabilidade da frequência fundamental (Pitch) presentes na produção oral de homens autodeclarados gays e heterossexuais. 145

Eduardo Barbuio, Emanuelle Camila Moraes De Melo Albuquerque, Paloma Pereira Borba Pedrosa DOI: $10.36229 / 978-65-86127-26-3 . C A P .17$

Capítulo 18: Buscando o "CIS" nas pesquisas sobre educação 153

Jeferson Reis Santos

DOI: $10.36229 / 978-65-86127-26-3 . C A P .18$

Capítulo 19: A temática de gênero nas práticas acadêmicas no âmbito escolar entre $2003-2014$ 158

Arthur Silva de Andrade, Beatriz Coelho Ferreira, Lucia Talita Santos de Lima, Renato Maciel dos Santos, Tuany Lorena Ferreira, Anna Karina Gonçalves Xavier

DOI: 10.36229/978-65-86127-26-3.CAP.19

Capítulo 20: Educação feminina na Bahia: Uma interlocução entre literatura e relações de gênero na obra de Mabel Velloso 166

Rita de Cássia Costa Moreira, Maria José Souza Pinho

DOI: $10.36229 / 978-65-86127-26-3 . C A P .20$

Capítulo 21: Um olhar de gênero sobre a Psicologia Escolar. 173

Iara Luzia Henriques Pessoa, Glauce Michelle Araújo Penha, Carlos Alberto Gomes de Brito DOI: $10.36229 / 978-65-86127-26-3 . C A P .21$

Capítulo 22: Educacão Inclusiva: Meu gênero não me define 178 Ana Beatriz Medeiros Ferreira DOI: $10.36229 / 978-65-86127-26-3 . C A P .22$ 


\section{SUMÁRIO}

Capítulo 23: Estruturas permeáveis: Corpo-caderno. 184

Alla Soüb(Mariana Ramos Soüb de Seixas Brites)

DOI: $10.36229 / 978-65-86127-26-3 . C A P .23$

Capítulo 24: Desconstruir como pessoa para se reconstruir como professxr: As diversas produções cotidianas trabalhar as questões de gêneros e sexualidades na escola

Luiz Otavio Ferreira da Luz

DOI: $10.36229 / 978-65-86127-26-3 . C A P .24$

Capítulo 25: Sob a óptica de discentes da área de saúde, ser travesti é "Ter atitude por se 'assumir' diferente" 201

Carle Porcino, Maria Thereza Ávila Dantas Coelho, Jeane Freitas de Oliveira, Cleuma Sueli Santos Suto, Dejeane de Oliveira Silva, Maria Virginia Almeida de Oliveira Teles, Pablo Luiz Santos Couto, Anderson Reis de Souza

DOI: $10.36229 / 978-65-86127-26-3 . C A P .25$

Capítulo 26: Lgbtfobia: Análise da posição político-jurídico dos ministros do STF....214 Witalo Brenno Martins Acioli, Elba Ravane Alves Amorim

DOI: $10.36229 / 978-65-86127-26-3 . C A P .26$

Autores: 


\section{Capítulo 1}

\section{A biologização do machismo no livro o remorso de Baltazar Serapião}

\section{Mylla Maggi Vieira da Costa \\ Joseval dos Reis Miranda}

Resumo: 0 determinismo biológico é o que impulsiona a perpetuação e afirmação de comportamentos misóginos e machistas em "O remorso de Baltazar Serapião", de Valter Hugo Mãe. Na narrativa, a figura da mulher mãe, irmã, esposa, prostituta e bruxa são construídas com base na dominação e perpetuação das relações assimétricas entre o gênero masculino e o feminino. 0 corpo, o sexo e das percepções cognitivas da mulher são constantemente deformadas, esmagadas e violentadas. 0 artigo objetiva suscitar uma análise do discurso patriarcal cristalizado na obra tendo como base teorias aliadas ao movimento feminista, como Bourdieu (1998) e Simone de Beauvoir (1967), dentre outros teóricos. 0 trabalho se organizará em duas partes. Na primeira, iremos abordar a desnaturalização do determinismo biológico na sociedade, com o intuito de desnudar crenças e teorias machistas. Na segunda parte, analisaremos fragmentos da obra literária em que discursos biologizantes se fazem presentes como justificativa para a marginalização dos corpos e das mentes femininas. A partir do vínculo entre as duas partes, obtivemos a possibilidade de identificar que os ideais deterministas marcam de forma abrupta todo o percurso do livro.

Palavras-chave: Biologização, Relações assimétricas, Movimento feminista, Gênero. 


\section{INTRODUÇÃO}

O livro o remorso de Baltazar Serapião, de 2006, do autor português Valter Hugo Mãe, está dividido em vinte e oito capítulos e narra à história de um vilarejo, situado em uma Idade Média não muito definida historicamente e temporalmente, com personagens peculiares que nos apresentam relações violentas, excludentes e de dominação, principalmente, masculina, que possuem a capacidade de prender o (a) leitor (a) através da fluidez e genialidade que o autor constrói os discursos existentes no livro.

Tendo em vista as relações violentas apresentadas durante a narrativa, com base nos pressupostos do movimento feminista, de Pierre Bourdieu (1998), Judith Butler (2015) e Simone de Beauvoir (1967), este artigo tem por objetivo analisar a reprodução da identidade, forjada pelas relações de poder patriarcais, do sujeito mulher utilizando-se de estratégias que biologizam o machismo no livro "o remorso de Baltazar Serapião" do escritor Valter Hugo Mãe, além de buscar uma interpretação analítica de aspectos intrínsecos à obra.

Nesse sentido, a nossa pesquisa parte da análise bibliográfica da obra já mencionada, constituindo-se uma abordagem qualitativa de pesquisa por meio do estudo de caso. Além disso, fizemos um levantamento bibliográfico sobre autores que versam sobre as questões de gênero.

Para uma melhor sistematização da nossa pesquisa, o trabalho está divido em dois principais momentos. No primeiro apresentaremos teorias sobre a construção discursiva, social e cultural de gênero, que desmistifica a ideia biologizante que por séculos foi tida como verdade e que serviu de justificativa para a violência sofrida pelas mulheres. Na segunda seção analisaremos alguns trechos do livro, em busca de vestígios da reprodução e utilização do discurso patriarcal hegemônico, para tentar justificar e sustentar a violência contra a mulher.

\section{GÊNERO COMO CONSTRUÇÃO DISCURSIVA, SOCIAL E CULTURAL: A DESNATURALIZAÇÃO DAS RELAÇÕES ASSIMÉTRICAS DE GÊNERO.}

O determinismo biológico foi o combustível que alimentou e alimenta as grandes instituições sociais e econômicas no decorrer dos séculos. 0 gênero é usado como justificativa para promover e reproduzir assimetrias de cunho trabalhista, relacional e violento. Há uma gama de teorias replicadas principalmente por forças religiosas ligadas à questão biológica que faz uso de questões como estatura, peso, massa corpórea, capacidade cognitiva, dentre outras especificidades. Tudo isso também se deve ao fato de o senso comum excluir o gênero como parte constituinte do indivíduo social e associar uma pessoa inteiramente ao sexo em que está inserida. Sobre isso, temos:

[...] os corpos de homens e mulheres não originam essências ou naturezas femininas e masculinas (Carvalho, 2011). Antes, são as formas de compreensão das diferenças e semelhanças entre esses corpos que determinam como os mesmos são apreendidos socialmente. A partir das diferenças percebidas entre os sexos, constrói-se todo um sistema simbólico sobre mulheres e homens (Scott, 1995), o qual repercute em praticamente todos os aspectos das sociedades ocidentais: a divisão sexual do trabalho, o acesso à educação, a violência sexual, entre outros. Uma decorrência dessa visão é que o gênero fica aberto à mudança histórica. Por mais que habitemos em uma sociedade que separa, de forma extremamente binária, um sexo masculino e um feminino, não podemos generalizar que todas as culturas, ao longo da história, adotaram tal perspectiva. Voltando ao exemplo de Laqueur (1990) a respeito da noção das mulheres enquanto "homens invertidos" que perdurou até o século XVIII, podemos adicionar que por mais que as diferenças anatômicas dos sexos fossem reconhecidas, essas diferenças não serviam de base para uma visão tão bipolarizada e oposicional de gênero: duas "naturezas", duas "essências" e dois "cérebros" antagônicos; um de Marte, outro de Vênus (SOUZA; ZEQUINI, 2012, p.18).

Ao tratar das diferenças, vemos que, historicamente, o parâmetro a ser comparado entre os gêneros é sempre o homem, aquilo que as mulheres têm e eles não. É sempre colocado como uma coisa ruim, que leva a pensarem o sexo feminino como frágil e destinado a serem diferentes dos homens, por isso, menores. Bourdieu (1998) discorre sobre a utilização dessas diferenças biológicas em conformação mítica à relação arbitrária da dominação masculina sobre o feminino. 
Por isso se configura essa percepção enraizada em uma sociedade patriarcal.

Esses esquemas de pensamento, de aplicação universal, registram como que diferenças de naturezas, inscritas na objetividade das variações e dos traços distintivos (por exemplo, em matéria corporal) que eles contribuem para fazer existir ao mesmo tempo que as "naturalizam", inscrevendo-as em um sistema de diferenças, todas igualmente naturais em aparência; de modo que as previsões que elas engendram são incessantemente confirmadas pelo curso do mundo, sobretudo pelos ciclos biológicos e cósmicos (BOURDIEU, 2002, p.8).

Segundo Simone de Beauvoir (2016, p. 11), "Ninguém nasce mulher: torna-se mulher. Nenhum destino biológico, psíquico, econômico define a forma que a fêmea humana assume no seio da sociedade". No livro "o segundo sexo", no qual essa frase está presente e é dividido em dois volumes, a filósofa encara o gênero como uma construção discursiva, social e cultural e busca, com isso, superar a perspectiva do determinismo biológico que, durante séculos, destinou aos sexos identidades "imutáveis" que resultaram em relações de poder excludentes, violentas e de dominação estrutural entre homens e mulheres.

Em uma perspectiva mais moderna, Judith Butler (2015), em seu livro "Problemas de gênero: determinismo e subversão da identidade" questiona o caráter cristalizado do machismo na naturalização ou biologização da feminilidade de ser mulher. 0 gênero, por anos confundido com sexo biológico, sustentou-se em relações hierárquicas de poder baseando-se em diferenças biológicas. Em seu livro, a autora propõe o questionamento: "Ser mulher constituiria um "fato natural" ou uma performance cultural, ou seria a "naturalidade" constituída mediante atos performativos discursivamente compelidos que produzem o corpo no interior das categorias de sexo e por meio delas?" (BUTLER, 2015, p. 9)

Para contestar verdades universais que se mantiveram estáveis durante anos, o movimento feminista surge como uma reação à institucionalização da permanência e perpetuação das relações assimétricas na sociedade. Isso não significa que antes do surgimento do movimento as mulheres não se incomodavam com o patriarcado compulsório, mas, que, foi a partir do encontro, aglomeração e troca de ideias entre uma quantidade considerável de mulheres que os ideais de igualdade começaram a fazer uma diferença real na sociedade. A primeira onda feminista (século XIX) foi marcada pelo direito ao voto, sendo, contudo, marcada por uma simpatia ao liberalismo. A segunda onda (a partir dos anos cinquenta até os anos noventa) trouxe à tona questões ligadas à sexualidade e direitos reprodutivos. Entra em ação o feminismo radical. Através dessa onda, foi possível suscitar o debate em relação ao determinismo biológico, que tanto atrasou, ceifou e prejudicou a vida de bilhões de mulheres (como atualmente ainda ocorre).

\section{A REPRODUÇÃO DAS RELAÇõES DE PODER ATRAVESSADAS POR IDENTIDADES PRODUZIDAS PELO PATRIARCADO NO LIVRO “O REMORSO DE BALTAZAR SERAPIÃO”}

A dominação masculina que existe socialmente construída está atrelada ao discurso que usa apontamentos de diferenças biológicas para legitimar a inferioridade feminina para com o homem. Isso acontece pela necessidade de desde os princípios o ser humano entender as coisas no mundo em sistemas de oposições homólogas ${ }^{1}$, por isso, as semelhanças nas diferenças formam sistemas de oposição, e, por conseguinte, um jogo de poderes. A partir das performances diferenciadas do corpo feminino e masculino, o personagem principal do romance naturaliza a inferioridade através da diferença dos ciclos naturais e normais - não inferiores, apenas diferentes - das mulheres. Como podemos ver quando ele narra à menarca de Brunilde:

[...] minha mãe roubou-a de nossos olhos, furiosa com o destino, e todos soubemos que se cobririam uma à outra de segredos, semelhantes e porcas de corpos, condenadas à inferioridade, à fraqueza. Um corpo que as obrigava, sem falta, a uma maleita reiterada, como um inimigo habitando dentro delas, era pior que se podia esperar, um empecilho de toda a perfeição, e tão belas se deixavam quanto doloridas e acossadas. Por isso eram instáveis, temperamentais, aflitas de coisas secretas e imaginárias, a prepararem vidas só delas sem sentido à lógica (MÃE, 2006, p.19). 
A diferença entre os sexos, principalmente anatômica, pode ser utilizada como justificativa natural para a diferença socialmente construída, segundo Bourdieu. Pelo fato da ordem masculina dispensar justificação (BOURDIEU, 2002, p.9), ela se constitui como a forma neutra no discurso e na sociedade, por isso é aquela a qual deve ser comparado ou subordinado o outro gênero, no caso, o feminino.

Ao falar sobre a irmã e a mãe, Baltazar associa a menstruação à podridão do corpo feminino e suas particularidades. Esse corpo é posto como inimigo da mulher, que é submetida a tão penosa situação de calamidade. Notamos que Baltazar, assim como a maior parte dos personagens do romance, só diferem elogios ao gênero oposto quando tal gênero está em posição de subserviência perante os homens. Na citação acima, podemos notar, também, que Brunilde e a mãe são postas num lugar de união e semelhanças nas dores. A menstruação associa-se, inclusive, à cognição. Soa como uma maldição.

[...] a menstruação não apenas traz consigo a conotação de um sistema produtivo que fracassou na produção, como também transmite a noção de uma produção desvirtuada, fabricando produtos sem uso, fora das especificações, invendáveis, desperdícios, sucatas. Por mais repugnante que possa ser, o sangue menstrual irá sair. Uma produção desvirtuada é também uma imagem que nos enche de horror e consternação (MARTIN, 2006, p. 93).

Martin (2006) evidencia a faceta do que é entendido e associado à menstruação. Ou seja, se a função maior da mulher habita na procriação, a menstruação seria um fator relacionado à fraqueza, à falha, à infertilidade do ventre que deveria florescer em abundância.

[...] mas deus quis que eu fosse este homem e tu a minha mulher, como tal está nas minhas mãos completar tudo o que no teu feitio está incompleto, e deverás respeitar-me para que sejas respeitada. nada do que eu te disser deve ser posto em causa, a menos que enlouqueças e me autorizes a pôr-te fim (MÃE, 2006, p. 48).

Neste sistema de oposições entre os gêneros, a superioridade masculina vai se legitimando através de suas diferenças biológicas, através de sistemas de valores que se baseiam na mítica da superioridade masculina. A significação simbólica dos valores em características biológicas se afirma e se naturaliza, por exemplo, quando o pênis assume uma posição ereta, acima, por isso considerado superior a genitália feminina. Ou, por exemplo, pelo fato de os órgãos sexuais masculinos serem para "fora" e a vagina ser para "dentro", legitima a falta de completude feminina que necessita da parte de fora do homem para "encaixar" e se completar. A noção de incompletude da mulher também abre espaço para o conservadorismo a respeito da sexualidade feminina, como a vagina é um órgão que não é exposto para fora, a própria noção simbólica da interioridade remete a uma repressão de algo que não é liberto, é enclausurado.

Podemos conferir na seguinte passagem: "ergui as mãos a cara e tentei acreditar que me casaria com a Ermesinda. a bela rapariga a esconder os olhos, e como dedicaria meus dias a enchê-los da minha imagem, para que viesse a sua condição de mulher apenas da minha condição de homem." (MÃE, 2006, p.25), o discurso machista que reitera que a condição de mulher da Ermesinda apenas seria afirmada e consolidada a partir do casamento com o Serapião, onde ela seria finalmente completa.

Temos no matrimônio um lugar de resignação, missão e destino. Em $O$ remorso de Baltazar Serapião, uma menina não pode fugir a essa sagrada celebração. Isso, claro, se a garota for virgem, "pura".

0 casamento conserva em grande parte esse aspecto tradicional. E, antes de tudo, impõe-se muito mais imperiosamente à jovem do que ao jovem. Há ainda importantes camadas sociais em que nenhuma outra perspectiva se propõe a ela; entre os camponeses a celibatária é um pátria; fica sendo a serva do pai, dos irmãos, do cunhado; o êxodo para as cidades não está a seu alcance; o casamento, escravizando-a a um homem, faz dela dona de um lar (BEAUVOIR, 2016, p.190). 
No romance temos exemplos de mulheres que não são "feitas" para casar, como é o caso de Teresa Diaba, que mantém relações sexuais com todos os homens da cidade. 0 prazer feminino é posto num lugar de obscuridade, vulgaridade e pecado. 0 fato de ela gostar das relações é motivo de julgamentos. Teresa é, inclusive, igualada a um animal que "lembra" uma mulher:

[...] a Teresa diaba era quem vinha muito por mim. Parecia uma cadela no cio, farejando, aninhada pelos cantos das árvores e dos muros, à espera de ser surpreendida por macho que a tivesse. Era toda carne viva, como ferida onde se tocasse e fizesse gemer. Abria-se como lençóis estendidos e recebia um homem com valentia se queixa nem esmorecimento. Era como gostava, total de fúria e vontade, sem parar, a ganir de prazer. [...] era como um animal que fizesse lembrar uma mulher [...] (MÃE, 2018, p.36)

Durante o livro, podemos enxergar como de fato as mulheres são apenas constituídas como sujeito a partir da relação com o homem. Pois, a condição de mulher das personagens só se concretiza a partir do casamento com as personagens masculinas.

Assim, a definição social dos órgãos sexuais, longe de ser um simples registro de propriedades naturais, diretamente expostas à percepção, é produto de uma construção efetuada à custa de uma série de escolhas orientadas, ou melhor, através da acentuação de certas diferenças, ou do obscurecimento de certas semelhanças. A representação da vagina como um falo invertido, que Marie Christine Pouchelle descobriu nos escritos de um cirurgião da Idade Média, obedece às mesmas oposições fundamentais entre o positivo e o negativo, $\mathrm{o}$ direito e o avesso, que se impõem a partir do momento em que o princípio masculino é tomado como a medida de todas as coisas (BOURDIEU, 2002, p.11).

Valendo-nos da teoria de "A construção social dos corpos" de Bourdieu (1998), percebemos como as diferenças do corpo são artifícios para a naturalização da inferioridade feminina. É uma construção que parte de ações-pensamentos. Os hábitos que foram consolidados a longo da história que se sustenta a partir de uma sexualidade de tudo sobre todas as coisas faz com que a categoria de gênero seja responsável pela divisão dicotômica do feminino e masculino. A partir dessa oposição, desenvolveu-se o jogo de poderes e dominação.

Em O remorso de Baltazar Serapião por diversas vezes é justificada a agressão física/psicológica e todos os tipos de abuso pelo fato de mulheres serem inferiores e por isso, dignas de opressão e agressão, pois, são dominadas pelo sexo oposto. Por isso ser uma mítica e ter se consolidado como costume sociocultural, o patriarcalismo é confirmado e rebatido em outras horas. Por exemplo, no diálogo de Serapião com a bruxa queimada que ronda a casa dos sargas e os acompanha em viagem até a casa de El Rei:

[...] homem de verdade consome-se de carnes, é normal. Nada normal para mim que recuso ser de homem, nada quero que homem algum me toque. E porque te casaste. sempre fui casada por pais ou homens que me mandassem, mulher solteira é má de vida e fica sem trabalho nem amizades. Pois mulher minha apanha tanto quanto deve, até que se ensine de tudo o que lhe digo [...] agradeço sinceridade, mas abdico de razões femininas, mulher é coisa de pouca sabedoria e nenhuma estabilidade, o que pensam hoje, amanhã não sabem. é perigoso que se ouça coisa que digam, assim que te abdico de proferires palavra, só palavras de sobrevivência te refiro, resto disso nada. Como queiras. Como quero. Peço perdão (MÃE, 2006, p.110).

A personagem é uma forte representação daquela mulher que não se submeteu a essa opressão. Visto que, na história, muitas mulheres foram queimadas principalmente pela Igreja Católica por serem consideradas profanas. Todas essas mulheres que não obedeciam aos dogmas eram consideradas bruxas. 0 termo de "bruxa" admite uma simbologia de algo que é místico, o que vai de encontro com a ideologia cristã. Percebemos neste diálogo a recusa da bruxa para com os homens, o que afirma uma "necessidade" que é mítica e não natural, de que mulher precisa de homem. A partir das respostas de Serapião vemos que ele sustenta a mítica, admitindo que sua a mulher apanha o quanto "deve" e que "mulher é coisa de pouca sabedoria", justificando suas agressões e abuso a partir de uma inferioridade que na realidade não existe. 
Podemos perceber durante a história a simbologia mística que a personagem da bruxa tem, pelo fato de considerarem que as mulheres que se rebelam ou vão de encontro à opressão dominam algum tipo de magia para fazer mal aos homens. Retomamos a ideia de que tudo que a mulher tem de diferente dos homens é para o mal e pesa do lado negativo. Assim pontua Bourdieu:

Simbolicamente votadas à resignação e à discrição, as mulheres só podem exercer algum poder voltando contra o forte sua própria força, ou aceitando se apagar, ou, pelo menos, negar um poder que elas só podem exercer por procuração (como eminências pardas). Mas, segundo a lei enunciada por Lucien Bianco ao falar das resistências camponesas na China, as armas do fraco são sempre armas fracas. As próprias estratégias simbólicas que as mulheres usam contra os homens, como as da magia, continuam dominadas, pois o conjunto de símbolos e agentes míticos que elas põem em ação, ou os fins que elas buscam (como o amor, ou a impotência, do homem amado ou odiado), têm seu princípio em uma visão androcêntrica em nome da qual elas são dominadas (BOURDIEU, 2002, p.21).

Vemos que quando as diferenças que as mulheres têm dos homens, quando utilizadas para resistir ou se sobressair de alguma forma para encontrar como lidar com os tipos de opressões as quais está sujeita na sociedade, elas são consideradas armas facilmente destruídas por apelarem para a mítica das diferenças femininas serem sempre algo carregado de simbologia negativa. Lembremo-nos do mito de Adão e Eva, onde o pecado só se estabeleceu porque Eva ofereceu a Adão o fruto proibido. Podemos perceber explicitamente como isso acontece em outra passagem de Serapião:

[...] é que as mulheres deus dá conhecimento de algo que não dá aos homens, como a concepção e como sentidos intuitivos para saber de acontecimentos antes de lhe dizerem. Por isso leem os olhos e sinais imperceptíveis que os homens não conseguem ver, como se tivessem forças sem nome a montar sobre tudo o que facilmente se conhece. Isso é coisa de bruxa (MÃE, 2006, p.113).

Vemos que ele se vale de chamar de "bruxa" todo e qualquer sinal mínimo de transgressão e que foge à regra do que é ser "normal" e "bom" que é ser homem. Volta-se sempre ao parâmetro comparativo do sexo masculino como neutro para naturalizar a inferioridade e comprovar maldade nas ações-pensamentos das mulheres. Retomamos a ideia de Bourdieu e a associação das habilidades conferida às mulheres e não aos homens, como sendo sempre utilizada para o mal.

Insuficientes para subverter realmente a relação de dominação, tais estratégias acabam resultando em confirmação da representação dominante das mulheres como seres maléficos, cuja identidade, inteiramente negativa, é constituída essencialmente de proibições, que acabam gerando igualmente ocasiões de transgressão (BOURDIEU, 2002, p.21).

O sexo feminino, desde que estabelece no mundo seu lugar de mulher, está conferido a uma cultura dominante misógina e que toma suas diferenças como sinais de malevolências. Quando, ao perceber seu estado de vítima, propõe-se a combater essas injustiças é duramente reprimida e exterminada. A mulher que luta por diminuir essa injustiça e desmistificar a inferioridade é classificada como alguém anormal, ou como uma bruxa.

Dessa foram, o lugar da mulher que luta, então, sempre se apresenta como um lugar de revolução a uma cultura que já está fortemente enraizada. De acordo com Glória Steinem $(1934)^{2}$, as mulheres devem apresentar ideias extremistas diante da crença de que os homens vieram ao mundo para controlar as mulheres. Visto que, a raiz dessa injustiça é que fazem crescer essas flores do mal. Fazendo uma correlação a uma passagem de Hugo Mãe: “cada flor vale muito, e muitas ferram pés como lobos".

${ }^{2}$ Glória Steinem (1934) é jornalista, feminista e escritora estadunidense. Criou e editou a revista feminista. Dentre seus inúmeros artigos, destacam-se "A verdadeira Linda Lovelace" e "Se os homens menstruassem". No Brasil, foi publicado o livro "Memórias da transgressão", uma coletânea de artigos publicados ao longo de vinte anos de carreira. Também foi lançado em 1992, pela Editora Objetiva, o livro A Revolução Interior - Um Livro de Autoestima, uma das suas obras mais lida nos EUA. 


\section{CONSIDERAÇÕES FINAIS}

Ao término da nossa análise, foi possível concluir como o discurso produzido pelas personagens homens, principalmente pelo protagonista, do livro "O remorso de Baltazar Serapião", do autor português Valter Hugo Mãe, reforça a ideia biologizante de gênero, que, durante séculos, sustentou e justificou as relações de poder assimétricas e violentas entre homens e mulheres.

A narrativa nos apresentou uma constante tentativa de naturalização dos estereótipos, excludentes e violentos, cristalizados historicamente a partir das vontades de verdade produzidas pelo patriarcado, de gênero. Sustentando, a partir da utilização do determinismo biológico, a dicotomia machista e misógina entre homens e mulheres, que, no livro, desencadeia recorrentes violências e dominações masculinas entre as personagens. Estes, que a todo o momento, fazem questão de reforçar e reproduzir a identidade, criada pelo discurso hegemônico patriarcal, do sujeito mulher.

Notamos, ao fim do estudo, que foi possível, através da análise, sustentar e atender aos nossos objetivos outrora detalhados, ou seja, conseguimos, de fato, identificar evidências biologizantes na obra, bem como interpretamos fragmentos chaves em comunhão com os nossos teóricos aqui apresentados.

\section{REFERÊNCIAS}

[1] Beauvoir, Simone de. O segundo sexo: A experiência vivida. 2. Ed. São Paulo: Difusão Europeia do Livro, 1967.

[2] Bourdieu, P. A dominação masculina. 2ª ed: Rio de Janeiro: Bertrand Brasil, 2002.

[3] Butler, J. Problemas de gênero: feminismo e subversão da identidade. 8 ed: Rio de Janeiro: Civilização Brasileira, 2015

[4] Mãe, Valter Hugo. $O$ remorso de Baltazar Serapião. São Paulo: Editora 34, 2006.

[5] Martin, Emily. A mulher no corpo: uma análise cultural da reprodução. Rio de Janeiro, Editora Garamond, 2006.

[6] Senkevics, Adriano Souza; Polidoro, Juliano Zequini. Corpo, gênero e ciência: na interface entre biologia e sociedade. Revista da Biologia 9(1): 16-21, 2012.

[7] Steinem, G. Memórias de transgressão: momentos da história da mulher do século XX. Rio de Janeiro: Record: Rosa dos tempos, 1997. 


\section{Capítulo 2}

\section{Contação de história e gênero: Personagens adolescentes em questão?}

\section{Ellen Borges Tenorio Galdino \\ Adélia Augusta Souto de Oliveira \\ Paula Orchiucci Miura \\ Luciana de Araújo Vieira}

Resumo: Em consonância com o Estatuto da Criança e do Adolescente, instituições de acolhimento são locais nos quais crianças e adolescentes permanecem sob a proteção do Estado, enquanto aguardam reintegração familiar ou designação para uma família substituta. 0 presente trabalho pretende relatar uma experiência durante o estágio curricular obrigatório do curso de Psicologia em uma instituição de acolhimento de Maceió/AL. Realizaram-se encontros potencializadores com intuito de produção de histórias de temática livre que resultaram em 9 histórias produzidas com a predominância de protagonistas masculinos. Percebeu-se que as narrativas apresentam associações do masculino à brincadeira, amizade e vínculo familiar, enquanto o feminino é associado à família na figura materna e a interesse sexual, repetindo valores machistas que compõe estruturalmente nossa sociedade. As atividades de produção de histórias possibilitaram o fortalecimento de vínculos entre os adolescentes e a estagiária, reforçando o valor da ludicidade no contexto de intervenção. Conclui-se a necessidade de intervenções que permitam uma rediscussão de papeis definidos culturalmente, possibilitando desconstruções de noções que perpetuem ideais machistas e excludentes.

Palavras-chave: Adolescência, Infância, Instituição de Acolhimento, Criação de História, Gênero. 


\section{INTRODUÇÃO}

No Brasil, a partir do reconhecimento de situações de vulnerabilidade, o Conselho Tutelar e o Juizado determinam a chegada da criança ou adolescente em instituições de acolhimento. Nesses locais, de acordo com o Estatuto da Criança e Adolescente - ECA (BRASIL, 1990), crianças e adolescentes são protegidos enquanto aguardam sua reintegração na família ou colocação em família substituta.

Assim, os assistidos devem permanecer no local por, no máximo dois anos, salvo em casos onde seja reconhecido que é do melhor interesse da criança ou adolescente permanecer na instituição por mais tempo. Esses locais têm seus parâmetros de funcionamento definidos por documentos oficiais como a cartilha Orientações Técnicas: Serviços de Acolhimento para Crianças e Adolescentes (BRASIL, 2009) e o Plano Nacional de Promoção, Proteção e Defesa do Direito de Crianças e Adolescentes à Convivência Familiar e Comunitária (BRASIL, 2006). A cartilha fundamenta o funcionamento de instituições de acolhimento, as organizando em quatro modalidades, sendo elas: abrigo institucional, casa lar, serviço de acolhimento em família acolhedora e república. Para cada modalidade, são indicadas especificidades referentes a fatores como público-alvo, infra-estrutura, quadro de recursos humanos e aspectos físicos do local. Já o Plano, destaca a importância da convivência familiar e comunitária, objetivando garantir o direito da criança e do adolescente.

A partir de um estágio curricular obrigatório do curso de Psicologia da Universidade Federal de Alagoas, foi vivenciada experiência em uma instituição de acolhimento no Estado de Alagoas. A instituição organiza-se como abrigo institucional, de acordo com a cartilha Orientações Técnicas: Serviços de Acolhimento para Crianças e Adolescentes (BRASIL, 2009) e é vinculada à Secretaria Municipal de Assistência Social, fazendo parte da rede de alta complexidade do Sistema Único de Assistência Social (SUAS).

Nessa perspectiva, construir histórias representa uma forma de elaborar questões internas (TOROSSIAN; XAVIER, 2012), bem como assume funções terapêuticas (WARPECHOWSKI, 2012). Assim, ao criar histórias, na

experiência de escritura, abre-se um campo intermediário entre o escutar e ser escutado, fantasia e realidade, verdadeiro e falso, estar dentro e estar fora, angústia e alegria. Contar histórias implica contá-las de diversas maneiras, poder dimensio-nar diversos ângulos ou pontos de vistas (TOROSSIAN; XAVIER, 2012, p. 221).

Para Warpechowski (2012), a contação de histórias é compreendida como forma de expressar de forma tolerável os sofrimentos cotidianos. Bettelheim (2002) cita possíveis sofrimentos infantis, como o medo do escuro, medo de animais e o medo da morte dos pais. Para o autor, além de oferecer a oportunidade de elaboração do conflito, as histórias permitem o reconhecimento de formas de resolução. Compreende-se que até mesmo na repetição de uma história, encontra-se uma forma de apropriação do texto (TOROSSIAN; XAVIER, 2012).

Histórias com temáticas de gênero permitem explorar situações do cotidiano. Assim, consideram-se as noções de gênero como construções históricas e sociais (LOURO, 1997), portanto relevante compreender e debater essas noções e suas determinações com os adolescentes. Assim, considerando a especificidade do local, o presente trabalho pretende relatar experiência de autoria, produção e criação de histórias, identificando as representações de gênero para crianças e adolescentes em situação de vulnerabilidade e em contexto de atendimento de alta complexidade.

\section{POLÍTICAS DE ASSISTÊNCIA SOCIAL E ALTA COMPLEXIDADE}

De acordo com dados publicados pela Fundação Abrinq pelos Direito de Crianças e Adolescentes (2017), obtidos pela Secretaria de Direitos Humanos da Presidência da República, as denúncias relacionadas à violação de direitos de crianças e adolescentes envolve: negligência $(72,8 \%)$, violência psicológica $(45,7 \%)$, violência física $(42,4 \%)$, violência sexual $(21,3 \%)$ e outras violências $(8,6 \%)$, num quantitativo total de 153 mil denúncias. A partir desses dados, percebe-se a vulnerabilidade a qual um grande número, de crianças e adolescentes, está submetido no contexto brasileiro. 
No reconhecimento de situações como estas, o Sistema Único de Assistência Social institui a Proteção Especial de Alta Complexidade, visando garantir "proteção integral - moradia, alimentação, higienização e trabalho protegido para famílias e indivíduos que se encontram sem referência e, ou, em situação de ameaça, necessitando ser retirados de seu núcleo familiar e, ou, comunitário. " (BRASIL, 2004, p. 38).

As políticas brasileiras de assistência social buscam garantir a crianças e adolescentes proteção e direitos básicos, reconhecidos no ECA (BRASIL, 1990), como direito à saúde, educação, cultura, lazer e, à convivência familiar e comunitária. Imprescindível nesse cenário, tal estatuto regulamentou políticas de atendimento, medidas de proteção, situações onde ocorreu ato infracional, medidas de pais ou responsáveis e do Conselho Tutelar. $\mathrm{O}$ estatuto consolida-se como documento legislativo diretamente referente à infância e adolescência, priorizando o interesse de crianças e adolescentes. Tal publicação concede voz a estes grupos e os compreendes como sujeitos de direitos (ainda que de modo diferenciado dos adultos).

O direito à convivência familiar e comunitária é destaque nas políticas brasileiras de assistência social. No Plano Nacional de Assistência Social - PNAS (BRASIL, 2005), a busca pela garantia de tal direito consta nos objetivos centrais, bem como a proteção social básica e a inclusão e equidade de grupos. Também enfatizando esse direito, o Plano Nacional de Promoção, Proteção e Defesa do Direito de Crianças e Adolescentes à Convivência Familiar e Comunitária (BRASIL, 2006) amplia o conceito de família (à consanguinidade, aliança e afinidade) e revisitando o conceito de família extensa, defende a convivência familiar como importante ambiente de cuidado para o desenvolvimento da criança e do adolescente, defendendo também programas em defesa da família, que venham a oferecer suporte, tornando possível evitar situações de vulnerabilidade. 0 reconhecimento da importância do vínculo familiar, em suas funções familiares, e do vínculo com a comunidade, como fundamental na construção da identidade, são fundamentais para compreensão das particularidades de cada caso.

Assim, compreende-se que as instituições de acolhimento são detalhadamente regulamentadas pelo Estado e que a estadia nesses locais

não implica em privação de liberdade, mas em amparar a criança e ao adolescente no cumprimento de suas necessidades básicas e em sua reinserção social. Consiste em um serviço de proteção integral, que inclui moradia, alimentação, higiene, educação e lazer (STEGANI; BAGATIN, 2013, p. 3).

A instituição enfatizada neste trabalho funciona de acordo com todas estas normatizações, objetivando, em seu serviço, a proteção da criança e do adolescente e buscando garantir seu direito à convivência familiar e comunitária. Tal local organiza-se como abrigo institucional, de acordo com a cartilha Serviços de Acolhimento para Crianças e Adolescentes (BRASIL, 2009). Desse modo, a instituição in loco situa-se em região residencial, em uma casa sem identificação de instituição de acolhimento, com amplo espaço para suprir necessidades básicas de moradia e lazer. Possui um numeroso quadro de recursos humanos, com cerca de 30 profissionais, abrangendo os três turnos durante toda a semana. A instituição é vinculada à Secretaria Municipal de Assistência Social e faz parte da rede de alta complexidade do Sistema Único de Assistência Social (SUAS).

\subsection{CAMINHOS PARA CONSTRUÇÃO DE HISTÓRIAS}

Nesse contexto, foi elaborada e executada uma proposta de intervenção de produção de histórias, com a autoria e contação de histórias e produção opcional de desenhos para ilustrar a narrativa. Sabemos da importância do uso de desenhos como formas de expressão de conteúdos internos, especialmente no campo de produção de conhecimento da Psicologia. Silva et al (2010) destacam o uso de testes como o Roschach e o de Apercepção Temática (TAT), que se utilizam dessa ferramenta. Com relação às representações sociais, associando desenho à produção de uma história, o método Desenho-Estória com Temas, é destacado por Aiello-Vaisberg (1997). A intervenção proposta assemelha-se ao que o autor discute, porém, com tema livre. No entanto, inverte-se a sequência dos procedimentos, visto que primeiro foi sugerida a produção da história, para somente depois ser confeccionado o desenho. Para Spinillo (1993), a produção de histórias orais é um recurso que permite analisar a competência narrativa (esquemas, organização, construções e convenções) mesmo de crianças que ainda não foram alfabetizadas. 
Neste trabalho focalizamos o conteúdo de cada narrativa e suas representações, a partir da criação e imaginação de cada criança e adolescente.

Dessa atividade, participaram oito crianças e adolescentes do sexo masculino, com idades entre 9 e 15 anos, que produziram nove histórias e desenhos. Cada assistido realizou a atividade individualmente, de modo que foi sugerido que criasse uma história, na qual tudo poderia acontecer, em qualquer época ou lugar. As histórias foram narradas por eles e transcritas pela estagiária. Após a produção, de forma opcional, os adolescentes poderiam produzir desenhos que ilustrassem a história criada.

Os autores das histórias foram identificados pelos nomes de personagens de animações, escolhidos pelas autoras, especialmente por suas características. Para tal etapa foram realizadas buscativas de personagens de produções infanto-juvenis, bem como de suas personalidades. Ao fim, os participantes foram caracterizados da seguinte maneira: Tai Kamiya, pelo fato de o adolescente ter um irmão, e fazendo uma associação entre os animais citados na narrativa e digimons; Buzz Lightyear, por sua identificação com aventuras espaciais e por seu jeito extrovertido; Jhonny Bravo, por seu comportamento sedutor, esforçando-se para conquistar as pessoas à sua volta; Bob Esponja, por seu modo simpático e amigável de agir; Charlie Brown, destacando sua simpatia e doçura; Goku, devido a sua forma gentil de se relacionar com a equipe técnica, além de seu interesse por viajar; Jackie Chan, por sua simpatia e interesse por artes marciais; e Wolverine, por sua concentração e seriedade.

\subsection{ASSIM AS HISTÓRIAS SE APRESENTAM.}

As histórias produzidas foram organizadas de acordo com as idades dos assistidos, em ordem crescente, considerando, de acordo com o ECA (BRASIL, 1990) crianças com idade de 0-12 anos incompletos e adolescentes de 12 a 18.

A primeira delas, "O menino que cuidava de vários animais". Nessa história Tai Kamiya, criança de 9 anos, narra: um menino que cria, um a um, três animais, e vivencia o luto com cada um deles. 0 primeiro é um gato, de quem o menino cuida até que fique adulto e morra. 0 segundo é uma lagartixa, também cuidada até crescer, sendo solta para encontrar a família, pelo fato de o menino não ter mais paciência. E o terceiro é um cachorro, que cresce até ficar velhinho, roubar carne de um prédio e ser morto. No fim da história, o menino, já velho, também morre.

Intitulada "Pai corajoso", uma história de aventura foi criada por Buzz Lightyear, criança de 9 anos. Sua narrativa indica que, em um jogo de bola entre dois meninos, a bola cai na lua e eles iniciam uma busca. (Neste dia houve jogo de futebol na casa). 0 menino pergunta ao pai se sabe ir até o espaço, e chega até o avô, que mora na China e é astronauta. A bola, num trajeto de volta para a Terra, encontra um meteoro, fura e cai no Sol, com uma queimadura. Encontra uma nave, que com um raio forte do Sol, cai na Terra, numa planta. 0 pai e o avô se machucam e as pessoas ajudam a tirar a nave, quebrada. 0 menino então, ao ver uma estrela cadente e desejar poder, recebe um poder de tudo. Passa a salvar as pessoas. Luta com homens perigosos, que com um soco, vão parar no espaço. Já adulto, joga bola com o filho. Uma mulher pega a bola e corre, fazendo com que o pai a siga para pegar a bola. Ao subir no prédio e ver um brilho forte da mulher, cai na água e encontra um Megalodon e um Tiranossauro-Rex, os quais mata. Entra na nave e busca o chefe de zerar (fazendo referência a jogos de videogame).

Devido a pedidos, esta criança produziu uma segunda história, intitulada "Macaco Esperto". Na sala, havia uma caixa de lápis de cor, ilustrada com dois macacos. Buzz Lightyear iniciou então uma história onde dois macacos eram "felizes para sempre". Uma moça compra o "macaco macho", que era "arengueiro" e muito querido. Porém, por bagunçar a casa da mulher, o macaco retorna ao zoológico. Lá encontra sua namorada e com ela vê um meteorito cair. Uma "cobra macho" aparece e pega a macaca. 0 macaco a defende e ameaça matar a cobra caso a machuque de novo. A cobra foge de medo e é engolida por um sapo. "Os macacos ficaram felizes brincando de pega-pega para sempre" e são comprados por uma pessoa e ficam quietos. Veem e chutam uma cobra e ficam felizes para sempre.

Em "Um sapo correu pelo mar", Jhonny Bravo, criança de 10 anos, faz autorreferência, conta já ter ido a Belém e encontrado um cachorro, que latia. Ele corre e se esconde na areia do mar. Encontrando caranguejos, dos quais não gostava, mata um e fica desesperado. Entra então no fundo do mar. Depois entra em uma cidade e pede informações. Descobre estar em Olho das Águas. 
Encontra um cachorro e o pega, mas seu dono aparece e o leva. Fica desesperado por não saber onde estava. Então chega numa cidade que conhecia, encontra a família e chora de alegria.

Na história intitulada "Alegria", o adolescente Bob Esponja, de 12 anos, f autorreferência. Na narrativa, apresenta-se e descrevem seus hobbies como jogar bola e andar de bicicleta. Afirma querer uma nova família e apresenta a instituição de acolhimento (ilustrada), como local no qual se encontra uma nova família, para "ficar com bondade e alegria" (sic).

Em "A menina que foi pro abrigo", Charlie Brown, adolescente de 13 anos, narrou a trajetória de uma menina desde sua chegada à instituição de acolhimento até sua saída. Chegando à atividade, pensativo e sorridente, o adolescente criou toda a história antes de começar a narrar, diferente dos demais adolescentes, que a criaram durante a narrativa. Após a narrativa, ilustrou a história desenhando a instituição de acolhimento. Em sua produção, uma menina foge de casa e é levada ao acolhimento institucional pelo Conselho Tutelar, no local faz novas amizades e continua indo à escola. Aos 18 anos, por ter completado a maioridade, a menina sai da instituição, porém já com emprego e casa. Assim compra coisas para a casa e vai visitar a mãe para confirmar se está tudo bem.

"O coelho é doido" foi uma história onde Goku, adolescente de 15 anos, descreveu um coelho que gosta de comer cenoura e laranja e que pula e fica doido quando come. Isso porque ao comer sente dor. "Foi como uma flecha no coração" (trecho final da história).

A história "As férias" foi criada por Jackie Chan, adolescente de 15 anos. Na atividade, o adolescente não conseguia pensar em uma narrativa. Iniciou assim pelo desenho, a partir do qual criou a história. Enquanto desenhava cantou e conversou a respeito de seu gosto por luta. A história apresenta uma família feliz que viaja para diferentes lugares nas férias. Motivada pelo sonho do filho de assistir a luta do Sena, a família viaja para a Califórnia para ir ao WWE.

A narrativa "O menino e sua fama", criada por Wolverine, adolescente de 15 anos, conta a história de um menino que cantava e era famoso. Seus pais não trabalhavam, pois pediam dinheiro ao filho. Um dia o dinheiro acaba e nunca é recuperado. Vão à falência.

\subsection{HISTÓRIAS DE ADOLESCENTES E SIGNIFICAÇÃO DE GÊNERO}

No campo conceitual podemos abordar que na infância, a criança conhece seu ambiente, aprendendo palavras, representações e conceitos, compreendendo seu contexto em formas e relações, de modo a significar e ressignificar criativamente sua realidade. Já a adolescência é um período no qual são vivenciadas descobertas "das próprias limitações, de curiosidade por novas experiências, caracterizada pela necessidade de integração social, pela busca da independência individual, do desenvolvimento da personalidade e definição da identidade sexual" (SOARES et al., 2008, p. 486).

No contexto de análise devemos considerar a especificidade da condição dos adolescentes em situação de acolhimento institucional, que vivenciaram vulnerabilidades nas diversas formas de violências. Nas produções, observa-se a presença dessa curiosidade nas narrativas de aventura, bem como o apelo à representação de família (seja como desejo, seja como relação conflituosa).

Do ponto de vista das reflexões sobre gênero podemos observar que, de acordo com Louro (1997), as noções de gênero são construídas e transformadas a partir de fatores sociais e históricos. Desse modo, a compreensão dessas representações precisa considerar uma sociedade em seu tempo e espaço, a qual, em seus grupos, pode apresentar diversos modos de compreensão de gênero. Essas noções fariam parte da identidade de cada sujeito. Atualmente, essas representações são atravessadas pela influência da mídia. Segundo Alves (2016), os adolescentes são mais vulneráveis à influência da mídia e não percebem como são influenciados. Para a autora, "a mídia com seu poder de persuasão apresenta um mundo de informações referentes à sexualidade aos adolescentes, mas não os capacita a lidar com as consequências dessas atitudes" (ALVES, 2016, p. 3). Em uma pesquisa realizada em Florianópolis (SC), Baggio et al (2009) identificaram que, apesar de a mídia expor o corpo feminino e encobrir o masculino, adolescentes de uma periferia expressaram, em desenhos, os gêneros de forma inversa. Enquanto os adolescentes ressaltaram genitais masculinos, representando poder e dominação; as adolescentes apresentaram o feminino como retraído e submisso, preocupado em esconder o próprio corpo. 
De acordo com Hoff (2004), a mídia manteve o corpo feminino como centro de seu interesse, privilegiando sua exposição, enquanto ocultou o corpo masculino. Associou assim o masculino ao trabalho, projeção, paternidade e casamento. Já o feminino, erotizado, foi associado à sedução, maternidade e outros papeis, no intuito de atingir ao público masculino.

Percebe-se que, entre as nove narrativas produzidas, somente uma apresentou como protagonista uma personagem do sexo feminino, enquanto 8 apresentaram protagonistas personagens masculinos. Se considerarmos as histórias como projeção de si, os personagens permitiram uma expressão de adolescentes meninos. Louro (1997) destaca que é a partir da valorização da sociedade a determinadas características em um tempo histórico que vai construir a representação de gênero, de modo que "para que se compreenda o lugar e as relações de homens e mulheres numa sociedade importa observar não exatamente seus sexos, mas sim tudo o que socialmente se construiu sobre os sexos." (p. 21). Desse modo, é perceptível que nesse contexto, os adolescentes destacam em suas narrativas as relações de amizade, família e brincadeira, positivadas no ambiente masculino e entre meninos. Por outro lado, as meninas foram associadas à função materna ou como objeto de desejo.

A história que destaca o feminino narra a trajetória de uma menina desde sua chegada à instituição de acolhimento. Outra personagem de destaque é a mãe, representada como preocupação da filha, que a visita para confirmar que está bem. Interessante notar que o masculino não aparece nessa narrativa. Nas demais oito histórias, temos a representação de protagonistas masculinos, com representações de família, namoro e brincadeira. A figura masculina apresenta-se em personagens fortes, capazes de grandes feitos como ter conquistado a fama, salvar a namorada, cuidar de outro ser, enfrentar inimigo. Verificamos que as situações engendradas permitem a expressão de poder. Por outro lado, o feminino, pouco retratado, associa-se à fragilidade que necessita de um salvador, à maternidade, ao acolhimento institucional, à sexualidade. A noção da mulher como frágil é sinalizada nas histórias e podem retratar a rotina da instituição, onde é identificada a associação da mulher a tarefas domésticas; uma representação que pode ser associada ao machismo, visto que reflete "um sistema de representações-dominação que utiliza o argumento do sexo, mistificando assim as relações entre os homens e as mulheres, reduzindo-os a sexos hierarquizados, divididos em polo dominante e polo dominado" (DRUMONT, 1980, p. 82).

Entre as três crianças, surgiram mais histórias com conteúdo de aventura, enquanto entre os adolescentes, referências à família e situação de acolhimento institucional foram mais frequentes. Tal fator indica a importância da ludicidade na infância, de modo a reproduzir, com elementos de fantasia, a realidade. Na adolescência, situações verossimilhantes foram produzidas, em associação ao desejo pela família e representação da instituição de acolhimento.

\section{CONCLUSÃO}

A autoria de histórias permite expressar e vivenciar, através de personagens e situações imaginadas, crianças e adolescentes, representações e sentimentos reais. Esse recurso permite uma interação entre narrador e a expectadora (estagiária). Essa vivência interativa e produtiva permite expressões imaginárias que repercutem positivamente na compreensão e operação psíquica de situações rotineiras.

As representações de gênero se caracterizam pelo feminino como mãe, protetora, que oferece carinho e cumplicidade; e o de objeto sexual, de modo a despertar interesse relacionado à sexualidade e afetividade. Temos uma manutenção da estrutura machista de sociedade, ou seja, uma visão machista da mulher, como dona de casa e objeto sexual, e do homem como respeitável, detentor de poder.

Conclui-se ainda pela relevância de intervenções que objetivem desconstruir e reelaborar as noções de gênero a partir de situações do cotidiano.

\section{REFERÊNCIAS}

[1] Aiello-Vaisberg, T. M. J. Investigação de Representações Sociais. In: Trinca, W. (org,) Formas de investigação clínica em psicologia: procedimento de desenhos-estórias: procedimento de desenhos de família com estórias. São Paulo: Vetor, 1997. p. 255-288. 
[2] Alves, A. B. Adolescência e a Construção da Identidade: Análise e Discussão da Sexualidade e Influência da Mídia na Adolescência. In: Encontro Regional Norte de História da Mídia, 4, 2016, Rio Branco. Disponível em: <www.ufrgs.br/alcar/encontros-nacionais-1/encontros-regionais/norte/ 4o-encontro-2016/gt-historia-da-midiaalternativa/adolescencia-e-a-construcao-da-identidade-analis e-e-discussao-da-sexualidade-e-influencia-da-midia-naadolescencia/view>. Acesso em: 13 jul 2017.

[3] Baggio, M. A. et al. O significado atribuído ao papel masculino e feminino por adolescentes de periferia. Esc. Anna Nery, Rio de Janeiro , v. 13, n. 4, p. 872-878, 2009 . Disponível em: <http://dx.doi.org/10.1590/S1414$81452009000400025>$. Acesso em 9 jul. 2017.

[4] Bettelheim, B. A psicanálise dos contos de fadas. Rio de Janeiro: Paz e Terra, 2002.

[5] Brasil. Lei no 8.069, de 13 de Julho de 1990.

[6] __ Orientações Técnicas: Serviços de Acolhimento para Crianças e Adolescentes. 2ª ed. Brasília: Ministério do Desenvolvimento Social e Combate à Fome, 2009. 169p.

[7] __ Plano Nacional Assistência Social. Brasília: Ministério do Desenvolvimento Social e Combate à Fome, 2005

[8] _ Plano Nacional de Promoção, Proteção e Defesa do Direito de Crianças e Adolescentes à Convivência Familiar e Comunitária. Brasília, 2006.

[9] Drumont, M. P. Elementos para uma análise do machismo. Perspectivas, São Paulo, n. 3, p. 81-85, 1980. Disponível em: <seer.fclar.unesp.br/perspectivas/article/viewFile/1696/1377>. Acesso em: 11 jul. 2017.

[10] Fundação Abrinq Pelos Direitos das Crianças e dos Adolescentes. Cenário da infância e adolescência no Brasil. Nywgraf Editora Gráfica Ltda: São Paulo, 2017. Disponível em: <http://www.chegadetrabalhoinfantil.org.br/wp-content/uploads/2017/03/Ce nario-2017-PDF.pdf>. Acesso em 30 maio 2017.

[11] HOFF, T. M. C. Corpo masculino: publicidade e imaginário. E-compós [on-line]. 2004 Disponível em: <www.compos.org.br/seer/index.php/e-compos/article/view/24/25> Acesso em 9 jul 2017.

[12] Louro, G. L. Gênero, sexualidade e educação. Petrópolis: Vozes, 1997.

[13] Silva, R. B. F.; Pasa, A.; Castoldi, D. R.; Spessatto, F. O desenho da figura humana e seu uso na avaliação psicológica. Psicol. Argum. Curitiba, v. 28, n. 60, p. 55-64, jan./mar. 2010. Disponível em: <www2.pucpr.br/reol/index.php/PA?dd1=3510\&dd99=pdf>. Acessado em: 11 jul. 2017.

[14] Soares, S. M. et al. Oficinas sobre sexualidade na adolescência: revelando vozes, desvelando olhares de estudantes do ensino médio. Esc. Anna Nery, Rio de Janeiro, v. 12, n. 3, p. 485-491, Sept. 2008. Disponível em: <www.scielo.br/scielo.php?script=sci_arttext\&pid=S1414-81452008 000300014\&lng=en\&nrm=iso>. Acesso em: 11 jul. 2017.

[15] Spinillo, A. G. Era uma vez... e foram felizes para sempre: esquema narrativo e variações experimentais. Temas psicol., Ribeirão Preto , v. 1, n. 1, p. 67-77, abr. 1993 . Disponível em <pepsic.bvsalud.org/scielo.php?script=sci_arttext\&pid=S1413-389X1993000100009 \&lng=pt\&nrm=iso>. acessos em 15 jul. 2017.

[16] Stegani, Mônica Marcondes; Bagatin, Thiago de Sousa. O papel do psicólogo nas instituições de acolhimento de crianças e adolescentes sob custódia judicial e em situação de vulnerabilidade social. Facel, Paraná, 2013. Disponível

em: <www.facel.com.br/pesquisa/0\%20PAPEL\%20D0\%20PSIC\%C3\%93LOGO\%20nas\%20institui\%C3\%87\%C3\%95ES \%20DE\%20acolhimento\%20DE\%20crian\%C3\%87AS\%20E\%20adolescentes\%20SOB\%20CUST\%C3\%93DIA\%20judi cial.pdf>. Acesso em: 01 abr. 2017.

[17] Torossian, S. D.; Xavier, M, A, Z. Contar e brincar entre a dor e o prazer - Intervenção e política no campo da assistência social. In: CRUZ, L. R.; Guareschi, N. (Org.). 0 psicólogo e as políticas públicas de Assistência Social. Petrópolis: Vozes, 2012, p. 205-227.

[18] Warpechowski, M. B. Era uma vez... Contação de histórias na comunidade. In: Cruz, L. R.; Guareschi, N. (Org.). O psicólogo e as políticas públicas de Assistência Social. Petrópolis: Vozes, 2012, p. 228-235. 


\section{Capítulo 3}

\section{A escrita da subalterna: Invisibilidade da mulher negra em A paixão segundo G.H. de Clarice Lispector}

\section{Ludmilla Carvalho Fonseca}

Resumo: Este trabalho tem como objetivo principal discutir a subalternidade e a invisibilidade da mulher negra no romance $A$ Paixão Segundo G.H de Clarice Lispector. Na obra em questão, a protagonista G.H. descreve a personagem Janair como uma mulher negra e empregada doméstica. Esta, por sua vez, pede demissão e, a partir desse momento, ao se dirigir ao quarto que a funcionária vivia, G.H. depara-se surpreendentemente com marcas da presença de Janair, que ela desconhecia, passando a contestar a sua condição de mulher branca privilegiada. Do mesmo modo que a protagonista do romance invisibiliza a mulher negra subalterna, conhecida somente pela voz dominante da mulher branca, a mesma subalterna promove a inquietação na mulher de classe abastada e a contestação dos seus valores hegemônicos de dominação social, de gênero e racial, lançando-a em um movimento de profunda ruptura existencial, causando a tomada de consciência. Como suporte teórico-metodológico para o desenvolvimento desta pesquisa, será utilizada a abordagem pós-colonial no que tange os temas invisibilidade e subalternidade, e as teorias de gênero vinculadas ao debate gênero-classe-raça.

Palavras-chave: Subalternidade, Invisibilidade, Tomada de Consciência. 


\section{INTRODUÇÃO}

No romance A Paixão Segundo G.H. o narrador-personagem apresenta Janair ao(à) leitor(a). Mulher negra, empregada doméstica num apartamento de alto padrão, ela aparece na obra de forma indireta, sua presença/ausência é apresentada somente pela voz da patroa branca de classe abastada. Tudo que se sabe da mesma é fruto da construção realizada por G.H. Assim, desenvolvem-se posturas pejorativas, por parte de G.H., sobre Janair, de abordagens centradas nos valores de mulheres socioeconomicamente privilegiadas e étnico-culturalmente dominantes.

O espaço que Janair vivia no apartamento também é descrito pela narrativa hegemônica de padrão euronorteamericano centrado. Na lógica subalternizante de raça, classe e gênero, o espaço legado à funcionária é o mais precário, pequeno e desprovido de qualquer conforto. A ideia de organização, limpeza e uso do quarto, que a patroa intui sobre a mulher subalterna, é rapidamente desfeito quando ela entra no cômodo.

Neste trabalho, a análise da obra em destaque busca-se partir do momento em que G.H. encontra o quarto desocupado pela empregada Janair, até o momento em que ela passa contestar todos seus valores dominantes arraigados. Ou seja, a mulher negra subalterna e invisibilizada pela mulher branca dominante é o agente condutor da profunda ruptura social, étnica e do seu papel de gênero que esta conduzia, da negação dos privilégios e da inquietação existencial que este encontro/desencontro vai operar.

\section{A MULHER INVISÍVEL INSUBMISSA}

Após o despejo de Janair, G.H. vai até o quarto outrora ocupado pela empregada. Ela supõe que o quarto está sujo e desorganizado, devido à "sua dupla função de dormida e de depósito de trapos, malas velhas, jornais antigos, papeis de embrulho e barbantes inúteis." (LISPECTOR, 2014, p. 32). No entanto, ela se depara com o aposento limpo, organizado, iluminado e vazio.

Nota-se que há um julgamento de classe com relação à empregada. G.H. diz que irá começar a limpeza do apartamento pelo fundo, e que irá "subindo" horizontalmente até o living. Como subir horizontalmente? Há uma relação de subalternidade ${ }^{3}$ entre a patroa e a empregada, inclusive uma relação de subalternidade com a noção de espaço: o superior (mesmo não estando acima geometricamente) destinado à patroa; o inferior, destinado à empregada, como se fosse a periferia da casa.

Essa relação entre centro-periferia, norte-sul, alto-baixo, colonizador-colonizado, patroa-empregada, inferior-superior, dentre diversos outros constituem o discurso dominante hierárquico que naturaliza as práticas de subalternidade, seguindo a perspectiva da violência epistêmica trazida por Gayatri Spivak (2010, p. 47).

O mais claro exemplo disponível de tal violência epistêmica é o projeto remotamente orquestrado, vasto e heterogêneo de se constituir o sujeito colonial como o Outro. Esse projeto é também a obliteração assimétrica do rastro desse Outro em sua precária Subje-tividade.

Por sua vez, no caso de Janair, soma-se a essa elaboração coercitiva do outro o fato de ela ser mulher. Uma subjetividade precária construída pelo discurso da mulher rica e branca. Desse modo, ela é subalterna por pertencer a determinada classe social submissa à classe dominante, mas também, por ser funcionária de uma patroa, uma mulher branca de classe abastada. Dupla subalternidade (social e de gênero), que a própria patroa, mesmo sendo mulher, impõe a Janair.

\footnotetext{
3 Gayatri Spivak (2010, p. 54), ao indagar sobre as possibilidades do subalterno falar, pontua alguns exemplos do que ela compreende enquanto pertencente a uma posição de subalternidade: "Estou pensando na população em geral não especialista ou acadêmica - ao longo do espectro de classes, para quem a epistême opera sua silenciosa função de programação. Sem considerar o mapa da exploração, sobre qual matriz de 'opressão' eles poderiam colocar sua multitude heterogênea? Considerando agora as margens (pode-se meramente dizer o centro silencioso e silenciado) do circuito marcado por essa violência epistêmica, homens e mulheres entre os camponeses iletrados, os tribais, os estratos mais baixos do subproletariado urbano. De acordo com Foucault e Deleuze (falando a partir do Primeiro Mundo, sob a padronização e regulamentação do capital socializado, embora não pareçam reconhecer isso), os oprimidos, se tiverem a oportunidade (o problema da representação não pode ser ignorado aqui), e por meio da solidariedade através de uma política de alianças [...], podem falar e conhecer suas condições. Devemos agora confrontar a seguinte questão: no outro lado da divisão internacional do trabalho do capital socializado, dentro e fora do circuito da violência espitêmica da lei e educação imperialistas, complementando um texto econômico anterior, pode o subalterno falar?"
} 
Spivak (2010) alarga a discussão da subalternidade incluindo o condicionante de gênero como central para que se possam entender os mecanismos de subjugação, sobretudo se forem considerados o fato de ser mulher e de país do Terceiro Mundo. ${ }^{4}$ Segundo ela,

[...] a construção ideológica de gênero mantém a dominação masculina. Se, no contexto da produção colonial, o sujeito subalterno não tem história e não pode falar, o sujeito feminino está ainda mais profundamente na obscuridade (SPIVAK, 2010, p. 67).

De qualquer maneira a ex-funcionária é julgada. Primeiramente, G.H. presume que o quarto estará desorganizado, como se a empregada fosse incapaz de ordená-lo, ou ainda, como se tivesse que conviver com os "trapos" lá depositados. Em seguida, a patroa reprova Janair por ter feito a limpeza e a arrumação:

Esperava encontrar escuridões, prepara-me para ter que abrir escancaradamente a janela e limpar com ar fresco o escuro mofado. Não contara é que aquela empregada, sem me dizer nada, tivesse arrumado o quarto à sua maneira, e numa ousadia proprietária o tivesse espoliado de sua função de depósito (LISPECTOR, 2014, p. 35).

Ao se ver numa posição social mais elevada que Janair, G.H., munida de seus privilégios, evidencia que somente a proprietária pode tomar decisões sobre a forma como se ordenam as coisas. Como se a ordem fosse algo que pertencesse única e exclusivamente a uma determinada categoria de pessoas.

A ordem é um mecanismo de dominação na concepção ocidental da mulher branca burguesa. Ao seu modo de ver as coisas, a desordem é o que resta ao subjugado, incapaz de tomar decisões sobre o destino dos eventos.

No caso de Janair, ela é uma subalterna insubmissa, pois corrompe a lógica de dominação imposta pela mulher branca, ao gozar da autonomia das suas decisões.

Ainda dentro do contexto da discussão espacial sobre o quarto e, considerando o discurso paradoxal que permeia todo o texto, nota-se que, logo após depreciá-lo, a personagem protagonista eleva-o a um "nível incomparavelmente acima do próprio apartamento" (LISPECTOR, 2014, p. 36). Ela equipara o quarto a um minarete ${ }^{5}$, evidenciando uma ideia de deslocamento do mesmo, como se o cômodo estivesse à parte do apartamento.

0 quarto da empregada, nesse caso, se encontra em uma posição privilegiada ao restante da casa, por estar fora do plano estrutural do prédio, como se estivesse isolado, estranho, e não participante do todo simétrico; disforme, tendo outra dinâmica de ser. Por outro lado, está estandardizado, acima, panóptico, numa posição privilegiada, como um mirante, um observatório, um farol, de onde partem as ordens, os chamados, as convocações, a luz que guia, dá as direções.

Nessa ocasião, G.H. eleva Janair à condição de gestora daquele lar, é quem mantém o equilíbrio, a limpeza e a organização; um outro tipo de poder: a dádiva ${ }^{6}$ da subalterna.

4 "Entre o patriarcado e o imperialismo, a constituição do sujeito e a formação do objeto, a figura da mulher desaparece, não em um vazio imaculado, mas em um violento arremesso que é a figuração deslocada da "mulher do Terceiro Mundo", encurralada entre a tradição e a modernização. Essas considerações poderiam revisar cada detalhe de julgamentos que parecem válidos para uma história da sexualidade no Ocidente" (SPIVAK, 2010, p. 119).

5 "O minarete é a torre de uma mesquita, local do qual o almuadem anuncia as cinco chamadas diárias à oração. Os minaretes, que também recebem o nome de almádena, são normalmente bastante altos se comparados às estruturas que o circundam. 0 objetivo do minarete é fazer com que a voz do almuadem, a pessoa que faz o chamado à oração (azan) possa ser ouvida a grandes distâncias." Disponível em: https://pt.wikipedia.org/wiki/Minarete (acesso em 23 de novembro de 2018).

${ }^{6}$ A dádiva enquanto um fenômeno social foi estudada inicialmente por Marcel Mauss, na obra Ensaio sobre a dádiva. Godbout (1998, p. 6), tomando como base esse estudo, define dádiva da seguinte forma: "De modo negativo, entende-se por dádiva tudo o que circula na sociedade que não está ligado nem ao mercado, nem ao Estado (redistribuição), nem à violência física. De modo mais positivo, é o que circula em prol do ou em nome do laço social. Uma primeira característica de um sistema de dádiva consiste no fato de que os agentes sociais buscam se afastar da equivalência de modo deliberado. Isso não significa que a dádiva seja unilateral. Pode sê-lo, mas essa não é uma característica essencial sua. Geralmente, ao contrário, há retribuição, e muitas vezes maior do que a dádiva. Mas a retribuição não é o objetivo. É um equívoco aplicar a ela o modelo linear fins-meios e dizer: ele recebeu depois de ter dado, portanto deu para receber; o objetivo era receber, e a dádiva era um meio. A dádiva não 
A metáfora (do minarete) demarca a mudança da compreensão que a protagonista tinha da empregada, conjuntamente a leitura que a mesma tinha da hierarquia da casa com o quarto da empregada. Processo epifânico que revela um outro olhar sobre o lugar da subalterna.

\section{A ESCRITA DA SUBALTERNA}

Dando seguimento à análise da obra A paixão segundo G.H. é preciso retornar ao ambiente do quarto da trabalhadora do lar Janair, que pedira demissão da casa de G.H., e a patroa fora verificar como está o lugar depois da partida da empregada. Juga-se que é a partir deste momento na narrativa que a tomada de consciência começa a se manifestar com maior densidade. No curso da narrativa é apresentada a percepção geométrica ${ }^{7}$ do espaço, onde a personagem protagonista mostra divergência de entendimento em relação à sua assimetria:

O quarto não era um quadrilátero regular: dois de seus ângulos eram ligeiramente mais abertos. E embora esta fosse a sua realidade material, ela me vinha como se fosse minha visão que o deformasse. Parecia a representação, num papel, do modo como eu poderia ver um quadrilátero: já deformado nas suas linhas de perspectivas. A solidificação de um erro de visão, a concretização de uma ilusão de ótica. Não ser inteiramente regular nos seus ângulos dava-lhe uma impressão de fragilidade de base como se o quarto-minarete não estivesse incrustado no apartamento nem no edifício (LISPECTOR, 2014, p. 36).

As expressões "erro de visão" e "ilusão de ótica" asseveram a percepção da deformação que G.H. tem do quarto. E a desproporção do ambiente, gerando uma "fragilidade de base", revela sua insegurança ao permear por um espaço, de certa forma desconhecido, pois um novo caminho começará a ser traçado naquele lugar.

Para uma mulher acostumada com o conforto, com a ordem, com os privilégios destinados à sua classe, é comum que o acesso ao território não domesticado pelo paradigma civilizatório da classe dominante, cause desordem na sua superficial estabilidade.

“O desenho era um ornamento: era uma escrita." (LISPECTOR, 2014, p. 37). G.H. faz essa afirmação quando se depara com três desenhos (um homem, uma mulher e um cachorro), feitos por Janair, na parede branca que sucede a porta.

As ilustrações foram feitas com ponta quebrada de carvão: rocha sedimentar formada em sua grande parte pelo carbono. Que por sua vez, é o elemento químico essencial aos processos vitais. Esse ingrediente básico da vida, também foi responsável pela origem da civilização através da escrita. Logo, a

funciona assim. Dá-se, recebe-se muitas vezes mais, mas a relação entre os dois é muito mais complexa e desmonta o modelo linear da racionalidade instrumental."

7 O conceito de espaço geométrico, neste caso, está fundamentado na abordagem fenomenológica-existencial desenvolvida por Maurice Merleau-Ponty (1999, p. 394 - 395), em que valoriza a relatividade simbólica e subjetiva no ato de percepção do próprio espaço geográfico, natural e geométrico. "A novidade da fenomenologia não é negar a unidade da experiência mas fundá-la de outra maneira que o racionalismo clássico. Pois os atos objetivantes não são representações. 0 espaço natural e primordial não é o espaço geométrico e, correlativamente, a unidade da experiência não é garantida por um pensador universal que exporia diante de mim os conteúdos da experiência e me asseguraria, em relação a eles, toda a ciência e toda a potência. Ela é apenas indicada pelos horizontes de objetivação possível, ela só me libera de cada ambiente particular porque me liga ao mundo da natureza ou do em si que os envolve a todos. Será preciso compreender como, com um único movimento, a existência projeta em torno de si mundos que me mascaram a objetividade e determina esta objetividade como meta para a teleologia da consciência, destacando estes 'mundos' sobre o fundo de um único mundo natural." Sobre a densidade da percepção subjetiva do espaço geométrico, Merleau-Ponty (1999, p. 387 - 388) reforça: "Da mesma forma, enfim, quando procuramos fundar o espaço geométrico, com suas relações intramundanas, na espacialidade originária da existência, nos responderão que o pensamento só conhece a si mesmo ou às coisas, que não é pensável uma espacialidade do sujeito, e que por conseguinte nossa proposição é rigorosamente desprovida de sentido. Ela não tem, responderemos, sentido temático ou explícito, ela se esvanece diante do pensamento objetivo. Mas ela tem um sentido não temático ou implícito, e este não é um sentido menor, pois o próprio pensamento objetivo se alimenta do irrefletido e se oferece como uma explicitação da vida de consciência irrefletida, de forma que a reflexão radical não pode consistir em tematizar paralelamente o mundo ou o espaço e o sujeito intemporal que os pensa, mas deve retomar essa própria tematização com os horizontes de implicações que lhe dão seu sentido." 
origem da vida é o carvão, sustantada na definição trazida por Capra (1996); a origem da escrita é o carvão. A protagonista está, portanto, diante de imagens que se assemelham a pictogramas, é a escrita da subalterna. Se a subalterna não pode falar, ela também, não deve escrever, aos moldes formais estabelecidos pelos padrões ocidentais normativos.

É estabelecida uma relação entre o princípio de tudo, através do carbono (elemento presente na origem do universo), o surgimento da sociedade (por meio da escrita), e o momento que antecede a tomada de consciência, como uma espécie de preparação, um mergulho da personagem para dentro de si que dará origem a uma nova mulher. Sendo assim, o desenho não é um ornamento, e sim, uma escrita, porque comunica algo, porque gera reflexão em G.H.

Ela pensa em si, pensa na figura masculina da ordem, do poder e do domínio que ela representa para Janair:

Meu mal-estar era de algum modo divertido: é que nunca antes me ocorrera que, na mudez de Janair, pudesse ter havido uma censura à minha vida, que devia ter sido chamada pelo seu silêncio de "uma vida de homens"? Como me julgara ela?

Olhei o mural onde eu devia estar sendo retratada... Eu, o Homem [...] (LISPECTOR, 2014, p. 38).

Na relação entre patroa-empregada existem sentimentos de solidariedade e de rivalidade, de compaixão e de indiferença. Na obra em questão, os atos de indiferença são latentes, pois que G.H. demora um tempo para se lembrar da fisionomia e do nome da empregada, que saíra apenas havia um dia. Trata-se de um grave problema que afeta o cenário social brasileiro: a invisibilidade social ${ }^{8}$.

Seja pela indiferença ou pelo preconceito, Janair é tratada como um ser humano invisível.

[...] Quis lembrar-me de seu rosto, e admirada não consegui [...]. A lembrança de sua cara fugia-me, devia ser um lapso temporário.

[...] E sua roupa? Não era de surpreender que eu a tivesse usado como se ela não tivesse presença: sob o pequeno avental, vestia-se sempre de marrom escuro ou de preto, o que a tornava toda escura e invisível. Janair tinha quase que apenas a forma exterior, os traços que ficavam dentro de sua forma eram tão apurados que mal existiam: ela era achatada como um baixo-relevo preso a uma tábua (LISPECTOR, 2014, p. 39).

Além de refletir sobre a invisibilidade de Janair na casa, a patroa também se atenta à possibilidade da empregada odiá-la: "[...] E, olhando o desenho hierático, de repente me ocorria que Janair me odiara [...]" (LISPECTOR, 2014, p. 38). E supõe que o cachorro desenhado na parede é uma transposição do sentimento adverso que ela tinha por G.H. "[...] E quanto ao cachorro - seria este o epíteto que ele me dava? [...]" (p. 38).

8 Júlia Tomás (2012, p. 2) discute a invisibilidade social da seguinte forma: "Propomos assim, seguindo esta teoria [hermenêutica e fenomenológica], que a invisibilidade social nasce da consciência constituinte do ato de 'não ver outrem'. Por conseguinte, este fenômeno é puramente subjetivo. Ao reduzir eideticamente o conceito da invisibilidade social surge a sua essência: a intersubjetividade. Ao considerar a intersubjetividade como a estrutura essencial da invisibilidade social observamos uma correlação entre o 'não visto' e os outros indivíduos, o 'não visto' sendo compreendido como aquele que é invisível aos olhos dos que o rodeiam e os indivíduos sendo entendidos como consciência constituinte. É evidente que uma filosofia do elo social não deve simplesmente reduzir os fenômenos ao Eu. A intersubjetividade, ao abrir um espaço para o discurso filosófico na análise social, implica uma dialética sobre o conhecimento dos feitos sociais. Sendo esta investigação um estudo sociológico, o que nos interessa aqui é o facto de a alteridade invisível não o ser somente para Mim, mas também o ser para Nós. A intersubjetividade é constituinte e operante a diversos níveis. Existe, por um lado, intersubjetividade entre mim e aquele que eu não vejo: o outro partilha mutualmente o sentido do mundo comigo e sabe que eu não o vejo. Por outro, existe uma intersubjetividade coletiva: nós não vemos o outro." (p. 2).

"A invisibilidade social vai depender (entre outras coisas) da percepção que os outros têm de mim. Se o outro não me vê é certamente porque eu não existo para o outro, no entanto existo fisicamente, logo sou visível. A não-percepção do outro é o resultado da sua vida da qual eu não faço parte. Para compreender o significado do comportamento social do 'não ver outrem' é necessário perceber a compreensão do ator, ou seja é fundamental conhecer as sedimentações da história individual e da história comum." (p. 3)

"A invisibilidade como experiência moral é sofrida porque está relacionada ao sentimento de inexistência social. [...] Para Honneth, este tipo de invisibilidade é uma situação social particular na qual 'os dominantes exprimem a sua superioridade ao não verem aqueles que eles dominam."' (p. 6 - 7). 
Verifica-se, então, que não há harmonia e solidariedade no período de convivência entre as duas mulheres, posto que para G.H., Janair é invisível, e esta demonstra ódio pela outra.

Nas relações de trabalho, é comum verificar esse desequilíbrio, caracterizado pelo controle, pela exigência de disciplina e organização, pela imposição de regras por parte das empregadoras, e, de outra parte, pela autodefesa, submissão, e mecanismos de resistência por parte das empregadas.

Pode-se dizer que a expressão de escritura da funcionária através dos desenhos na parede, a faxina no quarto, a reorganização e remoção dos objetos velhos sem utilidade são atitudes de insubordinação. Comportamento responsável por desestabilizar G.H., um momento epifânico, a inserção na tomada de consciência dessa outra, do seu papel no mundo, da sua presença que desafia e incomoda, é invisível ou oculta, mas que estremece as paisagens superficiais.

Alguns aspectos relevantes precisam ser destacados mediante a análise da obra em questão. Para tanto, é necessário ressaltar três conceitos para que se possa compreender a importância destes no processo de tomada de consciência da personagem protagonista. 0 primeiro deles é a pre-sença (dasein) ${ }^{9}$ elaborados por Martin Heidegger (2000), em Ser o tempo; os demais, exotopia e alteridade, tecidos por Mikhail Bakhtin (2010), em Estética da criação verbal.

No romance, a presença de Janair no quarto ocasiona o processo de entendimento próprio de G.H., que inicia. "[...] Coagida com a presença que Janair deixara de si mesma num quarto de minha casa, eu percebia que as três figuras angulares de zumbis haviam de fato retardado minha entrada como se o quarto ainda estivesse ocupado." (LISPECTOR, 2014, p. 39).

Pode-se dizer que há a presença de Janair no quarto, uma vez que ela deixou suas impressões através de já referida reorganização do cômodo e, principalmente, pelos desenhos. Dessa forma, Janair existe no quarto. A funcionária, sempre tida como ausente e invisível, passa a existir para G.H. Uma presença que faz pensar. Uma presença que leva à pre-sença.

Conforme Heidegger (2000, p. 78), “as características constitutivas da pre-sença são sempre modos possíveis de ser e somente isso."

[...] Ela [pre-sença] não "tem" a possibilidade apenas como uma propriedade simplesmente dada. E é porque a pre-sença é sempre essencialmente sua possibilidade que ela pode, em seu ser, isto é, sendo, "escolher-se", ganhar ou perder-se ou ainda nunca ganhar-se ou só ganhar-se "aparentemente" (HEIDEGGER, 2000, p. 78).

Posto isto, no cerne das discussões fenomenológicas, avançando nas questões ontológicas do ser, Heidegger preconiza que a condição de ser cabe a cada um; é uma possibilidade própria de cada ser ganhar-se; optar por ganhar ou não, perder ou não sua pre-sença, é uma determinação de cada indivíduo.

Em se tratando da protagonista G.H., interpretando sua própria existência, ela irá perceber que cabe somente a ela a ruptura com os elementos supérfluos que compõem a sua cotidianidade mediada10. " $O$ quarto era o retrato de um estômago vazio." (LISPECTOR, 2014, p. 40). O quarto representa quem tem

${ }^{9}$ No esforço de interpretação do pensamento heideggeriano, trazido pela tradutora Márcia de Sá Cavalcanti, "Présença não é sinônimo de existência e nem de homem. A palavra Dasein é comumente traduzida por existência. Em Ser e Tempo, traduz-se, em geral, para as línguas neolatinas pela expressão 'ser-aí', être-là, esser-ci etc. Optamos pela tradução de pre-sença pelos seguinte motivos: 1) para que não se fique aprisionado às implicações do binômio metafísico essência-existência; 2) para superar o imobilismo de uma localização estática que o 'ser aí' poderia sugerir. 0 'pre' remete ao movimento de aproximação, constitutivo da dinâmica do ser, através das localizações; 3) para evitar um desvio de interpretação que o 'ex' de 'existência' suscitaria caso permaneça no sentido metafísico de exteriorização, atualização, realização, objetivação e operacionalização de uma essência. 0 'ex' firma uma exterioridade, mas interior e exterior fundam-se na estruturação da pre-sença e não o contrário; 4) pre-sença não é sinônimo nem de homem, nem de ser humano, nem de humanidade, embora conserve uma relação estrutural. Evoca o processo de constituição ontológica de homem, ser humano e humanidade. É na pre-sença que o homem constrói o seu modo de ser, a sua existência, sua história etc. (cf. entrevista de Heidegger ao Der Spiegel, Ver. Tempo Brasileiro, n. 50, julho/set. 1977)." (HEIDEGGER, 2000, p. 309).

10 "Porque a cotidianidade mediana perfaz o que, em primeiro lugar, constitui o ôntico deste ente, sempre se passou por cima dela e sempre se passará, nas explicações da pre-sença. 0 que, onticamente, é conhecido e distante, o desconhecido, e o que constantemente se desconsidera em seu significado ontológico. [...] Não se deve, porém, tomar a cotidianidade mediana da pre-sença como uma simples 'aspecto'. Pois a estrutura da existencialidade está incluída a priori na cotidianidade e até mesmo em seu modo impróprio. De certa forma, nele está igualmente em jogo o ser da pre-sença, com o qual ela se comporta e relaciona no modo da cotidianidade mediana mesmo que seja apenas fugindo e se esquecendo dele." (HEIDEGGER, 2000, p. 79 - 80). 
fome, no sentido dado por Josué de Castro (1984), aquela produzida pelas profundas desigualdades sociais, pela exploração das trabalhadoras e pela segregação social, alimentando os privilégios e o controle dos meios de produção da classe dominante ${ }^{11}$. Nele (no quarto) delineiam-se elementos que permeiam a realidade socioeconômica de Janair e das demais empregadas brasileiras, que em sua maioria, são negras, reforçando a dominação de gênero, de classe e de raça ${ }^{12}$ no ambiente de trabalho. Seguindo a perspectiva do feminismo radical levantada por Ângela Davis (2016, p. 225):

As enervantes obrigações domésticas das mulheres em geral oferecem uma flagrante evidência do poder do sexismo. Devido à intrusão adicional do racismo, um vasto número de mulheres negras teve de cumprir as tarefas de sua própria casa e também os afazeres domésticos de outras mulheres. E com frequência as exigências do emprego na casa de uma mulher branca forçavam a trabalhadora doméstica a negligenciar sua própria casa e até mesmo suas próprias crianças. Enquanto empregadas remuneradas, elas eram convocadas a ser mães e esposas substitutas em milhões de casas de famílias brancas.

Retomando a descrição do quarto, sua mobília limita-se a uma cama, três maletas velhas, e um guardaroupa estreito. As descrições do colchão salientam particularidades de um ambiente inóspito, desagradável, seco, rude e áspero, destacando o estado de precariedade e segregação imposto a Janair pela patroa:

A cama, de onde fora tirado o lençol, expunha o colchão de pano empoeirado, com suas largas manchas desbotadas como de suor ou sangue, manchas antigas e pálidas. Uma outra crina fibrosa furava o pano que estava podre de tão seco e espetava-se erecta no ar. [...]

Sobre elas [maletas], e sobre a marca quase morta de um "G.H.", o acúmulo já sedimentado e tranquilo de poeira. E havia também o guardaroupa estreito: era de uma porta só, e da altura de uma pessoa, de minha altura. A madeira continuamente ressecada pelo sol abria-se em gretas e farpas." (LISPECTOR, 2014, p. 40).

O segundo e terceiro conceitos relevantes para a compreensão da composição da personagem no que diz respeito à tomada de consciência foram elaborados por Bakhtin. São eles: exotopia ${ }^{13}$ (ex - fora; topos lugar) e alteridade ${ }^{14}$ (do latim alteritas - outro).

11 "Impõe-se uma política que, acelerando o processo de desenvolvimento, quebrando as mais reacionárias forças de contenção que impedem o acesso à economia do país a grupos e setores enormes da nacionalidade, venham a criar os meios indispensáveis à elevação dos nossos padrões de alimentação. Porque a verdade é que nada existe de especifico contra a fome, nenhuma panacéia que possa curar este mal como se fosse uma doença de causa definida. A fome não é mais do que uma expressão - a mais negra e a mais trágica expressão do subdesenvolvimento econômico. Expressão que só desaparecerá quando for varrido do país o subdesenvolvimento econômico, com o pauperismo generalizado que este condiciona. 0 que é necessário por parte dos poderes públicos é condicionar o desenvolvimento e orientá-lo para fins bem definidos, dos quais nenhum se sobrepõe ao da emancipação alimentar do povo. É dirigir a nossa economia tendo como meta o bem-estar social da coletividade. Só assim teremos um verdadeiro desenvolvimento econômico que nos emancipe de todas as formas de servidão. Da servidão às forças econômicas externas que durante anos procuraram entorpecer o nosso progresso social e da servidão interna à fome e à miséria que entravaram sempre o crescimento de nossa riqueza." (CASTRO, 1984, p. 305).

12 Sobre essa temática, Ângela Davis (2011, p. 6) combate a ortodoxia no interior do marxismo por este não considerar as questões de gênero, classe e raça pelo viés da interseccionalidade e por dar primazia somente às questões de classe frente aos mecanismos de dominação: "As organizações de esquerda têm argumentado dentro de uma visão marxista e ortodoxa que a classe é a coisa mais importante. Claro que classe é importante. É preciso compreender que classe informa a raça. Mas raça, também, informa a classe. E gênero informa a classe. Raça é a maneira como a classe é vivida. Da mesma forma que gênero é a maneira como a raça é vivida. A gente precisa refletir bastante para perceber as intersecções entre raça, classe e gênero, de forma a perceber que entre essas categorias existem relações que são mútuas e outras que são cruzadas. Ninguém pode assumir a primazia de uma categoria sobre as outras."

13 Na ocasião em que busca definir o sentido de exotopia, Bakhtin (1997, p. 21 - 22), argumenta também sobre a difícil tarefa de conceber a relação harmônica entre o eu e o outro, elementos de compreensão da alteridade. "Esse excedente constante de minha visão e de meu conhecimento a respeito do outro, é condicionado pelo lugar que sou o único a ocupar no mundo: neste lugar, neste instante preciso, num conjunto de dadas circunstâncias - todos os outros se situam fora de mim. A exotopia concreta que beneficia só a mim, e a de todos os outros a meu respeito, sem exceção, assim como o excedente de minha visão que ela condiciona, em comparação a cada um dos outros (e, 
O termo exotopia, escolhido por Tzvetan Todorov para traduzir do russo vnenajodimost (substantivo de "encontrar-se fora"), conforme demonstra Irene Machado (2010, p. 16), "[...] tornou-se a matriz terminológica e conceitual das formulações da arquitetônica que procura abarcar a importância do olhar contido num campo de visão e também daquele que se revela excedente [...]".

No capítulo sobre A forma espacial da personagem, Bakhtin (2010) aprofunda o debate acerca do excedente de visão, base para o entendimento do conceito de exotopia. Segundo as palavras do autor,

Quando contemplo no todo um homem situado fora e diante de mim, nossos horizontes concretos efetivamente vivenciáveis não coincidem. Porque em qualquer situação ou proximidade que esse outro que contemplo possa estar em relação a mim, sempre verei e saberei algo que ele, da sua posição fora e diante de mim, não pode ver: as partes de seu corpo inacessíveis ao seu próprio olhar - a cabeça, o rosto, e sua expressão -, o modo atrás dele, toda uma série de objetos e relações que, em função dessa ou daquela relação de reciprocidade entre nós, são acessíveis a mim e inacessíveis a ele. Quando olhamos, dois diferentes mundos se refletem na pupila dos nossos olhos (BAKHTIN, 2010, p. 21).

Para dar contornos à abordagem da exotopia e da alteridade em Bakhtin (2010), partindo do olhar do eu para o outro, no romance em destaque, é interessante notar como a patroa descreve e constrói sua visão da subalterna. Na ocasião, G.H. revela sua visão de Janair:

[...] o rosto preto e quieto, [...] a pele inteiramente opaca que mais parecia um de seus modos de se calar, as sobrancelhas extremamente bem desenhadas, [...] os traços finos e delicados que mal eram divisados no negror apagado da pele. Os traços - descobri sem prazer - eram traços de rainha. E também a postura: o corpo erecto, delgado, duro, liso, quase sem carne, ausência de seios e de ancas (LISPECTOR, 2014, p. 39).

E, partindo da noção da invisibilidade que G.H. tinha de Janair, que possuía "quase que apenas a forma exterior", ela começa a se questionar a partir desse olhar sobre a empregada.

É de suma importância fazer breve consideração quanto a essa situação que gera o despertar da tomada de consciência na protagonista. Uma mulher branca, de classe abastada, com todos seus privilégios, se incomoda, reflete e mergulha em um caminho tortuoso de desconstrução de todas essas estruturas de dominação e privilégios social e racial que ela detinha vaidosamente. A mulher negra e subalterna a faz refletir sobre si:

E fatalmente, assim, como ela era, assim deveria ter me visto? Abstraindo daquele meu corpo desenhado na parede tudo o que não era essencial, e

correlativamente, uma certa carência - o que vejo do outro é precisamente o que só o outro vê quando se trata de mim, mas isso não é essencial para nosso propósito pois, em minha vida, a inter-relação 'eu o outro' é concretamente irreversível); tudo isso é compensado pelo conhecimento que constrói um mundo de significados comuns, independente dessa posição concreta que um indivíduo é o único a ocupar, e onde a relação 'eu e todos os Outros' não é absolutamente não-invertível, pois a relação 'eu e o outro' é, no abstrato, relativa e invertível, porque o sujeito cognoscente como tal não ocupa um lugar concreto na existência. Porém esse mundo unificado do conhecimento não poderia ser percebido como o único todo concreto que abarcasse toda a diversidade das propriedades existenciais, do mesmo modo que percebemos o que temos diante dos olhos, pois a percepção efetiva de um todo concreto pressupõe um contemplador único e encarnado, situado num dado lugar; o mundo do conhecimento e cada um de seus elementos só podem ser pensados. Da mesma forma, uma emoção interior e o todo da vida interior podem ser vivenciados concretamente - percebidos internamente - seja na categoria do eupara-mim, seja na categoria do outro-para-mim; em outras palavras, seja como vivência própria, seja como vivência desse outro único e determinado."

14 "Alteridade (lat. Alteritas, Alietas [...]) Ser outro, colocar-se ou constituir-se como outro. A alteridade é um conhecimento mais restrito do que diversidade e mais extenso do que diferença." (ABBAGNANO, 2000, p. 34). Para Bakhtin (2010, p. 109 - 110), o vínculo entre o eu e o outro é definido pelo ritmo, que fortalece a alteridade: "Na existência interior do outro vivenciada por mim (vivenciada ativamente na categoria de alteridade), a existência e o imperativo não estão rompidos nem são hostis mas estão organicamente vinculados, situados no mesmo plano axiológico; o outro cresce organicamente no sentido. [...] 0 ritmo é um beijo e um abraço no tempo axiologicamente adensado da vida mortal do outro. Onde há ritmo, há duas almas (mais exatamente, alma e espírito), há dois ativismos; a vida que vivencia e a que se tornou passiva para a outra, que a enforma e celebra ativamente." 
também de mim só vendo o contorno. No entanto, curiosamente, a figura na parede lembrava-me alguém, que era eu mesma (LISPECTOR, 2014, p. 39).

Olga de Sá (1993, p. 146) salienta a forma como G.H. interpretou as figuras: "O que quisera dizer Janair, desenhando as 'três múmias'? G.H. compreendeu-as, como índices irônicos de sua caricatura de vida, orientada para o vazio."

Como foi dito anteriormente, G.H. retrata diferentes processos de alteridade. 0 primeiro se dá nas interações entre ela e os seus iguais, ou seja, pessoas que, como ela, pertencem à classe abastada (indivíduos do mesmo grupo social), e se escondem por trás das máscaras de caráter ${ }^{15}$, envolvidas num processo de atuação como os demais, denominado de conformismo social.

O outro processo ocorre a partir do conflito ${ }^{16}$ que se estabelece entre G.H. e Janair, que será discutido ao longo do texto.

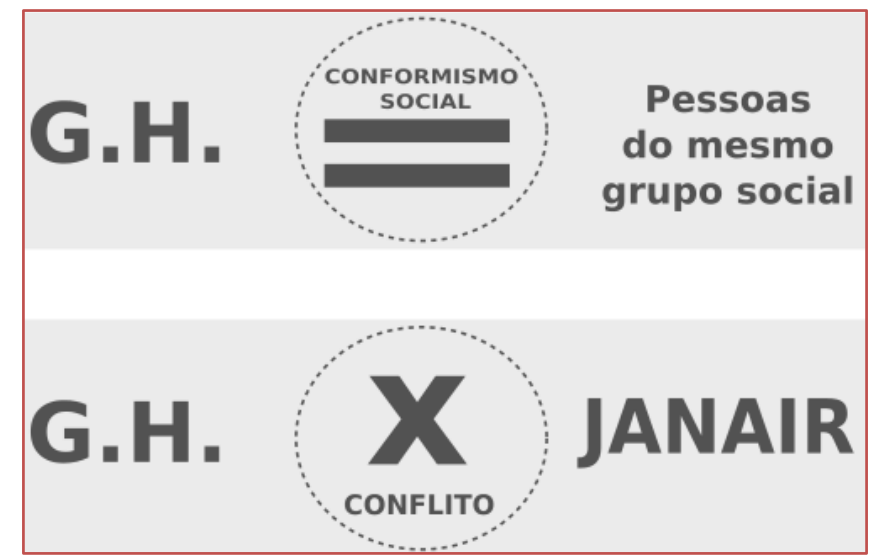

É nesse contexto dialógico que irá brotar a necessidade de fazer-se, de reconhecer sua existência ${ }^{17}$, no sentido dado pela fenomenologia. A protagonista mostra a necessidade de se deixar ser, de deixar "derramar" pre-sença. A seu respeito Heidegger (2000, p. 256) diz: "A pre-sença é um ente que, sendo, está

15 Tomando como base a discussão trazida por John Holloway (2013, p. 204), “A máscara de caráter é uma imagem teórica: a sujeição de nosso fazer ao trabalho abstrato cria um teatro, um palco sobre o qual os personagens se movem em intensa atividade. [...] a luta para não ir ao palco, para não submeter o nosso fazer ao trabalho abstrato, o desejo dos atores, mesmo no palco, de jogar fora as suas máscaras: a luta não de uma identidade, mas contra a identificação." Mais à frente Holloway (2013, p. 208) complementa: "Não existe sujeito puro, não há bela alma, por detrás da máscara. 0 ator se deteriora com o papel que ele representa. 0 rosto que foi forçado a se conformar numa máscara se esconde também porque foi desfigurado pela máscara: retira-a e verá um rosto que foi distorcido pela máscara e pelo seu ressentimento para com a máscara. Não há um nobre selvagem sob os quinhentos anos de discriminação e opressão; não há uma mulher perfeita esperando para ser reconhecida uma vez que a dominação masculina tiver sido removida; não há fazer puro oculto sob o trabalho abstrato."

16 "Essa luta contra a eventual posição axiológica do outro coloca de modo original o problema da forma externa autoinforme-confissão; aqui é inevitável o conflito com a forma e a própria linguagem da expressão, que, por um lado, são indispensáveis e, por outro, essencialmente inadequadas por conterem elemento estéticos fundados na consciência valorativa do outro [...]. Nenhum reflexo sobre mim mesmo pode me concluir integralmente, pois, sendo imanente a mim mesmo pode me concluir integralmente, pois, sendo imanente à minha consciência responsável e única, torna-se fator de sentido e valor do desenvolvimento ulterior dessa consciência; minha própria palavra sobre mim mesmo não pode ser essencialmente a última palavra, que me conclui; para mim, minha palavra é um ato, e este só vive no acontecimento singular e único da existência; é por isso que nenhum ato pode dar acabamento à própria vida, pois ele a vincula à infinitude aberta do acontecimento da existência." (BAKHTIN, 2010, p. 131 -132).

17 "A palavra existência resulta da aglutinação da preposição ek e do verbo sistere. No plano meramente vocabular, existência diz: 1) um movimento de dentro para fora, expresso na preposição; 2) a instalação que circunscreve e delimita um estado e um lugar; 3) uma dinâmica de contínua estruturação em que se trocam os estados, as passagens e os lugares. Devido à pregnância desse conjunto semântico é que Ser e Tempo reservou 'existência' para designar toda a riqueza das relações recíprocas entre pre-sença e ser, entificação privilegiada, o homem. Nessa acepção, só o homem existe. 'A pedra é' mas não existe." (HEIDEGGER, 2000, p. 310). 
em jogo seu próprio ser. Na constituição ontológica da compreensão, o "estar em jogo" evidenciou-se como o ser que se projeta para o poder-ser mais próprio."

Só que a água nunca fervera. Eu não precisava de violência, eu fervilhava o suficiente para a água nunca ferver nem derramar. Não, eu não conhecia a violência. Eu nascera sem missão, minha natureza não me impunha nenhuma; e sempre tive a mão bastante delicada para não me impor um papel. Eu não me impunha um papel, mas me organizara para ser compreendida por mim, não suportaria não me encontrar no catálogo. [...] Eu vivia mais dentro de um espelho. Dois minutos depois de nascer eu já havia perdido as minhas origens (LISPECTOR, 2014, p. 26).

Ao elaborar seu pensamento sobre o Nada, Platão o define como alteridade:

Resulta que há um ser do não-ser, tanto para o movimento quanto para todos os gêneros, já que em todos os gêneros a alteridade, que torna cada um deles outro, transforma o ser de cada um em não-ser, de modo que diremos corretamente que todas as coisas não são e ao mesmo tempo são e participam do ser. [...] Para Platão o Nada é a alteridade do ser, ou seja, a negação de um ser determinado (p. ex., do movimento) e a referência indefinida ao outro gênero do ser (ao que não é movimento). (ABBAGNANO, 2000, p. 695).

Diante dessa discussão, vale destacar uma passagem do texto em que G.H. declara: "Eu me preparava para limpar coisas sujas mas lidar com aquela ausência me desnorteava." (LISPECTOR, 2014, p. 41). Ela experimenta uma ausência (Nada) motivada pela negação do outro (Janair), e pela negação de si, e se deparando com o não-ser que ela, progressivamente, estará diante de seu ser.

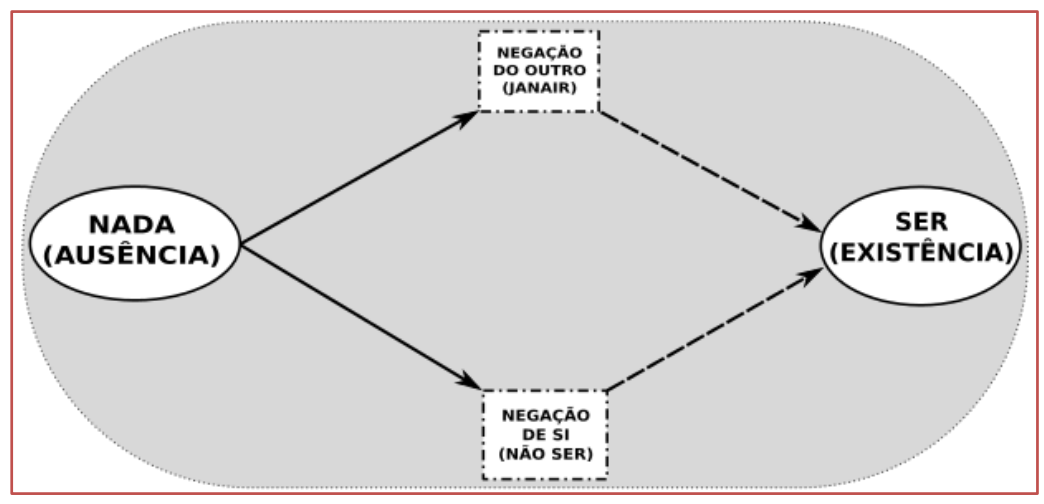

Para Heidegger, citado por Abbagnano (2000, p. 697), o Nada "é a própria anulação [...], ele é 'a condição que possibilita, em nosso ser-aí (Dasein), a revelação do existente como tal'. 0 problema e a procura do ser nascem de fato de o homem não ser todo o ser, de que seu ser é o Nada da totalidade do ser."

A dona do apartamento [G.H.] se refere à funcionária [Janair] utilizando as seguintes expressões: "representante de um silêncio", "estrangeira", "inimiga indiferente", e confessa sua indiferença combinada com aversão quando declara "[...] que sem sequer a ter olhado, a odiava." (LISPECTOR, 2014, p. 41).

Janair representa o perfil da mulher negra trabalhadora doméstica, inserida no processo de marginalização social, no qual a sociedade de classe naturaliza a desigualdade e a negação da subjetividade dos indivíduos explorados pelo trabalho precarizado e pela sujeição às lógicas de subalternidade.

A personagem se insere numa conjuntura social brasileira fruto de um passado escravista, denominado por Sueli Carneiro (apud Ratts, 2003, p. 4) de subalternização do gênero segundo a raça. Para a autora:

As imagens de gênero que se estabelecem a partir do trabalho enrudecedor, da degradação da sexualidade e da marginalização social, irão reproduzir até os dias de hoje a desvalorização social, estética e cultural das mulheres negras e a supervalorização no imaginário social das mulheres brancas, bem como a desvalorização dos homens negros em relação aos homens brancos. Isso resulta na concepção de mulheres e 
homens negros enquanto gêneros subalternizados, onde nem a marca biológica feminina é capaz de promover a mulher negra à condição pela de mulher e tampouco a condição biológica masculina se mostra suficiente para alçar os homens negros à plena condição masculina, tal como instituída pela cultura hegemônica.

Condizente com as ideias de Carneiro, Ratts (2003, p. 4 - 5) entende que "[...] no Brasil, essa subalternização do gênero implica na seguinte hierarquia: Em primeiro lugar situa-se o homem branco; em segundo, a mulher branca; em terceiro, o homem negro; e, por último, a mulher negra."

Apoiando-se nas discussões desses autores sobre a subalternização da mulher negra, é possível compreender com mais nitidez que o processo de formação sociocultural e socioespacial brasileiro foram constituídos por valores patrimonialistas, classistas e racistas.

Diante do exposto, a referência de Janair à rainha africana designa resistência em virtude da história de luta do povo negro; pelo fardo do trabalho árduo e degradante, que muitas vezes a ele foi e é delegado; pela criatividade de talento artístico-cultural que assegurou a defesa e o enfrentamento diante de tantas atrocidades.

Janair é uma rainha africana que dela fora destituída sua nobreza ao retirarem sua subjetividade, ao considerá-la (assim como acontece com a grande parte da população negra brasileira) incapaz de exercer funções que não a de sub-trabalhdora do precariado. ${ }^{18}$

Ela é uma soberana insubmissa quando pratica suas pequenas resistências cotidianas contra a patroa que exige uma postura subserviente. Seja como rainha do seu lar, como rainha do terreiro (mãe-de-santo), ou rainha do samba, as mulheres negras brasileiras carregam consigo a força das grandes guerreiras que a historiografia oculta, como: Dandara dos Palmares, Anastácia, Tereza de Benguela, Zeferina, Maria Felipa de Oliveira, Rainha Tereza do Quariterê, Na Agontimé, Zacimba Gaba e Aqualtune19, e várias outras combatentes da escravidão, do racismo e do machismo.

G.H. queria eliminar a presença de Janair e a aridez do quarto, posto que ambas a irritavam:

A primeira coisa que eu faria seria arrastar para o corredor as poucas coisas de dentro. E então jogaria no quarto vazio baldes e baldes de água que o ar duro sorveria, e finalmente enlamearia a poeira até que nascesse umidade daquele deserto, destruindo o minarete que sobranceava altaneiro um horizonte de telhados. Depois jogaria água no guarda-roupa para engorgitá-lo num afogamento até a boca - e enfim, enfim veria a madeira começar a apodrecer (LISPECTOR, 2014, p. 41).

18 Segundo Ruy Braga (2014, p. 36), "vivemos sob a sombra do "precariado", isto é, um grupo de pessoas despojadas de garantias trabalhistas, submetidas a rendimentos incertos e carentes de uma identidade coletiva enraizada no mundo do trabalho. [...] Decorrente da descentralização da produção, da financeirização das empresas, da precarização das formas de contratação e da generalização da terceirização da força de trabalho, as formas tradicionais de auto-organização política dos trabalhadores, em especial os sindicatos, têm enfrentado enormes desafios na contemporaneidade. 0 resultado da confluência de todas essas tendências tem sido o incremento em escala global do peso relativo do proletariado precarizado no interior das classes trabalhadoras de diferentes países, tanto no Norte quanto no Sul globais."

19 Essas guerreiras (Na Agontimé, Zacimba Gaba e Aqualtune) eram integrantes da monarquias nos seus territórios de origem. Aqualtune era princesa, filha do rei Mani-Kongo. Seu pai e seu reino foram derrotados na Batalha de Ambrúla por forças angolanas e portuguesas, pelo controle do território de Dembos, que separava Angola do Congo. No fim da guerra, seu pai foi decapitado e ela foi capturada por forças portuguesas. Foi vendida a senhores de escravos brasileiros junto de seus compatriotas. (disponível em: https://www.almapreta.com/editorias/realidade/aqualtune-a-luz-palmares - acesso em: 16/02/2019). Na Aontimé foi uma das esposas do rei Agonglo. Após o assassinato de seu esposo, ela teria sido vendida como escrava e enviada às terras brasileiras pelo rei Adandozan. Foi ela quem introduziu o vodun de Abomé no Brasil, praticado na Casa das Minas, no Maranhão (ARAUJO, Ana Lucia. Aquela que "salva" a mãe e o filho. Tempo, dez, vol. 15, n. 29, 2010, p. 43 - 66). Zacimba Gaba, princesa guerreira, "foi sequestrada em Cabinda, na África e colocada numa fazenda em São Matheus - ES. Ela lutou bravamente e conseguiu fugir, durante vários anos lutava em alto-mar para libertar negros e negras que chegavam sequestrados" (ARAUJO, Noélia da Silva Miranda de. Escrevivências de uma professora afroindígena. Odeere: Revista do Programa de Pós-Graduação em Relações Étnicas e Contemporaneidade - UESB, vol. 3, n. 5, janeiro-junho de 2018, p. 186 - 197). 
Uma outra questão motivada pela figura de Janair e pelo quarto seco - a perturba: Ela quer se indagar, quer lançar-se dentro de si. Para ela, é novidade julgar-se, porque amedronta perder suas "aspas", deixar de ser uma "réplica bonita", destruir o tédio que a alimenta e delicadamente a come. 0 tédio ${ }^{20}$ frequentemente manifesto no cotidiano do burguês.

Surge também uma espécie de "violência", sentimento nunca antes experimentado por ela: "Uma cólera inexplicável, mas que vinha toda natural, me tomara: eu queria matar alguma coisa ali." (LISPECTOR, 2014, p. 41). Quer matar a mulher estereotipada que admitira ser, e reconhecer-se a si mesma, em lugar de reconhecer-se no outro: "Enquanto eu mesma era, mais do que limpa e correta, era uma réplica bonita." (LISPECTOR, 2014, p. 29).

Mas é dificultoso renunciar às acomodações que sua condição socioeconômica lhe assegura, e consequentemente, é árduo deixar de ser uma repetição automática de um padrão de mulher. ${ }^{21}$ Planejando eliminar o que a incomoda no quarto, ocorre uma ideia que lhe causa conforto:

[...] eu cobriria aquele colchão de palha seca com um lençol mole, lado, frio, com um de meus próprios lençóis que tinham minhas iniciais bordadas, substituindo o que Janair deveria ter jogado no tanque. Mas antes rasparia da parede a granulada secura do carvão, desincrustando à faca o cachorro, apagando a palma exposta das mãos do homem, destruindo a cabeça pequena demais para o corpo daquela mulherona nua. E jogaria água e água que escorreria em rios pelo raspado da parede. Como se já estivesse vendo a fotografia do quarto depois que fosse transformado em meu e em mim, suspirei de alívio (LISPECTOR, 2014, p. 42).

Aliciadas à vontade de arrancar as impressões de Janair (objetivo que não se cumpre), questões que não fazem parte de suas reflexões cotidiana surgem. Indagações que não se agregam às concepções ideológicas do indivíduo que opta estar em conformidade com os valores de classe dominante, de forma que seu eu seja consumido, com a garantia de que ele seja membro de um grupo que produz sujeitos automatizados.

G.H. inaugura os questionamentos existenciais sobre seu passado, carente de auto-reflexão:

0 que queria essa mulher que sou? o que acontecia a um G.H. no couro da valise? Nada, nada, só que meus nervos estavam agora acordados - meus nervos que haviam sido tranquilos ou apenas arrumados? meu silêncio fora silêncio ou uma voz alta que é muda? (LISPECTOR, 2014, p. 42).

20 Sobre esse tema, Adorno (1995, p. 75) diz: "Tédio é o reflexo do cinza objetivo. Ocorre com ele algo semelhante ao que se dá com a apatia política. A razão mais importante para esta última é o sentimento, de nenhum modo injustificado das massas, de que, com a margem de participação na política que lhes é reservada pela sociedade, pouco podem mudar em sua existência, bem como, talvez, em todos os sistemas da terra atualmente. 0 nexo entre a política e os seus próprios interesses lhes é opaco, por isso recuam diante da atividade política. Em íntima relação com o tédio está o sentimento, justificado ou neurótico, de impotência: tédio é o desespero objetivo. Mas, ao mesmo tempo, também a expressão de deformações que a constituição global da sociedade produz nas pessoas. A mais importante, sem dúvida, é a detração da fantasia e seu atrofiamento."

${ }^{21}$ Gilles Deleuze (1988, p. 8), tratando da manifestação da diferença e da repetição na sociedade moderna, defende: "Nossa vida moderna é tal que, encontrando-nos diante das repetições mais mecânicas, mais estereotipadas, fora de nós e em nós, não cessamos de extrair delas pequenas diferenças, variantes e modificações. Inversamente, repetições secretas, disfarçadas e ocultas, animadas pelo deslocamento perpétuo de uma diferença, restituem em nós e fora de nós repetições nuas, mecânicas e estereotipadas. No simulacro, a repetição já incide sobre repetições e a diferença já incide sobre diferenças. São repetições que se repetem e é o diferenciante que se diferencia. A tarefa da vida é fazer com que coexistam todas as repetições num espaço em que se distribui a diferença." 


\section{CONSIDERAÇÕES FINAIS}

Nós nos vimos pelo olhar do outro. De fato, G.H. se vê como os demais integrantes da sua classe social a veem, o que não causa nenhum desconforto. Reconhece estar acostumada a ser julgada apenas por si mesma. Mas eis que ocorre a presença do seu oposto, e ela se reconhece nesse ser tão diverso de si. "Havia anos que eu só tinha sido julgada pelos meus pares e pelo meu próprio ambiente que eram, em suma, feitos de mim mesma e para mim mesma. Janair era a primeira pessoa realmente exterior de cujo olhar eu tomara consciência." (LIESPECTOR, 2014, p. 38).

Esse ponto de vista controverso da protagonista com relação à funcionária é um componente fundamental para seu autoquestionamento, pois ela passa a se ver de forma incomum, graças ao olhar divergente que Janair demonstra de sua patroa. Mesmo silenciada, Janair manifesta como a reconhece, através das gravuras, a escrita da subalterna insubmissa, ímpeto primitivo de insatisfação.

\section{REFERÊNCIAS}

[1] ABBAgNANO, N. Dicionário de filosofia. São Paulo: Martins Fontes, 2000.

[2] ADORNO, T. Palavras e Sinais. Modelos críticos 2. Petrópolis: Vozes, 1995.

[3] ARAUJO, A. L. Aquela que "salva” a mãe e o filho. Tempo, dez, vol. 15, n. 29, 2010, p. 43 - 66.

[4] ARAUJO, N. da S. M. de. Escrevivências de uma professora afroindígena. Odeere: Revista do Programa de PósGraduação em Relações Étnicas e Contemporaneidade - UESB, vol. 3, n. 5, janeiro-junho de 2018, p. 186 - 197.

[5] BAKHTIN, M. Estética da criação verbal. São Paulo: Martins Fontes, 2010.

[6] BRAGA, R. Precariado e sindicalismo no Sul global. Revista Outubro, n. 22, 2º semestre de 2014, p. 35 - 61.

[7] CAPRA, F. A teia da vida. Uma compreensão científica dos sistemas vivos. São Paulo: Cultrix, 1996.

[8] CASTRO, J. Geografia da fome. O dilema brasileiro: pão ou aço. Rio de Janeiro: Edições Antares, 1984.

[9] DAVIS, A. As mulheres negras na construção de uma nova utopia. São Paulo: Instituto Geledés - Instituto da Mulher Negra, 2011. Disponível em: <http://www.geledes.org.br/as-mulheres-negras-na-construcao-de-uma-novautopiaangela-davis/>. (acesso em: 21/01/2019).

[10] DAVIS, A. Mulheres, raça e classe. São Paulo: Boitempo, 2016.

[11] DELEUZE, G. Diferença e repetição. Rio de Janeiro: Graal, 1988.

[12] GODBOUT, J. T. Introdução à dádiva. Revista Brasileira de Ciências Sociais, vol. 13, no 38, 1997, p. 1 - 24.

[13] HEIDEGGER, M. O ser e o tempo. Vol.1. Petrópolis: Vozes, 2000.

[14] HOLLOWAY, J. Fissurar o capitalismo. São Paulo: Publisher Brasil, 2013.

[15] LISPECTOR, C. A paixão segundo G.H. Rio de Janeiro: Rocco, 2014.

[16] MACHADO, I. A questão espaço-temporal em Bakhtin: cronotopia e exotopia. Círculo de Bakhtin: teoria inclassificável. São Paulo: Mercado de Letras, 2010, vol. 1, p. 1 - 19.

[17] MERLEAU-PONTY, M. Fenomenologia da percepção. 2ª ed. São Paulo: Martins Fontes, 1999.

[18] RATTS, A. J. P. Gênero, raça e espaço: trajetórias de mulheres negras. Anais. Associação Nacional de PósGraduação em Ciências Sociais. Caxambu, 21 a 25 de outubro de 2003, p. 1 - 20.

[19] SÁ, O. de. Clarice Lispector - a travessia do oposto. São Paulo: Annablume, 1993.

[20] SPIVAK, G. C. Pode o subalterno falar? Belo Horizonte: Ed.UFMG, 2010.

[21] TOMÁS, J. A invisibilidade social, uma construção teórica. Colóquio “Crise das Socializações”. Abril, 2012, p. 1 


\section{Capítulo 4}

Feminismo negro, feminicídio e a violência de gênero contra as mulheres.

Angela Carla de Farias

Lina Maria Brandão Aras

Resumo: 0 presente artigo, que tem como objetivo promover uma discussão sobre a teoria feminista e as relações de gênero interseccionadas por raça e classe, no fenômeno da violência contra as mulheres, analisa o movimento feminista negro enquanto teoria crítica que identifica as peculiaridades das mulheres negras, levantando os pontos de convergência entre patriarcalismo, sexismo, heteronormatividade e racismo.

Palavras-chave: Gênero, Feminismo negro, Racismo, Violência, Políticas públicas. 


\section{INTRODUÇÃO}

No Mestrado realizado no Programa de Pós-graduação em Crítica Cultural da Universidade do Estado da Bahia, analisei processos de assassinatos de mulheres - denominados, à época, crimes passionais e agora feminicídios (após aprovação de Lei Federal específica de n 13.104/2015) -, na cidade de Inhambupe Bahia, ocorridos entre os anos de 1996 a 2006, um trabalho mais voltado à crítica cultural sobre os papéis de gênero. Agora, no Doutorado, busco discutir o assassinato de mulheres na perspectiva da crítica feminista, ao analisar o sistema judiciário e as políticas públicas no enfrentamento destes crimes, problematizando, com mais profundidade, os discursos processuais proferidos pelos operadores do direito, testemunhas e acusados, tendo como foco a cidade de Alagoinhas, uma cidade de médio porte do Litoral Norte da Bahia.

Já durante as pesquisas do Mestrado percebi que meu trabalho não problematizava a questão racial, mesmo eu tendo observado que nos processos que analisei as mulheres eram quase exclusivamente classificadas no laudo pericial como negras ou pardas, mas eu não me sentia instrumentalizada para discutir a questão racial no âmbito do feminismo e, mais especificadamente, no da violência de gênero contra as mulheres. Considerei que era extremamente necessário para a pesquisa descortinar as interseccionalidades que permeiam o gênero, a raça e a classe social de forma a conjecturar como cada um destes elementos/fenômenos sociais age simbioticamente no processo de subalternização da mulher. No objetivo de alcançar este intento, serviram de aporte teórico autoras que abordam criticamente as reais condições das mulheres, em especial, das mulheres negras mais destituídas de direitos sociais.

Sobre raça, analisa Kabengele Munanga: "o racismo é essa tendência que consiste em considerar que as características intelectuais e morais de um dado grupo são consequências diretas de suas características físicas ou biológicas" $(2004$, p. 25). Percebemos que o racismo representa a hierarquização das raças de forma a estabelecer historicamente mais direitos e oportunidades a um grupo em detrimento de outro subjugando diferenças culturais e identitárias. 0 processo de escravização das comunidades africanas teve como base de apoio a construção de um discurso de hierarquização racial que subalternizou e excluiu negros e negras das instâncias de poder (tomando como base os países colonizados onde se deu a escravidão, a exemplo do Brasil) e negou-lhes o acesso ao desenvolvimento econômico e social.

Vivemos em um país de extrema desigualdade econômico-racial-sexual, de forte herança patriarcal onde a desigualdade é justificada e naturalizada como atributos do "mérito", ou seja, como produto de qualidades individuais, um discurso que escamoteia as manobras que intentam a manutenção de benefícios por parte de colaboradores/beneficiários do pensamento racista (SCHUCMAN, 2012) e sexista. Nesta perspectiva, se, para os negros, o racismo aporte da escravidão teve um saldo perverso de destituição de direitos humanos e a não ascensão econômico-social tal qual tiveram os brancos, para as mulheres negras, este fator foi potencializado por uma sociedade além de racista, também sexista e heteronormativa (partindo do pressuposto de que não encontramos no mundo acidental mais especificadamente a configuração geográfica latina americana, de onde parte minha experiência e pesquisa, exemplos em que as mulheres exerçam um poder dominante nas esferas políticas, econômicas e sociais).

O sexismo pode ser caracterizado como um arcabouço de ideologias manifestadas em comportamentos, discursos e representações culturais e sociais através das quais são atribuídos características e espaços de atuação com base nos sexos, uma forma de discriminação que conduz à subalternização, à marginalização ou à exclusão das mulheres.

Historicamente, as mulheres estiveram alijadas dos espaços de poder com base em estereótipos limitadores da sua existência plena, da liberdade sobre seu corpo, seus desejos e da autonomia econômica, limitações que estão personificadas no controle da sua sexualidade, que "deve estar voltada" para a maternidade, para o cuidado da família e a manutenção material da liberdade de atuação masculina por meio do trabalho doméstico não remunerado, isto é, a heteronormatividade compulsória e a divisão sexual do trabalho.

0 pensamento biologizante em relação à raça (superioridade racial de um grupo em detrimento do outro com base na correlação de características fenotípicas às morais) serviu de apoio ao processo de hierarquização dos grupos raciais, diga-se, ao racismo. 0 sexismo bebeu na mesma fonte, a biologia, ao buscar conectar a anatomia biológica das mulheres a características temperamentais, comportamentais, a papéis sexuais e a modelos de vida preestabelecidos.

0 racismo interseccionado ao sexismo e à divisão de classes (alimentada pelo capitalismo em suas diferentes fases) representa o nó que complexifica a discriminação das mulheres negras. 
Pesquisas apontam não só o fato de as mulheres negras atuarem nos postos de trabalho mais subalternos ganhando os menores salários como também o crescente processo de feminilização da pobreza que, em grande escala, é composto por mulheres negras.

A população negra, em especial as mulheres negras, é mais vulnerável: sete em cada dez casas que recebem o Bolsa Família são chefiadas por pessoas negras, sendo que 37\% destas casas são chefiadas por mulheres negras. Entre as mulheres brancas, a taxa de desemprego é de cerca de $9 \%$, já entre as mulheres negras ultrapassa $12 \%$. No que diz respeito à renda, é válido ressaltar que as mulheres negras recebem $42 \%$ do salário dos homens brancos. Quem são os empregadores? Homens brancos são a esmagadora maioria neste agrupamento. Desta forma, é possível observar a desigualdade de gênero nos postos ocupados pelos "patrões" e, neste aspecto, as taxas de participação das mulheres brancas não são muito maiores que as dos homens negros (MARCONDES et al. 2013)22. 0 poder é "macho", branco, cristão e não é partilhado com outros grupos sociais.

Os dados sobre as desigualdades de gênero, raça e classe nos levam a indagar sobre o princípio da interseccionalidade que, na concepção de Crenshaw:

[...] trata especificamente da forma pela qual o racismo, o patriarcalismo, a opressão de classe e outros sistemas discriminatórios criam desigualdades básicas que estruturam as posições relativas de mulheres, raças, etnias, classes e outras. Além disso, a interseccionalidade trata da forma como ações e políticas específicas geram opressões que fluem ao longo de tais eixos, constituindo aspectos dinâmicos ou ativos do desempoderamento (2002, p. 177).

As mulheres negras amargam a injustiça social e a marginalização, o primeiro aspecto, ao serem expropriadas do fruto do próprio trabalho em benefício de outros, haja vista que as mulheres negras ganham menos que homens brancos e homens negros; e o segundo aspecto, ao serem obrigadas "a um trabalho indesejável" ou a não terem "acesso a um trabalho remunerado" e, em consequência disto, não alcançarem "um padrão de vida material adequado". A desvalorização das mulheres negras se expressa em múltiplas violências simbólicas, por meio de representações culturais racistas, banalizantes, sexualizadas e inferiorizantes; da "mãe preta" à "mulata sexual", a mulher negra é estigmatizada e os meios de comunicação cumprem muito bem o papel de desvalorização das mulheres negras embora isto venha se modificando, embora, com muita lentidão. Quando ligamos a televisão no Brasil, mesmo os canais fechados, parece que estamos refletindo a realidade visual de países de origem branca, dado o número de mulheres loiras: é o que Carneiro (2003) aponta como "loirização da televisão brasileira". Quando, raramente, um negro aparece na televisão, em telejornais e novelas, objetiva-se muito mais reforçar o simulacro do mito da democracia racial.

De acordo com a feminista negra bell hooks (2005), o racismo e o sexismo alinhados representam, por meio de símbolos e imagens, a mulher negra como aquela que está designada a servir aos outros. É importante frisarmos que a história colonial foi extremamente violenta com as mulheres negras nos aspectos físico, sexual e psicológico. Patricia Hill Collins (2012) discorre sobre as caricaturas ou imagens de controle sobre as mulheres negras: a mammy (mãe preta); a matriarca; a welfare mother (mãe dependente da assistência social); a jezebel ou a prostituta. Estas imagens de controle podem ser observadas nos cinemas e nas novelas.

A denúncia da condição das mulheres negras foi fruto das incansáveis reivindicações das feministas negras a exemplo de bell hooks, Audre Lorde, Patricia Hill Clollins, Sueli Carneiro, Lélia Gonzáles, Luíza Bairros entre outras revelaram que o feminismo só contemplava as necessidades das mulheres brancas de classe média.

O feminismo negro lutou e luta pelo reconhecimento positivo e pela equidade de direitos a um grupo especificadamente mais desvalorizado, para demarcar as diferenças e as reivindicações das mulheres negras, objetivando desarticular a ordem patriarcal, racista e classista de gênero. As feministas negras criticaram, vorazmente, a relação apática que muitas feministas brancas tinham ao examinar questões de raça.

\footnotetext{
22 É importante ressaltar que o IPEA, em 2013, divulgou uma pesquisa intitulada Dossiê Mulheres Negras: retrato das condições das mulheres negras no Brasil que atentou para o recorte raça, classe e gênero por meio de uma proposta interseccional cujo objetivo foi discutir a condição das mulheres negras no país, o que já representa um grande avanço fruto de reivindicações do movimento feminista negro (MARCONDES et al., 2013).
} 
Destituídas de poder econômico e com menor ascensão social, as mulheres negras estão mais vulneráveis às múltiplas violências de gênero e menos instrumentalizadas a buscar apoio institucional (falta mais pesquisas sobre violência de gênero contra as mulheres com recorte geográfico, racial, geracional, etc.). A violência de gênero, em suas diferentes manifestações, atinge todas as classes sociais e, para constatar isto, basta acompanhar o noticiário, no entanto, as mulheres negras, devido ao sexismo, racismo e, consequentemente, por fazerem parte das classes desfavorecidas estão mais expostas quantitativamente a este fenômeno.

Na concepção de Sandra Azerêdo, gênero seria "tanto uma categoria de análise quanto uma das formas que relações de opressão assumem numa sociedade capitalista, racista e colonialista" (1994, p. 207). No mesmo caminho, Patricia Collins (2012) nos desperta para o agenciamento das categorias de raça, classe, gênero e sexualidade. Segundo a pensadora, estamos vivenciando novas formas de capitalismo global que impulsionam mudanças sociais, econômicas e políticas e criam outras formas de racismo e sexismo; no entanto, persistem as desigualdades, a exemplo de a pobreza continuar sendo racializada.

Analisar a violência contra as mulheres no Brasil é uma tarefa complexa, seja pela pouca especificidade dos dados dos órgãos públicos (delegacias, judiciário, sistema de saúde) em identificar, de forma nítida, a pessoa que sofreu a agressão seja, também, quanto aos motivos que levaram ao fato (desentendimentos na família, intolerância religiosa, insegurança urbana, racismo, desigualdades socioeconômicas, violências sexuais, conflitos nas relações conjugais-afetivo-sexuais, falta de segurança na sociedade em geral).

A violência contra as mulheres, devido a sua alta incidência, se configura como um problema que precisa de uma atenção especial tanto da academia quanto do Estado, devendo ser desenvolvidos mecanismos de enfrentamento e prevenção, porém, ainda hoje, nos deparamos com dificuldades para dimensionar, detalhadamente, este fenômeno em todas as suas complexidades e especificidades. Conhecer e mapear adequadamente todos os aspectos de um problema social é a melhor forma de enfrentá-lo, enfraquecê-lo e minimizá-lo.

Os dados sobre o feminicídio, a última e cruéis forma de violência contra as mulheres, são alarmantes: 5.664 mulheres são mortas por ano, 472 por mês, 15,52 por dia e uma a cada hora e meia (IPEA, 2013). As mulheres jovens são as principais vítimas: $31 \%$ estão na faixa etária de 20 a 29 anos e $23 \%$ de 30 a 39 anos, ou seja, mais da metade dos óbitos (54\%) foi de mulheres de 20 a 39 anos. Outro fato revelado pela pesquisa é que as mulheres negras e pobres são as principais vítimas da violência. No Brasil, $61 \%$ dos óbitos foram de mulheres negras que, amargamente, representam as principais vítimas em todas as regiões, à exceção da Sul ${ }^{23}$. Merece destaque a elevada proporção de óbitos de mulheres negras nas regiões Nordeste (87\%), Norte (83\%) e Centro-Oeste (68\%). A maior parte das vítimas tinha baixa escolaridade, $48 \%$ daquelas com 15 ou mais anos de idade tinham até oito anos de estudo.

No ano de 20015 foi publicado um estudo mais recente patrocinado pela ONU e Governo Federal denominado Mapa da Violência 2015: Homicídio de mulheres no Brasil, 0 estudo demonstrou que homens negros e mulheres negras são vítimas prioritária em todos os estudos sobre violência, as taxas de homicídio da população branca historicamente tem caído, ao passo que aumenta a mortalidade de negros e negras. 0 número de mulheres brancas assassinadas em 2003 foi de 1.747 e caiu para 1.576 em 2013, houve uma queda de $9.8 \%$ em contrapartida o assassinato de mulheres negras em 2003 foi 1.864 e em 2013 aumentou significante para 2.875 um alarmante salto percentual de 54,2\%.

\section{CONCLUSÃO}

Historicamente as mulheres negras no Brasil desde a escravidão vem buscando estratégias de resistência contra o racismo, o sexismo e a exploração econômica, a presença de mulheres negras nas universidades e nos cursos de pós graduações vem provocando um deslocamento no sentido de discutir a situação das mulheres negras no país e impulsionar um pensamento feminista negro que represente suas reinvindicações.

\footnotetext{
${ }^{23}$ A região Sul possui um menor percentual de mulheres negras (20\%) em relação ao restante do país e um maior número de políticas públicas a exemplo de Delegacias Especializadas de Atendimento à Mulher (DEAMs) no comparativo com as regiões Norte e Nordeste isso poderia ser uma explicação para o número mais reduzido em comparativo com outras regiões.
} 
Intelectuais negras a exemplo de Lélia Gonzalez, Luiza Bairros e Sueli Carneiro percorreram uma árdua trajetória no sentido de dar visibilidade ao feminismo negro e suas agendas posicionando-se pela desconstrução de estereótipos sobre as mulheres negras e fortalecendo um pensamento decolonial que discuta a realidade das mulheres negras em especial no Brasil, América Latina e países pobres periféricos. 


\section{REFERÊNCIAS}

[1] Azerêdo, S. Teorizando sobre gênero e relações raciais. Revista Estudos Feministas, Rio de Janeiro, ano 2, n.esp., $\quad$ p. $203-216, \quad 2 . \quad$ sem. $1994 . \quad$ Disponível <https://periodicos.ufsc.br/index.php/ref/article/download/16103/14647>.

[2] Brasil. Lei no 11.340 , de 7 de agosto de 2006. Cria mecanismos para coibir a violência doméstica e familiar contra a mulher, nos termos do § 8o do art. 226 da Constituição Federal, da Convenção sobre a Eliminação de Todas as Formas de Discriminação contra as Mulheres e da Convenção Interamericana para Prevenir, Punir e Erradicar a Violência contra a Mulher; dispõe sobre a criação dos Juizados de Violência Doméstica e Familiar contra a Mulher; altera o Código de Processo Penal, o Código Penal e a Lei de Execução Penal; e dá outras providências. Disponível em: <http://www.planalto.gov.br/ccivil_03/_ato2004-2006/2006/lei/l11340.htm>.

[3] Brasil. Lei no 13.104, de 9 de março de 2015. Altera o art. 121 do Decreto-Lei no 2.848, de 7 de dezembro de 1940 - Código Penal, para prever o feminicídio como circunstância qualificadora do crime de homicídio, e o art. 1 da Lei no 8.072, de 25 de julho de 1990, para incluir o feminicídio no rol dos crimes hediondos. Disponível em: <http://www.planalto.gov.br/CCIVIL_03/_Ato2015-2018/2015/Lei/L13104.htm\#art1>.

[4] Carneiro, Suely. Mulheres em movimento. Estudos Avançados, v. 17, n. 49, p. 117-132, 2003. Disponível em: <http://www.scielo.br/pdf/ea/v17n49/18400.pdf>.

[5] Crenshaw, K. Documento para o encontro de especialistas em aspectos da discriminação racial relativos ao gênero. Revista de Estudos Feministas, v. 10, n. 1, p. 171-188, 2002.

[6] Collins, P. H. Rasgos distintivos del pensamiento feminista negro. Em: JABARDO, Mercedes (Org.). Feminismos negros: una antologia. Madrid: Traficante de Suenos, 2012.

[7] Hooks, B. Intelectuais negras. Estudos Feministas, v. 3, n. 2, p. 465-477, 1995.

[8] Lorde, Audre. Textos escolhidos [online]. S/D Difusão Herética, Edição Feminista e Lésbica Independente. 2009. Disponível em: <https://we.riseup.net/assets/171382/AUDRE\%20LORDE\%20coletanea-bklt.pdf> Acesso em: jul. 2015.

[9] Marcondes, Mariana M. et al. (Org.). Dossiê Mulheres Negras: retrato das condições das mulheres negras no Brasil. Brasília: IPEA, $2013 . \quad$ Disponível <http://www.ipea.gov.br/portal/index.php?option=com_content\&view=article\&id=20978>.

[10] Munanga, K. Uma abordagem conceitual das noções de raça, racismo, identidade e etnia. Cadernos PENESB, Programa de Educação sobre o Negro na Sociedade Brasileira, UFF, Rio de Janeiro, n. 5, p. 1534, 2004.

[11] Schucman, L. V. Entre o "encardido", o "branco" e o "branquíssimo": raça, hierarquia e poder na construção da branquitude paulistana. Tese (Doutorado em Psicologia Social) - Instituto de Psicologia, Universidade de São Paulo, 2012. Capítulos V, VI, VII. p. 67-110.

[12] Waiselfisz, Julio Jacobo. Mapa da Violência 2015 Atualização: Homicídio de Mulheres no Brasil. Rio de Janeiro: Cebela, $2015 . \quad$ Disponível em: <http://www.mapadaviolencia.org.br/pdf2015/MapaViolencia_2015_mulheres.pdf> Acesso em: junho de 2015. 


\section{Capítulo 5}

Uma noite no clube da Luluzinha: relato de experiencia sobre violência e gênero no Ocupa MinC/PI

\section{Luciana de Lima Lopes Leite}

Resumo: 0 objetivo deste artigo é apresentar e analisar um estudo de caso sobre violência de gênero presenciado na ocupação Ocupa MinC/PI, no ano de 2016, na cidade de Teresina/PI, durante meu trabalho de campo na pesquisa que desenvolvi junto ao Programa de Pós Graduação em Antropologia da Universidade Federal do Piauí, cujos sujeitos são as ocupações coletivas que utilizam práticas artísticas como tática de resistência em suas mobilizações e proposições. 0 presente fundamenta-se em bibliografias e pesquisas referentes a coletivos e iniciativas coletivas, ocupações coletivas, feminismos, violências e questões de gênero, bem como na Antropologia Urbana.

Palavras-chaves: Coletivos, ocupação, feminismo, violência de gênero. 


\section{CAMINHOS INTRODUTÓRIOS}

No dia que for possível à mulher amar-se em sua força e não em sua fraqueza; não para fugir de si mesma, mas para se encontrar; não para se renunciar, mas para se afirmar, nesse dia então o amor tornar-se-á para ela, como para o homem, fonte de vida e não perigo mortal.

Simone de Beauvoir

Atravessada pelas práticas e teorias feminista, bem como por questões de gênero há alguns anos, apresento e me proponho a analisar neste artigo um caso de violência de gênero presenciado em uma ocupação coletiva de resistência que ocorreu em Teresina/PI, no ano de 2016, mais especificamente na ocupação Ocupa MinC/PI, tendo como referencial teórico, a bibliografia relacionada a pesquisa que desenvolvi no Programa de Pós Graduação de Antropologia da UFPI, os textos discutidos no componente curricular "Violência de Gênero", no Mestrado de Ciências Sociais da mesma instituição, além das obras e ator@s com @s quais venho dialogando no meu Doutoramento em que os feminismos são umas das categorias centrais. Entendo feminismo a partir da perspectiva de bell hooks $(2019$, p.13) para quem [...] Feminismo é um movimento para acabar com sexismo exploração sexista e opressão".

A análise recai sobre um caso de violência contra uma mulher Trans, por parte de mulheres Cis que fizeram parte do movimento de ocupação OcupaMinc/PI, em uma noite cuja discussão versava sobre feminismo e violência contra a mulher.

Os movimentos feministas e suas reinvindicações a favor dos direitos das mulheres é uma luta que data do século XIX. No Brasil tais reinvindicações se intensificaram nos anos 80, quando a violência contra a mulher passou a ser vista não mais somente como um problema social, mas como um crime. A partir daí medidas intervencionistas foram criadas objetivando a conscientização, prevenção e combate a violência de gênero. Serviços de intervenção foram cridos como as Delegacias Especializadas no Atendimento as Mulheres/ DEAMs e os Centros de Referência. Os Centros surgiram na década de noventa tendo como modelo o SOS mulher sendo "um aparelhamento estratégico na rede antiviolência, dando auxílio aquelas mulheres que precisavam de atendimento psicológico, orientação social e jurídica”. (SILVEIRA, 2005 apud LIRA, 2013, p 02).

As transformações sociais e políticas ocorridas no Brasil nas últimas décadas do século XX, acompanhadas da redemocratização e do desenvolvimento dos movimentos femininos e feministas impulsionaram os estudos sobre gênero no país e, como pontua Lira (2013, p.02):

A visibilidade e poder da mulher na sociedade contemporânea vêm aumentando gradativamente através dos séculos, essa passou cada vez mais a adentrar em espaços pertencentes ao público masculino. Foram muitas as conquistas, passaram a ter voz ativa na política, livre acesso ao seu corpo e sexualidade, crescente participação no mercado de trabalho e maior acesso a educação. Mas apesar dos progressos, ainda se presencia a perseverança das desigualdades e hierarquias de gênero entre homens e mulheres nas esferas públicas e privadas, consequência do patriarcalismo e machismo presentes, ainda, em nossa sociedade, um exemplo concreto é a violência de gênero, particularmente a violência conjugal.

A pesquisa sobre as ocupações coletivas de resistência em Teresina, desenvolvida junto ao Programa de Pós Graduação em Antropologia da UFPI- PPGAnt, possibilitou fazer uma análise a cerca da participação ativa e política de mulheres Cis e Trans nesses movimentos onde muitas vezes estas se tornaram protagonistas na luta e resistência frente as reinvindicações coletivas, mas ainda assim sofreram situações de violência por parte de sujeitos de dentro e/ou de fora das ocupações, especialmente "violência simbólica, um constrangimento através do corpo", como apresenta Bourdieu (1995, p.137), sobretudo em relação a dominação masculina que:

Está suficientemente assegurada para precisar de justificação: ela pode se contentar em ser e em se dizer nas práticas e discursos que enunciam o ser como se fosse uma evidência, concorrendo assim para fazê-lo ser de acordo com o dizer. A visão dominante da visão sexual exprime-se nos discursos tais como os ditados, os provérbios, os enigmas, os cantos, os poemas ou nas representações gráficas tais como a decorações murais, os motivos das cerâmicas ou dos tecidos. Mas ela se exprime igualmente bem nos objetos técnicos ou nas práticas: por exemplo na estrutura do espaço, e em particular 
nas divisões interiores da casa ou na oposição entre a casa e o campo, ou ainda na organização do tempo, da jornada ou do ano agrário, e, mais amplamente, em todas as práticas, quase sempre ao mesmo tempos técnicas e rituais,e muito especialmente nas técnicas do corpo, posturas, maneiras, porte..

Muitos foram os casos de machismo e violência contra mulheres, Cis e Trans, legitimados pela dominação masculina, presenciados durante as ocupações realizadas em Teresina/PI, que acompanho desde o ano de 2014. No entanto, o artigo em questão - considerando os conceitos de poder, força e violência - é a análise de um estudo de caso de violência sofrida por uma mulher Trans, vítima de mulheres Cis, onde proponho a reflexão sobre a violência entre pessoas do mesmo gênero, impulsionada pelo patriarcado e o modelo eurocentado, hétero-normativo e judaico-cristão que orienta nossa sociedade.

\section{OCUPAMOS, LOGO RESISTIMOS!}

Ocupamos! Resistimos! Avançamos! Esses são alguns dos versos que se transformaram em gritos de guerra e ecoam em meio aos movimentos de ocupação que vem se multiplicando em terras tupiniquins. Em prol de uma reforma política, da legalização da maconha ou do aborto, da natureza, sustentabilidade e meio ambiente, da liberdade religiosa, das minorias étnicas, dos direitos LGBTQIA+, da igualdade de gênero, etc, grupos passaram a se organizar em coletivos e/ou iniciativas coletivas, ocupando espaços públicos e/ou privados, de maneira cada vez mais significativa, em todas as regiões do Brasil.

0 crescente surgimento de coletivos em Teresina e a curiosidade em relação as implicações político sociais desses, deram início a pesquisa, bem como minha experiência como ARTEvista, termo utilizado para designar ativista políticos e culturais que usam as linguagens artísticas em suas proposições a fim de chamar atenção para suas causas. Meu reconhecimento como ARTEvista, que teve início por volta de 2012, me despertou para a existência de um fazer coletivo e plural que se manifesta a partir de processos de identificação, interesses comuns e mobilizações coletivas de práticas artísticas e ocupações dos espaços públicos (LEITE, 2018), onde podemos perceber a participação ativa e por vezes o protagonismo de mulheres Cis e Trans.

Ao longo do século $\mathrm{XX}$, organizaram-se, em várias regiões do mundo, redes coletivas de ativistas e ARTEvista com processos organizacionais e metodológicos específicos, de caráter político social, podendo, inclusive, haver interrelações entre essas. Teresina entrou na rede. Diante dessa realidade tornei-me sujeita de ocupações coletivas de resistência, no primeiro momento como ARTEvista, em seguida, como pesquisadora.

É importante salientar a diferença entre coletivos e iniciativa coletiva. Os primeiros podem ser mais ou menos fechados, possuir formação fixa ou um núcleo central em torno do qual se agregam distintos parceiros. As iniciativas, porém, "são projetos com autogestão de equipes de trabalho constituídas por artistas ou mistas, formadas para determinado fim, sem objetivar a formação de um coletivo" (PAIM, 2012, p.7-8). Ambos buscam a realização e visibilidade de seus projetos e proposições através de várias linguagens artísticas (performances, instalações, intervenções, flash mobs, graffittis etc.) estando, na sua maioria, relacionadas a ocupação dos espaços públicos urbanos.

Em Teresina, a partir do ano de 2014, eclodiram várias ocupações coletivas cujas práticas artísticas eram usadas como tática de resistência: OcupARTHE, Viva Madalena, Ocupa Praça, OcupAngico, Ocupa MinC, OcupaUFPI, Ocupa Frei Serafim, são algumas das ocupações das quais participeu seja como ARTEvista e/ou pesquisadora.

Em todas as ocupações citadas pode-se perceber a participação ativa de mulheres Cis e Trans: artistas, estudantes, produtoras culturais, professoras, ambientalistas, multiprofissionais, avós, mães, filhas, mulheres de luta, empoderadas e que ainda assim muitas vezes sofreram a tentativa de terem suas vozes silenciadas e seu poder usurpado por sujeitos de dentro e/ou de fora das ocupações, a partir das relações de poder instituídas e legitimadas pelo patriarcado.

Diante dessa realidade, a partir da observação participante realizada na pesquisa, apresento e analiso um estudo de caso de violência de gênero presenciada na ocupação Ocupa Minc/PI, no ano de 2016, considerando para análise, além do conceito de poder onde [...] Tomaremos o poder como expressão dos direitos daquela parte da sociedade cujo desejo é não ser comandada nem oprimida (CHAUÍ, 1985. p. 34), o conceitos de força apresentado por CHAUí (1985. p. 34-35), onde:

[...] Entenderemos por força a ausência de poder, isto é, da capacidade coletiva para tomar decisões consensuais sobre a existência coletiva. Na relação de força 
há ausência de poder e presença do desejo de mando e opressão de uma classe sobre a outra e de um grupo social sobre outro. Entenderemos por força, portanto, as relações de exploração econômica, de dominação política, de exclusão cultural, de sujeição ideológica e de coação física e psíquica.

Saliento que os nomes d@s sujeit@s envolvid@s no estudo de caso apresentado são fictícios visando preservar a integridade moral dessxs, sejam vítimas ou agressorxs.

\subsection{NOITE DAS BRUXAS NO OCUPA MINC/PI}

Em maio de 2016 a Presidente do Brasil, Dilma Rousseff, sofreu um "impeachment", sendo destituída do cargo que passou a ser ocupado pelo Vice Presidente Michel Temer. Dentre as primeiras medidas do então Presidente Temer, uma incluía a extinção de alguns Ministérios, entre eles o Ministério da Cultura. A partir daí várias mobilizações surgiram em todo o país da qual participaram, principalmente, artistas, produtores e ativistas culturais, estudantes e membros de movimentos sociais que se organizaram dando início a movimentos de ocupação em todo território Nacional, a ocupação foi nomeada de Ocupa Minc.

Em Teresina, capital do Estado do Piauí, a ocupação aconteceu no prédio do IPHAN- PI, órgão que representa o Ministério da Cultura no Estado, localizado na Rua Magalhães Filho, 779, centro da cidade, no dia 22 de maio de 2016, resistindo até o dia 24 de junho do mesmo ano.

Durante os dias de ocupação inúmeras atividades foram desenvolvidas pelxs ocupantes e convidadxs: aula públicas das áreas de História, Direito, Pedagogia, Antropologia e Arqueologia; apresentações musicais, de dança e performances; saraus de poesia; oficinas de Artes; oficinas de empoderamento étnico e de gênero; debates sobre questões relacionadas a ocupações, movimentos sociais e coletivos, pichação, conjectura econômica, política, social e cultural, feminismo e violência contra a mulher.

Foi exatamente em uma noite em que o debate fora organizado em torno de questões envolvendo o feminismo e a violência de gênero, fruto dos anseios e protestos de mulheres ocupantes que estavam se sentindo incomodadas com situações de assédios por homens que faziam parte do movimento, que presenciei uma situação de violência de gênero que muito me impactou, me levando a refletir sobre essa problemática nas ocupações das quais fiz parte. Ao falar de violência, tomo como orientação mais uma vez os escritos de Chauí que entende a violência como:

[...] Uma realização determinada das relações de força, tanto em termos de classes sociais quanto em termos interpessoais. Em lugar de tomarmos a violência como violação e transgressão de normas, regras e leis, preferimos considera-la sobre dois outros ângulos. Em primeiro lugar, como conversão de uma diferença e de uma assimetria numa relação hierárquica de desigualdade com fins de dominação, de exploração e de opressão. Isto é, a conversão dos diferentes em desiguais e a desigualdade em relação entre superior e inferior. Em segundo lugar, como a ação que trata um ser humano não como sujeito, mas como uma coisa. Esta se caracteriza pela inercia, pela passividade e pelo silencio, de modo que, quando a atividade e a fala de outrem são impedidas ou anuladas, há violência. (CHAUÍ, 1985, p. 35).

Em um encontro organizado por membros do movimento coletivo Ocupa MinC/PI para se discutir questões relacionadas ao machismo e a violência contra mulheres, em que um convite aberto era feito a comunidade - leia-se aqui todas, todos e todxs -, um grupo de ocupantes, mulheres Cis, inicia as atividades com uma oração a Deusa - entidade pagã cultuada por doutrinas de influencia Celta como a Wicca. Após a oração uma das participantes lamenta a pequena participação dos homens que faziam parte do movimento, o que leva outras mulheres presentes a afirmarem que "não há lugar para fala de nenhum homem aqui". Iniciavam-se assim as primeiras divergências ideológicas sobre feminismos e violência de gênero.

Para F.R., militante feminista, "Homem não tem lugar de fala em discussões sobre feminismo e violência contra a mulher, pois são todos machistas e não existe isso de homem feminista".

Os desentendimentos continuaram. Algumas manas defendiam que aquele eram um momento de des[re]construção, o que tornaria importante também a participação masculina na discussão, não somente como ouvintes; outras permitiam que esses continuassem na roda em questão mas como sujeitos passivos e observadores; outras afirmavam que ali homem não tinha vez. Em meio a discursos inflamados e apaziguadores, gritos e silenciamentos, C.L.R, mulher Trans, ativista de movimentos coletivos de 
resistência em Teresina, pede licença para relatar uma violência que tinha sofrido minutos antes de chegar ao local do OcupaMinc/PI. Manos e manas escutam atent@s ao relato quando de repente, uma das idealizadoras do encontro interrompe a fala da companheira com um pedido de licença e questiona:

Com licença, mas ele é mulher ou homem? Porque eu realmente não entendo. Eu tenho muito amigos homossexuais, mas eles são homossexuais, não são mulheres. Não consigo entender quando você diz que "eu como mulher", você não é mulher. Eu sou mulher, eu tenho seios, eu tenho vagina, eu nasci mulher, eu me olho no espelho e vejo o meu corpo de mulher. Ele não é mulher e não pode chegar aqui querendo dizer que sabe como é a violência que nós mulheres sofremos todos os dias. (A.L. 2016)

Os ânimos se acirraram. Os manos tentaram defender a mana e recebem como resposta gritos de "Calem a boca!". Entre as manas, somente três das participantes do encontro se levantaram a favor do que foi considerado por elas uma situação de violência de gênero. Quando C.L.R. levantou a voz tentando se defender enquanto mulher Trans, foi acusada de machista por A.L. que gritou:

Vocês estão vendo? Ele é um homem e agora está partindo para cima de uma mulher, gritando com uma mulher. Isso é agressão, estou sendo agredida. Será que até aqui, em um momento para mulheres, um encontro de mulheres os homens conseguem ter voz e nos dizer o que sentimos? Até aqui ele vão conseguir ter voz e nos oprimir? (IDEM, 2016).

0 embate durou por mais algum tempo até que C.L. R. retirou-se do local e do movimento de ocupação Ocupa MinC/PI, após ter sido vítima de violência de gênero.

Neste caso, a violência se manifesta na desigualdade que existe entre os homens, mas os hábitos, os costumes, as leis, a mascaram de tal forma que ela passa a ser entendida como algo natural. Em outras palavras, a violência vai se institucionalizando gradativamente em uma sociedade e, quando ela se solidifica, a relação de força é tida e havida como relação natural, ou seja, "como se na natureza as relações fossem de imposição e não de equilíbrio" (ODÁLIA, 1983, p. 35 apud BARAZAL, 2014, p. 82).

Dessa forma, BARAZAL (2014, p.82) segue afirmando que, em se tratando de sociedade humana:

A violência é, ao mesmo tempo, uma criação natural, mas é, também produtora de si mesma quando se transforma em traços culturais. Isso porque o homem se organiza para estabelecer uma vida comum com seu semelhante e, para tanto, ele tem que definir os limites das ações a serem praticadas pelo grupamento social a que pertence.

Em uma sociedade patriarcal, eurocentrada, hétero-normativa, judaico cristã, como a brasileira, os limites definidos para as práticas sociais "aceitáveis" são excludentes, machistas, racistas, homofóbicos, violentos.

Eles matam! Nas relações de poder, força e violência, o discurso masculino sobre o corpo das mulheres, Cis e/ou Trans, é:

[...] Um discurso que não é simplesmente produzido e proferido por homens e ao qual seria necessário contrapor um discurso proferido por mulheres, visto que este último poderia (como tem ocorrido) ser apenas uma versão dos mesmo discursos anteriores sob a ótica feminina. Ao considera-los discursos masculinos, o que queremos simplesmente notar é que se trata de um discurso que não fala só de "fora" sobre as mulheres, mas sobretudo que se trata de uma fala cuja condição de possibilidade é o silencio das mulheres. (CHAUÍ, 1985, p. 43)

O silencio das mulheres ou mesmo a violência de mulheres Cis que não reconhecem as mulheres Trans como gênero feminino não pode, no entanto, ser transformado em mais uma opressão, julgamento, força e violência contra nós mulheres, mas compreendido como fruto de uma cultura patriarcal e machista. Uma cultura que necessita urgente de uma (re)educação que nos faça compreender as questões de gênero, o sexismo e opressão que nossos corpos - mulheres - enfrentam diariamente no país que mais mata Mulheres Trans e Travestis e está entre os primeiros no ranking de feminicídio. 
Saliento que para melhor compreender o estudo apresentado e analisa-lo sob a perspectiva de violência de gênero, considero que "[...] gênero não é só uma categoria de análise como é também uma categoria histórica e discursiva" (SAFFIOTI, 2004). Nesse caso, se faz necessário uma separação entre gênero e sexo, onde o primeiro não é definido pelo segundo, nos permitindo falar na existência de dois sexos opostos, o masculino e o feminino, mas também em diversos gêneros, tantos quantos a cultura for capaz de produzir. Dessa maneira:

Para entender esse processo de construção da sexualidade e da identidade sexual, é necessário perceber que o corpo físico nem sempre falará sobre identidade de gênero e os sentimentos da pessoa de acordo com o pressuposto heterossexual. (FERREIRA, Guilherme Gomes; SCHERER, Giovane; AGUINSKY, Beatriz Gershenson, 2012, p. 167)

No caso apresentado, a violência de gênero perpassa por processos de construção de sexualidade e identidade sexual a partir de discursos dominante e das relações de poder, força e violência entre os seres humanos.

\section{CONSIDERAÇÕES REFLEXIVAS}

As pesquisas sobre gênero no Brasil são relativamente recentes, bem como os estudos feministas e de violência de gênero, apesar dos avanços que podemos perceber nessa área nos últimos anos, sendo um dos temas que vem despertando bastante interesse dos componentes curriculares das Ciências Humanas.

O caso aqui apresentado é somente um dentre as inúmeras situações de violências sofridas diariamente por mulheres Cis e Trans em nosso país, caracterizado pela dominação masculina dentro de uma sociedade predominantemente cristã, heteronormativa e patriarcal.

Percebemos que nas ocupações coletivas de resistência, como na ocupação Ocupa MinC/PI, onde sujeitxs se unem em torno de interesses comuns, em prol de um bem supostamente coletivo, a violência de gênero contra as mulheres, Cis e Trans, se faz presente. Essa violência, validada por relações de poder e força, são por vezes direcionadas a mulheres Trans por mulheres Cis, a partir do momento em que a transexualidade é encarada como uma transgressão aos padrões morais e da normalidade. Nesses casos as agressões contra as mulheres Trans são legitimadas através de discursos ideológicos manifestados por instituições como a família, a igreja, a escola e até mesmo coletivos e iniciativas coletivas.

É preciso refletir, analisar e compreender as complexidades que envolvem as questões de gênero em uma sociedade ainda extremamente machista para que possamos prevenir e combater a violência de gênero, assim como aprender a conviver com as diversidades, não tolerando e sim respeitando xs sujeitxs e suas singularidades, sejam elas étnicas, religiosas, de orientação sexual e/ou gênero.

\section{REFERÊNCIAS}

[1] Barazal, Neusa Romero. Sobre violência e ser humano. Convert Internacional 15. Comoroc-Feusp/PpgcrUmesp/IJI - Univ. do Porto. Porto, 2014.

[2] Bourdieu, Pierre. A Dominação Masculina. 2 Ed. Rio de Janeiro: Bertrand Brasil, 2002.

[3] Chauí, Marilena. Participando do debate sobre mulher e violência. In: Perspectivas Antropológicas da Mulher, no 4, Rio de Janeiro: Zahar Editores, 1985: 25-62.

[4] Ferreira, Guilherme Gomes; Scherer, Giovane; Aguinsky, Beatriz Gershenson. "Não tenho preconceito, desde que fique longe": o discurso sobre gênero como construção social e a violência contra LGBT. In: Violências e gênero: coisas que a gente não gostaria de saber. 2 Ed. atual. ampl. - Porto Alegre: EDIPUCRS, 2012: 159 - 177.

[5] HOOKS, bell. O feminismo é para todo mundo: políticas arrebatadoras. Rio de Janeiro: Rosa dos Tempos, 2019.

[6] KASS, Haley. 0 que são pessoas Cis e Cisexismo. Disponível em: https://ensaiosdegenero.wordpress.com/2012/09/17/o-que-sao-pessoas-cis-e-cissexismo/>. Acesso em: 05 de janeiro de 2017.

[7] Leite, Luciana. Ocupar é ReXistir: práticas artísticas como tática de resistência nas ocupações do coletivo OcuparTHE, $\quad$ em $\quad$ Teresina (2014). $\quad$ Disponível em: https://sigaa.ufpi.br/sigaa/public/programa/defesas.jsf?lc=pt_BR\&id=342>. Acesso em 09 de janeiro de 2019. 
[8] Lira, Mayara Alves Lima. Atendimento às Mulheres em Situação de Violência no Centro de Referência Francisca Trindade, em Teresina-PI. Revista Latino-americana de Geografia e Gênero. V4. N ${ }^{\circ}$. Ponta Grossa, 2013: 7585.

[9] Mitsue, Fabiana Najima. Coletivos em rede: novas formas de organização. Dissertação de Mestrado. São Paulo: USP, 2010. Disponível em:http://fabianamitsue.files.wordpress.com/2011/05/fab iana-mitsue-najima_coletivos-em-rede_-pgeha_usp-final.pdf Acesso em: 15 de maio de 2013.

[10] Paim, Claudia. Táticas de artistas na América Latina: coletivos, iniciativas coletivas e espaços autogestionados. Porto Alegre: Panorama Crítico Ed., 2012.

[11] Rocha, Lúcia Naser. Coletivos Artísticos Brasileiros: um estudo de caso sobre discursos e subjetividade política nos processos colaborativos em artes. Dissertação de Mestrado. Salvador: UFB, 2009.

[12] Saffioti, Heleieth. I. B. Contribuições feministas para o estudo da violência de gênero. Labrys, Estudos Feministas. Revista Eletrônica, n. 1-2, Jul./Dez. 2002. 


\section{Capítulo 6}

\section{Violência sexual e relações de poder: 0 que pensam estudantes do interior da Paraíba?}

\section{Jaqueline Moreira de Souza}

Benícia Brenda Barbosa da Silva

Kasandra Campos de Oliveira

Laysa Maria Barauna Lima

Lúcia Temóteo

Resumo: As relações de poder delimitam os papéis de gênero na sociedade categorizando-os, de modo hierárquico, em dominante e objeto de domínio. A sociedade patriarcal ergue-se como fruto dessas relações, consolidando-se através dos veículos de manutenção, seja ideológico, coercivo ou econômico. A naturalização dessas formas de exercer o poder, por muitas vezes, as validam, tornando triviais as relações opressivas e os desarranjos sociais provenientes da opressão. 0 presente artigo tem como objetivo análisar o que pensam xs alunxs do ensino superior, de uma faculdade iteriorana na Paraíba, acerca da legitimação da violência sexual como produto das relações de poder entre os gêneros, tal como os fatores envolvidos nessas relações. Trata-se de uma pesquisa de caráter interventivo, onde se mediou um debate acerca das temáticas abordadas. A percepção dxs alunxs foram interpretadas por meio da análise de discurso. Xs alunxs consideram que elementos, como relação familiar, fatores psicológicos e valores patriarcais, influenciam direta ou indiretamente no modo como as vítimas vivenciam as situações de violência e opressão. Por outro lado, há significante ausência de informação, revelada nos posicionamentos dxs estudantes e que muitas vezes sustentam atitudes que possam vir a relativisar a violência sexual e de gênero. 0 diálogo é uma das bases para a transformação da sociedade tornando-a mais justa, informada e igualitária. É partindo desse pressuposto que o presente artigo expande os campos de diálogo, estabelecendo pontes entre conhecimento popular e saber científico, buscando com isso quebrar os paradigmas ainda existentes na sociedade.

Palavras-chave: Gênero e poder, Violência sexual, Espaço acadêmico. 


\section{INTRODUÇÃO}

Este artigo é resultado de um projeto de pesquisa intitulado "Discussões de Gênero e Sexualidade na Academia" realizado, no ano de 2018, por estudantes e professora do curso de Bacharelado em Psicologia de uma faculdade do sertão paraibano. 0 projeto ocorreu, simultaneamente, em várias turmas dos diversos cursos ofertados pela faculdade. Assim, apresentamos um recorte das discussões feitas numa sala de aula de um curso da área da saúde, momento em que foi exibido o vídeo "O silêncio de Lara", que aborda a questão do estupro no interior de uma família. Este artigo tem como objetivo analisar o discurso desses alunos, no que se refere ao gênero e à violência sexual no contexto familiar.

De acordo com Butler (2011), as categorias de gênero construídas sob o efeito do poder subsidiam uma hierarquia que dita qual gênero é dominante e qual é considerado abjeto. Outrossim, essas categorias estruturadas também atuam na questão da sexualidade, no que diz respeito à heterossexualidade compulsória. Nessa ótica, entende-se que a compreensão acerca dessa hierarquização deve acontecer a partir de uma análise crítica, visto que as bases constituintes dessas categorias de gênero são resultado de uma composição específica de poder dentro das convenções sociais.

Segundo o Atlas da violência (2018), no ano de 2016, houve 22.918 casos de estupro no Brasil. Distribuindo o percentual das vítimas de estupro, segundo a faixa etária, verifica-se um total de $50,9 \%$ com indivíduos de até 13 anos; 17,0\% entre 14 e 17 anos; e, 32,1\% maiores de idade. Com base no dado ora exposto, evidencia-se que a maioria dos casos de violência sexual é vivenciada, em sua maioria, pela figura feminina. Segundo Araújo (2002), vários fatores contribuem com a manutenção dos índices de violência sexual no Brasil, podendo-se destacar as situações de vulnerabilidade social. Nessas, pode haver a fragilidade nos vínculos afetivos-relacional e dificuldade no acesso a serviços que auxiliem a vítima nos processos decorrentes da violação dos direitos.

Um debate que vem sendo enfatizado nos diversos campos de conhecimento é a discussão em relação às questões de gênero e à problematização acerca dos seus conceitos e características. Firmino e Porchat (2017), baseados nas ideias de Judith Butler, abordam que o debate acerca do gênero contribui para as lutas políticas e se caracteriza como fundamento para as mudanças sociais em relação à sexualidade e identidades. Em contrapartida, um problema apontado pelo estudo e obra da filósofa gira em torno da instauração de práticas de violência, exclusão e preconceito provocados pelo gênero, visto que o mesmo se encontra dentro do sistema poder-saber. Nesse contexto, há a necessidade do aprofundamento do estudo de gênero, deslocando essa discussão para dentro da esfera das finalidades do poder.

Butler (2011) questiona as noções em relação à construção e à conceitualização do gênero, colocando indagações e sugerindo releituras acerca dos aspectos regulatórios, que fazem parte do social, que atuam sobre essa construção e produzem desigualdades de gênero que, apesar das modificações, ainda estão instaladas atualmente. Nesse contexto, é possível abordar que o gênero, ao mesmo tempo em que é construído culturalmente, também se encontra passivo a uma lei cultural que rege essa construção, através de efeitos do poder.

Vicentin (2009) aponta o ambiente familiar como um espaço frequente da prática da violência sexual contra crianças e adolescentes. Outro fator que merece ser destacado é que a autora, citando Padilha e Williams (2005), aponta o pai e o padrasto como principais agressores. As relações de gênero no ambiente doméstico apontam que, na maioria das vezes, o homem exerce o poder não apenas por meio da força bruta, da dependência financeira da mulher ou até através da ingerência do homem sobre o salário recebido pela companheira, mas, principalmente, por meio do campo simbólico enraizado por construções sociais patriarcais que se perpetuam figurando a mulher como submissa e inferior ao homem. Por outro lado, a sociedade figura o homem como detentor da virilidade e pulsões sexuais, legitimando as formas de possuir e controlar o corpo feminino, banalizando as violências praticadas (NADER; CAMINOTI, 2014).

Foucault aborda que o poder está relacionado à prática, ou seja, o poder é um exercício e a sua execução se encontra presente em todo o sistema social, agindo através de mecanismos entendidos como micropoderes, nos diversos campos e direções da vivência cotidiana. 0 poder está diretamente relacionado ao saber e, nesse sentido, o sistema poder-saber, sob a sexualidade e gênero, possui a repressão como propriedade. As relações de poder-saber, presentes na conjuntura social baseada no gênero e na heteronormatividade, ditam a normatização do gênero e se inserem nas manifestações das sexualidades (FIRMINO; PORCHAT, 2017).

O espaço da escola é composto pela diversidade de alunos e professores, com suas subjetividades e experiências, adquiridas ao longo da vida. Neste ambiente, no qual experiências e conhecimentos são construídos, bem como o entendimento sobre questões sociais e culturais, o diálogo acerca da sexualidade, 
tendo como um dos principais intuitos a diminuição da violência sexual faz-se relevante e necessário. Todavia, ainda há um tabu ao discutir sobre sexualidade em espaços educacionais, tal como no ambiente familiar.

Ressalte-se que são frequentes as discussões sobre educação sexual na infância, de forma a auxiliá-las a reconhecer atitudes abusivas. Mas falar de sexualidade, principalmente na infância, ainda é visto como um tabu e as formas de silenciá-la é um paradigma a ser quebrado. A busca por compreender as especificidades da sexualidade, de certo modo, é idealizada, muitas vezes, como uma peça que se apresenta de forma natural. Consentindo essa imagem, pode-se dizer que a forma de como este sentido é argumentado na condição social e política, ou até mesmo a respeito de seu feitio que fora construído, visto no seu contexto como um todo, levando em consideração fatores como classe social e lugar em que vive, gera, sem dúvidas, certo conhecimento sobre o tema colocado e dialogado (LOURO, 2000).

Considerado que historicamente a sexualidade e os estereótipos de gênero foram internalizados de forma repressiva no simbólico das crianças e adolescentes, é relevante a reflexão acerca das formas que concepções opressoras, presentes espaço escolar onde não há espaço para os corpos_que se insurgem ao sistema e que, de alguma maneira, não se encaixam em determinadas regras e normas. Posto isso, faz-se necessário, neste contexto, refletir sobre a importância de indagar os programas das unidades de ensino, levando em consideração que "[...] o currículo é, entre outras coisas, um artefato de gênero: um artefato que, ao mesmo tempo, corporifica e produz relações de gênero [...]” (SILVA, 2005, p. 97).

É de suma importância ressaltar que, no decorrer do processo da educação sexual, o vínculo escola-família é basilar para o andamento dessa ligação, posto que muitos dos processos que geram exclusão se iniciam no cotidiano familiar. É importante mencionar que os Parâmetros Curriculares Nacionais (PCNs) compreendem as ações da escola como um complemento à educação que inicialmente deve ser dada pela família. Desta forma, é dever do corpo escolar manter os familiares informados sobre a inserção de temáticas de Orientação Sexual na alegação curricular e explicar as teorias que darão norte à proposta. Ademais, é relevante mencionar ainda que o diálogo entre a escola e família deverá acontecer de todas as maneiras aptas a esse elo (BRASIL, 1997).

Nota-se que, na atualidade, muito embora com a força da mídia e sua influência e, ainda, as redes sociais com seu vasto espaço, inúmeras famílias se negam a abordar as temáticas sobre a educação sexual que, frequentemente, surgem e necessitam serem discorridas no meio da família. Desta forma, é urgente uma mobilização que atinja também os pais sobre a importância dessa educação, deixando claro que essa mobilização se dá por meio da troca de diálogo entre a escola e a família.

É nesse contexto que se faz necessário levantar discussões a respeito de como se dão essas relações na atualidade e nos diversos contextos, provocando o pensamento reflexivo, que se configura como uma ferramenta fundamental para as transformações sociais e enfrentamento da realidade, a fim de romper com os paradigmas em torno do corpo, da sexualidade e das construções sociais a esses direcionadas. Ademais, a produção científica é um importante veículo de conhecimento, ainda que o acesso a esse tipo de informações não seja acessível a grande parte da população. Nessa perspectiva, o presente trabalho busca contribuir com a produção científica em gênero e sexualidade, tema contemporâneo e que se faz cada vez mais necessário debater, abrindo espaços ao diálogo em uma faculdade particular do sertão da Paraíba, região onde há uma predominância do pensamento patriarcal.

\section{METODOLOGIA}

O presente estudo se deu com base em uma investigação de caráter qualitativo e de intervenção, com foco na análise do discurso dos sujeitos. Como descreve Guerra (2014), o método qualitativo pode ser considerado um rompimento necessário aos paradigmas metodológicos clássicos, por proporcionar que se considere o ser humano em sua totalidade, destacando a subjetividade e ausência de passividade do mesmo.

Portanto, conforme afirma a autora, tornou-se o mais utilizado pelas ciências sociais, pois possibilita intensificar a compreensão dos fenômenos vivenciados pelos indivíduos, atentando-se para a complexidade do seu objeto de estudo. Em consonância, Tuzzo e Braga (2016) explicam que isso se dá em razão dessa metodologia oferecer ao pesquisador incontáveis possibilidades de estruturar sua investigação e analisar os dados obtidos, o que resulta em um olhar mais amplificado da situação observada, que é necessário para a intervenção, sendo esta caracterizada pela construção de medidas que possam modificar positivamente a problemática encontrada. 
Partindo desse pressuposto, Prodanov e Freitas (2013) dissertam que o pesquisador passa a ter um papel ativo na busca da compreensão dos elementos que constituem o problema, na construção de ações que possam solucioná-lo e na avaliação do sucesso destas. Contudo, a análise do discurso, segundo Silva e Araújo (2017), colabora apresentando a relação existente entre a fala e a ideologia, na qual é possível verificar, com profundidade, a forma como os sujeitos compreendem o que está sendo retratado.

Para obtenção dos dados analisados na presente pesquisa, realizou-se um encontro com estudantes da área de saúde de uma faculdade particular localizada no sertão da Paraíba. Na oportunidade descrita, exibiu-se um média-metragem intitulado "O silêncio de Lara" cujo conteúdo retrata a história de uma adolescente que, ao fazer 14 anos, consegue denunciar o abuso sexual que vivenciava em segredo, desde a sua infância, e era razão de muita angústia. Após a exibição, esses estudantes, indagados pelas pesquisadoras, passaram a compartilhar de suas opiniões, sentimentos e histórias das quais possuíam conhecimento envolvendo o tema. Todo o diálogo foi arquivado por meio de uma gravação de áudio, previamente consentida pela turma, para que posteriormente pudesse ser utilizado nesta produção.

\section{RESULTADOS E DISCUSSÃO}

\section{Violência sexual e ambiente familiar}

Frequentemente, escutam-se nos noticiários casos de violência sexual praticados no ambiente familiar por pais, padrastos, tios ou outros membros da família. Ainda assim, é comum o silêncio para esse tipo de violência. Há violência sexual no ambiente familiar praticada também por cônjuges, esta ainda é mais velada

Diante desta realidade, pode-se apoiar nas ideias de Foucault (1988) para melhor compreender o silêncio dessas violências, quando o autor assinala a família conjugal como modelo de manifestação da sexualidade na qual há os detentores da verdade sobre o sexo e a eles é reservado o princípio do segredo, fazendo prevalecer a hipocrisia do puritanismo moderno.

Com relação à violência sexual, no contexto geral, há prevalência da mulher enquanto vítima, resultado da legitimação da violência perpetuada pelos costumes de uma sociedade patriarcal, como mencionado anteriormente. Com isso, frequentemente se encontram discursos que culpabilizam a vítima.

No trecho a seguir, proferido por um dos participantes da pesquisa, após a exibição do filme, pode-se notar esse tipo de discurso. 0 mesmo afirma que "Eu achei que a menina demorou demais pra denunciar". Nessa fala, há a culpabilização da vítima por não ter denunciado antes, permitindo que a violência se perpetuasse. 0 participante isenta de culpa o agressor, dando a entender que ocorreram outros episódios porque a vítima permitiu.

Em seguida, uma das participantes se posiciona frente ao comentário do colega: "Por mais que você perceba que vai ser bom pra você... Você não sabe o que tá passando naquela cabeça. É difícil entender uma pessoa que tem problemas com isso. Você não sabe se você vai poder confiar em vivendo com uma pessoa que qualquer um". Essa fala traz diversos elementos passíveis de análise, o que chama a atenção para fatores envolvidos na formalização da denúncia. Também pode ser citado o tempo dedicado a questões burocráticas, fatores psicológicos e até mesmo o medo da culpa empregada pela sociedade.

A participante completa a fala: "O que ela vai achar dos outros? Uma pessoa que era da família". Nesse momento, ela se refere à quebra do vínculo parental por meio da perca de confiança da vítima na figura na qual é depositada as expectativas de cuidar e manter sua segurança, gerando uma fragilidade na dinâmica familiar. Quando há a revelação da situação de violência para os demais membros que compõem o núcleo familiar, eclodem diversos sentimentos que podem gerar rupturas no vínculo familiar e, por muitas vezes, a vítima se culpa por essas rupturas (ANTONY; ALMEIDA, 2018). A Família entra em estado de vulnerabilidade, temendo a exposição pelo receio do julgamento da sociedade visto que, frequentemente, há casos em que a vítima é silenciada dentro da própria família. Como aponta um dos participantes: "[...] $e$ muitas vezes optam por silenciar a vítima, fazendo com que ela continue se submetendo ou sofrendo psicologicamente, né?". A vítima pode vir a se sentir desprotegida ao passo que se faz presente o sentimento de pertença a um núcleo familiar adoecido, tornando escassa a confiança em outras pessoas que possam auxiliá-la no processo de denúncia.

Um dos participantes traz em sua intervenção a importância de se falar da sexualidade: "Rapaz, eu acho que se deve usar esses sinais como auxílio na prevenção. Essa alteração brusca comportamental deve ser trabalhada, voltada mais pra questão familiar. Um dos maiores erros, arrisco dizer que o de todos aqui, é achar que nunca vai acontecer com a gente e isso acaba trazendo muita coisa pra si. Esse trabalho de 
intervenção, acho que deve ser feito mais com os responsáveis pelas crianças, pois essas são leigas sobre tudo. Essa intervenção deve ser voltada mais para os responsáveis pra que eles busquem uma proximidade maior com os filhos, que eles questionem se algo está acontecendo. Isso faz muita diferença... Perguntar como foi o dia do outro." Aqui o aluno sugere que seja falado sobre gênero e sexualidade com os pais e responsáveis pelas crianças. É necessário, entretanto, abordar o assunto em todos os contextos da sociedade, abrindo oportunidade para problematizações, desmistificações sobre o assunto, disseminação de informações, objetivando com isso a transformação da realidade (SFAIR; BITTAR; LOPES, 2015).

\section{Aspectos psicológicos da violência sexual e de gênero}

Todas as manifestações de violência possuem em sua estrutura diversos fatores psicológicos que influenciam o posicionamento dos envolvidos e geram consequências, principalmente, para as vítimas. Desta forma, quando se estuda a violência sexual e de gênero, faz-se indispensável que se discuta de forma intensa sobre isso, pois esse tipo de agressão tem um grande poder negativo sobre a vítima, principalmente se essa se tratar de uma criança ou adolescente, visto que irá resultar em problemas significantes em sua formação (LIMA; DIOLINA, 2013).

No início da presente pesquisa, uma aluna se posiciona dizendo: "Tem que ver também o psicológico dela nessa situação." Evidenciando, assim, a sua consciência de considerar todos os sentimentos vivenciados pela vítima para compreender todo o contexto e evitar os julgamentos que pessoas, desprovidas de conhecimento na área, costumam proferir. Em seguida, deixando ainda mais clara essa preocupação, uma colega complementa: "Ela demorou... Não sei se ela demorou, porque a situação psicológica é muito... O psicológico é difícil!"

Referindo-se ao fato de que geralmente se questiona o tempo que a vítima leva para revelar os abusos sofridos sem que se reflita sobre os pensamentos e sentimentos envolvidos entorno disto. Um aluno chama atenção afirmando: "Ela se culpou!" Trazendo para a discussão um dos sentimentos mais recorrentes entre as vítimas, pois tais atos são resultados das relações de poder, nas quais o abusador utiliza-se de mecanismos de dominação para explorar e inibir.

Buscando explicar mais um dos motivos que costumam colaborar para a tão discutida "demora" para a efetivação da denúncia, um aluno diz: "É porque na verdade, ela quando era criança, nem entendia o que estava acontecendo." Tal afirmação faz com que também se perceba a importância da disseminação do conhecimento sobre a educação sexual e o amplo diálogo sobre a temática como mecanismos de proteção para a criança e adolescente.

No tocante à vulnerabilidade, que a pouca idade e a falta de conhecimento geram, uma aluna observa: "Falando sobre chantagens... No começo ele oferecia bombons, depois celular, né?! Usando coisas que criança gosta, que adolescente gosta pra tentar induzir, né?! Fazendo com que a criança queira." E sua colega complementa: "É interessante que no início ela diz não querer o bombom, mas ele vai e começa a ameaçar." Alertando para táticas persuasivas que abusadores costumam usar para atrair e colocar a vítima em posição de submissão.

\section{A sociedade patriarcal e a legitimação da violência sexual e de gênero}

A construção histórica da masculinidade esteve voltada para superioridade masculina, legitimando e contribuindo para a construção e manutenção de uma sociedade machista e violenta, tanto em relação ao gênero, no que se refere à opressão voltada às mulheres, bem como a questão da sexualidade, no que se refere à homofobia. A masculinidade, da forma como foi construída, é prejudicial em diversos âmbitos do social e, principalmente, em todos os aspectos da vida das mulheres, visto que oprime, diminui e inferioriza (NIGRO; BARACAT, 2018).

Há uma nítida diferenciação dos papéis de gênero e da submissão da mulher ao homem, na qual a honra da mulher é atribuída à capacidade de guardar seu corpo para um único alguém e a esse pertencer, privando-se, muitas vezes, do prazer. Esse aspecto é evidenciado na fala de uma aluna, ao se referir à personagem do vídeo ter "perdido a honra": "você já acabou com a sua honra, bem dizer...". É possível perceber nessa fala a cultura de que enquanto ao homem a honra é atribuída à sua virilidade e capacidade de procriar, gozando de seus prazeres, ou seja, quanto mais poder o homem exerce, mais honrado ele é; por outro lado, quanto mais pura e submissa, mais honrada é a mulher. Essa ideia é complementada pela fala de outro participante quando ele afirma que: "Eu conheço um caso de um menino que a babá dele, 
quando ele tinha 6 anos de idade, ao dar banho ele, o colocava pra chupar seus seios. E na conversa do grupo familiar, eles falavam "Eita! Taradão, ein. Nossa, esse aí vai ser garanhão".

Ao se referir aos aspectos da construção da masculinidade, uma aluna salienta que "sobre o machismo... É muito colocado que o homem... Fala-se muito que essa fase do homem... Da adolescência onde ele está se descobrindo, né?! Por questões hormonais, passam a justificar certos atos como se eles fossem normais. Costumam dizer que isso é normal, que faz parte da fase do homem, da puberdade e que a mulher é diferente, pois no homem é tudo mais aflorado." Nessa fala, a aluna aborda a questão da naturalização dos atos prejudiciais praticados, tendo como explicação as questões hormonais que são utilizadas para justificar aspectos relacionados ao machismo e a violência, nos seus diversos segmentos, direcionada às mulheres.

Ainda, a aluna complementa e questiona: "E aí, isso é instinto?! É algo tão animal assim que um homem não consegue se controlar? É impossível de se perceber e até fazer um trabalho sobre isso se for necessário com um profissional? Pois isso é muito feio!". Vale destacar que, após essa fala, um grupo de alunos do gênero masculino gargalhou. 0 discurso da aluna reflete o que Nigro e Baracat (2018) enfatizam em relação à posição irracional colocada para o homem, que diz respeito à ideia de que o mesmo não é capaz de controlar os instintos, assim como animais selvagens e, dessa forma, os atos são naturalizados e impunes.

Essa naturalização do machismo e da masculinidade tóxica está diretamente relacionada à cultura de estupro que, como aborda Campos (2016), refere-se às práticas e ideias que sustentam métodos de controle da sociedade patriarcal. Sob essa perspectiva, uma aluna aborda que "Já ouvi muitas pessoas dizerem que essa fase do homem é mais aflorada, como se fosse uma desculpa.". A violência sexual, nessa cultura que naturaliza ações opressoras e violentas, está subsidiada por um poder invisível que regula e influencia a sociedade. Ao serem informados, durante o debate, sobre as estatísticas de que um caso de estupro é notificado no Brasil, a cada 11 minutos, e que os casos registrados representam apenas $20 \%$ do total de estupros (DESUMANIDADES, 2016), um aluno questiona "esses dados são de onde?". Tal questionamento permite refletir acerca da tentativa desenfreada de invisibilizar e duvidar dessa cultura que sustenta a sociedade.

\section{CONSIDERAÇÕES FINAIS}

Tornou-se evidente que, mesmo se tratando do espaço acadêmico, no qual se imagina que discussões acerca da presente temática devem acontecer de forma constante, a fim de promover esclarecimentos, há uma significante ausência de informação revelada no posicionamento dos estudantes, que muitas vezes sustentam atitudes que possam vir a relativizar a violência sexual e de gênero.

Diante disso, é importante compreender e reforçar que a ausência citada não se dá em vão. Sabe-se que, na maioria das vezes, acontece justamente pela também ausência de conhecimento em cima do tema trabalhado, o que causa no sujeito a ignorância.

Esse fato reforça o que foi encontrado na literatura utilizada para tal estudo, mostrando a necessidade de quebrar conceitos antigos, intensificar a disseminação de conhecimentos e promover reflexão para que o presente cenário seja modificado de forma benéfica. Ademais, frequentemente é visto que, muito embora questões como esta tenham conquistado um espaço significativo, principalmente nas academias e até mesmo em redes sociais, através de campanhas, rodas de conversa e palestras, lamentavelmente, ainda há uma falha no estado, bem como do próprio profissional que considera que tratar de questões como a problemática da violência sexual, por exemplo, pode ser uma "perda de tempo" uma vez que não há tanto interesse nos alunos.

Ariano Suassuna coloquialmente dizia que cachorro só gosta de osso porque nunca lhe deram um filé. Fazendo analogia ao pensamento do dramaturgo paraibano, pode-se dizer que o mesmo acontece no nosso cenário educacional brasileiro no qual, constantemente, muitos assuntos não são trabalhados justamente por ainda existir o tipo de falha mencionada acima, o que evidencia a urgência de trabalhar cada vez mais esse tipo de tese, tendo como objetivo fazer a informação chegar, com cada vez mais precisão, às pessoas.

A metodologia escolhida, para a realização deste estudo, proporcionou que o tema fosse abordado de forma ampla e bastante eficaz na função de compreender como os estudantes enxergam a problemática discutida, apresentar dados atuais e consistentes que lhes mostrassem outro ponto de vista cumprindo, assim, a proposta da intervenção e da construção de novos saberes. Através destas reflexões, ficou claro o fato de que a violência sexual e de gênero é um problema social e também de saúde. Partindo do pressuposto de que o conhecimento propicia maiores oportunidades de mudança, e levando em 
consideração a preocupação da Psicologia e o reconhecimento do seu papel social, este estudo busca colaborar para o campo científico e servir como ferramenta para a construção de uma sociedade mais justa, informada e igualitária.

\section{REFERÊNCIAS}

[1] Antony, S.; Almeida, E. M. Crianças vítimas de violência sexual intrafamiliar: uma abordagem Gestáltica. Revista do Nufen, Belém, v.10, n.2, p. 184-201, mai./ago. 2018.

[2] Araújo, M. F. Violência e abuso sexual na família. Psicologia em Estudo, Maringá, v. 7, n. 2, p. 3-11, jul./dez. 2002.

[3] Atlas da Violência no Brasil: base de dados. Disponível em: < http://www.ipea.gov.br/portal/images/stories/PDFs/relatorio_institucional/180604_atlas_da_violencia_2018.pdf >. Acesso em: 19/07/2019.

[4] Brasil. Parâmetros Curriculares Nacionais: pluralidade cultural, orientação sexual. Secretaria de Educação Fundamental. - Brasília: MEC/SEF, 1997.

[5] Butler, J. Problemas de gênero: feminismo e subversão da identidade. Edição em Língua Portuguesa. ed. Rio de Janeiro: Civilização Brasileira, 2003. 233 p.

[6] Campos, A. A. A cultura do estupro como método perverso de controle nas sociedades patriarcais. Revista Espaço Acadêmico, Maringá, p.1-13, 2016. Mensal.

[7] Coelho, M. G. Gênero desviantes: o conceito de gênero em Judith Butler. 2017. 101 f. Dissertação (Mestrado) Curso de Filosofia, Universidade Federal de Santa Catarina, Florianópolis, 2018.

[8] Desumanidades. Direção de Museu da Pessoa. [s.i.]: Cartola Filmes, 2016. (16 min.), son., color. Legendado. Disponível em: <https://www.youtube.com/watch?v=NFPSS3qoWeU>. Acesso em: 16 ago. 2019.

[9] Firmino, F. H.; Porchat, P. Feminismo, identidade e gênero em Judith Butler: apontamentos a partir de "problemas de gênero". Rev. Bra. Psicol. Educ., Araraquara, v. 19, n. 1, p.51-61, 2017.

[10] Foucault, M. História da sexualidade I: a vontade de saber. Tradução de Maria Thereza da Costa Albuquerque e J. A Guilhon Albuquerque. 10 ed. Rio de Janeiro: Graal, 2014.

[11] Guerra, E. L. A. Manual de Pesquisa Qualitativa. Ânima Educação. Belo Horizonte 2014. Disponível em: <http://disciplinas.nucleoead.com.br/pdf/anima_tcc/gerais/manuais/manual_quali.pdf>. Acesso em: 22 jul. 2019

[12] Lima, I. V. B.; Diolina, J. Consequências Psicológicas do abuso Sexual na Infância e Adolescência: uma Ferida Invisível. Disponível em: <http://www.site.ajes.edu.br/congre/arquivos/20150928161430.pdf> Acesso em: 06 jun. 2019.

[13] Louro, G. L. (org.) O corpo educado: pedagogias da sexualidade. 2 Ed. Belo Horizonte: autêntica, 2000.

[14] Nader, M. B.; Caminoti, J. M. Gênero e poder: a construção da masculinidade e o exercício do poder masculino na esfera doméstica. Anais. $2014 . \quad$ Disponível em: <http://www.encontro2014.rj.anpuh.org/resources/anais/28/1400262820_Arquivo_Generoepoderaconstrucaodam asculinidadeeoexerciciodopodermasculinonaesferadomestica.pdf>. Acesso em: 12/08/2019.

[15] Nigro, I. S.; Baracat, J. Masculinidade: Preciosa como diamante, frágil como cristal. Revista Científica Eletrônica de Psicologia: Olhares da psicologia sobre questões da atualidade, Garças, São Paulo, v. 30, n. 1, p.4-19, 2018. Semestral.

[16] Prodanov, C.C; Freitas, E.C. Metodologia do trabalho científico: métodos e Técnicas da Pesquisa e do Trabalho Acadêmico. 2. ed. Universidade Feevale - Novo Hamburgo, Rio Grande do Sul, 2013. Disponível em: <http://www.feevale.br/Comum/midias/8807f05a-14d0-4d5b-b1ad-1538f3aef538/E-

book\%20Metodologia\%20do\%20Trabalho\%20Cientifico.pdf> Acesso em: 22 jul. 2019.

[17] Sfair, S. C.; Bittar, M.; R. E. Educação sexual para adolescentes e jovens: mapeando proposições oficiais. Saúde Soc. São Paulo, v. 24, n. 2, p. 620-632, 2015.

[18] Silva, J. C. da; Araújo, A. D. de. A metodologia de pesquisa em análise do discurso. Grau Zero: revista crítica cultura, v. 5, n. 1, 2017. Disponível em: <https://www.revistas.uneb.br/index.php/grauzero/article/view/3492> Acesso em: 22 jul. 2019

[19] Silva, T. T. Documentos de identidade: uma introdução às teorias do currículo. 2. ed. Belo Horizonte: Autêntica, 2005.

[20] Tuzzo, S. A.; Braga, C. F. O processo de triangulação da pesquisa qualitativa: o metafenômeno como gênese. Revista Pesquisa Qualitativa, São Paulo, v. 4, n. 5, p. 140-158, dez. 2016. ISSN 2525-8222. Disponível em: <https://editora.sepq.org.br/index.php/rpq/article/view/38/31>. Acesso em: 22 jul. 2019. 
[21] Viana, A. J. B.; Sousa, E. S. S. O poder (in)visível da violência sexual: abordagens sociológicas de Pierre Bourdieu. Revista de Ciências Sociais. Fortaleza, v. 45, n. 2, p.155-183, 2014.

[22] Vicentin, S. C.; Valle, T. G. M. Relações familiares permeadas por violência sexual do pai contra a filha. In: Aprendizagem e desenvolvimento humano: avaliações e intervenções. São Paulo: 2009. p. 178-200. 


\section{Capítulo 7}

\section{A possibilidade de re(nascer): 0 caso das mulheres gestantes em uma unidade prisional em Minas Gerais}

\section{Juliana de Ávila Ferreira}

Cleide da Conceição Solano

Kátia Luciana Gonçalves Xavier

Raquel Quirino

Resumo: 0 artigo em apreço tem por objetivo descrever o nascimento, o desenvolvimento e maturação do Centro de Referência à Gestante Privada de Liberdade (MG). 0 ideário, sua fundação, os atores envolvidos estão em destaque, dado que se tornou um dos mais importantes empreendimentos no campo do sistema penitenciário nos anos 2000. Cuidar da gestante é cuidar da mulher esquecida, mas também da mulher mãe sempre lembrada pelo símbolo e pelo papel que representa. A privação de liberdade aparece como obstáculo a direitos invioláveis como do nascimento e da possibilidade de a mulher ser mãe. A mulher no cárcere recebe aqui o recorte de gênero, posto que o seu lugar no sistema é secundário e invisível aos olhos do modelo existente assentado no patriarcalismo e no poder masculino. Esse paradoxo é debatido ante o privilégio da mulher que, encarcerada, além de perder direitos é obrigada a assistir à privação de liberdade do infante recém-nascido, em desenvolvimento, ou por nascer. Finalmente, o artigo debate a crise do sistema, o aumento do aprisionamento das mulheres e as condições vexatórias pelas quais elas passam, lembrando que no sistema ainda são poucas as unidades femininas e, não raro, poucas são os(as) profissionais qualificados(as) para o atendimento desse público.

Palavras-chave: Crime, mulheres presas, instituições prisionais, gestantes encarceradas. 


\section{INTRODUÇÃO}

"Os muros. Ah, os muros!

Os muros da casa de dona Joana. 0 muro da escola. 0 muro que, há pouco, dividiu Brasília. 0 muro das prisões.

Ah, as prisões - Quantos muros representam prisões?

Mas os piores muros não são os de cimento e de tijolo, esses são facilmente derrubáveis - vejamos o de Berlim: de segregação à arte. Os piores muros são os sociais, os muros ideológicos, os muros culturais - os muros invisíveis aos ao Centro de Referência da Gestante Privada de Liberdade e ao Complexo Penitenciário Feminino Estevão Pinto, estabelecimentos prisionais visitados pelas autoras. A metodologia se assentou em dados e informações secundárias provenientes de órgãos olhos.

Reflitamos: quantas divisões? Quantas separações? Quanta segregação? Quantos muros ainda de pé?"

Colares $(2016)^{24}$

Primeiramente, cabe esclarecer que o presente artigo visa prestar uma contribuição ao debate sobre o sistema prisional brasileiro. 0 objetivo é traçar o panorama geral sobre o sistema prisional do país, tendo como enfoque principal as mulheres, especialmente as gestantes e nutrizes em situação de privação de liberdade em Minas Gerais. 0 trabalho é resultado de observações e documentos, sobretudo àqueles relacionados governamentais, bem como em normas, bibliografias e documentos a respeito do assunto.

Sem maiores digressões, é possível afirmar que o sistema penitenciário brasileiro, via de regra, acompanhado do termo "crise", tem se destacado nas produções acadêmicas e nos debates políticos contemporâneos. O Banco Nacional de Monitoramento de Prisoes (BNMP 2.0) 25 , mantido pelo Conselho Nacional de Justiça, revela que atualmente há mais de 860 mil pessoas privadas de liberdade no Brasil, entre internados, presos provisórios e condenados.

Em 2018, o então titular do Ministério da Segurança Pública, Raul Jungmann, avaliou que “superlotado e dominado pelo crime organizado, o sistema penitenciário brasileiro é o principal nó da segurança no país"26. Já em meados de 2019 os principais noticiários nacionais e internacionais registraram o saldo de mortos decorrentes de rebeliões ecludidas nas prisões do norte e nordeste do Brasil. 0 mais recente palco de violência foi Centro de Recuperação Regional de Altamira, localizado no Pará, no último dia 29 de julho, quando 58 presos morreram e, portanto, o maior massacre ocorrido em um mesmo estabelecimento desde o Carandiru em 1992, quando 111 presos foram assassinados.

Embora o sistema penitenciário brasileiro seja historicamente marcado pelo déficit de vagas, violência, precariedade da estrutura física e insalubridade de suas prisões, o destaque dado à crescente violência coletiva ocorridas nas prisões masculinas, potencializada pelas guerras entre de gangues e facções criminosas rivais, acabam por reduzir ainda mais o enfoque sobre as mais de 45 mil mulheres atualmente presas no Brasil27, relegando-as a uma certa "invisibilidade".

A invisibilização das mulheres na criminalidade e, por consequência no sistema prisional, não é recente. Michelle Perrot (2018, p. 272) ao relatar que na França de 1876 a 1880, entre os sessenta condenados à execução, nenhum era do sexo feminino, chama a atenção para certa 'indulgência' na balança da justiça.

Ao descrever sobre a hesitação de se condenar as criminosas e as delinquentes à morte, destaca que o pensamento da época é de que a mulher parecia menos ameaçadora e que sua criminalidade respondia à sua fragilidade e, ainda que o crime, o delito, eram assuntos de homem, atos virís na selva das cidades.

\footnotetext{
${ }^{24}$ André Felipe Vieira Colares (In memoriam), Mestre em Administração pela Universidade Federal de Minas Gerais e Professor Substituto na Universidade Federal de Ouro Preto.

25 Disponível em: https://portalbnmp.cnj.jus.br/\#/estatisticas. O Banco Nacional de Monitoramento de Prisões (BNMP 2.0) é um sistema eletrônico que auxilia as autoridades judiciárias da justiça criminal na gestão de documentos atinentes às ordens de prisão/internação e soltura expedidas em todo o território nacional, materializando um Cadastro Nacional de Presos. 0 banco de dados do BNMP é alimentado em tempo real pelas autoridades judiciais de todo país.

26 Disponível em: http://agenciabrasil.ebc.com.br/geral/noticia/2018-06/ministro-diz-que-sistema-penitenciario-eo-principal-no-da-seguranca

27 Número obtido em consulta ao BNMP 2.0.
} 
É fato, porém, que no Brasil até os anos 2000, quando o encarceramento feminino passou a chamar a atenção devido ao seu aumento exponencial, parece ter havido um certo consenso de que o crime era um "privilégio" dos homens, símbolo de virilidade, dado que o país tem origens patriarcais e machistas. Portanto, o poder masculino garantiu seu lugar em várias esferas da sociedade, inclusive na criminalidade. À mulher foi deixado o lugar da casa, o cuidado dos filhos e do companheiro. 0 julgamento das mulheres presas é, antes de tudo, moral.

A despeito de todas as conquistas feministas, em certa medida, todas as mulheres são prisioneiras. Cabe aqui citar a ilustre Audre Lorde 28 , que nos ensina: "não serei livre enquanto alguma mulher for prisioneira, mesmo que as correntes dela sejam diferentes das minhas".

Todavia, a reprodução da construção social existente sobre os papéis atribuídos aos homens e às mulheres, mostram a face mais perversa do sistema prisional, diretamente refletida na origem histórica das prisões femininas no Brasil, norteadas por um discurso moral e religioso nas formas de aprisionamento da mulher, conforme destaca Andrade (2011) em sua pesquisa sobre o surgimento dos presídios femininos no Brasil, que será objeto de breve explanação ao longo deste trabalho.

\section{PRESAS DO BRASIL: O QUE DIZEM OS NÚMEROS OFICIAIS?}

O Departamento Penitenciário Nacional (DEPEN), nos termos da Lei n. 7.210/84, denominada Lei de Execução Penal (LEP), é o órgão executivo da política penitenciária nacional. No âmbito do poder executivo $^{29}$, os dados oficiais sobre o tema são de responsabilidade do DEPEN, quem os divulga periodicamente com a publicação dos relatórios INFOPEN ${ }^{30}$ e INFOPEN Mulheres.

O INFOPEN Mulheres (2018) mostra que no Brasil há $726.712^{31}$ indivíduos privados de liberdade, considerando os dados referentes ao mês de junho de 2016. No mesmo relatório é possível verificar que, em números absolutos, o Brasil possui a terceira maior população carcerária mundial, atrás dos Estados Unidos (2.145.100) e da China (1.649.804).

No que se refere às mulheres encarceradas o Infopen Mulheres (2018) revela que entre 2000 e 2016, a população carcerária feminina brasileira aumentou de 5.601 para 42.355 detentas. Em termos internacionais, em números absolutos, o Brasil ocupa a quarta posição, atrás dos Estados Unidos (211.870), China (107.131) e Rússia (48.478).

Contudo, muito embora as mulheres representem $5,64 \%$ das pessoas presas nos país, o levantamento governamental aponta que elas foram mais encarceradas do que os homens entre os anos 2000 e 2016. A população feminina em privação de liberdade cresceu mais do que o dobro em relação a masculina, cujo aumento foi de 293\%, passando de 169 mil homens encarcerados em 2000 para 665 mil em 2016, enquanto que o número de mulheres encarceradas aumentou em $656 \%$ nos mesmos 16 anos.

No cenário nacional, a população prisional total de Minas Gerais é a segunda no ranking, com cerca de 9,41\% do total, equivalente a 68.354 indivíduos, atrás de São Paulo que conta com 33,03\% dos presos do país, correspondente a 240.061 presos.

Quanto às população carcerária feminina, Minas Gerais se mantém igualmente na segunda posição com $3.279(7,74 \%)$ mulheres privadas de liberdade, novamente antecedida por São Paulo que possui 15.104 $(35,66 \%)$.

\footnotetext{
${ }^{28}$ Nascida Audrey Geraldine Lorde (18/02/1934 -17/11/1992) foi uma escritora caribenha-estadunidense, poeta e ativista. Descrevia a si mesma como Negra, Lésbica, Feminista, também "Guerreira" e "Mãe". Escreveu diversos ensaios em questões como racismo, feminismo, sexualidade.

${ }^{29}$ No âmbito do poder judiciário, existe o painel BNMP 2.0, ferramenta on-line mantida pelo Conselho Nacional de Justiça, atualizado em tempo real pelos órgãos judiciais do Brasil. Todavia, na construção dessa sessão foram considerados os relatórios INFOPEN 2016 e o INFOPEN Mulheres 2018, ambos foram elaborados com base em dados referentes a junho de 2016. Não obstante, optou-se por utilizá-los como fonte de pesquisa devido ao detalhamento que contém, diferentemente do painel no BNMP 2.0 que possui dados atualizados em tempo real, porém de caráter mais generalista.

30 Criado em 2004, o INFOPEN - Levantamento Nacional de Informações Penitenciárias - compila informações estatísticas do sistema penitenciário brasileiro, por meio de um formulário de coleta estruturado preenchido pelos gestores de todos os estabelecimentos prisionais do país.

${ }^{31}$ Este número não inclui as centrais e núcleos de monitoração eletrônica (tornozeleira eletrônica) e nem prisões domiciliares.
} 
Em que pese a distinção entre estabelecimentos prisionais em masculinos e femininos no Brasil prevista na LEP, ainda há muitos presídios considerados mistos espalhados pelo país. De acordo com os microdados do INFOPEN 2016, disponibilizados pelo Ministério da Justiça e Segurança Pública há 1.443 estabelecimentos penitenciários no país sob gestão direta dos estados e União. Destes, 95 são destinados ao encarceramento de presas, 1.070 aos presos e 278 são mistos, ou seja, abrigam presos de ambos os sexos. Isso significa que pelo menos $74,15 \%$ das unidades prisionais brasileiras são voltadas somente para homens, enquanto $19,27 \%$ são mistas e apenas 6,58\% são destinadas exclusivamente a mulheres.

\section{BREVE HISTORICIZAÇÃO DO ENCARCERAMENTO FEMININO EM MINAS GERAIS}

A criação de estabelecimentos prisionais destinados à mulheres é relativamente recente. Legalmente houve tal exigência a partir da edição do Código Penal Brasileiro de 1940, a saber:

Art. 29. A pena de reclusão e a de detenção devem ser cumpridas em penitenciária, ou, à falta, em secção especial de prisão comum (...)

$\S 2^{\circ}$ As mulheres cumprem pena em estabelecimento especial, ou, à falta, em secção adequada de penitenciária ou prisão comum, ficando sujeitas a trabalho interno

No Brasil, os estados pioneiros no que se refere à criação de estabelecimentos penais destinados a mulheres foram Rio Grande do Sul (1937), Rio de Janeiro (1942) e São Paulo (1942), conforme destaca Andrade (2011).

A autora apontou que o primeiro deles, fundado em Porto Alegre/RS, era liderado pelas freiras da Congregação Nossa Senhora da Caridade do Bom Pastor ${ }^{32}$ e teve como denominação inicial 'Instituto Feminino de Readaptação Social', atual Penitenciária Madre Pelletier.

A primeira penitenciária feminina de Minas Gerais nasceu mais tardiamente. Com a aprovação da Lei no 260, de 05 de 194833, foi criada a "Penitenciária de Mulheres" em Belo Horizonte/MG, bem como disponibilizado recurso financeiro para inicio de sua construção.

Anteriormente, Lemos Britto (1925) relata que havia em Minas Gerais apenas uma prisão com o título de Penitenciária, a de Ouro Preto/MG e uma Cadeia Regional em Uberaba/MG, além de 156 cadeias públicas. De acordo com Câmera (1951), até 1827 os detentos em Minas Gerais estavam distribuidos nas centenas de cadeias espalhadas pelo Estado, todas em péssimas condições de higiene.

Câmara (1951) relata que em 31 de dezembro de 1949, existia nas diversas prisões do Estado um total de 2.344 homens e 62 mulheres. Específicamente, para abrigar as mulheres eram utilizadas as cadeias de Sabará e a de Tiradentes, "apesar de oferecem péssimas condições de higiene, lamentavelmente desprovidas do mínimo conforto necessário à vida miserável das sentenciadas". (ibdem, p. 122).

Em consonância com Câmera, em 1953, o Jornal Manchete publicou sobre Cadeia de Sabará, sob o título "Gangsters de farda' violentam mulheres", que trouxe à tona as péssimas condições estruturais daquela prisão e denunciou, dentre outras coisas, que os policiais que cuidavam do cárcere à época sorteavam as mulheres presas para estuprá-las à noite. Na ocasião a Cadeia de Sabará, chamada de "Penitenciária dos Horrores", a reportagem expôs ainda a fotografia de um bebê de 14 dias que havia nascido na prisão e a reclamação das mães chorosas por remédios.

Diante do exposto, não há dúvidas de que a criação da Penitenciária de Mulheres, à época, foi um marco na políticas públicas de encarceramento feminino, face às condições as quais eram submetidas. Todavia, passadas mais de sete décadas, a Penitenciária de Mulheres, atualmente denominada "Complexo Penitenciário Feminino Estevão Pinto" ainda é a única penitenciária feminina do estado de Minas Gerais.

Na listagem obtida junto à Secretaria de Justiça e Segurança Pública (SEJUSP), via Lei de acesso à informação (protocolo n 01451.000041/2019-79), foi verificada a existência de apenas outros 5 estabelecimentos prisionais exclusivamente femininos, porém são presídios, ou seja, em relação ao INFOPEN 2016, uma unidade feminina foi extinta nos últmos 3 anos.

de Nossa Senhora da Caridade do Bom Pastor é uma irmandade religiosa fundada em 1835 por Maria Eufrásia Pelletiernum, com sede em Angers (França).

33 Disponível em: < $33 \quad$ A Congregação https://www.almg.gov.br/consulte/legislacao/completa/completa.html?tipo=LEI\&num=260\&comp=\&ano=1948\&aba =js_textoAtualizado\#texto>. Acesso em 05 de set. 2019. 


\section{O SISTEMA PRISIONAL MINEIRO E SUAS PRESAS}

Em Minas Gerais, de acordo os microdados do INFOPEN 2016 há $205^{34}$ unidades prisionais dispersas pelo estado, sendo apenas 3,4\% (7) delas destinadas exclusivamente às presas, $54,63 \%$ (112) mistas e os demais 41,95\% (86) abrigam presos do sexo masculino. Ainda sobre as unidades femininas em Minas Gerais, consta que a capacidade das unidades femininas era para apenas 740 presas e nas mistas 1.698. Portanto, a capacidade do sistema prisional mineiro em 2016, dada base dos relatórios consultados, estava limitada a 2.438 mulheres presas, enquanto abrigava 3.373, conforme gráfico a seguir:

Gráfico 1 - População carcerária feminina de Minas Gerais (2008-2019)

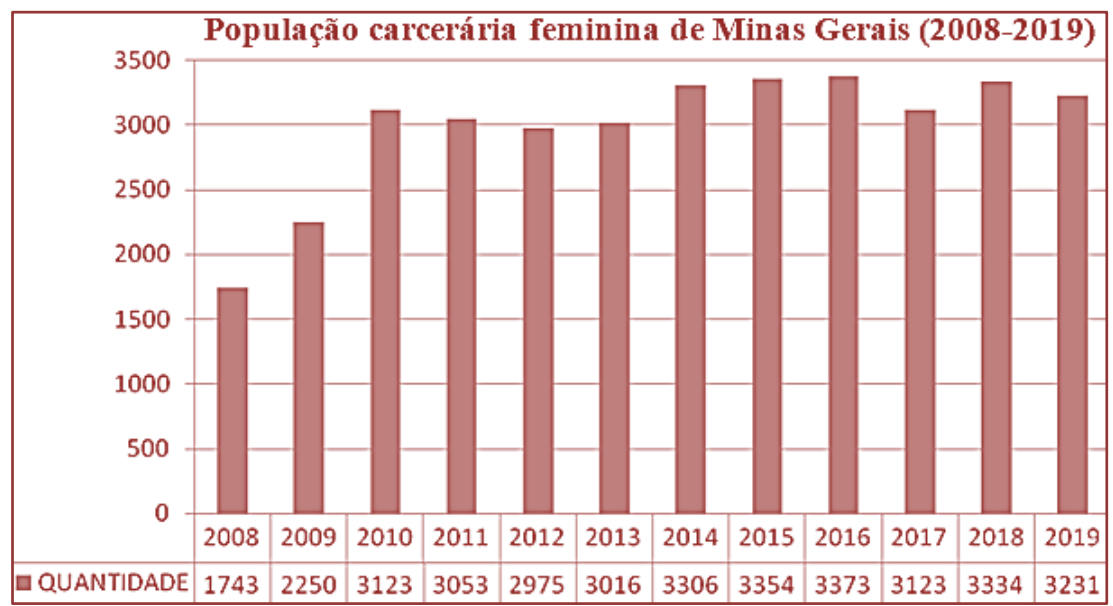

Fonte: elaborado pelas autoras a partir de dados obtidos junto à SEJUSP/MG, via Lei de acesso à informação (protocolo n 01451.000041/2019-79) ${ }^{35}$

A partir dessas informações é possível inferir que provavelmente ${ }^{36}$ cerca de $70 \%$ das mulheres encarceradas em Minas Gerais estão em estabelecimentos prisionais mistos. No artigo publicado por Colares e Chies (2010) os autores definiram deste tipo de prisão como "masculinamente mistos", ao destacarem:

A própria utilização dessa categoria - presídios masculinamente mistos envolve o recurso estratégico de manutenção da ambiguidade verificada nesses estabelecimentos prisionais, ou seja, encarcera objetivamente ambos os sexos num mesmo conjunto arquitetônico (logo, são mistos), mas sobrepõe ao feminino uma orientação androcêntrica nas práticas e nas dinâmicas carcerárias. (Colares e Chies, 2010, p. 408). (grifo das autoras)

A pesquisa de Colares e Chies (2010) foi realizada no Rio Grande do Sul, sob o pano de fundo do aumento do encarceramento feminino nos últimos anos, bem como o improviso institucional para enfrentá-lo.

Os autores do supracitado trabalho acadêmico se propuseram a investigar se as "invisibilidades femininas no cárcere masculino é algo decorrente da sua coexistência com presos homens ou se está diante de algo mais estrutural, ou seja, a prisão em si é masculina e masculinizante em todas as suas práticas, sejam essas dirigidas a quem for." (ibdem, p. 408). Os autores concluíram, dentre outros, que:

A punição para as mulheres se amplia na medida em que o aparelho prisional, além de obscurecer a presença feminina, desconsiderando suas necessidades específicas, com vistas ao condicionamento de seu

\footnotetext{
${ }^{34}$ Atualmente, conforme dados obtidos junto ao Observatório da SEJUSP há 194 unidades prisionais em Minas Gerais. Algumas unidades foram extintas nos últimos dois anos e os presos remanejados para outros estabelecimentos no estado.

$35 \mathrm{Na}$ ocasião do envio dos dados foi esclarecido que de 2004 a 2006 só existe um Mapa Carcerário dispoonível, de 2007 a 2018 foi utilizado o Mapa Carcerário do meio de cada ano (1ํㅡapa de julho)

36 Não é possível afirmar o percentual exato de presas encarceradas nos presidios mistos e/ou femininos pois os dados sobre a quantidade exata de mulheres em cada uma das unidades, ou seja, lotação efetiva não foi informada pela SEJUSP/MG.
} 
comportamento, utiliza-se do corpo feminino como dispositivo de controle do corpo masculino.(...)

Os presídios estudados, embora abriguem mulheres, são instituições cujas dinâmicas estão permanentemente associadas à sustentação da moralidade e da sexualidade viril. Essa condição acarreta práticas administrativas perversas por reafirmar 'o outro', a presença masculina, como princípio de orientação das intervenções formais, secundarizando e invisibilizando as mulheres em seus espaços. Para assegurar esse fim, são amplificadas as carências e as interdições sobre o corpo feminino, o que impõe às mulheres cargas adicionais de inseguranças e sofrimentos. (Colares e Chies, 2010, p. 421) (grifos nossos).

A LEP prevê também que "os estabelecimentos penais destinados a mulheres serão dotados de berçário, onde as condenadas possam cuidar de seus filhos, inclusive amamentá-los, no mínimo, até 6 (seis) meses de idade". Consultando novamente os microdados INFOPEN 2016, salta aos olhos constatar que apenas uma das 112 unidades prisionais mistas de Minas Gerais possui celas adequadas/dormitórios para gestantes e nenhuma possui berçário, unidade materno-infantil ou creche. Observando os sete estabelecimentos prisionais femininos mineiros os dados são mais estarrecedores, pois apenas duas delas contam com celas adequadas/dormitórios para gestantes, apenas uma possui berçário e nenhuma delas dispõe de creche. Portanto, é possível inferir que o estado de Minas Gerais não tem cumprido a legislação retrocitada. Seriam as presas mineiras prejudicadas do convívio com seus filhos nos termos da legislação vigente!? Indagamos isso, visto que apenas uma unidade possui berçário. Isso significa que as nutrizes, possivelmente em sua maioria, ficam mais distantes da sua família durante um período tão delicado quanto é o primeiro semestre da maternidade. Assim, indaga-se: quantas são as "condenações" as quais as mulheres encarceradas estão sujeitas!?

Em declaração recente a ministra Carmém Lúcia sobre as crianças que nascem nas prisões: "A Lei do Ventre Livre é de 1.871 e nós continuamos a ter brasileirinhos nascendo em penitenciárias sem ter feito nada. A minha preocupação é que eles nasçam e permaneçam em uma penitenciária, porque eles não têm o que pagar", concluiu a ministra. (Em reportagem publicada pela Agência Brasil 23/06/2018 ${ }^{37}$ ).

Especificamente sobre as crianças que "nascem" nas prisões, em Minas Gerais há um estabelecimento penitenciário especial, denominado Centro de Referência da Gestante Privada de Liberdade, que abriga gestantes e nutrizes acompanhadas de seus filhos até um ano de idade. Embora seja apenas uma unidade do tipo, se constituiu como um divisor de águas no tratamento penal. A unidade terá uma sessão dedicada ao longo desse trabalho.

\section{PERFIL DA POPULAÇÃO CARCERÁRIA FEMININA DE MINAS GERAIS}

Conforme já relatado, o aumento do encarceramento feminino no Brasil passou a ganhar notoriedade a partir dos anos 2000, quando o número de mulheres privadas de liberdade evoluiu mais rapidamente que os homens, em termos percentuais. Entre 2000 e 2016 a população carcerária femininas passou de 5.601 para 42.355 (INFOPEN Mulheres 2018), ou seja, um crescimento de quase oito vezes, conforme também foi divulgado pelo CNJ em $2017{ }^{38}$.

Até então, as mulheres que representam pouco mais de $5 \%$ das pessoas presas nos país, em certa medida, passavam despercebidas nas estatistíticas, pois se constituíam em um grupo pequeno nas amostras sobre a criminalidade. Comparando os dados do INFOPEN 2016 no ano 2000 e as informações que constam no BNMP 2.0, nos últimos 20 anos a população carcerária do masculina do aumentou em 383,42\%, enquanto a feminina em $709,80 \%$.

Assim, pode-se argumentar que as mulheres foram subestimadas nas estatísticas criminais e que toda criminologia tem por alicerce o homem delinquente. Contudo, na sociedade contemporânea, assistimos mudanças do perfil de quem está enclausurado(a).

Sabemos que hoje prendemos mais jovens, mais negros e mais pobres. Atualmente, é possível acrescentar nas estatísticas as mulheres que, encarceradas, em sua grande maioria é solteira, jovem e negra. Tais

\footnotetext{
37 Disponível em: http://agenciabrasil.ebc.com.br/geral/noticia/2018-06/ministro-diz-que-sistema-penitenciario-eo-principal-no-da-seguranca

${ }^{38}$ https://www.cnj.jus.br/numero-de-mulheres-presas-multiplica-por-oito-em-16-anos/.
} 
afrmações foram constatadas entre homens e mulheres mineiros, conforme demonstram os dados dos gráficos a seguir:

Gráfico 2 - População carcerária de Minas Gerais (2019) Percentual por sexo e faixa etária

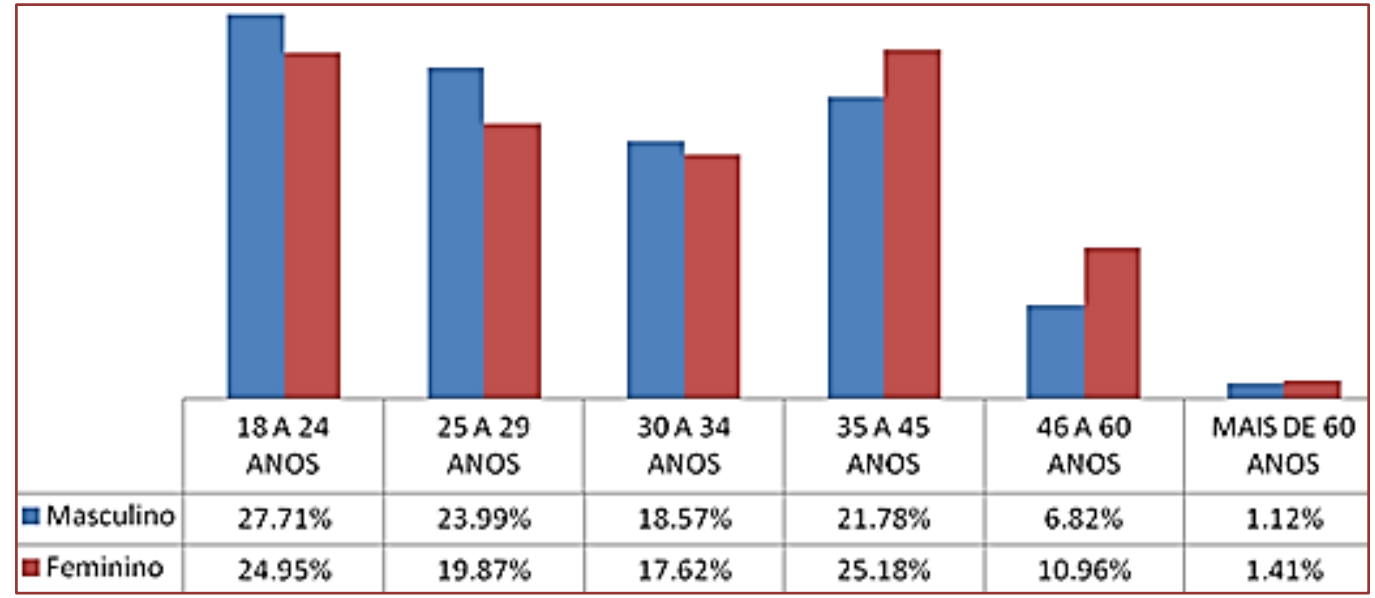

Fonte: elaborado pelas autoras a partir de dados obtidos junto à SEJUSP/MG, via Lei de acesso à informação (protocolo n 01451.000041/2019-79)

Gráfico 3 - População carcerária de Minas Gerais (2019)Percentual por sexo e escolaridade

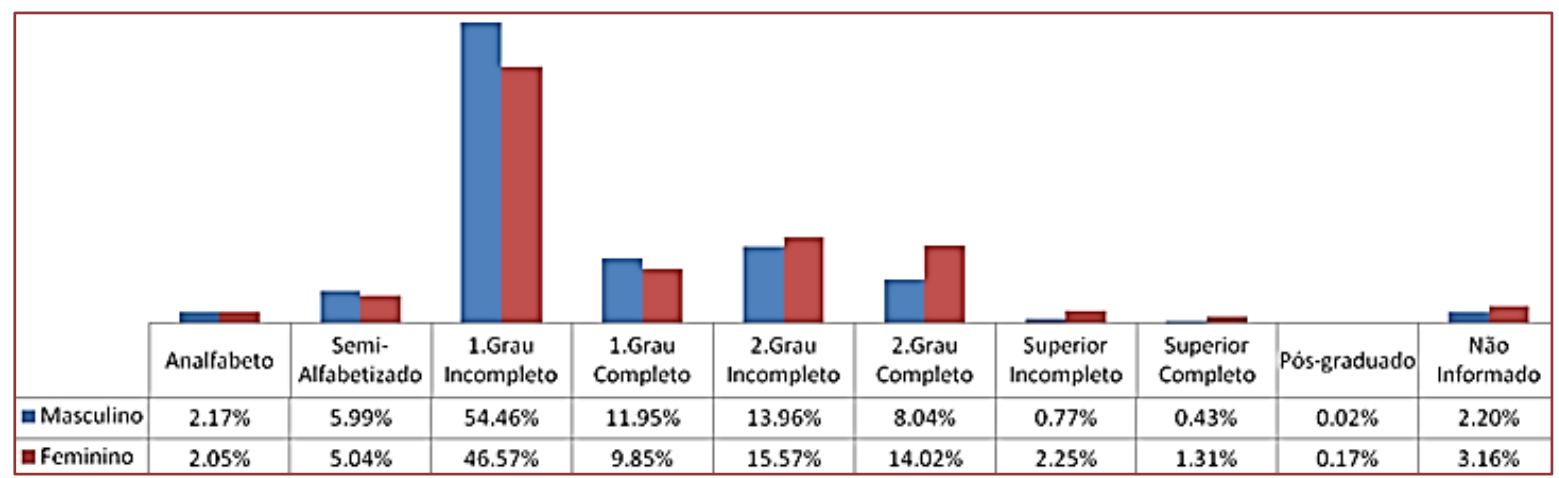

Fonte: elaborado pelas autoras a partir de dados obtidos junto à SEJUSP/MG, via Lei de acesso à informação (protocolo n 01451.000041/2019-79)

Gráfico 4 - População carcerária de Minas Gerais (2019)Percentual por sexo e cor da cútis

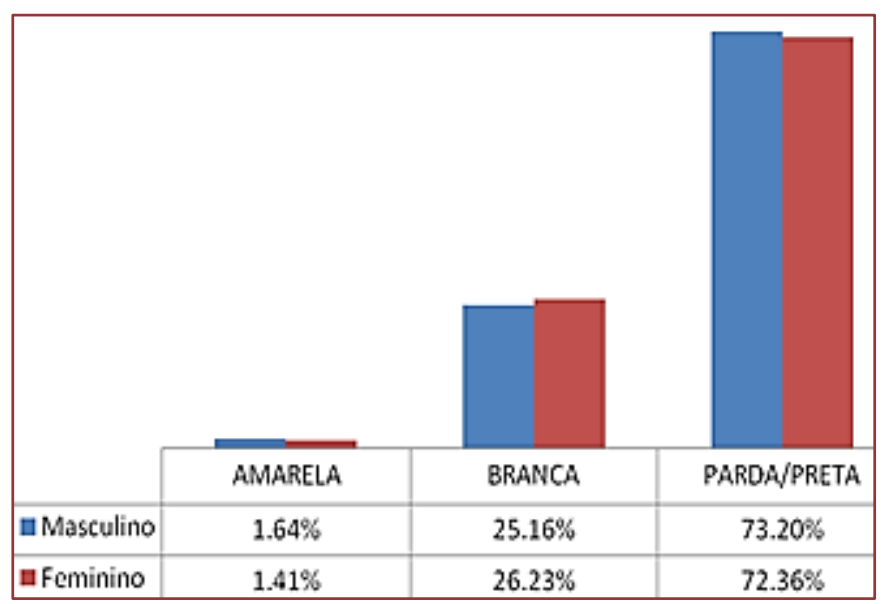

Fonte: elaborado pelas autoras a partir de dados obtidos junto à SEJUSP/MG, via Lei de acesso à informação (protocolo n 01451.000041/2019-79) 
Gráfico 5 - População carcerária de Minas Gerais (2019)Percentual por sexo e estado civil

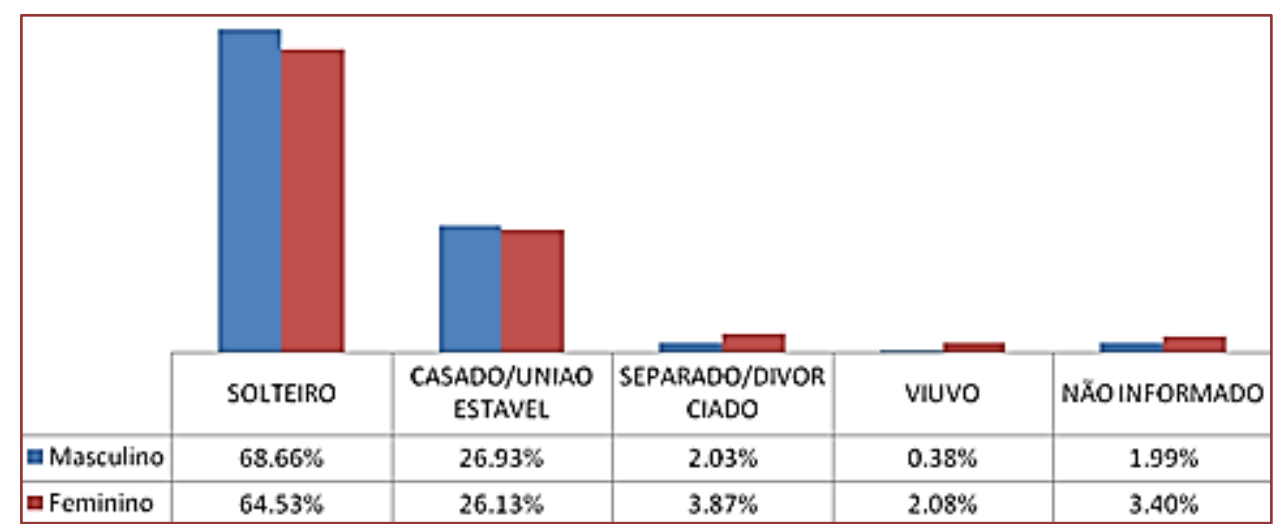

Fonte: elaborado pelas autoras a partir de dados obtidos junto à SEJUSP/MG, via lei de acesso à informação (protocolo n 01451.000041/2019-79)

Conforme pode ser verificado nos dados apresentados, a maioria dos presos mineiros, sejam eles homens $(51,70 \%)$ ou mulheres $(44,82 \%)$, tem até 29 anos. Quanto à escolaridade, constatamos que $62,66 \%$ dos homens e $53,66 \%$ das mulheres possuem até o primeiro grau incompleto (ensino fundamental). No que se refere à cor da cútis, mais de $70 \%$ das pessoas presas são pretas ou pardas. Por fim, no que se refere ao estado civil, foi verificado que a maioria deles são solteiros, sendo $68,66 \%$ dos homens e $64,53 \%$ das mulheres presas. Portanto, não se trata de uma falácia afirmar que existe uma seletividade no sistema prisional, visto que os presos são em sua maioria jovens, com baixa escolaridade, negros e solteiros.

Fechando esta sessão, é oportuno lembrar que segundo Michelle Perrot no livro denomominado 'Os exluidos da História', "feita para punir, mas também para reitengrar os delinquentes à sociedade, corrigir os costumes dos detentos, a fim de que seu retorno à liberdade não seja uma desgraça nem para a sociedade e nem para eles mesmos, a prisão acaba por excluí-los. (PERROT, 2018, p. 254).

\section{CENTRO DE REFERÊNCIA DA GESTANTE PRIVADA DE LIBERDADE - 0 INÍCIO}

Após descrever o perfil dos presos brasileiros e mineiros, a explanação se dará sobre o Centro de Referência da Gestante Privada de Liberdade (CRGPL), desde a sua idealização, inauguração e descrição do quadro atual de funcionário e perfil das presas.

Inaugurado no dia 21 de janeiro de 2009, o CRGPL, situado em Vespasiano/MG, é uma unidade prisional que abriga exclusivamente presas grávidas a partir do sétimo mês de gestação e aquelas com filhos de até um ano.

0 funcionamento da unidade teve início às vésperas da sua inauguração, quando recebeu a transferência de 45 (quarenta e cinco) presas da Penitenciária Industrial Estevão Pinto ${ }^{39}$, sendo seis grávidas e trinta e nove mães com os respectivos bebês.

O CRGPL, se comparado aos modelos tradicionais de penitenciárias ou presídios femininos do Brasil, oferece condições físicas e disciplinares diferenciadas, pois não há celas com grades e cadeados, as portas internas ficam abertas e as presas podem circular pelo espaço com seus filhos. Tal diferenciação foi ressaltada pelo então Secretário de Estado de Defesa Social na cerimônia de inauguração da seguinte forma: "no lugar de celas, grandes quartos com camas, berços e até alguns 'mimos' como shampoos, sabonetes e hidratantes infantis".

Outro detalhe que fez do ambiente do CRGPL diferenciado e mais leve, foi a inscrição em uma das paredes externas do imóvel da célebre e inspiradora frase da escritora Cecília Meireles: "Liberdade é uma palavra que o sonho humano alimenta; não há ninguém que explique e ninguém que não entenda".

Outra inovação do CRGPL foi no quesito quadro de servidores que laborariam na unidade. Além da equipe multisciplinar específica, formada por pediatra, ginecologista, dentista, psicólogas, assistentes sociais,

\footnotetext{
${ }^{39}$ Atualmente denominado Complexo Pentencário Feminino Estévão Pinto.
} 
terapeuta ocupacional e analista técnico jurídico, todas as servidoras da equipe segurança, ou seja, as agentes de segurança penitenciárias, eram também técnicas em enfermagem. Modelo único no país nesse quesito!

Tal diferencial possibilitou um pronto-atendimento em casos de emergência e demandas pré ou pós-parto, pois além disso, as agentes de segurança penitenciárias também foram habilitadas para orientarem as mães sobre os cuidados com os recém-nascidos, amamentação, cura do umbigo e no tratamento de doenças de menor gravidade em crianças de até um ano.

Sobre a categoria profissional, agente de segurança penitenciário, cabe aqui ressaltar que as funções desempenhadas por aquelas servidoras selecionadas para laborar no âmbito do CRGPL vão muito além das atribuições legais previstas na Lei no 14.695 de 30/07/2003, no seu artigo 6oㅡ, a saber:

Art. 6o - Compete ao Agente de Segurança Penitenciário:

I - garantir a ordem e a segurança no interior dos estabelecimentos penais;

II - exercer atividades de escolta e custódia de sentenciados;

III - desempenhar ações de vigilância interna e externa dos estabelecimentos penais, inclusive nas muralhas e guaritas que compõem suas edificações.

$\S 1$ o 0 Agente de Segurança Penitenciário fica autorizado a portar arma de fogo fornecida pela administração pública, quando em serviço, exceto nas dependências internas do estabelecimento penal.

Um dos idealizadores do projeto, ainda na inauguração ressaltou que "a grande diferença está na equipe técnica, especificamente treinada na área de saúde, e no ambiente, menos pesado que o de uma prisão convencional. Com isso, demos um salto no que diz respeito ao acautelamento de gestantes".

Em entrevista concedida à época, o Subsecretário de Administração Prisional, o senhor Genilson Ribeiro Zeferino, considerou que o Centro de Referência representaria um marco no aprisionamento de mulheres em Minas Gerais, e afirmou: "O que vamos fazer aqui é uma evolução do que desenvolvíamos na Penitenciária Estevão Pinto, onde mães e bebês ficavam antes desta inauguração".

De fato, o projeto foi um divisor de águas na política de encarceramento de gestantes e nutrizes privadas de liberdade em Minas Gerais. Tanto foi assim, que em 2011 a unidade teve a sua capacidade de atendimento duplicada, passando a comportat até 80 presas $^{40}$.

\section{0 CENTRO DE REFERÊNCIA À GESTANTE PRIVADA DE LIBERDADE - DEZ ANOS DEPOIS}

A unidade já funciona há mais de uma década e, aparentemente, continua colhendo bons frutos. De acordo com o relatório estatístico denominado 'Visita às mulheres grávidas e lactantes privadas de liberdade (2018)', consta que "em Minas Gerais as gestantes e lactantes de todas as regiões do estado são concentradas no Centro de Referência à Gestante Privada de Liberdade". 0 CRGPL foi descrito no referido relatório da seguinte forma:

A unidade destina-se exclusivamente à custódia de presas grávidas e lactantes e não possui grades separando os alojamentos coletivos, privilegiando a convivência entre mães e filhos lactantes.

0 estabelecimento concentra as presas grávidas e lactantes de todo o Estado.

A concentração dificulta o contato das mulheres com suas famílias e seus outros filhos, em função do tamanho do Estado.

Portanto, a unidade se manteve fiel ao seu propósito de criação e, à priori, atende a 100\% da demanda do estado de Minas Gerais. Todavia é importante ressaltar que ainda assim, sempre operou abaixo da sua capacidade, conforme constatado no gráfico a seguir:

${ }^{40}$ http://www.seap.mg.gov.br/index.php/imprensa/banco-de-noticias/1096-centro-de-referencia-a-gestante-privadade-liberdade-amplia-capacidade-com-inauguracao-de-nova-ala 
Gráfico 6 - Evolução da população carceráriaCentro de Referência da Gestante Privada de Liberdade (2009-2019)

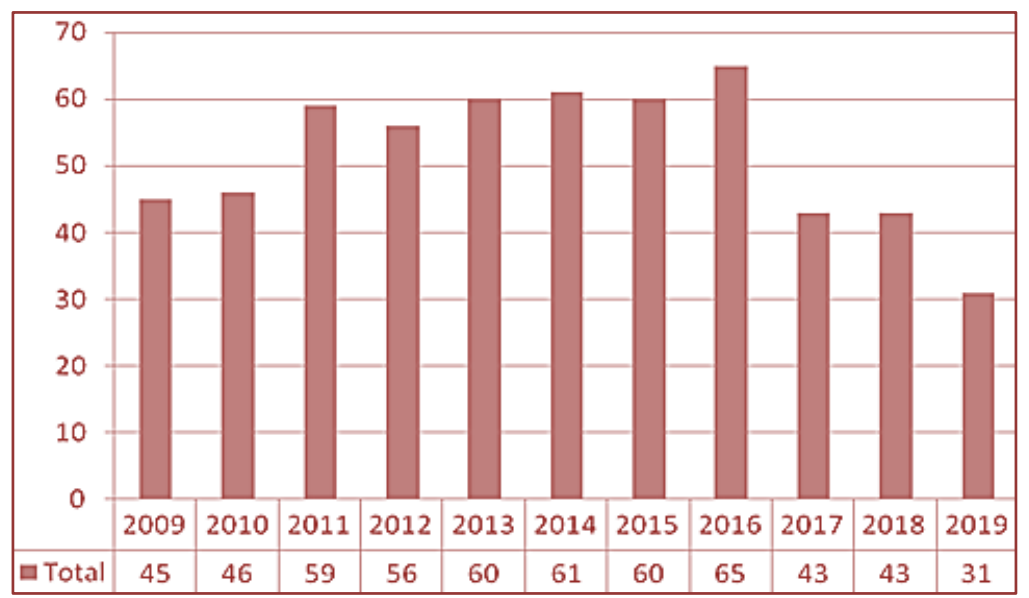

Fonte: elaborado pelas autoras a partir de dados obtidos junto à SEJUSP/MG, via Lei de acesso à informação (protocolo n. 01451.000041/2019-79)

Observando os períodos em que houve uma grande redução no quantitativo médio de presas no CRGPL, especialmente a partir de 2017. Coincide com esse período Lei 13.257/2016, que deu nova redação ao artigo 317 do Código de Processo Penal, da seguinte forma:

317. A prisão domiciliar consiste no recolhimento do indiciado ou acusado em sua residência, só podendo dela ausentar-se com autorizacao judicial.(...)

V - Mulher com filho de até 12 (doze) anos de idade incompletos.

A lei supracitada possui certa relação com a regra 52 de Bangkok, cuja redação é a seguinte: "A decisão do momento de separação da mãe de seu filho deverá ser feita caso a caso e fundada no melhor interesse da criança, no âmbito da legislação nacional pertinente". Portanto, o foco principal se dá sobre a criança, apesar de beneficiar diretamente a mãe. Todavia, por falta de estudos complementares, a possibilidade de prisão domiliciar é apenas uma hipótese provisória a ser estudada para explicar a redução da quantidade média de mulheres acauteladas no CRGPL nos últimos anos.

Com a redução de demanda e apesar do êxito na implementação do CRGPL, há notícias de que a unidade poderá ser fechada, conforme divulgou o G1 Minas em seu portal de notícias na internet ${ }^{41}$. Na reportagem publicada em 11/12/2019, sob o título: "Única unidade prisional exclusiva para grávidas e lactantes de MG pode fechar as portas na Grande BH: governo analisa mudança do Centro de Referência da Gestante para um presídio a um custo mais baixo". Em nota, a SEJUSP negou que o local será desativado, mas reconheceu que a mudança de Vespasiano "para outra unidade prisional com a estrutura física mais adequada, mais próxima da região hospitalar e a um custo de custódia e atendimento bem mais baixo para o Estado", está em análise.

A supracitada matéria jornalística relatou que uma reforma já havia sido realizada no Complexo Penitenciário Feminino Estevão Pinto, mas a transferência das presas do CRGPL foi vetada pela Justiça. De acordo com o juiz, Dr. Marcelo Augusto Lucas Pereira, o espaço reformado está longe de atender as exigências legais e “(...) para ser sincero, é um arremedo de centro de mulheres grávidas", disse o mesmo ao falar da obra na Estevão Pinto. Em nota, a SEJUSP alegou que atualmente apenas 38\% das vagas do Centro estão ocupadas, "não justificando sua locação no prédio atual devido aos custos de manutenção do espaço" e que "a política de dispor um espaço à gestante em cumprimento de sentenças judiciais será mantida na sua integralidade".

A seguir é descrito o quadro de servidores atualmente lotados no CRGPL:

\footnotetext{
${ }^{41}$ https://g1.globo.com/mg/minas-gerais/noticia/2019/12/11/unica-unidade-prisional-exclusiva-paragravidas-e-lactantes-de-mg-pode-fechar-as-portas-na-grande-bh.ghtml
} 


\begin{tabular}{|c|c|c|c|c|}
\hline \multicolumn{5}{|c|}{ Quadro de servidores - crgpl } \\
\hline Grupo & Cargo & Feminino & Masculino & Total \\
\hline Direção & Diretor & 2 & 1 & 3 \\
\hline Seguranca & $\begin{array}{l}\text { Agente de seguranca } \\
\text { penitenciario }\end{array}$ & 42 & 17 & 59 \\
\hline \multirow{8}{*}{$\begin{array}{c}\text { Técnicos e } \\
\text { administrativos }\end{array}$} & Advogado & & 1 & 1 \\
\hline & $\begin{array}{l}\text { Assistente } \\
\text { administrativo }\end{array}$ & 2 & 1 & 3 \\
\hline & Assistente social & 1 & & 1 \\
\hline & Enfermeiro & 1 & 1 & 2 \\
\hline & Odontologo & 1 & & 1 \\
\hline & Pedagogo & 1 & & 1 \\
\hline & Psicologo & 1 & & 1 \\
\hline & Técnico de enfermagem & 4 & & 4 \\
\hline Total & & 55 & 21 & 76 \\
\hline
\end{tabular}

Fonte: portal da transparência de mg - acesso em 20/08/2019

Conforme pode ser observado, atualmente o CRGPL já não conta com médicos em seu quadro de servidores e nem terapeuta ocupacional. Tal situação foi anteriormente registrada no relatório do CNJ 'Visita às mulheres grávidas e lactantes privadas de liberdade' (2018, p. 52), da seguinte forma: "não tem médico de qualquer especialidade. Algumas mulheres se queixaram da falta de atendimento médico para si e para seus filhos".

Dando seqüência nessa sessão, questiona-se: qual é o perfil das gestantes e nutrizes atualmente acauteladas no CRGPL? Para responder a essa pergunta, são apresentados os gráficos a seguir:

Gráfico 7 - CRGPL - Presas por faixa etária (2019)

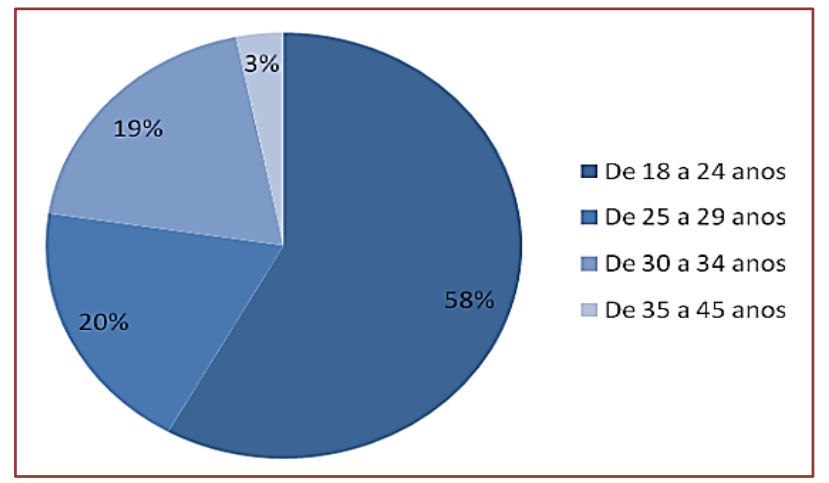

Gráfico 8 - CRGPL - Escolaridade das presas (2019)

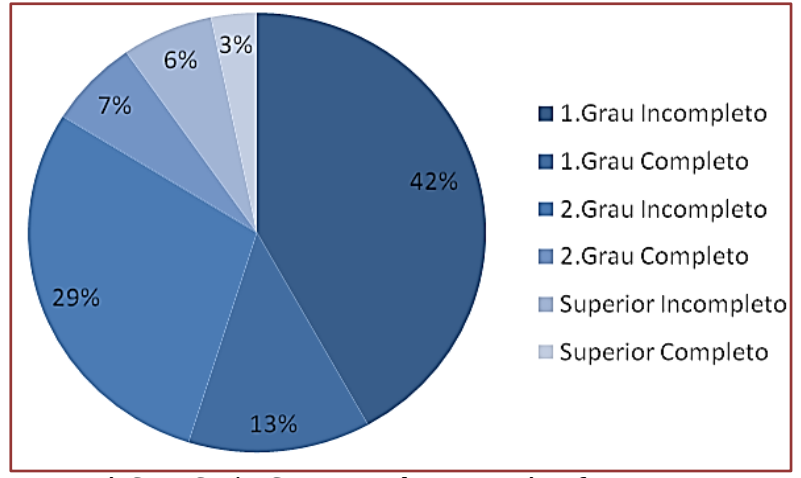

Fonte: elaborado pelas autoras a partir de dados obtidos junto à SEJUSP/MG, via Lei de acesso à informação (protocolo n 01451.000041/2019-79)

Conforme gráfico apresentado e adotando o conceito de jovem constante no estatuto da juventude (Lei n. $12.852 / 2013)$, conclui-se que a maioria das presas gestantes e nutrizes do sistema prisional de Minas Gerais, $78 \%$ são jovens, ou seja possuem até 29 anos. Quanto a escolaridade, pelo menos $42 \%$ delas possuem o ensino fundamental incompleto (antigo 1. Grau), portanto baixa escolaridade. 

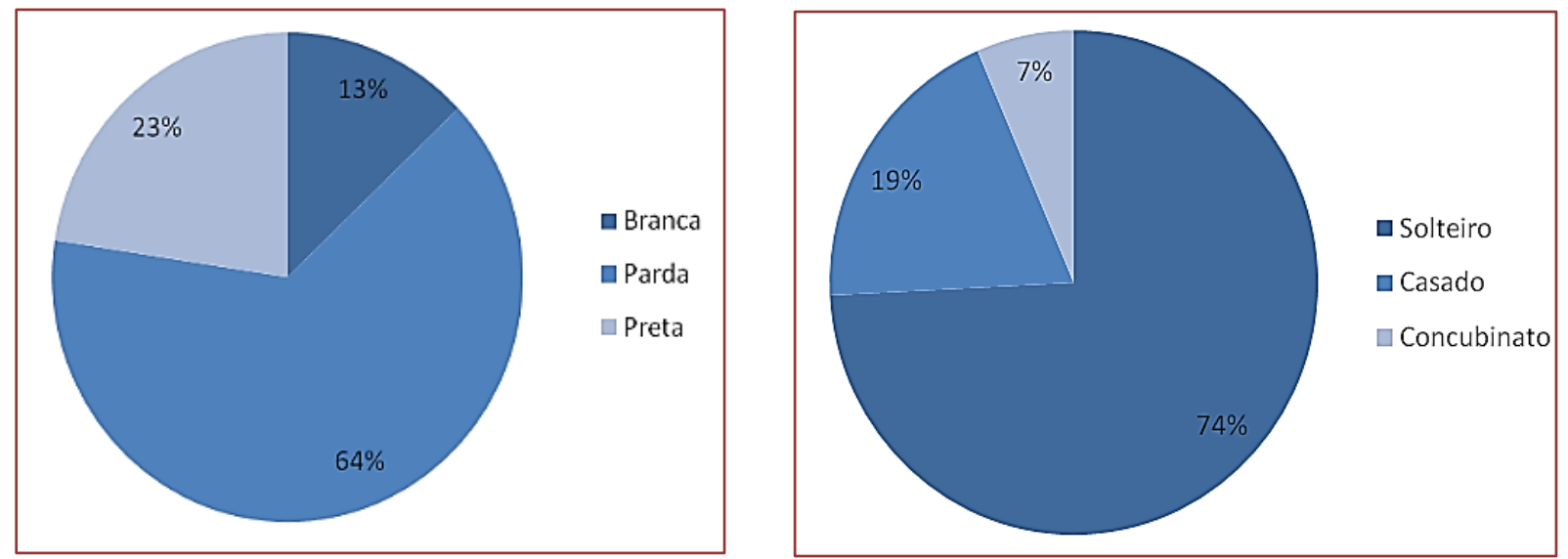

Fonte: elaborado pelas autoras a partir de dados obtidos junto à SEJUSP/MG, via Lei de acesso à informação (protocolo n 01451.000041/2019-79)

No que se refere à cor da cútis, temos que $77 \%$ são pretas ou pardas, considerando a categoria de análise utilizada pelo Instituto Brasileiro de Geografia e Estatística (IBGE), negro, que corresponde à soma de pretos e pardos. Por fim, no que se refere ao estado civil, 74\%, ou seja, a maioria delas é solteira.

Comparando o perfil das presas do CRGPL com as demais presas do estado de Minas Gerais, observamos que as mulheres gestantes e nutrizes são, em sua maioria, mais jovens em termos percentuais. Vejamos no gráfico 2 'População carcerária de Minas Gerais (2019) - percentual por sexo e faixa etária' que quase 1/4 das presas do estado (24,95\%) tem entre 18 e 24 anos, já as grávidas e nutrizes correspondem a mais de duas vezes proporcionalmente (58\%) e, portanto, são mães ainda muito jovens, possivelmente sem que houvesse planejamento da gestação.

No que se refere à escolaridade, notamos um aumento percentual na escolaridade das mulheres abrigadas no CRGPL em relação às demais presas do estado. São 53,66\% das presas mineiras com até o 1 . grau incompleto (ensino fundamental), contra $42 \%$ das mulheres do CRGPL.

Quanto à cor da cútis, observamos que há proporcionalmente mais mulheres negras (soma de pretas e pardas, 87\%) no CRGPL do que nas demais unidades (72,36\%). Por fim, no que se refere ao estado civil das presas, constatamos que, proporcionalmente há mais mulheres solteiras no CRGPL (74\%) do que no restante do sistema prisional.

Diante do exposto, concluímos que o perfil das gestantes e nutrizes privadas de liberdade que se encontram no CRGPL é muito semelhante ao que verificamos em relação aos demais presos do sistema prisional mineiro. Portanto, podemos afirmar que o perfil majoritário dos presos mineiros, sejam eles homens ou mulheres, mães ou não: jovens, com baixa escolaridade, negros(as) e solteiros(as).

\section{CONSIDERAÇÕES FINAIS}

A frase "bandido bom é bandido morto" nunca foi tão dita e repetida pelos cidadãos de bem, dado o momento político vivenciado no Brasil. Ao ponto que parece haver um certo clamor social por punições mais severas e por mais encarceramento, como se prisões superlotadas por si só fossem capazes de erradicar o crime da sociedade. Não há pena de morte no país e, no ritmo em que a população carcerária vem crescendo, não seria possível construir e custear a manutenção de tantas prisões.

Sabe-se que os crimes e contravenções acontecem todos os lugares, todos os dias e tem como autores pessoas de todas as classes sociais. Todavia, seria leviano deixar de ressaltar a seletividade do sistema prisional, visto que a maioria dos presos brasileiros são negros, jovens e possuem baixa escolaridade, conforme demonstraram as estatísticas apresentadas ao longo desse trabalho.

0 modelo prisional brasileiro tem demonstrado seu esgotamento e as transformações ocorridas durante todo o século XX até os dias atuais indicado que os avanços obtidos no campo dos Direitos Humanos nem sempre tem se refletido no sistema prisional brasileiro. 
No entanto, o Centro de Referência da Gestante Privada de Liberdade deve ser considerado como um progresso na humanização do tratamento penal das gestantes e nutrizes. 0 modelo é referência no Brasil e se destaca especialmente pela estrutura física e condições diferenciadas de disciplina e atendimento.

Conforme já relatado, infelizmente é possível que o CRGPL seja extinto. Apesar de já ter realizado a reforma no Complexo Penitenciário Estévão Pinto, o discurso adotado pelo governo é que está analisando a possibilidade de mudança da estrutura da unidade para "outra unidade prisional com a estrutura física mais adequada, mais próxima da região hospitalar e a um custo de custódia e atendimento bem mais baixo para o Estado".

Sobre isso, indagamos: como uma unidade prisional convencional, com todo o aparato de segurança e disciplina, seria uma estrutura mais adequada para o público atendido pelo CRGPL, especialmente para as crianças? A melhor saída seria mesmo retornar ao modelo abandonado há mais de dez anos, mantendo as presas grávidas, lactantes e seus filhos em um anexo de um estabelecimento penitenciário qualquer? Estaria o governo mensurando todos os custos, qualitativos e quantitativos, da política pública que pretende encerrar?

Muito longe que esgotar o tema, as autoras esperam ter contribuido para o debate sobre os sistema prisional, especialmente no que se refere às mulheres encarceradas, sejam elas mães ou não. Almejam que o tema desperte interesse acadêmico e que seja objeto de muitos outros estudos, devido a sua relevância social. É extretamente importante de trazer ao debate acadêmico essas tramas, que ficam subsumidas nas demais tramas sociais. 0 que acontece no sistema prisional é tão importante quanto quaisquer outros eventos que acontecem na sociedade em geral. Aqui, é importante retomar parte do texto descrito no início desse trabalho, indagando: Quantos muros representam prisões? Reflitamos: quantas divisões? Quantas separações? Quanta segregação? Quantos muros ainda de pé?"

Nunca é demais lembrar que a dignidade da pessoa humana é direito de todos, mas nem todos conseguem se fazer serem vistos e ouvidos, como é o caso dos presos, 'os excluídos da história' de Michelle Perrot, assim como as mulheres presas, no mínimo, duplamente excluídas.

Por fim, para não finalizar, encerramos com um fragmento de um texto a memorável Audre Lourde ${ }^{42}$, que reflete bem o sentimento das autoras:

O fato de estarmos aqui e que eu esteja dizendo essas palavras, já é uma tentativa de quebrar o silêncio e estender uma ponte sobre nossas diferenças, porque não são as diferenças que nos imobilizam, mas o silêncio. E restam muitos silêncios para romper. (grifo nosso)

\section{REFERÊNCIAS}

[1] Andrade, Bruna Soares Angotti Batista de. Entre as Leis da Ciência, do Estado e de Deus: o surgimento dos presídios femininos no Brasil. Dissertação de Mestrado em Antropologia Social da Universidade de São Paulo. 2011

[2] Brasil. Conselho Nacional de Justiça. Painel Banco Nacional de Monitoramento de Prisões. Disponível em: <https://portalbnmp.cnj.jus.br/\#/estatisticas>. Acesso em 02 de fev 2020.

[3] Brasil. Conselho Nacional de Justiça. Relatório estatístico: visita às mulheres grávidas e lactantes privadas de liberdade. 2018. Disponível em: < https://www.cnj.jus.br/wp-

content/uploads/2018/10/a988f1dbdd2a579c9dcf602c37ebfbbd_c0aaccbe4a781a772ee7dce8e4c9a060.pdf>. Acesso em 02 de out. 2019.

[4] Brasil. Constituição da República Federativa do Brasil (1988). Presidência da República. Casa Civil. Subchefia para Assuntos Jurídicos. Brasília, 1988.

[5] Brasil. Lei de Execução Penal. Lei no 7.210, de 11 de julho de 1984 . Disponível em http://www.planalto.gov.br/ccivil_03/leis/L7210compilado.htm. Acesso em 08 de junho de 2015 (1984).

[6] Brasil. Ministério da Justiça e Segurança Pública. Departamento Penitenciário Nacional - DEPEN. Levantamento Nacional de Informações Penitenciárias - INFOPEN Mulheres. Brasília, 2016. Disponível em: < http://depen.gov.br/DEPEN/depen/sisdepen/infopen/relatorios-sinteticos/infopen-dez-2016-rev-120720190802.pdf >. Acesso em 10 julho 2019.

\footnotetext{
42 "The Transformation of Silence into Language And Action", traduzido pelo blog Mulheres Rebeldes. Foi publicado em Cadernos de Crítica Feminista, Ano 7 N. 6, SOS Corpo, Recife, 2013.
} 
[7] Brasil. Ministério da Justiça e Segurança Pública. Departamento Penitenciário Nacional - DEPEN. Microdados - Levantamento Nacional de Informações Penitenciárias - INFOPEN Mulheres. Brasília, 2016. Disponível em: < http://depen.gov.br/DEPEN/depen/sisdepen/infopen/bases-de-dados/bases-de-dados >. Acesso em 10 julho 2019.

[8] Brasil. Ministério da Justiça e Segurança Pública. Departamento Penitenciário Nacional - DEPEN. Levantamento Nacional de Informações Penitenciárias - INFOPEN Mulheres. Brasília, 2018. Disponível em: <http://depen.gov.br/DEPEN/depen/sisdepen/infopenmulheres>. Acesso em 20 julho 2019.

[9] Brito, José Gabriel de Lemos. Os systemas penitenciários do Brasil, 3 vols. Rio de Janeiro: Imprensa Nacional, 1924-25.

[10] Colares, A. F. V. Nossos muros! Farol - Revista de Estudos Organizacionais e Sociedade, Belo Horizonte, v. 3, n. 7, p. 383-384, ago. 2016. Disponível em: <https://revistas.face.ufmg.br/index.php/farol/issue/view/186>. Acesso em 17 ago. 2019.

[11] Colares, Leni Beatriz Correia; CHIES, Luiz Antônio Bogo. Mulheres nas so(m)bras: invisibilidade, reciclagem e dominação viril em presídios masculinamente mistos. Estudos Feministas, Florianópolis, 18(2): 352, maioagosto/2010. Disponível em: https://doi.org/10.1590/S0104-026X2010000200007. Acesso em 22 julho 2019

[12] Camara, J. Sette. Sistema Penitenciário em Minas Gerais. 1951. Disponível em: <https://www.direito.ufmg.br/revista/index.php/revista/article/view/807>; Acesso em: 30 de junho de 2019.

[13] Infopen Mulheres. Levantamento Nacional de Informações Penitenciárias. Organização de Thandara Santos. $2^{2}$ ed. Brasília, DF, Ministério da Justiça e Segurança Pública. Departamento Penitenciário Nacional, 2018.

[14] Minas Gerais. Lei no 260, de 5 de novembro de 1948. Cria uma Penitenciária de Mulheres, em Belo Horizonte. Disponivel em https://www.almg.gov.br/consulte/legislacao/completa/completa.html?num=260\&ano=1948\&tipo=LEI. Acesso em 11 de Set. 2019.

[15] Perrot, Michelle. Os excluidos da História: operários, mulheres e prisioneiros. 2018. 8 ed. Rio de Janeiro: Paz e Terra.

[16] Regras de Bangkok: Regras das Nações Unidas para o tratamento de mulheres presas e medidas não privativas de liberdade para mulheres infratoras. Disponível em: < https://www.cnj.jus.br/wpcontent/uploads/2019/09/cd8bc11ffdcbc397c32eecdc40afbb74.pdf>. Acesso em: 04 de set 2019. 


\section{Capítulo 8}

A inserção do gênero feminino na condução de motocicleta no Município de Maceió-AL e a relação com a acidentalidade

Jessica Yolanda Figueiredo de Barros

Karine da Silva Santos

Resumo: Este trabalho apresenta os resultados de uma análise realizada sobre o índice de mulheres, usuárias do Serviço Social do DETRAN/AL no período de 2010 a 2016, condutoras de motocicleta no município de Maceió e a relação com os acidentes de trânsito.

Palavras-chave: Gênero feminino, motocicleta, acidentes. 


\section{INTRODUÇÃO}

Saffioti (1987) reflete que o termo gênero é uma construção inicial histórica na relação de homens e mulheres, sendo construído para definir um modelo de masculinidade e feminilidade, bem como os padrões de comportamento de homens e mulheres. No entanto, gênero refere-se ao conjunto de relações desiguais como atributos, crenças e atividades definidas, haja vista que é ser homem ou mulher está inserido na maioria das sociedades desiguais. Assim, as desigualdades de classes aprofundaram outras desigualdades como gênero, raça, idade, orientação sexual, etnia, deficiência e religião. Neste sentido, compreende-se que gênero é uma categoria criada para se referir ao caráter fundante da construção cultural das diferenças sexuais, a tal ponto que as definições sociais das diferenças sexuais é que são interpretadas a partir das definições culturais de gênero.

Com o advento da Revolução Industrial, deu-se de forma ampla a entrada do sexo feminino nas atividades laborativas das indústrias, com o objetivo de baratear a mão de obra, diminuir os salários e manter um controle maior ao novo grupo de operárias, sendo possível inserir a mulher no contexto da produção em máquinas que se adequavam ao seu corpo. (SAFFIIOTI, 2015, p. 81)

Com a segunda guerra mundial as mulheres passaram a assumir alguns papéis que eram predominantemente masculinos, a exemplo do trabalho na indústria bélica, para substituir os homens que estavam na guerra. Desta forma, passaram a administrar os negócios da família e a ocupar postos dos homens no trabalho. $\mathrm{O}$ final da guerra trouxe muitos impactos e mudanças para o mundo do trabalho, pois muitos dos homens sobreviventes retornaram mutilados e impossibilitados de voltar para suas atividades laborativas, uma parte deles adquiriu problemas psicológicos e muitos outros foram excluídos da vida social, o que resultou num novo tipo de sentimento e atitude por parte das mulheres, que começaram a se afastar do seio familiar para alavancar os trabalhos realizados pelos maridos. A entrada das mulheres no mercado do trabalho também se deve à necessidade da mulher contribuir financeiramente com o rendimento familiar.

Dentre outros fatores que levaram a mulher a ocupar o espaço do trabalho tem-se o desenvolvimento de métodos contraceptivos, como o uso do anticoncepcional, que fez com que as mulheres passassem a ter menos filhos, bem como o avanço das inovações tecnológicas advindas do capitalismo globalizado, que estimulou a especialização das mulheres para o mercado de trabalho.

Destaca-se que a situação de submissão da mulher no Brasil também é contraposta na década de 1930, quando esta passou a ser eleitora, e mais massivamente na década de 1940, com o início do feminismo, que ocorreu em um processo gradual de conquistas econômicas, sociais e jurídicas, buscando o reconhecimento da mulher como um sujeito de direitos. Neste sentido, é importante salientar que uma das grandes conquistas da mulher ocorreu no cenário político, uma vez que a representatividade feminina se faz necessária nos processos de luta pelos direitos das mulheres, em meio a um contexto social ainda marcado por preconceito e violência de uma sociedade construída sob a égide do machismo e patriarcalismo.

Na década de 70 as mulheres já representavam uma quantidade considerável do eleitorado, marca que foi se ampliando com o passar dos anos. Quanto aos espaços de negociação coletiva tem-se certa dificuldade de inserção do sexo feminino, que ocupa um papel secundário, devido às resistências dentro da estrutura sindical que inclui uma quantidade mínima de mulheres à frente dos cargos de direção. Isso também se deve ao fato das mulheres trabalhadoras executarem funções de baixa qualificação e alta rotatividade, estando mais vulneráveis a serem controladas pela gestão e suscetíveis ao desemprego.

Contudo, com o passar dos anos, o papel da mulher no mercado de trabalho foi se intensificando, onde passaram a conquistar seu lugar no espaço do trabalho e aumentar sua responsabilidade no comando das famílias, o que levou a ocupar posições hierárquicas e de liderança, melhorando o nível de escolaridade e redução da defasagem salarial que ainda existe em relação aos homens.

Apesar dos avanços femininos na esfera do trabalho, ainda há muito que se avançar, visto que ainda há uma elevada representatividade do número de mulheres que trabalham sem vínculo empregatício, devido, dentre outros fatores, ao baixo nível de escolaridade. A partir do momento em que o trabalho feminino foi incorporado na sociedade capitalista, às relações de produção passaram a estarem ligadas as relações de gênero. Deste modo, a divisão sexual do trabalho é reforçada e apropriada pelo capital na medida em que o trabalho feminino é incorporado no processo produtivo sob condições precárias e deterioradas. 
Diante do exposto, o interesse em discutir a temática da inserção do gênero feminino na condução de motocicleta surgiu após a apreensão da realidade do campo de estágio em Serviço Social na Subchefia ligada a Chefia de Educação para o Trânsito e Controle de condutores do Departamento Estadual de Trânsito de Alagoas - Detran/AL. Durante esse processo, foi verificado que há uma ausência de produção teórica no âmbito do sexo feminino inserido na condução de motocicleta para realizar atividades cotidianas e atividades de trabalho. Desta forma, iniciamos um estudo preliminar que contemplasse esta realidade ainda tão pouco explorada, com o propósito de que posteriormente, a pesquisa pudesse ser expandida de forma contínua pelos setores do Detran/AL, bem como por diversos órgãos que compõem o sistema trânsito, áreas afins e demais interessados pela temática.

Esse tema chamou atenção ao se analisar o espaço trânsito no Departamento, onde fica evidente o fato de haver uma vulnerabilidade do sexo masculino em relação ao envolvimento nos acidentes de trânsito, em contraposição ao envolvimento da mulher no decorrer dos anos. Essa vulnerabilidade torna clara a disparidade entre ambos os sexos no que se refere à probabilidade de acidentes estarem atrelados a fatores ligados diretamente ao contexto histórico-cultural e às relações sociais baseadas numa perspectiva patriarcal que se estabeleceu na sociedade. Nessa perspectiva, historicamente a mulher é mais cuidadosa no trânsito, fator que possibilita uma baixa exposição deste seguimento aos condicionantes que propiciam os acidentes de trânsito. De tal modo, através da pesquisa foi possível criar subsídios para a formulação de ações que rebatem diretamente no universo do gênero feminino que conduz motocicleta.

Diante do exposto, os objetivos da pesquisa realizada sobre o índice de mulheres condutoras de motocicleta e a relação com os acidentes de trânsito no município de Maceió-AL, é fomentar uma discussão acerca do gênero feminino que utiliza motocicleta no cotidiano, com a utilização dos dados obtidos; subsidiar ações socioeducativas para os motociclistas, com vistas à diminuição dos índices de acidentes de trânsito e contribuir com a socialização de informações sobre o gênero feminino que conduz motocicleta e a interface com os acidentes de trânsito.

\section{METODOLOGIA}

A metodologia adotada compreende a um estudo exploratório com uso de pesquisa bibliográfica e documental. No decorrer da pesquisa documental foi desenvolvido um breve estudo no universo feminino que utiliza a motocicleta em suas atividades cotidianas, a fim de possibilitar a apreensão de informações que foram utilizadas no decorrer do projeto. Para tal, também se utilizou dados estatísticos fornecidos por diversos órgãos de trânsito e áreas afins.

A pesquisa supracitada foi realizada mediante a utilização das pesquisas documentais baseadas nas entrevistas sociais realizadas pelo Serviço Social do Detran/AL com as mulheres, vítimas de acidentes de trânsito, que vão ao setor em busca de informações sobre os direitos na área de trânsito, sobretudo, acerca do Seguro Obrigatório que cobre Danos Pessoais Causados por Veículos Automotores de Via Terrestre DPVAT. 0 público alvo totalizou 34 usuárias que utilizam a motocicleta como veículo de mobilidade, acessibilidade e ferramenta de trabalho. Os instrumentos utilizados para a pesquisa foram entrevistas sociais manuais e eletrônicas realizadas a partir do ano de 2010 até o ano de 2016.

\section{RESULTADOS E DISCUSSÃO}

Ao longo do trabalho, foram expostas questões relativas à temática de gênero no âmbito da inserção da mulher de forma mais assídua nas relações sociais, no que diz respeito à ascensão da mulher na economia, política, na esfera do trabalho e, sobretudo, na condução de veículos, algo que se acentuou em meados da década de 1990. Como foi citado, de acordo com os registros do Detran/AL em 1990, 17.734 (dezessete mil setecentos e trinta e quatro) mulheres passaram a ser condutoras de veículos automotores. Nesse mesmo ano não houve nenhum registro de mulheres condutoras com categoria $\mathrm{A}$, ou seja, que se habilitava para conduzir motocicleta.

No que se refere às mulheres na condução de motocicleta, temática da pesquisa, de um montante de 118.756 (cento e dezoito mil setecentos e cinquenta e seis) mulheres condutoras de veículos, 2.631 (dois mil seiscentos e trinta e um) são habilitadas na categoria A. Logo, identificou-se que no decorrer dos anos subsequentes à década de 1990, houve um aumento gradativo de mulheres na condução de veículos automotores, sobretudo, na condução da motocicleta, veículo de fácil acesso aquisitivo, cuja utilização se dá por uma grande massa da população. 
Esse veículo torna os condutores e passageiros muito vulneráveis à dinâmica do espaço trânsito e assim, suscetíveis aos acidentes.

Diante do que foi analisado ao longo da pesquisa, verificou-se que de acordo com os dados da Chefia de Controle de Condutores do Detran/AL, 76\% dos condutores habilitados são do sexo masculino e 24 \% são do sexo feminino. A grande predominância do sexo masculino que possui CHN e a baixa incidência do sexo feminino inserido na condução de veículos pode estar vinculada a fatores histórico-culturais, visto que apesar dos grandes avanços conquistados pelo emponderamento feminino na sociedade e no mundo do trabalho, ainda há muito que avançar. Apesar da disparidade de gênero na condução de veículos, a proporção de mulheres que sofrem acidente é muito inferior ao quantitativo de homens. Este fato pode ter uma ligação com questões culturais e comportamentais.

Após a idealização e desenvolvimento do Projeto de Pesquisa, foi traçado o perfil das usuárias condutoras de motocicleta, onde foram coletados alguns dados socioeconômicos das entrevistas sociais para poder realizar uma análise crítica desse universo que vem crescendo gradativamente com o passar dos anos.

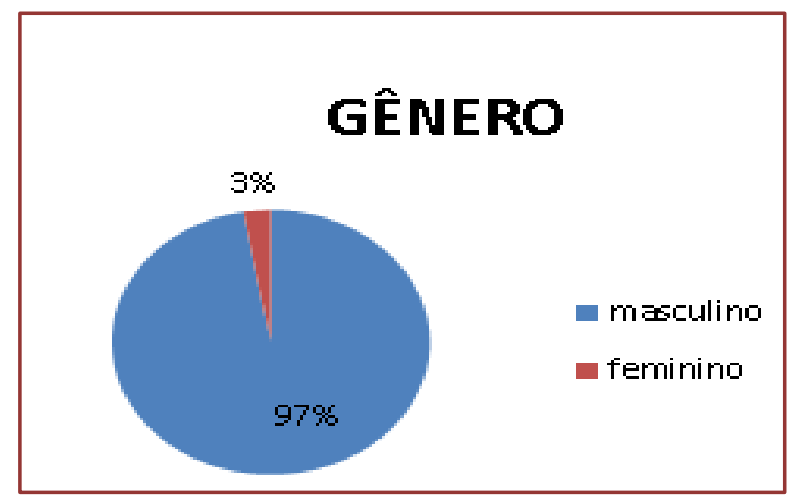

A realidade apreendida com os usuários do Serviço Social do Detran/AL a partir do ano de 2010 a 2016 demonstra que de um montante de 1.216 motociclistas, 1.182 são do sexo masculino, totalizando $97 \%$ da amostragem e 34 do sexo feminino, sintetizando 3\%.A realidade desses índices demonstra a predominância de motociclistas do sexo masculino envolvidos em acidentes de trânsito.

A disparidade de gênero diante dos acidentes pode estar vinculada a fatores que condizem ao contexto histórico-cultural ligado as relações sociais estabelecidas na sociedade, que é de caráter machista, no qual estabelece a invisibilidade e naturalização do papel procriativo, doméstico e emocional que recai sobre as mulheres, o que responde a mínima inserção das mulheres na condução de veículos e, quando estão na condição de condutoras, se envolvem menos em acidentes.

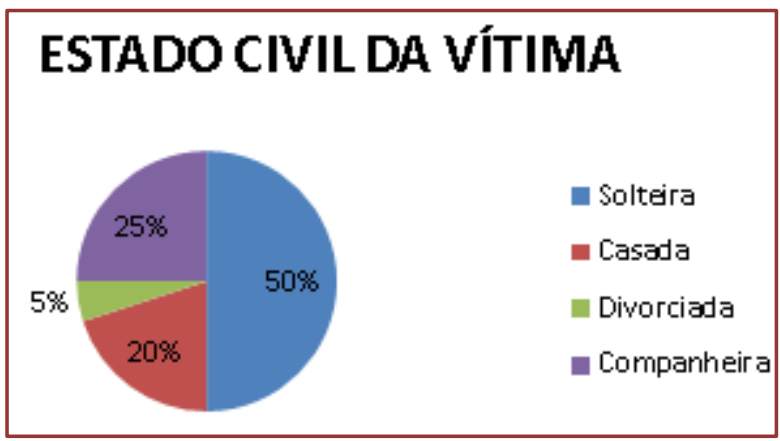


O gráfico acima expõe que 50\% das usuárias atendidas pelo Serviço Social eram solteiras, 25\% tinham companheiro, $20 \%$ eram casadas e apenas 5\% eram divorciadas. Diante desta realidade verifica-se que os impactos advindos dos acidentes de trânsito rebatem diretamente nas relações sociais e econômicas, refletindo em toda a conjuntura do núcleo familiar. Assim, tais impactos trazem sequelas que vão além das condições físicas, atingindo todo o núcleo familiar.

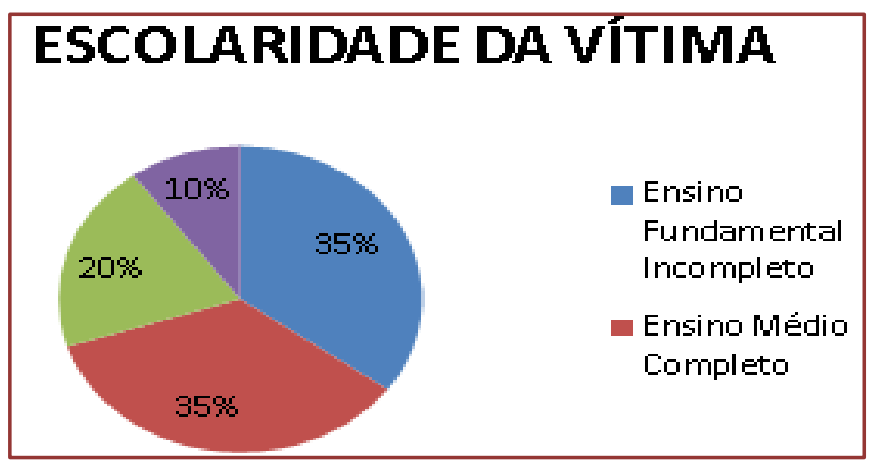

No que diz respeito à escolaridade das vítimas, verifica-se que 35\% possuem o ensino fundamental incompleto, $35 \%$ possuem o ensino médio completo, $20 \%$ possuem o ensino superior completo, e $10 \%$ possuem o ensino superior incompleto. Com base no gráfico percebe-se que a maioria das condutoras de motocicleta, vítimas de acidentes de trânsito, teve acesso a educação formal. No entanto, ao analisar o gráfico das profissões, infere-se que as mesmas não estão inseridas no mercado de trabalho conforme sua área de formação, estando em grande parte no mercado informal como alternativa para suprir as necessidades básicas de subsistência.

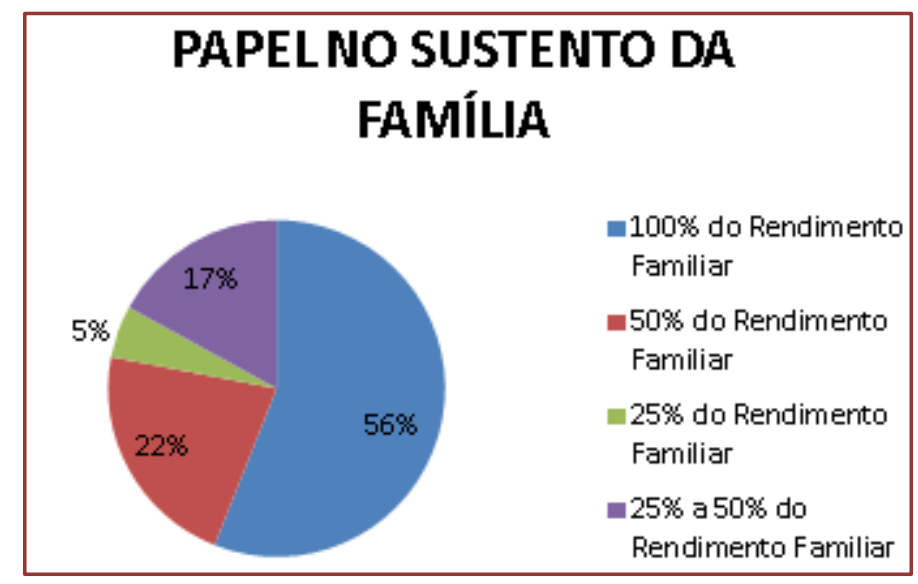

De acordo com os dados acima, verifica-se que 56\% das usuárias são responsáveis por $100 \%$ do sustento da família, $22 \%$ é responsável por $50 \%$ do rendimento familiar, 17\% das usuárias contribuem de 25 a $50 \%$ no rendimento da família e $5 \%$ contribuem com $25 \%$ do sustento familiar.

Destacamos que o somatório das usuárias motociclistas que são responsáveis por 100\% da renda da família e das usuárias que contribuem com 50\%do rendimento da familiar é de 78\%. Assim, ao analisarmos estes dados é possível identificar que as usuárias que buscaram o Serviço Social após o acidente exercem um papel primordial na subsistência da família. 
Acrescentamos que grande parte das condutoras de motocicleta que são vítimas de acidente fica provisoriamente ou permanentemente inabilitada de exercer as atividades laborativas, ficando desprovidas das condições objetivas de vida, atingindo todo o núcleo familiar.

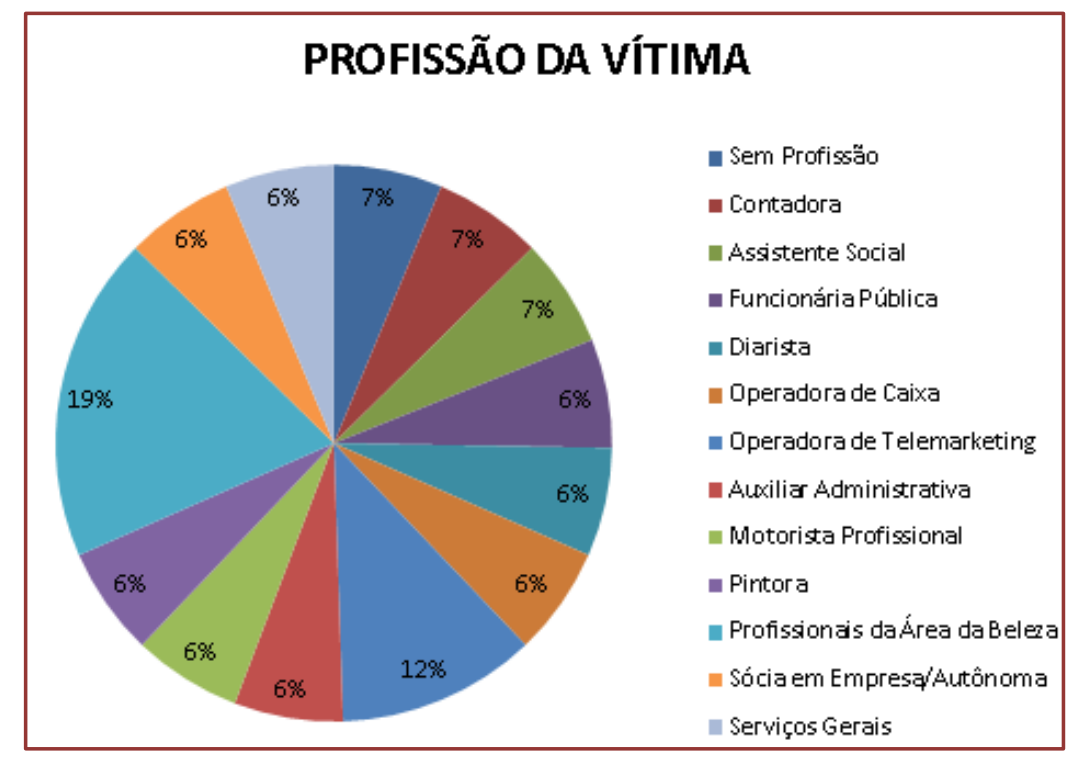

Com relação às atividades ocupacionais das vítimas, tem-se as profissões com respectivamente com 6\%: Contadora, Assistente social, Funcionária Pública, Diarista, Operadora de Caixa, Auxiliar Administrativa, Motorista Profissional, Pintora, Motofretista, Vendedora e Empresária. A profissão com o maior número de usuárias foi a de Profissional da Beleza com 19\%. Destaca-se ainda que a profissão de Operadora de Telemarketing também ganhou destaque com $12 \%$ e que $7 \%$ das entrevistadas não tinham nenhuma atividade ocupacional definida.

É possível verificar que as condutoras de motocicleta de Maceió, entrevistadas pelo Serviço Social, tinham variadas profissões, o que demonstra que apesar dos elevados índices de desemprego e baixa qualificação profissional proveniente da falta de educação escolar, todos os indivíduos estão expostos diversas formas de violência, dentre elas a violência no trânsito.

Através destes dados, fica evidente que grande parte da população não tem acesso a educação básica e consequentemente está mais exposta à violência no trânsito. A precariedade de educação no Brasil está vinculada a ausência do Estado no cumprimento de suas obrigações constitucionais, pois este não promove o conhecimento a todas as camadas da sociedade, inviabilizando o acesso a direitos legalmente constituídos. 


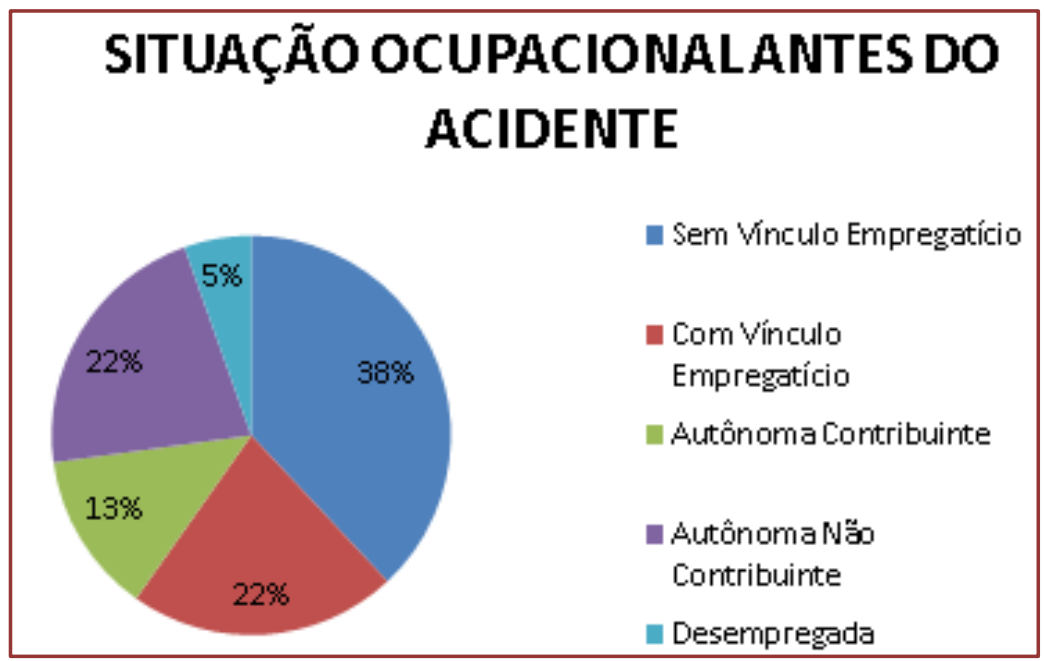

0 estudo do gráfico acima revela que antes do acidente, 13\% trabalhavam de forma autônoma, contribuindo com a previdência social, 22\% trabalhavam de forma autônoma não contribuinte, 38\% trabalhavam sem vínculo empregatício, 22\% tinham vínculo empregatício e 5\% estavam desempregadas.

Diante do que foi apresentado, podemos destacar a baixa incidência das motociclistas que trabalhavam com vínculo empregatício antes do acidente. Os dados citados sintetizam a situação socioeconômica atual do país, que rebate no desemprego latente da sociedade brasileira. Assim, como forma de buscar suprir as condições objetivas de vida, as pessoas passam a trabalhar de forma autônoma ou se submetem ao trabalho sem vínculo empregatício.

Fica evidente que os acidentes de trânsito potencializam as mazelas que permeiam a vida dos sujeitos sociais, traduzidas principalmente na dificuldade de acesso aos direitos sociais, especialmente aos relacionados aos cuidados com a saúde.

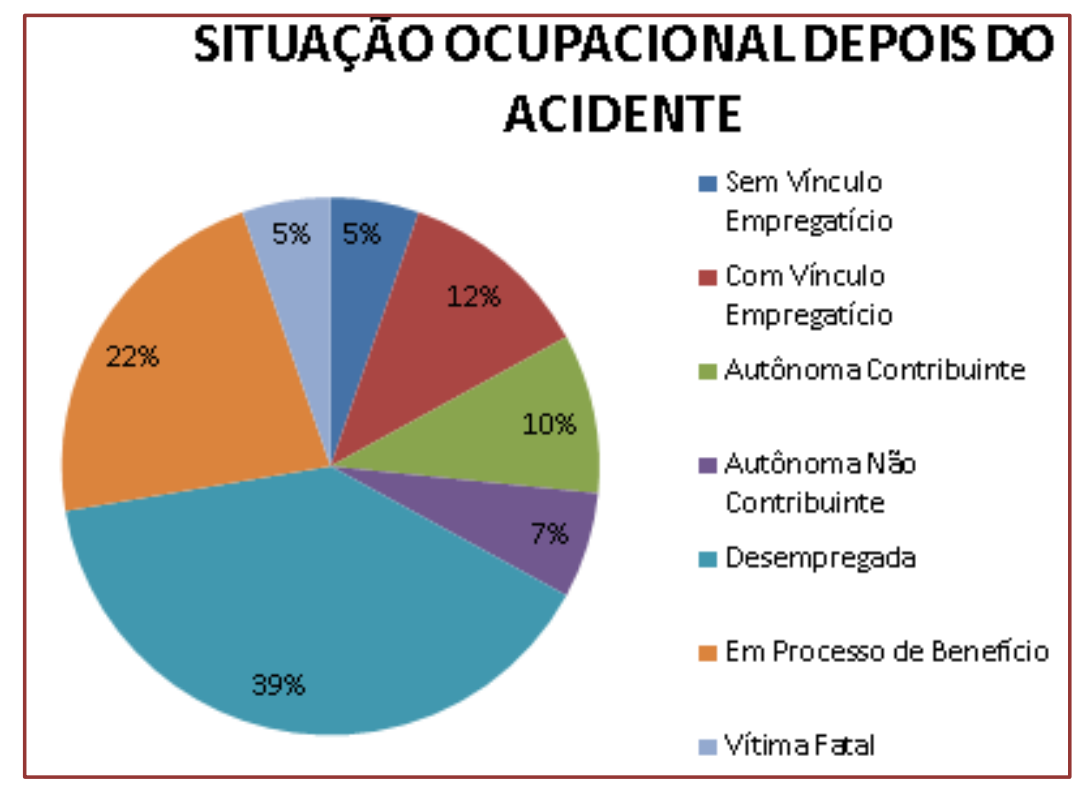


De acordo com o gráfico de situação ocupacional posterior ao acidente, verifica-se que 39\% das usuárias ficaram desempregadas após o acidente, 22\% entraram em processo de benefício, 10\% passaram a trabalhar de forma autônoma, contribuindo com a previdência social, 7\%passaram a trabalhar de forma autônoma não contribuinte, $12 \%$ permaneceram com vínculo empregatício, $5 \%$ perderam vínculo empregatício e $5 \%$ foram vítimas fatais.

Ao comparar este gráfico com o gráfico de situação ocupacional antes do acidente, vimos que 30\% das motociclistas passaram a trabalhar sem vínculo empregatício. Assim, 27\% das mesmas ficaram desempregadas após o acidente. Fica evidente que uma das grandes consequências dos acidentes é a dificuldade da manutenção do emprego, visto que de acordo com o gráfico, 9\% das usuárias perderam o vínculo empregatício, o que reflete diretamente na manutenção das condições objetivas da vida humana.

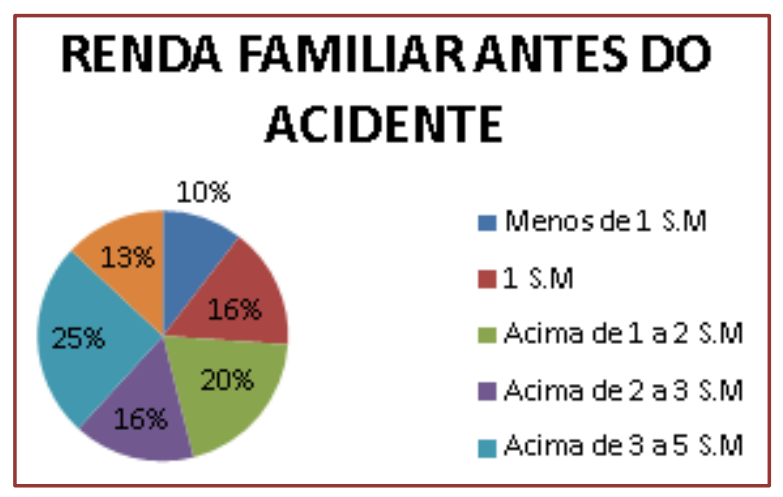

Com base no gráfico, $25 \%$ das usuárias possuíam renda familiar antes do acidente de 3 a salários mínimos, 20\% era acima de 1 a 2 salários mínimos, 16\% era acima de 2 a 3 salários mínimos, 16\% tinham renda familiar de 1 salário mínimo, 10\% sobreviviam com uma renda familiar de menos de 1 salário mínimo e 13\% das usuárias não informaram a renda familiar antes do acidente.

Destaca-se que $26 \%$ das condutoras entrevistadas possuíam renda familiar de menos de 1 salário mínimo a 2salários mínimos e 10\% sobreviviam com menos de um salário mínimo. Avalia-se que os dados acima traduzem a conjuntura socioeconômica da sociedade brasileira, onde grande parte das famílias vive com condições as socioeconômicas precarizadas e minimalistas.

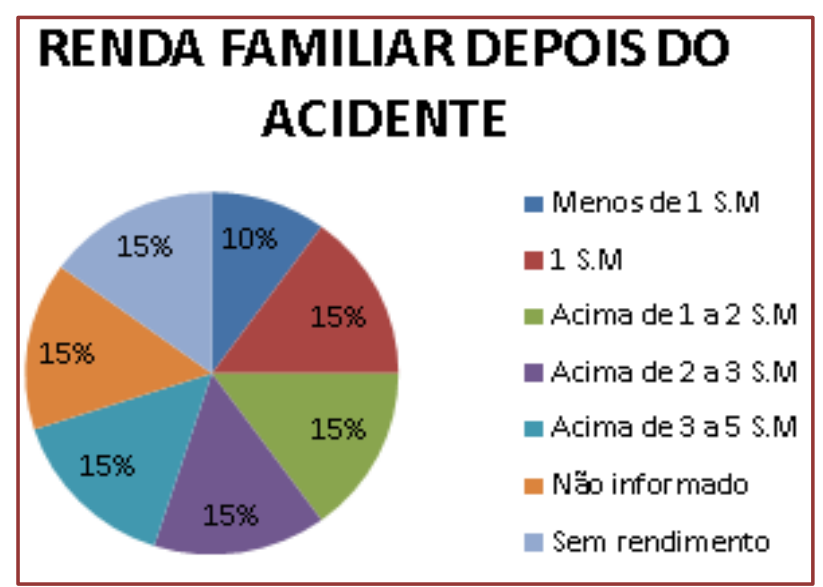


O gráfico acima demonstra que a renda familiar das usuárias do Serviço Social do Detran/AL e público alvo desta pesquisa após o acidente é :15\% - 1 salário mínimo, 15\% - 1 a 2 salários mínimos, 15\% - 2 a 3 salários mínimos, $15 \%$ - 3 a 5 salários mínimos, $10 \%$ - menos de 1 salário mínimo. Destaca-se que 15\% das usuárias não informaram a renda familiar após o acidente e $15 \%$ sobrevivem sem nenhum rendimento na família.

Este gráfico é um retrato da situação ocupacional das condutoras de motocicleta de Maceió, pois ficam evidentes as consequências que os acidentes traz na estrutura das famílias, que rebate diretamente na capacidade produtiva e na manutenção do emprego, visto que muitas vezes a vítima do acidente é o provedor da família, o que consequentemente modifica a renda de sua família.

\section{CONCLUSÕES}

A pesquisa retratou a realidade dos acidentes de trânsito no município de Maceió. Apesar de constituir um recorte dessa realidade, expressa uma totalidade marcada por tragédias diárias, que ultrapassam as reveladas pelas estatísticas, pois os acidentes impactam fortemente na vida das pessoas no âmbito familiar, socioeconômico, emocional e dentre outros.

A utilização da motocicleta para as atividades cotidianas também pode estar ligada a ineficiência de investimento em transporte público, o que leva as pessoas a usarem esse veículo como alternativa de locomoção, manutenção do trabalho, inclusive como ferramenta para exercer o trabalho no ramo informal. Os acidentes impactam diretamente nas condições objetivas de vida, visto que muitas vezes, as vítimas adquirem sequelas por um determinado tempo ou permanentemente.

As elevadas estatísticas de acidentes envolvendo motocicletas também estão associadas à aderência da população a estes tipos de veículos, que ocasiona o aumento da frota no estado. A adesão da população às motocicletas se justifica mediante a iniciativa do governo de estimular o consumo ao mercado automobilístico, facilitando o acesso da população com baixo poder aquisitivo. A necessidade de trabalho, para manter as condições objetivas de vida, faz com que a população, em especial a parcela mais carente, adquira tais veículos.

Todas essas questões tornam evidente que os órgãos do Sistema Trânsito, por meio de um trabalho intersetorial, necessitam realizar ações educativas e preventivas de forma ininterrupta, uma vez que essas mulheres por estarem mais expostas e vulneráveis no espaço trânsito, quando não entram em óbito devido ao acidente, podem adquirir sequelas permanentes que incidem no período mais produtivo da vida. É possível identificar que a ausência de uma política de infraestrutura e urbanização eficiente intensificam os elevados índices acidentes de trânsito. Assim, trabalhar as questões relacionadas ao trânsito requer a adoção de estratégias que agreguem ações educativas, fiscalizadoras e de engenharia, com ações intersetoriais e de incentivo à mobilização, organização e participação da sociedade. Trabalhar trânsito requer, antes de tudo, internalizar a cultura da preservação da vida.

\section{REFERÊNCIAS}

[1] Alves, M. E. R; Teixeira, Marlene. Feminismo, gênero e sexualidade para o Serviço Social - Brasília: Editorial Abaré, 2015.

[2] Garcia, Lucelene. A mulher e a evolução dos seus direitos. Disponível em: <http://espacovital.jusbrasil.com.br/noticias/1944790/a-mulher-e-a-evolucao-dos-seus-direitos> Acesso em: 20 de novembro de 2016

[3] Baylão, André; Schettino, Elisa. A Inserção da Mulher no Mercado de Trabalho Brasileiro. Disponível em: <http://www.aedb.br/seget/arquivos/artigos14/20320175.pdf> Acesso em: 15 de janeiro de 2017

[4] Yannoulas, Silvia. Dossiê: Políticas Públicas e relações de gênero no mercado de trabalho. Disponível em: <http://www.cfemea.org.br/images/stories/publicacoes/dossiepprgmt.pdf> Acesso em: 22 de janeiro de 2017

[5] Lessa, Sergio. Abaixo a família monogâmica. São Paulo: Instituto Lukács. 2012. 
[6] Marx, Karl. O capital: Crítica da economia política: livro I; tradução de Reginaldo Sant'Anna. $29^{\circ}$ ed. - Rio de Janeiro: Civilização Brasileira, 2011.

[7] Netto, José; BRAZ, Marcelo. Economia política: uma introdução critica - 3. ed. - São Paulo: Cortez, 2007. - (Biblioteca básica de Serviço Social; v. 1).

[8] Sarkis, Pedro. Perspectivas em confronto: Relações de gênero ou patriarcado contemporâneo? Disponível em: <http://www.compromissoeatitude.org.br/wpcontent/uploads/2012/08/MACHADO_GeneroPatriarcado2000.pdf> Acesso em: 10 de fevereiro de 2017

[9] Saffioti, Heleieth. Gênero, patriarcado, violência - 2. ed. - São Paulo: Expressão Popular: Fundação Perseu Abramo, 2015.

[10] Vieira, Anderson. Voto das mulheres no Brasil completa 80 anos. Disponível em: <http://www12.senado.gov.br/noticias/materias/2012/03/08/voto-das-mulheres-no-brasil-completa80-anos>Acesso em: 25 de novembro de 2016 


\section{Capítulo 9}

\section{Uma reflexão sobre a ausência de lésbicas e mulheres bissexuais em festas LGBTIAQ+ na cidade de Recife}

\section{Fernanda de Carvalho Azevedo Mello}

Resumo: 0 presente artigo tem por objetivo aprofundar teoricamente um dos principais obstáculos para a realização de pesquisas antropológicas que abordem vivências e experiências lésbicas, a saber, a baixa frequência com que um número significativo desse grupo de mulheres é encontrado em um único lugar. Trabalhos de pesquisadoras do Rio de Janeiro, Porto Alegre, Natal e Recife já nomearam o fenômeno e por vezes chegaram a caracterizá-lo. Os dados aqui considerados foram obtidos a partir de observação participante em 7 estabelecimentos comerciais e 8 festas independentes. As localidades em que esses eventos ocorrem acaba falando sobre a disposição da cidade quando se trata de oferta de entretenimento voltado ao seguimento LGBTIAQ+. Esses ambientes são marcados pela presença masculina, destacando, comparativamente, a presença pouca expressiva de lésbicas e mulheres bissexuais. Sob a ótica dos fenômenos urbanos, as festas são, para lésbicas, mulheres e homens bissexuais, travestis, transsexuais, pessoas interssexuais, agênero, assexuados, pessoas queer e demais denominações, manifestações de alegria e espontaneidade que permitem liberdades ceifadas durante o cotidiano. A desproporcionalidade entre quem ocupa e quem não ocupa esses espaços pode ser um indicativo de que essas festas possuem nuances que resultam em barreiras simbólicas que causam o fenômeno.

Palavras-chave: Cidades, Lésbicas e Mulheres Bissexuais, Festas LGBTIAQ+. 


\section{INTRODUÇÃO: FESTA NA CIDADE}

De acordo com o sociólogo alemão Louis Wirth (1979), membro da Escola de Chicago, a cidade pode ser definida como "um núcleo relativamente grande, denso e permanente, de indivíduos socialmente heterogêneos". Argumentando que nenhuma das características acima citadas pode constituir individualmente uma cidade, ele aponta para uma dinamicidade urbana que independe da sua baixa taxa de natalidade. Segundo ele, a cidade tem sido o local de convergência de povos e culturas favoráveis a criação de novos híbridos biológicos e culturais. Ela é responsável pela reunião de povos de diferentes origens no planeta justamente por sua diversidade e não por um pensamento homogêneo. A cidade existe enquanto localidade e seu modo de vida urbano existe como modelo para quem nela reside. Não há necessidade humana que a cidade não supra, entre elas, uma alternativa à monotonia e a rotina também é apontada por Wirth como um dos atrativos da cidade. Denominando o 'fornecimento de emoções' uma das "principais funções da recreação urbana", onde se apresenta a possibilidade para a autoexpressão. 0 senso de comunidade, no entanto, é monetizado a ponto da imparcialidade, e até mesmo as relações de parentesco perdem espaço na vida do indivíduo:

"O superficialismo, o anonimato, e o caráter transitório das relações urbanosociais explicam, também, a sofisticação e a racionalidade geralmente atribuídas ao habitante da cidade. Nossos conhecidos têm a tendência de manter uma relação de utilidade para nós, no sentido de que o papel que cada um desempenha em nossa vida é sobejamente encarado como um meio para alcançar os fins desejados. Embora, portanto, o indivíduo ganhe, por um lado, certo grau de emancipação ou liberdade de controles pessoais e emocionais de grupos íntimos, perde, por outro lado, a espontânea autoexpressão, a moral, o senso de participação, implícitos na vida numa sociedade integrada. Isso constitui essencialmente o estado de anomie ou de vazio social a que se refere Durkheim ao tentar explicar as várias formas de desorganização em sociedade tecnológica" (Wirth, 1979, p. 101).

A atitude blasé (Simmel, 1979) surge como uma resposta psicológica aos diversos estímulos urbanos. Incapaz de dar conta de tudo que acontece ao seu redor, indivíduo blasé cessa todos os esforços de reagir com "energia apropriada". Tal atitude é responsável pela reserva típica das moradoras e moradores das cidades, marcadas pela indiferença entre aquelas e aqueles que compartilham do mesmo espaço cotidiano. De acordo com Jean Duvignaud (1983), a festa, enquanto fenômeno de interesse antropológico, surge como o oposto da reserva urbana. Ela é capaz de colocar as pessoas frente a frente a um mundo aparentemente sem estruturas ou normas. 0 indivíduo consume-se em busca de uma ausência de normas que o liberte; e renasce, para enfrentar novamente a rotina.De acordo com Duvignaud, "a festa, em si, ao contrário, não implica qualquer outra finalidade senão ela mesma" (p. 66), e seria o local onde "as pessoas aí realizam o impossível, isto é, a comunicação comum além de todo espaço e a permanência, o confronto aceito da destruição e da sexualidade" (p. 68).

O professor e antropólogo José Guilherme Magnani (1993), tem uma visão diferente da festa enquanto produto da cidade. Segundo ele, o lazer e a diversão constituem um elemento de grande importância no estudo de uma sociedade, ainda que muitas vezes não seja visto dessa forma. Como as pessoas escolhem passar seu tempo livre, muitas vezes, diz mais a respeito de quem elas são do que o trabalho remunerado que exerçam. Nem o lazer, tampouco a cidade, se apresentam de maneira uniforme para todas e todos. No entanto, a experiência de cidade individual terá relação direta com a forma de lazer escolhida. Em uma reflexão sobre a experiência da rua enquanto categoria de atenção antropológica, ele afirma:

"Estas formas de apropriação não são o resultado de escolhas individuais, nem são aleatórias: são resultado de rotinas cotidianas, ditadas por injunções coletivas que regulam o trabalho, a devoção, a diversão, a convivência e que deixam suas marcas no mapa da cidade. 0 resultado é um desenho bastante particular e que se sobrepõe ao desenho oficial da cidade: às vezes rompe com ele, outras vezes o segue, outras ainda não tem alternativa senão adequar-se". (Magnani, 1993, p.13)

A não aleatoriedade do lazer surge como objeto de interesse nesse artigo, pois nele vamos abordar a escassa presença de lésbicas e mulheres bissexuais em festas e boates, opção de lazer amplamente difundida entre pessoas LGBTIAQ+. 0 título ("ausência de lésbicas...") precisa ser um pouco explorado ainda nessa seção. Não se trata de uma ausência completa, isto é, há sim lésbicas e mulheres bissexuais nesses ambientes. No entanto, esta participação raramente ultrapassa $30 \%$ do público total. 
Trago no título o resultado do levantamento que fiz como parte inicial da pesquisa realizada entre os anos de 2018 e 2019 para a dissertação provisoriamente intitulada "O Gênero da Festa: uma etnografia lésbicofeminista da participação de lésbicas e mulheres bissexuais em espaços LGBTIAQ+ de Recife", financiada pela Fundação de Amparo a Ciência e Tecnologia do Estado de Pernambuco (FACEPE) e desenvolvida através do Programa de Pós-Graduação em Antropologia da Universidade Federal de Pernambuco (UFPE).

\section{METODOLOGIA: NOTAS SOBRE A PRODUÇÃO CIENTÍFICA E ATIVISMO}

A autoridade de uma antropóloga acerca de um tema costuma ser bastante questionada quando ela passa a advogar em favor da minoria que ela propõe estudar. Este estudo, mesmo abordando uma questão quantitativa, tem uma abordagem qualitativa. É, portanto, destacada a importância do indivíduo como intérprete do mundo a sua volta, onde será necessário desenvolver métodos que priorizem a perspectiva individual (Goldenberg, 2002). A pesquisa qualitativa tem por tradição da Escola de Chicago a produção de conhecimentos que servirão de base para políticas públicas que visassem contribuir e amenizar as mazelas urbanas que aquela cidade possuía, durante a primeira metade do século XX (Goldenberg, 2002). No Brasil, a história tem sido parecida.

Em uma rápida revisão da composição do campo militante por parte dos pesquisadores acadêmicos mostra-se que a ciência social no Brasil não consegue dissociar-se completamente do movimento social organizado que reivindica políticas públicas de autoafirmação. Especialmente no quesito da produção de conhecimento feminista, que busca dissecar hierarquias e explicitar descriminações de gênero e devidas interseções. A produção de conhecimento feminista, de acordo com artigo publicado por Anahi Mello, Felipe B. M. Fernandes e Mirian Grossi (2013), tem uma proximidade muito grande do ativismo político. Trata-se de "um campo híbrido de produção de conhecimento que informa e que forma práticas políticas. A partir da localização de Mello enquanto sujeita múltipla (mulher surda, lésbica e pesquisadora), assim como de Fernandes (2011), cujo caminho acadêmico sempre esteve ligado às conquistas contra a LGBTIAQ+fobia, não podemos descartar a relação de codependência entre a produção de conhecimento científico e a militância política de grupos minoritários. De acordo com Luís Roberto Cardoso de Oliveira (2010), são três os compromissos assumidos pela/o antropóloga/o: compromisso ético, moral e político diante de suas/seus sujeitas/os de pesquisa, fornecendo todas as informações pertinentes a pesquisa em desenvolvimento; o compromisso com a verdade, seguindo critérios de validade científica; e por último o compromisso com a sociedade e a cidadania ao retribuir o conhecimento produzido a partir de suas/seus interlocutoras/es. Até mesmo o código de ética da Associação Brasileira de Antropologia (ABA, 2012) versa a respeito da representação política do grupo pesquisado, em comprometimento com a polifonia da produção científica. Conhecer tão bem um grupo em suas condições essenciais e passar a militar em sua causa parece ser a realidade para muitas antropólogas e antropólogos.

\section{METODOLOGIA: MÉTODO E LOCAIS}

O conteúdo deste artigo foi produzido a partir de dados obtidos durante observação participante durante os anos de 2018 e 2019. Este método pesquisa foi legitimado como primordial para o exercício da Antropologia no início do século XX, por Bronislaw Malinowski que escreveu sobre o local privilegiado que sua inserção entre os nativos lhe assegurou. Em Os Argonautas do Pacífico Ocidental ele relata sobre como viver entre os trobriandeses e praticar seus costumes lhe garantiu acesso a traços culturais que passariam despercebido caso não participasse da vida cotidiana.

As críticas à autoridade do método desenvolvido por Malinowski para falar (escrever) pelos trobriandeses após a publicação de seu diário pessoal não podem ser desconsideradas em nenhuma observação participante. Não é minha intenção dar conta da realidade total dos locais ou apresentar uma visão totalizante altamente objetiva. Para este artigo, limito-me a debater a baixa participação de lésbicas e mulheres bissexuais em festas e bares LGBTIAQ+ em Recife. Perspectiva epistêmica que trago é de um conhecimento situado, uma vez que todos os conhecimentos são situados e, portanto, parciais (Haraway, 1995): 
"A alternativa ao relativismo são saberes parciais, localizáveis, críticos, apoiados na possibilidade de redes de conexão, chamadas de solidariedade em política e de conversas compartilhadas em epistemologia [...] quero argumentar a favor de uma doutrina e de uma prática de objetividade que privilegie a contestação, a desconstrução, as conexões em rede e a esperança na transformação dos sistemas de conhecimentos e nas maneiras de ver [...] (A parcialidade) é a condição de ser ouvido nas propostas a fazer de conhecimento racional. São propostas a respeito da vida das pessoas; a visão desde um corpo, sempre complexo, contraditório, estruturante e estruturado" (Haraway, 1995, p. 23-24,30).

Dessa forma, o presente artigo busca prover uma versão parcial contestativa da realidade encontrada nos ambientes analisados, conforme tabelas abaixo. Foram consideradas dois tipos de festas: festas que acontecem semanalmente em bares e boates concentrados no cruzamento das ruas das Ninfas com a rua Manoel Borba, no bairro da Boa Vista; e festas independentes, onde produtores independentes alugam casas de show para oferecem diferentes propostas de festas.

Tabela 1. Locais de Pesquisa

\begin{tabular}{|l|l|l|}
\hline$\#$ & Nome & \multicolumn{2}{l|}{ Tipo } \\
\hline 1 & Clube Metrópole & Bar/Boate \\
\hline 2 & Bar do Céu & Bar/Boate \\
\hline 3 & Miami Club & Casa de festa \\
\hline 4 & Place bar & Bar/Boate \\
\hline 5 & Conchitas & Bar \\
\hline 6 & Amigos do Pop & Bar \\
\hline 7 & Aquarius Bar & Bar \\
\hline 8 & Kissers & Festa independente \\
\hline 9 & Carola & Festa independente \\
\hline 10 & Funtastic & Festa independente \\
\hline 11 & A Tarantina & Festa independente \\
\hline 12 & Atomic & Festa independente \\
\hline 13 & Bate koo & Festa independente \\
\hline 14 & Rebuceteia & Festa independente \\
\hline 15 & Ocupe Sapatão & Festa independente \\
\hline
\end{tabular}

A boate mais conhecida e antiga em funcionamento de Recife é o Clube Metrópole. Localizada no cruzamento da Rua Manoel Borba com a Rua das Ninfas, no bairro da Boa Vista, centro do Recife, a Metro, como é chamada, viu muitas concorrentes fecharem as portas por falta de público, principalmente. 0 sucesso da boate é tanto que a empresária Maria do Céu abriu o bar/boate Bar do Céu quase ao lado, e a casa de festas Miami Pub ao lado da boate. A ampliação da quantidade de opções de entretenimento festivo naquela região já estava anunciado. 0 Place Bar conta com uma pequena área que é tanto bar como pista de dança. O Conchitas cresceu de tamanho e deixou o antigo espaço (que hoje é o Place Bar) para uma casa espaçosa que abre de quinta a domingo, alternando entre bandas e DJs. O Amigos do Pop é um bar karaokê mais a frente na rua Manoel Borba. 
Fechando o quadro de estabelecimentos comerciais, o Aquarius Bar mira um público masculino mais velho. Essa região da boate tem uma particularidade que vale a pena ser ressaltada por conhecida como o locus LGBTIAQ+, ou "alternativo" na concepção de alguns. Casas noturnas e bares que tem funcionamento regular às quintas, sextas e sábados, por vezes recebem festas independentes, deixando tudo em casa, por assim dizer.

Dentre os lugares pesquisados, as festas produzidas por grupos independentes representam o maior número de inserções em campo. Ao total, aconteceram quase cem edições de festas independentes consideradas para a amostragem, sendo 8 selos. Foram frequentadas pela autora o total de 43. Elas aconteceram em 25 localidades diferentes ao redor da cidade, sendo que só o Bar do Céu recebeu 21 festas no biênio considerado. 0 motivo é simples. A casa funciona impreterivelmente todas as sextas e sábados. Constantemente recebe festas independentes por remunerar os produtores, que em suas festas acumulam também a função de DJ. A agenda da casa para festas de fora, como deve ser imaginado, é lotada. Não é barato produzir festas e a garantia de uma casa cheia e alguma remuneração pelo trabalho e custo da produção e divulgação tornam-se bastante atrativo para qualquer produtor.

A pouca variação de localidades que recebem essas festas acaba por falar da disposição das festas na cidade: poucas vezes elas se estendem até a periferia. A Tarantina é uma festa que tradicionalmente realiza suas edições no Biruta Bar, localizado na Brasília Teimosa, bairro periférico do Recife. 0 ingresso na porta do evento, no entanto, fica além da realidade do bairro, chegando facilmente a $\mathrm{R} \$ 85$. 0 valor do ingresso de festas como A Tarantina, isto é, open bar, foi apontado por Lylian, interlocutora que também é historiadora e lésbica preta, como motivo para sua escassa participação em festas LGBTIAQ+. Além do alto custo dos ingressos, pessoas que moram mais distantes do centro da cidade, onde estão situadas a maior parte dessas localidades (em torno de $65 \%$ delas), enfrentam a dificuldade para voltar para casa. Se optarem por voltar de ônibus, terá de aguardar na parada de ônibus pelo "bacurau", ônibus que passa a cada uma ou duas horas entre os horários de 00:00 até 4:00 na madrugada. As 5 da manhã os serviços de ônibus são normalizados. Essa opção não se apresenta como uma opção válida para as mulheres, por temerem assalto, e, nomeadamente, estupro. A alternativa é ter dinheiro pra pegar um carro de aplicativo na volta a casa.

Cada festa independente traz consigo uma identidade que a diferencia das demais. A Festa Kissers incentiva abertamente o beijo na boca; a Carola busca reunir os devotos da música pop; a Funtastic só toca em suas pick-ups o pop dos anos 1990 e 2000; A Tarantina tem um caráter político mais ressaltado e recebe muitos universitários; a Atomic se propõe a trazer novos sons e estilos. 0 diferente apelo que cada uma traz consigo, no entanto, não representa grande variação entre de público. Dito de outra forma, após alguns meses frequentado essas as festas, é possível reconhecer os rostos do público. A presença feminina, no entanto, seguia limitada em 20 a $30 \%$.

As três últimas festas independentes da lista merecem ser debatidas em separado. A Bate Koo é uma festa organizada por mulheres negras, lésbicas e/ou mulheres bissexuais. A Ocupe Sapatão propõe ser um espaço para lésbicas (em específico) socializarem. É proibida a entrada de homens heterossexuais. A participação de mulheres é equiparável a de homens nas duas festas. A Rebuceteia é uma festa surgida a partir de um grupo no Facebook onde lésbicas e mulheres bissexuais partilham alguns causos de suas vidas e aumentam, a partir da interação gerada, sua rede de relacionamentos. A entrada de homens não é permitida. As três apresentam participação expressiva de mulheres, apresentadas aqui em ordem crescente, sendo a última constituída $100 \%$ por mulheres. No biênio da pesquisa, no entanto, foram realizadas apenas 12 edições somando os três selos: a Bate Koo (8), a Rebuceteia (3), e a Ocupe Sapatão (1). É possível apontar que há uma escassa oferta de entretenimento noturno que ofereça um ambientes que lésbicas se sintam confortáveis em frequentar, visto que de todos os espaços que constituíram parte da pesquisa de campo, apenas os mencionados neste parágrafo não apresenta uma uma disparidade padrão de 3 mulheres a cada 7 homens.

Faz-se importante voltar uma última vez ao título. Se, afinal, há mulheres nesses espaços, como que nosso título fala em "ausência"? Pelas limitações deste artigo, não debateremos a presença das mulheres que estão nesses lugares ou das que seriam lésbicas, apenas. 0 que exploraremos melhor, nas páginas que seguem, serão as obras de algumas autoras que tiveram de lidar e contornar essa mesma ausência na realização de suas pesquisa com lésbicas e/ou mulheres bissexuais. 


\section{LESBICAS EM FESTAS}

A principal dificuldade ao se propor trabalhar academicamente com lésbicas e suas vivências é justamente encontrá-las em seus momentos de interação social. Através da observação de espaços voltados ao público LGBTIAQ+ de Recife, foi constatada uma tendência já conhecida por antropólogas de outros estados do país: poucas mulheres LBT participam de festas e espaços LGBTIAQ+. A antropóloga Andrea Lacombe (2005) abraçou o desafio de dissertar sobre a sociabilidade lésbica no Rio de Janeiro. A escolha de seu local de pesquisa, no entanto, foi problemática justamente pela dificuldade de encontrar um local público onde lésbicas socializassem livremente. Ela cita dois casos de ambientes voltados ao público lésbico - as boates La Girl e Dama de Ferro - que abriram mão de sua identidade lésbica inicial por uma chance na competitiva cena noturna carioca: na época de sua pesquisa ambos os estabelecimentos recebiam mais homens gays que mulheres. Após um extenso mergulho na noite carioca, Lacombe descobriu um bar/boteco onde as masculinidades eram exercidas pelas mulheres, donas do espaço, da fala e da moralidade do lugar. Sua análise é centralizada na configuração do bar Flôr de André enquanto âmbito particular onde são observadas as relações sociais centradas em mulheres lésbicas masculinas (ou, mais adequadamente, que performam (Butler, 2016) masculinidades). Não foi de seu interesse aprofundar os motivos pelos quais essas lésbicas não frequentavam outras cenas LGBTIAQ+, tampouco houve aproximação entre linhas teóricas que sugerissem algum tipo de segregação de lésbicas e mulheres bissexuais (com esse tipo particular de performatividade) de outras pessoas queer. As explicações, então, em que ela esbarrou foram a de que os demais ambientes eram lugares de homens gays, onde elas não se encaixam e tampouco se sentem à vontade para permanecer.

A etnografia de Nádia Elisa Meinerz (2011) investigou o estabelecimento das parcerias entre mulheres de classe média na região de Porto Alegre (RS). 0 estudo dela busca visibilizar às trajetórias afetivo-sexuais de lésbicas e suas parceiras, assim como revelar suas preferências para lazer e sociabilidade, sem nunca perder de vista a forte influência da classe social de suas interlocutoras. "Entre Mulheres: Etnografia sobre relações homoeróticas femininas em segmentos médio urbanos na cidade de Porto Alegre" argumenta que não há estabelecimentos lésbicos e por isso, lésbicas e mulheres bissexuais não se reuniam expressivamente em um ambiente. De acordo com Meinerz (2011), Porto Alegre também conta com histórias de estabelecimentos lésbicos que funcionaram por pouco tempo devido ao baixo público. A música, é apontada como elemento importante na escolha de locais para divertimento, para as mulheres lésbicas. A autora afirma que dois outros elementos mais que tornam a música em si irrelevante: o público e principalmente o comportamento desse público são mencionados por elas como motivos para não frequentar a cena LGBTI. As mulheres da etnografia de Meinerz atendiam a eventos específicos, através de suas próprias redes de relações sociais por recusarem a alcunha de lésbica e consequentemente a participação no que Perlongher (1986) chamou de guetogay, região da cidade que passa a ser reconhecida ou identificada pelas práticas homossexuais de seus frequentadores/moradores, práticas geralmente tidas como escusas pela sociedade. Ela não precisou, no entanto, enfrentar a ausência de lésbicas em espaços voltados ao público LGBTIAQ+ enquanto entrave metodológico para o desenvolvimento de sua pesquisa. Espertamente, ela desenvolveu a pesquisa para sua dissertação a partir do estabelecimento de redes de relações. E estabeleceu redes a partir da técnica da bola de neve (snow ball).

A pesquisadora do PPGAS da Universidade Federal do Rio Grande do Norte, Suzanne Freire Pereira se dedica a estudar o circuito de lazer e sociabilidades lésbicas na capital do estado. Tratando a questão de forma mais positiva, ela quer destrinchar o consumo lésbico em Natal sem desviar-se da realidade que se repete nas capitais pernambucana, carioca e gaúcha que nosso artigo se limitará em abordar: lésbicas são minoria nos espaços LGBTIAQ+. Debatemos seu trabalho ainda em produção durante a III Reunião da Antropologia da Saúde, em 2019.

Completando o giro voltando à capital do frevo, encontramos no repositório da UFPE a dissertação de Luís Braúna Lopes de Souza (2016) pelo Programa de Pós-Graduação em Psicologia: Programa de PósGraduação em Psicologia da Universidade Federal de Pernambuco, "Festa no Gueto? Memórias e discursos em torno do "Mercado GLS" em Recife/PE". Ele busca construir uma memória da "noite GLS" - pois a esta denominação ele recorre para designar um mercado, separando pessoas e o movimento LGBT - da cidade. Alguns lugares reaparecem aqui neste artigo, como o Clube Metrópole, o Bar do Céu (à época chamado de Santo Bar) e o Conchitas (este mudou de local e está maior que antes). Outros, como o Nosso Jeito Bar, o Castelo Marrom (popularmente conhecido por "Castelinho"), que em sua dissertação aparecem como espaços que recebem prioritariamente lésbicas, não estão mais em funcionamento. 
A participação numérica inferior de mulheres não rendeu grandes reflexões acerca das desigualdades de gênero e raça que encontramos nos ambientes que pesquisamos em comum. Possivelmente a existência, na época, de um ou dois bares que eram (re)conhecidos por seu público de mulheres LB tenham se mostrado condição suficientemente satisfatórias para não incitar nele a curiosidade sobre a desproporcionalidade de gêneros. As mulheres travestis ou transexuais são, na dissertação de Souza (2016) intersecionadas por um recorte de classe (baixa) que é determinante em suas participações em ambientes "GLS". Sobre as mulheres LB e seu comparecimento a bares, em detrimento de boates, ele diz:

\begin{abstract}
“(...) podemos compreender a frequência de mulheres nesses espaços pela possível "rejeição à batida eletrônica, tendência nas casas noturnas, preferindo um som com 'mais letra', ou seja, a preferência por bares (ou locais que misturam essas estéticas) é explicada pelo fato delas preferirem escutar MPB, samba ou rock nacional cantado por cantoras, de preferência ao vivo".

Dessa maneira, no cenário atual do circuito GLS da cidade do Recife, não se tem uma referência determinada, de um espaço exclusivamente voltado a frequência de mulheres lésbicas, que contribuam para a diminuição da invisibilidade desse público no mercado de lazer e sociabilidade" (Souza, 2016, p. 90).
\end{abstract}

As preferências musicais das mulheres são apontadas como elemento captado pelos bares em questão e transformado em (ou aproveitado como, não foi possível distinguir a partir de minha leitura) atrativo direcionado para lésbicas e mulheres bissexuais. São também ligeiramente deterministas, atrelando a vivência lésbica (plural justamente por não ser determinante) a um ideário da lésbica da MPB, representadas pelas cantoras Ana Carolina e Maria Gadu. "Shimbalayê", nome de uma famosa canção de Maria Gadu, é um sinônimo para lésbicas, comumente ouvido nas minhas inserções em campo tão abrangente foi a associação entre lésbicas e MPB. A conotação, a depender de quem fala, e é normalmente um homem gay, pode ser negativa e nos remete a imagem de uma mulher em toda seu charme homossexual tocando um violão, item mais indispensável ao estereótipo da lésbica MPB que o próprio estilo das canções tocadas. Meu argumento é que este tipo de interpretação - de uma realidade que se apresenta como um emaranhado de redes: de quem conhece quem e quem participa de quê - gera estereótipos fundamentados em uma ou outra lésbica de um ou outro lugar que interferem na identificação da lésbica (mulher que se relaciona com outra mulher) enquanto lésbica (figura política reivindicadora de direitos). Parece-me uma estratégia necessária quando se mira um grupo comercialmente, a saber, determiná-lo. Recorrer a estereótipos, por exemplo. Mas isso não encerra a questão deste artigo. Isso sequer explica que tal questão existe. 0 recorte de classe é sempre resgatado como ilustrador de quem participa, quem não participa, quem ocupa e quem não ocupa o entretenimento ofertado na cidade, mas o de gênero não tem, nem de longe, o mesmo destaque.

\title{
5. LÉSBICAS E AS LINHAS DE INVESTIGAÇÃO TEÓRICA
}

Para pensar o fenômeno, é importante trabalharmos a idéia de "identidade lésbica", da qual nos fala Almeida e Heilborn (2008). Essa seria uma identidade preciosa por ser construída sob condições adversas, isto é, marcada constantemente por conflitos familiares e pela luta contínua por afirmação de direitos. A visibilidade é o paradigma que as autoras associam diretamente ao movimento de lésbicas e seria, portanto, fruto da pauta de lésbicas organizadas que acreditam que a partir da visibilidade e reconhecimento, alcançarão os direitos pelos quais batalham. Elas defendem que o caminho mais curto para a autoaceitação de mulheres que não se afirmam ou identificam como lésbicas, mas que mantêm relacionamentos homoafetivos é através da naturalização das existências lésbicas, ou seja, a medida que tais existências se tornam comuns e visíveis, mais mulheres conseguem se enxergar enquanto lésbicas por terem encontrado um "modelo lésbico" que se adeque a sua realidade. Segundo elas, isso acontece devido à uma aversão historicamente imposta pela sociedade à mulheres que ousam ir na contracorrente da heteronormatividade, pilar do patriarcado. Cheryl Clarke (1988) já falava sobre a lesbianidade ser um ato de resistência por dissociar-se em todas as esferas do domínio masculino. Voltando a Almeida e Heilborn (2008), "muitas ainda prefeririam o ocultamento dessas práticas à possibilidade de visibilidade, como meio de não se inscreverem em um processo demandante de delicada negociação com diferentes sujeitos e em distintas esferas do cotidiano" (p. 231). 
Em outras palavras, lésbicas recusam assumir uma identidade ou exercer livremente sua sexualidade por medo de serem associadas diretamente à estereótipos que elas próprias já recusaram em algum momento de sua vida. Há uma limitação gigantesca de "modelos lésbicos" e os mais conhecidos provavelmente já passaram pelo escrutínio social e sequente desaprovação e, por tal, alvo de piadas.

A produção dentro das ciências sociais sobre a homossexualidade feminina também esbarra no entrave da "identidade lésbica": parece impossível determinar apenas uma. Ainda de acordo com nossas autoras acima, essa dificuldade ocorre por conta da resistência dessas mulheres de serem rotuladas exclusivamente como homossexuais ou lésbicas. Essa resistência pode dialogar com a baixa frequência de lésbicas e mulheres bissexuais em espaços LGBTIAQ+ no Recife e em outros espaços.

Estabelecer uma identidade lésbica parece ser um caminho que levaria a essencialismos. "Identidade", dentro da antropologia, é um conceito que se traduz em constantes mudanças. Não é possível estabelecer apenas uma identidade para qualquer sujeito por que ela ou ele é mais que apenas a coisa que é determinada (e limitada) por tal identidade. Um sujeito é, dessa forma, formado por várias identidades, sendo a sua subjetividade a coleção dessas identidades, ou seja, tudo o que faz um indivíduo ser efetivamente quem é.

De acordo com Monique Wittig (1981) lésbicas não são mulheres. Ao afirmar isso, ela se embasa que o gênero, aparentemente relacionado a um fato estritamente biológico (o sexo), é na verdade um fazer gênero, um movimento de ressignificação diária. Ela chama a atenção para a necessidade de uma ressignificação do papel da sexualidade na determinação dos gêneros. Seu argumento é desenvolvido a partir da observação da opressão sofrida por lésbicas ao longo de suas vidas para exercerem bem o 'ser mulher', que inclui sonhar com uma família aos moldes patriarcais. Os modos nos quais a sexualidade irá se expressar em desejos ou práticas varia também hierarquicamente entre os indivíduos interseccionados por outros marcadores de opressão como raça e classe social.

Em entrevista à Irene Meijer e Baukje Prins (1998), Judith Butler afirma seu interesse em destacar o movimento lésbico e em diferenciá-lo da atual forma de estudar a história da mulher. Os padrões heteronormativos são tidos como centro da coerência interna ou unidade de cada gênero. Sobre a centralidade da heterossexualidade nos estudos sobre gênero, Judith Butler se assume preocupada, e traz a lesbianidade como elemento contraditório ao discurso construtivista:

"Se o lesbianismo for entendido como uma dentre muitas formas de impropriedade, então a relação entre sexualidade e gênero permanece intacta no sentido de que não nos perguntaríamos sob quais condições o lesbianismo realmente afeta a noção de gênero. Não é simplesmente a questão de o que é uma mulher própria ou imprópria, mas o que não é absolutamente concebível como uma mulher! (...) Quem é considerada uma mulher 'imprópria'? Quem passa a ser denominada imprópria no texto que a historiadora estuda? Que tipos de atos são classificados ou designados ou nomeados? E quais são tão inomináveis e inclassificáveis que se tornam impróprios à impropriedade, ficando fora do impróprio? (...) Ainda não somos capazes de considerar aqueles atos e práticas e modos de vida que foram brutalmente excluídos desse mesmíssimo binário próprio e impróprio. Eles não são a pré-história benigna desse binarismo, mas sim seu violento e inominável avesso. E é isso que eu quero continuar a abordar" (Meijer; Prins, 1998, p.166).

\section{CONSIDERAÇÕES FINAIS}

Este trabalho tratou de abordar a ausência de lésbicas e de mulheres bissexuais em Recife/PE. Trata-se do resultado de uma observação participante conduzida por dois anos na capital pernambucana e que é parte integrante da pesquisa de dissertação conduzida pelo PPGA-UFPE intitulada "O Gênero da Festa: uma etnografia lésbico-feminista da participação de lésbicas e mulheres bissexuais em espaços LGBTIAQ+ de Recife". Para afirmar os dados apresentados neste artigo, foram consideradas 15 localidades, entre estabelecimentos comerciais (7) e festas independentes (8). 
Percorrendo as festas e estabelecimentos mais conhecidos e tradicionais da cidade que oferecem divertimento para pessoas de gêneros e sexualidades dissidentes, foi possível confirmar através da observação que a presença masculina se mantem em proporcionalidade de 7 para cada 3 mulheres, as vezes alcançando 4 homens para cada mulher. 0 fenômeno, embora encontrado e citado por algumas antropólogas ainda carece de um entendimento mais aprofundado.

A antropologia tem mostrado nos últimos anos verdadeiros alongamentos para conseguir produzir conhecimento sobre lésbicas e suas vivências. Um dos principais motivos é a dificuldade de encontrá-las em um só ambiente. As estratégias metodológicas, como as que utilizou Andrea Lacombe, ou outros recortes do objeto de estudo, como nos mostrou Nádia Eliza Meinerz, requerem criatividade. Estudar lésbicas não se trata apenas de observá-las, mas antes de tudo é importante saber onde encontrá-las. Não são protagonista de festas e nem permanecem alvo de interesse para estabelecimentos comerciais por muito tempo. Observa-se uma tendência de curta vida para botecos, bares ou boates voltadas à mulher LBT enquanto sujeito consumidor.

\section{REFERÊNCIA}

[1] ABA (2012). Código de Ética do Antropólogo e da Antropóloga. In: Associação Brasileira de Antropologia. Disponível em: < http://www.portal.abant.org.br/codigo-de-etica/ >, acessado em 26 de maio de 2019.

[2] Almeida, G.; Heilborn, M. L. Não Somos Mulheres Gays: identidade lésbica na visão de ativistas brasileiras. In: Gênero. Niterói, V. 9, N. 1, 2. Sem. 2008. P. 225-249

[3] Butler, Judith. Problemas de Gênero: Feminismo e Subversão da Identidade. Rio de Janeiro: Civilização Brasileira, 2016.

[4] Cardoso de Oliveira, Luís R. A Antropologia e seus compromissos ou responsabilidades éticas. In: Fleischer, Soraya; Schuch, Patrice. (orgs). Ética e Regulamentação na Pesquisa Antropológica. Brasília: Letras Livres, Ed. UnB, 2010, p. 25-38.

[5] Clarke, Cheryl. El lesbianismo: Um acto de resistência. In: MORAGA, Cherríe; Castillo, Ana (eds.). Esta puente, mi espalda. San Francisco: Ism Press, Inc., 1988, 99-107.

[6] Duvignaud, Jean. Festas e Civilizações. Trad.:L. F. Raposo Fontenelle. Fortaleza: Edições Universidade Federal do Ceará. Rio de Janeiro: Tempo Brasileiro, 1983.

[7] Fernandes, Felipe Bruno M. A Agenda Anti-homofobia na educação brasileira (2003-2010). Tese (doutorado em Ciências Humanas) Programa de Pós-Graduação em Doutorado Interdisciplinar em Ciências Humanas, Universidade Federal de Santa Catarina, Centro de Filosofia e Ciências Humanas, Florianópolis/SC, 2011.

[8] Goldenberg, Mirian. A arte de pesquisar: Como fazer pesquisa qualitativa em ciências sociais. $6^{\mathbf{a}}$ ed. Rio de Janeiro: Editora Record, 2002.

[9] Haraway, Donna. Saberes localizados: a questão da ciência para o feminismo e o privilégio da perspectiva parcial. Cadernos Pagu, n.5, p. 07-41, 1995.

[10] Lacombe, Andrea. "Pra homem já tô eu": Masculinidades e socialização lésbica em um bar no centro do Rio de Janeiro. Dissertação de Mestrado, PPGAS-MN, Rio de Janeiro, 2005

[11] Magnani, José Guilherme. Rua, símbolo e suporte da experiência urbana. Cadernos de História de São Paulo 2, Museu Paulista-USP, jan/dez 1993.

[12] Meijer, Irene Costera; PRINS, Baukje. Como os corpos se tornam matéria: entrevista com Judith Butler. Journal of Women in Culture and Society, Chicago, v.23, n.2, p. 275-287, 1998.

[13] Meinerz, Nádia Elisa. Entre Mulheres: Etnografia sobre relações homoeróticas femininas em segmentos médio urbanos na cidade de Porto Alegre. Rio de Janeiro: Editora UERJ, 2011.

[14] Mello, Anahi; Fernandes, Felipe B. M.; GROSSI, Mirian P.. Entre Pesquisar e Militar: engajamento político e construção da teoria feminista no Brasil. Revista Ártemis, vol. XV nำ1; jan-jul, 2013, p. 10-29.

[15] Perlongher, Nestor. O negócio do michê. 2ª̣ed. São Paulo, Editora Fundação Perseu Abramo, 2008.

[16] Simmel, Georg. A Metrópole e a vida Mental. In Velho, Otávio G. O Fenômeno Urbano. Rio de Janeiro: Zahar, 1979. p. 11 25 .

[17] Souza, Luiz Henrique Lopes de. Festa no Gueto? Memórias e discursos em torno do "Mercado GLS" em Recife/PE. Dissertação (mestrado em Psicologia). Programa de Pós-Graduação em Psicologia, Universidade Federal de Pernambuco, Centro de Filosofia e Ciências Humanas, Recife/PE, 2016

[18] Wirth, Louis. Urbanismo como modo de vida. In Velho, Otávio G. O Fenômeno Urbano. Rio de Janeiro: Zahar, 1979. p. 11 - 


\section{Capítulo 10}

"Espelhos da noite": Identidades vestidas pelo controle social

\section{Rose Cláudia Oliveira de Andrade \\ Maria de Fátima Araújo Di Gregorio}

Resumo: Este artigo resulta de uma pesquisa de mestrado que tem como temática "As garotas do KM 43": identidade(s), prostituição, família(s) e escola. Analisa a trajetória de vida das prostitutas do Km 43 - Distrito Stela Câmara Dubois - Jaguaquara, Bahia, localidade que tem um bordel de estrada cujas mulheres constituem um grupo atuante entre "ser mãe e prostituta", exigindo reflexão do processo histórico, cultural, educacional, sócio econômico e político dessas mulheres que possuem identidades que são negociadas na sociedade. Para tanto, busca-se por meio das narrativas, ouvir a voz dessas mulheres que de alguma forma são visibilizadas no local, constituindo um grupo coletivo que apresenta acepções em uma sociedade marcada pelo preconceito e discriminação. Nesse viés, perceber por suas falas como elas enunciam e lidam com suas identidades, especialmente as étnicas. A pesquisa tem como sujeitos, as mulheres que em suas histórias tem pontos e razões os quais convergem para pobreza, desemprego, formação precária, violência familiar, falta de oportunidades na vida dentre outras formas de violência instituída contra mulheres. Ancora-se na história oral, cuja coleta de informações objetiva compreender de que maneira as prostitutas do KM 43 vem construindo suas identidades na dinâmica entre prostituição, família e escola, identificando a inserção no âmbito da prostituição, suas trajetórias de vida pessoal e profissional, com intuito de elucidar suas vivências. Constitui como pesquisa social, empírica, de natureza qualitativa, ancorada em teóricos que dialogam com as categorias em estudo.

Palavras-chave: Prostituição, família, identidade. 


\section{1.“ESPELHOS DA NOITE”: IDENTIDADES VESTIDAS PELO CONTROLE SOCIAL ${ }^{43}$}

\subsection{TESSITURAS INICIAIS}

Debater a prostituição sob o prisma das relações sociais é pensar sobre as dinâmicas estabelecidas que demarcam a construção simbólica e histórica dessas mulheres que contam suas histórias, reconstroem sua identidade ao confrontar-se com as possibilidades de recriação e transmissão de seu universo cultural no momento em que elabora a vivência da prostituição.

Os processos identitários remetem as heranças, legitimam a identidade étnica, principalmente ao que diz respeito o papel das mulheres que transitam na comunidade local e devem ser compreendidos a partir das histórias de vida. Ouvir a enunciação das identidades étnicas sob a ótica das mulheres que vivem em situação de prostituição é pensar em contextos e vivências, considerando-se que o seu cotidiano é marcado por estigmas, preconceitos e violências, significa ainda contribuir para problematizar as formas de lutas por reconhecimento e empoderamento na sociedade, bem como, tornar visíveis as realidades as quais são submetidas ao assumirem suas identidades.

Esta investigação resulta de uma pesquisa de mestrado do Programa de Pós-Graduação stricto sensu em Relações Étnicas e Contemporaneidade- PPGREC - Universidade Estadual do Sudoeste da Bahia/UESB, Campus de Jequié, com inserção na linha de pesquisa n. 2: etnia, gênero e diversidade sexual que tem como temática "As garotas do KM 43": identidade(s), prostituição, família(s) e escola. Analisa a trajetória de vida das prostitutas do Km 43 - Distrito Stela Câmara Dubois - Jaguaquara, Bahia. Ademais, esta pesquisa possui o Certificado de Apresentação para Apreciação Ética (CAAE) 99015318.6.0000.0055, aprovado pelo parecer no 2.978 .072 .

Diante disto, objetiva-se com esse estudo compreender de que maneira as prostitutas do KM 43 vem construindo suas identidades na dinâmica entre prostituição, família e escola, identificando a inserção no âmbito da prostituição, suas trajetórias de vida pessoal e profissional, com intuito de elucidar suas vivências. Além disso, visando atender a complexidade da pesquisa, os seguintes objetivos específicos foram traçados: 1) Identificar a inserção das mulheres na prostituição em diferentes contextos e espaços sociais; 2) Elucidar a trajetória de vida das prostitutas; e 3) Analisar a partir das narrativas, como as mulheres que se prostituem se percebem etnicamente, identificando os marcadores inseridos na prostituição.

O corpus selecionado para análise são as entrevistas concedidas a partir da técnica da história oral. 0 campo da pesquisa é o KM 43 - Distrito Stela Câmara Dubois, do município de Jaguaquara Bahia, localizado às margens da rodovia BR 116. Propõe uma amostra constituída de quatro colaboradoras mulheres prostitutas e mães, moradoras da comunidade pesquisada. $\mathrm{Na}$ utilização das falas das prostitutas, atendendo à solicitação das mesmas, estabelece-se o critério de não identificar seus nomes. Os registros são assinados pelos condinomes batom, espelho, esmalte e escova que se reportam aos depoimentos das mulheres pesquisadas.

Para tanto, busca-se por meio das narrativas, ouvir a voz dessas mulheres que de alguma forma são visibilizadas no local, constituindo um grupo coletivo que apresenta acepções em uma sociedade marcada pelo preconceito e discriminação. Nesse viés, perceber por suas falas como elas enunciam e lidam com suas identidades, especialmente as étnicas. A pesquisa tem como sujeitos, as mulheres que em suas histórias tem pontos e razões os quais convergem para pobreza, desemprego, formação precária, violência familiar, falta de oportunidades na vida e outras formas de violência instituída contra mulheres em uma sociedade desigual e violenta. Mulheres que são mães e assumem diante da sociedade a prostituição como profissão. Será que são estigmatizadas e hostilizadas? Como se dá a relação delas com os grupos de mães e entre outros grupos? Quem são essas mulheres? Como é ser vista como prostituta? Quais os enfrentamentos e lutas? Qual identidade é mais fixada?

0 estudo é uma pesquisa social, entra em um campo que permite "penetrar num mundo polêmico onde há questões não resolvidas e onde o debate tem sido perene e não conclusivo" (MINAYO, 1999, p.20). Dessa forma, opta-se pela metodologia com abordagem qualitativa, em que qualquer investigação social necessita revelar o aspecto primordial do seu objeto, que se traduz no qualitativo. A investigação problematiza a relação entre sujeitos, portanto é dialógica, na qual a pesquisadora é parte integrante do processo investigativo.

\footnotetext{
${ }^{43}$ Este artigo resulta de uma pesquisa de mestrado do Programa de Pós-Graduação stricto sensu em Relações Étnicas e Contemporaneidade- PPGREC - Universidade Estadual do Sudoeste da Bahia/UESB, Campus de Jequié.
} 
Tem-se a história oral como "um conjunto de procedimentos que se inicia com a elaboração de um projeto e que continua com o estabelecimento de um grupo de pessoas a serem entrevistadas" (MEIHY; HOLANDA, 2013, p. 15), essas pessoas são colaboradoras, de maneira que valoriza as subjetividades a partir do anunciado e das vivências narradas, que podem revelar afirmações ou negações, saberes e significados no processo de construção das identidades.

Esses grupos, no caso específico dessa investigação as prostitutas, perpassam por lutas sociais e conquistas de espaços no percurso de reconhecimento por uma identidade social. O processo histórico, cultural, educacional, sócio econômico e político no país e as politicas públicas mais recentes de apoio e reconhecimento à classe desvelam lutas e contradições vividas por essas mulheres. No caso dessa pesquisa, as vivências se corporificam nas histórias de cada uma que tem pontos e razões que convergem para baixa escolaridade, abandono, preconceito e vulnerabilidade social. Assim, ouvir as vozes das mulheres que se evidenciam em especificidades de vulnerabilidade social nos diferentes contextos e espaços sociais exige um olhar reflexivo acerca das lutas e disparidades de gênero no cotidiano das relações na sociedade contemporânea. Nesse cenário, como conceber a prostituição?

Uma compreensão mais abrangente sobre o fenômeno da prostituição se faz necessário problematizar os significados vigentes, seu contexto, as contradições, suas desconexões com antigas significações, de modo a compreender o contexto da contemporaneidade e promover o debate sobre a prostituição em diferentes contextos e espaços sociais.

A prostituição sob o prisma da construção da identidade étnica de mulheres que se confrontam com outras mulheres pensa-se no embate identitário e na dinâmica que se estabelece entre grupos e lugares. Promove diálogos, revela os aspectos e fatores ligados à prostituição na localidade, considera as peculiaridades que denunciam e evidenciam as identidades das mulheres prostitutas no contexto entre famílias, escola e trabalho. Ser mãe e prostituta. Nesse cenário de debate, essa proposta de trabalho se apropria da história de vida das prostitutas, redimensiona o debate sobre a prostituição no mundo contemporâneo e visibiliza as experiências de vida das prostitutas no contexto das relações étnicas.

A investigação aponta para os conflitos entre o mundo da escola, de ser mãe e o mundo da prostituição. Vivências de mulheres menosprezadas e hostilizadas pela própria família. Evidencia a história de vida entre lutas pela sobrevivência e formas de resistências.

\section{ENTRE DESAFIOS E SUPERAÇÕES}

Para mudar o mundo, é preciso mudar as maneiras de fazer o mundo, isto é, a visão de mundo e as operações práticas pelas quais os grupos são produzidos e reproduzidos ${ }^{44}$.

Fig. 1 - Fotos do Distrito Stela Câmara Dubois

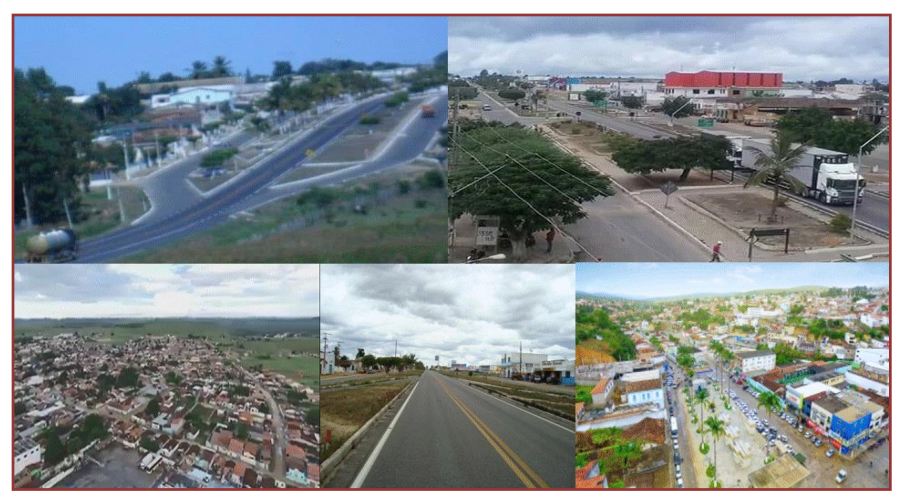

Fonte: Google acessado em 26 de janeiro de 2019

As mudanças ocorrem a todo tempo nos cenários com elevados números de problemas socioculturais que se constituem na dinâmica da relação entre o "eu" e os "outros", no que tange aos processos de construção

\footnotetext{
${ }_{44}$ C.f a obra de BoURDIEU, Pierre: Coisas ditas1930-2002. Tradução Cássia R. da Silveira e Denise Moreno Pegorim;
} revisão técnica Paula Montero. São Paulo: Brasiliense, 2004. 
de identidades em uma sociedade marcada por inúmeras desigualdades. Nessa dinâmica, compreende-se que grupos os minoritários são fragilizados e vulneráveis, cujas histórias de vida necessitam ser registradas.

Reportando-se a Rago (1985), a prostituição é considerada como um desvio que se fundamenta-se nas reflexões médicas de higienização, desenvolvida no final do século XIX. Conforme a autora observa-se que a prostituta foi, nesse período, rotulada como degenerada, decaída, mulher sexualmente doente, devendo assim, ser afastada da convivência das "boas famílias” e pagar um alto preço por sua condição social.

Mulheres de má vida, meretrizes insubmissas, impuras, insignificantes, o que fazer com essas loucas que recusam o aconchego do casamento, que negam a importância do lar e preferem circular enfeitadas pelas ruas, desnudando partes íntimas do corpo, exalando perfumes fortes e extravagantes, provocando tumultos e escândalos, subversivas que rejeitam o mundo edificante do trabalho, surdas aos discursos moralizantes e que perseguem a todo custo a satisfação do prazer? (RAG0, 1985, p. 85).

Conforme Beavoir (1980, p.376) “a prostituta é um bode expiatório; o homem descarrega nela sua torpeza e a renega, [...] a prostituta não tem direitos de uma pessoa, nela se resumem , ao mesmo tempo, todas as figuras da escravidão feminina". Assim, percebe-se a prostituição como o resultado de relações sociais hierárquicas de poder; como resultado igualmente de uma situação moral invertida; como objetificação total da mulher nas instâncias sexual e econômica submetida à ordem masculina ; como instituição partícipe do funcionamento do sistema patriarcal; como uma forma trabalho. Segundo a autora "a maior parte das prostitutas estão moralmente adaptadas à sua condição". (BEAVOIR, 1980, p.388).

Prostituição é um trabalho penoso onde a mulher oprimida sexualmente e economicamente, submetida ao arbítrio da polícia, à uma humilhante vigilância médica, aos caprichos dos clientes, destinada aos micróbios e à doença, é realmente submetida ao nível de uma coisa.(BEAVOIR, 1980, p.389).

Rodrigues (2009) afirma que na concepção concebida como um "mal necessário", a prostituição é vista como "a profissão mais antiga do mundo" uma forma de naturalizar esse exercício e reafirmar o domínio dos homens sobre as mulheres, enfatizando que os corpos femininos sempre estiveram à disposição dos seus consumidores, os homens. Nesse entendimento, a prostituição é considerada como desvio de pessoas doentes que não se adequam ao padrão e normas vigentes que para os moralistas, se consolida para atender ao prazer masculino, uma vez que em nossa cultura o sexo não é desonra para o homem.

Nessa expectativa, as reflexões sobre prostituição demandam pensar os estilos de vida das prostitutas, de forma a haver um deslocamento dessas discussões do eixo moralista para um campo mais amplo que seja permeado pelas questões politicas, sociais e étnicas em defesa dos direitos humanos. Contudo, embora, tenham ocorrido transformações e avanços em torno da prostituição ainda são explícitos os elementos ligados à dominação de gênero, violência e estigmatização. Goffman (2004) menciona que estas marcas estão ligadas a etnia, corpo, situação social desenvolvendo estigmas.

Em primeiro lugar, há as abominações do corpo - as várias deformidades físicas. Em segundo lugar, as culpas de caráter individual, percebidas como vontade fraca, paixões tirânicas ou não naturais, crenças falsas a partir de relatos conhecidos de, por exemplo, distúrbio mental, prisão, vício, alcoolismo, homossexualismo, desemprego, tentativas de suicídio e comportamento político radical. Finalmente, há os estigmas tribais de raça, nação e religião que podem ser transmitidos através de linhagem e contaminar por igual todos os membros de uma família. (GOFFMAN, 2004, p.14).

A identidade existe sempre em relação à outra. Quer dizer, existe uma relação dialética entre identidade e reconhecimento social que se dá a partir dessas construções que podem ser positivas ou negativas, as quais designam determinados comportamentos dos sujeitos. Assim, repleta de violências e estigmas, a prostituição se assemelha a uma atividade que outorga elementos arcaicos de uma moral sexual civilizada. A reflexão sobre prostituição exige novos olhares que vão além dos discursos sobre sexualidade decorrentes da chamada "revolução sexual".

Constata-se no decorrer da história que as prostitutas têm as marcas da ausência de estudo, situação de pobreza e revelam laços familiares rompidos e a condição de vida à margem de experiências preconceituosas e discriminatórias. As mulheres são violentadas pelo discurso da masculinidade hegemônica, o qual reproduz a lógica da dominação masculina nas instituições como família, escola e 
estado. Evidencia-se em suas histórias, uma infância e adolescência negada pelos direitos à cidadania. Nesse contexto de traumas, frustrações e humilhações elas buscam superar a dor do sofrimento e lutam pela vida.

A falta de amparo dos pais, abandono pelos amantes ou maridos, ausência de oportunidade de trabalho e estudo, sedução e exploração, escravidão sexual, medo, são causas elencadas por Beauvoir (1980) para a prostituição. Portanto, sob o signo do social a existência da prostituição é posta num contexto de violência implícita ou explícita, desmascarando "a mais antiga profissão do mundo".

Scott (1992) ressalta quanto à questão de gênero que com a proliferação dos estudos do sexo e da sexualidade, o gênero se tornou um termo particularmente útil, porque oferece um meio de distinguir a prática sexual dos papéis atribuídos às mulheres e aos homens, pensado simetricamente o lugar de fala das mulheres durante toda a história da humanidade que foi de lugar da subalternidade, subserviência e em contrapartida, os homens assumiram um lugar privilegiado.

Gênero é uma categoria útil de análise histórica, por induzir a compreensão de homens e mulheres em termos relacionais. É um elemento constitutivo de relações sociais fundadas sobre as diferenças percebidas entre os sexos; é o primeiro modo de dar significado às relações de poder (SCOTT, 1992, p 75).

Com base nessa explanação, compreende-se gênero como um elemento constitutivo das relações sociais fundamentado nas diferenças percebidas entre os sexos, é uma forma primária de dar significado às relações de poder; um campo primitivo dentro do qual ou por meio do qual se articula o poder. Assim, nas várias maneiras de entender a complexidade das interações humanas o gênero assume mecanismo de decodificação de várias formas de interações.

Para Silva, "questionar a identidade e a diferença como relações de poder significa problematizar os binarismos em torno dos quais elas se organizam" (SILVA, 2014, p. 83), isto é, o questionamento implica desconstruir esses binarismos, mostrar como eles não são essencialmente dados e ativamente produzidos de modo a manter relações hierárquicas e de privilégio. Butler (1999, p. 155) argumenta que a formação do sujeito através do imperativo heterossexual exige a produção simultânea de um domínio de seres abjetos que formam o exterior constitutivo relativamente ao domínio do sujeito. 0 objeto se refere às zonas inabitáveis da vida social.

As narrativas das prostitutas exprimem subjetividades daquilo que é desprezível e vergonhoso, discursos construídos no campo da idealização do individual e de um coletivo, a prostituição é realização ou um aprisionamento, considerando as pressões sociais, regulações da sexualidade que aparecem e suscitam o preconceito e aprisionamento das mulheres acerca das suas subjetividades em seus processos de construções indenitárias.

Nesse sentido, a transgressão dos papéis problematiza a natureza biológica de homens e de mulheres, tem um discurso que leva à manutenção da tal ordem compulsória que inscreve o sexo e as diferenças sexuais fora do campo do social. Desconstruir essa norma de caráter social de estruturas que parecem naturalizadas, de acordo Butler (2003), é uma questão de gênero, já que este é um ato intencional, um gesto performativo que produz significados.

As mudanças da sociedade contemporânea afetadas determinantemente pela expansão do capitalismo com seus modos de produção e com o desenvolvimento das classes médias, sobretudo na Europa, foram alicerçadas pelas expressões do processo de proliferação do discurso e reafirmação das sexualidades heterogêneas que eclodiram a partir da década de 60 com o surgimento dos movimentos sociais.

Esses movimentos, embora, não romperam totalmente com a lógica e mecanismos do saber/poder que consiste em "estratégias de relações de força, sustentando tipos de saberes e sendo por eles sustentadas." (FOUCAULT, 1979, p. 246) foi decisivo por uma das expressões mais diretas da evolução do processo de proliferação do discurso e reafirmação das sexualidades heterogêneas. "O dispositivo de sexualidade tem, como razão de ser, não o reproduzir, mas o proliferar, inovar, anexar, inventar, penetrar nos corpos de maneira cada vez mais detalhada e controlar as populações de modo cada vez mais global" (FOUCAULT, 2011, p.118). 
Conforme Foucault (1979), um dispositivo é sempre um dispositivo de poder, que opera em um determinado campo e se desvela pela articulação que engendra de uma multiplicidade de elementos, pela relação de poder que entre eles se estabelece. 0 dispositivo expressa, ainda, um objetivo estratégico que atende a uma urgência histórica. Entende que um dispositivo corresponde a "um tipo de formação que, em determinado momento histórico, teve como função principal responder a uma urgência. 0 dispositivo tem, portanto, uma função estratégica dominante". (FOUCAULT, 1979, p. 244).

Em cada momento da história a dominação se fixa em um ritual; ela impõe obrigações e direitos; ela constitui cuidadosos procedimentos. Ela estabelece marcas, grava lembranças nas coisas e até nos corpos; ela se torna responsável pelas dívidas. (FOUCAULT, 1979, p. 25).

Nesse contexto de movimentos marcados por críticas, discussões e reivindicações prevalece a busca incessante que em torno da liberação dos costumes, do direito ao prazer e à diferença, da não discriminação e do reconhecimento da diversidade e das minorias sexuais "não é simplesmente a questão de o que é uma mulher própria ou imprópria, mas o que não é absolutamente concebível como uma mulher" (BUTLER, 2002, p. 165) que na situação de prostituta ocupa um lugar que, de alguma forma, se relaciona ao lugar que a mulher ocupa dentro do binário próprio e impróprio, especialmente quando.

Ainda não somos capazes de considerar aqueles atos e práticas e modos de vida que foram brutalmente excluídos desse mesmíssimo binário próprio e impróprio. Eles não são a pré-história benigna desse binarismo, mas sim seu violento e inominável avesso (BUTLER, 2002, p.166).

É importante atentar que nesse contexto que o movimento feminista ressurge de maneira mais radical, torna assim, mais visível e expressivo questiona a ordem de dominação masculina e a reivindicação de igualdade de direitos entre homens e mulheres, exprime a necessidade de mais participação das mulheres nos espaços sociais, econômicos e políticos. Teorizar a prostituição como construída através de um processo de abjeção coloca a prostituta em um lugar além do próprio e impróprio parece ser um caminho promissor, ainda que teoricamente ousado, em direção a ações mais efetivas de enfrentamento do estigma da prostituição e seus impasses, na medida em que possibilita sair da dicotomização e lançar luz na complexidade dessa construção, e entender o significado da prostituição a partir de suas práticas.

A inserção das mulheres no mercado de trabalho em busca de autonomia, independência e liberdade traz uma série de ressignificados sobre a atuação das mulheres em espaços que até então eram reservados aos homens. Nas famílias e na sociedade de modo geral, as relações entre homens e mulheres se firmam em novas configurações. Nesse contexto, as dinâmicas familiares ganham espaços organizacionais, dá visibilidade às famílias enredadas, monoparentais, geralmente constituídas de mulher e prole; filhos criados por terceiros em função da dupla jornada de trabalho dos pais; casais que optam por não terem filhos e famílias reconstituídas.

As novas relações familiares se definem pela atividade sexual concentrada no desejo que é individual, o principio de fazer/ser, que traz uma cadeia de significados pautados no prazer. Percebe-se que o exercício sexual vai se tornando cada vez mais pautado no prazer e desvinculado do modelo patriarcal de casamento monogâmico legítimo e com fins reprodutivos.

Em uma crescente desconstrução, esse modelo patriarcal está progressivamente dando lugar às configurações familiares e modalidades de laços sexuais e afetivos mais flexíveis, menos duradouros e adequados às rápidas e constantes transformações da economia capitalista. Também, os avanços das tecnologias aceleram esses processos, exercem papéis fundamentais nas mudanças relativas ao campo da sexualidade no mundo atual. Nesse contexto de mudanças, o discurso contemporâneo sobre a sexualidade se caracteriza por possibilitar uma multiplicidade de expressões que comportam desde as formas mais antigas e tradicionais de exercício da sexualidade até as formas mais modernas.

A partir desse cenário de mudanças e transformações sociais e culturais, é que a prostituição merece reflexão porque os diferentes contextos e espaços nos quais as mulheres estão inseridas se relacionam pela lógica imbricada das representações de gênero, sexo e classe. Frente a estes fatos, a prostituição não possui uma noção única e impermeável, na verdade existem várias prostituições que desafiam a refletir acerca das mudanças no modo como a sociedade atribui significado a prostituição.

0 discurso social sobre as identidades se reflete nas diferentes famílias, como um espelho. Em cada caso, entretanto, há uma tradução desse discurso, que, por sua vez, devolve ao mundo social sua imagem, filtrada pela singularidade das experiências vividas. As transformações políticas, econômicas, culturais e 
sociais deram a sociedade brasileira novas formas de organizações que interferiram nas dinâmicas sociais e familiares e na atuação das mulheres nos diferentes espaços.

Mediante as novas configurações da sociedade brasileira é que as prostitutas aparecem entre os diferentes grupos étnicos, produzem as relações que se constituem de acordo com a cultura, a região e a classe social dos sujeitos. Os espaços e contextos em que essas mulheres estão inseridas dialogam com a família, escola e trabalho de maneira que as identidades são afirmadas e/ou negadas. Desse modo, as mulheres prostitutas se apropriam de traços culturais para produzirem identidades que se manifestam das relações de vivências as quais as remetem a um sujeito sociocultural.

Esse processo de construção identitário é estabelecido através do movimento de inclusão e exclusão, impõe limites entre os grupos de contato, em que as relações de pertencimento étnico tornam-se marcadas pela identidade e diferença. Identidade referenciada pela cultura eurocêntrica que expressivamente circula nos espaços da sociedade apresentando-se como dominante e oficial. Diferença no que diz respeito às marcas simbólicas da representação dos povos que não possuem atributos do grupo considerado colonizador. Nesse aspecto, a língua, religião, costumes, vestimentas, hábitos e códigos são considerados inferiores nas situações de interação em que a identificação e/ou diferenciação são evidenciadas através das representações de fronteiras entre nós e eles.

As histórias de vida trazem consigo os diferentes processos de identidade e identificação. Há uma visibilidade desses processos a depender do lugar de fala e das representações do sujeito no universo das relações étnicas.

Os limites do mundo familiar, demarcados pela historia que a família conta sobre si, criando sua identidade, são abalados pela ação individualizada de cada um de seus membros, que reagem singularmente às relações internas e que trazem à convivência cotidiana a experiência também singular com o mundo exterior. A tensão entre os distintos discursos familiares denota a singularidade da família no mundo contemporâneo: ela é, ao mesmo tempo, auto referida na sua construção do "nós" - nisto que constitui o mundo privado - e permanentemente influenciada pelo mundo exterior - o publico -, que lhe traz a inevitável dimensão do "outro", com a qual tem que lidar. Assim, a família constitui-se pela construção de identidades que a demarcam, em constante confronto com a alteridade, cuja presença se fará sentir insistentemente, forçado a abertura, mesmo quando persistirem as resistências. A família, então, constitui-se dialeticamente (SARTI, 2004, p. 19).

Na contemporaneidade, as mulheres têm revelado papéis diferenciados daqueles que as colocavam em condições de submissão aos modelos familiares hegemônicos. Há realidades em que as mulheres aparecem com variações de comportamentos de acordo as diferentes classes sociais. A própria natureza do sistema patriarcal se desfez com a divisão do trabalho entre o marido e a esposa criando, de certo modo, condições para a afirmação da identidade feminina, devido as suas atuações junto à família.

Silva (2014) destaca o discurso colonial e a sua ligação com relações de poder que existem na demarcação das fronteiras determinantes das diferenças. Segundo o autor, é por meio da representação que a identidade e a diferença adquirem significados, ao utilizar padrões para estabelecer aceitação ou negação, inclusão ou exclusão de um individuo em determinado grupo, indica posições de pertencimento do sujeito. Normalizar significa padronizar uma identidade como paradigma para as demais.

[...] é por meio da representação que, por assim dizer, a identidade e a diferença passam a existir. Representar significa, neste caso, dizer: 'essa é a identidade', 'identidade é isso'. É por meio da representação que a identidade e a diferença se ligam a sistemas de poder. Quem tem o poder de representar tem o poder de definir e determinar identidade (SILVA, 2014, p. 91).

Essa realidade na qual quem detém o poder de representação apresenta condição de nomear e classificar seus pares é visível nos espaços da sociedade. Vale salientar que o contexto social, histórico e político são definidos pela multiplicidade de sujeitos, culturas, saberes, e crenças. A identidade e diferença são produções sociais e interdependentes, considera-se, assim como Hall (2014), que as identidades são firmadas por meio das diferenças, designando posições assumidas e/ou negadas pelos sujeitos.

Ao reportar às narrativas das colaboradoras desta pesquisa, a manifestação da diferença passa a existir no meio social a partir do outro, o diferente, colocando sempre em questão as identidades. Remete-se nesse caso, as falas que evidenciam aqueles (outro) que apontam e indicam quem elas são e um (eu) quando elas 
se reconhecem como prostitutas e mães afirmando e/ou negando o pertencimento a um determinado grupo.

Dessa forma, a identidade e a diferença se complementam através da relação de contraste. Ao contar sobre as suas trajetórias, a memória trouxe os estigmas que permeiam o imaginário social das mulheres em determinados contextos. Questões como família, educação, classe social, trabalho, etnia e gênero são apontadas como fatores que contribuíram para os estigmas na história de vida dessas mulheres. Identidades construídas pelos embates, lutas e silenciamentos que se expressam nas vivências da prostituição e se dialogam no espaço familiar. Com isto, Bourdieu (2002) compreende que as mudanças reais ocorridas na sociedade contemporânea a partir de suas práticas desvelam as formas de legitimação que justificam a dominação social, estereótipos e as formas de opressão que definem e limitam um grupo de pessoas na sociedade.

Ao pensar sobre as identidades das mulheres que se assumem como mães e prostitutas, no entendimento de Goffman (1988) a identidade de um determinado indivíduo é construída a partir dos parâmetros e expectativas estabelecidas pelo meio social. Para ele, os critérios de categorizar as pessoas e a dimensão de atributos considerados como semelhantes e naturais para os membros de cada uma das categorias são determinados pela sociedade. São os ambientes sociais, escola, família, trabalho e igreja que determinam as categorias de pessoas que neles podem ser encontradas. Entretanto, as rotinas das relações nesses espaços sociais determinados, proporcionam interações com outras pessoas previstas sem atenção ou reflexão particular.

Então, quando um estranho nos é apresentado, os primeiros aspectos nos permitem prever a sua categoria e os seus atributos, a sua "identidade social" para usar um termo melhor do que "status social", já que nele se incluem atributos como honestidade, da mesma forma que atributos estruturais como ocupação (GOFFMAN, 1988, p.12).

As diferentes abordagens sobre identidade são desenvolvidas a partir de um conceito que envolve a dimensão individual e coletiva. Nessa direção as identidades das prostitutas são construídas na dialética entre um indivíduo e a sociedade. Em outros termos, ela revela o resultado das diversas interações entre o sujeito e o seu ambiente social, que o aproxima ou o distancia conforme suas semelhanças. As famílias se identificam pelas marcas sociais de lutas e silêncios em suas caminhadas. As histórias desvelam identidades marcadas pelas relações de sentimentos familiares rompidos. Nesse contexto, se anunciam embates identitários que se manifestam das relações de vivências enquanto mulheres, prostitutas e mães. As memórias alicerçadas em sonhos, conquistas, mas também, em sofrimentos e violências que são semelhantes entre essas mulheres em um mundo vivenciado por elas como sustento e sobrevivência, em uma sociedade preconceituosa e excludente. Nesse universo de enfrentamentos diários elas buscam melhores condições de vida para suas famílias.

A identidade étnica não é estática e se constitui a partir dos conflitos identitários que se formam através das relações sociais. Diferenças e semelhanças familiares ocorrem dialeticamente das representações de poder que produzem e reproduzem desigualdades. Desse modo, as identidades das prostitutas são acentuadas pelo viés dos processos de inclusão ou exclusão. Elas se organizam a fim de definir o "eu" e o "outro", o "nós e eles" manifestando as categorias de diferenciação e assimilação.

Nesse entendimento, a identidade étnica ocupa lugar emergente no qual o sujeito, que no caso desta pesquisa são as mulheres prostitutas, baseia-se em si para situar-se etnicamente. Essas mulheres e as suas peculiares vivências constituem as suas identidades étnicas em uma sociedade, atuam como elementos essenciais na construção cultural da comunidade, "um grupo social que no interior de um sistema sociocultural mais amplo, reivindica e possui um estatuto especial em razão de um complexo de traços que ele representa ou presume representar". (POUTIGNAT E STREIFF-FERNART, 2011, p. 80).

De acordo com Hall (2004), o mundo contemporâneo tem produzido formas complexas de subjetivação, pois simultaneamente busca abertura de espaço para interdependência transnacional das identidades e das interações globais e provoca um movimento que busca retomar os aspectos locais que sustentam a demarcação de diferenças.

Tomando as relações étnicas, neste estudo, as prostitutas pensadas a partir de uma lógica hegemônica evoca-se a cultura no sentido de "território de luta" (HALL, 2004, p. 246), local onde está em jogo modos de ser, sentir, pensar, agir dos sujeitos sociais em que os significados e sentidos das representações estão em permanente disputa e negociação. Assim, a identidade constrói-se em situações específicas através de 
representações culturais e sociais pois é entendida com um "modo de construir sentidos que influencia e organiza tanto nossas ações, quanto a concepção que temos de nós mesmos". (HALL, 2004, p. 50).

\section{ESPELHOS DA NOITE: MULHERES QUE FALAM!}

Eu não dei por esta mudança, tão simples, tão certa, tão fácil:- Em que espelho ficou perdida a minha face? ${ }^{45}$

Fig. 2 - Foto do Restaurante Primavera

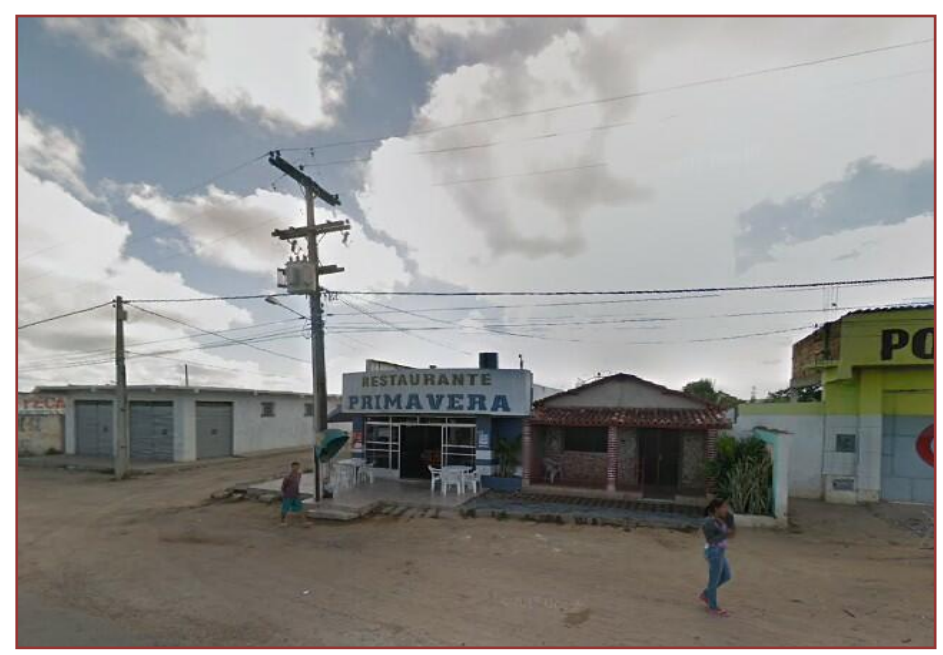

Fonte: Google acessado em 26 de janeiro de 2019

A prostituição se mostra para conservadores e fundamentalistas como afronta as expectativas sociais atribuídas ao papel da mulher e apesar de sua evolução no mercado capitalista, a prestação de serviços sexuais não garante direitos trabalhistas nem sociais. Essa prática traz para outros grupos, aspectos negativos relacionados a ideia de ser mulher fora da normatividade social e o preconceito se faz presente e afeta os diversos espaços que cada um pertence: escola, família, igreja e comunidade. Dentre os aspectos negativos a ser evidenciados, está a violência que por vezes é banalizada pela sociedade, sobretudo, quando é atribuída à prostituta, diminui o valor de violação aos princípios desses grupos.

0 discurso social sobre as identidades se reflete nas diferentes famílias, como um espelho. Em cada caso, entretanto, há uma tradução desse discurso, que, por sua vez, devolve ao mundo social sua imagem, filtrada pela singularidade das experiências vividas.

Uma coisa que eu queria tanto, que meu irmão, minhas irmãs me perdoasse pelo o que eu seja, meu irmão uma vez eu nunca esqueço o que ele fez comigo, eu bati na porta, minha mãe ainda tava viva na época, eu pensei que era minha mãe que ia abrir a porta pra mim, mas não era, foi meu próprio irmão, me deu um tapa na cara e eu não tenho mágoa dele, não tenho raiva dele, porque ele fez isso, que pelo meno era pra ele demostrar o que ele é. Meus irmãos, minhas irmãs mermo que filhos de outra mulher, mas eu não sinto raiva deles. (ESMALTE)

Fui criada com minha mãe, eu não tenho pai, ela não diz quem é antes eu tinha muita curiosidade de saber quem que era ele, perguntava muito a ela, mas hoje eu não me interesso muito. Mas já me interessei muito, em ir atrás, saber quem é, de ter o reconhecimento, o pai né, saber quem que é a falta talvez, por causa de ser criada só com minha mãe, passava certos perrengues, falar vamos dizer assim, então eu tinha curiosidade mesmo se ele não convivesse com minha mãe como não conviveu e eu não conheci, eu acho que se eu tivesse contato talvez eu

45 C.f obra de MEIRELES, Cecília. Poesia completa. Organização de Antônio Carlos Secchin. Rio de Janeiro: Nova Fronteira, 2001. $2 \mathrm{v}$. 
poderia buscar outra forma, entendeu, junto a ele, sei lá, que assim, o convívio com minha mãe foi muito difícil. Talvez se eu tivesse a presença dele, com ele seria mais fácil. Foi uma forma que eu encontrei, pra mim é normal, sei que tem muitas pessoas que falam que ver por outro lado, ver com outros olhos, mas eu não ligo não, até porque quando eu sempre precisei foi a isso que eu recorri. (ESPELHO)

Eu cuidava dos meus irmãos, minha mãe saia pra trabalhar e eu cuidava deles, até os quatorzes anos sempre foi eu. Teve uma época da minha vida que eu muito ignorante com minha mãe (se refere à adolescência), apanhei muito, isso acabou quando eu tive meu filho, comecei a ter responsabilidade desde os dezoito anos com a maternidade. (BATOM)

De acordo com as narrativas das colaboradoras, a família e seu sentimento importam para sua estima. Pela identidade, a diferença está intrinsicamente ligada a sua atividade de prostituição, afeta os laços de família, que s se romperam desde a mãe até os irmãos. A identidade e a diferença estão estreitamente relacionadas às formas pelas quais a sociedade produz e utiliza classificações entre um grupo ou vários e, nesse caso, a divisão e classificação de mulheres se institui, não de forma hierarquiza, mas valorativa. Nesse sentido, identidade e a diferença se traduzem no mesmo grupo, se tornando diferencial na medida em que o sentimento de família, de laços rompidos precisam ser resgatados através da ideia de não abandonar filhos, cuidá-los.

Ser mulher, mãe e ser prostituta é assumir frente às inúmeras formas de preconceitos o lugar de luta em contraponto as referências que as estigmatizaram historicamente. Vítimas de ausências de pais, de estudos, de oportunidades, adentram na vida de estrada é então, se tornarem prostitutas, tem consciência de si e das relações com os outros, reconhecem sob a ótica de ser mãe. Daí é importante considerar as diferenças entre prostituição como profissão, mas não como mãe, pois se reconhecem boas mães e pelos filhos lutam. Ao serem questionadas como se percebem no contexto da prostituição, as colaboradoras revelam.

Fico com meus filhos de dia, de noite vou trabalhar, não tenho ninguém pra me ajudar, nunca pedi nada pra ninguém, trabalho, pra me é um trabalho honesto, cuido deles, eu mando tudo pra escola, sempre amei e sempre vou amar na onde eles estiver, eu trabalho pra eles, dando as coisas, falta muitas coisas, falta muitas coisas dentro de casa, que eu tivesse pelo menos o pai pra ajudar meus filhos, mas eu não tenho, só tenho eu sozinha. (ESMALTE)

Eu não vou mentir, eu me vejo como uma garota de programa, todo mundo tem preconceito por isso, meu pai mermo me esculhamba, me xinga, fala que eu sou tudo na vida, que eu sou uma prostituta, eu acho que não sou isso, sou muito mais de que isso. Me sinto abandonada por todos. (ESPELHO)

Tenho sete irmãos. Meus irmãos tem um que odeia eu, que é filho de outra mulher, porque eu sou uma garota de programa ele não gosta de mim por causa disso, mas é melhor a gente ser o que a gente é, de que roubar, matar, eu não quero essa vida pra mim, ser garota de programa é muito mais melhor. (ESMALTE)

Todo mundo olha com olho de maldade, porque é prostituta, gosta de homem casado, vai tomar meu marido, que vai fazer, vai acontecer, e não é exatamente isso, pelo menos, eu sou assim, o que é seu é seu o que é meu é meu, porque todo mundo olha e fala assim, ah, porque faz programa, anda dando em cima de homem casado, eu não sou assim [...] (BATOM)

Primeira coisa que eu fazia era sair desse lugar, pra ninguém ficar falando mal de mim, todo mundo firca jurgando as pessoas, tem gente que passa por mim e vira a cara, não gosta de mim, que eu arrumasse uma pessoa hoje, falasse assim, Branca tu quer sair hoje dessa vida? Primeira coisa que vou agradecer muito a Deus, sair, sai dessa vida, pra mudar tudo de vorta. (ESMALTE)

Eu vou ali em cima no posto, você não me vê em nenhum lugar a não ser ali, então ali, eu chego ali, fico ali, tem um rapaz que vende churrasco ali, meu ponto é ali, geralmente eu tô ali, deu o horário dele vim embora, eu não fico, eu saio daqui as sete horas, eu não sinto tanta vergonha, se me ver lá meia noite, uma 
hora da manhã eu já sinto vergonha, meu horário de ficar na rua é até meia noite, passou no máximo, você não vê eu lá na rua. (BATOM)

$\mathrm{Na}$ época quando eu tinha treze anos, eu fui estuprada maltratada, eu botei muitas coisas na minha cabeça, que um dia eu queria ser o que sou na vida, eu não me importo que as pessoas me xingue, que me fala coisas, que me xingue que eu sou puta, que eu sou rapariga, normalmente que eu sou isso, meu pai, minhas irmãs tudo me iscuiamba, mas eu não ligo. 0 que aconteceu comigo eu não quero que aconteça com ninguém, que é muito sofrimento, muita dor, hoje eu tenho filhos, eu sei o que eu passo nessa vida, faço de tudo pro meus filhos, dou tudo o melhor pra meus filhos, pra não ser uma coisa pior. (ESCOVA)

Porque a pessoa ser garota de programa não é quarquer uma, não é eu acho que não, porque tá fazendo seu trabalho alí, não tá roubando, não tá matando, tá botando comida dentro de casa pra dar pros filhos, sem pedir nada pra ninguém, eu sei que uma parte é ruim, que tá vendendo o corpo ali, mas é melhor fazer isso que muitas coisas pior. (ESMALTE)

A ferrenha discriminação de grande parcela da população, seja por comentários depreciativos, olhares de lado e até mesmo agressões verbais e físicas está em evidencia na fala dessa colaboradora. 0 sentimento de abandono atribuído a todos, está implícito subjetividades que denunciam uma distancia entre o mundo da prostituição e as vivências no meio social. A fala ilustra o pensamento nas experiências e vivências de sentir-se prostituta e os controles e resistências que estão intrinsecamente vinculados nas relações que contribuem para a elaboração de uma imagem positiva ou negativa no âmbito das sociabilidades.

Sentirem-se sozinhas e abandonadas por todos são sentimentos revelados por essas mulheres ao lidar com sua identidade de prostituta, que, inclusive, aparece conflituosa quando se apropria do estereótipo "garota de programa" para definir e limitar os sentimentos que se manifestam ao construir suas acepções sobre a prostituição, e tem como estratégia o uso do campo simbólico, significados culturais sobre prostituição que são produzidos e representados por meios e sistemas dominantes de representação. Esses espaços de vivências das prostitutas são mediados pelos significados de representatividade nos encontros das identidades mais ou/e menos fixada no processo de identificação ao assumirem a prostituição como trabalho e condição de sobrevivência.

A identidade é, portanto, um processo interminável de interações entre pessoas que são negociadas em um território cultural, ou seja, constroem-se identidades em interação com o outro, desde as primeiras relações estabelecidas no grupo social, em contato com a família, a comunidade, a cultura, em espaços diversos onde os sujeitos adquirem informações e elaboram suas subjetividades.

Os sentimento de tristeza e dor se manifestam nas narrativa e representam as fragilidades dos laços afetivos familiares. As afirmativas sobre a diferença dependem das negações "do que eu não sou", assim, a diferença apresenta enquanto produto derivado da identidade; são construções produzidas no contexto das relações culturais e sociais. A disputa por identidade envolve o campo social em que há negociações dos recursos simbólicos e materiais. Implica em ações de incluir e excluir, do "nós" e "eles" consiste na demarcação de fronteiras entre os que estão dentro e os que estão fora.

0 mundo social é composto de estruturas socialmente construídas, o espaço social é composto de estruturas discriminatórias, de maneira que as práticas vêm acompanhadas de quem as praticou, são inseparáveis do "sistema simbólico" que Bourdieu (2004) impõe na visão de mundo a partir de um processo de divisão de grupos, classificado e hierarquizado. Os conflitos são expressões nas formas de dominação e as distâncias espaciais refletem as distâncias sociais.

Quando eu estou lá em cima no trabalho, eu fico tão sossegada, não vejo ninguém me iscuambando, as pessoas só me tratam muito bem, nunca me tratou mal, muitos me dá conselho pra eu sair dessa vida, mas eu não tenho como sair, não adianta a gente sair e deixar os filhos, sem dar nada pro meus filhos (ESMALTE)

A vida que eu levo mermo que é ruim, ou mermo que não, mas pra me é uma parte que eu esqueço muitas coisas, na onde que tô , no meu trabalho. Mas eu não dou conselho pra ninguém ficar nessa vida, meus irmãos não gosta de mim, a única que gosta de mim que tá com minha filha tomando conta, porque o resto nunca gostou de mim. (ESCOVA) 
Vejo como uma necessidade, pra dar conta da vida, porque aqui, muitos empregos que tem, eu não teria condição nem de manter o aluguel de casa e minhas despesas. Geralmente o que oferece aqui, você vai pagar um aluguel, uma água, uma luz e não vai sobrar nada, eu tenho que me manter, eu tenho que comer, tenho que beber, eu tenho que me vestir, cumprir com meus compromissos do dia a dia. (BATOM)

São tantas coisas, não sei por onde começar, ah, eu lembro, eu no restaurante, sempre ajudava minha mãe, essas coisas assim, aparece, eu estudei, tipo, de onde minha mãe morava até a cidade era três km, normalmente a gente pegava carona com o carro do posto que tinha lá mais na frente e voltava né. Eu fiquei até a segunda série, nessa minha adolescência ai depois quando eu casei, que fui embora para o Paraná eu ainda continuei, fiz o supletivo, parei na quinta ainda. Então eu conheci meu ex-marido, eu tinha uns quinze anos, ai a gente se envolveu, hoje em dia eu penso assim que por eu ter ido embora com ele, ter tido filhos, eu acho que foi mais um recurso pra fugir de certos problemas em casa né. Algo diferente que eu faria, eu acho que eu não pararia de estudar, e mesmo depois que eu parei de estudar eu ainda tentei varias vezes, mas com filhos e tudo né, tudo dificultou, eu voltaria a estudar e faria outras coisas diferentes, eu acho que eu perdi muitas oportunidades nesse caminho, mas foi uma forma (ESPELHO)

Na condição de prostituta, se evidencia a mulher chefe de família, aquela como afirma todas as colaboradoras que enfrentam uma luta mediante o preconceito e, ao se identificarem garota de programa, demonstra resistência em sua trajetória. "Sou muito mais que isso" em evidência no depoimento de Escova, possibilita pensar nas mais variadas formas de violências de gênero vivenciadas por essas mulheres. Neste sentido, a violência de gênero tem suas causas no próprio homem, da própria família ou não, uma vez que exerce ou não seu papel de proteção, ou seja, assume comportamentos violentos como reflexos de valores aprendidos e repetidos, social e culturalmente. Por este motivo, as tentativas de se resolver o problema da violência contra a mulher considerando somente os seus efeitos não resultam eficazes, pois a família muitas vezes não exerce seu papel de amar, proteger e cuidar.

Os caras me pegaram, me botaram no carro, me amarraram me fez bem o que quis comigo, mas Deus me deu tanta força que hoje tô aqui. É uma vida triste, eu não quero essa vida pra ninguém. (ESCOVA)

Quando você chega a uma certa idade e vê seus filhos crescendo, se tornando adultos, eu não quero minha filha, agora tá com seis anos chegando (pensamento interrompido), agora ela me pergunta, mamãe a senhora vai pra onde, fazer o que, agora ela ainda dá pra levar, mas quando tiver numa certa idade. (BATOM)

Eu tava iniciando essa vida de programa eu conheci ele, ai fui embora não deu certo, eu voltei e ai continuei e daí eu já não consegui relacionar mais com ninguém, assim sério pra, já não conseguia mais acreditar e até hoje assim, até agora não achei ninguém que eu acredite, e ai continuei, algo pra fazer pra sustentar meus filhos, foi aí que eu comecei a fazer programa, achei apoio de estranhos sim, da minha família mesmo não. (BATOM)

Na lógica da dominação o dominado reconhece o poder exercido pelo dominante. As instituições tais como Estado, Família e Escola colaboram como agentes de perpetuação da relação de dominação, pois elaboram e impõe princípios de dominação que são exercidos no campo social. Essas instituições determinam comportamentos, impõe regras, valores que são absorvidos pelas instituições familiares, de forma que através da comunicação é aprendido instintivamente por meio de esquemas inconscientes da ordem masculina.

Estar na prostituição é segundo as colaboradoras ter condição financeira para manter o sustento da família. Ser mulher, mãe e ser prostituta é assumir frente às inúmeras formas de preconceitos o lugar de luta em contraponto as referências que as estigmatizaram historicamente. Observa-se os sentimentos de desprezo por si mesma. Estes fenômenos são frequentes entre os dominados e são levados a aceitação e à interiorização de uma imagem de si mesmos construída pelos outros que de acordo as narrativas se destacam ao elaborarem as vivências da prostituição, os marcadores da imagem de mãe e prostituta são fixados no que concerne ao sentimento de pertencimento. 
Eu não sou feliz, porque o que eu queria ter era tá na minha casa cuidando dos meus filhos, sem precisar ter que tá saindo toda noite, toda noite tá na rua, era isso que eu queria, eu tá na minha casa, com um emprego, sair da minha casa e dizer que vou trabalhar que tenho orgulho do meu emprego, não é uma coisa, o que você é? Prostituta, qual é o orgulho que eu vou ter disso? Eu queria minha casa, minha família, um trabalho de verdade. (BATOM)

La na rua eu vou pra rua, faço minhas correrias na rua, o que eu fiz fica lá na rua, dentro da minha casa eu tento sempre fazer pra não dá demonstração. Não levo ninguém dentro da minha casa, hoje eu sou solteira, não tenho ninguém, confiar pra colocar alguém dentro a minha casa com minha filha eu tenho que ter certeza do que tô fazendo. Meu filho mais velho ele sabe, já ela, eu não quero que cresça, vendo eu vivendo numa situação dessa, ele não me pergunta nada, não cobra nada. (BATOM)

As afirmações sobre a prostituição como um trabalho representa uma não aceitação à sua condição de prostituta e a identidade negativa surge então como uma identidade vergonhosa que rejeitada em maior ou menor grau o seu pertencimento. Nesse caso, pode se traduzir, na medida do possível, em uma tentativa para eliminar os sinais exteriores da diferença negativa. Envergonha-se de si mesmo na experiência do rechaço de sua ação (ser prostituta), reconhecimento de uma identidade negativa. Por exemplo, determinados grupos querem passar a ideia de bons trabalhadores. Mas nem todos os grupos contam com a mesma capacidade de identificação, já que é a posição no sistema de relações que liga os grupos que lhes concede esse poder.

Famílias constituídas por vários processos e dinâmicas, marcadas por preconceitos, decepções amorosas, ausencia de estudos, relacionamentos afetivos fragilizados, abandono de pais e sobrecargas de responsabilidades. Mulheres que lutam mediante o contexto de vulnerabilidade social. Assumir a prostituição se constitui primeiramente pela necessidade iminente de sobrevivência. A educação dos filhos torna-se uma disputa diária, é que predomina nos discursos das colaboradoras, como afirma Batom, "Eu vou sempre à escola, participo das reuniões, sempre acompanhei meus filhos na escola" atribuem a prostituição como trabalho que lhes dá condição de dar aos seus filhos o que elas não tiveram uma vida digna com direito a educação, o que elas consideram essenciais para não ficar à margem da sociedade.

Eu não tô aqui porque eu desejo tá aqui, se eu não tiver aqui eu não vou ter condição de pagar um aluguel, de pagar uma agua, de pagar uma luz, de pagar uma internet dentro de casa pro meus filhos, de pagar uma compra que eu fiz. 0 lugar não oferece nada além, o pai do meu filho foi presente até quando ele tinha oito anos, depois a gente não teve mais contato nenhum. Ele encontrou noticias do pai pelo face e descobriu que tem um irmão e uma irmã, meu filho fez contato, mas até hoje não tivemos noticias. 0 pai da minha filha não dá importância nenhuma pra ela, de um tempo pra cá ele vem demonstrando o pai que eu queria que ele fosse desde quando eu engravidei dela. Ele não sabe nem onde fica a escola, eu queria mudar pra minha casa, por alguma coisa pra eu trabalhar sem eu precisar tá fazendo o que faço, um trabalho, um trabalho de verdade, vou trabalhar e cuidar da minha casa e dos meus filhos sem precisar eu tá saindo a noite. (BATOM)

Algum jeito pra poder criar meus filhos, foi muito difícil no começo, eles eram pequenos e, pra achar alguém pra cuidar. Eu sempre cobro muito deles sobre isso, é o que eu mais cobro né, eu acho que isso é importante pra eles amanhã ou depois, então eu acho muito importante. Todos eles estudam, o menino rompeu alguns anos, mas continua estudando. (ESPELHO)

A educação tem importância fundamental para mudanças estruturais, lugar estratégico para a ruptura do ciclo de exploração. Questões como a ausência de escolaridade, desemprego e famílias rompidas pelos laços afetivos se anunciam nas histórias de vida dessas mulheres que carregam o estigma da diferença a partir de vários indicadores (família, educação e trabalho) presentes nas identidades de prostituta e mãe. As identidades são nesse sentido, criadas pelas articulações de poder que são resultantes de opressão e privilégios de certos grupos em detrimento de outros. 


\section{TESSITURAS FINAIS}

No Brasil, as mulheres aparecem na maioria em relação aos grupos que são discriminados e marginalizados. As prostitutas cabem o estigma da inferioridade que vivem à margem da sociedade sem direito à cidadania. Neste entendimento, há de se pensar sobre as condições de ocupação das mulheres prostitutas que constroem suas identidades nas relações individuais e sociais evidenciadas por conflitos e lutas. A prostituição tem sido um tema polêmico tanto para a família quanto para a sociedade. Torna-se de certa forma, um tema emblemático em que as mulheres se confrontam em uma sociedade desigual e violenta.

Nessas trajetórias, há experiências de famílias em desarmonia e conflito. Famílias fragmentadas em seu núcleo e papéis de amar e cuidar. Evidencia-se a realidade da vida dessas mulheres, menosprezadas e hostilizadas pela própria família, história de vida entre lutas pela sobrevivência e formas de resistência. Histórias marcadas por situações de pobreza, marginalização, preconceito e violência. .

Detecta-se a partir das narrativas, lacunas sinalizadas por situações de abandono ou ausência da mãe e/ou pai no convívio familiar, laços afetivos rompidos, que conforme as colaboradoras contribuem determinantemente em suas vivências. Verifica-se um grau de escolaridade baixo, bem como a ausência e insuficiência da educação, a iniciação na prostituição no período da adolescência, momento de rompimento com a escola, perda de vinculo familiar. Todas as mulheres ressaltaram serem oriundas de famílias com baixo poder aquisitivo e a prostituição um indicativo como fonte de renda e sobrevivência. Afirmam-se como profissionais, ingressas em um universo caracterizado como trabalho. Em suas identidades se manifestam marcadores de opressão e inferioridade e se contrapõem às identidades masculinas. Traz à tona os estigmas familiares e sociais marcados em suas identidades.

\section{AGRADECIMENTOS}

Agradeço as contribuições da minha orientadora de mestrado professora Dra. Maria de Fátima Aráujo Di Gregório. "ESPELHOS DA NOITE”: IDENTIDADES VESTIDAS PELO CONTROLE SOCIAL permite aos leitores uma "viagem" pelas vivências de mulheres que são mães e se identificam como garotas de programa em uma sociedade que a ordem social e patriarcal oprime e violenta. Meu carinho espacial as mulheres colaboradoras dessa pesquisa.

\section{REFERÊNCIAS}

[1] Beauvoir, Simone de. O segundo sexo. Tradução Sérgio Milliet. Rio de Janeiro: Nova Fronteira, 1980.

[2] Bourdieu, Pierre. A dominação masculina. Trad. de Maria Helena Kühner. 2.ed. Rio de Janeiro: Bertrand Brasil, 2002.

[3] ___. _. Coisas ditas 1930-2002. tradução Cássia R. da Silveira e Denise Moreno Pegorim; revisão técnica Paula Montero. São Paulo: Brasiliense, 2004.

[4] Butler, Judith. Corpos que pesam: sobre os limites discursivos do "sexo" In: Louro, Guacira Lopes (org.), 0 Corpo educado: pedagogias da sexualidade. Trad. Tomaz Tadeu da Silva. Belo Horizonte: Autêntica, 1999.

[5] C_ Como os corpos se tornam matéria: entrevista com Judith Butler. Revista Estudos Feministas, 10 (1), $155-167, \overline{2002}$.

[6] ___.Problemas de gênero: feminismo e subversão da identidade. Rio de Janeiro: Civilização Brasileira, 2003.

[7] Foucault, Michel. Microfísica do poder. Rio de Janeiro, Graal, 1979.

[8] __. _. História da Sexualidade I - A vontade de Saber. Rio de Janeiro: Graal, 2011.

[9] Goffman, Erving. Estigma: Notas sobre a Manipulação da Identidade Deteriorada. Rio de Janeiro: Zahar Editores,1975/2004.

[10] _ _ _ A representação do eu na vida cotidiana. Petrópolis: Vozes, 1988.

[11] Hall, Stuart. A identidade cultural na pós-modernidade. 9 ed. Rio de Janeiro: DP\&A, 2004.

[12] _._. Quem precisa da identidade? In.:Silva, Tomaz Tadeu da (Org.). Identidade e diferença: a perspectiva dos estudos culturais. Petrópolis: Vozes, 2014.

[13] Meihy, J. C. S. B.; Holanda, F. História Oral: Como fazer, como pensar. 2ª ed. São Paulo: Contexto, 2013. 
[14] Meireles, Cecília. Poesia completa. Organização de Antônio Carlos Secchin. Rio de Janeiro: Nova Fronteira, 2001. 2 v.

[15] Minayo, M. C. S. O desafio do conhecimento: pesquisa qualitativa em saúde. 6º. Ed. São Paulo: Hucitec, Rio de Janeiro: Abrasco, 1999.

[16] Poutignat, Philippe; Streiff_Fenart, Jocelyne. Teorias da Etnicidade. Seguido de Grupos Étnicos e suas fronteiras de Fredrik Barth. Tradução de Elcio Fernandes. 2 ed. - São Paulo: Ed. Unesp, 2011.

[17] Rago, L. M. Do cabaré ao lar: a utopia da cidade disciplinar. Brasil 1890-1930. Rio de Janeiro: Paz e Terra, 1985.

[18] Rodrigues, M. A prostituição no Brasil contemporâneo: um trabalho como outro qualquer? Rev. Katál: Florianópolis v. 12, n. 1, p. 68-76, jan./jun. 2009.

[19] Sarti, C. A. A Família como Ordem Simbólica. Psicologia USP, São Paulo, 11 - 28. 2004.

[20] Scott, Joan Wallach. Gênero: uma categoria útil de análise histórica. Educação \& Realidade. Porto Alegre, vol. 20, no 2, jul./dez. 1992.

[21] Silva, Tomaz Tadeu da (Org.). Identidade e diferença: a perspectiva dos estudos culturais. Petrópolis: Vozes, 2014. 


\section{Capítulo 11}

Reflexões sobre organização lésbica na Bahia em tempos de ditadura

\section{Zuleide Paiva da Silva}

Resumo: Reconhecendo o "complô do silêncio" que cerca a construção discursiva sobre a existência lésbica como um "nó" que enlaça o patriarcado, capitalismo, racismo, classe, este trabalho objetiva refletir Grupo Libertário Homossexual (GLH), uma organização lésbica (in)visível da Bahia em tempos de ditadura. Para tanto, recorre às fontes bibliográficas e oral. A leitura das fontes revela o GLH como primeira bandeira lesbofeminista da Bahia, e aponta a auto-organização lésbica como caminho de empoderamento feminino.

Palavras-chave: Organização lésbica. Visibilidade Lésbica. Lesbofeminimo. 


\section{INTRODUÇÃO}

Os movimentos de lésbicas como expressões dos movimentos sociais surgem no Brasil em tempos de ditadura civil, quando mulheres que se reconheciam e eram socialmente reconhecidas como lésbicas para além de assumirem publicamente o amor por outras mulheres, se organizaram em defesa dessa amor, tecendo coalizões entre mulheres com fios do continuum lésbico produzidos por Adrienne Rich (1980). Embora pouco se fale sobre lesbianidades durante a ditadura brasileira, diferentes estudos apontam que no Brasil os movimentos de lésbicas surgem a partir de 1979 (MACRAE, 1990; FACCHINI, 2005; ALMEIDA, 2007; LESSA, 2007); período que compreende a chamada "Era da participação", entre 1978-1989 (GOHN 2012). Esse tempo, conforme Green (2014), foi de lenta abertura política, e de deslizamento entre os conceitos de homossexualidade, comunismo, desordem e oposição ao regime. Segundo Marisa Fernandes, uma das fundadoras da primeira organização lésbica do primeiro movimento de lésbicas de São Paulo, relata que "Durante a ditadura militar, o modo de vida LGBT sofreu repressão com as tentativas de ocultar suas manifestações, porque a violência do estado autorizava e apoiava a perseguição contra os homossexuais" (FERNANDES, 2014, p.147).

Na Bahia, na luta contra a repressão imposta pela ditadura, na construção da lesbianidade como ato de resistência (CLARKE, 1990) um grupo de estudantes lésbicas da Universidade Federal da Bahia UFBA, militantes do movimento estudantil, criaram o GLH-Grupo Libertário Homossexual no bojo da na primeira onda do movimento homossexual, mas o que se observa em torno desse grupo é o "complô do silêncio" que promove o apagamento das lésbicas em diferentes tempos históricos (NAVARRO-SWAIN, 2001). Diante dessa observação, o propósito dessa comunicação é refletir o GLH a partir de fontes bibliográficas e oral. Para tanto, foi realizada entrevista com uma das fundadoras do Grupo em 14 novembro de 2014. 0 resultado sugere o GLH como a primeira bandeira lesbofeminista da Bahia.

\section{2.“LURDINHA”, ATITUDE E REBELDIA LÉSBICA}

"Era uma vez um grupo de lésbica que criou o 1ํo Jornal Lésbico de Salvador, quiçá da Bahia, chamado "Amazonas". Naquele tempo, a vida não era cor de rosa, nem azul. Era verde oliva..." (LURDINHA, GLH)

"Lurdinha" é Maria de Lurdes Almeida Motta, nascida em 1953, professora de literatura da Uneb, locada no Campus V, em Santo Antônio de Jesus. Menina branca, nascida em Senhor do Bonfim, no interior da Bahia, ainda criança mudou-se com a família para Feira de Santana, onde morou até 17 ou 18 anos. Depois da morte dos seus pais, precisou assimilar a filosofia da luta pela vida e adaptar-se às condições criadas pela realidade na qual estava inserida. Para tanto, mudou-se para Salvador, e em 1977 ingressou no Curso de Letras da UFBA, quando passou a ter contato com o pensamento de esquerda, abrindo diante de si, um leque de possibilidades de ser e existir na capital. Rompendo com o condicionamento das estudantes para suportarem uma forma de vida acadêmica alienada, Lurdinha, que sempre se percebeu lésbica, ingressou no movimento estudantil em busca de experiência de participação nos movimentos de contestação, nas lutas democráticas por justiça social, e logo se vinculou a Libelu - Liberdade e Luta, corrente de inspiração trotskista, que captou a imaginação dos estudantes "com suas palavras de ordem ousadas e uma maior abertura para os temas vinculados à contracultura" (MACRAE, 1990, p.22). Mas a Libelu, e todo o pensamento de esquerda giravam em torno da luta de classe e do enfrentamento ao regime militar. A homossexualidade era então percebida pelos "esquerdistas", como bem aponta Lurdinha, como um desvio pequeno-burguês, não uma questão política.

[...] Eu participei do Congresso de reconstrução da UNE, que elegeu o Rui como presidente. E quando terminou o Congresso e todo mundo soube e comentou que o presidente que nós elegemos naquele momento era gay, foi um choque para os comunistas. 0 pessoal empalideceu. Ninguém quis acreditar que o Ruy era gay. Ninguém quis aceitar que ele era gay. Foi uma confusão danada. Eu fiquei decepcionada com a esquerda empalidecida. E senti medo da repressão sexual (LURDINHA. GLH, Entrevista, 2014).

Se o presidente eleito era gay não se pode afirmar, embora a imprensa da época tenha feito muitas insinuações nesse sentido. Lurdinha, tinha consciência de que a descriminalização das relações sexuais entre pessoas do mesmo sexo não implicou um abrandamento do preconceito que se tinha contra esse tipo de relação. Quando viu o novo dirigente da UNE ser aviltado em função da sua homossexualidade presumida, solidarizou-se com ele, e seguiu o fluxo do desejo, ou do ditado popular: é preciso mudar tudo pra que nada mude. Leitora de Kollontai (2007, p.27), Lurdinha sabia que "a delicada flor da moral sexual 
é uma felicidade adquirida à custa da escravidão da mulher". Sua consciência, de alguma forma gritava irada que era preciso reagir.

E da indignação com a esquerda que associava a homossexualidade ao comportamento burguês, e, consequentemente, à contra revolução, surgiu o GLH, uma pequena ilha de lesbos.

[...] Se nos juntarmos e nos oferecermos apoio- sem, contudo, nos isolarmos-, nossa chance de sucesso e sobrevivência numa sociedade chauvinista serão maiores. Afinal, os homens sempre se apoiaram e sempre souberam juntar as forças - dentro de um exército, ou só para jogar um futebolzinho. E você? Já formou o seu grupinho? Já encontrou a sua pequena Lesbos? (LEONEL, 2001, p.39)

\section{GLH, UMA BANDEIRA LESBOFEMINISTA!?}

Depois do congresso de reconstituição da UNE, Lurdinha e um pequeno grupo de estudantes lésbicas que se indignaram com a reação dos movimentos de esquerda frente a eleição do então estudante de Comunicação da UFBA, Ruy César Costa Silva, filiado ao PC do B, se se viram impelidas a pensarem sua própria sexualidade e a própria esquerda.

E a gente conversa com a professora Margot Piva sobre as inquietações da esquerda, e foi conversando com ela que surgiu a ideia de criação do GLH. [...] Até esse momento ninguém tinha pensado em formar um grupo de lésbica. [...] Nós éramos um pequeno grupo de amigas homossexuais do Diretório Acadêmico. Aí nos perguntamos por que não? Então decidimos criar o grupo. Por que queiramos discutir a questão da nossa sexualidade, [...]. E foi assim, depois de muita discussão criamos o GHL (LURDINHA, GLH, Entrevista, 2014).

Filha do deputado Mario Piva (MDB-BA), um dos 173 deputados federais cassados durante ditadura militar, Margot Piva, conforme Adriana Carneiro (2011, p.31), foi exilada em Londres, e na volta do exilio ajudou na fundação do Grupo Feminista Brasil Mulher - Núcleo Salvador. Conforme Mott (1987, p. 136), a professora era doutora em Matemática, crítica cinematográfica da revista Sappho de Londres, uma das responsáveis pelo Jornal "Maria Maria", do Grupo Feminista Brasil Mulher-Sessão Bahia. Confome Mott (1987) Margot Piva morreu precocemente, em 1984. Em seu livro póstumo, "Falando de mim", publicado em Salvador pela Editora Contemp em 1984, ela "[...] tira o véu de seu interior, mostrando uma faceta sombria de muitos e muitas homossexuais sempre sequiosos, mas nem sempre bem sucedidos em encontrar sua outra metade" (MOTT, 1987, 136). Para Mott a vida de Margot Piva poderia ter sido mais longa e mais alegre se ela tivesse sofrido menos com a repressão à maneira como amava suas iguais. Para Lurdinha, Margot Piva foi uma referência acadêmica e política que expandiu a gramática do político e a poética na sua vida, revelando novas formas de existir lésbica.

Então, quando vimos a esquerda empalidecer com a homossexualidade do Rui, criamos nosso grupo com incentivo e apoio de Margot que nos aproximou da literatura sobre o tema[...]. Ela nos indicou muita leitura dizendo que para formar um grupo era preciso muita leitura. Ela lia muito, escrevia poesias. Margot tinha poesia na alma guerreira. A gramática e a poética da Margot foi sem dúvidas um incentivo para todas nós (LURDINHA. GLH, Entrevista, 2014).

Lida e interpretada pelas lentes Jill Johnston (1975) o GLH foi uma pequena "nação lésbica, onde cada habitante, para além de não reprimir seus desejos pessoais e sexuais, colocou em questão o sistema de verdades do coletivo de homens e mulheres ao qual estava ideologicamente vinculada, tencionando assim a estrutura que sustenta a lógica de subordinação dos interesses das mulheres aos interesses dos homens, tirando delas sua agencia política.

O GLH era assim, um grupo de estudantes lésbicas que soube aproveitar, viver as oportunidades que a universidade oferece. Mas não era só de estudantes. Tinham outras meninas, algumas nem estudavam. Mas a maioria de nós era da universidade, e nós vivíamos intensamente os acontecimentos políticos da época que pipocavam em todos os lugares. [...]. A universidade nos oportunizava isso de alguma forma, e nós compartilhávamos nossas experiências no grupo. Entre nós havia muita afetividade e compromisso político. (LURDINHA. GLH, Entrevista, 2014). 
O que o GLH buscava era a felicidade. Para tanto, era preciso lutar pelas liberdades democráticas, pelo direito à liberdade do pensamento e do corpo, pelo prazer, contra todos os preconceitos, por uma sexualidade livre e plena. As lutas do GLH estavam articuladas às agendas internacionais contra as ditaduras, contra a guerra do Vietnã, pelo direito de Israel se constituir um Estado Livre, contra Código Penal do Irã. Mas, embora a agenda do grupo fosse bastante ampliada, as estudantes concentravam esforços na luta pelo fim da violência contra as mulheres, então protagonizada na Bahia pelas feministas do Brasil-Mulher e na luta contra violência e discriminação sexual, então protagonizada pelo GGB. Mas a relação entre as lésbicas e as feministas não era amistosa, apesar do empenho de Margot Piva em estabelecer aliança entre os grupos.

O feminismo ampliava nossa compreensão da problemática em torno da sexualidade. Mas sempre que íamos às reuniões do Brasil-Mulher, as feministas nos olhavam com desconfiança. Elas se achavam. Todas muito importantes. Nós erámos estudantes, todas homossexuais. Eu não me importava, nem me intimidava. Chegava lá, batia na mesa, falava o que eu precisa falar e depois saia. Mas eu sabia, todo mundo sabia, que depois que a nós saíamos do espaço, elas falavam das lésbicas, nos chamavam de sapatão, essas coisas. (LURDINHA. GLH, Entrevista, 2014).

A relação entre feministas heterossexuais e lésbicas sempre foi problemática (SILVA, 2016), As armadilhas da heterossexualidade obrigatória, que transforma as lésbicas em uma espécie de contaminação da imagem das feministas (RICH, 2010; WITTIG, 2010), tornavam a relação entre as lésbicas do GLH e as feministas do Brasil Mulher muito difícil, como sugere o depoimento de Lurdinha.

[...] Elas tinham medo de serem chamadas de lésbicas, sapatão. Na verdade eu não tinha paciência com aquelas mulheres, que nos olhavam atravessado. Era impressionante como elas se incomodavam. Elas não queriam ser associadas às lésbicas. [...] Sabe quando olha para você com cara de desdém? Pois era assim que elas nos olhavam. Eu não gostava. Mas nós gostávamos muito de Margot Piva, e participávamos de tudo, e aprendíamos muito com as feministas, que eram todas muito inteligentes, guerreiras. 0 Brasil-Mulher era uma referência em todo Brasil (LURDINHA. GLH, Entrevista, 2014).

A literatura feminista mostra que a experiência brasileira não é isolada. A tensão entre lésbicas e feministas heterossexuais é relatada em diferentes países, a exemplo da Espanha (BARBADILLO, 2008), América Latina (YUDERKYS, 2004), México (HERNANDÉZ, 2006), dentre outros. Esses estudos, para além de evidenciarem o quanto o feminismo heterossexual da segunda onda foi refratário às suas questões específicas, evidencia que a luta pela livre orientação sexual e pela autonomia é o que mais se destaca no surgimento dos primeiros coletivos de lésbicas de cada país. Porém, apesar dos conflitos entre lésbicas e mulheres heterossexuais feministas, as memórias de Lurdinha reiteram a afirmativa de Yuderskys Espinosa (2006), de que não se pode pensar o movimento de lésbicas na América Latina sem dar conta do pensamento e da práxis política do feminismo, pois é no interior dos movimentos ampliados de mulheres latino-americanas que as lésbicas emergem como sujeitas politicas com ideias de rebeldia, de liberação e liberdade para as mulheres, contribuindo com aportes fundamentais para o desenvolvimento de um marco conceitual e analítico para pensar o patriarcado e suas múltiplas manifestações e complexidade. A pequena "nação lésbica" da Bahia, orientada por Margot Piva, se apropriou das temáticas do feminismo através da leitura fomentada pela professora.

A gente tinha acesso a literatura feminista, a literatura homossexual. Na verdade a gente lia, estudava muito. Sabia o que estava acontecendo no mundo. A questão do socialismo nos importava muito. Angola estava em processo de revolução. Recrudesciam as lutas pela implantação de um regime de esquerda e as pessoas queriam libertar sua sexualidade. Quem apoiava a luta em Angola, quem deixava de apoiar? [...] Liamos tudo sobre Cuba. Mas tínhamos dúvidas. 0 socialismo de Cuba permite a homossexualidade? Não permite? Como é o socialismo de Cuba? É tropical? É moreno? Nós refletíamos sobre essas questões e escrevíamos no jornal (LURDINHA. GLH, Entrevista, 2014). 
Assim, se apropriando da literatura, a pequena nação lésbica da Bahia, se organizou de forma não institucionalizada, e todas as terças-feiras, às 19h, se reunia na Biblioteca Pública do Estado. Se a Biblioteca estivesse fechada, o encontro era realizado na escadaria em frente à Biblioteca. Depois o grupo passou a se encontrar na Praça da Piedade. Sem formalidade, sem autoritarismo, e sem centralismo, mantendo a autonomia organizativa a partir do consenso, não do voto, o GLH construiu sua identidade coletiva no movimento das lutas feministas libertárias, reconhecendo a dupla discriminação que todas sofriam, por serem mulheres e lésbicas.

A primeira decisão em relação ao grupo foi criar uma bandeira intelectual. Uma identidade. Todas do grupo eram lésbicas. 0 que seria essa identidade? A identidade seria uma posição na sociedade, uma posição política e intelectual, contrária às normas morais vigentes. Isso pra nós era muito importante. [...]. Sim, a identidade era homossexual. A liberdade sexual acima de tudo. A liberdade de expressão sexual era bandeira intelectual que nos movimentava, e o feminismo era bandeira intelectual que impulsionava o movimento (LURDINHA, GLH, Entrevista, 2014)

Observa-se que nas formulações identitárias de Lurdinha, em diferentes momentos, são acionadas as categorias "homossexual" e "lésbica" referindo-se a si mesma e ao grupo. Nada estranho, considerando que até meados dos anos 90, o movimento de lésbicas brasileiro estava restrito a poucos grupos espalhados pelo país. Como destaca Facchini (2005), o termo "Lésbica" só foi incluído no nome do movimento homossexual a partir do 1993, no VIII Encontro Brasileiro de Lésbicas e Homossexuais. Porém, se por um lado o grupo não marcou a identidade lésbica no seu nome, ele anuncia sua lesbianidade coletiva no seu produto cultural, o Jornal Amazonas, produzido e editado pelo próprio grupo com apoio de Margot Piva. No contexto feminista, "Amazonas" simboliza guerreiras, mulheres de "outra espécie", sem homens, indomáveis, cuja imagem desestabiliza a ordem do discurso vigente.

O Jornal Amazonas foi uma produção focada na condição lésbica, com a intenção de divulgar o pensar e o fazer do grupo e promover a leitura sobre temáticas relevantes para as lésbicas. Todas as integrantes do grupo participavam do processo de produção do jornal sob orientação da professora Margot Piva. 0 resultado final era um jornal bem humorado e muito bem feito. Infelizmente, do Jornal Amazonas existem apenas as lembranças de Lurdinha, e as leituras que fazemos delas. Lurdinha afirma que guardou a memória do grupo até 1995, quando fez doação de todo o material guardado (memórias de reunião, folderes, manifestos, e alguns exemplares do Jornal Amazonas) para o acervo do GLB, que infelizmente foi perdido. Considerando que não há história sem fontes, o desaparecimento dos arquivos das organizações lésbicas é um grande prejuízo para a memória coletiva do ativismo das lésbicas. Com o desaparecimento das fontes produzidas pelas organizações lésbicas se perde a transmissão da experiência entre ativistas mais antigas na militância e outras mais novas, fato que provoca nas novas militantes a desagradável sensação de estarem começando do zero, além de promover a impossibilidade das novas gerações de militantes se inscreverem em uma história política configurada por um acervo de experiências e pensamentos aos quais se pode recorrer, se apropriar, negar, validar, questionar, e, sobretudo perceber-se inserida no continuum lésbico de afeto e luta. Como bem afirma Lurdinha, "[...] o apagamento da nossa memória elimina nossa existência".

Feliz com a possibilidade resgatar e compartilhar sua memoria através de fragmentos da história do GLH, Lurdinha afirma que não se lembra muito das datas, mas, sugere que o GLH existiu com vigor entre 1979 e 1985, desenvolvendo atividades no campo da cultura, organizando festivais de poesias, concursos literários. Mesmo não se lembrando bem das datas, as referências apresentadas por Lurdinha negam as fontes bibliográficas que apontam o desaparecimento do GLH meses após a sua criação. Embora ela não tenha relacionado o fim do grupo à morte da sua mentora Margot Piva, é possível inferir que o grupo não tenha resistido tamanha perda. Mas, antes de se dispersar e desaparecer, logo pós a morte de Margot Piva, o GLH se aproximou do então movimento homossexual e ajudou a organizar o II EBHO - Encontro Brasileiro de Homossexuais, junto com o Grupo Gay da Bahia e Adé Dudu, o primeiro grupo de homossexuais negros da Bahia. A expectativa da organização do II EBHO era mostrar para a sociedade que homossexuais não são anormais, doentes. A luta era, e continua sendo, "[...] por uma sociedade sem opressores nem oprimidos: um Brasil justo, pluralista, igualitário, libertário e alegre. Luxo para todos" (GGB, p.102). 
Conforme Martinho (2006), o movimento homossexual, que nasceu em 1978 e teve seu pico de expansão em 1980, começou a declinar a partir de 1981, mergulhando numa grande crise entre 1981 e 1984. Para a autora, "De meados da década de 80 até inicio da década de 90, o Movimento Homossexual viverá uma espécie de limbo político, subsistindo graças aos esforços heroicos de grupos como o GALF (SP). GGB (BA), Triangulo Rosa (RJ) e Dialogay (SE) (MARTINHO, 2006, s.p). Nesse processo de refluxo, Lurdinha foi sugada pelo mercado de trabalho.

Eu me lembro que comemoramos quando a homossexualidade deixou de ser uma doença, mas o grupo já estava disperso. Eu estava trabalhando em escola particular e o trabalho docente me levou para outros caminhos. Eu estava preocupada com a questão da formação, e o movimento homossexual tinha outros interesses. Era muito brilho, muito ego (LURDINHA. Fala Pública Roda de Conversa Negritude e Lesbianidade, 2015)

O fato é que após o II EBHO, o GLH desapareceu das linhas da história do movimento, deixando como legado para as futuras organizações lésbicas da Bahia a luta contra a imposição da heterossexualidade

\section{CONSIDERAÇÕES FINAIS}

O GLH e toda a sua vivencia política na "Era da participação" era apenas uma lembrança quase apagada na memória de Lurdinha, que vive a lesbianidade inscrita no seu corpo sem anunciações, sem visibilidade política. Mas ao compartilhar suas memórias, Lurdinha possibilitou a conexão entre passado e presente, evidenciando fios do continuum lésbico que hoje constitui o corpo político das lésbicas da Bahia como uma "máquina de guerra", de desconstrução do pensamento heterossexual (WITTIG, 1977). Como legado politico, a luta iniciada pelo GLH é gramática da justiça erótica, aqui pensada pelas lentes de Rios (2007) como garantia do respeito por diferentes possibilidades de estruturação da pessoa concebida como ser desejante. Assim percebida, a luta do GLH é resistência poética que reconhece o erótico para além da prática sexual e incorpora na sua formulação as diversas formas sensíveis que as pessoas se utilizam para se expressar no mundo (RIOS, 2007, p.21). 0 GLH Na luta por justiça erótica em tempos verde oliva é aqui percebido como uma matriz de educação para a liberdade, um grupo que fomentou mudança de mentalidade produzindo e positivando o reconhecimento de si e a lesbianidade, permitindo assim que o reconhecimento pelos próprios indivíduos dos processos inconscientes que marcam sua subjetivação fosse repassado para as gerações seguintes, possibilitando dessa forma o engajamento das lésbicas como sujeitas desejantes no processo de constituição de si e da sociedade em que vivem. No processo de produção do reconhecimento do ser lésbica, na luta contra a imposição da heterossexualidade, o GLH se inscreveu na história como "nó" proeminente do corpo político das lésbicas da Bahia, um rasgo no pano patriarcal que esconde as lésbicas em todos os tempos da história.

\section{REFERÊNCIA}

[1] Almeida, G. E. da Silva. Da invisibilidade a vulnerabilidade: percursos do "corpo lésbico" na cena brasileira face a possibilidade de infecção por DST e AIDS. Tese. [Doutorado em Saúde Coletiva], Universidade do Estado do Rio de Janeiro, Rio de Janeiro, 2005, 342f.

[2] Barbadillo, Gracia Trujillo. Deseo y resistência: treinta años de movilización lesbiana em el estado español. Madrid: EGALES, 2008.

[3] Carneiro, Adriana Jacob. Gênero e mídia: a cobertura do Dia Internacional da Mulher. Dissertação [ Mestrado em Cultura e Sociedade]. Salvador, Universidade Federal da Bahia, 2011, $200 f$.

[4] Clarke, Cheryl. Lesbianism: An Act of Resistance." The Columbia Reader on Lesbians and Gay Men in Media, Society, and Politics. Columbia University Press, 1990. Tradução livre disponível em: $<$ http://ebookbrowsee.net/lesbianismo-um-ato-de-resistencia-cheryl-clarke-pdf-d281612776>. Acesso em fevereiro, 2017.

[5] Facchini, Regina. Sopa de letrinhas? Movimento homossexual e produção de identidades coletivas nos anos 90. Rio de Janeiro: Garamond, 2005. 
[6] Fernandes, Marisa. In: Green, James N.; Quinalha, R.(Orgs). Ditadura e homossexualidades: repressão, resistência e a busca da verdade.São Carlos: EdUFSCar; 2014. p. 125-148.

[7] Gohn, Maria da Glória. Teoria dos movimentos sociais: paradigmas clássicos e contemporâneos. 10.ed. São Paulo: Cortez, 2012.

[8] Green, James N.; Quinalha, R.(Orgs). Ditadura e homossexualidades: repressão, resistência e a busca da verdade.São Carlos: EdUFSCar; 2014.

[9] Hernandéz, Lorena Rosas. Lesbianismo en México. Dissertação. [Mestrado em Sociologia]. UInversidad Autonoma Metropolitana, México, 2006. Disponível em:

http://zaloamati.azc.uam.mx/bitstream/handle/11191/937/Lesbianismo_en_Mexico.pdf?sequence=4 Acesso em Junho, 2017.

[10] Johnston, Jill. Lesbian nation. New York : Simon \& Schuster, 1975.

[11] Kollontai, A. A nova mulher e a moral sexual. São Paulo: Expressão Popular, 2007.

[12] Leonel, Vange. Grrrrls: garotas iradas. São Paulo: Edições GLS, 2001.

[13] Lessa, Patricia. Lesbianas em movimento: a criação de subjetividades (Brasil, 1970-2006). Tese (Doutorado em História), Universidade de Brasília, Brasília, 2007, 261f.

[14] Lurdinha (GLH). Fala Pública. Roda de Conversa Negritude e Lesbianidade [15/05/2015], Gravado por Eide Paiva, Salvador, Solar Boa Vista, 1 arquivo áudio (02:00:15).

[15] Macrae, Edward. A Construção da igualdade. Campinas: Ed. UNICAMP, 1990.

[16] Martinho, Mirian. Década de 80: início da organização lésbica no Brasil. Lesbianismo erudito [Blog], São Paulo, 2006a. Disponível em: < http://coletaneapratica.blogspot.com.br/2011/07/miriam-martinho.html> Acesso em junho, 2017.

[17] Mott, Luiz. O Lesbianismo no Brasil. Porto Alegre: Mercado Aberto, 1987.

[18] Navarro-Swain, Tania. 0 que é lesbianismo. São Paulo: Brasiliense, 2001.

[19] Rich, Adrienne. Heterossexualidade compulsória e a existência lésbica. Revista Bagoas, n.5, [1980] 2010. Disponível em: <http://www.cchla.ufrn.br/bagoas/v04n05art01_rich.pdf> Acesso em fevereiro, 2014.

[20] Rios, Luís Felipe. Justiça erótica: é possível? Notas sobre a homossexualidade na clínica psicológica infantojuvenil. IN: Encontro Anual da ANPOCS, 31, Caxambu, MG, Anais... Caxambu, MG, 2007.Disponível em: <http://portal.anpocs.org/portal/index.php?option=com_docman\&task=doc_view\&gid=3083\&Itemid=231> Acesso em junho, 2017.

[21] Saffioti, Heleieth. Gênero, patriarcado e violência. São Paulo: Editora Fundação Perseu Abramo, 2004.

[22] Silva, Z. P. Sapatão não é bagunça: estudo sobre as organizações lésbicas da Bahia. Tese [Doutorado em Difusão do Conhecimento], UFBA, IFBA,UNEB, UEFS, SENAI-CIMATEC, LNCC, Salvador, 2016, 407f.

[23] Wittig, Monique. El pensamiento heterosexual y otros ensayos. 2. ed. Barcelona: Egales, [1981] 2010.

[24] Yuderkys, Espinosa. Cuatro hipótesis y disputas para pensar el moviemiento de lesbianas en América Latina. Buenos Aires, 2006. Disponível em:

http://www.glefas.org/glefas/files/biblio/cuatro_hipotesis_y_dos_disputas_para_pensar_el_mov_de_lesbianas_en_al_y uderkys_espinosa.pdf > Acesso em junho, 2017. 


\section{Capítulo 12}

\section{O direito fundamental à não identificação do gênero no registro de nascimento}

\section{Mariana de Barros e Silva Pinheiro}

Giorge Andre Lando

Resumo: A ideia de gênero restrita a apenas duas hipóteses ligadas ao sexo biológico aparentou ser um paradigma quase que insuperável dentro da sociedade, porém, na contemporaneidade, já não impede que as pessoas possam decidir e se expressar de acordo com o seu verdadeiro gênero ou mesmo pela preferência em não se identificar por nenhum. É fato que o Estado e a sociedade criaram ao longo do tempo entraves morais responsáveis por dificultar a clareza sobre a compreensão a respeito da extensão do próprio corpo e de sua autodeterminação. A contemporânea ampliação da discussão sobre gênero oportunizou, dessa forma, o crescimento do debate em torno dos conceitos do que é gênero e sua ligação com a sexualidade. A pesquisa desenvolvida fundamentouse, portanto, na busca pela efetividade dos direitos da personalidade, especificamente no que se refere ao direito de identidade de gênero e o respeito à dignidade de pessoas que não têm o gênero definido, ou porque lhes faltam ainda discernimento para realizar essa autodeclaração; ou porque existe sofrimento diante da complexidade de sua condição, o que a impede de definir formalmente o seu próprio gênero; e ainda, existem aquelas pessoas que preferem não serem identificadas pelo sexo biológico e nem pelo gênero. Foi utilizada a metodologia de estudo documental e pesquisa bibliográfica. Inferiu-se, logo, a importância da discussão sobre o direito fundamental à não identificação do gênero em decorrência do sexo biológico nos registros de nascimento a qual perpassa não somente pela exegese dos direitos da personalidade mas como também reflete os questionamentos suscitados na busca pela autodeterminação corporal e na formação da identidade de gênero, sendo colocado em questão o envolvimento da burocracia e interferência desmedida do Estado nesse sentido.

Palavras-Chave: Direitos da personalidade; Identidade de gênero; Autodeterminação Corporal; Registro de Nascimento. 


\section{INTRODUÇÃO}

No âmbito atual da discussão sobre os direitos da personalidade cresce o estudo do direito a identidade de gênero como fundamental à garantia do direito à dignidade das pessoas que não se adequam no binômio sexo-gênero preestabelecido pela heteronormatividade.

É fato que o Estado e a sociedade criaram ao longo do tempo entraves morais responsáveis por dificultar a clareza sobre a compreensão a respeito da extensão do próprio corpo e da autodeterminação. Porém os pressupostos sociais sobre o que é gênero já não impedem que os indivíduos possam decidir e se expressar de acordo com o seu gênero verdadeiro ou mesmo pela preferência em não se identificar por nenhum.

Contudo, a ampliação da discussão sobre gênero oportunizou o crescimento do debate em torno dos conceitos filosóficos do que é gênero e sua ligação com a sexualidade do indivíduo. Com isso, o presente estudo tem por finalidade reconhecer o direito fundamental à não identificação do gênero/sexo biológico no registro de nascimento das crianças recém nascidas, bem como de adultos com a pretensão de alterar o registro.

Nesse sentido, a pesquisa fundamenta-se a partir do surgimento de uma produção acadêmica interessada na efetividade dos direitos da personalidade, especificamente no que se refere ao direito de identidade de gênero e o respeito à dignidade de pessoas que não tem o gênero definido, ou porque lhes faltam ainda discernimento para realizar essa autoidentificação; ou, ainda que dotadas de consciência, exista sofrimento diante da complexidade de sua condição, o que a impede de definir formalmente o seu próprio gênero; e ainda, pessoas que preferem não serem identificadas pelo sexo biológico e nem pelo gênero.

\section{A EFETIVIDADE DOS DIREITOS DA PERSONALIDADE E A IDENTIDADE DE GÊNERO}

Observada a formação cultural das sociedades humanas, o binarismo da ideia de gênero foi adotado para facilitar a atribuição de tarefas ligadas ao mesmo, ou seja, para a determinação das atividades que poderiam ser realizadas pelos homens e pelas mulheres. A divisão parece começar dentro das diferenças de força física e habilidades motoras e culmina no estabelecimento das relações de poder, com o homem sempre numa posição superior à mulher. Como explica Butler,

[...] um discurso restritivo sobre gênero que insista no binarismo homem e mulher como a maneira exclusiva de entender o campo do gênero atua no sentido de efetuar uma operação reguladora de poder que naturaliza a instância hegemônica e exclui a possibilidade de pensar na sua disrupção (2014, p. 6).

Nesse sentido, a identificação de gênero a partir do sexo biológico se tornou uma prática extremamente comum e constante na sociedade e as instituições, de modo geral, exigem que as pessoas sejam identificadas pelo sexo anatômico. Dessa forma, o primeiro ato jurídico exigido pelo ordenamento brasileiro, após o nascimento com vida da criança, é o registro público e a emissão da certidão de nascimento onde deve constar a identificação do sexo biológico da pessoa natural.

Acontece que, com o avanço do diálogo sobre a sexualidade e com a quebra de tabus sociais, os indivíduos começaram a expor com maior frequência as divergências que percebiam pessoalmente para com essas atribuições, normalmente relacionadas à própria sexualidade. Entretanto, as diferenças observadas entre aqueles que se encaixam nos gêneros masculino e feminino e os que não se enquadram fizeram com que os últimos fossem perseguidos socialmente, taxados de anormais e obrigados a adotar uma das classificações do binarismo, a fim de manter o status quo e não causar desconforto a sociedade ou desestabilizar as estruturas de poder. A identificação das pessoas pelo sexo biológico, assim que nascem, equivale a uma violação ao direito à autodeterminação corporal e à autonomia privada, uma vez que desconsidera, totalmente, a formação da identidade individual de gênero e, portanto, dos direitos da personalidade.

É ante esse cenário que surge a necessidade de reiterar e pensar meios de garantir os direitos fundamentais da personalidade a esses indivíduos marginalizados em decorrência da identidade de gênero diversa daquela estabelecida pela norma heterossexual. Com o intuito de esclarecer sobre a necessidade de garantir o direito à não identificação do gênero nos registros públicos, é preciso analisar conceitos como a dignidade humana e a autonomia privada frente ao Estado, o direito sobre o corpo e a sua decorrente autodeterminação, bem como o direito a identidade de gênero. 


\section{A DIGNIDADE DA PESSOA HUMANA, A IDENTIDADE DE GÊNERO E A AUTONOMIA PRIVADA}

Dentro dos chamados direitos da personalidade, a dignidade da pessoa humana corresponde à consciência que o ser humano tem de si e como se valora, ou seja, à convicção de que pertence à sociedade e de que seus direitos são garantidos independemente das diferenças entre seus pares. A dignidade não é somente o primeiro fundamento de todo o sistema constitucional e último recurso que abrange os direitos individuais, mas também "constitui núcleo fundante, estruturante e essencial de todos os direitos fundamentais previstos na ordem constitucional" (CARDIN; BENVENUTO, 2013, p. 120).

Considerando que a identidade de gênero é resultado de um construto social que se dá de forma contínua, a determinação imediata do sexo biológico em registro de nascimento pode prejudicar esse processo de construção do gênero, tendo em vista, também, que a prévia imposição da identificação do sexo biológico irá acarretar em desconforto às pessoas com identidade de gênero diferente. Portanto, entende-se, que identificar as pessoas pelo sexo anatômico é atribuir maior importância à forma, e menos a dignidade humana.

Por sua vez, a autonomia privada, núcleo do direito fundamental à liberdade, assegura as pessoas o direito de autodeclararem a própria identidade, inclusive a de gênero, desassociada do sexo biológico, ou seja, pela genitália a nativitate, ou de qualquer outro padrão que ofenda a dignidade da pessoa. Ademais, o direito a serem reconhecidas como cidadãs ou cidadãos não do sexo biológico ou do gênero autodeclarado, uma vez que estes não são, e nunca foram condições para que as pessoas fossem reconhecidas como sujeito de direitos, embora seja atributo que compõe a personalidade dos indivíduos, resguardado pela dignidade humana.

Dentro dessa discussão surge a concepção da identidade como formação cultural e que não necessariamente advém da determinação do sexo ao nascimento, como ensina a célebre teoria formulada por Simone de Beauvoir em seu livro "O segundo sexo" (Le deuxième sexe, 1949). Nesse sentido, Butler (2003, p. 28) afirma que os limites das análises de gênero "pressupõem e definem por antecipação as possibilidades das configurações imagináveis e realizáveis de gênero e cultura". Ao estabelecer limites, as concepções de gênero e cultura dissidentes acabam por ser marginalizadas e desconhecidas uma vez que não discutidas. Butler formula, assim, a ideia de que o gênero é efeito e não um sentido em si do sujeito, ou seja, a identidade ou a essência seriam expressões particulares de cada indivíduo, refletidas as nuances e disparidades dentro de concepções parecidas.

\section{O DIREITO SOBRE O CORPO E A AUTODETERMINAÇÃO CORPORAL}

No que concerte o direito à autodeterminação corporal, a sua relação é intrínseca com a garantia da dignidade e a autonomia privada, pois se considera demonstra mais importante ter a liberdade de viver e ser como entende, do que obedecer o dever ser estabelecido pelo corpo social.

No âmbito da discussão sobre o não identificação do gênero nos registros públicos, surge a temática das modificações corporais que nascem para tentar aproximar a realidade biológica/física da psíquica. Daí emergem tópicos como o da ingestão de hormônios e o das cirurgias de redesignação sexual, os quais, por sua vez, fazem advir discussões sobre a idade mínima e suficiente que garanta a capacidade para fazer essa escolha; os efeitos para com a saúde do indivíduo e ainda as maneiras adequadas de prestar ajuda na transição do mesmo. No sentido de trazer ao indivíduo transgênero a possibilidade de realização de mudanças corporais a fim de garantir a dignidade do mesmo, o Ministério da Saúde instaurou o Processo Transexualizador por meio do Sistema Único de Saúde em 2008. Nesse âmbito diz Fiuza e Pereira:

Com o financiamento público da cirurgia de transgenitalização e das demais etapas do processo, buscou-se garantir a igualdade do acesso e a orientação de boas práticas assistenciais, tendo como pilares a humanização e o combate a processos discriminatórios como estratégias para a recuperação e promoção da saúde, já que a saúde é tida como um direito social pela Constituição da República de 1988 (2015, p. 61).

Diante desse cenário, entende-se que a garantia de maior liberdade de formação da identidade de gênero, o acompanhamento afetuoso e próximo, a performance de intervenções médicas financiadas pelo SUS e a aceitação e reconhecimento das diferentes formas de concepção do gênero não somente diminuem o estresse e a confusão na autodeterminação dos corpos, mas pretendem à preservação da dignidade dos indivíduos. 
Nesse sentido, vale o registro feito por Lira e Lando (2019, p. 48) a respeito da decisão referente a Ação Direta de Inconstitucionalidade n. ${ }^{\circ} 4.275 / \mathrm{DF}$, ajuizada pela Procuradoria Geral da República (PGR), "quando então o Supremo Tribunal Federal julgou pela possibilidade de alteração do nome e gênero no assento do Registro Civil, sem a necessidade de judicialização e/ou comprovação de realização de procedimento cirúrgico de redesignação de sexo para efetivação desses direitos civis." Observa-se, que, o Estado, por intermédio do Judiciário, passa a compreender o seu papel em garantir o direito de cidadania e o dever de promover dignidade a todas as pessoas, independente da forma física, sexo anatômico, orientação sexual e/ou gênero diverso do binarismo sexual.

\section{A DISCUSSÃO SOBRE GÊNERO NO CENÁRIO NACIONAL}

Dentro do contexto brasileiro, Berenice Bento e Guacira Lopes Louro são importantes vozes no debate nacional. Bento, em seus trabalhos, trata das questões de gênero e, mais especificamente, em sua obra "O que é transexualidade" (2008), a socióloga brasileira expõe as dificuldades cotidianas da vida de transexuais, decorrente do pensamento patriarcal e do tratamento patológico dado à identidade dessas pessoas. Como Bento diz,

O objetivo desse livro é fornecer reflexões que possibilitem problematizar os limites das instituições sociais ao lidar com estas demandas e a necessidade de se repensar os critérios de normalidade e anormalidade que são postos em cena todas as vezes que estamos diante das pessoas que vivem o gênero para além da diferença sexual (2008, p. 14).

Por sua vez, Guacira Lopes Louro trata das questões de gênero e sexualidade dentro do ambiente da educação. Sua obra é importante para essa pesquisa, pois ao explicitar as relações de poder que se estabelecem a partir da diferenciação individual pelo gênero e também ao explorar a construção escolar das diferenças - onde demonstra a perpetuação de práticas machistas e homofóbicas diluídas na prática pedagógica -, Guacira informa as adversidades vividas pelos indivíduos que não se identificam ou como pertencentes ao gênero estabelecido em seu registro de nascimento ou como heteronormativos.

Voltando a cirurgia de redesignação sexual, Bento e Pelúcio (2012) ensinam que o endocrinologista Harry Benjamin defendia a imposição da cirurgia de transgenitalização como única forma terapêutica, por compreender que o tratamento tinha como critério fundamental, para definir o "transexual de verdade", a relação de abjeção, de longa duração, com suas genitálias. Ou seja, a definição médica de transexualismo estava diretamente ligada a repulsa a genitália, e a sua retirada era a solução para a saúde mental da paciente.

Contudo, Castel (2001, p. 91) narra que o "transgenerismo tornou-se pouco a pouco um movimento libertário com vastas ramificações, notadamente acadêmicas e literárias, [...], e utiliza a Internet do mesmo modo que os protestos pelos direitos cívicos dos anos 60." O autor também relata a existência dos primeiros protestos do movimento contra a cirurgia mutiladora para satisfazer os estereótipos conformistas do gênero.

A nova perspetiva dos transgêneros estimulou a reflexão e, consequentemente, a elaboração de uma definição atualizada da transexualidade. 0 movimento contra a despatologização somente se fortaleceu no final da primeira década do século $\mathrm{XXI}^{46}$. Contudo, ganhou o devido espaço, e com ele muitos avanços: a transexualidade deixou de ser considerada uma doença mental de acordo com a Classificação Internacional de Doenças (CID-11) em 2018; A autodeclaração ou autodeterminação da identidade de gênero se tornou fundamental para o conceito de transexualidade; a cirurgia de redesignação sexual atualmente é um direito e não uma condição para ser considerado transexual; a partir da maioridade é possível requerer extrajudicialmente a mudança de gênero.

\footnotetext{
46 "As primeiras manifestações nesse sentido ocorreram em Madri, Barcelona e Paris, em 2007. No ano seguinte, mais cidades tiveram mobilizações contra a patologização transexual. Em 2009, os desdobramentos da Campanha se estenderam. 0 mês de outubro daquele ano foi um marco nesse sentido, quando foram realizadas em 29 cidades de 17 países iniciativas pela eliminação do transtorno de identidade de gênero dos manuais internacionais de diagnóstico. As atividades daquele ano tiveram origem em Paris, com a iniciativa do Coletivo Manis de Visibilidade Trans (também conhecido como Existrans)." (BENTO, PELÚCIO, 2012, p. 574)
} 
Fachin apresenta uma exposição bastante esclarecedora a respeito dos direitos essenciais quando se passa considerar a verdade pessoal da pessoa transexual:

Fica evidente, portanto, que a exigência da cirurgia de redesignação sexual vai de encontra à eleição da pessoa transexual, de modo que cabe exclusivamente a ela, compreendendo todas as suas implicações, realizá-la ou não. Impor um prérequisito a um direito fundamental mutila, em nosso ver, a própria definição de direitos fundamentais e direitos de personalidade, que se baseiam na ideia de inerência ao ser humano. Uma vez se tratando de direitos inerentes ao sujeito, impor condições se transmuta em genuíno autoritarismo, contra sujeitos que tem a prerrogativa de viverem a vida exercendo suas potencialidades e suas liberdades: é o que o direito deve garantir. (FACHIN, 2014, p. 56)

Consequentemente, conforme bem observado por Nascimento (2014. p. 379) "pensamos que ser (ou estar) travesti, transexual, transformista, drag depende, antes de mais nada, de uma autoidentificação e de um reconhecimento enquanto tal pelo seu grupo de sociabilidade e/ou movimento político", condição oportunizada para as pessoas transgênero pelo Provimento n. 73/2018 do Conselho Nacional de Justiça CNJ, que permite a mudança do nome e do gênero no Registro Civil de pessoas naturais, independentemente de cirurgia ou sentença judicial.

Por conseguinte, o gênero feminino não mais coincide com a mulher cis, e nem mesmo está limitado a mulher trans e sua neovagina. A atual definição de gênero feminino inclui as mulheres trans com pênis, porque leva em consideração a autodeterminação corporal e a identidade de gênero. 0 órgão genital das mulheres cis, que tradicionalmente era considerado o principal símbolo do feminino, perdeu espaço para a verdade pessoal autodeclarada, onde a vagina ou o pênis são desconsiderados em benefício da promoção da dignidade da pessoa, seu bem-estar e demais direitos da personalidade. Por fim, "cabe ao Estado apenas o papel de reconhecer o gênero, nunca de constituí-la [...]". A mulher trans "tem a liberdade de alterar o registro público a partir da sua autodeterminação, cabendo ao Estado apenas o dever de declaralo." (Lando et al., 2018, p. 54)

\section{CONSIDERAÇÕES FINAIS}

Depreende-se desse quadro teórico que a identificação do sexo biológico nos registros de nascimento interfere na compreensão interna de corpo e na sexualidade, além de cercear direitos fundamentais como o da dignidade humana, autonomia privada, identidade de gênero e autodeterminação corporal.

Finalmente, infere-se a importância da discussão sobre o direito fundamental à não identificação do gênero em decorrência do sexo biológico nos registros de nascimento perpassa não somente pela exegese dos direitos da personalidade mas como também reflete os questionamentos suscitados na busca pela autodeterminação corporal e na formação da identidade de gênero, sendo colocado em questão o envolvimento da burocracia e interferência desmedida do Estado nesse sentido.

\section{REFERÊNCIAS}

[1] Bento, Berenice. 0 que é transexualidade. Rio de Janeiro: Brasiliense, 2008. $2^{\underline{a}}$ edição, 2012.

[2] Bento, Berenice; Pelúcio, Larissa. Despatologização do gênero: a politização das identidades abjetas. Revista Estudos Feministas, Florianópolis, v. 20, n. 02. p. 559-581, 2012.

[3] Bolesina, Iuri. Gervasoni, Tamiris Alessandra. 0 direito à identidade pessoal no Brasil e seus fundamentos jurídicos na atualidade. Revista Saber Humano, v. 8, n. 13, p. 65-87, jul./dez. 2018.

[4] Butler, Judith. Problemas de Gênero: feminismo e subversão da identidade. Rio de Janeiro: Editora Civilização Brasileira, 2003. 236p.

[5] Butler, Judith. Regulações de gênero. Cadernos Pagu, Campinas, n. 42, jan./june 2014.

[6] Cardin, Valéria Silva Galdino; Benvenuto, Fernanda Moreira. Do reconhecimento dos direitos dos transexuais como um dos direitos da personalidade. Revista Jurídica Cesumar, v. 13, n. 1, p.113-130, 2013.

[7] Castel, Pierre-Henri. Algumas Reflexões para estabelecer a cronologia do "fenômeno transexual" (19101995). Revista Brasileira de História, São Paulo, v. 21, no 41, p. 77-111, 2001.

[8] Fachin, Luiz Edson. O corpo do Registro no Registro do Corpo; Mudança de Nome e Sexo sem Cirurgia de Redesignação. Revista Brasileira de Direito Civil, São Paulo, v. 01, p. 36-60, 2014. 
[9] Lando, Giorge Andre; Nascimento, Elaine Ferreira do; Monte, Liana Maria Ibiapina do; Queiroz, Alessandro Pelópidas Ferreira de. A fluidez do gênero e o direito à não identificação do sexo biológico. Revista Feminismos, Salvador, v. 6, n. 1, p. 46-56, 2018.

[10] Lira, Roberta J. de L. Santos; Lando, Giorge Andre. O direito de ser trans para além da existência dos cidadãos pela metade. (S.L.): Prática Forense, ano III, no 31, p. 47-51, 2019.

[11] Nascimento, Silvana de Souza. Variações do feminino: circuitos do universo trans na Paraíba. Revista de Antropologia, São Paulo, v. 57, n. 2, p. 377-411, 2014. 


\section{Capítulo 13}

A dificuldade qualificada de ser pessoa digna em Salvador, Bahia: Usurpação de direitos fundamentais de travestis e transexuais em situação de rua

\section{Fábio Periandro de Almeida Hirsch \\ Iarlis Neves Brandão}

Resumo: 0 trabalho focaliza a busca pela dignidade da pessoa humana na cidade de Salvador, mais precisamente de travestis e transexuais em situação de rua. 0 cenário de necessidades materiais associadas à condição de preconceito ainda presente aos profissionais do sexo e, em particular, aos homossexuais, configura um caldo de cultura altamente propício para a ampla e constante violação dos direitos fundamentais mais elementares. Baseando-se em uma revisão bibliográfica associada entrevistas semiestruturadas com profissionais que trabalham diretamente com pessoas em situação de rua e com o público LGBT, efetivou-se seleção dos direitos fundamentais mais violados para a população de travestis e transexuais em situação de rua na cidade de Salvador, sinalizando quatro deles (saúde, trabalho, habitação e integridade física e moral), como sendo, hipoteticamente, os mais infringidos. 0 objetivo foi realizar um comparativo entre os dados obtidos e promover uma singela contribuição para autoridades e entidades com interesse no tema de forma a orientar a criação de alternativas e políticas públicas que visem reduzir a condição de vulnerabilidade dessa específica população.

Palavras-chave: Direitos Fundamentais, Dignidade de Pessoa Humana, Travestis e Transexuais em situação de rua, Salvador. 


\section{INTRODUÇÃO}

Uma das maiores preocupações da sociedade civil organizada contemporânea é garantir ao maior número possível de destinatários as benesses da dignidade da pessoa humana. A tarefa, contudo, não é das mais fáceis, haja vista que as relações familiares, corporativas e institucionais estão, a cada dia, mais competitivas, complexas e, infelizmente, ainda muito emprenhadas de preconceitos de gênero.

A severa crise econômica que abateu o mundo e, em particular, o Brasil e a Bahia, aliada às reações normalmente adversas em face daqueles que, exprimindo sua sexualidade, se reconhecem como travestis ou transexuais, moldam um perigoso quadro de desproteção de profissionais do sexo que atuam e habitam as ruas da capital baiana, Salvador.

A realidade dos travestis e transexuais em situação de rua na cidade de Salvador, Bahia, é a preocupação central do presente trabalho, fruto de reanálise de pesquisa desenvolvida no âmbito da Centro Universitário Jorge Amado - UNIJORGE e que foi aprovada com a nota máxima perante banca examinadora composta pelo autor e à qual se submeteu, com invulgar desenvoltura, o coautor.

A formação humanista, aliando psicologia e direito, gerou um objeto de pesquisa recortado com foco total na análise das violações a direitos fundamentais dos alvos pesquisados, buscando, de forma a mais fidedigna possível, expor uma triste mas atual realidade vivenciada por grande contingente de pessoas na cidade de Salvador - a qual é conhecida pelos seus encantos, mas também testemunha, no mais das vezes calada e complacente, a lesão à dignidade de pessoas humanas que são pisoteadas pela sociedade apenas porque buscam sobreviver com respeito.

A justificativa para a pesquisa é a necessidade de valorização e respeito de um grupo de trabalhadores e trabalhadoras que, mesmo diante de condições desfavoráveis, ausente a perspectiva de proteção direta ou indireta por meio de políticas públicas que amparem suas necessidades, merecem proteção e terem viabilizadas suas expectativas de desenvolvimento pessoal e profissional.

A pluralidade inata da cidade de Salvador, acolhedora com as diversidades, também justifica um olhar mais crítico direcionado ao fenômeno. Compatibilizar o respeito com a proteção é a tarefa mais difícil de se obter, o que motivou a pesquisa.

Ademais, a pesquisa também se justifica pelo fato que existe um grande interesse acadêmico em solucionar problemas de ordem social, sendo ele fonte de grandes trabalhos. Contudo, notou-se que a temática do transgênero em situação de rua ainda apresenta pouca expressão entre pesquisadores, o que a torna rica na produção de novos conhecimentos e necessária para solucionar a dualidade entre a homofobia e a exclusão social. Diante disso, é imperioso que sejam feitas cada vez mais discussões, ampliando assim as teorias científicas, para auxiliar os sujeitos desta pesquisa e desse modo, facilitar a criação de alternativas para sair dessa condição de extrema vulnerabilidade.

O objetivo geral é apontar meios para que o transgênero possa usufruir de forma mais integral possível os direitos fundamentais que também lhe são oferecidos pela Constituição Federal de 1988 no Brasil.

Os objetivos específicos são: identificar, de forma científica, os direitos fundamentais mais violados em relação aos transgênero em situação de rua; expor a realidade a que esse público é submetido corriqueiramente - por estar em situação de rua e por fazerem parte de um grupo marginalizado socialmente devido a sua identidade de gênero; contribuir para a formulação de políticas públicas por parte das autoridades em busca do enfrentamento das condições indevidas que são experimentadas pelos travestis e transexuais de Salvador; formar profissionais que terão condições técnico-jurídicas de exigir socialmente dignidade para marginalizados, entre outros grupos e indivíduos, enfrentando com fundamentos o quadro de estigmatização dos vulneráveis.

\section{METODOLOGIA}

A marginalização social de um país é um retrato das relações econômicas, sociais e culturais que nele são travadas. E, por esta razão, muitos são os estudos científicos voltados para este campo de pesquisa, para desta forma entender, discutir e tentar chegar a soluções possíveis para essa realidade presente em quase todas as nações.

O Brasil possui uma Constituição na qual busca atribuir direitos e deveres para que todas as pessoas que o compõe possam ter dignidade e, com isso, sejam consideradas cidadãs dignas, tendo leis que regulamentam esta intenção. 
Contudo, é possível perceber que existe um descompasso entre a realidade vivida no cotidiano e a legislação, existindo ainda muita exclusão e marginalização de sujeitos, que não possuem seus direitos mais básicos, aqueles que são chamados de fundamentais pelo legislador.

Hoje é fato que existe uma legislação constitucional e infraconstitucional que trata da exclusão social vivida por milhões de brasileiros, apontando, desse modo, que apenas a existência de leis não resolve a problemática, passando a ser necessária a criação e ampliação das políticas públicas.

Diante dessa realidade, de muitas pessoas, de serem extirpadas de seus direitos básicos é que este artigo busca fazer uma análise da questão: quais são os direitos fundamentais mais violados e negados ao transgênero em situação de rua no município de Salvador/Bahia?

Deve-se esclarecer que o grupo de pessoas em situação de rua é heterogêneo e comporta subgrupos, estando as travestis e transexuais em uma dessas categorias, as quais possuem seus direitos violados diariamente.

Por serem os direitos fundamentais extensos e este trabalho se tratar de um artigo, o que limita aprofundar-se em todos eles, optou-se primeiramente por delimitar estes direitos, o que ocorreu com base em literatura já existente. Utilizou-se para isso, como fonte primária de pesquisa, autores como Flávia Piovesan, Bauman e um compilado de artigos organizado por Ada Pelegrini Grinover em conjunto com outros autores.

Chegou-se ao que se acredita ser o resultado dessa pesquisa literária e a um desenho hipotético, elencando-se quatro deles, que são os direitos: à habitação, à saúde, ao trabalho e à integridade física e moral, que são comumente violados.

Foram realizadas entrevistas semiestruturadas com profissionais que atuam de forma geral com o público LGBT (Lésbicas, Gays, Bissexuais e Transgêneros) ou com pessoas em situação de rua, já que os sujeitos foco dessa pesquisa fazem parte de ambos os nichos, para assim chegar ao melhor resultado possível.

A seguir, comparou-se o resultado da revisão bibliográfica e o que foi dito nas entrevistas realizadas, para assim, fazer uma análise coerente de quais os direitos que mais interferem e contribuem para a marginalização as travestis e transexuais em situação de rua. Ao final, incluindo as opiniões, foi apresentado o relatório final.

\section{RESULTADOS}

Através do Relatórios de Pessoas em Situação de Rua de Salvador (2010), foi dada visibilidade para uma população excluída/marginalizada e a partir disso é possível criar estratégias para dar condições para que esses sujeitos possam ter acesso aos seus direitos fundamentais.

O censo realizado informou que o número total de pessoas em situação de rua na cidade de Salvador foi de 2076, contudo deste total apenas 2010 quiseram responder o questionário. Desse número, foram selecionadas 421 pessoas para responderem a pesquisa de forma mais aprofundada a pesquisa.

Diante da seleção amostral, de 421 pessoas, quando comparada com número total dos moradores de rua, percebe-se uma equidade entre os números encontrados. Por esse motivo o levantamento deste perfil ficará restrito ao número amostral.

Por meio das informações obtidas dessa pesquisa é possível verificar que a população masculina é predominante, representando $79,3 \%$ do total levantado. Quanto à idade, o que se destaca é que $73,3 \%$ da população de rua possui entre 18 a 44 anos. Este fato revela que grande parte da população que se encontra nessa situação está em idade de grande potencial de produção econômica.

Foram encontrados todos os níveis de escolaridade nessa parcela pesquisada, sendo que $64,6 \%$ possui ensino fundamental incompleto e $14 \%$ nunca estudou, contudo $5,8 \%$ possui ensino fundamental completo, superior incompleto ou completo. Assim, observa-se que mesmo a maior parte sendo composta por pessoas do ensino fundamental incompleto existe uma heterogeneidade (mínima) em todos os quesitos pesquisados sobre esta questão.

Também foi verificado que a renda média dessa população varia de $R \$ 20,00$ a $R \$ 120,00$ por mês, o que mostra o nível de precariedade na qual se encontram. Ainda foi abordado qual o último local de moradia dessa população, o que levou ao conhecimento de que a grande maioria, 90,4\%, é da zona urbana. Diante dessa afirmação, deve-se desconstruir a ideia que a população que vive na rua é composta por pessoas que saíram da zona rural e foram para a zona urbana em busca de outras oportunidades. 
Ainda dentro desta perspectiva foi possível observar que a maioria dessa população urbana é composta de $76,5 \%$ de pessoas da própria capital, 19,9\% de outros municípios da Bahia e um número reduzido de pessoas advindas de outros estados (3\%). Verifica-se assim, que a migração do interior da Bahia para a capital tem tido uma significativa redução.

Os motivos que levam as pessoas a irem morar na rua são os mais variados, contudo, problemas familiares (com pai, mãe e irmão) são os que se apresentam com maior incidência. Das pessoas pesquisadas 31\% responderam ser este o motivo de ter ido para as ruas. Outro fator preponderante, com percentual de $23,7 \%$, decorre do uso do álcool e outras drogas. 0 desemprego figurou em terceiro lugar como motivo para se tornarem pessoas em situação de rua foi, com 15,9\%.

A principal atividade geradora de renda da população em situação de rua é heterogênea, tendo sido verificado diversas fontes, mas a de catador de materiais reciclados se sobrepôs às demais, sendo composta por $28,5 \%$ da amostra. A pesquisa também permitiu observar que apenas $27,3 \%$ desse nicho são formados por pessoas que sobrevivem de pedir dinheiro ou alimentos, com um contraponto de 72,7\% de pessoas que possuem alguma forma de trabalho, sendo que $44,2 \%$ afirmam ter uma profissão contra $54 \%$ que não se enquadram nessa categoria. Cabe ainda ressaltar que desse total apenas $1 \%$ afirma trabalhar com carteira assinada.

Quanto aos benefícios sociais oferecidos pelo governo à população em situação de rua, a amostra pesquisada se enquadra da seguinte forma: $3,9 \%$ recebem bolsa família; $2,9 \%$ são aposentados; $1,9 \%$ recebem cesta básica de alimentos e 5,2\% recebem outro tipo de benefício, sendo que um número elevado não soube responder $(19,5 \%)$. Fica demonstrada uma falha de atendimento por parte dos programas sociais para com essa população, o que é um erro, pois reflete um não oferecimento de condições básicas para uma vida digna e acesso a direitos fundamentais.

Ainda dentro dessa compreensão se faz necessário ressaltar que apenas $21,3 \%$ possuem certidão de nascimento; $17,7 \%$ possuem RG; $12,5 \%$ possuem título de eleitor; $12 \%$ têm CPF e apenas 10,2\% possuem carteira de trabalho. Estes documentos são essências para a atuação como cidadãos e assim terem acesso a programas sociais e atendimentos básicos na saúde, por exemplo.

A Constituição Federal garante o direito de ir e vir do cidadão, contudo, quando perguntado para a população em questão se elas já foram impedidas de entrar ou colocadas para fora de algum local, foi verificado que $22 \%$ foi impedido de entrar em estabelecimento comercial; $14,3 \%$ impedido de entrar em transporte coletivo; $2,9 \%$ em instituições para a retirada de documentos; $14,3 \%$ em shopping center; $4,6 \%$ em bancos; $2,5 \%$ na rede de saúde e $28 \%$ em outros locais, sendo que os demais não souberam ou não se lembravam responder sobre o ocorrido.

O Relatório de Violência Homofóbica no Brasil, que pesquisou o ano de 2013 e foi publicado em 2016, afirma que entre as violações discriminatórias a mais presente é por orientação sexual, contando com $77,1 \%$, das denúncias realizadas. Desse número, $15,1 \%$ é relacionado a identidade de gênero (dados pesquisados do disque 100, ouvidoria do SUS [Sistema Único de Saúde] e ouvidoria da Secretaria de Políticas para as Mulheres). Denúncias contra a homofobia superam as denúncias raciais, discriminações sociais, contra pessoas deficientes e religiosas, entre outras.

Nessa pesquisa observou-se que entre as violências homofóbicas mais graves, como homicídio e lesões corporais, as travestis e transexuais são as mais atingidas dentro do grupo LGBT. A homofobia é uma doença social que chega a toda a população LGBT, mas que atinge mais fortemente as pessoas que apresentam modificações corporais, como as transgêneros (BRASIL, 2016b).

Também foi feito um levantamento com relação às vítimas de violência homofóbica em situação de rua, sendo que quando as denúncias são realizadas tenta-se aplicar um questionário sociodemográfico, que, no entanto, não é de caráter obrigatório para o registro da queixa. Das pessoas que ofereceram queixas, $69,7 \%$ declararam não serem moradores de rua, $28,7 \%$ não responderam a este item e apenas $1,6 \%$ das denúncias foram relacionadas a pessoas em situação de rua.

0 número apresentado pelo Relatório de Violência Homofóbica no Brasil: ano 2013 (2016) com relação a população LGBT em situação de rua é pequeno quando comparado com o todo apresentado, contudo é importante dizer que o quantitativo demonstrado corresponde apenas as denúncias realizadas nesses três órgãos citados acima. No Brasil existe uma grande quantidade de crimes que não são registrados, correspondentes de cifras ocultas, e que muitos desses sujeitos buscam delegacias para realizarem boletins de ocorrências. 
A Carta Maior brasileira entende que a integridade física e moral do cidadão deve ser preservada e que quando ocorrem violações a direitos elas devem ser combatidas. Este entendimento pode ser notado, por exemplo, em seus artigos: $3^{\circ}$, IV; $4^{\circ}$, II e $5^{\circ}$, III. A integridade física e moral do cidadão é garantida pela legislação brasileira não apenas pela sua constituição, mas também em seus códigos penais e civis, retirando essa obrigação apenas do direito público, o que a coloca de forma compartilhada com o direito privado.

Dessa maneira o indivíduo que sofrer agressões físicas e morais pode exigir que seus agressores sejam punidos penalmente e civilmente, exigindo ainda que a violação seja cessada. Assim é possível sedimentar o direito de defender o indivíduo e a coletividade. Contudo, a jurisdição é um instrumento para garantir direitos e obrigações positivadas, ela não muda valores e preconceitos culturais. Por este motivo, a educação da sociedade é fundamental para não creditar ao judiciário a solução para todos os problemas sociais, sobrecarregando-o e gerando uma justiça morosa e falha.

Por fim, pode-se perceber que todos os direitos humanos estão entrelaçados, sendo um dependente do outro e por este motivo não tem hierarquia entre eles, mas é possível inferir que existe uma valoração, que é criada à medida que ocorre mais a ausência de um direito que do outro ou quando um pode contribuir para a conquista dos demais.

A dignidade humana é composta de vários elementos, contudo o que é mais importante para uma determinada pessoa não necessariamente tem a mesma relevância para outra. Diante disso, buscou-se aqui mostrar a importância e os valores desses quatro direitos fundamentais elencados neste artigo, ressaltando as suas ligações entre si, para assim comparar com a visão dos profissionais que trabalham com travestis e transexuais em situação de rua sobre estes ou outros direitos fundamentais.

\section{DISCUSSÃO}

O perfil do transgênero de rua de Salvador, Bahia, foi enfocado. Quando se busca desenvolver ações sociais para propiciar às pessoas em situação de rua seus direitos fundamentais e de acolhimento institucional é fundamental a criação de um perfil, para desse modo direcionar esses sujeitos nas instituições, para encaminhamentos ou mesmo para resoluções de seus problemas.

Para demarcar esse grupo de forma mais clara, é necessário trazer o conceito de pessoas em situação de rua e que abrange o grupo proposto por este projeto. Mesmo ao saber que existe uma heterogeneidade em todo e qualquer grupo formado por pessoas, se faz importante que ocorra um desenho próximo da realidade desses sujeitos em situação de rua e mais especificamente de travestis e transexuais para que desse modo se possa chegar a ações eficazes que favoreçam direitos fundamentais para os mais vulneráveis.

O relatório de pesquisa das pessoas em situação de rua, realizando pela Prefeitura de Salvador, por meio do SETAD (Secretaria Municipal do Trabalho, Assistência Social e Direitos do Cidadão) em parceria com o Ministério Público do Estado da Bahia e a Fundação José Silveira (2010), traz o mesmo conceito que é utilizado pela Pesquisa nacional sobre pessoas em situação de rua (2008), que classificam essa população como:

Grupo populacional heterogêneo, composto por pessoas caracterizada por sua condição de extrema pobreza, pela interrupção ou fragilidade dos vínculos familiares e pela falta de moradia convencional regular. São pessoas compelidas a habitar logradouros públicos (ruas, praças, cemitérios...), áreas degradadas (galpões, ruinas, prédios abandonados...) e ocasionalmente utilizar abrigos e albergues para pernoitar (Brasil apud Salvador, 2010)

Ao fazer uma análise da sociedade atualmente, Macerata et. al. (2014) traz que vive-se em um mundo paradoxal, onde existe uma busca compulsiva pela individualidade, procurando as peculiaridades de cada um, e simultaneamente a isso, também ocorre uma tentativa de homogeneizar desejos sustentados na pose de bens, sendo esta a condição para a validação do sujeito em sua comunidade.

Pode-se inferir, a luz do parágrafo anterior, que quem não está dentro dessa concepção desejante e não possui bens encontra-se à margem dessa sociedade, e como cada vez mais as pessoas se tornam individualistas, a dificuldade de inserção das pessoas em situação de rua na cidadania torna-se cada vez maior. Partindo desta ideia é possível ter uma noção do quão excluídas são as pessoas em situação de rua, que passam a carregar um estigma social que os segregam. 
Diante dessa concepção é possível dizer que as condições sociais nas quais travestis e transexuais em situação de rua vivem são mais estigmatizantes, pois carregam marcas sociais que se sobrepõem, os colocando dentro da expressão "lixo humano" trazido por Bauman (2004).

Saliente-se que uma forma de reduzir o números de transgêneros moradores de rua pode ser a criação de uma política de desconstrução do preconceito relacionado a identidade sexual. Sendo ainda que é ponto fulcral a percepção de que essa não aceitação familiar, segundo o entrevistado, trata-se do maior direito violado, que é o direito a integridade moral.

O preconceito enraizado na sociedade pode ser mais temível que qualquer outro tipo de opressão, pois esta passa a ser encontrada nos menores detalhes, o que escraviza e maltrata o sujeito, sendo assim, necessário a desconstrução das opiniões preconceituosas e dos sentimentos pregnantes.

A integridade moral é um direito fundamental do cidadão que está previsto na constituição brasileira, devendo ele ser oferecido a todos os cidadãos para que dessa forma possa haver respeito entre as pessoas. Este direito quando é desrespeitado é gerador de sofrimento psíquico e mais ainda quando ocasionado por membros de sua própria família, o que o potencializa mais ainda.

Diante disso, pode-se inferir que uma forma de reduzir o número de travestis e transexuais em situação de rua é a readaptação delas em suas famílias. Porém, para isso, é basilar que sejam construídos programas de educação sexual para a sociedade e para estas famílias em especial.

\section{CONCLUSÕES}

De forma geral as pessoas em situação de rua vivenciam a marginalidade social das mais diversas maneiras e níveis. Por este motivo não possuem acesso aos bens e serviços oferecidos à coletividade, já que encontram empecilhos para serem beneficiadas destes, como por exemplo: a falta de documentos, o medo de serem maltratadas, apresentarem alguma pendência judicial e temerem por isto ou simplesmente a falta de banho ou a impossibilidade de ficarem esperando o atendimento, pois necessitam buscar o alimento diário, como também o preconceito e o descaso sofridos nas instituições (Paiva, 2016).

Essa falta de prestação de serviços para esta comunidade não caracteriza a necessidade da criação de um novo modelo de sistema de saúde, dentre outros direitos, mas demonstra ser fundamental uma reforma para reconfigurar o mesmo, para modificar e adequar as instituições e os profissionais às reais necessidades da população em situação de rua (Paiva, 2016) e em especial para as travestis e transexuais, que possuem características ainda mais peculiares.

A dignidade humana é composta de vários elementos, contudo o que é mais importante para uma determinada pessoa não necessariamente tem a mesma relevância para outra. Diante disso, buscou-se aqui mostrar a importância e os valores desses quatro direitos fundamentais elencados neste artigo, ressaltando as suas ligações entre si, para assim comparar com a visão dos profissionais que trabalham com travestis e transexuais em situação de rua sobre estes ou outros direitos fundamentais.

No início dessa pesquisa acreditou-se que os direitos fundamentais mais violados para as travestis e transexuais em situação de rua na cidade de Salvador eram: habitação, saúde, trabalho e integridade física e moral. Ao fazer a relação da revisão bibliográfica e as entrevistas realizadas, percebeu-se que as realidades eram próximas. Diante disso, percebe-se que estes direitos são violados por diversos atores sociais, inclusive o próprio núcleo familiar, com desdobramentos mais sérios.

Devido a interligação existente entre os direitos fundamentais que dão as diretrizes para viver com dignidade constatou-se que a educação é um fator importante e que poderia modificar a realidade de muitos desses sujeitos que estão nessas condições de vulnerabilidade absoluta. De acordo com os profissionais entrevistados esse direito é visto como o ponto nevrálgico, pois mesmo sendo um possível modificador de condições sociais, o mesmo não é oferecido de forma adequada.

Constatou-se também que apesar da existência de legislação voltada para a proteção das transgêneros em situação de rua esta é insipiente sendo insuficiente para modificar uma cultura impregnada de preconceitos. Conclui-se assim que os legisladores devem envidar esforços para criar leis específicas para o combate a homofobia.

Concluiu-se que a banalização do sujeito é presente em qualquer meio social, mas que nessa população pesquisada mostra-se mais forte e mais constante, sendo necessária a melhoria das políticas públicas existentes para a modificação dessa realidade, que se mostra cruel. 


\section{REFERÊNCIAS}

[1] Alves, K. Proteção dos direitos fundamentais das pessoas em situação de rua: CNDDH, um novo paradigma. Direitos Fundamentais das Pessoas em Situação de Rua. Org. Grinover, A. et. al. Belo Horizonte: Editora D’Plácido, 2014.

[2] Bauman, Zygmunt. Vidas desperdiçadas. Tradução de Carlos Medeiros. Rio de Janeiro: Zahar, 2005.

[3] Bobbio, Norberto. Era dos direitos, trad. Carlos Nelson Coutinho, Rio de Janeiro: Campus, 1988

[4] Brasil. Secretaria Especial de Direitos Humanos do Ministério das Mulheres, da Igualdade Racial e dos Direitos Humanos. Relatório de Violência Homofóbica no Brasil: ano 2013. Brasília: 2016b. Versão eletrônica, disponível em: http://www.sdh.gov.br/assuntos/lgbt/dados-estatisticos/Relatorio2013.pdf, acessado em $01 / 10 / 2016$.

[5] Central Única dos Trabalhadores (CUT). No mundo do trabalho, travestis e transexuais permanecem excluídas. Escrito por: Walber Pinto • Publicado em: 02/06/2015 - 17:15. Última modificação: 22/06/2016. Disponível em: http://www.cut.org.br/noticias/travestis-e-transexuais-permanecem-excluidas-do-mundo-dotrabalho-c7fe/ . Acessado em 12/11/2016.

[6] Macerata, I. et. al. Direitos Humanos e população em situação de rua: as singularidades no encontro com a rua. Grinover, A.; et. al. (Orgs.). Direitos Fundamentais das Pessoas em Situação de Rua. Belo Horizonte: Editora D’Plácido, 2014.

[7] Município de Salvador. Relatório de Pesquisa sobre a população em situação de rua no município de Salvador-BA: Programa Salvador Cidadania, 2010.

[8] Paiva, I. et. al. Direito à saúde da população em situação de rua: reflexões sobre a problemática. Revista Ciência \& Saúde Coletiva. $N^{\circ} 21,2016$.

[9] Silva, M. Mudanças recentes no mundo do trabalho e o fenômeno população em situação de rua no Brasil 1995-2005 / Maria Lucia Lopes da Silva; Ivanete Salete Boschetti Ferreira. Brasília, 2006. Dissertação (mestrado) Universidade de Brasília, Departamento de Serviço Social, Programa de Pós-Graduação em Política Social, 2006. 


\section{Capítulo 14}

\section{A visibilidade transgênero no Instagram}

\section{Lucíola Carla Correia da Silva}

Resumo: Estimulado pelo surgimento de dispositivos portáteis e acessíveis como smartphones equipados com câmeras digitais, o sujeito da contemporaneidade acessa e cria conteúdos de maneira autônoma, motivado, à princípio, pela maleabilidade e instantaneidade desses novos aparatos tecnológicos. Visto que os antigos modos de se criar produtos midiáticos priorizavam apenas retratar padrões tradicionalistas e invisibilizavam a existência da transgeneridade ou do transativismo, surge um movimento independente, dentro das redes sociais, que através de imagens e textos, vai legitimar a presença transgênero no convívio social. Esse estudo objetivou traçar um panorama da quantidade de perfis que atualmente abordam tais questões, dentro do Instagram, e que encontram-se produzindo para este público específico. Através do uso da Netnografia, a pesquisa resultou na observação de duas personalidades de relevância na plataforma, e a partir deste recorte, constatou-se que a necessidade de ocupação desses espaços on-line reside no desejo de inspirar seus seguidores a assumirem suas identidades de gênero e lutarem por sobrevivência também fora da Internet.

Palavras-chave: Transgêneros, Transexuais, Cultura Participativa, Instagram, Influenciadores. 


\section{INTRODUÇÃO}

A sociedade atual atravessa uma profunda modificação na forma de se comunicar na contemporaneidade, relações interpessoais reconfiguram-se para meios remotos e proporcionam a sensação de proximidade entre os agentes comunicadores, visto que o acesso se dá livre de barreiras físicas, tornando a produção de conteúdo na internet massificada, espontânea e cada vez mais veloz. De acordo com Martino (2014. p. 37) com o surgimento de comunidades em rede e ferramentas de conteúdo gerado pelo usuário, o espectador compreende a oportunidade de reivindicar maior representação dentro desenvolvimento dos produtos audiovisuais veiculados junto aos seus pares, e através da informação disseminada de maneira igualitária.

No momento em que surge o ciberespaço, o fluxo contínuo de dados pode ser alimentado por todos aqueles que compõem esse universo dentro da Internet e contribuem para torná-lo uma extensão das vivências que já se davam fora deste ambiente, naquilo que Levy $(1999$, p. 10) vai chamar de Cultura Participativa. Constitui-se, dessa forma, uma reorganização da estrutura da produção de conteúdo midiático dentro do novo milênio, expectadores que anteriormente apenas absorviam o que era ditado pela cultura de massa nos meios clássicos de comunicação, começaram a opinar, criar perfis, discursos textuais e imagéticos. Por outro lado, o sentimento de representatividade de vários segmentos do público que consome mídia, não é recente, nem nasce com o surgimento da Internet e das novas tecnologias, assim como diversas nuances da coexistência social foram ressignificadas após a massificação dos aplicativos e diversificação dos discursos, percebemos, na atualidade, movimentos em busca de maior democratização e quebra de estereótipos impostos em épocas anteriores. A medida que os meios de produção de conteúdo se tornam ferramentas de utilização livre, emergem movimentações nítidas na desestabilização do sistema de valores em vigência por muito tempo na nossa sociedade, que prezava pela desumanização e mínimo espaço de debate sobre os direitos de determinadas minorias defendidos por grupos ideológicos e sociais, tais quais: 0 movimento negro, o feminismo e a causa LGBTQ+. Ainda bastante conflituosa é a aceitação, por parte majoritária da sociedade, do convívio e inserção das pessoas transexuais dentro do mercado de trabalho, da naturalização de suas relações interpessoais, e da desvinculação do estigma de transtorno mental entre indivíduos que não se sentem confortáveis nos papeis do gênero que lhe foi imposto, uma vez que:

Identidade de gênero é o gênero com o qual uma pessoa se identifica, que pode ou não concordar com o gênero que lhe foi atribuído quando de seu nascimento (...) uma pessoa pode nascer com um sexo biológico (homem ou mulher) e se identificar com o gênero oposto (masculino ou feminino). Orientação sexual é atração afetivo-sexual por alguém, vivência interna relativa à sexualidade (heterossexual, homossexual ou bissexual). Identidade de gênero e orientação sexual são dimensões diferentes, que não devem ser confundidas (SILVA, et al, 2015. pag.2)

O não esclarecimento sobre essas questões gera a incompreensão das lutas dos trangêneros dentro escopo geral da sociedade, visto que tais pessoas se percebem como presas a uma identidade que não lhes pertence. Este fato, de per si, já repercute na rejeição por parte de quem não vive o dilema. Complexificando ainda mais os aspectos dessas subjetividades, Silva et al (2015), vai estabelecer que dentro do grupo dos trangêneros existem os travestis, que é a classificação dada a pessoas do sexo masculino e traços ainda masculinizados, mas que não se identificam com os papeis atribuídos socialmente a esse gênero. Mulheres transexuais que são nascidas com o sexo biológico masculino, mas que possuem a real conviç̧ão de que são mulheres, inclusive se submetem a cirurgias de redesignação de gênero, enquanto que os homens transexuais, são pessoas nascidas com o sexo feminino, mas que também não concordam com essa condição e passam por mudanças corporais em função disso. Dentro do grupo das pessoas transgênero também existem indivíduos que transitam entre os dois gêneros ou na neutralidade entre eles, conhecidos como "não-binários".

Nos meios comunicacionais anteriores, lidar com essa multiplicidade de experiências, não interessava ao modelo de cultura heterossexual dominante, entretanto, com a democratização na produção de conteúdo, com a facilidade de manuseio das ferramentas audiovisuais nos celulares e com o imediatismo de postagens na Internet, essa situação se reverte no aumento de páginas produzidas por transgêneros, num processo de formação de um movimento que estabelece identidades e se fortalece na empatia com outras pessoas em iguais circunstâncias ao redor do mundo, na identificação fortalecida pelas imagens e experiências compartilhadas.

Diante desta nova realidade, é imprescindível que a comunidade acadêmica volte o seu olhar para a pesquisa deste universo de apreciação: A visibilidade que é dada aos transgêneros através da criação de 
perfis no Instagram sobre essa temática. As redes sociais são o principal meio impulsionador na formação dessas identidades, visto que a liberdade dos usos nos suportes gera, por consequência, o maior número de usuários participando do processo de maneira autônoma. Existem inúmeras redes que possuem uma capacidade aglutinadora de seguidores bastante volumosa, entretanto, o Instagram, atualmente, lida com toda a carga simbólica que envolve a imagem: enquanto que o discurso escrito evoca do imaginário, a fotografia e o vídeo funcionam como espécie de "espelho do real" (DUBOIS, 1994, p.45). Esses suportes, ainda que passíveis de edições ou polissemias, proporcionam a experiência maciça do expectador se identificar através da materialidade da imagem, na prova irrefutável de que aquele discurso é legítimo, já que a fotografia é a chancela da veracidade, algo que é fator primordial na formação das comunidades de seguidores e na criação da identidade visual desses grupos. 0 objeto de estudo Instagram e a potência transativista dos discursos nesta rede proporcionam diversos vieses para análise que não se esgotam apenas nesta pesquisa isoladamente, a critério de recorte temático para melhor apreciação, dentro dos objetivos específicos, verificamos as principais hashtags que aglutinam comunidades de seguidores nesse universo, e em seguida, selecionamos dois dos perfis de relevância dentro da hierarquia do aplicativo, para averiguarmos de que maneira esses usuários utilizam-se do discurso imagético em prol de seus ideais, e por fim, reconhecemos de que maneiras esses recursos auxiliam a chancelar a reivindicação por mais visibilidade social para a comunidade transgênero.

Como resultados, constatou-se através das próprias ferramentas de busca do aplicativo e contagem de seguidores, que a quantidade de perfis de pessoas transgênero na web possui números significativos e tende a crescer à medida que suas publicações são vistas e assimiladas sem os filtros da mídia tradicional e que a profusão de imagens e vídeos afirmando essas vivências fortalece a representação e construção dessas identidades no convívio social.

\section{METODOLOGIA}

0 percurso metodológico para essa análise fundamenta-se na abordagem experimental de pesquisas qualitatitvas e quantitativas (FRAGOSO, et al. 2011) em redes sociais na internet, focando não apenas em um único método, mas na compilação de diferentes conceitos que tentam elucidar as estruturas decorrentes de interações dos atores sociais, compreendendo os elementos básicos sobre os seguidores e influenciadores formados nessas redes. Dentro desta estrutura, pretendemos utilizar enquanto critério de escolha no banco de dados do Instagram, em primeiro lugar: As redes formadas por hashtags de maior relevância para a cultura transgênero, e em seguida: Dois perfis elencados de acordo a popularidade entre o público do aplicativo e citações a respeito do tema, que são os perfis de Rosa Luz e Lucca Najar.

Outra abordagem significativa proposta por Hine (2000, p.15) supõe a análise da internet dentro dessas duas perspectivas: Enquanto artefato cultural e enquanto Mídia, o que justifica a escolha específica dos personagens na análise: São personalidades que usam a ferramenta como disseminação de suas vivências e produtos culturais, e que também se apropriam do Instagram como instrumento midiático, se estabelecendo enquanto influências do discurso militante.

Todas essas apreciações baseam-se na metodologia etnográfica antropológica, algo que expande a análise estrutural da rede para outros campos do conhecimento por fornecerem, segundo Fragoso, et al (2011, p. 45): "uma estrutura para pensar sobre aspectos do cyberspaço que podem ser observados como campos para um etnógrafo". Isso nos leva ao desenvolvimento de uma Etnografia Virtual (FRAGOSO, RECUERO, AMARAL, 2011) ou Netnografia (KOZINETS, 2010), que consiste na análise do comportamento de indivíduos e grupos sociais dentro do cyberespaço, acompanhando suas dinâmicas e cujas consequências extrapolam para o off-line. Nessa perspectiva, vamos analisar os discursos verbais e imagéticos no sentido de contribuir para representatividade da cultura transexual.

\section{DESENVOLVIMENTO}

As questões de gênero e todas as suas nuances e reivindicações ainda não pacificadas na sociedade perpassam necessariamente pelo próprio conceito de gênero e suas transformações ao longo do tempo, culminando nos movimentos de diversidade. 
O conceito foi construído para explicar as interações estabelecidas entre os homens e mulheres socialmente, os papéis que cada um assume, e as relações de poder instituídas entre eles para além da condição e determinação biológica: "Falar sobre gênero nos leva a uma profunda reflexão pautada em um contexto biológico e sociocultural imposto a todos". Santos (2016, p.10).

Ainda na atualidade, a tradição dos costumes patriarcais intrinsicamente ligados às nossas características na sociedade em geral, se faz presente em todas as instituições. Costumes estes, que colocaram o gênero masculino no papel da liderança incólume e no status de força, poder e superioridade sob o único gênero oposto: 0 feminino. Santos (2016, p. 10).

Ainda pontua que esses papeis traçam "uma noção de que o homem ocupa seu lugar como personagem dominante, enquanto as mulheres encontram-se subjugadas aos ideais atribuídos historicamente e assegurados, sobretudo, por instituições como igreja, cultura, e pela sociedade". Quanto mais arraigada às reminiscências tradicionais deste patriarcalismo, mais complexa se torna a desestabilização dos papeis do homem e da mulher para esta realidade social, uma vez que essas verdades são postas como naturais e, sobretudo, de ordem divina:

Levando em consideração a crença de que o corpo é um atributo natural e que define a identidade de homens e mulheres enquanto pessoas de um sexo ou de outro, as mudanças corporais realizadas pelas travestis e transexuais implicam em dificuldade de convivência nos espaços sociais normatizados. (SILVA, et al 2015. Pag. 3)

Em sociedades, comunidades e instituições ainda presas às amarradas da herança colonial e religiosa, tais quais as brasileiras, é tortuoso o processo de aceitação de pessoas que nascem aprisionadas a um gênero, mas optam por pertencer a outro, ou a nenhum gênero pré-determinado:

A não aceitação familiar os leva a morarem outros ambientes. 0 acesso aos serviços de saúde, às políticas públicas e à circulação, em diferentes territórios e instituições, também é dificultado. Sem muita opção de moradia e meios de se sustentar, podem ir viver no contexto da rua e da noite e encontrar na prostituição um meio de sobrevivência, o que os coloca em situação de risco (SILVA, et al 2015. Pag. 3).

Nota-se em pesquisa recente promovida pelo grupo Gay da Bahia, que o Brasil teve registros de "445 assassinatos por orientação sexual em 2017 e é o país que mais mata transexuais no mundo, de acordo com a Transgender Europe (TGEU)" (LUPI, 2018), ainda que existam subnotificações sobre os dados em países da Ásia, Africa e Oceania, o número é considerado alarmante e essa situação já é suficiente para a luta constante por reconhecimento, não só por parte de todo o ciclo de convivência que perpassa a vida da pessoa transexual, como até mesmo no difícil processo de auto aceitação e superação do medo de assumirse diante da intolerância e violência dentro desta realidade.

O curioso é que, de maneira contraditória, diversos estudos comprovam a existência dessas pessoas desde séculos anteriores em diferentes locais e épocas. Historicamente, constam registros de pessoas transgênero desde a antiguidade, GREEN (1998) cita dois poetas romanos Manilo e Juvenal, que aludiam a homens que viviam e se comportavam como mulheres, exibindo certa repulsa ao serem vistos como do gênero oposto. A historiadora Emily Skidmore, descobriu que há aproximadamente 120 anos, pessoas nascidas como mulheres se vestiam e se identificavam como homens, em localidades remotas nos Estados Unidos (BOTELHO, 2017). Lili Elbe, famosa mulher trans ${ }^{47}$ do início do século XX, cujo nome de batismo era Einar Wegner, foi uma das pioneiras dentro dos tratamentos médicos de redesignação. Sua história foi retratada no filme A Garota Dinamarquesa (Focus Features, 2015).

A partir do momento que a internet democratiza a comunicação e dá voz a esses casos, rompe-se o modelo midiático anterior, em que o público trans não possuía a representação adequada e era marginalizado pela cultura hegemônica, visto que as grandes empresas de comunicação e produtores de cinema não tinham o costume de desafiar e causar desconforto nas crenças dominantes de sua audiência. Dentro das redes, e posteriormente, fora delas, eclode a visibilidade a esses casos e por consequência, o desejo de aceitação e inclusão das pessoas trans dentro das leis, das relações de trabalho e convivência pacificada.

\footnotetext{
47 Neste estudo, o termo "Homem Trans.", "Mulher Trans." e "Pessoa Trans." representa a abreviação de "Transexual” na nomenclatura aplicada entre os grupos LGBTQ+
} 


\section{RESULTADOS E DISCUSSÃO}

Nos diversos aplicativos, sobretudo no Instagram, o uso das Hashtags permite a categorização das publicações de forma organizada, gerando comunidades de perfis dentro de um mesmo tema (SALLES, 2019). Utilizando o marcador "\#" dentro dos assuntos que se deseja enfatizar sobre a imagem, ela torna seu conteúdo detectável e permite que os usuários localizem rapidamente outras publicações relevantes com interesses em comum. A escolha por esse sistema, se deu por razão de refinar as buscas dentro da temática e também por proporcionar o recorte para perfis brasileiros, cujos costumes e crenças estão mais próximos do público de abrangência deste estudo, entretanto, as palavras \#trans, \#transgender, \#transdayofvisibility e \#transisbeautiful também estão entre as mais usadas pelos brasileiros na comunidade mundial. Realizando a busca na ferramenta para determinar as palavras específicas dentro do próprio Instagram, que elenca em quantidade de seguidores que utilizaram determinada "etiqueta" (tradução para a palavra hashtag), percebeu-se que as categorizações mais usadas por perfis brasileiros, em agosto de 2019, são: \#trânsgênero, com $106 \mathrm{k}^{48}$ de seguidores, \#mulhertrans com 20.4k de seguidores, \#transbrasil com 18k de seguidores e \#homenstrans com 1000+49 de seguidores. Vale ressaltar também, a relevância do termo \#naobinario com 5000+ de seguidores, e a constatação de que o termo \#semgenero aglutina diversos elementos que não fazem parte do universo LGBTQ+ ou que até sem posicionam contra as teorias de gênero.

A seleção dos dois perfis da análise se deu por observação das matérias de maior relevância no sistema de Search Engine Optmization ${ }^{50}$ do Google (MESQUITA, 2017), publicadas em sites sobre a popularidade de determinados perfis transexuais na rede. Alguns perfis possuem maior número de seguidores, como o @Mandycandyreal, perfil de uma mulher trans influenciadora dos segmentos de moda e beleza, entretanto, além da popularidade, a quantidade de postagens sobre a a própria condição, como fator de militância, foi o norteador da pesquisa observacional enquanto mídia e artefato da cultura de gênero. (HINE, 2000).

\subsection{ROSA LUZ @ROSADOBARRACO}

Rosa Luz é uma mulher trans negra de 23 anos, nascida na periferia do Distrito Federal e atualmente morando na cidade de São Paulo. Começou a produzir conteúdo sobre sua rotina e o processo de aceitação de sua real identidade através do YouTube, em 2016, e migrando para o Instagram no mesmo ano. Artista visual, compositora e cantora de Rap, a influencer possui um perfil com mais de 29 mil seguidores onde disponibiliza fotos, vídeos e interage com o público, não apenas sobre a condição transgênero, mas também abordando temas como: raça, classe e a experiência de ter crescido na periferia. Rosa se identifica como travesti, no sentido de desvincular o tom pejorativo ligado ao termo, e exaltar o processo de luta que essas pessoas enfrentam ao decidirem assumir-se para sociedade, família e para si mesmas. 0 conteúdo do Instagram exalta fotos em primeiro plano da artista, em poses que demonstram orgulho, elementos artísticos, livros e símbolos imagéticos que reforçam o seu discurso militante, à primeira vista, antes mesmo de se acessar os textos. A página também apresenta vídeos com suas performances, músicas com trechos autobiográficos e sessões de destaques paras os conteúdos mais completos em outras plataformas, esses fatores imediatamente transmitem a mensagem de aceitação para outras pessoas que buscam o perfil da Rosa Luz a fim de compreender melhor como é existir e sobreviver dentro do contexto de pobreza e preconceito, e de ser aceita enquanto pessoas trans que busca encontrar outras alternativas que fujam da prostituição e marginalidade.

\footnotetext{
$481 \mathrm{~K}$ é a unidade de medida de 1000 de seguidores, assim como 10k significa 10mil seguidores. (NAPOLES, 2019). $491000+$ é mais uma categorização do Instagram para demonstrar que a rede emergente, perfil ou comunidade atingiu um número superior a mil seguidores, porém inferior a 2.000 .

50 SEO são estratégias de visibilidade utilizadas pelos portais e que o algoritmo do Google também usa como critério de relevância para elencar o topo de suas buscas.
} 
Imagem 1 - Fotos do perfil de Rosa Luz no Instagram com manifestações ativistas @roosadobarraco.

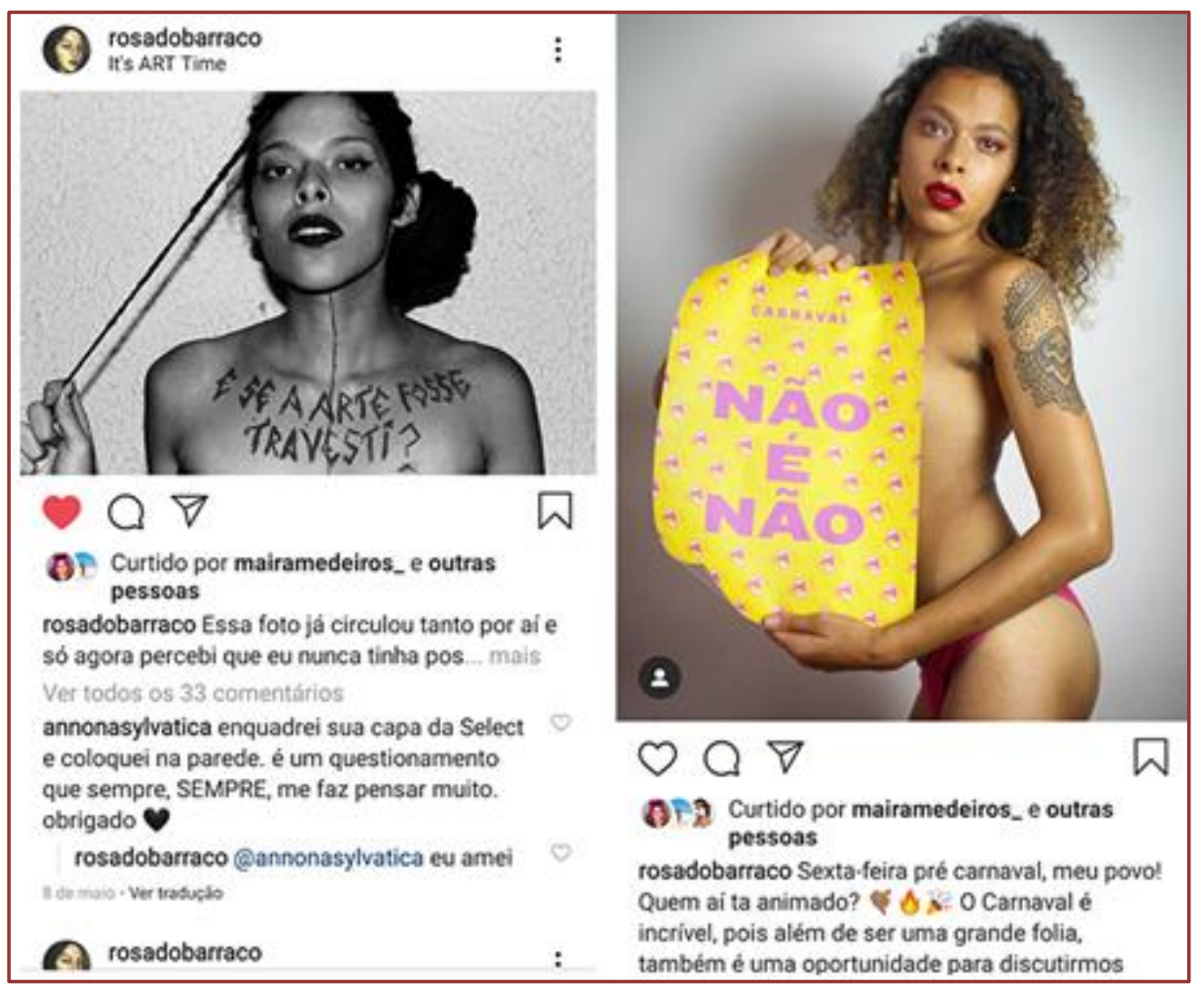

Em suas postagens Rosa explica sobre as pressões que sofreu na faculdade ao decidir assumir-se travesti, preconceito de professores, ameaças de grupos de ódio on line, e a dificuldade de inserção no mercado de trabalho. As respostas em suas publicações, entretanto, reforçam de maneira positiva que o apoio do público é crescente e entusiasmado, comprovando que sua mensagem vem sendo assimilada exponencialmente na rede.

\subsection{LUCCA NAJAR @LUCCA.NAJAR}

Lucca Najar é um homem transexual nascido em Belo Horizonte, de 27 anos, e que possui um perfil no Instagram com mais de 37 mil seguidores. Até os 24 anos, Lucca vivia como mulher. 0 influenciador explica em seus vídeos, postagens e entrevistas, que não compreendia perfeitamente o desejo de se parecer fisicamente com o pai durante sua infância. Já na fase da adolescência, criava perfis masculinos falsos na Internet para enfim poder viver a nova identidade que lhe era desejada, porém não permitida socialmente. Na vida adulta, percebeu a dificuldade de encontrar roupas que não se enquadrassem na binaridade dos gêneros e foi a partir destes conflitos, e após o contato com outras histórias semelhantes na internet, que Lucca entendeu a necessidade de ser assumir transexual. Em conjunto com sua formação de Videomaker, decidiu criar o canal no YouTube em 2016. Diante da popularidade de seus vídeos e a migração do público para o Instagram, no mesmo ano, também conectou-se nesta rede. As postagens são detalhadas: Lucca possui destaques em que fala dos estágios da transição para o corpo masculino, os hormônios que se deve aplicar, o custo e seus efeitos físicos, a relação com a família e namorada, uma sessão para pergunta dos seguidores, e as complicações no momento de escolher os médicos para a cirurgia de redesignação de gênero: A mastectomia. Outro fator importante constatado nesta observação, é que ao se acessar a timeline das imagens, imediatamente percebe-se que se trata de um perfil engajado na causa LGBTQ+, em função dos símbolos e cores que se referem a este universo, imediatamente perceptíveis, antes mesmo de se ver os depoimentos e os textos: 
Imagem 2 - foto e timeline do perfil de Lucca Najar com manifestações de transativismo.

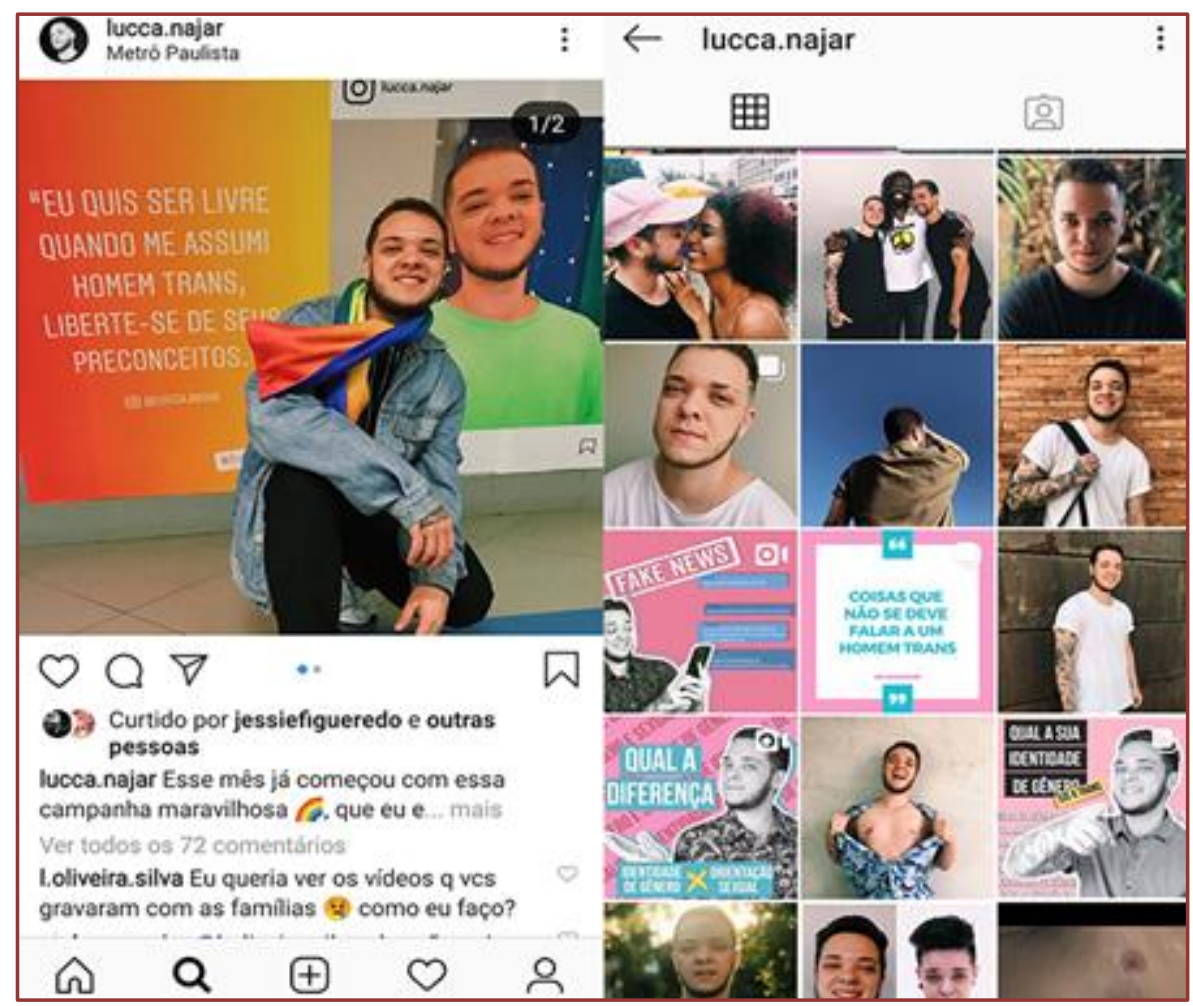

O público responde de maneira ativa no perfil do influencer, através de elogios, mensagens de apoio e perguntas. A possibilidade de interação direta por comentários e enquetes estimula na criação de mais conteúdo e incentiva diretamente na publicação de perfis semelhantes, conforme declarado por Lucca em um de seus vídeos publicados. Ele também exibe seu corpo, após a transformação, o que leva seu expectador a perceber que o sucesso da transição corporal pode, e deve, ser desmistificada e bemsucedida.

\section{CONSIDERAÇÕES FINAIS}

Após o estudo netnográfico e observacional fornecido pelo banco de dados de etiquetas relacionadas a gênero, redesignação e transexualidade disponível na plataforma Instagram, nota-se a multiplicidade de histórias dentro da Internet que abordam essas questões e anseiam por visibilidade e representação. Nos exemplos identificados através das hashtags específicas, os perfis se colocam abertos para a apreciação do público, de forma a demarcar presença e assim desestabilizar antigos padrões impostos pela cultura patriarcal, tradicionalista e que se fez dominante ao longo da história. 0 uso do percurso metodológico neste estudo faz-se adequado dentro de várias propostas de pesquisas sobre a formação de comunidades autônomas na Internet.

Ressalta-se também, a importância do surgimento do cyberespaço para as discussões tomarem corpo e alcançarem o receptor ideal desse tipo de mensagem, que por sua vez também pode tornar-se disseminador do mesmo conteúdo. A democratização do meio audiovisual produz um sistema de retroalimentação que se expande de forma transmidiática, criando um repositório constantemente atualizado com novos relatos em textos, vídeos e fotografias, dentro das perspectivas da inteligência coletiva. A utilização das imagens é a potência simbólica definitiva de se afirmar enquanto ser transgênero, conforme identificado nas fotos e vídeos produzidos pelos dois perfis do Instagram escolhidos: 0 público acessa as imagens impregnando-as da chancela da realidade e, neste sentido, acreditam em sua legitimidade, reproduzindo também esses discursos. 
Esse movimento não organizado formalmente, porém alinhado dentro dos mesmos valores simbólicos, desvela os caminhos propostos dentro deste corpus. Retomando os autores citados anteriormente a respeito dos dogmas sociais e tradicionalistas, a tendência natural, durante muitos anos em nossa história, era a marginalização dessas subjetividades, contudo, ao se fazerem presentes na rede social, as pessoas transgênero reafirmam o desejo de representatividade como presença, como militância e como garantia de sobrevivência.

\section{REFERÊNCIAS}

[1] A Garota Dinamarquesa. Direção de Tom Hooper. Los Angeles: Focus Features, 2015. 1 DVD (119 min.).

[2] Botelho, Raquel. Pesquisadora conta em livro 120 anos de histórias de homens trans. Disponível em: <https://www1.folha.uol.com.br/equilibrioesaude-120-anos-de-historia-de-homens-trans.shtml> acesso em jul. de 2019.

[3] Dubois, Philippe. 0 ato fotográfico e outros ensaios. Papirus Editora, 1994.

[4] Fragoso, S.; Recuero, R; Amaral, A. Métodos de pesquisa para internet. Porto Alegre: Sulina, 2011.

[5] Green, R. Mythological, historical and cross-cultural aspects of transsexualism. New York: Garland Publishing; 1998.

[6] Hine, Christine (org.) How can qualitative Internet Researchers define the boundaries of their Project? Conversations about method. p. 01-20. Los Angeles: Sage, 2009.

[7] Kozinets. Robert V. Netnography. Doing Ethnographic Research Online. Disponível em: <https://www.researchgate.net/publication/267922181_Netnography_Doing_Ethnographic_Research_Online> acesso em 07 de jun. de 2019.

[8] Lévy. Pierre. Cybercultura. Tradução: Carlos Irineu da Costa. São Paulo: Editora 34. 1999.

[9] Lupi, Leonardo. Jornal do Brasil: Orgulho e Preconceito. Disponível em:

<https://www.jb.com.br/pais/artigo/2019/07/1012067-orgulho-e-preconceito.html> acesso em 07 de jan. de 2019.

[10] Martino, Luis Mauro Sá: Teoria das Mídias Digitais: Linguagens, Ambientes e Redes. Rio de Janeiro: Vozes Editora, 2014.

[11] Mesquita, Renato. O que é SEO: o guia completo para você entender o conceito e executar sua estratégia . Disponível em: < https://rockcontent.com/blog/o-que-e-seo/> acesso em 02 de jun. de 2019.

[12] Nápolles, Katarina. Entenda como funciona o novo algoritmo do Instagram. Disponível em: < https://postgrain.com/blog/algoritmo-instagram/> acesso em 14. mai. de 2019

[13] Salles, Filipe. 6 ferramentas para encontrar melhores hashtags do Instagram no seu segmento. Disponível em: $\quad<$ https://www.apptuts.com.br/tutorial/redes-sociais/ferramentas-encontrar-melhores-hashtags-instagramsegmento/> acesso em 10 ago. de 2019.

[14] Santos, Patrícia Nogueira Costa. Sobre a teoria do agendamento, gênero e publicidade. Disponível em: <http://dspace.bc.uepb.edu.br/jspui/handle/123456789/10338> acesso em 10 de ago. de 2019.

[15] Silva, et al. Os impactos das identidades transgênero. Rev Ter Ocup Univ São Paulo. 2015 set.-dez.;26(3):364-

72. 


\section{Capítulo 15}

Relato de experiência do Projeto de Extensão "Babado, gritaria e confusão: Focus para a saúde da população LGBT"

Pâmela Tays de Holanda Silva

Matheus dos Santos Carvalho

Jaqueline Paulino Gomes

Jéssica Gabriele Burity da Costa

Patrícia Maria de Brito França

Amanda Oliveira Bernardino Cavalcanti de Albuquerque

Resumo: Durante a formação acadêmica de enfermagem, a tríade do ensino, pesquisa e extensão retrata um fator de grande significância na grade curricular do estudante. As promoções de ações em saúde, proporcionam uma melhor qualidade de vida para a comunidade que é beneficiada com essas atividades, como também possibilita o aprendizado e vivência acadêmica. 0 principal objetivo do projeto, foi voltado para saúde da população LGBT, em que visa atingir as dimensões emocionais e corporais da autoestima. Trata-se de um estudo descritivo tipo, relato de experiência intitulado "Babado, gritaria e confusão: Focus para a saúde da população LGBT", concluído no Centro Universitário Tiradentes, por graduandos do curso de enfermagem. Os resultados mostraram uma metodologia ativa, dialógica e interativa, capaz de fomentar conhecimento, cooperação e a estimulação da assistência de saúde para a população LGBT.

Palavras-chave: Relato de experiência, LGBT, Saúde. 


\section{INTRODUÇÃO}

Em 1990 surge a lei orgânica da saúde 8080 que conduz o surgimento dos princípios do Sistema Único de Saúde (SUS) estabelecidos na tríade de: Universalização, equidade e integralidade). Sua abrangência na assistência é garantida através da constituição a partir da

Universalidade que estabelece o acesso universal às ações e aos serviços de saúde, sem restrições de origem, raça, gênero, classe, religião ou qualquer outra forma de discriminação; a integralidade que implica na obrigatoriedade de oferecer uma atenção à saúde de qualidade, que vai da proteção e prevenção a todos os níveis de complexidade dos cuidados, envolvendo não apenas os aspectos biológicos, como também os psicossociais e culturais do atendimento, e necessitando, portanto, de ações intersetoriais; e a equidade que busca a correção das injustiças com populações historicamente vulneráveis, por meio de políticas e ações específicas, buscando reduzir as desigualdades em saúde (GUIMARÃES,2017 p.3).

Mesmo a população LGBT tendo garantia de seus direitos previstos na constituição, ainda é pertinente um impasse do atendimento e dos direitos humanos pautado a partir dos princípios do SUS. A partir desses ideais os serviços de atenção e cuidado à saúde livre de homofobia é questões pertinentes à saúde mental e a atenção a outras vulnerabilidades que atendem a esse público (BRASIL, 2008).

No dia 01 de dezembro de 2011, A Política Nacional de Saúde voltada para Lésbicas, Gays, Bissexuais, Transexuais e Travestis (LGBT) instituída pela Portaria $\mathrm{N}^{\circ} 2.836$ foi estabelecida com intuito de promover um avanço na assistência livre de preconceito e descriminação oferecida pelos profissionais no Sistema Único de Saúde (BRASIL, 2013).

A partir dessa premissa esse projeto de extensão teve como objetivo específico promover o conhecimento teórico/prático dos graduandos sobre a Política Nacional de Saúde LGBT como também, orientações para o público, voltadas para autoestima, tendo a tríade do SUS (universalização, equidade e integralidade) como eixo para a promoção de uma assistência voltada a dignidade humana e cuidado com o corpo.

Na assistência de enfermagem, o profissional enfermeiro (a) apresenta um papel de suma importância na viabilização das Políticas Públicas de Saúde, fazendo com que seu dinamismo como profissional do cuidado seja voltado conjuntamente para um processo de ensino, promovendo um papel de educador para sensibilizar o público profissional e cliente sobre as desigualdades marcadas diariamente, evidenciadas por gestos, olhares, palavras, discursos de ódio e violência, tornado assim um conjunto de ações homofóbicas no Sistema Único de Saúde - SUS (QUERINO Et al., 2017).

Para Daniel Borrillo (2010), a homofobia é a intolerância, rechaço, temor, preconceito e perseguição de pessoas que não cumprem com as normas de gênero masculino dominante, com o papel estabelecido culturalmente pelo poder masculino para homens e mulheres. Desse modo, Molina (2011) menciona que,

ao estudarmos sobre a homossexualidade e, consequentemente, a desconstrução dos papéis sexuais do feminino e masculino, devemos repensar a representação e os discursos de identidade, do conhecimento e do poder cultural que circulam no aparato do saber/poder na sociedade, para que possamos (re) analisar e (re) construir o discurso da própria sexualidade (MOLINA, 2011, p.4).

Apesar das conquistas na representatividade social, ainda persistem resistência na saúde quanto aos cuidados em saúde ofertados e direcionados ao público LGBT. Problemas esses evidenciados, pelo não conhecimento, negligência e preconceito encarnado por profissionais e gestores de saúde. Esse conjunto de evidências, acarreta uma obstáculo simbólico perante as especificidades inerentes a este grupo, proporcionando impasse no cumprimento dos princípios do Sistema Único de saúde durante o atendimento de saúde (GUIMARÃES Et al., 2017).

Dessa forma o projeto possibilitou aplicação da educação em saúde através de metodologias ativas com os participantes, que provocou interação comunicativa sobre relato de vida e opiniões do público, proporcionando aos graduandos experiências dentro da área de enfermagem, mas também esclarecendo ao público LGBT sob uma melhor qualidade de saúde. A partir dessa premissa, fez necessário pautar o projeto na teoria Transcultural de Madeleine M. Leininger, que utiliza um conjunto intergrupal das hipóteses de enfermagem fundamentadas não apenas na relação enfermeiro/cliente, mas o envolvimento das necessidades culturais de indivíduos, família, comunidade e grupos, enfatizando às crenças e aos 
valores, com a finalidade de realizar um cuidado de enfermagem eficiente e eficaz através do conhecimento científico e humanizado, capaz de viabilizar a prática do cuidado universal que seja culturalmente específico (MOURA, CHAMILCO E SILVA, 2003).

Assim, baseado nessa teoria, foi proposto realizar um projeto de extensão voltado a políticas de populações afirmativas, como público LGBT que é constituído por valores, crenças, normas e práticas de vida, partilhados e transmitidos no pensamento, nas decisões e nas ações. Proporcionando os integrantes do projeto desde a academia a serem futuros profissionais e aprender a importância da intervenção educativa por meio da incorporação de conteúdos acerca da temática na matriz curricular dos cursos de enfermagem promovidas a diferentes tipos de culturas e pessoas e de uma assistência humanizada, ponderada, livre de qualquer descriminação e preconceito através da Política Nacional de Saúde LGBT.

\section{METODOLOGIA}

Trata-se de um estudo descritivo tipo, relato de experiência elaborado por um projeto de extensão do Centro Universitário Tiradentes campus Caxangá, por graduandos do curso de enfermagem que teve como objetivo principal realizar ações educativa para a promoção da Saúde da Comunidade LGBT.

O projeto foi encaminhado a Pró-reitoria de pesquisa e extensão (PROPEX) e submetido ao Programa Institucional de bolsas de extensão (PROBEXT/UNIT-PE) onde aconteceu um processo de seleção e avaliação pelo Comitê técnico-cientifico da UNIT-PE. Logo, após a avaliação o projeto foi aprovado e contemplado com recurso financeiro.

A base metodológica utilizada para elaboração do projeto foi baseado na teoria transcultural de Madeleine M. Leininger, que segundo Monticelli Et al., (2010) enfatiza que o processo de novas evidências cientificas de enfermagem devem contribuir para um avanço no processo saúde/doença, sendo esse serviço realizado pelo enfermeiro com intervenções, ações e linguagens populares.

Essas bases de evidências cientificas são existente em alguns principais desafios para os pesquisadores da enfermagem transcultural durante o terceiro milênio, sendo eles: Desfrutar de forma mais esclarecedora e íntegra os conhecimentos e experiências da enfermagem cultural em todas as áreas clínicas de enfermagem; promoção e uso das políticas, princípios, paradigmas e perspectivas teóricas da enfermagem transcultural para guiar as decisões e ações da enfermagem; abordagem de questões éticas, morais e legais, relacionadas à diversas culturas; utilização de fundos para a educação e pesquisa transcultural e a necessidade de estabelecer uma rede global de enfermagem transcultural. (ORIÁ,XIMENES E ALVES, 2015)

A construção do projeto se desenvolveu entre os meses de agosto à dezembro, com a operação das atividades desempenhada no ambulatório LGBT Darlen Gasparell, localizado em Pernambuco no município de Camaragibe, onde o mesmo promove diariamente atendimentos de saúde exclusivos para a população LGBT.

No dia 28 de novembro de 2018, as atividades procedeu-se com , 4 profissionais de saúde, 8 graduandos de enfermagem e 15 participantes, dentre eles: gays, lésbicas, bissexuaais e transexuais, que dipõem dos atendimentos prestados no local.

No segundo circuito foi utilizado metodologias ativas com roda de conversa em que o principal ojetivo do diálogo foi atingir as dimensões emocionais e corporais da autoestima, sendo esses, alvo de preconceito, obtendo efeito direto e negativo sobre a autoestima MAJOR, MCCOY, KAISER E QUINTON, 2003).

A autoestima se torna um conjunto de pensamentos, ideias e sentimentos que a própria pessoa avalia de si mesmo, essa avaliação tornasse positiva ou negativa e é evidenciado em momentos da vida social, de formato emocional, corporal e psíquico-fisiológicos. Dispor da autoimagem positiva, é tornar a vida livre de padrões, tensões e frustrações, afim de objetivar suas metas (MOSQUERA \& STOBÄUS, 2005).

A partir dessas acessões, foi possível analisar a realidade do atendimento de saúde para com a populção LGBT, captando suas necessidades e tornando um conjunto de conhecimento teórico/prático e cultural, próximo à agregar à experiência acadêmica e assim sensibiliza-los sobre sua autopercepção, livre de padrões estéticos culturais impostos pela sociedade. Essa sensibilização se tornou algo construtivamente positiva para os indivíduos, proporcionando um olhar holístico sobre sua qualidade de saúde mental e dos seus ideais biopsicossociais. 
Para Nietsche et al. (2018) o alcance dessa temática desde a graduação possibilita um conjunto de saber que incluí o compromisso, reflexão e o cuidado essencial da saúde. Formando assim, profissionais capacitados, sensibilizados e empoderados frente às diferentes realidades assistidas.

\section{DESENVOLVIMENTO}

O trabalho, retrata um relato de experiência do projeto de extensão intitulado "Babado, gritaria e confusão: Focus para a saúde da população LGBT" do Centro Universitário Tiradentes. Esse projeto foi submetido ao Programa Institucional de bolsas de extensão (PROBEXT/UNIT-PE) e avaliado pelo Comitê técnico-científico da UNIT-PE, sendo o mesmo aprovado.

A partir da aprovação, o projeto teve o intuito de promover uma intervenção educativa entre universitários integrados nesse projeto para com a população LGBT, afim de sensibiliza-los positivamente sobre sua autopercepção e despertar um olhar holístico sobre sua qualidade de vida. Proporcionando também aos graduandos o desenvolvimento do conhecimento sob a temática e vivências desse público.

Assim sendo, durante a ação educativa proposta, pode ser observado que o público alvo compartilhou seus pensamentos, experiências, conquistas e opiniões, contribuindo para sensibilização da sua autoestima, em prol da melhoria da qualidade de vida e saúde do indivíduo.

\subsection{RESULTADOS E DISCUSSÃO}

\subsection{A EXPERIÊNCIA NO OLHAR DOS DISCENTES}

O contato com o público presentes nas atividades possibilitou aos discentes um novo olhar sobre a saúde do público LGBT. A partir das bases cientificas proposta para o estudo do tema, foi possível conhecer sobre os movimentos sociais da população LGBT ao longo dos anos para conseguir seus direitos e acesso a saúde.

Além disso, sustentar o tema com a Teoria Transcultural de Madeleine M. Leininger, enfatizando as necessidades individuais, sociais, espirituais e seus valores pessoais, viabilizando a prática do cuidado universal que seja culturalmente específico foi de grande valia para experiência profissional e pessoal.

Diante dessa experiência tornou-se notório a importância de estudos sobre a política dessa população afirmativa durante a graduação, mesmo fora da grade curricular, afim de provocar no estudante a sensibilização sobre a promoção de uma assistência livre de preconceito, homofobia e descriminação no sistema de saúde.

\subsection{A EXPERIÊNCIA NO OLHAR DOS PARTICIPANTES}

Durante o diálogo foi notório observar que, no decorrer da discussão, além do roteiro de tópicos relacionados às questões de autoestima, tema que foi o objetivo de ser trabalhado no projeto, outros assuntos surgiram pelo público como:

- $\quad$ Estilo de vida e experiência de ser LGBT;

- $\quad 0$ que já tinha deixado de viver pelo preconceito exercido na sociedade;

- Preconceito por sua aparência e vestimenta;

- $\quad$ Experiência nos atendimentos de saúde; - Homofobias, etc...

Dessa forma, a partir dos relatos, a exploração do assunto realizado pelo grupo se fez de grande importância, em face de sua flexibilidade, o que permitiu que os participantes expusessem seus depoimentos e assim contribuísse para que os mesmos interagissem e contribuíssem para que os graduandos do projeto tivessem conhecimento de sua realidade de vida, obstáculos, valores, culturas e saberes referente ao público LGBT.

Os resultados e perspectivas geradas com a proposta, a partir da avaliação do público, manifestaram interesse pelas atividades e ressaltaram a importância de estendê-la a outros grupos ainda não assistidos. 
FIGURA 1: Local onde ocorreus as ações.

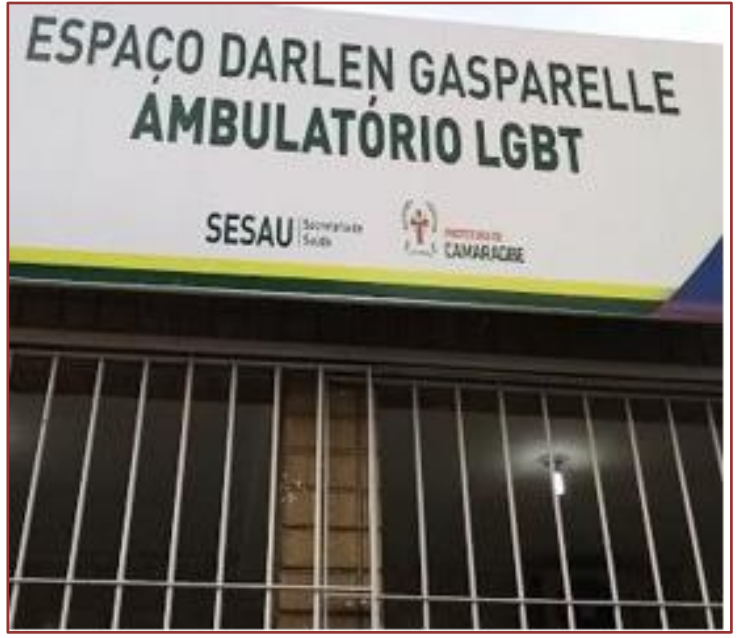

Fonte: Arquivo dos autores.

FIGURA 3: Broches confeccionados pelos autores

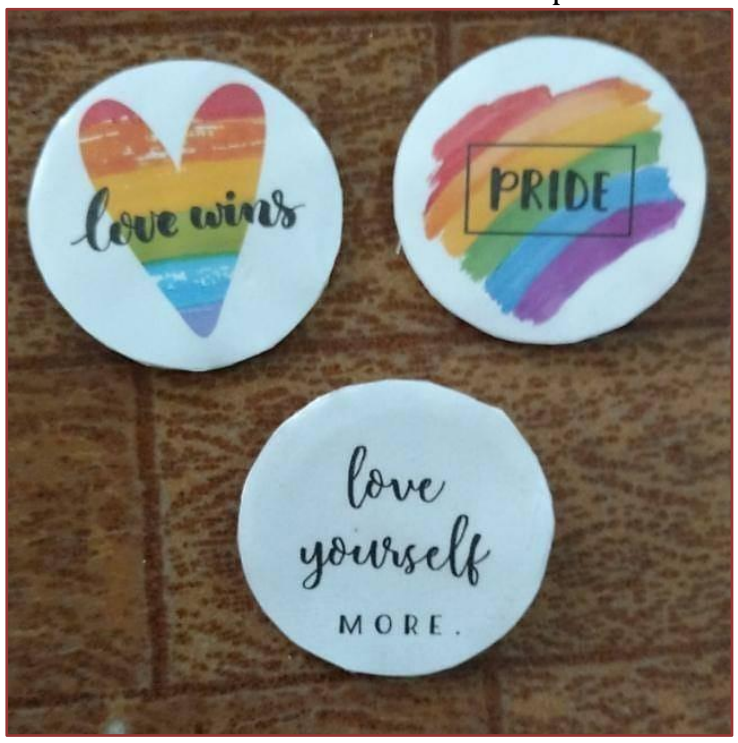

Fonte: Arquivo dos autores

FIGURA 5: Oficina de estética

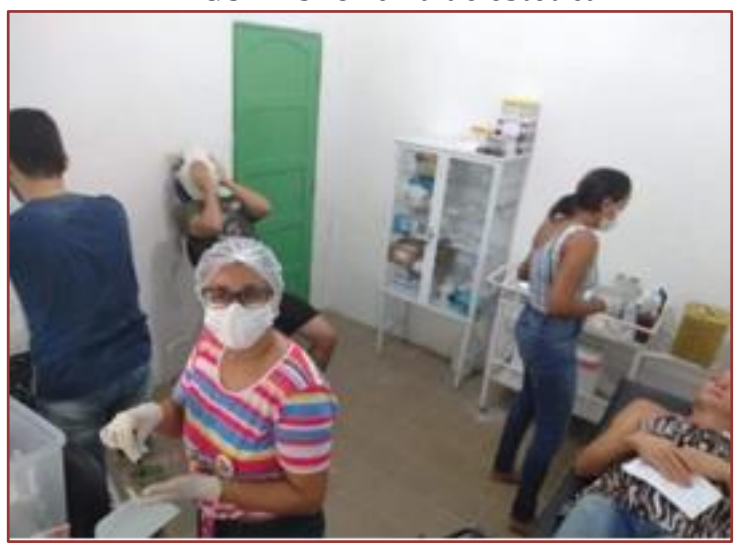

Fonte: Arquivo dos autores
FIGURA 2: Momento da roda de conversa.

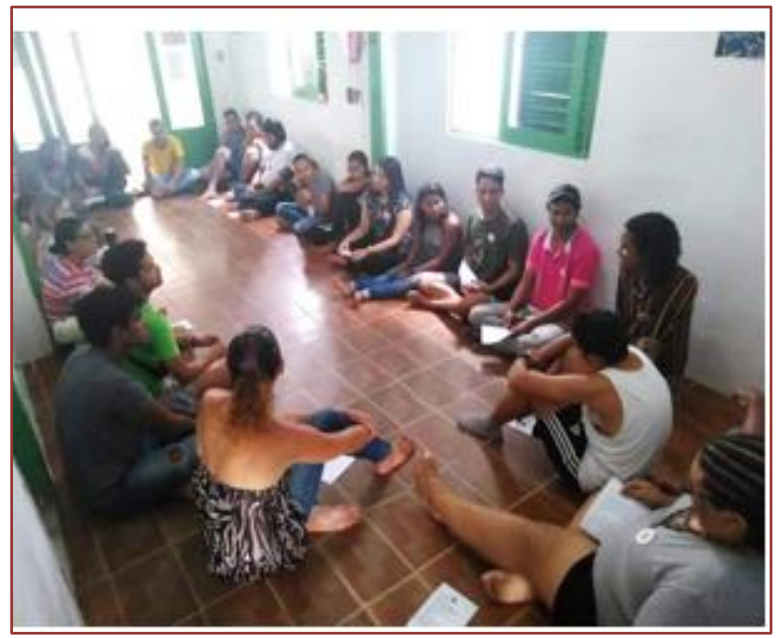

Fonte: Arquivo dos autores.

FIGURA 4: Colagem de frases motivacionais

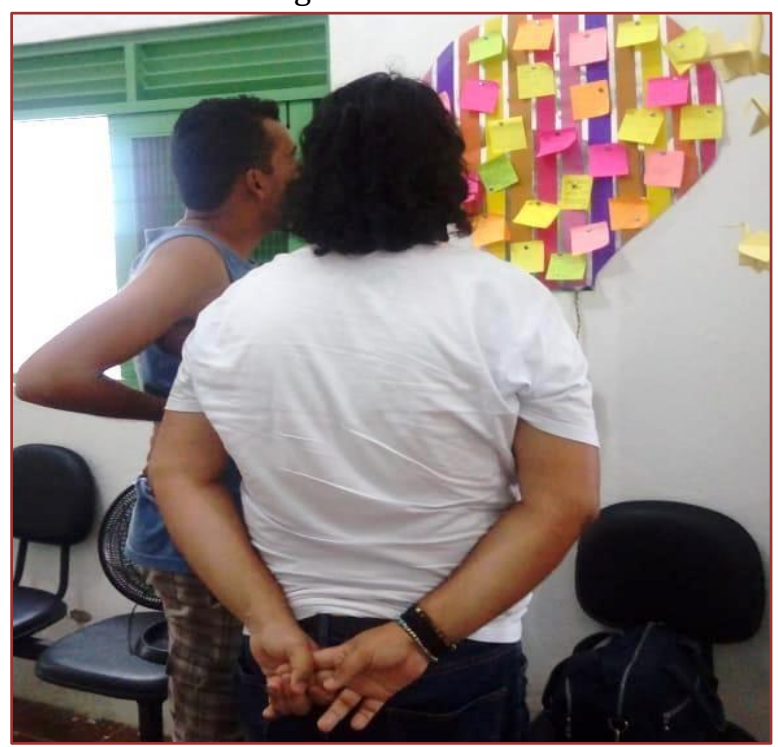

Fonte: Arquivo dos autores

FIGURA 6: Momento final.

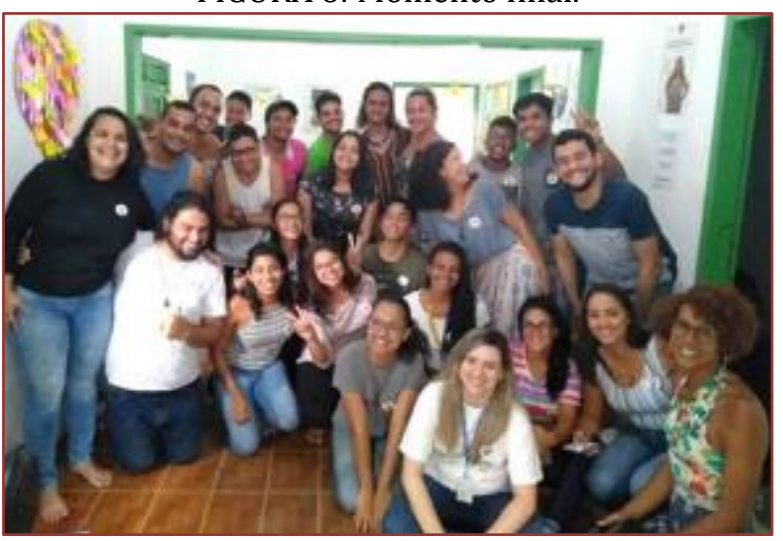

Fonte: Arquivo dos autores 
No processo de implementação das atividades houve o primeiro desafio que foi a busca por uma instituição que abrisse as portas para o nosso projeto. Procuramos a Gestos e o Instituto Boa Vista e ambas negaram a nossa participação, pois, não acharam conveniente receber grupos que não fossem membros dessas ONGS.

Em seguida, fomos em busca de outras instituições e visitamos o ambulatório LGBT Darlen Gasparell, em Camaragibe-PE. Nosso primeiro encontro com a equipe multiprofissional do local, foi marcado para apresentarmos uma planilha com as ideias previstas no projeto. A princípio, o projeto era voltado para algumas doenças infecto-contagiosas, cuidados com a saúde e alimentação saudável, porém, ao discutirmos com a equipe multiprossional da unidade os mesmos comunicaram que o principal problema com o público do ambulatório era a autoestima, pois sofriam muito preconceito e discriminação; partir disso, houve a necessidade de modificar as ideias previstas na planilha.

Iniciamos mais uma reunião com a equipe do projeto para discutir como iriamos abordar o assunto e houve a ideia de formular circuitos que seriam desenvolvidos no dia da ação. A ideia foi apresentada novamente a equipe do ambulatório, onde ocorreu a aprovação. Logo em seguida, cada paciente do ambulatório recebeu o convite enviado pela equipe do local, provocando nos convidados curiosidade do que seria proposto.

Os circuitos foram separados em três etapas, sendo o primeiro circuito as boas vindas e acolhimento do público. No segundo circuito, ocorreu a roda de conversa (FIGURA 2), em que cada pessoa se apresentou, e em seguida foi entregue a letra da música Belo Balão de Gonzaguinha. Nesse momento, a mediadora solicitou que todos fechassem os olhos e dedicassem sua atenção na letra da música. Logo, após escutar a canção, iniciamos o debate, ouvindo o que cada pessoa tinha compreendido; além do roteiro previstos, novos assuntos surgiram, mas o objetivo do projeto continuou mantido.

No terceiro circuito (FIGURA 4), ocorreu a distribuição de post it para escrever mensagem positiva e em seguida ser posto no balão, proporcionando uma atividade coletiva e harmoniosa. Sucedeu-se também a distribuição de broches (FIGURA 3), elaborado a partir dos autores com mensagem e imagens das causas LGBT.

Em seguida ocorreu oficinas de estética (FIGURA 5) tendo massagens, limpeza de pele, design de sobrancelha, e sorteio de uma cesta, contendo produtos de higiene pessoal para os participantes, e por fim foi oferecido o coffee break para todos os envolvidos.

Dessa forma, a exploração do assunto se fez de grande aproveito, diante de sua flexibilidade no decorrer da conversa, o que permitiu que os participantes expusessem opiniões, conhecimentos e depoimentos das mais variadas experiências vividas por fazer parte da comunidade LGBT.

Assim, refletindo sobre toda a experiência com o público, cabe enfatizar no âmbito da enfermagem que a pesquisa qualitativa sobre a saúde da população LGBT revela uma oportunidade para se explorar com propriedade, estudos de implantação de programas, bem como ações de saúde para com esse público. A percepção dos participantes que estavam envolvidos diretamente com o e a experiência favoreceu uma reflexão crítica sobre a saúde dessa população afirmativa e possibilitou a sensibilização do público alvo sobre o tema abordado.

\section{CONSIDERAÇÕES FINAIS}

O desenvolvimento deste trabalho com a população LGBT permitiu constatar que para formação e condução das ações é necessário o estudo sobre os movimentos e diretrizes de saúde desse público, seguindo criteriosamente os objetivos selecionados, como também analisar o perfil do público.

Ao conduzir a presente pesquisa, tornou-se evidente que a grande problemática enfrentada pelo público LGBT situa-se no preconceito enfrentado diariamente pela sociedade, tornando esse um dos pontos primordiais para que sua autoestima sofra ataques e consequente sua saúde mental também.

Portanto, reitera-se que a presente iniciativa, de elaborar um material educativo para promoção de saúde da população LGBT foi uma experiência construtiva, gratificante e viável, muito embora considere-se que muito há a ser conhecido e realizado na área. Encaminhasse assim, aos leitores, o aprofundamento dos pressupostos teórico-metodológicos. Afim de colaborar com as novas pesquisas e estudos referido a este tema, este artigo coloca-se como um convite aos interessados a desenvolver pesquisas e trabalhos que utilizem essa técnica, com intuito de contribuir em prol da saúde desse público. 


\section{REFERÊNCIAS}

[1] Borrillo, Daniel. Homofobia: história e crítica de um preconceito. Belo Horizonte: Autentica, 2010.

[2] Brasil. Ministério da Saúde. Política nacional de saúde integral de lésbicas, gays, bissexuais, travestis e transexuais. Brasília: Ministério da Saúde, 2013. p. 32.

[3] Brasil. Ministério da Saúde. Saúde da população de gays, lésbicas, bissexuais, travestis e transexuais. Rev. Saúde Pública, 42(3), 2008, p.570-573.

[4] Guimarães, R. C. P.; Cavadinha E. T.; Mendonça, A. V. M.; Sousa, M. F.

[5] Assistência à saúde da população LGBT em uma capital brasileira: o que dizem os Agentes Comunitários de Saúde? Tempus - Actas de Saúde Coletiva, Brasília, v. 1, n. 11, mar. 2017. p.121-139.

[6] Major, Brenda; Mccoy, Shannon; Kaiser, Cheryl; Quinton, Wendy. Prejudice and self-esteem: A transactional model. European Review Of Social Psychology, [s.l.], v. 14, n. 1, jan. 2003. p.77-104.

[7] Monticelli, Marisa. Aplicações da teoria transcultural na prática da enfermagem a partir de dissertações de mestrado. Texto Contexto Enfermagem, Florianópolis, v. 2, n. 19, jun. 2010. p.1-9.

[8] Mosquera, Juan José Mouriño; STOBÄUS, Claus Dieter. Auto-imagem, Auto-estima e Auto-realização: Qualidade de Vida na Universidade. Psicologia, Saúde \&

[9] Doenças, Porto Alegre, v. 1, n. 7, jan. 2006. p.83-88.

[10] Moura, Maria Aparecida Vasconcelos; Chamilco, Rosilda Alves da Silva Isla; Silva, Leila Rangel da. A Teoria Transcultural e sua aplicação em algumas pesquisas de enfermagem: uma reflexão. A Escola Anna Nery Revista de Enfermagem, [s.l.], v. 3, n. 9, dez. 2005. p.334340.

[11] Nietsche, E. A.; Tassinari, T. T.; Ramos, T. K.; Beltrame, G.; Salbego, C.; Cassenote, L. G. Formação do enfermeiro para o cuidado à população homossexual e bissexual: percepção do discente. Revista Baiana de Enfermagem, [s.l.], v. 32, 18 jul. 2018. p.1-11.

[12] Oriá, Mônica Oliveira Batista; Ximenes, Lorena Barbosa; Alves, Maria Dalva Santos. Madeleine leininger e a teoria da diversidade e universalidade do cuidado cultural - um resgate histórico. Online Brazilian Journal Of Nursing, [s.l.], v. 4, n. 2, jul. 2015. p.1-7.

[13] Querino, M. S; Almeida, S. S.; Oliveira, S. C. S.; Umann, J.; Filho, I. M. M. Ações da equipe de enfermagem na implementação da política de lésbicas, gays, bissexuais, travestis e transexuais- revisão de literatura. Revista de Divulgação Científica Sena Aires, [s.l.], v. 1, n. 6, jun. 2017. p.46-58. 


\title{
Capítulo 16
}

\section{Diversidade sexual e LGBTQfobia: Desconstruindo o preconceito na academia}

\author{
Anderson Alexandre de Araújo Sá \\ Kasandra Campos de Oliveira \\ Laysa Maria Barauna Lima \\ Lúcia Maria Temóteo
}

Resumo: Historicamente, a educação sempre foi alvo de grupos dominantes que definiam o seu curso com a finalidade de garantir os seus interesses. Assim, depois de muitas lutas e conquistas, temas como diversidade sexual e gênero são discutidos como um meio de compreender ideologias dominantes, por exemplo, a heteronormatividade e o preconceito em relação aos indivíduos LGBTQ+. Neste contexto, o objetivo deste artigo é expor os efeitos da educação na desconstrução do preconceito, englobando temáticas como diversidade sexual e LGBTQfobia, a partir de uma perspectiva pós-estruturalista inserida no debate em sala de aula. A metodologia adotada foi uma intervenção realizada com estudantes em classe de uma faculdade privada, no sertão paraibano, com caráter e natureza exploratório-descritiva e abordagem qualitativa, nas quais foram utilizadas frases que remetiam ao preconceito sofrido pelo público LGBTQ+, e realização do debate como ferramenta discursiva. Desta forma, o debate revelou posicionamentos que naturalizavam a heteronormatividade, relacionados à fragilidade de informação, por parte dos universitários, diante dos temas que, consequentemente, perpetuam uma ideologia dominante binária, focada nas percepções do que é masculino e feminino, identidade de gênero e seus papéis sociais, seguido de uma participação de homens-cis mais ativa que mulheres-cis. Portanto, embora esta atividade tenha atingido o seu objetivo, ainda é necessária a discussão desses temas, pois houve uma carência de informes entre os estudantes que participaram, atentando para a perspectiva de uma discussão em outras esferas educacionais. Contudo, a atividade proporcionou uma reflexão a respeito do preconceito em relação à diversidade sexual.

Palavras-chave: Diversidade Sexual, LGBTQfobia, gênero, educação. 


\section{INTRODUÇÃO}

Ao entender a sexualidade como parte da personalidade humana e logo, de caráter subjetivo, compreendemos a pluralidade que permeia sua construção, conforme aspectos psicológicos, sociais, culturais e emocionais, embora os debates acerca da diversidade sexual ainda permeiem por um viés biológico e inato que influencia a limitação e reforça situações de opressão. Neste contexto, o ambiente educacional, tendo em vista seu aspecto de instituição social, deve apresentar significativa contribuição ao processo de formação ética e subjetiva dos sujeitos. Assim, estar em conformidade com os Parâmetros Curriculares Nacionais (PCN), ainda em vigor, significa que a sexualidade adquire espaço como tema transversal no aspecto da cidadania, em que há o reconhecimento da diversidade e, não somente, limitada à educação sexual, como salientam Silva e Lastória (2019). Todavia, Silva, Brancaleoni e Oliveira (2019) apontam à dificuldade de se trabalhar tal tema, uma vez que os valores sociais dominantes e limitantes, acerca da sexualidade, constituem-se como entraves na formação docente dos educadores e nas condutas institucionais.

Fernandes et al. (2016), sinaliza a necessidade de contestar a hegemonia heteronormativa que põe à margem a diversidade sexual e de gênero na sociedade. Os autores sublinham a importância de políticas públicas efetivas que assegurem combater tal hegemonia, não limitada somente ao viés biológico e preventivo sexualmente. Ao contrário, que se preocupe com a repressão social exercida pela visão sociocultural e política nacional, caracterizada pelo enaltecimento das relações heterossexuais, limitação identitária ao genital biológico, em consonância com a emblemática dos papéis de gênero, e o machismo que ressoam no ambiente educacional. Reconhecem, ainda, a resistência de diversos setores da educação de ampliarem a concepção de diversidade disposta nos parâmetros educacionais, aspecto que retrata as práticas sociais de repressão e opressão a nível macro institucional e se contrapõem ao ideal de educação humanitária e inclusiva.

Rizza, Ribeiro e Mota (2016) apontam que a maior parte das disciplinas sobre gênero e sexualidade é optativa e que somente um terço dos docentes que as ministram são pesquisadores da área temática, o que põe em questão se a inclusão da sexualidade nos currículos de ensino superior é de fato efetiva, ou apenas cumpre um planejamento. Neste contexto, é necessário cursos que forneçam informações e discussões acerca do tema, constituindo subsídios para o questionamento e desconstrução acerca da heteronormatividade ${ }^{51}$ e a compreensão e respeito em direção aos indivíduos (SOUSA; SILVA; SANTOS, 2014).

De qualquer forma, é inegável que ocorreram diversas transformações no ensino superior, no que concerne ao aumento de discussões acerca das questões envolvidas no tema da sexualidade na contemporaneidade. A visibilidade desta temática se deu, principalmente, a partir dos movimentos nos meios sociais e educacionais que propuseram tais debates e, por conseguinte, foram introduzidos também no âmbito superior de ensino. Ademais, outro fator de suma relevância para inserção de tais discussões se refere ao aumento de preconceitos e violências, como a homofobia, o sexismo e o racismo (RIZZA; RIBEIRO; MOTA, 2016).

De acordo com Junckes e Silva (2009), a educação escolar, como um todo, apresenta um caráter complexo, visto que, ao mesmo tempo em que possui como princípio ser um veículo facilitador da cidadania e respeito à pluralidade, em contrapartida, reproduz conceitos heteronormativos instituídos como padronização de comportamentos e formas de ser. Outrossim, tendo em vista o tabu ainda existente na contemporaneidade, em relação à discussão da sexualidade, o ambiente escolar, muitas vezes, silencia e/ou nega questões referentes à discussão da pluralidade sexual e de gênero, o que influencia o crescimento de preconceitos, violência e enaltecimento da heteronormatividade (SOUZA; SILVA; SANTOS, 2014).

Silva e Souza (2015) abordam que o ambiente escolar conduz os indivíduos a agirem conforme as regras heteronormativas estabelecidas culturalmente. Diante disto, fica evidente a relevância de uma revisão e ressignificação da função do ambiente educador, no que diz respeito à implantação de estratégias que conecte o indivíduo à realidade na qual está inserido.

\footnotetext{
51 A heteronormatividade, de acordo com Butler (2010), representa uma materialização dos corpos orientada pela demarcação e diferenciação de uma sociedade essencialmente binária que compreende a heterossexualidade como fator normativo na constituição da identidade e das relações humanas.
} 
Assim, facilite a interpretação e ação diante do mundo de forma racional e conscienciosa, no tocante ao reconhecimento da diversidade sexual e na promoção de respeito, tolerância e desconstrução da heteronormatividade.

Por fim, o objetivo deste artigo é expor os múltiplos efeitos da educação a partir de uma prática interventiva realizada com estudantes, em sala de aula, de uma instituição privada, a respeito da LGBTQfobia e outros assuntos pertinentes, por meio do diálogo e reflexão, possibilitando a democratização da educação como estratégia libertadora, na promoção de direitos constitucionais no ensino superior.

\section{METODOLOGIA}

O estudo se deu a partir de uma análise de natureza exploratório-descritiva, dentro de uma abordagem qualitativa e de intervenção, tendo como foco a análise de discursos de alunos do ensino superior da Faculdade Santa Maria, localizada em Cajazeiras, no sertão da Paraíba, para obtenção dos dados na presente pesquisa. A iniciativa da intervenção surgiu a partir de um Projeto de Extensão em Gênero e Sexualidade, coordenado por uma professora da instituição, que teve como proposta levar a discussão para turmas, de cursos variados, acerca de assuntos pautados no Gênero e Sexualidade.

De acordo com Borges e Luzio (2010), a investigação de caráter social apresenta uma consciência histórica e articula propensões e perspectivas de mundo historicamente construídas, isto é, a pesquisa que envolve o social considera o sujeito pertencente a uma determinada dinâmica, o que inclui valores e significações que estão em constante transformação. Neste sentido, na pesquisa qualitativa, a ênfase se encontra no processo de investigação e a mesma se dá em relação a situaç̃ões e fenômenos sociais, tanto do passado, como presente e futuro. Ainda sob esta perspectiva, os métodos utilizados mais frequentemente para esse tipo de pesquisa, e que foram utilizados no presente estudo, são a coleta de dados, observação participante e análise documental (ROCHA et al., 2017).

Foi realizado inicialmente uma dinâmica com 6 alunos, na qual cada um recebeu frases ditas largamente em espaços públicos e veiculadas pela mídia, cujo conteúdo apresenta discursos preconceituosos disferidos ao público LGBT+. Buscou-se trazer falas comuns na sociedade, as quais despertassem familiaridade nos alunos e provocassem reações. A turma se organizou em duplas e foi proposto que lessem as frases uns para os outros e, a partir disso, explanassem os sentimentos despertados em forma de debate, bem como opiniões, relatos e conhecimentos envolvendo a temática.

Explanou-se dados estatísticos da homofobia no Brasil, buscando informá-los sobre a gravidade da violência. Em seguida, iniciou-se a apresentação acerca da diferença entre pontos importantes como orientação sexual, sexo, gênero e identidade de gênero, assim como a explicação das siglas LGBTQ+ e questões que englobam identidade de gênero e suas caracterizações. Todo o debate foi gravado, transcrito e utilizado como dados analisados neste arquivo.

\section{RESULTADOS E DISCUSSÃO}

\subsection{PERCEPÇÕES ACERCA DA HOMOSSEXUALIDADE NO ÂMBITO EDUCACIONAL}

0 debate revelou posicionamentos que naturalizam a heteronormatividade, estando ligados à fragilidade de compreensão e informação por parte dos universitários diante da temática de diversidade sexual que, por sua vez, perpetua normas pautadas integralmente na visão masculina e feminina em relação ao sexo, identidade de gênero e o papel social de gênero, refletindo estereótipos e preconceitos que causam invisibilidade ao público LGBTQ+. Outrossim, o discurso, durante o debate, com conteúdo preconceituoso, deu-se, em sua maioria, por parte dos estudantes do gênero masculino, revelando a força da cultura patriarcal e machista sob a manutenção da LGBTfobia. No entanto, essa prática gerou revisões de posicionamentos, reflexões e questionamentos através do debate por parte do grupo de alunos. As falas dos participantes aparecem de forma indireta e indistinta, visto que se captou o debate, sem nomear os autores do discurso.

Eu não tenho problemas com lésbicas. Inclusive, adoro vê-las se pegando (FRASE 1).

Duas percepções surgiram no momento da discussão da frase apresentada. Um participante se posicionou dizendo que achava o conteúdo desta frase normal e que não tinha problemas com gays ou lésbicas, pois não havia distinção entre ser lésbica ou não. 
O outro participante contestou a normalidade da frase, mas que ela deveria ser repudiada e acentuou que a fala é comum ser dita por homens.

A primeira colocação revela uma atitude equivocada, pois o estudante não entendeu a sutileza do conteúdo implícito na fala e partiu para generalizar a "normalidade" da orientação sexual. Neste contexto, cabe aqui trazer uma reflexão sobre a homossexualidade feminina. De acordo com Ferreira et al., (2017), a lesbianidade se expressa de uma maneira diferenciada quando colocada em comparação com a homossexualidade masculina, principalmente, no que concerne às questões relativas a como esse desejo é interpretado por parte de um grupo de gênero masculino. Neste contexto, o matrimônio, a repressão sexual, a presença da mídia, a educação familiar, são definidores dos papéis de gênero feminino, que quando postos em discussão, sempre voltam a mesma figura, o homem heterossexual como representação do destino das pautas femininas.

Por outro lado, outro participante, declarou que o pensamento por trás da frase carecia de espanto, provavelmente por perceber a posição da mulher enquanto objeto, denunciada na frase. Neste caso, levase a pensar que o homem, enquanto figura patriarcal, está constantemente em seu discurso, modulando e reforçando, ao lado de outras instituições, o comportamento das mulheres, funcionando como um gatilho para que a repressão se perpetue e provoque a invisibilidade do feminino na contemporaneidade (FERREIRA et al., 2017; GONZALEZ, 2014).

\section{Ser gay tudo bem, mas não dê em cima de mim (FRASE 2).}

Nesta frase, os participantes revelaram que há violência (física ou verbal) quando um homem hétero reage em festas diante de flertes lançados por homens homossexuais. É como se a masculinidade destes fosse frágil. Neste âmbito, como discorre Lehnen (2015), o fato remete a uma construção do homem enquanto indivíduo viril, ao qual a sociedade propõe a defesa de um ser com força física, símbolo de potência sexual e o (auto) controle, favorecendo a construção do domínio masculino na sociedade. Ademais, a revelação do lado homossexual produz um efeito a partir do qual ser sensível e frágil revela um componente temperado por nuances de desconstrução em meio a uma sociedade patriarcal, isto é, remove a máscara do "masculino" imposto e resgata uma parte reprimida do ser masculino (TREVISAN, 1997).

Um dos participantes ilustrou a violência contra homossexuais relatando o sofrimento de um amigo que se declarava homossexual e o processo de rejeição dos outros por conta de sua orientação. Diante o exposto, compreender a homossexualidade e suas questões envolve ressignificar "[...] os eventuais conflitos familiares e dificuldades com relação à aceitação da homossexualidade [...]" (SILVA et al., 2015, p. 680). Por outro lado, um dos pesquisadores ressaltou que o sofrimento não está ligado à questão da orientação sexual, mas às imposições da sociedade, destacando que a homossexualidade não é responsabilidade do sujeito que a ocupa, mas de uma sociedade normativa que insiste em vê-la como algo que fere as linhas do que é posto como normal.

Em um dado momento, foi questionado por um dos participantes, se a homossexualidade é algo que o indivíduo já nasce ou se ele decide ser assim, visto que um dos seus amigos demonstrava ser gay, porém ficava com meninas e era tachado como safado. Neste contexto, existem dois pontos que merecem ser interpretados: o primeiro, refere-se ao "demonstrar ser gay", colocando a homossexualidade como uma categoria que possui características comportamentais; o segundo, o reducionismo através do qual a sexualidade é posta para muitos indivíduos na nossa sociedade. Esta última informação, conforme Judith Butler (2010), em seu livro Problemas de gênero, foi questionado através da reflexão sobre múltiplos assuntos em relação ao sexo, gênero e sexualidade, colocando que este último está para além de uma visão estigmatizada em meio a uma sociedade movida pela heteronormatividade.

À orientação sexual, pode-se se dizer, que é fluída e para qual não existe uma regra, em que é preciso saber diferenciar orientação sexual de identidade de gênero e que existe uma construção social, na qual a sociedade coloca o que é certo para homens e para mulheres. Sobre a orientação sexual ser fluida, Miskolci (2009) aponta que, historicamente, o que se convencionou de chamar de Teoria Queer, causou uma desnaturalização do sexo e do gênero, isto é, algo que não é determinado pela a natureza, mas sim algo que é construído no discurso político, social e cultural, fazendo com que o sujeito elabore a sua identidade e que sua sexualidade possa ser vista como algo muito mais fluído, quebrando o paradigma estrutural que normaliza os indivíduos através do discurso. 


\subsection{A TRANSEXUALIDADE}

Embora nenhuma das frases usadas na dinâmica tratasse de forma direta da transexualidade, essa temática veio à tona, evidentemente por estar dentro do conceito da diversidade sexual. Os participantes, por exemplo, questionaram sobre o que seria ser mulher trans, homem trans e se cabe ao indivíduo a escolha de ser cisgênero ou transgênero. A respeito disso, Rodrigues e Alvarenga (2015) apontam que a transexualidade pode ser definida quando o indivíduo não se identifica com o sexo biológico imposto, mas com o gênero oposto ao seu sexo. Neste caso, morfologicamente, a pessoa pertence a um determinado sexo, porém, psicologicamente, esta acredita ser do sexo contrário. Ademais, é difícil chegar a uma conclusão científica a respeito da transexualidade, apesar de ser objeto de estudo de várias áreas do conhecimento.

Segundo Carvalho e Oliveira (2017), no contexto educacional, pincipalmente, em sociedades que possuem a rede de ensino formal massificada, há uma forte expressão do número de indivíduos que não possuem informações a respeito dos sujeitos que se identificam de uma forma diferentes dos padrões morais reconhecidos e legitimados por uma cultura dominante, impedindo que estas realidades não sejam incluídas e visíveis ao resto da população, como fonte expressiva da diversidade de gênero. Ademais, isto gera preconceito, causando sentimento de injustiça nos grupos compostos por crianças, adolescentes e jovens, quando ainda se encontram no período escolar.

Por outro lado, a medicina ainda compreende a transexualidade como uma patologia, bem como os principais manuais de diagnóstico que a classificam como uma desordem da personalidade relacionada à identidade de gênero. Isso foi alvo de críticas por parte das ciências humanas e sociais e de muitas (os) transsexuais, pois compreendem que esta abordagem corrobora para uma manutenção de rótulo e estigmas sociais, desrespeitando a emancipação desses sujeitos e contribuindo fortemente ao reforço dos padrões socialmente aceitos. Por isso, não reconhecer a transexualidade como objeto de discussão, é mascarar a realidade de indivíduos que se identificam como tal e enaltece uma cultura pautada na privação dos direitos, menosprezo e reprodução de desigualdades na esfera social (CARVALHO; OLIVEIRA, 2017; BENTO; PELUCIO, 2012; BUTLER, 2009).

\section{CONSIDERAÇÕES FINAIS}

Embora a atividade realizada para coleta de dados tenha ocorrido dentro de um espaço de produção e troca de conhecimentos, ficou evidente que ainda há uma carência de informações e reflexões dentro do espaço escolar sobre temas relacionados à diversidade sexual. É relevante entender e, por conseguinte, reforçar, que esse tipo de escassez faz do sujeito uma vítima que, infelizmente, acaba se expressando de forma negativa, muitas vezes por não ter informações necessárias ao entendimento destes assuntos causando, assim, a neutralidade diante de temas como os que foram trabalhados.

Por este motivo, essa ação revigora o que foi pesquisado no decorrer do estudo, evidenciando a importância de romper conceitos que causam até mesmo uma hierarquização dentro do próprio grupo LGBTQ, uma vez que quando algum membro se considera mais "macho", logo, "menos gay" simplesmente por não ser tão afeminado, fazendo com que esse comportamento cause exclusão social. A propagação de conhecimento e a promoção de reflexão nos estudantes são urgentes para, no decorrer desta desconstrução, acontecer uma dedução não somente do que a heteronormatividade tem germinado, mas também, de todas as condutas discutidas por toda a extensão dessa análise.

A metodologia assente para a realização deste estudo possibilitou que houvesse uma troca de conhecimento entre os estudantes e que, sobretudo, houvesse ainda um momento no qual todos pudessem estar refletindo diante de tudo o que foi dialogado e exposto. É de suma importância mencionar o quão significativo pode ser o estímulo à consciência crítica de cada um, de modo a serem, a todo instante, capazes de perceberem os fios que tecem a realidade social e que superam a ideologia da opressão entre a diversidade sexual no país. 


\section{REFERÊNCIAS}

[1] Borges, Roselania Franciscone; Luzio, Cristina Amélia. Pesquisa qualitativa em saúde mental: alguns apontamentos. Revista de Psicologia da Unesp. São Paulo, v. 9, n. 1, p.14-23, 2010.

[2] Bento, Berenice Alves de Melo; Pelucio, Larissa. Despatologização do gênero: a politização das identidades abjetas. Revista Estudos Feministas. Florianópolis, v. 20, n. 02, p. 559-568, agosto, 2012.

[3] Butler, Judith. Desdiagnosticando o gênero. Physis. Rio de Janeiro, v. 19, n. 1, p. 95-126, 2009.

[4] __ Problemas de gênero. Feminismo e subversão de identidade. Trad. Renato Aguiar. Rio de Janeiro: Civilização Brasileira, 2010.

[5] Carvalho, Guilherme Paiva de; OLIVEIRA, Aryanne Sérgia Queiroz de. Gênero, transexualidade e educação: reconhecimento e dificuldades para emancipação. Revista Educação e Emancipação. São Luís, v. 10, n. 4, p.58-75, set./dez. 2017.

[6] Fernandes, C. Diversidade sexual e políticas educacionais: possíveis aproximações. In: Freitas, L. G.; Brzezinski, I. Políticas educacionais: neoliberalismo, formação de professores, tecnologia, diversidade e inclusão. Anápolis: Editora UEG, p. 377-395, 2016.

[7] Ferreira, Sandro Augusto Silva et al. Homossexualidade Feminina, Liberdade Sexual e Interiorização do Ensino Superior. Cadernos de Gênero e Diversidade. Bahia, v. 3, n. 2, p.27-47, ago. 2017.

[8] Gonzalez, Débora de Fina. Entre público, privado e político: avanços das mulheres e machismo velado no Brasil. Cad. Pesqui., São Paulo, v. 44, n. 151, p. 239-243, mar. 2014.

[9] Junckes, Ivan Jairo; Silva, Joseli Maria. Espaço escolar e diversidade sexual: um desafio às políticas educacionais no Brasil. Didáticas Específicas. ISSN: 1989-5240, v. 5, n. 1, p.142-161, set. 2009.

[10] Lehnen, Jeremy. Machos em crise? A masculinidade nos romances de Daniel Galera. In: Barberena, R; Dalcastagnè, R. (Orgs.). Do trauma à trama: o espaço urbano na literatura contemporânea. Porto Alegre: Luminara Editorial, p. 273-300, 2015.

[11] Miskolci, R. A Teoria Queer e a Sociologia: o desafio de uma analítica da normalização. Sociologias. Porto Alegre, n. 21, p. 150-182, jan./jun. 2009.

[12] Rizza, Juliana Lapa; Ribeiro, Paula Regina Costa; Mota, Maria Renata Alonso. Disciplinas que discutem sexualidade nos currículos do Ensino Superior brasileiro: produzindo um diagnóstico da situação atual. Linhas. Florianópolis, v. 17, n. 34, p.197-224, ago. 2016.

[13] Rocha, Anacélia Santos et al. 0 dom da produção acadêmica: manual de normalização e metodologia de pesquisa. Belo Horizonte: Dom Helder, 2017.120 p.

[14] Rodrigues, Edwirges Elaine; Alvarenga, Maria Amália de Figueiredo Pereira. Transexualidade E Dignidade da Pessoa Humana. Revista Eletrônica do Curso de Direito da Ufsm. v. 10, n. 1, p.72-93, 21 out. 2015.

[15] Santos, J. A. Gênero na teoria social: Papéis, interações e instituições. Revista Eletrônica de Ciências Sociais. Juiz de Fora, v. 1, n.1, p. 113-129, 2007.

[16] Silva, Caio Samuel Franciscati da; Brancaleoni, Ana Paula Leivar; de Oliveira, Rosemary Rodrigues. Base nacional comum curricular e diversidade sexual e de gênero: (des)caracterizações. Revista Ibero-Americana de Estudos em Educação. v. 14, n. esp. 2, p. 1538-1555, 2019.

[17] Silva, Fernando Guimarães Oliveira da; Souza, José Antonio de. Relações de poder em práticas escolares heteronormativas e o espaço da diversidade sexual. An. Sciencult. Paranaíba, v. 6, n. 1, p.416-430, 2015.

[18] Silva, Lilian de Souza; Lastória, Luiz A. Calmon Nabuco. Educação e diversidade sexual. Revista Interdisciplinar de Direitos Humanos, v. 7, n. 1, p. 279-293, 2019.

[19] Silva, Mônica Magrini L. et al. Família e orientação sexual: dificuldades na aceitação da homossexualidade masculina. Temas em Psicologia. v. 23, n. 3, p.677-692, Associação Brasileira de Psicologia, 2015.

[20] Souza, Elaine de Jesus; Silva, Joilson Pereira da; Santos, Claudiene. Diversidade sexual na escola: uma análise das representações sociais de educadores/as. Educação e Cultura Contemporânea. Sergipe, v. 11, n. 25, p.390-422, 12 fev. 2014.

[21] Trevisan, J. S. O espetáculo do desejo: homossexualidade e crise do masculino. In: Caldas, Dario (Org.). Homens. São Paulo: Senac, 1997. 


\section{Capítulo 17}

\section{Análises das médias de variabilidade da frequência}

fundamental (Pitch) presentes na produção oral de homens autodeclarados gays e heterossexuais

\section{Eduardo Barbuio}

\section{Emanuelle Camila Moraes de Melo Albuquerque}

Paloma Pereira Borba Pedrosa

Resumo: 0 objetivo da investigação cujos resultados apresentamos nesse trabalho foi buscar, na fala de 14 homens, separados em dois grupos quantitativamente equiparados: 7 indivíduos autodeclarados gays e 7 autodeclarados heterossexuais, pistas acústicas - a exemplo de aspectos frasais e sons de vogais e de consoantes - as quais seriam usadas como norteadoras para que juízes leigos pudessem atribuir, à fala dos participantes, valores relativos à orientação sexual dos indivíduos. A análise do corpus apoia-se nos pressupostos da Sociolinguística Variacionista de Labov (1972, 1974, 1982, 1994) e Eckert (1989, 1997, 2000, 2003, 2005, 2010, 2012); em trabalhos sobre testes de percepção da fala realizados, dentre outros, por Gaudio (1994); Smyth, Jacobs e Rogers (2003); Levon (2007); Campbell-Kibler (2011); Lopes (2012) e Tracy, Bainter e Santariano (2015). Médias consideravelmente maiores de variabilidade do Pitch dos informantes gays também foram verificadas. Na maioria dos aspectos, as médias dos informantes homosssexuais que constituíram a pesquisa aproximaram-se mais das médias dos informantes gays participantes das pesquisas em Língua Inglesa que das médias apresentadas por nossos informantes heterossexuais. Assim, devido às semelhanças encontradas nos resultados de algumas pesquisas, obtidos entre os homens gays falantes de Língua Inglesa e Portuguesa, parece plausível afirmar a existência de alguns aspectos universais característicos e típicos de uma chamada "fala gay".

Palavras-Chave: variação; fala gay; sociolinguística. 


\section{INTRODUÇÃO}

A tradição dos estudos linguísticos aponta que uma língua não se constitui apenas por aspectos internos, puramente estruturais. A influência de fatores extralinguísticos, de ordem social, cultural e histórica, é determinante não apenas no que diz respeito às orientações para a interação humana, mas também caracteriza, em certa medida, a maneira como os indivíduos se relacionam com a língua, a ponto de produzir variantes linguísticas responsáveis por identificar uma comunidade de fala em um dado contexto.

Partindo desse pressuposto, os estudos orientados pelo viés da Sociolinguística buscam, entre outros objetivos, estabelecer as relações entre os processos de variação que se observam na língua, em um dado recorte, seja em tempo aparente ou em tempo real. Considerando a importância de análises dessa natureza, as quais revelam não apenas diferenças linguísticas, mas traços identitários marcados a partir da fala característica de um grupo, o presente estudo se propôs a analisar a presença de supostos marcadores na fala de indivíduos autodeclarados gays. A fim de verificar tais diferenças variacionais entre a fala de homens heterossexuais e gays autodeclarados, a fala produzida por um grupo de indivíduos participantes da pesquisa serviu como nosso objeto de investigação.

Uma das características físicas mais básicas de um som é a sua frequência fundamental, que se caracteriza por ser o número de vezes que as partículas de ar vibram num determinado intervalo de tempo; isto é, é a frequência de repetição de uma onda sonora complexa (LADEFOGED, 1967). Sua medida é feita em ciclos por segundo, que correspondem à velocidade na qual uma forma de onda se repete por unidade de tempo (COUPER-KUHLEN, 1986).

Segundo Braid (2003), a frequência fundamental da voz, normalmente também referida pela sigla F0, é o menor componente periódico resultante da vibração das pregas vocais e a primeira frequência produzida na glote. A frequência fundamental das pregas vocais é determinada por uma complexa interação entre comprimento, massa e tensão (COLTON e CASPER, 1996). Lehiste (1970) concorda com os autores e considera que a pressão subglótica e a lubrificação das pregas vocais também têm papel importante na determinação da frequência fundamental, além da massa, comprimento e tensão das pregas vocais.

No nível perceptivo, esta frequência representa, para os ouvintes, o correlato acústico responsável pela percepção da melodia, ou seja, é percebida como a altura melódica da voz, ou tom (KENT e READ, 1992). A frequência fundamental (F0) é considerada o mais importante dos parâmetros para que se tenha a percepção de altura (sons agudos ou graves) e também de intensidade (sons fortes ou fracos) de vozes. Quanto maior ou menor uma frequência, respectivamente maiores e menores serão a altura e a intensidade dos sons.

\section{FREQUÊNCIA FUNDAMENTAL (PITCH)}

A respeito da percepção da frequência fundamental (F0), Braid (2003, p.51) considera que:

Em análise de fala, as taxas de repetição dos padrões periódicos numa forma de onda são denominadas frequência fundamental, entretanto, perceptualmente, esta impressão auditiva é chamada de pitch. 0 pitch corresponde à sensação de som grave ou agudo, e suas escalas.

Portanto, em nosso trabalho, nos referiremos a altura dos sons (agudos ou graves) como pitch. 0 hertz é a unidade de medida utilizada para mensurar os sons, e é representada pelo símbolo $\mathrm{Hz}$. Importa ressair que, quando nos referirmos aos valores de um pitch em Hz, esses aparecerão por meio do símbolo F0.

As pessoas com vozes dentro de uma faixa mais aguda são consideradas como tendo um pitch alto, por conseguinte, as de vozes mais graves, pitch baixo. Portanto, os sons de menor pitch, ou de menores valores de F0, são mais graves, a exemplo das vozes masculinas, que geralmente apresentam um pitch médio de cerca de $120 \mathrm{~Hz}$. Já as vozes femininas apresentam um pitch mais alto, com valores médios de F0 de 230 $\mathrm{Hz}$ (Kent e Read, 2015, p.46). Ou seja, o F0 da voz feminina é geralmente o dobro da masculina. Essa diferença é principalmente resultante da maior quantidade de massa vibrante ser maior em homens, devido ao maior volume de suas pregas vocais, o que faz com que elas vibrem em uma velocidade mais lenta, gerando menos ciclos glóticos por segundo.

Independente da característica pessoal de voz (grave ou aguda), as pessoas alteram o pitch durante sua fala, pois esse elemento é responsável pela entonação. Diversos autores, dentre eles Cruttenden (1986), 
Pierrehumbert (1987) e Moraes (1993) consideram o pitch como a característica prosódica mais importante da entonação. Para Roach (2009), não há uma definição que apresente uma resposta completamente satisfatória para o termo entonação, que muitas vezes é também confundido com o termo prosódia, que, por sua vez, também não aponta uma definição tão clara. A respeito das definições desses conceitos, Kent e Read (2002, p.229) explicam que há:

One major disagreement is with the pair of terms, prosody and intonation. Some writers regard them as synonyms, while others mark an important distinction between them. [...] Intonation is similar to prosody in that its parameters are vocal frequency, intensity, and duration, but intonation refers to a narrower range of phenomena, generally the patterns of pith rises and falls and the patterns of stress in a given language. Prosody includes these effects, but also embraces tempo (pause and lengthening), vocal effort, loudness, and other phenomena. 52

Todo falante, ao proferir sua voz, produz naturalmente variação do pitch. Isso acontece pelos diversos tons que são usados para se expressar. Ao se realizar a análise do traçado gráfico, o qual geralmente é referido como curvas de contorno de pitch, são encontrados os valores instantâneos da frequência fundamental em função do tempo (BRAID, 2003). Como já mencionado, a análise do pitch é o parâmetro fonético mais utilizado nos estudos relacionados à questão da percepção e características da produção da fala de homens gays e heterossexuais (GAUDIO, 1994; SMYTH e ROGERS 2002; SMYTH, JACOBS e ROGERS 2003; MUNSON et al., 2006; MUNSON, 2007; ZIMMAN, 2010). Diante disso, consideramos a análise de pitch como um procedimento bastante promissor em nossa pesquisa. Isso porque acreditamos que podia haver certa relação entre os resultados dos testes de percepção, respondidos pelos juízes, e as características do pitch das vozes de nossos informantes.

\section{METODOLOGIA}

Em nosso estudo, avaliamos a média geral do pitch, por esse ser esse um parâmetro sempre utilizado nas pesquisas realizadas em língua inglesa com informantes gays e heterossexuais. Também verificamos a média de variabilidade, por meio da mensuração dos valores de menor e maior valor do pitch, encontrados nas vozes dos informantes.

Por meio do parâmetro da variabilidade, buscamos verificar se nossos resultados assemelham-se aos encontrados por Munson et al. (2006), que, em sua pesquisa, verificou médias extremas de valores de F0 na fala dos informantes gays, com picos bem mais altos e valores mínimos bastante inferiores às médias apresentadas pelos informantes heterossexuais. Trata-se, pois, das características chamadas por Kulick (2000) de "roller coaster intonation"53 e que seriam peculiaridades de variabilidade de pitch, encontradas em falas de mulheres com vozes percebidas como mais agudas.

Em todas as análises de produção fizemos uso do software de análise acústica e de síntese de voz chamado PRAAT (BOERSMA e WEENINK, 2016). Esse software fornece inúmeros dados de vários elementos acústicos de um determinado som. Para obter os valores de média de pitch e os valores mínimos e máximos de trechos da fala de cada informante, usaremos o recurso de análise de pitch disponível no menu "PITCH" do software PRAAT, como podemos ver na Figura 1:

\footnotetext{
52 Uma grande discordância está entre os termos "prosódia" e "entonação". Alguns escritores se referem a eles como sinônimos, enquanto outros apontam uma importante distinção entre eles. [...] Entonação é parecida com prosódia no sentido de que seus parâmetros são frequência vocal, intensidade e duração, mas entonação se refere a uma gama mais restrita de fenômenos, geralmente os padrões de altura de pitch e tonacidade de uma língua. A prosódia inclui esses efeitos, mas também abrange o tempo (pausa e duração), esforço vocal, sonoridade, e outros fenômenos. (Tradução nossa).

53 Entonação de montanha-russa.
} 
Figura 1. Procedimentos de análise da média e de valores máximos e mínimos de pitch

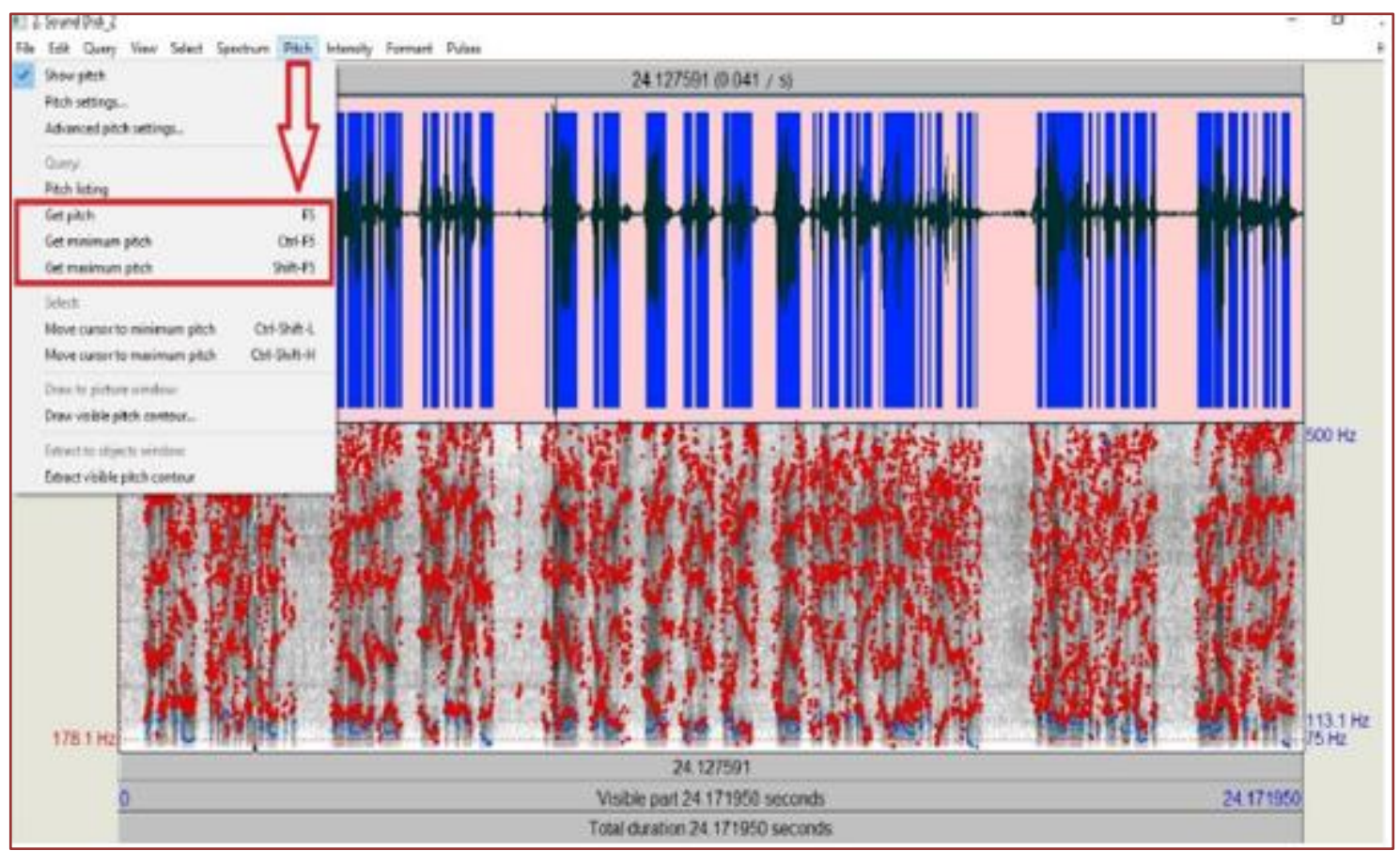

Os valores de média geral de pitch, valores mínimos, máximos e de variabilidade, foram obtidos a partir da verificação das vozes de cada um dos 14 informantes. Em seguida, fizemos as médias apresentadas pelos 7 informantes que compõem o grupo formado por homens gays e dos outros 7 que formam o grupo dos homens heterossexuais. A partir daí, buscamos compreender se houve diferenças significativas de pitch entre esses grupos.

\section{RESULTADOS E DISCUSSÃO}

Como mencionado, segundo Kent e Read (1992), para os ouvintes, o pitch é o correlato acústico responsável pela percepção da melodia, ou seja, é percebida como a altura melódica da voz, também referida por tom.

Das pesquisas realizadas com falantes de língua inglesa, que objetivaram o estudo da percepção e de características de produção da fala de homens identificados como heterossexuais e homossexuais, a questão do pitch foi a mais frequentemente abordada. Entre esses estudos, podemos mencionar os trabalhos desenvolvidos por Gaudio (1994); Smyth e Rogers (2002); Smyth; Jacobs e Rogers (2003); Munson et al. (2006); Munson (2007); Levon (2007); Podesva (2007); Zimman (2010, 2013) e Tracy, Bainter e Santariano (2015).

No que tange aos aspectos do pitch, abordados nesses estudos, quase todos os pesquisadores analisaram a média do valor de pitch e sua variabilidade, por meio da mediação de seus picos mais elevados e valores mais baixos de produção.

Embora algumas dessas pesquisas não tenham encontrado, de fato, diferenças significativas com relação à média de pitch dos informantes (GAUDIO, 1994; LINVILLE, 1998; SMITH et al. 2003; MUNSON et al. 2006; MUNSON, 2007; ZIMMAN, 2010), consideramos esse um procedimento a ser levado em conta em nosso trabalho. Assim, fizemos essa opção, por ser tal procedimento frequentemente utilizado entre os parâmetros de análise sobre aspectos, envolvendo a fala de homens, e os que também buscam dar conta da questão da orientação sexual. Além disso, ainda merece destaque o fato de não termos conhecimento de análises, anteriormente realizadas, que tenham incluído o pitch entre os propósitos das investigações, com falantes de língua portuguesa. 
Desse modo, por meio do software PRAAT (BOERSMA e WEENINK, 2016), verificamos os valores de médias de pitch dos informantes do grupo formado por homens gays e de outro composto por homens heterossexuais. Por meio do gráfico 2, temos os valores conferidos por cada um dos dois grupos:

Gráfico 2 - Valores de médias de pitch do grupo de homens gays e do grupo de homens heterossexuais em (HZ)

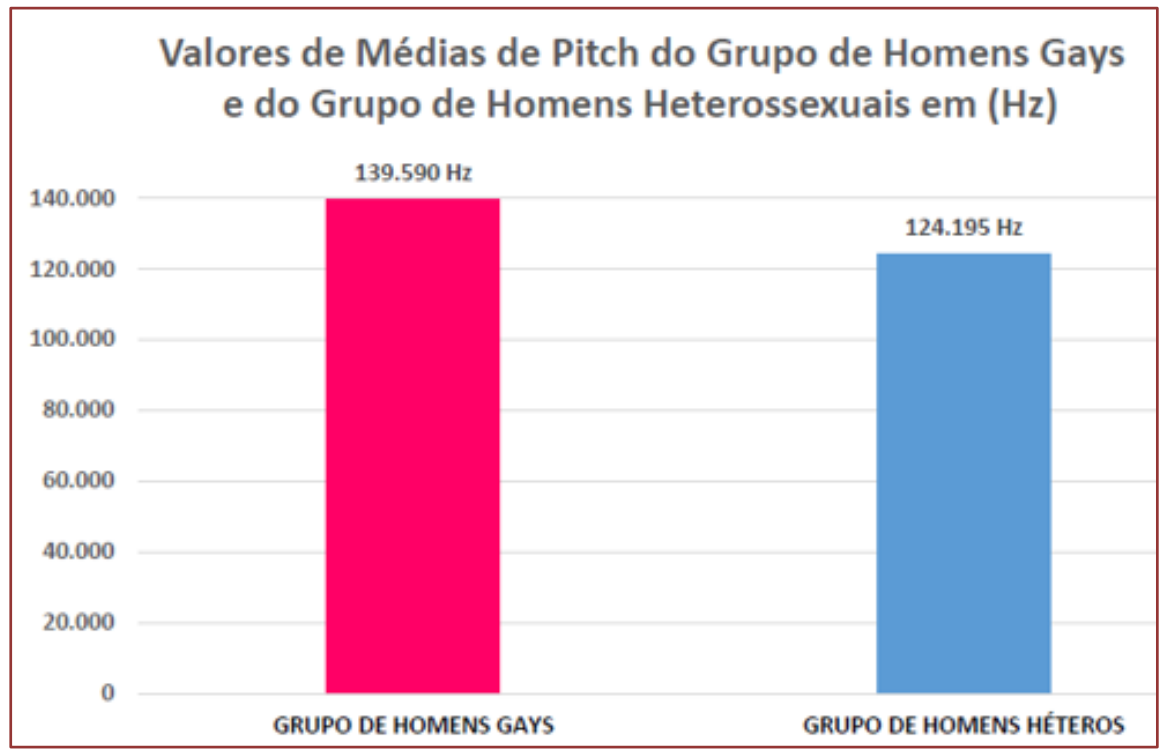

Segundo Kent e Read (1992), enquanto a média de pitch da voz de um falante homem geralmente varia em torno de $100 \mathrm{a} 120 \mathrm{~Hz}$, a de mulheres se apresenta em torno de 200 a $220 \mathrm{~Hz}$. Com valores de 139,590 para o grupo de homens gays e de 124.195 para o grupo de homens heterossexuais, pode-se afirmar que os valores de média de pitch de ambos são mais próximos aos que os autores consideram por uma média masculina. Portanto, mesmo o grupo dos gays, que apresentou uma média maior, ainda se revela distante da média feminina.

A média do pitch do grupo de gays foi de cerca de $11 \%$ maior que a média do grupo de heterossexuais. Essa diferença não se distancia muito das médias encontradas em outros estudos, em que médias de pitch de grupos de homens gays e heterossexuais foram comparadas. Gaudio (1994) observou uma diferença de $10 \%$ a mais, na média dos informantes gays. Na pesquisa de Munson et al. (2006), também os gays apresentaram uma média de pitch $7 \%$ maior do que os heterossexuais. Os dois pesquisadores consideraram que essas médias não representam uma diferença relevante, e que teriam pouca influência no processo de percepção da orientação sexual dos informantes de suas pesquisas.

Pelos valores observados em nossa análise e, pelo fato da média do grupo gay apresentar uma diferença de cerca de $11 \%$ maior que a média dos heterossexuais, também não acreditamos que a média do pitch de nossos informantes seja um elemento que diferencie significativamente as peculiaridades da fala gay e da fala heterossexual, e, com isso, provavelmente não exercem grande influência no processo de percepção da orientação sexual dos informantes.

Observaremos, a seguir, as médias dos valores mais elevados; as médias dos valores mais baixos registrados e as médias da variabilidade, que representa o valor mais baixo, subtraído do valor mais alto, apresentados pelos dois grupos de informantes: 
Gráfico 3. Médias dos maiores e menores valores e variabilidade do pitch dos informantes gays (rosa) e heterossexuais (azul) em (HZ).

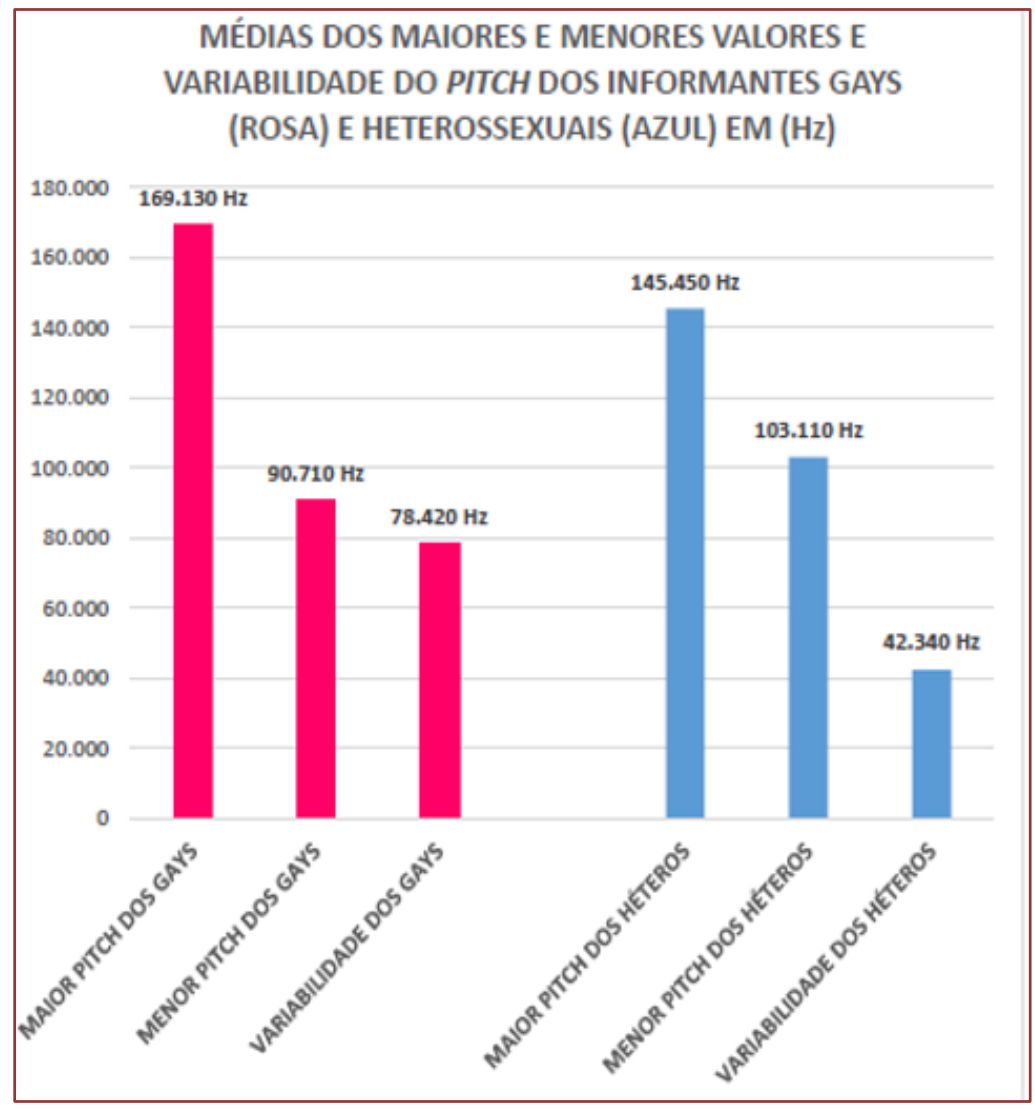

Ao observarmos os valores apresentados no gráfico 3, pode-se notar que as médias dos grupos de informantes gays e heterossexuais apresentaram valores diferentes nos três parâmetros observados. A média de valor de pitch mais elevado do grupo dos gays foi de $169.130 \mathrm{~Hz}$, contra $145.450 \mathrm{~Hz}$ dos heterossexuais. Trata-se, pois, de uma diferença de cerca de 14\% maior para os gays, o que nos permite concluir que as vozes dos informantes gays, participantes de nossa pesquisa, apresentaram picos um pouco mais agudos do que as vozes dos heterossexuais. Por outro lado, o valor médio de menor pitch apresentado pelo grupo gay foi mais baixo que o do grupo heterossexual (média de $103.110 \mathrm{~Hz}$ para os heterossexuais contra $90.710 \mathrm{~Hz}$ para os gays). Tais valores mostraram-se cerca de $12 \%$ menores, o que demonstra que, em alguns momentos das gravações utilizadas em nosso teste de percepção, os gays apresentaram vozes sutilmente mais graves que as dos heterossexuais.

Já a média de variabilidade, apresentada pelo grupo gay, foi cerca de $46 \%$ maior do que a do grupo heterossexual, com médias de 78,420 Hz contra 42,340 Hz. Portanto, os valores de pitch mais altos e mais baixos, observados nas vozes dos informantes gays, apresentaram uma média de variabilidade consideravelmente maior do que a dos heterossexuais.

Kulick (2000) denomina as vozes com variabilidade de pitch e presença de médias baixas e picos elevados de "roller coaster intonation"54. Conforme já discutido anteriormente em nosso trabalho, para esse pesquisador, tais características são geralmente mais observadas nas peculiaridades de vozes femininas.

Embora os valores de média de pitch encontrados nas vozes dos falantes gays sejam menores que os valores médios de pitch atribuídos às vozes femininas, podemos considerar que a chamada entonação de montanha russa seja provavelmente uma característica peculiar da fala do grupo de informantes gays participantes de nossa pesquisa. Suas falas, porém, não se apresentam tão agudas quanto as vozes femininas.

\footnotetext{
${ }^{54}$ Entonação de montanha-russa.
} 
Entonação de montanha russa, em vozes não tão agudas quanto a de mulheres, também foram características de produção encontradas na fala de informantes do grupo de homossexuais no estudo de Smyth, Jacobs e Rogers (2003).

0 trabalho de Munson et al. (2006) também concluiu que alguns informantes gays apresentaram variabilidades extremas de pitch; depressões com valores mais baixos e picos mais altos que a média dos informantes heterossexuais. No entanto, os pesquisadores consideraram que o número de participantes envolvidos em sua pesquisa era muito pequeno, e que essa característica foi observada somente na fala de 3 informantes. Ainda assim, em um estudo subsequente, realizado pouco tempo depois, com um número maior de informantes, os resultados encontrados em Munson (2007) não confirmaram essa suposta peculiaridade da "fala gay".

\section{CONSIDERAÇõES FINAIS}

Em nosso trabalho, consideramos que a chamada entonação de montanha russa (encontrada na fala dos informantes gays) - com uma taxa de variabilidade quase $50 \%$ maior do que entre os falantes heterossexuais - representa uma característica peculiar da fala do grupo de informantes gays participantes de nossa pesquisa, uma vez que todos os indivíduos homossexuais apresentaram essa mesma característica.

Pelo fato de os dados obtidos em nossa investigação confirmarem os resultados encontrados em pesquisas realizadas com outros informantes também gays, falantes de língua inglesa (SMYTH, JACOBS e ROGERS, 2003 e MUNSON et al., 2006), identificamos a possibilidade de a chamada entonação de montanha russa ser considerada uma característica mais universal, típica das comunidades de fala gays.

\section{REFERÊNCIAS}

[1] Avery, Jack D.; Liss, Julie M. (1996). Acoustic characteristics of less-masculine-sounding male speech. Journal of the Acoustical Society of America 99, 3738-3748. Braid, Antônio Cesar Morant. Fonética Forense: tratado de perícias criminalísticas. Campinas: Millenium, 2003.

[2] Behlau, M. et al. Avaliação de voz. In: Behlau M. Voz - o livro do especialista. Rio de Janeiro: Revinter; 2004, p. 156-60.

[3] Campbell-Kibler, Kathyryn. Intersecting variables and percieved sexual orientation in men. American Speech.86(1): 52-68, 2011.

[4] Crist, S. Duration of onset consonants in gay male stereotyped speech. U. Penn Working Papers in Linguistics, Volume 4. 3. 1997.

[5] Eckert, Penelope. The Whole Woman: Sex and gender differences in variation. Language Variation and change 1, 245-268, 1989.

[6] Eckert, Penelope. Age as a sociolinguistic variable. In: Coulmas, Florian. The handbook of sociolinguistics. Oxford: Blackwell, 1997, p. 151-16.

[7] Eckert, Penelope. Linguistic Variation as Social Practice. Blackwell Publishers, 2000.

[8] Flipsen, Peter. et al. Acoustic Characteristics of /s/ in adolescentes. Journal of Speech, Language, and Hearing Research 42:663-677, 1999.

[9] Fuchs, Susanne \&Toda, Martine. Do diferences in male versus female /s/ reflect biological or sociophonetic factors? In interdisciplinary Guide to Turbulent Sounds, Susanne Fuchs, Martine Toda \&MarzenaZygis 9eds), 281-302. Berlin: Mouton de Gruyter, 2010.

[10] Gaudio, R. P. Sounding gay: Pitch properties in the speech of gay and straight men. American Speech, 69(1), 30-57, 1994.

[11] Heffernan, K. "Evidence from HNR that /s/ is a social marker of gender." Toronto WorkingPapers in Linguistics23.2: pp. 71-84, 2004.

[12] Jacobs, Greg. Lesbian and Gay Male Language Use: A Critical Review of the Literature. American Speech 71:49-71, 1996.

[13] Kent, Ray D. \& Read, Charles. The Acoustic Analysis of Speech. San Diego: Singular Publishing Group, 1992.

[14] Kublic, D. 2000. “Gay and Lesbian Language.” Annual Review of Anthropology 29: 243-285.

[15] Lakoff, R. (1975). Language and woman's place. New York: Harper Colophon Books. 
[16] Linville, S.E. Acoustic correlates of perceived versus actual sexual orientation in men's speech. Folia PhoniatricaetLogopaedica, 50, 25-48, 1998.

[17] Levon, E. Hearing gay: Prosody, interpretation and the affective judments of men's speech, American Speech 81 (1): 56-78, 2006.

[18] McConnell-Ginet, Sally (1988). Language and gender. In Frederick J. Newmeyer (ed.), Linguistics: The Cambridge Survey, IV:75-99. Cambridge \& New York: Cambridge University Press.

[19] Munson, B. et al.The influence of perceived sexual orientation on fricative perception. Journal of the Acoustic Society of America.119, 2427 - 2437, 2006.

[20] Munson, Benjaminet al. The acoustic and perceptual bases of judgments of women and men's sexual orientation from read speech. Journal of Phonetics 34(2): 202-240, 2006.

[21] Munson, Benjamin. "The acoustic correlates of perceived masculinity, perceived femininity, and perceived sexual orientations" Language naSpecch 50(1): 125-142, 2007.

[22] Pierrehumbert, Janet B. et al. "The influence of sexual orientation on vowel production." Journal of the Acoustical Society of America 116(4): 1905-1018, 2004

[23] Podesva, Robert J., et al.The California vowel Shift and gay identity.American Speech 86(1): 32-68, 2001.

[24] Podesva, Robert J. Phonation type as a stylistic variable: the use of falsetto in constructing a persona. JournalofSociolinguistic, Hoboken, vol. 11(4), 478-504, 2007.

[25] Rendall D, Vasey PL, McKenzie J. The Queen's English: An alternative, biosocial hypothesis for the distinctive features of "gay speech" Archives of Sexual Behavior. 2008;37:188-204.

[26] Smyth, R., Jacobs, G. and Rogers, H. Male voices and perceived sexual orientation: an experiment and theoretical approach. Language in Society 32, pp. 329 - 350. Cambridge University Press. 2003.

[27] Tracy, Erick C., Bainter, Sierra A., Santariano, Nicholas P. "Judgments of self-identified gay and heterossexual male speakers: Which phonemes are most saliente in determining sexual orientation?" Journal of Phonetics 52 (2015): 13-25.

[28] Zimman, Lal. Hegemonic masculinity and the variability of gay-sounding speech.The Perceived Sexuality of Transgender Men.Journal of Language and Sexuality John Benjamins Publishing Company, 2013. 


\section{Capítulo 18}

\section{Buscando o "CIS" nas pesquisas sobre educação}

Jeferson Reis Santos

Resumo: O presente trabalho pretende mapear os usos dos termos "cisgeneridade" e "cisnormatividade" nas pesquisas em educação produzidas no Brasil. Foram analisados 34 trabalhos que revelaram o uso dos termos como marcador social dos/das autores/autoras dos trabalhos e dos/das interlocutores/interlocutoras das pesquisas e como estratégia intelectual para despatologizar as identidades trans e desnaturalizar as identidades cis.

Palavras-chave: Gênero, cisnormatividade, cisgeneridade, educação. 


\section{INTRODUÇÃO}

Este trabalho buscou mapear a presença dos termos "cisnormatividade" e "cisgeneridade" nas produções acadêmicas produzidas no Brasil na área de educação, focando, especialmente, nas aplicações destes pelos autores e autoras e nos referenciais teóricos utilizados. A cisgeneridade pode ser entendida, de modo geral, como "a identidade de gênero das pessoas não-transgêneras" (JESUS, 2012) que, a partir da cisnormatividade - ou seja, o estabelecimento desta como norma - produz efeitos de subalternidade e abjeção sobre as transgeneridades (BAGAGLI, 2017). Sigo a compreensão de Vergueiro (2015) que aponta a incorporação da cisgeneridade e da cisnormatividade como conceito e categoria analítica como uma postura teórica e política decolonial. Além disso, compreendo aqui a incorporação de conceitos produzidos pelos movimentos transfeministas no contexto das discussões sobre as sociologias das ausências e das emergências (SANTOS, 2004) e do seu desdobramento em pedagogias das ausências e das emergências (GOMES, 2017).

A decisão de realizar essa pesquisa é fruto de deslocamentos realizados durante o meu percurso do mestrado ligado aos estudos de gênero no Programa de pós-graduação em Educação na Universidade Federal de Minas Gerais onde compreendi que não apenas a homossexualidade, a nordestinidade, a classe social e a negritude mestiça devem ser anunciadas como elementos que constituem as minhas experiências, mas também aquilo que ao ser não-anunciado, não-problematizado e naturalizado traduz-se em privilégios e vantagens sociais, sendo, no meu caso, a cisgeneridade. Além disso, entendo que a principal justificativa desse trabalho é acompanhar os usos da cisgeneridade e da cisnormatividade na produção acadêmica em educação seguindo uma tendência tímida, mas urgente, de desnaturalizar as normas para aprofundar a compreensão sobre as relações entre gênero e educação na produção acadêmica e na formulação de políticas públicas. Não faz parte dos objetivos deste trabalho definir se os termos estão sendo utilizados de maneira "correta" ou "incorreta" pelos/pelas pesquisadores/as, mas apresentar um panorama geral de como eles têm sido incorporados nas produções acadêmicas em educação, servindo também como um possível ponto de partida para a compreensão da importância de levar tais reflexões para o seu fazer/pensar pedagógico.

\section{METODOLOGIA}

Para realizar esta pesquisa foram utilizados os repositórios acadêmicos Scielo e Google Scholar e o repositório de teses da Coordenação de Aperfeiçoamento de Pessoal de Nível Superior (CAPES) em buscas a partir dos termos "cisgeneridade" e "cisnormatividade". Para as buscas com o termo "cisgeneridade" foram retornados 497 resultados no Google Scholar, 1 no Scielo e 12 no repositório da CAPES, para o termo "cisnormatividade" foram apresentados 240 resultados no Google Scholar, 1 na Scielo e 11 no Repositório de Teses da CAPES.

Após a análise dos resultados iniciais, foram levantadas 38 produções na área de Educação. A definição dos trabalhos aqui analisados não levou em conta de maneira restrita os trabalhos realizados em cursos de pedagogia, em programas de pós-graduação em Educação ou publicados em revistas e anais de eventos desta área, mas buscou incluir todos os que tratassem de temas caros às discussões educacionais, especialmente os que tratam do cotidiano escolar e das desigualdades nas trajetórias de escolarização, dado às reflexões produzidas pela literatura acadêmica sobre o impacto da norma cisgênera nas vivências das pessoas trans* na escola e nos seus processos de evasão/expulsão e ausência do sistema educacional. Do total de 38, 4 foram excluídas das análises nesta pesquisa, os artigos "Pedagogia micropolítica decolonial na universidade: reflexões sobre modos de re-sentir" de Rafael Siqueira de Guimarães, "Parece uma mulher, mas é um traveco: produções discursivas marginais e transfóbicas nas vivências de uma travesti professora" de Marcos Lopes de Souza e "Pedagogias transgressoras: as potencialidades descolonizadoras de pedagogias que tratem de gênero e sexualidade" de Emmanuel Henrique Souza Rodrigues, todas publicadas no v. 18 em 2019 na revista Espaço Acadêmico, foram excluídas pois o site do periódico esteve fora do ar todas as vezes que foi consultado e as publicações não foram encontradas em outros lugares. A quarta publicação excluída foi "Sexualidades e gêneros na escola: de quais sentidos se apropria a prática pedagógica?" de Denise Braga publicado nos anais do V colóquio internacional educação, cidadania e exclusão em 2018 pois o mesmo texto constava nos anais do V Enlaçando Sexualidades em 2017 com o título "Sexualidades e gêneros no intramuros da escola: de quais sentidos se apropria a prática pedagógica", permanecendo somente o último neste levantamento. Foram analisadas, portanto, 34 produções. 


\section{RESULTADOS E DISCUSSÃO}

Em relação ao tipo de produção, 5 são textos em anais de eventos, 8 são artigos publicados em revistas acadêmicas, 1 capítulo de livro, 7 trabalhos de conclusão de curso de graduação, 1 trabalho de curso de especialização, 8 dissertações de mestrado e 4 teses de doutorado. Em relação ao ano de cada trabalho, eles foram produzidos em 2013 (1), 2014 (1), 2015, (2), 2016 (5), 2017 (10), 2018 (8) e 2019 (7). 55

Pelas dimensões reduzidas e pelo caráter exploratório do presente trabalho, a análise das produções não será apresentada aqui caso a caso, mas a partir do agrupamento destas em categorias a partir de seus pontos em comum. Apesar disso, alguns comentários serão realizados sobre trabalhos que apresentem características excepcionais que justifiquem tal procedimento. Um dos primeiros dados analisados na pesquisa é a diversidade de perspectivas pelas quais tem sido abordada a relação entre cisgeneridade e educação. As pesquisas analisadas aqui foram produzidas nos cursos de graduação em Biologia (3), Ciências Sociais (2), Serviço Social (1) e Pedagogia (1); nos Programas de Pós-Graduação Stricto Sensu em Educação (5), Psicologia (2), Relações Étnicas e Contemporaneidade (1), Ciências da Religião (1), Ensino e Processos Formativos (1), Educação em Ciências (1) e Interdisciplinar em Ciências Humanas (1) e no Programa de Pós-Graduação Lato Sensu em Gênero e Diversidade na Escola (1). Tais pesquisas foram realizadas na Universidade de Brasília (1), na Universidade Federal Rural do Rio de Janeiro (1), na Universidade Federal do Rio de Janeiro (1), na Universidade Federal de Santa Catarina (4), na Universidade Federal do Rio Grande do Sul (2), na Universidade Federal do Paraná (2), na Universidade Federal de Alagoas (1), na Universidade Estadual de Feira de Santana (1), na Universidade Federal de São Carlos (1), na Universidade Estadual do Sudoeste da Bahia (1), na Pontifícia Universidade Católica do Rio Grande do Sul (1), na Universidade Católica de Pernambuco (1), na Universidade Federal de Goiás (1), na Universidade Estadual de São Paulo (1), na Universidade de São Paulo (1). Os trabalhos presentes em anais de eventos foram apresentados no encontro da Associação Nacional de Pós-Graduação e Pesquisa em Educação (1), no Seminário Internacional Enlaçando Sexualidades (1), na Conferência Internacional de Estudos Queer (1) e na Reunião de Antropologia da Ciência e Tecnologia (1); os artigos foram publicados nas revistas acadêmicas Debates Insubmissos da Universidade Federal de Pernambuco (1), na Ensino em Re-Vista da Universidade Federal de Uberlândia (1), na Educação Popular da Universidade Federal de Uberlândia (1), na Humanidades e Renovação da Universidade Estadual do Tocantins (1), na Laboratório de Ensino de História e Educação da Universidade Federal do Rio Grande do Sul (1), na Educação, Cultura e Sociedade da Universidade do Estado de Mato Grosso (1), na Intermeio da Universidade Federal do Mato Grosso do Sul (1) e na Inter-Ação da Universidade Federal de Goiás (1). Estas informações apontam para uma crescente disseminação das reflexões sobre a cisgeneridade/cisnormatividade nas produções acadêmicas brasileiras em Educação, tanto sob uma perspectiva disciplinar quanto em

Outro ponto relevante é analisar o referencial teórico sobre cisgeneridade utilizado pelas autoras e autores. Das 34 produções analisadas, 15 adotam a cisgeneridade e/ou a cisnormatividade sem apresentar nenhum referencial teórico que discuta especificamente estes conceitos, estes 15 podem ser divididos entre os que utilizam os termos sem fornecer nenhuma definição (6) e os que apresentaram a sua concepção sobre (9). Nas outras produções é possível perceber a presença predominante de intelectuais atuantes no movimento transfeminista como a Jaqueline Gomes de Jesus, a Viviane Vergueiro, a Hailey Kaas, a Amara Moira e a Beatriz Pagliarini Bagagli. Podemos avaliar a partir disso que a presença das pessoas trans* na produção acadêmica sobre gênero tem questionado regimes de verdade e, ao discutir a cisgeneridade, tem sido capaz de abalar o pressuposto não anunciado sobre o seu aspecto natural. Os usos da cisgeneridade podem estabelecer diálogos interessantes com as discussões sobre Epistemologias do Sul que, nas palavras de Santos, significa

la búsqueda de conocimientos y de critérios de validez del conocimimento que otorguen visibilidade y credibilidade a las prácticas cognitivas de las classes, de los pueblos y de los grupos sociales que han sido historicamente victimizados, explotados y oprimidos por el colonialismo y el capitalismo globales. (SANTOS, 2009, p. 12)

Além disso, é relevante destacar que parte das produções utilizaram como referências posts em blogs onde são publicados textos escritos especialmente por pessoas trans* como o transfeminismo.com, o feminismotrans.wordpress.com e dicionariodegeneros.com.br.

\footnotetext{
55 Os trabalhos consultados em 2019 foram publicados até setembro deste ano, mês em que foi finalizada a produção deste texto.
} 
Um dos principais usos da cisgeneridade nas pesquisas é para realizar a apresentação do lugar social do/da autor/autora. Tal estratégia epistêmica pode ser interpretada a partir das reflexões de Grosfoguel

0 essencial aqui é o lócus da enunciação, ou seja, o lugar geopolítico e corpopolítico do sujeito que fala. Na filosofia e nas ciências ocidentais, aquele que fala está sempre escondido, oculto, apagado da análise. A "ego-política do conhecimento" da filosofia ocidental sempre privilegiou o mito de um "Ego" não situado. O lugar epistémico étnico-racial/sexual/de gênero e o sujeito enunciador encontram-se, sempre, desvinculados. Ao quebrar a ligação entre o sujeito da enunciação e o lugar epistémico étnico-racial/sexual/de gênero, a filosofia e as ciências ocidentais conseguem gerar um mito sobre um conhecimento universal Verdadeiro que encobre, isto é, que oculta não só aquele que fala como também o lugar epistémico geopolítico e corpo-político das estruturas de poder/conhecimento colonial, a partir do qual o sujeito se pronuncia. (GROSFOGUEL, 2008, P. 119).

Além de utilizá-los para fazer a enunciação de si e a caracterização do perfil das/dos interlocutoras/interlocutores das pesquisas, a presença dos termos cisgeneridade/cisnormatividade nas pesquisas em educação também busca utilizá-los como parte constituinte de suas apreensões sobre a realidade social. Sendo assim, tais termos aparecem definidos frequentemente como "força social" (oliveira, 2014), "padrão hegemônico de gênero" (santos, 2016), "ordem regulatória" (amaral; souza, 2017), "estrutura normativa" (silva et. Al, 2018) e "identidade colonizadora" (marin, 2019).

\section{CONSIDERAÇÕES FINAIS}

Pelas dimensões do trabalho aqui proposto, muitas das questões apresentadas merecem um desenvolvimento maior em outros trabalhos. Apesar disso, foi possível perceber como os pesquisadores e pesquisadoras tem produzido análises e reflexões sofisticadas ao utilizar a cisgeneridade e a cisnormatividade em suas pesquisas. A inclusão de tais termos na agenda acadêmica deve estar aliado a um compromisso político-epistemológico realmente comprometido com o projeto de emancipação social e de descolonização - especialmente, nesta campo, da prática pedagógica que frequentemente reproduz violências.

\section{REFERÊNCIAS}

[1] Amaral, Cleide de Jesus Braga; Souza, Marcos Lopes de. A sinergia de uma proposta colaborativa sobre os corpos, gêneros e sexualidades em uma escola do ensino fundamental: fatores potencializadores. InterMeio: Revista do Programa de Pós-Graduação em Educação. Campo Grande, v. 23, n. 46, 2017

[2] Bagagli, Beatriz Pagliarini. Orientação sexual na identidade de gênero a partir da crítica a heterossexualidade e cisgeneridade como normas. Letras Escreve, Macapá, v. 7, n. 1, 2017

[3] Gomes, Nilma Lino. O Movimento Negro Educador: Saberes construídos nas lutas por emancipação. Petrópolis, ed. Vozes, 2017

[4] Grosfoguel, Ramón. Transmodernidade, pensamento de fronteira e colonialidade global. Revista Crítica de Ciências Sociais, 80, 2008

[5] Jesus, Jaqueline Gomes de. Orientações sobre identidade de gênero: conceitos e termos. Goiânia: Ser-Tão, 2012. Disponível em: <http://www.sertao.ufg.br/uploads/16/original_Orienta \%C3\%87\%C3\%95ES_ Popula\%C3\%87\%C3\%830_Trans.pdf?1334065989> Acesso em: 05/10/2019 Marin, Yonier Alexander Orozco. 0 que podemos e devemos aprender professores/as cisgênero das professoras/es trans para uma educação decolonial? In: Anais da VII Reunião de Antropologia da Ciência e Tecnologia, Anais Eletrônicos, Florianópolis, 2019

[6] Oliveira, Elisabete Regina Baptista de. "Minha vida de ameba": Os scripts sexo-normativos e a construção social das assexualidades na internet e na escola. 225 p. Tese (Doutorado em Educação) - Faculdade de Educação, Programa de Pós-Graduação em Educação, Universidade de São Paulo, 2014

[7] Santos, Boaventura de Sousa. Uma Epistemología del Sur, Clacso, 2009

[8] __ Por uma sociologia das ausências e uma sociologia das emergências. In: Santos, Boaventura de Sousa (org.). Conhecimento Prudente para uma Vida Decente. São Paulo, Cortez, 2004. 
[9] Santos, Juliano Bonfim dos. "Além da camisinha na banana": a experiência da participação de jovens nas discussões sobre diversidade sexual e gênero na escola. 126 p. Dissertação (Mestrado em Psicologia) Instituto de Psicologia, Programa de Pós-Graduação em Psicologia, Universidade Federal de Alagoas, Maceió, 2016.

[10] Silva, Bibiana Harrote Pereira da, et. al. Gênero e ensino de história: reflexões sobre práticas de iniciação à docência no PIBID/História (UFRGS). Revista do Laboratório de Ensino de História e Educação da UFRGS. Porto Alegre, v. 5, n. 7, 2018.

[11] Vergueiro, Viviane. Por inflexões decoloniais de corpos e identidades de gênero inconformes: uma análise autoetnográfica da cisgeneridade como normatividade. Dissertação (Mestrado). Programa multidisciplinar de PósGraduação em Cultura e Sociedade - Instituto de Humanidades, Artes e Ciências Professor Milton Santos, Universidade Federal da Bahia. Salvador, 2015 


\title{
Capítulo 19
}

\section{A temática de gênero nas práticas acadêmicas no âmbito escolar entre 2003 - 2014}

\author{
Arthur Silva de Andrade \\ Beatriz. Coelho Ferreira \\ Lucia Talita Santos de Lima \\ Renato Maciel dos Santos \\ Tuany Lorena Ferreira \\ Anna Karina Gonçalves Xavier
}

Resumo: A partir da década de 80, o Brasil começou a se transformar politicamente devido a redemocratização do país. E, desde então, o movimento feminista galgou espaços nunca antes alcançados na história nacional. Um dos ganhos foi a eleição de mulheres em Assembleias Legislativas e na Constituição Federal de 1988, estar presente a igualdade de direitos entre homens e mulheres. Já na década de 90, documentos como os Parâmetros Curriculares Nacionais, legitimaram a necessidade de se trabalhar as questões de gênero, pauta feminista desde os anos de 1980, quando incluiu este, como um dos temas transversais a serem trabalhados em todos os níveis de ensino, fundamental I, fundamental II e médio. A partir de então, professores e professoras tiveram que iniciar essa temática em suas salas de aula, cuja metodologia é muito variada. E este cenário foi reforçado quando em 2003, criou-se a Secretária de Política para Mulheres. Sendo assim, o objetivo deste artigo, apresentar o estado da arte sobre a questão de gênero nas escolas, através das teses e dissertações da CAPES, no período de 2003 à 2014. Este trabalho se enquadra no tipo de pesquisa qualitativa de natureza bibliográfica exploratória-descritiva, cujo instrumento utilizado foi por mecanismo de metabusca, através do BDTD em procura avançada. Foi realizada a análise temática dos dados coletados.

Palavras-chave: Feminismo; Igualdade de gênero; práticas pedagógicas, professoras/ES. 


\section{INTRODUÇÃO}

Por volta da década de 70/80, o Brasil começou a se transformar politicamente devido a redemocratização do estado brasileiro. As diferentes mulheres que estiveram unidas, cujo processo foi iniciado ainda na década de 1970, durante o regime militar, muitas delas saíram às ruas na campanha pela anistia, contra a violência, contra a carestia. Já na década seguinte, em 1980, através das eleições diretas, concretizou a eleição de algumas dessas mulheres para a Assembleia Legislativa, especialmente no estado de São Paulo. Conseguiram ser eleitas um percentual considerado baixo, $5 \%$, mas, com efeito pedagógico positivo para o precesso, pois, além de visibilizar os problemas das mulheres, foram congregados na Constituição de 1988, temas importantes para a vida das brasileiras, além da igualdade de direitos entre mulheres e homens (BRABO, 2008). E, desde então, o movimento feminista galgou espaços nunca antes alcançados na história nacional. Neste cenário, sobre a caminhada histórica de luta do movimento feminista brasileiro, a favor dos direitos das mulheres, podemos ressaltar que houve conquistas, e dentre elas, a evolução das leis e mudanças nos costumes.

No entanto, pode-se ainda afirmar que algumas situações denunciadas pelas feministas naquela época, ainda estão presentes no Brasil, como: a violência, tanto na vida privada como pública, a diferença salarial, as jornadas dupla de trabalho (incluindo o trabalho doméstico), e ainda estão para se resolver a questão dos direitos reprodutivos e direitos sexuais, além do gênero ser uma questão ainda difícil para educadoras e educadores trabalharem dentro da prática docente no âmbito dos ensinos fundamental e médio.

As políticas públicas abarcam várias áreas e implantam-se como ferramenta ideológica de governo e materialização de ações, trazendo consigo algum cunho político, social e/ou político, após delineadas e formuladas, podem constituírem-se em "planos, programas, projetos, bases de dados ou sistema de informação e pesquisas" (Souza, 2006, p. 34).

0 governo constrói as políticas, e sua reavaliação deve ser constante, cujo objetivo de avaliar acerca de suas metas e efetivação junto ao público destinado. Pensando na política pública como estratégia de governo, para resolver algum problema da população, indagamos, como o Estado Brasileiro tem pensado as políticas públicas educacionais para igualdade de gênero e diversidades?

Na década de 90, documentos como os Parâmetros Curriculares Nacionais (PCN's), legitimaram a necessidade de se trabalhar as questões de gênero em todos os níveis de ensino, fundamental I, fundamental II e médio. A presença dos temas transversais como gênero e raça em documentos como os PCN's deve-se a presença maciça do movimento feminista no processo de redemocratização do país. Neste documento destaca-se, as relações de gênero como referências fundamentais para a constituição da identidade/subjetividade de crianças e jovens e são coerentes com os fundamentos e princípios da Constituição Federal, na medida que trazem como espinha dorsal da educação o exercício da cidadania e apresentam a inclusão de temas da vida cidadã, objetivando destacar a importância da "dignidade da pessoa humana, a igualdade de direitos, a participação ativa na sociedade e a corresponsabilidade pela vida social" (Vianna,Unbehaum, 2004, p.96).

Esse documento representa um significativo avanço em relação à adoção de uma perspectiva de gênero. Especialmente sobre o fomento das discussões sobre as temáticas de gênero, os PCN's objetivam:

[...] o combate a relações autoritárias, questionar a rigidez dos padrões de conduta estabelecidos para homens e mulheres e apontar para sua transformação, incentivando, nas relações escolares, a diversidade de comportamento de homens e mulheres, a relatividade das concepções tradicionalmente associadas ao masculino e feminino, o respeito pelo outro sexo e pelas variadas expressões do feminino e do masculino. (BRASIL, 1997, p.144).

Entretanto, a questão de gênero se perdeu depois de ter sido incluída no currículo das escolas, mesmo depois dos debates dos anos de 1980, os temas transversais incluídos nos parâmetros curriculares nacionais, incluíndo gênero foram recebidos com muita resistência na década mencionada e ainda hoje é questão polêmica. Embora tudo o que foi feito não garantia mudanças, esperava-se que ao vivenciar a democracia e assimilar os valores de igualdade, de liberdade, de direitos, meninas e meninos passariam a se ver como sujeitos de direitos e compreenderiam o seu papel de cidadão e cidadã, questão essencial para a consolidação democracia. 
Conforme Blay (1988), o movimento das mulheres brasileiras construiu uma ação política contra as decisões do poder. Orientando as ações para a construção de um novo espaço público, do qual elas também fazem parte. Começaram a problematizar as ações e omissões de quem deveria defender, como os sindicatos e associações de classe, discriminações disseminadas pela imprensa e ensino, buscando mudanças dentro da estrutura sindical, da organização político-partidária e das próprias leis que regem os direitos civis. Esse processo culminou com a criação dos Conselhos da Condição Feminina e das Delegacias de Defesa da Mulher, inicialmente no Estado de São Paulo.

Já em 2007, foi proposto o Plano Nacional de Educação em Direitos Humanos, no qual pôde contribuir para o resgate e ampliação do debate acerca da igualdade de direitos de mulheres e homens nas escolas e na sociedade. Outro ganho do movimento feminista, em termos de política de Estado, que contribuiu para mudanças no que diz respeito à educação para a igualdade de gênero, foi a criação da Secretaria Especial de Políticas para as Mulheres, no primeiro dia do governo do presidente Luiz Inácio Lula da Silva, em 2003, objetivando desenvolver ações conjuntas com todos outros Ministérios e Secretarias Especiais e apresentava como metas, a incorporação das especificidades das mulheres nas políticas públicas e o estabelecimento das condições necessárias para a sua plena cidadania. Apesar do reduzido avanço, frente as conquistas que se almeja no cenário político, não se pode negar que a história de luta das mulheres revela êxitos.

Ainda em 2007, o Ministério da Educação e do Desporto, iniciou um processo de formação contínua para educadores e educadoras das escolas públicas estaduais, versando sobre Ética e cidadania: construindo valores humanos na escola, no qual as questões dos direitos e de gênero foram contempladas, buscando contribuir para mudanças no que se refere à educação em direitos humanos e sensibilidade à questão de gênero.

No entanto o trabalho docente feminino, além de ser um processo regulador produzido pelo sistema capitalista, encontra-se engendrado por uma heteronormatização, no qual valoriza-se o masculino, acentuando-se controle via sistema social, sobre a vida das mulheres. E tal situação pode ser uma das explicações para a insensibilidade de educadoras e educadores a respeito da questão de gênero. Além do fato de os cursos de formação de educadoras/es não abordarem a temática. A profissão magistério de certo modo discrimina a mulher, na medida que não proporciona a reflexão necessária acerca da questão do "ser mulher" e da questão de gênero (Brabo, 2005).

A pesquisa teve por objetivo analisar as produções acadêmicas sobre igualdade de gênero nas escolas de ensino fundamental no Brasil, no período correspondente a 2003 a 2014, especialmente teses e dissertações, no banco de teses e dissertações da CAPES. A escolha por este período possui como motivação o fato de ter sido o momento brasileiro em que mais pautas feministas e de outros movimentos de minorias foram atendidas pelo Governo Federal, muito em função do modelo de gestão que se iniciava.

A partir do contexto histórico descrito acima, nos permitiu trazer para o diálogo das interpretações autoras como as feministas pós-estruturalistas como Butler (2003), Rubin, (1993/ 2003), como também Foucault (1988/2013).

O conceito de gênero proporcionado por Judith Butler(2003) nos promove o entendimento da performatividade dos corpos, cujas relações de poder estão neles engendrados, revelando a necessidade de pensar o sistema sexo/gênero para além dos binarismos. A necessidade de educadoras e educadores estarem sensíveis a essa questão possibilitará uma prática educativa menos contributiva para uma sociedade misógina, machista e homofóbica, quando educadoras e educadores não se posicionarem binariamente em relação a existência humana.

Gayle Rubin (1993/2003) contribuirá para pensar a respeito da opressão das mulheres e a circulação de acordo com os ditames do Estado e dos sistemas econômicos. Sua teoria possibilitará refletir sobre qual lugar da mulher (menina) neste intervalo entre 2003 a 2014, na visão dos educadoras e educadores.

Por último, Michael Foucault (1988/2013) contribuirá através do seu conceito de biopolítica para analisarmos como as práticas docentes contribuem para o governo dos corpos e de que forma essas práticas são produtoras de subjetividades. 


\section{MÉTODO}

Este trabalho de abordagem qualitativa, é de natureza bibliográfica exploratória- descritiva, pois a medida em que tentará proporcionar maior familiaridade com o tema pesquisado, assumirá a forma de estado da arte das produções acadêmicas sobre a temática. 0 material selecionado como fonte de pesquisa, são as teses e dissertações do banco da CAPES/ BDTD, cujo mote é, políticas educacionais, iguldade de gênero no trabalho docente do ensino fundamental. Como instrumento utilizado para obtenção das teses e dissertações, foi realizado por mecanismo de metabusca (Gil,2010). A identificação e localização das produções acadêmicas, deu-se pela leitura exploratória, tendo como objetivo, verificar em que medida a produção acadêmica consultada interessa à pesquisa.

Desse forma, o método utilizado para a coleta dos dados deu-se da seguinte forma: inicialmente pelo acesso ao BDTD busca avançada com a inclusão das palavras chaves feminismo; Ensino Fundamental; Gênero. Neste primeiro filtro buscamos coletar especialmente através da leitura dos títulos e resumos encontrar teses e dissertações que atendessem nossos objetivos e apesar de surgirem pesquisas, ainda inserido os filtros, muitos trabalhos não atendiam ao objetivo principal que foi analisar as produções acadêmicas sobre práticas docentes quanto a questões de gênero no ensino fundamental no período de 2003 à 2014. Um segundo filtro foi utilizado pela inserção das palavras chaves feminismo, educação e gênero. E neste segundo filtro ampliou-se mais o universo dos trabalhos para várias áreas de conhecimento que fugiam do universo do ensino fundamental.

Do universo coletado que parcialmente atendiam o objetivo da nossa pesquisa totalizou em 151 trabalhos, entre teses e dissertações, sendo que incluídos no corpus da pesquisa somaram 14 e 137 foram excluídos.

Outro objetivo a ser alcançado foi identificar as produções acadêmicas por região do país quanto a quantidade e especificidade. Dessa forma todas as pesquisas foram agrupadas segundo as cinco regiões do país.

Este percurso utilizado nos possibilitou nos aproximarmos da diversidade de produções acadêmicas segundo as regiões do país, como também observamos a disparidade de produções entre as mesmas regiões.

\section{RESULTADOS}

Os dados coletados que compõem o estado da arte da pesquisa nos revelou através do primeiro filtro, quando inserimos os descritores feminismo, ensino fundamental e gênero, para produções acadêmicas no período de 2003 à 2014, que há um total de 18 pesquisas acadêmicas entre teses e dissertações que discutissem práticas docentes relacionadas igualdade de gênero, em escolas do ensino fundamental, no qual foi encontrada, 7 na região Sul, 5 na região Nordeste, 4 na região Sudeste, 2 na região centro-oeste e 0 na região Norte. Desse total, apenas 6 foram aceitos para serem analizados e 12 não foram aceitos.

Os motivos para que algumas pesquisas fossem aceitas como integrantes da coleta de dados foi o fato dessas mesmas relatarem a questão da prartica pedagógica dos professoras/es. Do mesmo modo, as que não fizeram parte diz respeito aos fato dessas pesquisas trazem a discussão das questões de gênero na formação profissional do educadora/r.

No entanto, os dados coletados através da inserção dos descritores feminismo, educação e gênero, nos trouxe um quantitativo maior de pesquisas acadêmicas dentro do período pesquisado. Encontramos 133 pesquisas acadêmicas entre teses e dissertações. Sendo que 49 foram pesquisas produzidas na região Sul, 36 na região Nordeste, 34 na região sudeste, 14 na região centro-oeste e 0 na região Norte. Desse total, apenas 8 fizeram parte do corpus da pesquisa e 125 não foram incluídas. Destes 8 trabalhos, 4 ja haviam sidos selecionados na busca com o primeiro filtro.

O motivo para a exclusão dessas pesquisas, diz repeito ao fato do interesse dos pesquisadores/as versarem sobre as questões de gênero na formação profissional durante o período em que eram universitários/as em várias áreas como enfermagem, gestão de recursos humanos, licenciaturas e profissões na área de exatas. 


\section{DISCUSSÃO}

Apesar da introdução dos temas transversais nos documentos oficiais do MEC, no início dos anos 2000, ainda é observado uma baixa produção acadêmica acerca das práticas docentes sobre gênero no ensino fundamental. Isto pode ser justificado pela invisibilidade dentro da formação das/os docentes a inserção de temas como gênero nas grades curriculares da graduação, principalmente de pedagogia, conforme afirmou Tânia Brabo (2005).

O que observamos das produções acadêmicas é que elas revelaram uma prática pedagógica de professoras/es ainda arraigada a heteronormatividade, a padrões sociais definidos do que é feminilidade e masculinidade; assim como a presença da relação sexo/gênero como um sistema que permeia discursos e práticas pedagógica no espaço escolar. A essencialização dos corpus pela presença dos discursos biológicos fizeram também presentes nas pesquisas.

A pesquisa de mestrado de Priscila Dornelles (2007) a respeito da separação ou não de meninas e meninos nas aulas de educação física escolar encontrou revelou que entre os professoras/es pesquisados por ela:

“[...] o discurso biológico define e essencializa algumas marcas corporais como determinantes na constituição de meninos e meninas, diferenciando-os/as, hierarquizando-os/as e separando-os/as na Educação Física escolar. A "estrutura muscular inferior" das meninas é significada como origem de outros atributos considerados naturais no universo feminino, como menor força e energia. Essa discursividade sobre o corpo atribui à estrutura muscular/física a medida para classificar e separar meninos e meninas através de um movimento que também constitui os corpos dos meninos como referentes e possuidores de força, potência e agressividade." ( p. 137)

A precepção binária dessas/es professoras/es de educação física escolar, em geral proporcionada por uma formação exclusivamente biológica, contribui para que meninas e meninos compartilhem de mais um espaço dentre muitos que não educam para quebrar padrões e esteriótipos de corpos que são percebidos como devendo funcionar em acordo com o sexo biológico. Afinal, não há meninas mais altas, fortes, robustas e agressivas do que alguns meninos da mesma idade? Como também percebemos a presença de meninos menos agresivos que meninas em jogos competitivos?

As relações de poder perpassam pela perfomatividade dos corpos (Butler, 2003), de certo a construção social dos corpos produziram padrões sociais do que é ser feminino e masculino. No entanto, refletir sobre esses padõres se faz necessário quando nos deparamos com aquelas meninas e aqueles meninos que quebram a norma daquilo que está no imaginario de como se comportam em atividades esportivas competitivas. Dessa forma, olhar para o que foge da norma, ajuda a pensar a norma como estar e essa sim, é que está fora da ordem, parafraseando Caetano Veloso, em sua canção Fora da ordem de 1991.

Em sua pesquisa de doutorado, Dornelles (2013) continua demontrando que as práticas pedagógicas desta área de conhecimento segue artiriculada a percepção de uma forma fixa e etapista da sexualidade:

“[...] os sujeitos são 'cristalizados' pela idade cronológica de seus corpos quando se trata das pautas políticas de regulação da sexualidade. Com isso, as práticas pedagógicas promovidas por essa disciplina escolar pautavam, basicamente, o pressuposto da assunção unilinear (sexo-gênero-prática sexual) da sexualidade a partir da adolescência."(p.162)

Essa forma de pensar e construir sujeitos produz subjetividades (Foucault, 2013) que seguem reproduzindo nas novas gerações uma ideia de que o que é diferente não é normal e deve ser rechaçado. Essa forma de regular a sexualidade continua a ser exercida por disciplinas que ainda percebem sujeitos como binários e que funções, atitudes e comportamentos devem não contrariar o sistema sexo/gênero.

Gilva Matos (2014) quando fez sua pesquisa, realizou observações de aulas, análise do material de leitura utilizado nos eventos de leitura, e análise dos relatos de diálogos com as/os educadoras/es e da aplicação de questionário, numa escola da rede municipal da Paraíba, afirma que nada há no projeto de leitura que problematize a reprodução da desigualdade de gênero. E que: 
"[...]os/as colaboradores/as uma formação discursiva reproduzindo e produzindo a iniquidade de gênero, a reprodução de regras e valores que elegem uma visão androcêntrica e heterossexual, traçando para os que não pertencem a este modelo o estigma de diferente, de abjeto, passível de ser enquadrado". (p.125)

Gayle Rubin (2003) nos ajuda a refletir sobre a opressão das mulheres e das meninas, pois o lugar do homem é sempre o da primeira ordem. Mocinhos, bandidos, heróis ou não, os meninos tem o privilégio de exista um personagem para se identifiquem, fantasiem, ou seja, encontram na leitura desse projeto alicerce para continuarem a reproduzir a figura masculina como sujeito universal. $\mathrm{E}$ as meninas? $\mathrm{O}$ que lhes restam? Capturar a imagem da figura universal e distanciar-se porque não se sente representada, ocupando o segundo lugar, ou o segundo sexo?

Assim, essa ausência de discussões sobre desigualdade de gênero junto as/os alunas/os, pode contribuir para a manutenção do status quo da opressão pela via do negligenciamento das contigências entre meninas e meninos, o que as/os fazem ser como são. E no caso das meninas pode surgir a naturalidade das opressões vividas por causa das ausencias de possibilidades de refletir sobre que lugar esse herói ocupa e porque não há uma representatividade para as meninas, principalmente as que quebram as normas de um ordem social ainda vigente.

Mas nem tudo está perdido, Diana Lusa (2010), em sua pesquisa de mestrado encontrou olhares e práticas pedagógicas de professoras e professores que visam construir um mundo sem desigualdades de gênero. É possivel perceber isso quando a autora afirma:

“[...] cada um/a a sua maneira, estas docentes e este docente que observei estão contribuindo para um outro tipo de formação [...]. São professoras e professor que têm presente as discussões de gênero e talvez por isso pensem mais e acabem fazendo as crianças pensarem mais sobre o "ser menina" e o "ser menino" como algo que se vai construindo." (p.89)

A dissertação de Amanaiara Miranda (2014) demonstra que as questões relacionadas a gênero/sexo/sexualidade, por parte dos professores pesquisados se baseam em pressupostos teóricos e filosóficos específicos da Biologia, Psicologia e da Religião para pensar ou atuar na Educação Infantil. Seu estudo demonstrou que o discurso docente de um modo geral se desenvolve sob a ideia de que a criança é um ser assexuada e heterossexual, ignorando interpelações das crianças que fogem da heteronormatividade. No entanto algumas professoras seguem com discursos de que deve-se ter uma educação que respeite as diferenças.

Mas, de um modo geral, a pesquisa demonstrou que os estereótipos de gênero apontaram para:

"a construção e manutenção dos papéis de gênero estabelecidos para homens e mulheres, numa perspectiva de inferiorização do feminino sob o masculino. A figura do homem serve como referência para a força física, desobediência, razão, dentre outros. A figura da mulher serve como referência para o cuidado com o outro, delicadeza, fragilidade, dentre outros". (p. 142)

A construção do sistema sexo/gênero (Butler, 2003), produzido pelos saberes científicos, contribuíram para uma produção de subjetividade (Foucault, 2013), que continua sendo repassada para as novas gerações. Os papéis e funções sociais muito questionados, principalmente devido a ascenção da mulher no mercado de trabalho, ainda muito aquém do desejado, por motivos que aqui não podemos explanar, ainda são reproduzidos nos discursos de educadoras e educadores. Ser delicada ou delicado não deve ser caracterizado como aspecto do feminino e assim inferiorizado.

Se em uma época da história do processo civilizatório, houve divisões do trabalho para mulheres e homens devido a constituição biológica, homens vão para a caça e mulheres preparam os alimentos, foi porque naquela época a subsitência pedia tal divisão. De lá para cá, muita coisa mudou, o homem não precisa mais caçar animais perigosos para trazer comida para casa e a mulher de hoje precisa contribuir para o orçamento doméstico. Então o mundo do trabalho atual precisa de agressividade, competitividade e robustez para conseguir e manter-se no mundo do trabalho e assim trazer comida à mesa? Os corpos femininos e masculinos estão aptos para o exercício de qualquer função profissional, não há mais do que duvidar sobre isto. 
Então porque ainda ensinar as crianças que há um sujeito universal e que o segundo sexo é inferiorizado, quando as próprias crianças não clamam por isso? Porque a heteronormatividade é compulsória.

Não podemos mais aceitar o que a pesquisa de Rita de Cássia Moreira (2008), encontrou em sua dissertação de mestrado:

"Ao longo desta dissertação, as respostas a esses questionamentos foram se evidenciando a cada entrevista, cada análise, cada observação. Em tudo a forte marca, o indelével sinal de que a construção da identidade feminina (e masculina também) ainda está pautada no modelo historicamente criado, reproduzido e validado socialmente de mãe/mulher, pai/provedor."(p.161)

\section{CONSIDERAÇÕES FINAIS}

Dessa forma, podemos afirmar que apesar de todo o avanço conquistado com o feminismo, construindo uma visão menos binária das relações de gênero, ainda há muito no que se avançar. Ainda com a introdução dos temas transversais nos documentos oficiais do MEC, no início dos anos 2000, ainda é observado uma baixa produção acadêmica acerca das práticas docentes sobre gênero no ensino fundamental. Isto pode ser justificado pela recente e incompleta formação das(os) docentes que contemple temas como gênero e sexualidade nas grades curriculares da graduação, defendida pela pedagogia feminista.

Educadoras/es precisam compreender seu importante papel para a construção de uma sociedade menos misógina, machista e homofóbica, precisam não se posicionarem binariamente em relação a existência humana, merecendo ser vista como diversa e plural, para criarmos a consciência e respeito a todas/os. Agindo desse forma, não estamos dizendo que a escola passará a produzir gays e lésbicas, como já foi proferido por alas mais conservadoras da sociedade, mas que haja mais respeito e possamos ser apenas pessoas vendo pessoas.

\section{REFERÊNCIAS}

[1] Blay, E. A. (2002) Gênero na Universidade, Educação em Revista, Universidade Estadual Paulista, Faculdade de Filosofia e Ciências, n.3, Marília, UNESP-MaríliaPublicações, pp. 73- 78, 2002.

[2] Brabo, Tânia Suely Antonelli Marcelino. A cidadania da mulher professora, São Paulo, Editora Ícone, 2005.

[3] Educação e democracia: o papel no movimento feminista para a igualdade de gênero na escola, ex æquo , n.o 17, pp. 155-165, 2008.

[4] Brasil. Parâmetros Curriculares Nacionais para o Ensino Fundamental I. Brasília: MEC/SEF, 1997.

[5] Butler, Judith. Problemas de gênero: Feminismo e subversão da identidade. Rio de Janeiro: Civilização Brasileira, 2003. 235 p.

[6] Dornelles, Priscila Gomes. A (hetero)normalização dos corpos em práticas pedagógicas da Educação Física escolar. Porto Alegre: Faculdade de Educação da Universidade Federal do Rio Grande do Sul, 2013.

[7] Dornelles, Priscila Gomes. Distintos destinos? : a separação entre meninos e meninas na educação física escolar na perspectiva de gênero. Porto Alegre: Faculdade de Educação da Universidade Federal do Rio Grande do Sul, 2007.

[8] Foucault, Michel. História da Sexualidade: a vontade de saber. 13. ed. Rio de Janeiro: Edições Graal, 1988. 1 v.

[9] Genealogia da Ética, Subjetividade e Sexualidade. Rio de Janeiro: Forense Universitária, 2013. 9 v.

[10] Gil, Anonio Carlos. Como Elaborar Projetos de Pesquisas. 5. ed. São Paulo: Atlas, 2010. 200 p.

[11] Lusa, Diana. Anos iniciais da escolarização e relações de gênero:representações de docentes sobre gênero. Pelotas. Universidade Federal de Pelotas, 2010.

[12] Matos, Gilva Vasconcelos da Silva. Leitura e relações de gênero: as discursividades dos(as) educadores(as) nas mediações de práticas leitoras. Paraíba. Universidade Federal da Paraíba.2014.

[13] Miranda, Amanaiara Conceição de Santana. Gênero/Sexo/Sexualidade: representações e práticas elaboradas por professoras/es da educação infantil na rede municipal de ensino em Salvador. Salvador. Universidade Federal da Bahia. 2014.

[14] Moreira, Rita de Cássia Costa. Sinais de gênero nas diferentes linguagens que tecem o discurso na escola. Salvador. UFBA/FACED, 2008. 
[15] Rubin, Gayle. O tráfico de mulheres. Notas sobre a 'Economia Política' do sexo. Tradução de Christine Rufino Dabat. Recife: SOS Corpo, 1993.

[16] Pensando sobre sexo: notas para uma teoria radical da política da sexualidade. Cadernos Pagu, Campinas: Núcleo de Estudos de Gênero Pagu, n. 21, p. 1- 88, 2003.

[17] Souza, Celina. Políticas Públicas: uma revisão da literatura. Sociologias, Porto Alegre, a. 8, n. 16, p. 20-45, jul/dez, 2006.

[18] Vianna, Cláudia Pereira; Unbehaum, Sandra. O gênero nas políticas públicas de educação no Brasil: 19882002. Cadernos de Pesquisa, São Paulo, v. 34, n. 121, p.77-104, 2004. 


\section{Capítulo 20}

Educação feminina na Bahia: Uma interlocução entre literatura e relações de gênero na obra de Mabel Velloso

Rita de Cássia Costa Moreira

Maria José Souza Pinho

Resumo: A história de mulheres e homens é atravessada por linguagens, por relações de gênero e poder que inserem diferentemente os sujeitos na história. A forma como as mulheres tiveram acesso aos processos e espaços educacionais, é fator determinante de sua participação no mundo público. Neste artigo, uma breve e provocativa análise da trajetória da professora e escritora baiana Mabel Velloso: sua formação, sua experiência em educação, seu envolvimento com a leitura e a literatura, suas publicações e suas implicações com a tradição cultural baiana, na busca de uma profícua interlocução entre a sua história, a História da Educação e das mulheres na Bahia.

Palavras-chave: História, Relações de gênero, Educação feminina. 


\section{INTRODUÇÃO}

Excluídas da educação formal até o século XVIII, aproximadamente, quando o advento da burguesia inscreveu profundas mudanças e marcas na história e na realidade social: na economia, a ascensão do capitalismo e a necessidade de mão-de-obra; na família, pautada nos rígidos e conservadores ideais vitorianos, o modelo nuclear - pai, mãe e filhos; na educação, o espaço escolar como reduto exclusivo do saber legitimado; as mulheres eram educadas em casa, para que impregnadas do pensamento moral e dos bons costumes, exercessem a sua missão/destino: a maternidade. Em casa, até o momento em que eram enviadas aos conventos, as meninas eram educadas para a assunção do papel social de esposa, mãe, cuidadora.

A escola como instituição responsável pelo ensino formal (inicialmente para meninos) nasceu, fortaleceuse e legitimou-se no seio desta ideologia burguesa e do ideal de formar meninos/homens para a "vida" e, consequentemente, para o espaço público ${ }^{56}$; ao tempo em que formava meninas para o lar, para vida em família, para o espaço privado, e para a maternagem. Uma escola fortemente inspirada nos ideais romanos de educação (formação de jovens e de carreira cujo interesse seja a ocupação do espaço social), onde a valorização do intelecto e a instrução literária fincada em modelos foram determinantes para a separação entre o ambiente doméstico (interpretado como feminino) e o não doméstico (fora de casa, masculino).

Uma escola marcadamente presente na trajetória da professora e escritora baiana Mabel Velloso: em sua formação (o magistério), em sua experiência educativa (professora primária e Diretora de escola pública), em seu envolvimento com a leitura e a literatura, em suas publicações - rico acervo da tradição cultural baiana, em sua ação como contadora de história e formadora.

Neste artigo, um breve e provocativo mergulho na prosa poética de Mabel Velloso e, ao mesmo tempo, na história da educação feminina na Bahia; nesta interlocução, um encontro com a História, a Educação, a Literatura, as Relações de Gênero.

\section{EDUCAÇÃO FEMININA: ESCRITA E LIBERDADE}

Os primeiros conventos/escolas para mulheres foram fundamentais para a manutenção da cultura e do pensamento dominante - heterossexual e androcêntrico - mas também para a "libertação" feminina. Nos conventos, inicialmente a única via de acesso para a formação feminina - a possibilidade de pensar numa mulher educável, pronta para ajustar-se ao modelo da mulher ideal (incansável, bem formada, maternal, submissa) - a mãe - dona de casa. Na escola, o domínio da escrita e de conhecimentos que dessem suporte para o bom desempenho do papel doméstico, um papel decisivo para a formação e reprodução de mão-deobra, papel que permitiria à mulher maternar de acordo com os padrões éticos e religiosos do período.

Cuidado, atenção, carinho, idoneidade e proximidade com a maternagem, configuraram a atividade docente no Brasil como forma legitimada de inserção das mulheres no universo do trabalho e na ocupação do espaço público. Uma ocupação apontada como caminho para a realização pessoal, profissional e cidadã pois era preciso ser útil à pátria num momento de grandes transformações políticas e econômicas porque passava o país no século XX. Assim ilustra Jane Almeida (1998, p. 33) sobre a instrução feminina no século XIX:

Mantida dentro de certos limites, a instrução feminina não ameaçaria os lares, a família e o homem. Essa educação, que a princípio e de acordo com a tradição portuguesa, fora negada sob o pretexto de que o conhecimento e sabedoria eram prejudiciais e desnecessários a sua frágil constituição física e intelectual, acabou por revelar-se desejável a partir do momento em que a mulher passou a ser vista, na sociedade da época, como a principal mantenedora da família e da pátria.

A modernização da sociedade, os discursos que defendiam o papel da mulher como "talhado" para o magistério, a discutível associação à maternidade e ao essencialismo ${ }^{57}$, favoreceram sua entrada e permanência neste campo profissional.

\footnotetext{
56 Cabe ressaltar que Público e Privado são expressões aqui utilizadas como categorias de análise feminista e compreendem a concepção historicamente construída de Público: como espaço masculino, legitimado (fora de casa); e Privado como espaço feminino, desvalorizado (doméstico).

57 Ideia de uma essência universal e comum a todas as mulheres, espinha dorsal do determinismo biológico
} 
Nessa perspectiva, a mulher-professora foi vista como sinônimo de cuidado, de ternura, de docilidade e, não necessariamente, de competência. Sua ação profissional seria vocação, seria missão o que favoreceria um imaginário que as distanciava de reivindicações político-salariais (Faria Filho, 2005). Já o homem professor era visto como profissional revestido de autoridade, de poder, de competência.

Apesar da paradoxal situação de dirigida (submissa ao marido), e dirigente na função professora/dona de casa, a docência feminina marcou, no cenário brasileiro, a tentativa de uma reconhecida ocupação do espaço público pelas mulheres. Mesmo porque, o avanço do capital e a crescente urbanização e industrialização trouxeram, em seu bojo, a mudança de mentalidade, de papéis e atuação na vida social, para mulheres e homens. Tornava-se necessário, portanto, adequar a educação feminina ao novo projeto social. Vale ressaltar, que essa adequação ainda estava longe do reconhecimento ideal, mas evidenciava-se como um processo irrefreável de transformações e de configuração de um novo olhar sobre a questão feminina. Como bem analisa Helleieth Saffioti (1976: p. 179-180):

[...] Deste maior ajustamento da estrutura da família às novas condições de vida urbano-industrial adviriam profundas alterações na educação feminina. Se, por um lado, o ideal da educação doméstica se conservava, por outro lado, a necessidade da educação escolarizada para a mulher fazia sentir-se de maneira crescente. Obviamente, este processo não representava a consciência de que a mulher deveria receber educação idêntica à do homem, nem a equiparação social dos papéis tradicionalmente atribuídos a representantes de um e outro sexo.

Dos primeiros movimentos em prol da educação feminina realizada nos conventos, à outra ação sobre a educação e a inserção das mulheres na dinâmica social, transformações e permanências. Este mesmo convento que cerceava e autorizava a leitura feminina e sua apresentação à língua escrita, se tornou também o passaporte para a sua consciência crítica, um paradoxo que permitiu a muitas mulheres dar um decisivo passo em direção à sua visibilidade histórica.

Da leitura de missais, da Bíblia, dos cânticos religiosos e dos romances familiares e educativos, para a escrita. Uma escrita, de início, ligada à religiosidade, à formação cristã, às íntimas expressões de um diário fechado a "sete chaves", às correspondências entre amigos e familiares. Da escrita íntima para o mundo, para os jornais, as revistas, os livros. Um caminho de poucos registros históricos, quando comparados ao acervo masculino, mas de muitos vestígios. Como historiam Michele Perrot e Georges Duby (1994), essas mulheres, pioneiras da escrita, ilustraram diferentes tempos e contextos históricos com uma original e situada, visão de mundo.

Um caminho também vivido por Mabel Velloso - o Colégio de freiras, como de tantas outras mulheres ao longo da história, marcou o início de sua formação escolar. Um espaço prenhe de ideologias, de estereótipos, representações sobre ser mulher, ser homem; espaço de assimetrias, de relações de poder. Inicialmente num Colégio de Freiras em Santo Amaro, o Nossa Senhora dos Humildes (onde estudou até o 4 o ano primário) e depois em Salvador, juntamente com suas irmãs e irmãos recebeu educação esmerada, nos melhores colégios da época. 0 que lhe permitiu circular entre a poesia, a música, a literatura, os manuais de comportamento, a severa disciplina e neles, a ampliação da leitura de mundo e a manutenção da ideologia vigente.

Um colégio de referência, sempre perto de casa, não interno (o externato foi incorporado à prática escolar nos primeiros anos do século XX), mas cheio de exigências, de austeridade. Neste espaço as meninas internalizavam valores morais, costumes, tradições, fé católica e conhecimentos específicos para que assumissem seu papel de mulher: a casa, os filhos, o marido. Como afirma Elizete Passos (1995, p. 121) "[...] as mulheres deviam receber uma educação firme, capaz de prepará-las para ocuparem-se da casa e dos filhos".

O Santa Bernadete 58 foi o Colégio de freiras onde Mabel Velloso ingressou no 5ํo ano, já em Salvador. 0 ano vivido neste colégio deixou fortes marcas na jovem Mabel Velloso:

\footnotetext{
58 Colégio situado na Ribeira, mais especificamente no Convento da Penha, criado por freiras alemães refugiadas da guerra, sob a inspiração da Congregação das Freiras Missionárias da Imaculada Conceição da Mãe de Deus, em 1930.
} 
Primeiro que lá tive logo zero em redação; a freira/professora mandou todo mundo escrever o dia mais feliz da vida, botou no quadro "escrever sobre o dia mais feliz da vida" - e eu escrevi. E quando veio todo mundo dando nota boa, o meu foi zero porque eu descrevi o dia mais feliz da minha vida: um banho que eu tomei de cachoeira e tinha que ser o dia da primeira comunhão, aí foi o primeiro zero e o único que eu tomei na minha vida. Eu fiquei muito assustada e decepcionada (Velloso, Mabel - depoimento pessoal)

Marcas ressignificadas quando do seu ingresso, aos 14 anos, no Ginásio Itapagipe (hoje João Florêncio Gomes); Colégio Estadual inaugurado em 1949 e inspirado numa educação para a sensibilidade, para a musicalidade, para o conhecimento.

Dirigida pelo educador baiano Doutor Adroaldo Ribeiro Costa ${ }^{59}$, conhecido por suas ideias originais e inovadoras em educação, esta instituição teve participação fundamental na formação educacional de Mabel Velloso. Neste colégio, tão diferente daqueles gerenciados pelas Irmãs, a jovem Maria Isabel encontrou como relata, a "salvação da minha vida". Nele escrevia bastante e com prazer redação, dissertação, composição sobre temas livres, sob a orientação das professoras Candolina e Iramaya, professoras de Língua Portuguesa e ícones da educação na Bahia entre 1930 e 1970. Não à toa Caetano Velloso registrou no poema/canção Neide Candolina (1991), sua homenagem a esta grande educadora: “[...] Ela é Neide Candolina total. E a cidade, a baía da cidade, a porcaria da cidade, tem que reverter o quadro atual para lhe ser igual".

Educada sob os inflexíveis padrões do Colégio de freiras, e ao mesmo tempo num ambiente familiar "onde as coisas eram todas muito naturais", Mabel Velloso viveu sua experiência educativa e escolar, como menina/mulher educável entre as décadas de 1930 e $1950^{60}$. Em Santo Amaro, cidade histórica e patriarcal do Recôncavo Baiano, ela viveu as primeiras experiências com as letras ouvindo histórias, poemas e canções com a mãe, o pai e a cozinheira.

No tradicional bairro da Ribeira, a jovem Mabel Velloso desenvolveu outro olhar sobre a escola, a educação, as trocas sociais. Aí caminhou pelas leituras clássicas, pela emoção da escrita "livre", pela valorização de sua capacidade criativa e escritora, pelo amor à docência, por novas possibilidades de pensar. Para ela (em depoimento): "Foi muito bom, mas um tempo muito bom meu tempo de aula, de escola de tudo, foi muito bom - tanto que eu acho que escola é a coisa melhor do mundo".

No Instituto Normal, hoje ICEIA, formou-se professora. O Instituto Normal da Bahia, construído entre anos de 1936 a 1939, em seus 176 anos de história, foi inaugurado 1939, abrigou (e inda abriga) estudantes de diferentes idades e classes sociais. Seu ensino público e gratuito focalizava crianças do Jardim de Infância, (hoje Educação Infantil) ao Magistério. Numa estrutura construída sob a inspiração arquitetônica modernista da década de 30 , salas amplas, bem ventiladas, com largas galerias, era apto para atender à crescente demanda educativa da capital baiana. Lá, para a jovem, sensível e já ativa professora Mabel Velloso, havia inspiração. Avidamente ensinava saberes, vida, arte, sensibilidade, poesia; assim exercitava seus dotes docentes, sua veia poética, sua paixão pela literatura.

Sua eclética experiência com as valsas, cantaroladas pela mãe, D. Canô, os poemas de Castro Alves e Artur Sales declamados pelo pai na hora de dormir, os textos bíblicos, as/os docentes que marcaram sua vida, os manuais de conduta lidos e interpretados na escola e a forte influência da cultura regional promoveram, num misto de ansiedade, beleza e medo, um olhar sensível, poético e ao mesmo tempo lúcido sobre a realidade, a docência e as relações sociais. Promoveram, na mulher Mabel uma formação fincada no compromisso de ensinar, na experiência prática, no prazer e no desejo de educar para a consciência crítica e a sensibilidade.

\footnotetext{
${ }^{59}$ Adroaldo Ribeiro Costa (1917-1984), advogado, escritor, compositor, professor e jornalista, cedo envolveu-se com o magistério e com atividades literárias, teatrais e esportivas com seus alunos. . Fundou, com a professora Denise Tavares, a Biblioteca Infantil Monteiro Lobato e foi professor, e diretor do Instituto Normal da Bahia - ICEIA

60 Período de grandes transformações e acontecimentos: no Brasil a Revolução de 30 e a ditadura da Era Vargas, o Modernismo, o fortalecimento do cinema e da música nacional e das chanchadas, a saga dos cangaceiros; no mundo: o Fascismo de Adolf Hitler, a $2^{\underline{a}}$ Guerra Mundial, a Bomba Atômica, o sucesso das produções de Hollywood, os Anos Dourados, as tecnologias de massa...
} 


\section{AS MUITAS VOZES E HISTÓRIAS DE MABEL}

A vida, e a trajetória escolar e docente de Mabel Velloso se configuraram numa complexa mistura de experiência, sentimentos, aprendizagens, silêncios e história. Um caminho que a levou a romper a muralha do silêncio feminino, como tantas antes dela ousaram fazer (PERROT, 2008), Mabel Velloso revelou seus escritos. Não sem medo, não sem receio. Seus textos, inicialmente poéticos, foram lidos por sua advogada e amiga que imediatamente cuidou para que fossem publicados. Vem daí a primeira exposição pública de seus desabafos no livro Pedras de Seixo (1980), motivando uma série de outras publicações onde em prosa e poética revela sinais, traços e íntimos detalhes de sua história, trajetória, e construção de identidades: Mulher nos cantos e na poesia (1987), Terno (1995), Poemas Grisalhos (1997), Candeias (2000), Donas (2003) e Conversando com Nossa Senhora (2011).

A confortável situação financeira da família (seu pai, José Telles Velloso, era funcionário da Agência dos Correios e Telégrafos onde desempenhava a função pública de Agente Postal Telegráfico) lhe permitia o acesso à literatura clássica e aos poetas de que mais gostava: Artur Sales ${ }^{61} \mathrm{e}^{\text {Castro Alves }}{ }^{62}$. Com eles e sua poética, Seu Zezinho, como era chamado, embalava as noites de seus filhos, despertava neles fortes sensações e educava para o amor à leitura, à literatura, à palavra, à família.

Já a mãe, Dona Canô dirigia o bastidor, aparelho para bordar, em formato circular que lembrava a Mabel Velloso, um volante. Neste "volante", sua mãe dirigia os fios, superava obstáculos, fazia escolhas, driblava e marcava caminhos, educava. Enquanto bordava, Dona Canô cantava, conversava e repetia; repetia e ensinava; ensinava modelos, papéis, canções e tradições; e despertava na menina Mabel Velloso sonhos, quereres, poesia. No livro Donas (2003, p. 29), ela revela a força dos ensinamentos de sua mãe nos longos e prazerosos momentos em que a canção, emprestando sonoridade e leveza ao dia a dia, ensinava.

Na educação de Mabel Velloso a presença de um ensinamento fortemente vinculado à cristandade como revela no livro Conversando com Nossa Senhora. Esta mesma cristandade revela Maria que, com diferentes nomes e representações expõe um projeto de vida para outra forma de poder; não o poder criador, a autoridade suprema vinculada à masculinidade, mas o poder da doação, da abnegação e do amor incondicional associado à feminilidade e à maternidade: "[...] Toda criança aprende cedo a chamar Mãezinha do Céu. Para que cresça com saúde e seja sempre uma boa criança. [...] Uma só Maria com tantas invocações. Cada uma oferecendo mais segurança, força e fé". (Velloso, 2011, p 21). Uma formação determinante para as interpretações sobre o ser e o fazer de mulheres e homens na dinâmica social ao longo dos tempos.

Relatando a sua, e tantas outras histórias nas teias do seu discurso, Mabel Velloso nos convida a pensar e a despertar. Pensar na força das construções ideológicas veiculadas através dos processos educativos levados a termo pela família, pela religião e pela escola. Uma força presente nos modelos herdados e vividos, nos exemplos do cotidiano, nas canções, na literatura, nos manuais didáticos, enfim, nos veículos que entretendo, também educam mulheres e homens para a assunção de papéis sociais e para a manutenção da assimetria entre os sexos.

Mãe e professora. Papéis historicamente "talhados" para as mulheres. Uma construção social que define a conduta e os sentimentos adequados para que sejam aceitas e legitimadas socialmente. A não assunção da conduta maternal pode acarretar desajustes, pressões, desqualificação e exclusão social. Uma mulher que se nega a "atender o chamado da maternidade", da doçura, da submissão ao homem, do casamento e do amor abnegado e incondicional, é rechaçada socialmente. Vale destacar que este é um "chamado" que só existe no espaço das construções ideológicas, como aponta Simone de Beauvoir ([1949] 1980: p. 278): “[...] Não existe "instinto" materno: a palavra não se aplica em nenhum caso à espécie humana. A atitude da mãe é definida pelo conjunto de uma situação e pela maneira porque a assume. É [...] extremamente variável.".

\footnotetext{
${ }^{61}$ Artur de Sales (1879 - 1952), poeta baiano, natural de Salvador, tem sua produção poético/literária situada entre os anos de 1901 a 1930. Foi nomeado imortal pela Academia Baiana de Letras, onde ocupou a cadeira de número 03 até sua morte em 1952(Veiga, 1984). São dele os poemas Lúcia e Ocaso no Mar, citados por Mabel Velloso como os preferidos de seu pai para ninar os filhos.

62 Antonio de Castro Alves (1847 - 1871), um dos mais famosos poetas românticos da Bahia, conhecido e amado como "poeta dos escravos", teve sua produção marcada pela temática da liberdade e do amor. Seu envolvimento com a tendência revolucionária, a abolição da escravatura e a defesa da educação pelos livros "Livros, livros à mão cheia" o destacam como um precursor de boas novas e de lutas, para que o povo "[...] pudesse aprender a pensar" (Alves, 1997 p. 25) e assim participar ativamente da sociedade.
} 
Sendo mãe, Mabel Velloso acatava o modelo esperado, naturalizado para a feminilidade. Sendo professora abraçava a vocação, a missão de educar como próprias para a condição feminina, como extensão da sua função materna. Uma função que exigiria cuidado, atenção, disponibilidade e doçura, "próprias" da maternagem e apropriadas quando do ingresso das mulheres no espaço público (seja na docência, seja em outras áreas de atuação profissional).

Para mulheres e homens, culturalmente condicionados a assumir posturas e papéis socialmente legitimados, uma espécie de aprisionamento sustentado pelo determinismo biológico. Um cárcere, ainda que sem muros, sem grades, sem portões, mas de muitas janelas. Janelas discursivas que dizem de escolhas, assunções, de padrões sociais, de adequação, de tradição. Mas que silenciam e cerceiam reais possibilidades de existência para mulheres e homens concretos e impregnados de subjetividade, para além dos estereótipos que são impostos e "naturalmente" internalizados nos processos de socialização.

Tecendo e ensinando, contando e reproduzindo Mabel deixou profundas marcas na história da educação da Bahia. Desde que se formou em Magistério, em 1955 no ICEIA Mabel não parou de se dedicar à educação. E a literatura sempre foi a marca de sua metodologia. Por meio de suas histórias, as crianças descobrem sensações, emoções, tradições culturais. Em seus poemas, o traço intimista de quem viveu intensamente e tem muitas histórias pra contar.

Escreveu Terno (1995), uma "ode" à antiga e ainda viva, no Recôncavo baiano, tradição católica de homenagear a visita dos Reis Magos ao Menino Jesus com cânticos, flores e muita luz. Candeias (2000, p. 7) relato dedicado "[...] a todos que nasceram nas terras das Candeias e principalmente a quem renasceu nas águas dos seus milagres". Nele expõe sua devoção a Nossa Senhora das Candeias e seus saberes sobre a aparição de Nossa Senhora neste local, a construção da Igreja da cidade, as lembranças das romarias e dos romeiros, das evidencias de graças alcançadas e da enorme fé de um povo.

Escreveu Irmã Dulce: a luta de cada um, publicado pela editora Callis em 2005, onde relata a história desta mulher forte e de saúde frágil, possuidora de uma fé e vontade inabalável de ajudar o próximo. Conhecida mundialmente por sua índole caridosa, sua abnegação e firmeza de caráter, a Irmã Dulce dos Pobres (1914-1992) foi membro da Congregação das Irmãs Missionárias da Imaculada Conceição da Mãe de Deus. Reverenciada pela população baiana por seus feitos em nome do povo e, em especial a fundação das Obras Sociais Irmã Dulce, é conhecida como o Anjo bom da Bahia.

Escreveu as biografias de Caetano Veloso e Gilberto Gil, para a Coleção Mestres da Música no Brasil, da Editora Moderna. Publicação que busca, através de uma linguagem acessível a diferentes e jovens leitores, divulgar informações acerca dos grandes nomes da música nacional. Neles, Mabel Velloso tece, com indiscutível poética, o entrelaçamento entre a história de vida (recheada de musicalidade) desses autores, e a cultura regional. São obras que dizem de experiência de vida, de família, de amigos, de tradições e dos complexos processos de ensino e aprendizagem

Essas e tantas outras publicações, não lhe permitiram "viver da escrita", sua manutenção está diretamente atrelada à remuneração que recebe como professora pública aposentada. Fatores como o volume das tiragens em cada edição (e a dificuldade de reedição); o desinteresse editorial por poemas (ainda mais quando escritos por mulheres); e de grandes editoras que abracem suas produções locais (já que por decisão pessoal e política se nega a integrar o circuito editorial sul/sudeste) repercutem de maneira significativa no volume financeiro que obtém com suas obras.

\section{CONSIDERAÇÕES FINAIS}

Contanto e encantando Mabel Velloso abriu portas, janelas, novas possibilidades. Hoje, com mais de 80 anos, participando ativamente de projetos culturais, da formação de contadores de história pela Santa Casa de Misericórdia da Bahia, das aulas de poesia na Faculdade Livre da Maturidade e de eventos ligados à educação e à cultura, ela prega que para viver é preciso envelhecer "velhice é igual a trio elétrico, só não vai quem já morreu" (uma analogia à música de Caetano Velloso, Atrás do Trio Elétrico). Atenta e participativa em diferentes instâncias que veiculam educação e literatura, ela continua escrevendo e fazendo história. Assim recomeça a cada dia sua vida. Esta é a senha necessária para constantemente reabrir a porta, escancarar as janelas e assim desconstruindo, recomeçar. 
Em sua vasta obra, sua ação docente, linguagens e significações, interrogações e exclamações; e a representação de mulher, mãe e professora internalizada ao longo de sua formação pessoal, social e profissional. Valores éticos, morais, religiosos, políticos, ideológicos, evidenciados e abertos a leituras, interpretações e aprendizagens se descortinam na interface entre os estudos de gênero, a história da educação e a história das mulheres.

E nas linguagens, nas linhas, em cada palavra, a visita ao passado, a descrição do presente e a esperança num futuro que vê pelas janelas, pelo jardim, pela que com destreza desliza em suas mãos. Escrevendo e contando ela tece o diálogo, a escuta, o silêncio, os fatos; tece a harmonia e nos entrelaça em seus olhares, experiências e emoções. Faz tentativa, e avança num relato que é denúncia, desabafo, ensino, reprodução; mas que é também possibilidade de reconstrução, transformação. Assim Mabel aposta na vida e ensina poeticamente que é preciso libertar-se. Ela intui, se entrega e escreve a sua, a nossa história. E nós, aprendemos com ela.

\section{REFERÊNCIAS}

[1] Almeida, Jane Soares de. Mulher e Pedagogia: a paixão pelo possível. São Paulo: Ariés, Philippe. História social da criança e da família. Rio de Janeiro: LTC, 1981.

[2] Beauvoir, S. O segundo sexo. V.2. São Paulo: Nova Fronteira, 1980.

[3] Dick, S. M.. Processo histórico de feminização do magistério baiano. In: Congresso Brasileiro de História da Educação. Sergipe: SBHE, 2008 Disponível em: <http://www.sbhe.org.br/novo/congressos/cbhe5/pdf/246.pdf>. Acesso em: 01.05.2016

[4] Duby, George; Perrot, Michele. História das Mulheres no Ocidente: do Renascimento à Idade Moderna. Porto: Afrontamento, 1994.

[5] Faria Filho, L. M et alli. A história da feminização do magistério no Brasil: balanço e perspectivas de pesquisa. In: A escola e seus atores: educação e profissão docente. Belo Horizonte: Autêntica, 2005.

[6] Perrot, Michelle. Minha História das Mulheres. São Paulo: Contexto, 2008.

[7] Saffioti, H. I. B. A Mulher na sociedade de classes: mito e realidade. Petrópolis: Vozes, 1976.

[8] Velloso, M. Janelas. Salvador: EGBA, 1990.

[9] Candeias: milagres, romarias. Salvador: FCJA, 2000.

[10] Donas. Salvador: EPP Publicações e Publicidade, 2003.

[11] Gilberto Gil. São Paulo: Moderna, 2002. (Coleção Mestres da Música).

[12] Caetano Veloso. Coleção Mestres da Música. São Paulo: Moderna, 2002.

[13] Conversando com Nossa Senhora. Salvador: Oiti, 2011.

[14] Terno. Salvador: BDA-Bahia, 1995.

[15] \& Rocha, C.. Mulher nos cantos e na poesia. [S.l], 1987.

[16] Poemas Grisalhos. Salvador: FCJA, 1997. Veloso, C. E. V. T. Neide Candolina. Disponível em http://www.vagalume.com.br/caetano-veloso/neide-candolina.html 


\section{Capítulo 21}

\section{Um olhar de gênero sobre a Psicologia Escolar}

\section{Iara Luzia Henriques Pessoa}

Glauce Michelle Araújo Penha

Carlos Alberto Gomes de Brito

Resumo: 0 presente estudo surgiu a partir de uma leitura sobre as questões de gênero na escola, a qual afirmou-se insuficiente para responder inquietações sobre o tema. Isto é porque marcadores sociais como gênero, sexualidade, raça etc. são importantes para a construção da identidade do sujeito. Esses marcadores são atravessados constantemente por discursos normatizadores veiculados por instituições que detém o poder, como a escola, que transforma esses corpos. Pois, a escola como uma das primeiras instituições na vida de um sujeito, esses discursos interferem na construção da identidade, sobretudo naquela não normativa. Foi elaborada a presente revisão bibliográfica não sistemática a partir do marcador gênero na escola que trouxe questionamentos sobre como o tema está sendo desenvolvido em trabalhos acadêmicos, assim como algumas reflexões sobre a diferença de como meninos e meninas são tratados e apontados em sala de aula. 0 referencial teórico utilizado foi o pós-estruturalismo que demonstra essas relações como sendo indissociáveis da rede de poder de nossa sociedade, tanto quanto tratando a escola como um lugar de produção de um corpo escolarizado, e de relações de gênero rígidas, assim como explicitamente normativas. A partir dessa construção e inquietações percebemos que é necessário pensar em mudanças que reverberem na educação. Esta seria de qualidade, participativa tal como desgenerificada, culminando numa educação inclusiva não só socialmente, mas democraticamente, englobando todos os grupos e marcadores sociais tidos como não normativos em nossa sociedade. Transformando a educação em um instrumento de revolução social.

Palavras chave: Questão de Gênero, Psicologia Escolar, Pós-Estruturalismo, Escola. 


\section{INTRODUÇÃO:}

A partir do artigo de Modesto (2017), o qual tem como objetivo maior contribuir com os estudos sobre o fracasso escolar com aproximações entre a psicologia e os discursões sobre as questões escolares a partir da perspectiva de gênero. Sentiu-se, então, a necessidade da construção do presente texto, pois apesar da autora basear sua fundamentação teórica em Pearse e Connel (2015) que afirmam que o gênero pode ser compreendido como um tipo de estrutura social. Sob o lastro teórico de Pearse e Connel Modesto elenca o gênero como uma maneira pela qual a sociedade lida com os corpos e as consequências desse lidar na vida das pessoas e do coletivo, portanto construído socialmente. Abrindo assim as portas para um conceito multidimensional de gênero subtraindo da diferença entre macho e fêmea, isto é a divisão biológica culturalmente instituída como verdade absoluta. A essa visão instituída, socialmente majoritária, contrapõe-se as categorias que se ocultam no interior dessa classificação já normatizada chamadas de macho e fêmea.

Contudo, mesmo com o viés do seu embasamento teórico Modesto (2017) e trazendo em seu artigo uma dimensão material e estrutural do gênero em consonância com as autoras supracitadas, houve grande utilização de argumentos estatísticos, além de um grande entrelaçamento do marcador social de raça, ofuscando a questão do gênero. Por esse motivo, então, não fizemos uso de dados estatísticos, somente de pesquisa bibliográfica para a construção do presente artigo, além de separamos este marcador social (raça) de nossa pesquisa simplesmente por motivos metodológicos. Mas, na realidade da instituição escolar, há uma correlação entre esses marcadores, e a promoção da diferenciação e desigualdade de gênero, além de como essas crianças agem após o período escolar (Connel, 1996). Segundo elas, um regime implícito institucionalmente que é retroalimentado por alunos, professores, educadores e todos que participes desse ambiente institucional. Entretanto o instituído nesse caso é passível de transformação, as relações de poder, divisão de trabalho, padrões emotivos e simbolizações precisam ser discutidas e postas em questionamento junto com os agentes da instituição escolar.

Quanto às expectativas generificadas alerta para seus impactos na vida escolar, a exemplo do encaminhamento de meninas com problemas comportamentais e de meninos com problemas disciplinares a atividades extras. Mas não é sabido se, na verdade, o que se encontra nessa situação seria uma menina assertiva e um menino que simplesmente não possui permissão ou até conhecimento de termos vocabulares para expor o porquê de sua indisciplina. Outro exemplo é de classificações descontextualizadas por profissionais não conhecedores da história de vida e de trajetória escolar dos alunos ali avaliados; e ainda fazendo uso de instrumentos frágeis inconsistentes ou inadequados, como classificatórios de limitações mentais. Sendo inclusive diagnósticos, que isentos de generificações ou sendo utilizados instrumentos mais adequados poderiam trazer outros contextos totalmente diferentes, falta de atenção, problemas adaptativos ou mesmo não aceitação do não saber. Demonstrando uma faceta da escolaridade que é a classificação e enquadramento de alunos que não se adaptam tão facilmente às tarefas escolas como fracassados.

A autora deixa reflexões quanto ao desafio de pensar o fracasso escolar nesse contexto. Questiona se a psicologia tem feito articulações com a vasta produção da educação sobre gênero e se essa ciência estaria aberta a usar padrões diferentes dos seus para explicar problemas de pesquisa. Reflete ainda a posição dos professores quanto aos questionamentos de diagnósticos instituídos aos quais discordem, pois os docentes se sentem "desconhecedores" das técnicas e não aptos para palpitar quanto ao diagnóstico feito por um outro profissional com o uso de um instrumento normatizado. Enfim discutir relações de gênero na escola implica problematizar relações de poder, salários, formações, visões ideologizadas, padrões esperados, noção de fracasso escolar etc.

Assim diante dos desafios citados pela autora e a educação como prioridade dentro do contexto escolar, bem como a escola como lugar de aprendizado e por nos colocarmos no lugar de busca por elementos teóricos que venham colaborar com questões generificadas no contexto escolar e suas implicações para esses agentes. Pois, todo conhecimento provoca inquietações, modificações e busca por novos saberes que possam contribuir com o entendimento sobre o tema central contextualizado no ambiente escolar. Então, traremos algumas reflexões utilizando a perspectiva pós-estruturalista com o objetivo de concluir nossas elucubrações acerca do tema. 


\section{REVISÃO BIBLIOGRÁFICA CONTEXTUALIZANDO TEORICAMENTE 0 TEMA EM QUESTÃO:}

Trazendo dados estatísticos que colaboram com o proposto pelo seu referencial teórico Modesto (2017) reflete e contextualiza-os. 0 processo de redemocratização do ensino como fator que influenciou a redução das taxas de analfabetismo feminino e que não reverberou em avanços masculinos, incita questionamentos. A progressão continuada com sua ineficácia quanto à inserção escolar, causando alunos a estarem no último ano do fundamental 2 e ainda não estarem hábeis a entender textos simples. Assim como entrada precoce masculina no mercado de trabalho, o que dificulta ainda mais a atenção desses alunos com as questões escolares, sendo a maioria deles que abandonam a escola para somente trabalhar. Assim como a gravidez precoce como um possível motivo para a evasão escolar de meninas em idade escolar, além de possivelmente explicar os números tão altos de meninas que somente estudam e não trabalham no artigo supracitado.

A taxa potencializada de analfabetismo entre nordestinos, residentes de zonas rurais e negros em detrimento a outras regiões e raças denunciando uma superposição de grupos vulneráveis. Marcadores socias como raça e gênero são de vital importância para a construção da identidade de um sujeito, que são construídas a partir de discursos a cerca de ambos. E é por esse motivo que a escola como uma das primeiras instituições educativas da vida de um sujeito que os discursos nela existentes interferem tanto nessa construção de gênero como na construção negra, porém no caso da identidade negra já se encontra como não normativa, mas na de gênero até a identidade masculina (Gomes, 2002), que é normativa, é influenciada por esses discursos que permeiam na escola. E assim como a identidade feminina é tida sempre em oposição à masculina, e sendo tida em oposição a esta (Louro, 2017), isto é como secundária; a identidade da pessoa negra é vista em oposição com a da pessoa branca, secundarizada e excluída.

Então como dito por Gomes (2002) e por Louro (2017) é necessário que essas identidades sejam tratadas não como em oposição a uma primeira normativa, mas como mais um tipo de vivência. Assim como é mais superficial e simples tratar as dificuldades de meninas com matemática como algo intrínseco, é também mais "natural" diminuir as questões históricas, culturais, sociais e econômicas a comportamentos individuais (Gomes, 2002). Igualmente como é um reducionismo pensar mostrado em livros didáticos escolares de quem "deve ser" a pessoa negra reforça o estereótipo e impede de que nós conseguimos vê-lo como sujeito histórico e social, assim como esse não-lugar para as mulheres em livros didáticos reforça a normatização também daqueles que se encontram dentro da normatividade.

Então, de acordo com Souza (2010) e as principais pesquisas relatadas em seu artigo, o discurso percebido, em geral, é o discurso da justiça social, da escola para todos, inclusive para pessoas com necessidades educativas especiais. Mas, a partir de tudo que foi dito anteriormente e que será dito posteriormente, é percebível que o que é dito nas políticas públicas não é o que acontece na realidade das escolas. Porque a escola é para todos aqueles que se comportam, tiram notas boas, não questionam, obedecem, estão dentro das características normativas e não tem nenhum tipo de necessidade educativa especial (Arroyo, 1992). Da mesma maneira de que o que acontece na realidade é uma necessidade da instituição escolar de socializar conteúdos para um possível ingresso numa universidade e não na educação de um individuo que será um adulto na sociedade. Isto é, a escola abre mão de socializar e manutenção do status quo, garantindo então, o "acesso" ao conhecimento e a permanência, mas exclui uma formação integral (Souza, 2010). Ou seja, o objetivo seria de que homossexuais continuem em um lugar de desconhecimento, ou melhor, que nossas crianças permaneçam na "inocência", perante a existência deles. No caso das mulheres seria que elas continuassem obedientes, não questionadoras e tolhidas (Louro 2017). E para os negros continuarem no papel de coadjuvantes sendo somente existentes como classe trabalhadora (Gomes, 2002). E nesse contexto de acordo com Souza (2010) o psicólogo deveria construir o conhecimento a partir de um contexto não normativo, dando voz a essas pessoas que na maioria dos espaços sociais não tem.

E é por isso que a diversidade sexual e de gênero deveria ser trabalhada em escolas, principalmente a existência transexual, a qual vai de encontro com as normas com relação a gênero. Além de que os números de evasão escolar dentro dessas pessoas têm aumentado significativamente, devido a preconceito de educadores e alunos (Monteiro et al, 2017). Se desde os primeiros anos escolares as crianças não fossem ensinadas que existe brinquedos de meninos e meninas, e, além disso, fossem tratados com igualdade, talvez essas identidades que vão de encontro a norma fossem tratadas com menos choque e preconceito. De acordo com Louro (2017) o discurso pode instaurar diferenças de gênero, e, como a arquitetura também é um discurso, para pessoas transexuais o banheiro se tornou um marcador de identidade, além de um problema (Monteiro et al, 2017). Pois o entendimento do biológico, isto é, órgão sexual como marcador do ser homem ou mulher, quer dizer poder usar o banheiro feminino/masculino ou nenhum destaca um preconceito dentro das escolas (Monteiro et al, 2017). 
Assim como a pessoa negra, a pessoa pertencente a um gênero ou sexualidade não normativa, a pessoa com altas habilidades e superdotação faz parte desse grupo classificado como diferente do padrão estabelecido (Bahiense; Rossetti, 2014, p. 200). No entanto essas são tratadas, como problema e não como possibilidade. E, assim como deveriam ser trabalhadas pelo psicólogo escolar e pelos próprios docentes, a questão das AH/SD precisa de um conhecimento específico e um trabalho por parte dos educadores, principalmente com aqueles que se enquadram como $\mathrm{AH} / \mathrm{SD}$ como com aqueles alunos que estão convivendo com esses "diferentes". Numa cultura neoliberal de enquadramento, há uma veemente necessidade de dizer o que é e assim dizendo estará dizendo o que não é. Isso é muito perceptível na dificuldade de lidar com o diferente. Na contemporaneidade ainda existe uma necessidade de colocar em movimento, fazer circular essa criança estigmatizando-a, cristalizando-o, o que mostra um olhar reducionista para essa questão. Pode-se citar a aprendizagem direcionada a um grupo de alunos enquanto os que não se enquadram nesses contextos, qualquer que seja o motivo, são fluidos e problematizados.

Bem como essas pessoas tidas como "diferentes" ou fora da normal são alvos de "atitudes agressivas, intencionais, deliberadas e conscientes que visam causar dor, sofrimento, perseguição e exclusão" (Campos; Jorge, 2010, p. 110), um tipo de violência escolar mais conhecida como bullying. É um erro culpabilizar a vítima do bullying por sua diferença, porém a sociedade elege critérios de classificação do que é considerado normal, então, aquele que não possuir essas características tidas como normal, sofre preconceito e discriminação (Goffman, 1992 apud Campos; Jorge, 2010). 0 conflito no ambiente escolar e pontual, nele e com ele se descobre o limite do outro e o seu próprio limite, entretanto o bullying se caracteriza pela humilhação o desrespeito constante, contínuo, premeditação. Vitimando sujeitos frágeis física e emocionalmente.

De acordo com Campos e Jorge (2010) todas as meninas que não se encaixarem no "ideal" para seu gênero e sexualidade, ou seja, não se encaixarem como heterossexuais, delicadas, atraentes, doces e meigas, poderá sofrer bullying tanto de outras meninas como de meninos. Meninos tenderiam a praticar um bullying com meninas voltados para a sexualização, palavras ofensivas e humilhação, e com meninos tenderiam mais a praticar bullying físico ligado à agressividade que é tanto incitada desde sua primeira infância (Campos; Jorge, 2010; Louro, 2017). Entre as meninas os efeitos são mais velados, o deixar de lado, isolamento social, fofocas e o olhar de deboche são alguns exemplos. No caso dos meninos a pressão que eles sofreriam seria para que se encontrassem num padrão de masculinidade, força, não demonstrar sentimentos, o que serviria para que esses meninos não sofressem bullying de seus colegas. Um fator que merece ênfase é a cristalização do agressor e do agredido quando nos referimos ao bullying, e essa fragiliza sujeitos em vias de formação. Entretanto a posição do agressor geralmente é subestimada, pois ele também sofre, provavelmente reproduzindo uma vivência do lar, portanto o psicólogo escolar precisa ter um olhar cuidadosos para as duas posições nesse contexto, seja o agressor ou o agredido.

\section{CONSIDERAÇÕES FINAIS}

Desde criança somos bombardeados com a ideia de que meninos podem fazer determinadas coisas e meninas não. Que meninos são mais agressivos e corajosos, e meninas mais recatadas e delicadas. Se fizermos uma enquete entre varias gerações identificaremos muitas questões como fila dividida entre meninos e meninas, menino ser proibido de chorar na frente dos colegas, uma menina ser reprimida ou assediada por usar um short, isso é coisa de menino ou aquilo é coisa de menina sendo esses discursos muitas vezes produtos de estereótipos e hierarquias sociais. Entretanto não basta só o desejo da escola ser um espaço socialmente privilegiado para a reflexão e os novos aprendizados é preciso um esforço bem maior multidiplinar com lócus diferenciados (escola, família, sociedade). No entanto cabe-nos focalizar na instituição escolar. Nesse sentido seria importante um esforço para somar à formação do corpo docente bem como da equipe técnica da escola as questões de gênero, pois as relações de gênero e sexualidade são fundamentais para educação de meninos e meninas em relação de reconhecimento e respeito à diferença.

Portanto vê-se a importância dessas discussões conscientizadoras, democráticas e com a participação ativa da família, no âmbito escolar, sobretudo em seu currículo, pois as consequências da educação escolar vão além da caderneta de notas. Na família, a questão de gênero veste-se de uma complexidade abrangente, pois pode ser essa, a primeira responsável pela inculcação dessas características, bem como pela bipolarização dos sexos. Aos meninos e meninas são atribuídas (os) brincadeiras, atitudes, roupas, carinhos, normas, cuidados, possibilidades e realidades diferentes. 
Diante dos estudantes, por conseguinte, o estimulo a debates, pesquisas, bem como o uso de não só punições para qualquer caso de discriminação que ocorra dentro ou fora da sala, dentro ou fora dos muros da escola, sendo utilizado como oportunidade para retomar o assunto articulados com técnicas e formas de mediar essa reflexão e estimular nesses o desejo de se posicionar sobre essa realidade, buscando o questionamento dessa normatividade e não somente a punição daquele que agiu seja com violência, seja com preconceito.

Precisamos de uma revolução de ideias e articulação entre saberes, sobretudo sobre as ideias e métodos hegemônicos de ensinar e aprender. A psicologia escolar tem um papel primordial nesse processo e certamente o desejo maior não é o de aumentar notas em exames, mas sobretudo a inclusão. Entretanto não se trata de incluir em salas mais avançadas simplesmente para drenar salas superlotadas ou para maquiar índices, mas sobretudo para preparar sujeito mais capazes e habilitados, potencializados em suas competências e habilidades, consequentemente mais exitosos em sua cidadania. Entretanto é urgente pensar em mudanças que reverberem em educação de qualidade inclusiva e relevante para todos. Partindo da consideração de que quando a educação é prioridade inovar é uma necessidade. Inovar que tem como um dos sinônimos atualizar, o sistema educacional no sentido de levá-lo a ser mais democrático, participativo, desgenerificado, portanto, e com avaliação sistemática, interna e externa com intuito de tornar a educação um instrumento de revolução social. Colaborando, portanto, com as mudanças supracitadas.

\section{REFERÊNCIAS}

[1]

Arroyo, Miguel. Fracasso-sucesso: o peso da cultura escolar e do ordenamento da educação básica. Em Aberto, Brasília, v. 11 n. 53, p. 46-53. 1992.

[2] Bahiense, Taisa; Rossetti, Claudia. Altas habilidades/superdotação no contexto escolar: percepções de professores e prática docente. Rev. bras. educ. espec., Marília, v. 20, n. 2, p. 195-208, 2014

[3] Campos, Herculano; Jorge, Samia. Violência na escola: uma reflexão sobre o bullying e a prática educativa. Em Aberto, v. 23, n. 83, p. 107-128. 2010.

[4] Gomes, Nilma. Educação e Identidade Negra. Aletria: Revista de Estudos de Literatura, s/n, v. 9, p. 38-47. 2002.

[5] Louro, Guacira. Gênero, sexualidade e educação: uma perspectiva pós-estruturalista. Petrópolis: Vozes, 16 ${ }^{\underline{a}}$ ed. $5^{\mathfrak{a}}$ reimpressão. 2017.

[6] Modesto, Ângela. Um olhar de gênero sobre a psicologia escolar. Seminário Internacional Fazendo Gênero 11 \& 13th Women's Worlds Congress, Florianópolis, 2017.

[7] Monteiro, Felipe et al. Transexualidade infantil na psicologia: uma revisão bibliográfica. Revista Mangaio Acadêmico. v. 2, n. 3, 2017.

[8] Souza, Marilene. Psicologia escolar e políticas públicas em educação: desafios contemporâneos. Em aberto, v. 23, n. 83, p. 129-149. 2010. 


\section{Capítulo 22}

\section{Educacao inclusiva: Meu gênero não me define}

\section{Ana Beatriz Medeiros Ferreira}

Resumo: Neste artigo caminhamos dentro de um universo da educação inclusiva, que, para muitos, ainda tem um olhar para as pessoas com deficiências, mas a educação inclusiva tem um papel muito mais além. Ela vem nos mostrar a amplitude da palavra "inclusiva", incluir, todos os marginalizados nesta sociedade excludente. Buscando dar visibilidade ao processo dos estudantes que são LGBTT (lésbicas, gays, bissexuais, travestis e transexuais) que são atores sociais normalmente preteridos. Procurando subsídios para uma reflexão, sobre o percurso desses estudantes no âmbito educacional e seu impacto social em meio das reviravoltas que se encontram as transformações que têm se aplicado às políticas públicas.

Palavras-chave: Educação inclusiva, homossexualidade; movimentos sociais; identidades coletivas. 


\section{INTRODUÇÃO}

Este artigo tem por objetivo trazer uma reflexão sobre a inclusão escolar dos estudantes (LGBT), Lésbicas, gays, bissexuais e trans, assim como as questões de gêneros, e seu impacto em sala de aula. Além de pesquisar questões filosóficas, políticas e sociais, embarca em uma parte da história de movimentos LGBTS. Este trabalho científico tem como metodologia, a pesquisa bibliográfica como fontes: livros, artigos científicos, revistas científicas e e-books, teóricos como Teresa E. Moantoan, Foucault entre outros deram sua contribuição à este trabalho cientifico. Nesse sentido tem sua relevância à outros pesquisadores, pois essa pesquisa tem uma visão histórica metodológica da educação inclusiva e as questões da sexualidade no âmbito educacional, suas facilidades e entraves.

Diante do quadro da contemporaneidade, deveríamos ter maior abertura no que tange às questões de debate sobre sexualidade. As redes sociais, a mídia, os meios de comunição de massa, internet, todos trazem informações que são de fácil acesso, porém no âmbito educacional, existe ainda um "tabu" no que diz respeito a esse tema. Onde geralmente se coloca como assunto pessoal, sem ter um envolvimento, como se os estudantes fossem assexuados, como se os indivíduos que estão dentro da escola não tivessem desejos e não tivessem prazeres, sujeitos à margem das práticas sociais. Segundo Facchini (2009 p.62), "As reivindicações do movimento têm se visibilizado a ponto de suscitarem projetos de lei em todos os níveis do Legislativo, assim como a formação de Frentes Parlamentares em âmbito nacional e estadual". Ao ignorar o estudante como um ser que tem uma pratica sexual, que tem um gênero e se ater apenas a passagem de um conteúdo pré-estabelecido, o professor nega o estudante como um ser integralizado. Tal docente acaba por não estar trabalhando o estudante de forma holística, negando o ser como um todo, vendo só a cognição. Porém a realidade é outra e estão cada vez mais visíveis estudantes que demonstram sua sexualidade, seu gênero, sua ideologia e cabe ao professor se adaptar e procurar adequar às novas gerações, onde uma grande maioria de estudantes não tem medo de se mostrar.

A Educação inclusiva está voltada para incluir a todos, somos todos diferentes, independente de capacidades, cor, raça, orientação sexual ou definição de gênero. A educação é para todos tal como está preconizado na Constituição (BRASIL, 1990) e em diversas leis, que legitimam o direito a uma educação de qualidade e equidade social a todo indivíduo.

\section{METODOLOGIA}

Trata-se de uma pesquisa integrativa buscando sintetizar o conhecimento sobre um determinado assunto. Neste caso, para condução da revisão de literatura, o presente estudo apresentou uma abordagem em cima do assunto: Educação Inclusiva e Grupos LGBT.

A pesquisa foi realizada a partir do levantamento bibliográfico de literatura publicada a partir do ano 2000. Foi feita uma seleção da literatura de artigos, livros, periódicos e teses publicadas na língua portuguesa em base de dados Scielo e Scholar Google. Para a busca da literatura foram utilizadas quatro palavras chaves "Movimentos Sociais", "Educação Inclusiva", "Identidades Coletivas" e "Homossexualidade".

Após a seleção da literatura foram aproveitados doze artigos e três livros para elaboração do presente artigo.

\section{DISCURSOS SOBRE SEXUALIDADE NO CONTEXTO ESCOLAR}

A prática docente é, por várias vezes, repensada no que tange a discursos de sexualidade no âmbito escolar, pois hoje já existe uma quebra de paradigmas ao se falar de orientação sexual e identidade de gênero. Como tais temas costumam ser evitada e pouco discutida a verticalização no tema torna-se dificultada, pois ainda é considerado um "tabu" por muitos no meio social e até mesmo pela unidade de ensino. Segundo FACCHINI (2009), a noção de comunidade, que é cara ao movimento LGBT, se dá pelo fortalecimento da visibilidade e do mercado próprio ao público. Todavia, no Brasil, os movimentos ainda estão tomando força, mas, em um período ainda muito recente, esta "fala" ainda se deixava a desejar em vários aspectos: 
Durante o século XX, a categoria "homossexual" popularizou-se, chegando ao senso comum. Não podemos dizer, porém, que as classificações médicas e/ou legais foram simplesmente transpostas para a população em geral, que as adotou prontamente. Todo o processo relativo à categorização de um "comportamento homossexual" foi permeado, desde então, por conflitos com categorias locais e por apropriações e traduções dessas classificações. Nessa direção, o movimento homossexual não pode deixar de ser visto como um dos atores sociais que disputam o sentido do termo. (Fachinni 2009, p.58)

Na década de oitenta com o movimento gay, teve a busca de uma troca de percepção de que os homossexuais eram pessoas estranhas, exóticas, enquanto apenas os heterossexuais considerados como normais e que inspiravam respeito. 0 objetivo desse movimento era segundo GARMSON (2006), resgatar a subjetividade gay ou lésbica negada através da história. Em busca de seus direitos civis esses movimentos contribuíram de maneira bastante efetiva e direta. Segundo Neto (2007) o individuo homossexual seria uma variação natural da sexualidade humana, assim como a diversidade étnica, desse modo gays e lésbicas teriam a mesma vivência, tanto no passado como no presente, independente do momento cultural vivenciado da sociedade e o histórico.

No caso de uma justiça popular, não há três elementos; há as massas e os seus inimigos. Em seguida, as massas, quando reconhecem em alguém um inimigo, quando decidem castigar esse inimigo - ou reeducá-lo - não se referem a uma idéia universal abstrata de justiça, referem-se somente à sua própria experiência, à dos danos que sofreram, da maneira como foram lesadas, como foram oprimidas. Enfim, a decisão delas não é uma decisão de autoridade, quer dizer, elas não se apoiam em um aparelho de Estado que tem a capacidade de impor decisões. Elas as executam pura e simplesmente.(Foucault, 1984, p 27)

Diante de todo este quadro histórico, ao voltarmos para as distorções dentro da escola muito está por ser feito, na atual conjuntura estamos diante de um quadro político pedagógico bastante delicado.

Em começos dos anos 2000 amplia-se o leque de partidos que têm se aproximado da temática LGBT e de setoriais, das ações de políticas públicas e parlamentares e das candidaturas que se organizam a partir de vários partidos. Essa mudança provavelmente vem sendo operada de modo mais significativo a partir da retomada do regime democrático.(Facchini 2009, p.62)

Existe, entretanto, uma parcela significativa de políticos em diversas esferas de poder, que advogam contra uma pluralidade de ideias.

\section{EDUCAÇÃO INCLUSIVA: EDUCAÇÃO NÃO TEM IDENTIDADE DE GENERO}

Segundo a Constituição Federal (Brasil, 1990) a educação é um direito que deve ser concedido de forma universal. Todos devem ter acesso a ela. Entendendo a educação como uma forma de transformar os espaços temos o pensamento de Moantoan que diz:

E inegável que os velhos paradigmas da modernidade estão sendo contestados e que o conhecimento, matéria-prima da educação escolar, está passando por uma reinterpretação. As diferenças culturais, sociais, étnicas, religiosas, de gênero, enfim, a diversidade humana está sendo cada vez mais desvelada e destacada e é condição imprescindível para se entender como aprendemos e como compreendemos o mundo e a nós mesmos.(Moantoan 2003,p.12)

Existe uma população, de baixa renda familiar, que se depara com uma situação de pobreza econômica e intelectual. Segundo a fala de Soares (2010, pag. 208) temos a ideia que: "Da mesma forma, utilizam-se da garantia do direito social da propriedade para alcançar a proteção de posições jurídico-subjetivas de natureza pública no âmbito da seguridade social".

A educação inclusiva está voltada para uma ação, onde a escola atenda a todos, como está na Constituição de 1988 (Brasil, 1990) e na LDB, na lei de diretrizes de base. Compreende a educação não só aos "ditos" normais. Todo o individuo é diferente do outro, ninguém é igual, cada pessoa tem sua especificidade e dentro da sua especificidade respeitar as especificidades do outro. A globalização e a emergência das mídias digitais faz com que as políticas públicas relacionadas à inserção do público LGBT aconteça em maior escala. 
Nesse sentido, políticas inclusivas começam no âmbito tradicional dos estados nacionais, deles não se podendo eximir sob o risco de tornarem-se figuras abstratas e sem efetividade. Mas elas só fazem sentido pleno em um mundo globalizado, no qual se possa realizar a essência da humanidade, pondo ênfase no que é comum à espécie humana, em que a superioridade axiológica da humanidade vista ut genus sobreponha-se a uma vista dos países uti singuli. Essa tomada de posição traz à lembrança algumas posições assumidas por intelectuais e organismos que pensaram a humanidade dessa perspectiva. (Cury, 2005, p 12)

Encontramos uma realidade em que alguns estudantes se encontram com baixa autoestima, e sofrem preconceito em seu meio, tanto familiar quanto social. Ao pensarmos no âmbito educacional, nos deparamos com uma realidade bastante crítica, na qual os estudantes passam por diversas dificuldades, muitos, por sua sexualidade, são discriminados, marginalizados, postos em condições extremas de rejeição e não suportam. Isto faz com que eles acabem saindo do âmbito escolar, sendo mais um nas estatísticas de evasão escolar, estatística essa que não faz distinção de gênero e sexualidade, ficando assim invisíveis. Já que estamos tratando de jovens para entrar neste debate podemos pensar no que Macedo, Goibbi e WASchburgeri (2009) trazem: A ressignificação da identidade. 0 adolescente já deixou a infância, não mais cabe a ele as atitudes de criança. Não mais cabe a irresponsabilidade, mas também não cabe a adultez (Oliveira, 2006). Desta forma a evasão ganha certa forma, mas não há formas em números, há apenas as estatísticas que podem ser entendidas apenas se examinadas a fundo e como diria Mello:

"Um olhar mais detido sobre o fenômeno recente da multiplicação de iniciativas estaduais e municipais voltadas para o combate à evasão escolar de travestis e transexuais talvez seja ilustrativo dessa falta de articulação entre as ações implementadas nas distintas esferas de governo." (Mello, 2012, p.114)

Há caminhos longos a ser percorrido quando falamos de justiça social e principalmente para aquelas pessoas em situações de risco e vulnerabilidade, mas existe algumas iniciativas de políticas publicas voltadas para os estudantes LGBTS.

Não restam dúvidas, porém, de que investigar processos sociais, políticos, culturais e econômicos em curso - no presente e em tempo real - é um desafio que nos coloca diante dos limites e das fragilidades do olhar de pesquisadoras e dos questionamentos acerca de nossa capacidade de compreender os fenômenos sociais em toda sua complexidade, dinamicidade, intangibilidade e porosidade. Isso é particularmente relevante quando se observa o grande número de iniciativas isoladas, relativas à proteção de direitos de pessoas LGBT, que têm sido propostas pelo Poder Executivo, nos três níveis de governo, o que torna praticamente impossível manter um mapeamento atualizado. Talvez o exemplo mais emblemático seja o do crescente número de portarias,... 0 caráter fragmentado dessas iniciativas, cujo alcance às vezes se restringe a áreas específicas como saúde, educação ou assistência social, explicita como as demandas da população LGBT têm encontrado acolhida crescente por parte da administração pública, ao mesmo tempo em que ainda não são objeto de políticas públicas mais organicamente articuladas e de alcance nacional. Esse exemplo talvez seja a melhor expressão de como, em face da ausência de uma legislação federal que explicitamente assegure direitos civis para a população LGBT, o movimento social tem encontrado alternativas, ainda que parciais e de alcance limitado, recorrendo ao apoio de governadoras, prefeitas, secretárias de governo e gestoras públicas sensíveis às suas demandas. ( Mello, 2016, p.410,411)

Um costume que pode ser visto em diversas instituições de ensino é que quando o aluno atinge certo limite de má-conduta, este é levado para uma orientação pedagógica ao passo que fica entendido como alguém que não é tolerado, um proscrito. Segundo FOUCAULT, em seu livro Vigiar e Punir (1999, p.78) "Para o povo que aí está e olha, sempre existe mesmo na mais extremada vingança do soberano, pretexto para uma revanche". 
"o corpo só se torna força útil se é ao mesmo tempo corpo produtivo e corpo submisso. Essa sujeição não é obtida só pelos instrumentos da violência ou da ideologia; pode muito bem ser direta, física, usar a força contra a força, agir sobre elementos materiais sem no entanto ser violenta; pode ser calculada, organizada, tecnicamente pensada, pode ser sutil, não fazer uso de armas nem do terror, e no entanto continuar a ser de ordem física" .(Foucault 1999,p.29)

A uniformidade vem de um padrão, e este padrão é quebrado quando se encontram pessoas com pensamentos distintos dentro da instituição. Logo toda a má-conduta que recai por sobre o LGBT é, antes de tudo, um reflexo de uma conduta geral e heteronormativa. Pois, segundo Foucault (1984), o poder faz com que aqueles que não o possuam tenham que se sujeitar às normas dos que o possuem. Fazendo com que aquilo que não é da maioria seja amoral e fora das normas das instituições.

Diante de alguns fatores que são implícitos em diversas situações nos faz repensar em nossas prisões ocultas, que nos oprime e nos reprime diante de uma sociedade cruel e preconceituosa, essa dita regras e se não cumpridas nos leva a uma marginalidade, o diferente causa estranheza em todos os sentidos.

\section{RESULTADOS E DISCUSSÃO}

A partir de todos os artigos levantados temos a imagem de que o público LGBT acaba como proscrito no meio escolar apesar de todas as leis serem contrárias ao fato, a lei do Poder que circula a sociedade faz com que os sujeitos tenham que docilizar seus corpos em detrimento de sua vontade.

0 adolescente que vive toda uma pletora de mudanças, físicas (Oliveira, 2006) e psíquicas (Macedo, Gobbi, Waschburgeri, 2009). Precisa se individualizar, precisa mostrar a si mesmo e ao mundo que é, de alguma forma, singular. Dito isto temos a mudança hormonal da idade somada com o local social que é a escola, que causa diversas necessidades. Muitas delas, sociais. Muitas delas, uma busca por ser alguém individualizado e autônomo (Oliveira, 2006).

E o peso dessa individualidade num ambiente heteronormativo é a exclusão. Aquele que é preterido e posto de lado por não se enquadrar numa possibilidade limitada de modos existentes para ser único, fazendo com que essa individualidade não seja tão individual assim.

A escola surge nesse meio como uma forma de balancear os poderes. Tendo que ressignificar o papel dela mesma como não apenas um lugar para passagem de informação, mas como um local que prima a socialização, e que tem no professor um agente de mudança, como diria Romero (2015), o professor deve assumir um papel para além do de transmissor de conhecimento, mas um agente integrador e integrativo. Alguém que faz com que os pesos das forças dos Poderes (Foucault, 1984) seja balanceado por uma presença que transfere capacidade de reação à minoria.

\section{CONCLUSÃO}

Os corpos estranhos, diferentes que sofrem preconceitos que causam uma dor pungente. A educação inclusiva vem quebrar paradigmas, mostrando que todos somos diferentes. Analisar a educação inclusiva através de um referencial humano é muito importante, a existência do patamar filosófico aonde vai além do senso comum, rompe com ideias pré-estabelecidas sobre o assunto, concepções superadas.Somos diferentes através dessa diferença nos tornamos iguais, a luta de movimentos LGBTS para melhores condições de dignidade, justiça social e educação, são aspectos positivos de tomada de consciência, surgir as políticas publicas com leis que legitimam esses direitos.

\section{REFERENCIAS}

[1] Brasil. [Constituição (1988)]. Constituição da República Federativa do Brasil: promulgada em 5 de outubro de 1988. 4. ed. São Paulo: Saraiva, 1990.

[2] Cury , C. R. J. , Políticas Inclusivas e Compensatórias na Educação Básica, Programa de Pós-Graduação em Educação da Pontifícia Universidade Católica e Faculdade de Educação da Universidade Federal de Minas Gerais crcury.br@terra.com.br, 2005

[3] Facchini R., França, I. L., De cores e matizes: sujeitos, conexões e desafios no Movimento lgbt brasileiro. Revista latino americana ,Sexualidad, Salud y Sociedad , n 3, 2009 
[4] Foucault, M. I Hhlll Microfísica do poder / Michel Foucault; organização e tradução de Roberto Machado. Rio de Janeiro: Edições Graal, 4 ed. 1984.

[5] Foucault, M. F86v Vigiar e punir: nascimento da prisão; tradução de Raquel Ramalhete. Petrópolis, Vozes, 1999. 288p.

[6] Gamson, J. (2006). As sexualidades, a teoria queer e a pesquisa qualitativa. In N. K. Denzin \& Y. S. Lincoln. 0 planejamento da pesquisa qualitativa: teorias e abordagens. (pp. 345- 362). Porto Alegre: Artmed/Bookman.

[7] Macedo, M. M. K.; GOBBI, A. S.; Waschburgeri, E.M. P. Marcas corporais na adolescência: (im)possibilidades de simbolização. Psicol. rev., Belo Horizonte, v. 15, n. 1, p. 90-105, abr. 2009.

[8] Mantoan. M. T. E. Inclusão escolar : o que é? por quê? como fazer? — São Paulo : Moderna , 2003. — (Coleção cotidiano escolar)

[9] Mello, L.; Freitas, F.; Pedrosa, C.; Brito, W. Para além de um kit anti-homofobia: políticas públicas de educação para a população LGBT no Brasil. Bagoas - Estudos gays: gêneros e sexualidades, v. 6, n. 07, 26 nov. 2012.

[10] Mello, L., Brito, W., \& Maroja, D. (2016). Políticas públicas para a população LGBT no Brasil: notas sobre alcances e possibilidades. Cadernos Pagu, (39), 403-429. $\quad$ Recuperado de https://periodicos.sbu.unicamp.br/ojs/index.php/cadpagu/article/view/8645062

[11] Neto, O. A. L. (UFSCar) A Teoria Queer e as sexualidades no contexto brasileiro: desafios teórico metodológicos.2007- Caxambu, MG.

[12] Oliveira, M.C. S. L. Identidade, narrativa e desenvolvimento na adolescência: uma revisão crítica. Psicol. estud., Maringá, v. 11, n. 2, p. 427-436, Ago. 2006.

[13] Soares, D. de A. .0 direito fundamental à educação e a teoria do não retrocesso social. Revista de Informação Legislativa Brasília · ano $47 \cdot$ no 186 P. 298, abril/junho 2010

[14] Romero, P. Breve estudo sobre Lev Vygotsky e o sociointeracionismo. 2015. Disponível em: <http://educacaopublica.cederj.edu.br/revista/artigos/breve-estudo-sobre-lev-vygotsky-e-o-sociointeracionismo>. 


\title{
Capítulo 23
}

\section{Estruturas permeáveis: Corpo-caderno}

\author{
Alla Soüb(Mariana Ramos Soüb de Seixas Brites)
}

Resumo: Este artigo apresenta as considerações acerca da metodologia de registro de performance por meio de escritos. Apresentando registros de performance produzidas entre 2015 e 2017 é possível percepcionar o modo que literatura e artes visuais se entrecruzam em minha vivência dissidente, margeada. A composição e estruturação dessa teoria está arraigada de conceitos criados coletivamente pelo Grupo de Pesquisa Corpos Informáticos. A culminância destas intersecções é a própria noção de corpo-caderno. Esta nova nomenclatura conecta e propõe uma analogia entre caderno e corpo que humaniza os rastros e percursos do caderno e não objetifica o corpo como "suporte" da performance. O corpo é meio, fim e início - é o mundo e suas relações. A escrita aparece como tom de sussurro, realçando a noção de incompletude da leitura que demanda da composição imaginativa do leitor(a) para que se complete. O registro da performance nunca é a performance em si, com essa brecha que a literatura e a pele brincam de compor outros mundos a partir da experiência sentida no corpo. Corpo-caderno não é fixo, é mutante variável que se compõe diante-para-com a pessoa que o lê: nós e(m) euS.

Palavras-chave: Registro; Cicatriz; Autoficção; Performance. 


\section{INÍCIO DE TRILHA}

Chego até aqui, primeira pessoa, eu, Alla, nome que me dei para contar a possibilidade outra em pesquisarse no mundo para-com arte. Eu, corpo racializado, gorda, lésbica, bolsista, mineira quase brasiliense, preciso me apresentar para você leitora. Aqui, você é agente ativa, a leitura é sua composição, criação. Eu, artista de rua, performática diriam, cria do Grupo de Pesquisa Corpos Informáticos e, por isso, o singular da primeira pessoa não me contempla mesmo quando só. Pela força do coletivo aprendi a compreender multiplicidades, euS, ainda em primeira pessoa, mas não só, plural. Trago reflexões que partem de minha trajetória pessoal na arte e na academia, simultaneamente. Essa pesquisa conta com a co-labor-ação de Maria Beatriz de Medeiros. Eus, as escritas, as fuleragens ${ }^{63}$ e as elas, outras de Bia. Nós: múltiplasmilhares. Caracol sem fim: a outra dentro da outra, na outra, dentro em outra, que outra, a outra que somos. Todas essas escrevem, tanto na folha quanto sem palavras (com o corpo) no corpo da cidade. Dessa forma, nossas ações performáticas se metamorfoseiam em textos (registros-escrito-poéticos) e nossos corpos estão presentes em tudo, do grifo ao grito.

Aproveitando a brecha da literatura, escrevemos com prazer, aproximamos a escrita da água e não deixamos estancar e não criamos a praga do mosquito. A escrita nos guardará para que um outro olhar, brincadeira ou leitura, nos conserve ou rebele. Escrevo, mas o último sentir não é meu. Se fosse texto parado, ainda de gaveta, não faria sentido. Quero exaltar vivências esquecidas, brincar de deslizar do outro lado da dobra. Escrita meu grito-presente, um grito de quem quer ser encontrada e quer encontrar as forças que não deixam que esse barranco despenque. 0 barranco sou eu mesma, meu corpo, uma geografia para que as águas da escrita percorram, cavem leitos e explodam nascentes. Voltar a escrever é uma história de fertilidade.

Leitora, teu corpo também é terra. Ao abrir os olhos, toma um pouco de poesia para não esturricar, leia ou crie: imagine. Repara que, desde sempre, seu corpo está cravado, mais que pele, mais que osso, mais que carne, seu corpo traz a maior complexidade literária que precisa escorrer. Vai beber da água da poesia que, às vezes, explode no seu sexo, deságua na cabeça. É refrescante escrever o mundo, reinventá-lo, para não só viver as velhas escrituras impostas. Na rua, no cru, é sentida a potência de ser desvio, os olhares de estranheza nos deslocam. Como resposta, sentimos a paixão pelo aqui-agora, pela sinceridade (violenta) da rua. Durante ataques de ódio nos fortalecemos para voltar às ruas com outros planos de fuga e estratégias de ocupação. Nosso movimento é diferente, cérebro decomposto na pele, corpo-fala sem mordaça. Identidades marginais atiçadas e aguçadas contra a máquina de Estado.

\section{ALERTA}

Motor sensível ligado, escrevemos nas encruzilhadas histórias de ações. Recontando a história da história. Vivendo o prazer do entre, na possibilidade múltipla de cicatrizar nossas feridas históricas e identitárias ainda abertas. Obs.: sabemos que algumas não fecham.

\section{3."P” DE PARTIDA, PROVOCAÇÃO}

Uma vez que as ações acontecem em um tempo irrepetível (aqui-agora) variadas são as formas de se gerar registro de tais acontecimentos. Os mais utilizados e comumente agregados aos acervos museográficos são a fotografia e o vídeo. Ambos possuem as características de trazer a imagem da ação em um espaço-tempo outro. A imagem e o vídeo conservam em si um olhar específico - da pessoa que produziu ou editou as imagens, do tipo de material utilizado para captá-las, etc. - é, inclusive, por meio desses registros históricos de imagens que podemos ter acesso a ações anteriores à nossa existência. Não é possível pormenorizar esse tipo de técnica de registro, que agrega muito valor à possibilidade de construir uma linha histórica dessas ações, fuleragem, performance, arte-vida. Porém, os registros não nos servem somente para a função histórica da arte. Os registros são o ponto de partida para outras criações.

$\mathrm{Eu}$, fundida de poesias, fuleragens e teatro, sempre recorri ao uso da palavra escrita para dizer o que por muito não conseguia oralmente. Sendo assim, cadernetas e blocos de anotações sempre foram materialidades do meu pensar-agir artístico. Após alguns anos fazendo ações, percebi que praticava uma rotina em relação aos registros destas práticas. Em sua maioria, logo após a realização, sentava e escrevia (em forma de escrita automática, rabiscos e garatujas, sem revisão e preocupação gramatical e/ou de 
formatação). Escrevia, escrevia, escrevia. Percebi que o registro que eu mesma fazia era sempre por meio da palavra escrita, mesmo que houvesse vídeos e fotos que fossem feitos por terceiros. Esses textos pósação são o registro sensitivo desse eu-corpo, e eles, por si só, já não são mais a ação em si, são outra coisa, desdobramento, e, também, não existiriam caso a ação não acontecesse. Ambos existem em um regime de mutualismo, em que os dois lados da relação se beneficiam. A ação pode ser desdobrada por meio da palavra escrita e a palavra escrita que encontra seu ponto de inspiração na experiência do corpo. As palavras destes registros, então, não fazem parte das palavras-sentadas, aquelas feitas no escritório, palavras achatadas de bunda na cadeira; dizem mais respeito a outro tipo de escrita, aquela que coça, que incomoda até que tenha rumo para o papel; nascem do suor do corpo que brinca e se arrisca, são transcrições da carne para o papel.

Quando a ação em tempo real acaba, seus rastros ainda reverberam por meio de seus feitores ou iteratores ${ }^{64}$, sendo ponto de partida para que outras possibilidades artísticas se desenrolem através dos registros: videoarte, fotografia, poesias, colagens, etc. A necessidade de falar sobre o registro é da ordem de frisar que a performance e a fuleragem deixam marcas, rastros e reflexões naqueles que a presenciaram. Como, por exemplo, uma ação que aconteça em espaço público e se torne viral na internet. ${ }^{65}$

0 registro pode, também, ser uma bela mentira, "mentira como verdade poética" (MORI, 2015, p. 12). 0 registro é brincadeira: como contar algo que não volta e que desde seu surgimento não possui só uma versão? O registro não é único, o registro é múltiplo por essência, por se simpatizar com os burburinhos, com a fofoca e, como já nos colocaria a tradição oral (não podemos esquecer que é a mais antiga forma de registro), "quem conta um conto aumenta um ponto". A ação abre o leque da imaginação, das tantas possibilidades pessoais em sentir sobre um mesmo fato, abre o leque e balança no vento todas as versões. Nenhuma é falsa. Não há imaginação errada, esse registro-imaginação, poesia ou rastro, não é a mimese do acontecido. A ação é inspiração, provocação e ponto de partida, "P".

Buscar outras formas de registro é, também, escolher de que maneira recontaremos nossas vivências e experiências, conscientemente ou inconscientemente. Daqui a cinquenta anos, por exemplo, o que restará das vivências dos anos 2000? Brincar o registro é brincar com o futuro, com um jogo que é criado agora. Não é sobre a verdade dos fatos, é sobre a possibilidade de escolher criar rastros de resistência em uma época. Sabemos que nem mesmo a história dos livros didáticos é real. (muito menos ela!). É apenas uma das versões que foi escolhida e manipulada como verdade, a do colonizador/opressor. Ao multiplicarmos o registro, também damos voz às minorias e às histórias que normalmente estariam no limbo do esquecimento: arte de rua.

Essa escolha parte da vontade de entender como a palavra escrita se torna múltipla por sua ausência de imagem fixa, e convida a leitora a criar para si imagens e versões pessoais do ocorrido. Mesmo com toda fixidez de um texto escrito, esse se esbeira evocando a imaginação de quem o lê. Portanto, a estagnação de palavras escritas só existe para gavetas e estantes.

Como desdobramentos e registros das performances ocorridas seguem poesias e prosa descendentes de ações performáticas que fiz. Vale ressaltar que a performance como ponto primordial para a continuação da poética funciona como big-ben: início de outros universos.

\footnotetext{
64 "A fuleragem não é obra de arte nem acontecimento, é ocasião (oca grande), acaso e improviso. Ela é mixuruca e não efêmera, renuncia à obra, ao espaço in situ e mente. Escreve livros, organiza eventos, expõe em galerias e até ganha editais. A fuleragem se dá por parasitagem na paisagem física ou virtual, com participação iterativa do espectador que dança, canta, pula corda ou se excita na frente da enceradeira vermelha. Ela critica a escrita, a linguagem e mente te convidando a leitura deste livro." (AQUINO, F. \& MEDEIROS, M.B., 2011, p.202)

Deleuze e Guattari, assim como Derrida, se referem ao conceito de "iteração": conceito mais amplo e aberto do que o de "interação". "Nós tomamos a liberdade de trazer esse conceito para o campo da arte e da performance. Na interação, caminho por caminhos pré-estabelecidos pelos idealizadores do projeto, da obra. Videogames são interativos. A participação iterativa é co-laborativa, co-labor-ativa, prevê a participação ativa do espectador; a possibilidade de modificação da proposta artística pelo iterator: iter (caminho), na fuleragem, a ação pode ser modificada, no caminho, pelo iterator. Alguns dizem "participador". No participador, a dor permanece, na iteração, o transeunte, o errante, se torna iterator. (MEDEIROS, 2017, p.38)

65 Referência a performance Pelos Pelos (2013), feita pela Coletiva Tete-a-Teta, durante o evento Performance Corpo Política (2013), organizado por Corpos Informáticos, em Brasília-DF.
} 


\subsection{DOR, ACONTECE UM BAILE (2017)}

“andava pelada antes do antes ainda

eu nem era eu

por que lá todes éramos

não queremos suas roupas

moldura fluida,

corpo-vento que dança em gingas aquosas,

re-volto para ti, lugar de onde nunca deveria ter saído,

te amo em toda sua flacidez.

nudez como resistência estética, política e poética.

nudez como resistência estética, política e poética.

nudez como resistência estética, política e poética.

nudez como resistência estética, política e poética

corpo como peso y pouso". (alla)

\subsection{CINZA E BROTO (2016)}

Scanner de uma das páginas de escritas compartilhadas na ação duracional "Broto e Cinza”, acontecida no Lago Oeste - DF, 2016.

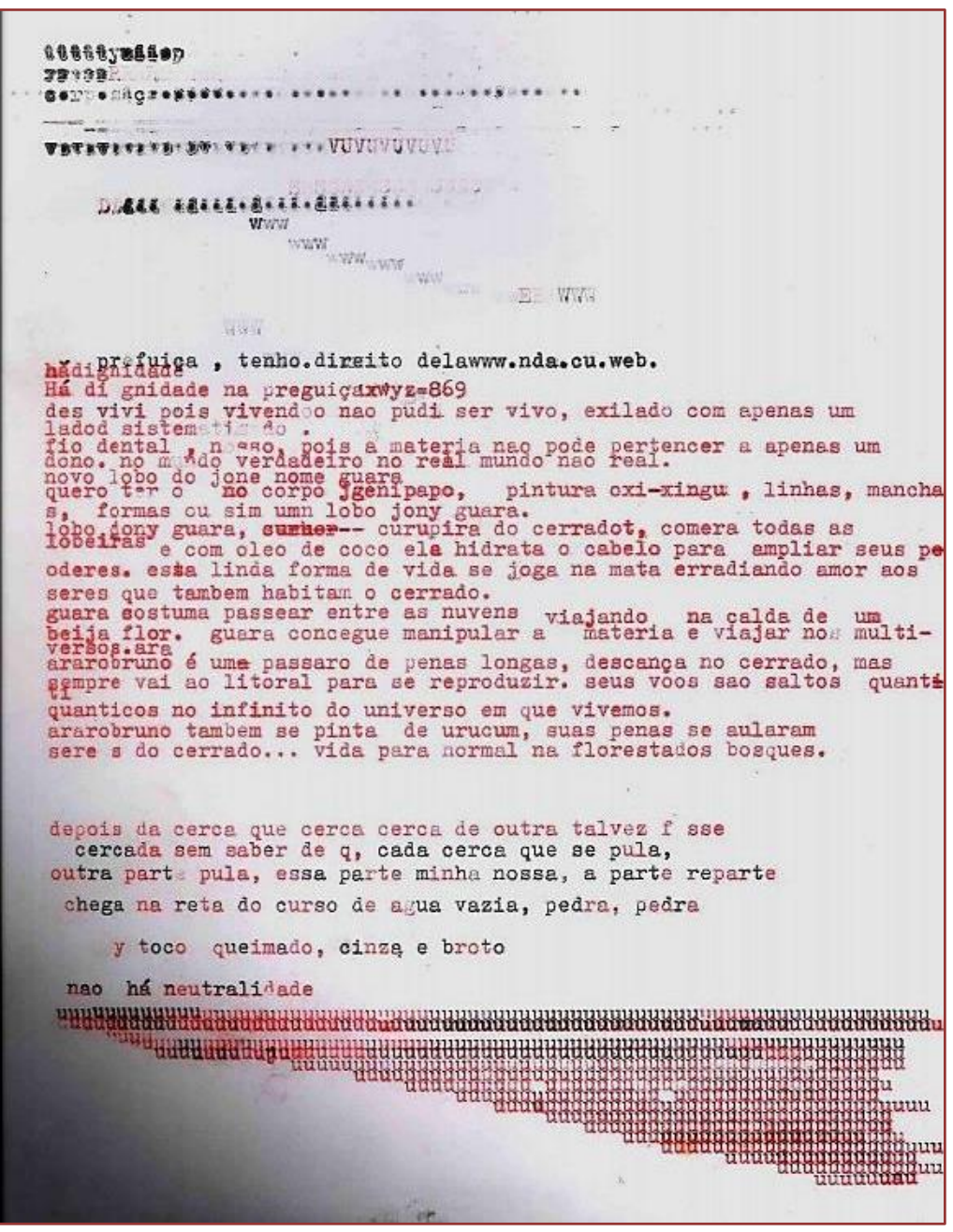


(...)

Vou antecipar a viagem já que o abismo é meu vizinho. Frente a frente compartilhamos horizontes. Nos vemos e sabemos um do outro. (Sabemos nada!)

No plano da viagem vou ao abismo. Aquela outra vista de tão longe mesmo mundo de mim.

Outro lugar da mesma casa.

(Onde estou? Morada em mim)

Eu não vai à viagem por que mim precisa ir só. As preocupações de 'eu' revelam a mim que estou mais calma que antes. Mim discorda. Esse caminho, que em algum momento já estive, é em minha memória desgastado. A lembrança é o fragmento da memória.

(Lembrança vagante revive memória sentida, mas o que chega até aqui estória)

Todo dia parece uma data viável.

\section{(..)}

É daqui que visualizo a menor montanha do mundo. Ela se localiza na rua que fica em frente de onde sempre vou. Parei no caminho, ela me desvia e aceito: não tenho relógio para ter pressa.

Ela fica em cima de um bloco de concreto quebrado pela raiz de uma árvore grande. De tamanha pequeneza, quis logo subir esquecendo toda pressa, que mesmo sem relógio, habita em mim. Sendo assim no primeiro passo, na primeira tentativa, já tinha passado a montanha e chegado ao outro lado.

0 relógio batia em minha veia rala. Foi preciso reparar, diminuir o passo, a pressa, o impacto. Experienciar outro tempo, eu flutuante.

Quando a ponta do meu pé toca o topo, se esfarela a pouquíssima terra vermelha que há. 0 mais alto da menor montanha do mundo é o chão. De lá as casas são tão altas que quase estrelas e as estrelas tão altas que só se pode ver de olhos fechados. A formiga é o novo dinossauro.

(a pequenice começou a comer minhas sensações)

Em cima da onde consegui chegar tudo era abismo e mal podia mexer meus pés. 0 vento ventava a queda: propício fim e o início da diversão. Sem pensar e sem impacto, me lancei. No micro das frações do tempo em queda me deliciava com o prazer do movimento. Se o tempo era pequeno, não sei de que tamanho sou.

Escalar. Mirar. Pular de um abismo ao outro.

Enfrentar. Abismar. Saltar.

(Passeando passaram dias em que escrever não se encaixou no roteiro. Até que na lua cheia o céu ficou transparente com todos os planetas escancarados, meu olhar passou a grade ignorando-a. Saiu andando com minhas pernas e de 
repente o trilho do trem estava iluminado. Reconheci que era esse o caminho de minha velha lembrança, o revivi como pude. Preferindo as beiradas. 0 frio congelante fazia eu sentir mais quente ainda o calor que gero: criação fulminante, monstra fogueira no epicentro de querer esvaziar-se de mim. Todo fogo precisa de ar.) (outrys n'alla. Acervo pessoal.)

\section{DOS REGISTROS DE PERFORMANCE AOS REGISTROS EM CORPO: TUDO ESCRITA}

A escritura transborda o papel, o suporte, cria corpo que é voz e vez de quem escreve. Escrever no mundo é, substancialmente, arriscar-se em território desconhecido. Revolto os olhos a mim e as escritas que me compõem cicatrizes visíveis e invisíveis. Texto sem letra, textura em dermes. Sulcos profundos desse órgão-casca que nos envolve. Viver é inscrever de-com-para o mundo. Esse corpo, mutante, me caderna nele. Leitura no tato, no cheiro, o encontro me escreve. A ideia de corpo-caderno é uma analogia que transcende a concepção de corpo como suporte para algo e propõe humanizar os trajetos do caderno em detrimento da objetificação do corpo. 0 corpo acontece, fala, escreve, grifa-grita.

No corpo, marcas e processos, cicatrizes, estrias, celulites, cortes e acidentes são o novo léxico indecifrável, pessoal e ficcional. Enigmática derme de leitura não letrada. Percursos acidênticos ${ }^{66}$ me fazem crer poesia nas pereba: suturas que criam alteridades.

Ainda que em sua forma histórica recente a literatura se dê por meio da escrita fonética, produzindo romances, poemas, peças, biografias e ensaios ficcionais, seu modo operatório abala as oposições ditas metafísicas que acabei de nomear e que são infinitas, embora modeladas pela oposição primacial entre dentro e fora ou interioridade e exterioridade. A particularidade do literário não significa que se trate de um simples exemplo da escritura em geral, mas sim de uma forma histórica a partir da qual o gesto mesmo de inscrição e certo poder "dizer tudo" que o acompanha, como logo veremos, servem para pensar o que é imprimir e deixar rastros. Tais rastros e traços nunca são perenes, contudo se destinam ao máximo da permanência possível, ao menos como restos. (DERRIDA, 2014, p. 16)

As marcas falam por sentidos: memória, desenho, profundidade... sinais sem alfabeto e de léxico composto. Olhar sem ver, tocar o corpo já conhecido subjetivamente é possibilidade de reencontrá-lo, experimentarse. 0 de novo será sempre outro, somos corpos em rede.

Paradoxo do invólucro em que vivemos, a pele marca o tempo, o tempo marca a pele. Ao nascer, viemos folha lisa, caderno, pele rígida e nunca provada; o crescimento faz marcas. 0 tempo impresso sobre a pele faz pelanca, se estica, se rasga, renova, modifica, cicatrizando os riscos experimentados. 0 sensor-pele é ininterrupto, exterioriza o ritmo do corpo e seus possíveis desejos. 0 sensor-pele é popular, livro de livre acesso e independente de alfabeto: para lê-lo é necessário acessar os sentidos e não o código-padrão. São milhares de volumes em tiragem única, independentes, apesar de não solitários: matilha de corpocaderno. Sensores-pele, vibratilidade em registro, se conectam, compondo entre si cadernos vivos. Manoel de Barros diz que "a palavra tem que chegar ao grau de brinquedo para se tornar séria" (2010, p. 348), nesse grau brinquedos as palavras se despalavreiam, lemos paisagens sob tempo.

Tempo: agente ativo da modificação na geografia dos cadernos-corpo. Espera-se do corpo, enquanto sinal de vida, absorver a ferida ressignificando-a. Espera ativa, cicatrização e sua escritura sobre pele: cadernocorpo. Corpo todo afetado, compondo com o rastro da incógnita Tempo.

Caderno: Espaço-tempo para processos. As escrituras se apropriam de devires ${ }^{67}$, do movimento do próprio corpo e da construção de si como espaço em/de arte. Se por vezes escrevo, sinto no escrito voz, movimento, gosto, baba, suor e gozo. Escrevo e escorro.

Pele: diário exposto que não cansa de rasurar-se. A epiderme, camada mais exterior da pele, é uma parte do tecido tegumentar que se alastra em camadas mais profundas, marcas não são resumidas somente pelo

66 Palavra de Chico Cesár, aparece na música "Museu”, 2015.

${ }_{67}$ Devir é, a partir das formas que se tem, do sujeito que se é, dos órgãos que se possui ou das funções que se preenche, extrair partículas, entre as quais instauramos relações de movimento e repouso, de velocidade e lentidão, as mais próximas daquilo que estamos em vias de nos tornarmos, e através das quais nos tornamos. É nesse sentido que o devir é o processo do desejo. (DELEUZE \& GUATARRI, 1997, p.55) 
que se vê. Cicatrizes de amor estão cravadas onde? A capacidade de retirar de si uma cicatriz não desvincula o corpo da própria história. A pele em camadas, massa folhada de nós, possui memória sósentidas, invisíveis de tão profundas. O corpo incorpora os fatos, transforma em carne, mantém uma memória dissociável das noções lógicas cerebrais. Corpo fala e faz cicatriz-ação.

Nós, Corpos Informáticos, ampliando o conceito de performance para a vida, estamos à margem, marcados, afetados, sangrando, em vermelho, corpo e encontro. Ao analisar a derme que envolve, reencontro muitos rastros: toda cicatriz é denúncia de vida, caso fosse morte, seria ferida aberta. Rastros que já não tenho certeza de onde vieram rabiscam meu corpo, eterno rascunho não-refeito, nãotranscretível: sinal nomadizante ${ }^{68}$.

Na construção desse mapa secreto hibridizam-se memórias que a cabeça já tinha esquecido, estórias sobre peles, mentiras, caminhos, invasões e tantas outras sensações e querências. Misturadas às cicatrizes estão parte do meu/seu eu-caderno, parte dessa construção identitária. Me reconheço nas estranhezas das fendas cicatrizadas em cada parte que agora olho e sinto por mais tempo. É tudo isso que me torna eu mesma, singular, e cria também as alteridades enquanto elas próprias: singularidades. Fechar as feridas, amar as cicatrizes são processos que demandam tempo - outro tempo não cronológico, tempo-corpo.

Então escrever é o modo de quem tem a palavra como isca: a palavra pescando o que não é palavra. Quando essa não-palavra - a entrelinha - morde a isca, alguma coisa se escreveu. Uma vez que se pescou a entrelinha, poder-se-ia com alívio jogar a palavra fora. Mas aí cessa a analogia: a não-palavra, ao morder a isca, incorporou-a, o que salva então é escrever distraidamente. (LISPECTOR, 1980, p. 43)

Cicatrização enquanto possibilidade de escrevinhação polissêmica. Corpo insiste e faz, pelas cicatrizes reconta o que as palavras silenciam. Inauguram, a cada novo instante, uma escritura íntima em carne: "meu corpo é o meu protesto"69. (PANAMBY, 2009).

Ao me reler, constato que sou ruim para fazer descrições das coisas, mas, tudo bem, isso não interessa nem à performance, nem ao registro e tampouco à pele: a estas cabe transpassar o próprio texto/gesto meramente descritivo a fim de alargá-lo, reinventando lógicas outras, priorizando a sensibilização ao entendimento. A escritura é curva no caminho do texto, forma mais cativa de falar sensações, de adjetiválas, compor detalhes na imanência do vivido. 0 texto transpõe o corpo, imagetiza e fragmenta sensações, mas não poderá dá-las ao exato. 0 corpo sincero, aqui-sendo, se insere sendo corpo-caderno.

"O prazer do texto seria irredutível a seu funcionamento gramatical, como o prazer do corpo é irredutível à necessidade fisiológica." (BARTHES, 2010, p. 24). As reflexões geradas através do com-tato das palavras e ações artísticas, são transbordamentos da performance, pedaço de raiz da mar(Ogonha ${ }^{70}$ que, ao ir-semver, esparrama-se solo adentro buscando novas florescências. Em si, carregam um sentido de incompletude, bem como o corpo, as linguagens artísticas, estéticas e literárias compõem, além da visão, a esfera política da sociedade. No sentir do corpo - em todos sentidos - está imersa uma possível teoria da performance. 0 corpo pós-durante-ante a experiência engendra em si mesmo a teoria, re-cria, imagina. Talvez a teoria mais exata, o final da história amoral, seja experimentar/fazer com o corpo, prazeres, arriscar-se em próprias lógicas e questionamentos. Propício precipício. Cada corpo é potencialmente político e toda a cidade passível (e necessitada) de in-vazão. "Caminhante, não há caminho." (MACHADO, online, sem data). Poeticamente busco/amos brechas concretas para seguir incertezas do caminhar deambulante em arte.

As letras e as marcas nos poemas, agora, adormecem e sentem fome: garatujas-vivas. Fiz-me gatafunha, me desfaço das pautas. Escritura agora dura a eternidade de um quase-nada: são meus passos na lama, o remendo dos asfaltos frente à casa de vovó, a borra de café na xícara, a leitura de lábios que pronunciam uma língua totalmente desconhecida. A escritura se estende além do código, escorrendo, sem que nenhuma contenção lhe caiba, esparrama-se em corpos-caderno. Não se entende - sente, degusta, deseja.

\footnotetext{
68Logo, não há regras para atos de linguagem. Expandindo, entendemos que na arte de rua não havendo um contexto fixo e prevendo-se parasitagem, teremos sempre iteração, uma repetição sempre outra. Daí resulta a necessidade da prática do improviso, do desvio, a abertura à participação do iterator e/ou seu silêncio. Os transeuntes se acostumaram ao silêncio. Para retirá-los desse lugar do consumidor passivo, há necessidade de sinais nomadizantes. Arte de rua é sinal nomadizante. (MEDEIROS, p.77, 2017)

69 Performance ritual de suspensão corporal de Sara Panamby. Realizada por Filipe Espindola (Studio Nômade/Campinas) e Milze Kakaua (Muse From Hell) em 12/06/2009 no estúdio do artista Otávio Donasci.

$70 \quad$ Referência ao conceito mar(ia-sem-ver)gonha de Corpos Informáticos.
} 
Caminhos torpes e dúbios são esses do fim que anunciam tanta bobeira, balbúrdia e fuleragem como táticas de sensibilização e $r$-existência poética.

\section{REFERÊNCIAS}

[1] Aquino, F. \& Medeiros, M.B. Corpos Informáticos. Performance, corpo, política. Brasília: PPG-Arte/UnB, 2011.

[2] Barthes, Roland. O prazer do texto. Trad.: J. Guinsburg - São Paulo: Perspectiva, 2010.

[3] Brites, Mariana Ramos Soüb de Seixas. Escritura poética como escrita para a arte e suas possibilidades em registro: do caderno ao corpo. 2017. [173] f., il. Dissertação (Mestrado em Arte) — Universidade de Brasília, Brasília, 2017.

[4] Contemporânea, Evocações da Arte; Informáticos, Corpos. Corpos Informáticos (BR): Corpos Informáticos. Disponível em: <https://performatus.net/catalogo-artistas/corpos-informaticos/>. Acesso em: 15 abr. 2019.

[5] Davino, Leonardo. Museu. 2015. Disponível em: <http://lendocancao.blogspot.com/2015/09/museu.html>. Acesso em: 24 mar. 2019.

[6] Deleuze, G \& Guattari, F. Mil Platôs: Capitalismo e Esquizofrenia, Vol. 4. São Paulo, 34, 1997.

[7] Derrida, Jacques. Essa estranha instituição chamada literatura: uma entrevista com Jacques Derrida. Trad. Marileide Dias Esqueda. Belo Horizonte: UFMG, 2014.

[8] Informáticos, Corpos. Corpos.org. 2005. Disponível em: <corpos.org>. Acesso em: 23 abr. 2019.

[9] Informáticos, Corpos. Pelos Pelos. 2013. Disponível em:

$<$ http://performancecorpopolitica.net/?gallery=mariana-brites-e-alexandra-martins-pelos-pelos $>$. Acesso em: $18 \mathrm{fev}$. 2019.

[10] Informáticos, Corpos. Performance Corpo Política: performance latino-americana. 2010. Disponível em: <www.performancecorpopolitica.net>. Acesso em: 12 mar. 2019.

[11] Lispector, Clarice. Água viva.10. ed. Rio de Janeiro: Nova Fronteira, 1980.

[12] Machado, Antônio. Cantares. sem data. Disponível em: <http://blogs.utopia.org.br/poesialatina/cantaresantonio-machado/>. Acesso em: 24 mar. 2019.

[13] Medeiros, Maria Beatriz de. Arte, performance e rua. 2017. Disponível em: <http://www.periodicos.ufop.br/pp/index.php/raf/article/download/580/536>. Acesso em: 02 maio 2019.

[14] Medeiros, Maria Beatriz de. Sugestões de conceitos para reflexão sobre a arte contemporânea a partir da teoria e prática do Grupo de Pesquisa Corpos Informáticos. 2017. Disponível em: <http://periodicos.ufrn.br/artresearchjournal/article/download/11808/8698>. Acesso em: 15 abr. 2019.

[15] Panamby, SaraElton. Meu corpo é meu protesto. 2010. Disponível em: <https://www.youtube.com/watch?v=wxTKpKwBu28>. Acesso em: 11 fev. 2019. 


\section{Capítulo 24}

Desconstruir como pessoa para se reconstruir como professxr: As diversas produções cotidianas trabalhar as questões de gêneros e sexualidades na escola

\section{Luiz Otavio Ferreira da Luz.}

Resumo: Este artigo discute questões sobre gêneros e sexualidades e traz reflexões acerca da sua difícil abordagem no espaço escolar. Com embasamento nas discussões sobre as regulações de silenciamentos, a dualidade entre o normal e o anormal e as expressões da heteronormatividade presentes em nossos cotidianos, compreende a escola como um espaço de convivência e de trocas de experiências, possibilita a socialização e apreensão de novas aprendizagens, onde as questões de gêneros e sexualidades estão presentes a todo o momento. A pesquisa reflete, a partir dos discursos de professorxs da educação infantil de escolas de uma cidade da Baixada Fluminense - Rio de Janeiro, quais os mecanismos cotidianos de professorxs para lidar com seus conhecimentos e desconhecimentos, quando estas temáticas surgem em sala de aula. Nas suas falam expressam que necessitam se descontruir como pessoas para reconstruir como professorxs, pois suas práticas, que constroem seus saberes, que não partem somente de sua formação acadêmica, mas que compreende toda sua vida e construções que se deram a partir de suas experiências no campo cultural familiar e religioso.

Palavras-Chave: Educação Infantil; Gênero e sexualidade; Escola. 


\section{INTRODUÇÃO}

A pesquisa, em caráter preliminar de estudo para confecção de tese, aborda questões sobre gêneros e sexualidades no espaço escolar e tem por objetivo problematizar, a partir das falas de professorxs, principalmente aqueles que se auto declaram cristãos, as compreensões que estes produzem e constroem seus saberes nos seus cotidianos. Visto que muito do que produzem ou não em relação a essa temática, está vinculado aos conhecimentos e desconhecimentos sobre a questão em que podemos compreender que a academia não os discute durante o processo de formação.

Sobre a questão da produção de saberes que se tecem nos múltiplos espaços/tempos, Tardif (2011, p.54) esclarece que é na própria prática docente desenvolvido pelo profissional, um saber plural, formado de diversos saberes provenientes das instituições de formação, da formação profissional, dos currículos e da prática cotidiana e desta forma, podemos compreender que diante sua formação múltipla, o professxr, quando deseja, necessita se reconstruir como pessoa a partir de suas crenças e profissional para lidar com questões estanques as suas produções de saber. Sobre a perspectiva freireana de ou reproduzirmos as normas, padrões e desigualdades ou tentarmos transformar esta realidade é que se pauta a principal questão desta pesquisa: Se reconstruir como professxr, para além de toda sua formação acadêmica e produções de saberes durante toda a vida nos mais diversos espaços para poder trabalhar com questões de gênero sexo e sexualidade no espaço escolar.

Diante a nossas experiencias como pesquisadorxs da área em contato com escolas, podemos perceber que muitos professorxs sentem-se perdidos entre o querer fazer, produto dos desejos sobre seus alunos nas questões de gênero, sexo e sexualidade e as condições pelas quais se colocam em impedimento, produto de sua cultura, verdades e crenças. Desta forma, limitados sobre suas próprias perspectivas, vivenciam uma dualidade funcional que em muitos casos desrespeitam as singularidades destes alunos. Ou seja, o que se percebe quando essas questões aparecem na prática cotidiana do professxr em sala de aula, estes se atêm a informações apoiadas meramente no dispositivo da fisiologia do aparelho reprodutor numa perspectiva da ciência e conhecimento, mesmo que apenas prévio, do corpo, deixando de lado outras questões que poderiam ser abordadas, mas que são deixadas de lado por medo de como este trabalho pode ser verificado por terceiros, despreparo em lidar com as questões ou ainda limitados a algo referente, como exposto, às suas crenças.

\section{QUESTÕES DE GÊNERO, SEXUALIDADE, ESPAÇO ESCOLAR E SUAS REGULAÇÕES}

Diante as experiências como professor da rede pública e particular, tanto dos anos iniciais e finais do ensino fundamental e Médio, quanto pesquisador da área de gêneros, e sexualidades, me fizeram compreender que o espaço de discussão sobre tais questões na escola mostra-se e é de difícil tarefa, contudo muito necessária, visto que a escola é o ambiente mais frequentado pela criança, depois do espaço famíliar. Tal ponto traduz a necessidade de cada dia mais problematizarmos nos espaços escolares, tendo em vista a sexualidade como parte integrante e constituinte dos sujeitos, independentemente de seu contexto social ou nível de aprendizagem, num conteúdo de trabalho sobre sexualidade, para além de um simples tema transversal como nos foi apresentado nos antigos PCNs.

Silva (2004), em seus estudos sobre diversidade, afirma que algumas questões como etnia, gênero e raça começam a ser apontadas pelo currículo escolar apenas muito recentemente e após os estudos pósestruturalistas e dos estudos culturais por meio do vínculo entre conhecimento, identidade e poder.

Em se tratado sobre os estudos culturais, vamos a Teoria Queer, onde o mesmo autor afirma que as pesquisas da teorização feminista sobre gênero, permitem defender a hipótese de que há uma construção social para a questão da sexualidade. Ou seja, a influência da teoria queer sobre a construção dos currículos tem uma fundamental importância, visto que vai ao encontro daquilo que temos como existente.

Seguindo pelos estudos culturais e a Teoria Queer, podemos compreender que o caminhar entre a academia e a escola, faz desta um ótimo espaço para estudar as questões das sexualidades, já que as diversas relações apresentadas aqui são de mais fácil observação nesse espaço e por isso proporciona que o pesquisador possa perceber de forma

Pelos caminhos que percorremos como profissionais da educação, podemos perceber pistas de que, apesar de mudanças e transformações contemporâneas, o referido processo ainda carrega práticas e mecanismos regulatórios tanto formação dos professorxs na academia, quanto nas identidades dos profissionais da educação. 
Podemos compreender que muitos professorxs conferem importância do estudo na área da sexualidade, reconhecendo a necessidade da educação sexual nas escolas, respeitando as "práticas sexuais" para o desenvolvimento saudável dos estudantes como seres humanos. E principalmente o respeito as sexualidades e os diversos gêneros existentes dentro do espaço escolar. Da mesma forma, como professor, aposto na perspectiva que muitos desses docentes já vivenciaram situações difíceis relacionadas à sexualidade em sala de aula e já se questionaram sobre as dificuldades em lidar com o assunto, ainda mais no contexto atual, quando a temática da diversidade sexual está em voga e permeando meios políticos com discussões acaloradas como as novas propostas da BNCC .

Prevista pelo Plano Nacional de Educação (PNE), a BNCC é um documento que visa sistematizar o que vem sendo ensinado e discutido nas escolas de educação básica. Tem como princípios ser uma listagem de objetivos de aprendizagem a serem alcançados em cada uma das etapas da formação e nas áreas de conhecimento através da unificação nacional do currículo eliminando as desigualdades existentes entre diferentes regiões do território nacional, garantindo o direito a uma educação de qualidade.

Interessante ressaltar, aliado aos diversos profissionais que se colocam contra o documento pelos mais variados motivos dentre eles o principal de descaracterizar o estudante em sua condição de diferença, o trabalho docente a partir de sua condição criativa e a desconsideração da complexidade da vida na escola. Também traço algumas considerações referentes a questão da sexualidade nos contextos do cotidiano da escola.

Tendo por base o documento da BNCC, o termo "sexo" aparece apenas 2 vezes em seu conteúdo. Ambas, na unidade 4 - Hereditariedade: padrões e processos de armazenamento, transmissão e expressão de informação na parte de organização curricular do componente Biologia para o Ensino Médio. Já o termo "sexu" que compreende as palavras "sexuada", "sexual", "sexualidade" e "homossexualidade" aparecem apenas 26 vezes.

Para o termo "sexu", este aparece pela primeira no documento na expressão orientação sexual na parte: Direitos à aprendizagem e ao desenvolvimento que se afirmam em relação a princípios éticos, no capitulo 2 onde são apresentados os princípios da BNCC.

As crianças, adolescentes, jovens e adultos, sujeitos da Educação Básica, têm direito: ao respeito e ao acolhimento na sua diversidade, sem preconceitos de origem, etnia, gênero, orientação sexual, idade, convicção religiosa ou quaisquer outras formas de discriminação, bem como terem valorizados seus saberes, identidades, culturas e potencialidades, reconhecendo-se como parte de uma coletividade com a qual devem se comprometer (p.34)

Posteriormente a essa primeira aparição do termo citado, novamente só vamos encontra-lo novamente no campo de experiências, direitos e deveres da aprendizagem, no item "O eu, o outro, o nós".

O corpo expressa e carrega consigo não somente características e físicas e biológicas, mas também marcas de nosso pertencimento social que repercutem em quem somos e nas experiências que temos em relação ao gênero, à etnia ou raça, à classe, à religião e à sexualidade. (p.70).

As questões apontadas a partir de um documento normativo como a BNCC tornam-se de fundamental importância para as discussões sobre sexo, gênero e sexualidade, pois de acordo com o que foi observado no documento, ou melhor, a forma como algumas questões foram suprimidas do documento, pode nos alertar sobre a volta de um posicionamento propriamente conservador e por qual motivo não dizer higienista a educação onde o sexo e a sexualidade podem ser simploriamente entendida ou desentendida apenas como parte biológica. A medicina durante muito tempo tratou o sexo de forma biológica e apenas com caráter reprodutivo. No entanto, podemos observar que o discurso médico baseado em uma visão biológica, ao postular uma relação direta entre a sexualidade e a reprodução, força um distanciamento entre a primeira e a subjetividade e cria uma norma do que seria um desenvolvimento sexual normal, caracterizando como doença ou desvio a sexualidade que se diferencia dessa norma. E assim não podemos deixar de assistir os discursos de Michael Foucault sobre a sexualidade.

Através de tais discursos multiplicaram-se as condenações judiciárias das perversões menores, anexou-se a irregularidade sexual a doença mental; da infância à velhice foi definida e cuidadosamente caracterizados todos os desvios possíveis; organizaram-se controles pedagógicos e tratamentos médicos; em torno das mínimas fantasias, os moralistas e, também e sobretudo, os médicos, trouxeram à baila todo o vocabulário enfático da abominação: isso não equivaleria a buscar meios de reabsorver em proveito de uma sexualidade 
centrada na genitália tantos prazeres sem fruto? Toda esta atenção loquaz com que nos alvoroçamos em torno da sexualidade, há dois ou três séculos, não estaria ordenada em função de uma preocupação elementar: assegurar o povoamento, reproduzir a força de trabalho, reproduzir a forma das relações sociais; em suma, proporcionar uma sexualidade economicamente útil e politicamente conservadora. (FOUCAULT, 1988, p. 43-44).

A visão da medicina enfatiza que a sexualidade do indivíduo não está relacionada ao prazer, mas sim à reprodução da espécie. Desta forma, quando o sexo é entendido apenas como forma de reprodução, seu exercício fora desses planos é considerado como algo da esfera do não natural e do pecaminoso, que deve ser controlado e regulado. Para tanto, a partir desse momento, utilizarei o termo regulação para poder compreender as diversas formas como o sexo e a sexualidade estão sendo regulados na sociedade, nos espaços da escola e principalmente na educação infantil.

Em uma compreensão sobre as dinâmicas das sexualidades existentes nos espaços de uma escola, podemos considerar, com base nos discursos existentes sobre a sexualidade, tanto por parte da própria escola como por grande parte dos professorxs e demais funcionários e funcionárias, certa dificuldade em se tratar das questões relacionadas ao tema. Com o suposto objetivo de manter o controle e ordenação sobre seus espaços, diversos dispositivos de controle são praticados, regras impostas ou técnicas punitivas para que os comportamentos entendidos como normais sejam desenvolvidos. Todos esses dispositivos podem ser compreendidos como táticas de disciplinamento. Louro (2001) diz que diante de várias estratégias de disciplinamento da sexualidade as crianças experimentam a censura e o controle, aprendem a vergonha e a culpa, o que gera um aprendizado de que a sexualidade é da esfera do privado. A questão da sexualidade em sala de aula, na maioria das vezes, ainda é tratada como um tabu.

Ainda que o tema da sexualidade seja cada vez mais debatido fora da escola (na mídia, por exemplo), tal questão ainda é, em geral, um tabu em sala de aula, pelo menos nos discursos legitimados pelos/as professores/as. Estes frequentemente colocam a sexualidade no reino da vida privada, anulando suas percepções e consequências sociopolíticas e culturais ao compreendê-la como uma problemática individual. Em tais discursos, os corpos não têm desejo, não se vinculam a prazeres eróticos e, na verdade, não existem como forças constitutivas de quem são nas práticas sociais. (LOPES, 2008, p. 125).

É necessário compreender que a sexualidade está presente no espaço escolar, pois está nos corpos de todos os sujeitos que a habitam (LOURO, 1997), assim como é importante perceber que esse espaço, para além de uma ideia tradicionalista da educação onde os objetivos da instituição escolar estão voltados para a transmissão de conteúdos, também pode ser entendido como um local onde existem outras construções, como a dos sujeitos. Na contemporaneidade, o espaço da escola tem ocupado um lugar bastante interessante para a compreensão sobre o período da infância. Podemos entender que é no espaço escolar - nas creches, na educação infantil e ainda nos anos iniciais do ensino fundamental, por exemplo onde as crianças passam grande parte de seu tempo em atividades, que elas, de uma forma geral, têm na interação e na relação com seus pares, uma das formas do processo criativo e do desenvolvimento da aprendizagem.

Louro (2000) em relação à sexualidade humana de uma forma geral concorda com Foucault e compreende que:

A sexualidade, afirma Foucault, é um "dispositivo histórico" (1988). Em outras palavras, ela é uma invenção social, uma vez que se constitui, historicamente, a partir de múltiplos discursos sobre o sexo: discursos que regulam, que normatizam, que instauram saberes, que produzem "verdades". Sua definição de dispositivo sugere a direção e a abrangência de nosso olhar: um conjunto decididamente heterogêneo que engloba discursos, instituições, organizações arquitetônicas, decisões regulamentares, leis, medidas administrativas, enunciados científicos, proposições filosóficas, morais, filantrópicas [...] o dito e o não-dito são elementos do dispositivo. 0 dispositivo é a rede que se pode estabelecer entre esses elementos (FOUCAULT, 1993, p.244; LOURO, 2001, p. 6).

Segundo Rodrigues (2011) quando uma das manifestações da sexualidade infantil se expressa no espaço público, pode tornar-se objeto de punição, controle, correção e disciplinarização dos corpos. Assim, as crianças desde cedo, através de um discurso baseado na moral cristã que aloca o sexo como pecaminoso, numa via apenas de reprodução, são, através dos discursos morais, chamadas, muitas vezes, a ocupar um 
lugar fixo e determinante no enquadramento de sua sexualidade. Entendo o enquadramento realizado sobre a sexualidade infantil, no modo e na relação que se faz sobre a sua existência ou não nos discursos, neste caso, de seus pais e responsáveis, na maneira pela qual se dirigem aos seus filhos dizendo que está errado ou ainda que "essas brincadeiras" não são para sua idade. Ou seja, o controle da sexualidade, ou menor na expressão da sexualidade pelos corpos e expressões, são moldados a partir de discursos que se fazem sobre os objetos e não sobre os sujeitos (FOUCAULT,1988).

$\mathrm{Na}$ contemporaneidade, necessitamos enquadrar para controlar, necessitamos definir lugares para os sujeitos. E nesses lugares determinados, os comportamentos e os sujeitos que lá poderão estar. Assim, a sexualidade das pessoas atua como um marcador de lugar de identidade (no singular) e de diferenças.

Como lembra Foucault (1988), a sociedade ocidental organiza em torno do sexo técnicas religiosas, médicas e sociais de controle e punição, e essas técnicas também são usadas para controlar a sexualidade infantil.

Vamos estabelecendo quem vigia quem, quem controla quem, enfim, vamos construindo identidades, tanto daqueles que devem estar num ponto do processo, quanto daqueles que se situam na outra extremidade, até que sejamos capazes de nos autovigiar, autocontrolar e autogovernar, incorporando as normas que muitas vezes não colocamos em discussão e naturalizamos. Como nos lembra Britzman (2000), a sexualidade não se constitui em problema, mas ela é o lugar em que os problemas se afixam (FERRARI, 2010, p. 258).

Desde crianças, sofremos, portanto, uma autorregulação dos comportamentos para a atividade sexual e do corpo. A sexualidade que está presente nas crianças, e não só nelas, quando entendemos que é inerente aos corpos e parte constituinte dos sujeitos, passa a ser alvo de controle e disciplinarização. Pois, as marcas culturais de cada sujeito ou família fazem com que as crianças entendam que a sua sexualidade não deve ser explorada ou exposta. E de tal forma algumas crianças procuram realizar suas experiências escondidas, já que poderão sofrer reprimendas ou punições por isto.

No contexto da escola, essa contenção pode ser vista na medida em que o assunto não é falado, é escondido, e quando ocorrem, alguns artifícios são criados para que possa então ser silenciado. Para Foucault (2010), a escola possui diversos instrumentos para trabalhar a sexualidade, aqui vistos como artifícios pela ação dos professorxs e funcionários da instituição. Ela pode ser entendida dessa forma como lugar de correção, espaço por excelência das pedagogias preventivas e coercitivas, laboratório de construção no corpo dos currículos.

Campo da anomalia vai se encontrar desde bem cedo, quase de saída, atravessado pelo problema da sexualidade [...] De um lado, porque esse campo geral da anomalia vai ser codificado, policiado, vão lhe aplicar logo, como gabarito geral de análise, o problema (p. 211).

As ideias da negação do sexo, da sexualidade na criança, da regulação sexual nos contextos da educação, mais precisamente na educação infantil, numa tentativa do controle da expressão da sexualidade infantil através do castigo estabelecido pela instituição, estão, para Foucault (1988), não na própria repressão da sexualidade, já que ela está presente em todos os âmbitos da vida humana, mas sobre tudo nos discursos sobre ela, pois falar a respeito de sexo significa controlá-lo e institucionalizá-lo, facilitando assim a prática vigiada, normatizada e controlada da sexualidade, e dessa forma, o próprio comportamento dos sujeitos. Foucault (1988) ainda afirma que:

Existe, talvez, uma outra razão que torna para nós tão gratificante formular em termos de repressão as relações do sexo e do poder: é o que se poderia chamar o benefício do locutor. Se o sexo é reprimido, isto é, fadado à proibição, à inexistência e ao mutismo, o simples fato de falar dele e de sua repressão possui como que um ar de transgressão deliberada. Quem emprega essa linguagem coloca-se, até certo ponto, fora do alcance do poder; desordena a lei; antecipa, por menos que seja, a liberdade futura. Daí essa solenidade com que se fala, hoje em dia, do sexo. Os primeiros demógrafos e os psiquiatras do século XIX, quando tinham que evocá-lo, acreditavam que deviam pedir desculpas por reter a atenção de seus leitores em assuntos tão baixos e tão fúteis. Há dezenas de anos que nós só falamos de sexo fazendo pose: consciência de desafiar a ordem estabelecida, tom de voz que demonstra saber que se é subversivo, ardor em 
conjurar o presente e aclamar um futuro para cujo apressamento se pensa contribuir. (FOUCAULT, 1988, p. 12).

Dessa forma, a problemática dos discursos que habitam muitas escolas sobre a utilização dos conceitos normal, anormal, normalidade, anormalidade, em relação aos comportamentos expressos pelos os alunos é de fundamental importância.

Em relação ao que é considerado como o anormal, as sexualidades que não se enquadram dentro do modelo padrão são vistas como desviantes da norma pretendida e aludida como natural e habitual. Assim, podemos compreender que os conceitos mencionados se apresentam um como antítese do outro. Ou seja, o anormal é o contrário do normal, a anormalidade contrária à normalidade. Podemos, com isso, considerar que há uma dependência de um termo ao outro. Só existe o normal quando existe o seu contraponto: o anormal. Em Canguilhem (2009), encontramos uma apresentação do "anormal" baseado no "normal". Para ele, um conceito só existe em relação ao outro, isto é, a anormalidade só pode ser pensada com origem na normalidade. Contudo, o mesmo autor define que:

0 anormal, enquanto (a)normal, é posterior à definição do normal, é a negação lógica deste. No entanto, é a anterioridade histórica do futuro anormal que provoca uma intenção normativa. 0 normal é o efeito obtido pela execução do projeto normativo, é a norma manifestada no fato. Do ponto de vista do fato há, portanto, uma relação de exclusão entre o normal e o anormal. Essa negação, porém, está subordinada à operação de negação, à correção reclamada pela normalidade (CANGUILHEM, 2009, p. 111).

Assim, ao articularmos as definições estabelecidas pelo dicionário e as palavras de Canguilhem (2009), podemos perceber que há uma tentativa de neutralizar as relações entre aqueles que são considerados normais e aqueles que não são, portanto, desconsiderando-se a complexidade presente nessas inserções (SEPULVEDA, 2012). Dando continuidade a esse pensamento, Sepulveda (2012) recorre a Veiga Neto (2001) para compreender que:

Como sabemos, frente aos incômodos que palavras como normal e anormalidade podem nos causar, são possíveis algumas alternativas. [...] Uma terceira alternativa - aliás, compatível com a anterior - consiste em simplesmente naturalizar a relação normais-anormais, isso é, pensar a norma em termos naturais, como algo que aí está, à espera de ser entendida e administrada pelos especialistas. Desse modo a anormalidade se reduz, também aqui, a uma questão técnica, ainda que se possa embutir, junto a ela, uma discussão política em prol do anormal e, muitas vezes, da sua inclusão social (VEIGA-NETO, 2001, p. 108 apud SEPULVEDA, 2012, p.82).

A partir do pensamento do autor acima, desenvolvido por Sepulveda (2012), volto à questão do princípio das regulações para compreender os ajustamentos que se fazem nos comportamentos de alguns alunos nos espaços da escola. Para tanto, retorno ao conceito de normalizar que define uma ideia de "tornar-se normal, voltar à normalidade". Assim, podemos compreender que há uma busca a partir de uma vontade de normalizar, transformar todos em "normais", ou seja, uma forma de correção dos modos de existência e expressão da sexualidade

Não podemos afirmar aqui que haja uma regulação compulsória dentro do espaço escolar para a constituição do masculino e do feminino a partir de um padrão de comportamentos intrínseco à fala e atitudes, mas podemos compreender que é pelas atitudes tomadas pelos professorxs em sala de aula, quando diferenciam os gêneros masculino e feminino, colocando o que um menino pode e uma menina não pode fazer, que esses contribuem para a formação de sujeitos que entendem a heterossexualidade como a orientação sexual correta, como o padrão de comportamento desejável. Esta prática muito provavelmente levará a uma produção de discurso sobre a heteronormatividade na escola, pois a regulação existente na fala dos professorxs sobre os comportamentos aceitos ou não segue o padrão social considerado como ideal, moldando os comportamentos desejáveis no espaço escolar.

Ainda segundo os autores, é criado em 1991, por Michael Warner, uma tentativa de dar conta de uma nova ordem social, o conceito de heteronormatividade.

Isto é, se antes essa ordem exigia que todos fossem heterossexuais, hoje a ordem sexual exige que todos, heterossexuais ou não, organizem suas vidas conforme o modelo "supostamente coerente" da heterossexualidade. (COLLING; NOGUEIRA, 2014, p.179). 
Por essa perspectiva podemos compreender que os discursos existentes nas escolas em relação às questões da sexualidade e do gênero estão a todo momento vinculados às problematizações que se baseiam em princípios da heteronormatividade. Butler (2003) nos diz que a sociedade exige uma coerência entre sexo-gênero-desejo e prática sexual e, ao fazer isso, a heterossexualidade deixa de ser apenas uma entre tantas formas de viver a sexualidade para se tornar uma imposição, uma coerção sobre os corpos. Pertencente a essa sociedade, carregamos conosco esse discurso e o reproduzimos na nossa vida e em nosso trabalho. Essa compreensão de os discursos e a sexualidade serem afetados por uma construção social vai além quando tratamos da educação infantil, visto que em relação à idade das crianças constituídas nesse espaço, há contribuição de outros valores que são atravessados pelas crenças e saberes sobre a faixa etária, caracterizando-a como uma fase onde não há, ainda, uma exploração da sexualidade, assim anulando sua existência.

\section{ANÁLISE DA QUESTÃo DO GÊNERO E DA SEXUALIDADE NO ESPAÇO ESCOLAR: COMO SE DÃO AS AÇÕES DOS PROFESSORXS.}

A pesquisa se desenvolveu em um município da Baixada Fluminense-RJ. Foram lançados aos professorxs da educação infantil e do primeiro ciclo dos anos iniciais do ensino fundamental, um questionário on-line com quatro breves perguntas(1 - se possui alguma fé? Qual?; 2 - Compreende a importância sobre as discussões de Gênero, Sexo e Sexualidade no espaço escolar?; 3 - Realizam algum trabalho que abordem as questões de gênero, sexo e sexualidade no espaço escolar e 4 - Quais são os possíveis motivos impeditivos para realização de um trabalho efetivo?

Do montante de professorxs da rede, conseguimos respostas de 122 professorxs atingindo um número total de 22 escolas. As análises das respostas se deram de forma quantitativa, onde preliminarmente desejamos quantificar alguns sujeitos a partir de suas respostas.

Nas escolas alcançadas pela pesquisa, pudemos perceber as dificuldades encontradas em lidar com as questões referentes à expressiva sexualidade apresentada por alguns alunxs. Nos discursos preliminarmente obtidos dos professorxs, pode-se observar que existe uma grande vontade de lidar com naturalidade com a questão, contudo, a partir da constituição como pessoa, os seus traços culturais e verdades inerentes a sua crença, estxs professorxs não conseguiam desenvolver propriamente uma relação sem a qual o preconceito estivesse arraigado.

Diante esta realidade e após analise das repostas obtidas nos questionários apresentados, podemos compreender que existem muitas questões que devem ser discutidas com relação a abordagem sobre gêneros e sexualidade no espaço escolar. Com relação a primeira pergunta, referente a fé dxs professorxs, 42\% Protestantes, 33\% Católicos, 10\% Matriz Afro Brasileira, 10\% entendem que a religião é algo pessoal e não interfere no trabalho como professxr e $5 \%$ não possuem religião.

Como nos importava compreender como pensam xs professorxs que se auto declaram cristãos, vamos a segunda questão a análise dos 75\% que se autodeclararam Protestantes e Católicos. Destes 84\% Entendem que sim, compreende a importância sobre as discussões de Gênero, Sexo e Sexualidade no espaço escolar 10\% Afirmam que as políticas públicas necessitam legitimar a questão, 4\% discordam, 2\% se abstém a questão. Daqueles que compreendem a importância sobre as discussões de Gênero, Sexo e Sexualidade no espaço escolar, somente 5\% realizam algum trabalho que abordem as questões de gênero, sexo e sexualidade no espaço escolar, enquanto outros 5\% desenvolvem algum tipo de trabalho, mas não se sentem à vontade e $90 \%$ disseram que não.

Investigando um pouco mais a fundo, através das respostas daqueles que disseram não, desejamos saber quais são os possíveis motivos impeditivos para realização de um trabalho efetivo e assim, entendemos que $35 \%$ questões relacionadas a fé, $45 \%$ desconhecimentos sobre a questão, $20 \%$ medo sobre os julgamentos que podem decorrer. Ou seja, podemos compreender que mesmo aquelxs professorxs que se auto declaram cristãos, mas que entendem a necessidades de trabalhos referentes as questões de sexualidade e gêneros no espaço escolar, poucos são os que realmente desenvolvem, visto que ainda há um entrave de questão da fé, desconhecimentos sobre a questão e ainda medos e julgamentos.

Desta forma, podemos compreender na breve pesquisa de caráter apenas qualitativos, que sobre as respostas apresentadas não há de se concluir ou fazer projeções para trazer resultados de um manual sobre sexualidade e gênero nos cotidianos das escolas, na educação de crianças. Na diversidade de pontos que surgem como pistas em relação a questão da sexualidade, compreender que há uma profunda necessidade de discussões sobre a inserção do assunto nos currículos da formação é uma hipótese que pode vir a ser questionada visto que há uma necessidade muito mais ampla sobre a discussão verificada 
na própria fala dxs professorxs que vai além da formação, mas na própria cultura e construção histórica destes sujeitos.

Para além de formalidades de uma pesquisa acadêmica, perceber as angustias sobre as questões vivenciadas nos cotidianos da escola é também compreender que sobre muitas perspectivas, que a desqualificação sobre o trabalho docente em relação à temática da sexualidade, torna-se injusta visto que há muito mais vontade, independente de diversos fatores que vão desde a cultura ou uma formação deficiente, com medos ou estranhamentos, de acertar do que errar

\section{REFERÊNCIAS}

[1] Brasil. Parâmetros Curriculares Nacionais (PCNs) Orientação Sexual. Brasília: MEC, 1998.

[2] Brasil. Ministério da Educação. Secretaria de Educação Básica. Secretaria de Educação Continuada, Alfabetização, Diversidade e Inclusão. Secretaria de Educação Profissional e Tecnológica. Conselho Nacional da Educação. Câmara Nacional de Educação Básica. Diretrizes Curriculares Nacionais Gerais da Educação Básica. Brasília: MEC, SEB, DICEI, 2013.

[3] Brasil, Ministério da Educação. Base Nacional Comum Curricular (BNCC), 2o versão, abril de 2016, in: http://basenacionalcomum.mec.gov.br/documentos/bncc-2versao.revista.pdf

[4] Brasil, Rcnei - Referencial Curricular Nacional da Educação Infantil - Brasil, $1998 . \quad$ In: http://portal.mec.gov.br/seb/arquivos/pdf/eduinf_esp_ref.pdf

[5] Butler, Judith. Problemas de Gênero - Feminismo e Subversão da Identidade, Ed: Civilização brasileira, Rio de Janeiro, 2003.

[6] Canguilhem, G. O normal e o patológico. Rio de Janeiro: Forense Universitária, 2009.

[7] Colling, Leandro; Nogueira, Gilmaro. Relacionados mas diferentes: Sobre os conceitos de homofobia, heterossexualidade compulsória e heteronormatividade. In: Rodrigues, A.; Dallapicula, C.; Ferreira, S. R. S. (Orgs.). Transposições: lugares e fronteiras em sexualidade e educação. Vitória: Edufes, 2014.

[8] Ferrari, Anderson. Você já deve saber sobre minha "orientação sexual" (se não sabia, ficou sabendo agora, hehe) - subjetividades e sujeitos em negociação. In: Ferrari, Anderson. Sujeitos, subjetividades e Educação. Juiz de Fora: UFJF, 2010.

[9] Foucault, M. História da sexualidade II: o uso dos prazeres. Rio de Janeiro: Graal, 1985.

[10] _ _ Vigiar e Punir: nascimento da prisão. Petrópolis: Vozes, 1987.

[11] _ _ História da sexualidade I: a vontade de saber. Rio de Janeiro: Graal, 1988.

[12] _ _ _ O Nascimento da Clínica.Tradução Roberto Machado. 5 ed. Rio de Janeiro: Forense Universitária, 1998.

[13] _. A ordem do discurso. São Paulo: Loyola, 2000.

[14] __. Ética, sexualidade, política. Col. Ditos e Escritos V. Rio de Janeiro: Forense Universitária, 2004.

[15] _ _ Os Anormais. São Paulo: Editora WMF Martins Fontes, 2010.

[16] Lopes, Luiz Paulo Moita. Sexualidades em sala de aula: discurso, desejo e teoria queer. In: Moreira, Antonio Flávio; Candau, Vera Maria. Multiculturalismo: diferenças culturais e práticas pedagógicas. Petrópolis, RJ: Vozes, 2008.

[17] Louro, Guacira Lopes. Gênero, sexualidade e educação: uma perspectiva pós-estruturalista. Rio de Janeiro: Vozes, 1997.

[18] _. Pedagogias da Sexualidade. In: Autêntica, $\overline{2001}$. O corpo educado: pedagogias da sexualidade. Belo Horizonte:

[19] Louro, Guacira. Heterornormatividade e homofobia. In Brasil: Diversidade Sexual na Educação: problematizações sobre a homofobia nas escolas. Brasília: Ministério da Educação, Secretaria de Educação Continuada, Alfabetização e Diversidade, Unesco, 2009.

[20] Louro, Guacira. Educação e docência: diversidade, gênero e sexualidade. In: Revista Brasileira de Pesquisa Sobre Formação Docente. Autêntica: Belo Horizonte; vol. 3 - no 4, 2011.

[21] Louro, G. L; Felipe, J; Goellner, S. V. Corpo gênero e sexualidade: um debate contemporâneo na educação. Petrópolis: Vozes, 2012.

[22] Rodrigues, Alexsandro. A escola como possibilidade de investigação: corpo, sexualidades e currículos como investimento político. In: Ferraço, Carlos Eduardo. Currículo e Educação Básica: por entre redes de conhecimentos, imagens, narrativas, experiências e devires. Rio de Janeiro: Rovelle, 2011. 
[23] Sepulveda, Denize. Emancipação Social e exclusão no cotidiano escolar: a homofobia e sua influência nas tessituras identitárias. Tese (Doutorado em Educação) - Programa de Pós-Graduação em Educação, Universidade do Estado do Rio de Janeiro, 2012.

[24] Silva, Tomaz Tadeu (Org.). Documentos de identidade. Belo Horizonte: Autêntica, 2004.

[25] Tardif, Maurice. Saberes docentes e formação profissional. 11o edicação. Petropolis, Vozes, 2011. 


\section{Capítulo 25}

Sob a óptica de discentes da área de saúde, ser travesti é "Ter atitude por se 'assumir' diferente"

\section{Carle Porcino}

Maria Thereza Ávila Dantas Coelho

Jeane Freitas de Oliveira

Cleuma Sueli Santos Suto

Dejeane de Oliveira Silva

Maria Virginia Almeida de Oliveira Teles

Pablo Luiz Santos Couto

Anderson Reis de Souza

Resumo: Neste artigo objetivou-se compreender os sentidos das representações sociais de estudantes do Bacharelado Interdisciplinar em Saúde sobre a pessoa travesti. Tratase de uma pesquisa qualitativa norteada pela Teoria das Representações Sociais, desenvolvida com 243 estudantes que responderam ao teste de associação livre de palavras com a expressão indutora "pessoa travesti". 0 corpus constituído pelas evocações e as justificativas para os termos classificados como mais importantes, processados pelo software IRAMUTEQ, resultou na produção da nuvem de palavras e da classificação hierárquica descendente conformada em quatro classes, com aproveitamento de 75,82\%. Para o grupo investigado não se nasce, 'torna-se' travesti e esta condição foi associada à orientação sexual (homossexualidades), cuja vivência é marcada por situações de violência e preconceito, além de reconhecerem o "direito" de "se assumirem" e de "se expressarem" em consonância ao gênero que reivindicam para si. Pretende-se contribuir para que estudantes e profissionais de saúde possam refletir acerca do acolhimento e dispensa de cuidados a esse segmento populacional.

Palavras-chave: Travestis. Representações Sociais. Educação Superior. 


\section{INTRODUÇÃO}

No Brasil, é evidente a necessidade de refletir acerca da complexidade que perpassa a formação superior em saúde, no que se refere ao enfrentamento e a incorporação do reconhecimento da cidadania junto ao processo saúde-doença (Biscarde; Pereira-Santos; Silva, 2014). No entanto, quando se trata do acesso, acolhimento, demandas e/ou necessidades no âmbito da saúde de pessoas que divergem da cisheteronorma, percebe-se o quanto a dispensa de cuidados e o processo de formação profissional em muito se distancia da realidade e da real necessidade desse segmento populacional.

Frente a esse contexto, os avanços ainda são incipientes quando se vislumbra o cuidado integral sob a perspectiva da formação dos profissionais de saúde. Se, por um lado, o perfil desses profissionais demonstra qualificação insuficiente, por outro as mudanças se tornam emergentes (Batista; Gonçalves, 2011). Apesar da complexidade frente aos processos de mudanças, a universidade necessita tanto de investimentos em apoio técnico, quanto do empreendimento de esforços para garantir a realização da sua missão (Feuerwerker, 2003).

Formar profissionais para atuação em saúde, com perfil que atenda às necessidades sociais, se configura num dos maiores desafios no âmbito do ensino superior, considerando as particularidades demandadas pela natureza desse trabalho. Nesse sentido, são evidentes os esforços despendidos por Instituições de Ensino Superior (IES), na medida em que privilegiam a articulação entre teoria e prática como alternativa em suas ações educativas, ao facultarem, junto ao corpo discente, competências e habilidades no que concerne ao trabalho em equipe, de modo a desenvolver o potencial crítico e reflexivo (Pereira et al., 2015).

Aponta-se, que, entre os pressupostos que fundamentaram a implantação dos Bacharelados Interdisciplinares (BI), foi ponderado que, tradicionalmente, o modelo de ensino centrado na profissionalização mostrou-se associado a uma escolha precoce por carreiras, em estreita relação com altos índices de evasão. Nesse caso, a opção pelos BI é vista como uma oportunidade para melhor conhecerem cada profissão e amadurecerem sua escolha profissional (Mota; Teixeira, 2016). Além disso, de acordo com o projeto pedagógico, o Bacharelado Interdisciplinar em Saúde (BIS) objetiva agregar uma formação "geral, humanística, científica e artística ao aprofundamento no campo da saúde, promovendo o desenvolvimento de competências e habilidades [...] gerais e específicas [...] para uma posterior formação profissional" (UFBA, 2010, p. 7). Desse modo, as discussões em torno da política de saúde no decorrer da graduação possibilitam, à/ao egressa/o do BIS, o desenvolvimento de competências e habilidades, assim como a capacidade de "realizar uma leitura pertinente, sensível e crítica da realidade natural e humana em que está inserido[a]" (Almeida Filho, 2008, p.144). Por conseguinte, as/os discentes são estimuladas/os a pesquisarem e a desenvolverem seminários críticos, reflexivos e interdisciplinares, com vistas a delimitarem e analisarem as diferentes dimensões da saúde, associando a esta as sexualidades, subjetividades, corpos, identidades, diversidade cultural, arte, ciência e tecnologias, a partir de múltiplos olhares (Coelho; Teixeira, 2016).

Os conhecimentos aprendidos e apreendidos no universo da saúde provêm de diferentes campos do saber e, por isso, sofrem um processo de desarticulação dos contextos em que emergem. A partir daí, se constituem novos arranjos de ideias, conceitos e modelos relacionados ao cuidado na dimensão da saúde. Tais aspectos possibilitam a ampliação de horizontes, a visão sistematizada dessa prática, incorporando novas formas de conhecimento e contribuindo de modo mais assertivo para o desenvolvimento científico nas áreas da educação e saúde (Cianciarrulo, 2007).

Torna-se fundamental (re)conhecer as explicações e ideias circulantes no campo da saúde, considerando que estas possibilitam o (re)dimensionamento das práticas no âmbito institucional, assim como dos padrões de referência que orientam as trocas simbólicas e a comunicação junto aos grupos envolvidos (MOREIRA, et al. 2011). Dessa forma, faz-se necessário apreender as representações sociais de estudantes e profissionais de saúde, quando se pensa sobre a importância dos significados para o planejamento e a dispensa de cuidados a outrem, em uma temática relevante como a que engloba as travestilidades.

0 termo travesti, no contexto atual, tem sido utilizado com uma conotação negativa, como se a pessoa que assim se apresenta se 'utilizasse de um disfarce para ser o que não se é'. Assim, as travestis são pessoas que "vivenciam papéis de gênero feminino, mas não se reconhecem como homens ou como mulheres, mas como membros de um terceiro gênero ou de um não gênero" (Jesus, 2015, p. 55). 
Em função de serem pouco compreendidas, em particular por profissionais de saúde, as travestis costumeiramente enfrentam barreiras, preconceitos e violências quando demandam e/ou acessam os serviços de saúde. Essas situações, além de impactar na saúde e qualidade de vida, promovem distorções na equidade, um dos princípios mais importantes do Sistema Único de Saúde (SUS) (Romano, 2008; Porcino; Coelho; Oliveira, 2014). A esse respeito, na tentativa de coibir o preconceito enfrentado por esse segmento, por ocasião do acesso e/ou atendimento dispensado por profissionais de saúde no SUS, o Ministério da Saúde (MS), em parceria com o movimento social organizado, lançou, em 2004, a primeira campanha nacional: "Travesti e respeito: já está na hora dos dois serem vistos juntos. Em casa. Na boate. Na escola. No trabalho. Na vida". (Brasil, 2004a). Nova campanha é lançada em 2010, pelo MS: "Sou travesti: tenho direito de ser quem eu sou" (Brasil, 2010). Em 2012, por ocasião de participação no XIX Encontro Nacional de Travestis e Transexuais que Lutam contra a Aids (Entlaids), em Brasília, foi disponibilizado pelo MS um stand para que as travestis e transexuais presentes no evento pudessem fazer o Cartão Nacional de Saúde com a utilização do 'nome social'.

Entretanto, há quase duas décadas, depois do lançamento da primeira campanha, as mudanças são pouco expressivas em detrimento das violações aos direitos fundamentais. Apesar de o SUS ter como premissa a garantia do acesso integral e igualitário à saúde à toda a população brasileira, observa-se que, no que tange à saúde de pessoas travestis, a integralidade é falha e não existe articulação entre os níveis de atenção à saúde, bem como inexiste um trabalho em rede. Também observamos que direitos básicos, como, por exemplo, a reivindicação para serem tratadas pelo nome social, nem sempre são levados em consideração por profissionais de saúde. Nesse caso, por não respeitarem sua expressão e identidade de gênero pautada no/pelo feminino, é como se o atendimento fosse dispensado ao seu documento de identificação e não à sua pessoa (Porcino; Coelho; Oliveira, 2014). Outrossim, de acordo com a Carta dos Direitos dos Usuários da Saúde (Brasil, 2011), a pessoa deve ter assegurado o uso do nome de preferência.

A partir de atividade profissional desenvolvida pela primeira autora em uma Organização Não Governamental $(\mathrm{ONG})$, no que concerne às questões relacionadas à saúde, observamos que as pessoas travestis possuem demandas gerais e específicas, como, por exemplo: podem requerer acompanhamento com endocrinologista e acesso à hormonioterapia, para que possam "transicionar" com segurança, privilegiando a promoção da saúde e a qualidade de vida; considerando a faixa etária, também necessitam realizar a prevenção do câncer de próstata. No que se refere à administração de medicamentos por via intramuscular, as/os profissionais de enfermagem devem redobrar a atenção, pois, para aquelas que possuem silicone líquido industrial em nádegas e quadris, outras áreas do corpo devem ser privilegiadas em virtude da possibilidade da formação de abscesso.

Convém ressaltar que as travestilidades perpassam pela autorreferência, ou seja, é a própria pessoa que diz como se identifica a partir da autoadeterminação. No entanto, por se tratar da identidade de gênero, esta não deve ser confundida com a orientação sexual, como costumeiramente é vista/tomada (Jesus, 2015), nem concebida como um transtorno, fundamentado em uma determinada concepção de gênero (Bento, 2014), mas sim como mais uma possibilidade de expressão, pautada pela autoidentificação. A esse respeito, o Conselho Federal de Psicologia (CFP) reitera que as vivências de pessoas travestis não se constituem como uma condição psicopatológica. Nesse caso, a emissão de laudos, relatórios e/ou pareceres por psicólogas/os em situações específicas não deve imprimir uma visão patologizante, visto que é a própria pessoa que define o gênero a que sente pertencer (CFP, 2018).

À vista disso, trazer à tona esta discussão, pautada nas e/ou pelas representações sociais de estudantes que experienciam a formação em saúde, na perspectiva do BIS, objetiva, de modo especial, contribuir para a reflexão no que se refere aos desafios e avanços que perpassam esse processo formativo. Nesse seguimento, uma representação se constitui em uma modalidade de conhecimento particular, que tem a função de produzir e moldar comportamentos, bem como proporcionar a comunicação entre indivíduos (Moscovici, 2013).

Outrossim, as representações permitem acessar as dimensões simbólicas, culturais e práticas no que se refere aos fenômenos sociais, à medida que "estabelecem articulações entre os diferentes setores da vida social [...] sob a forma de relações de sentidos e de acordo com uma lógica própria, a lógica das representações" (Jodelet, 2009, p. 111-112). Nesse sentido, é relevante explorar as representações sociais sobre a pessoa travesti entre estudantes de cursos da área da saúde, na modalidade interdisciplinar, para se compreender como o conhecimento construído socialmente subsidia os comportamentos, condutas e ações no que tange à saúde desse segmento populacional, tendo em vista que visões conservadoras e patologizantes ainda predominam e fundamentam, a priori, o discurso biomédico. Portanto, este artigo buscou compreender os sentidos das representações sociais atribuídas por estudantes do Bacharelado Interdisciplinar em Saúde da Universidade Federal da Bahia (UFBA), sobre a pessoa travesti. 


\section{METODOLOGIA}

Esta é uma pesquisa de abordagem qualitativa, delineada sob o referencial teórico das representações sociais, realizada no período de outubro de 2015 a janeiro de 2016, com 243 estudantes do BIS da UFBA, regularmente matriculadas/os no componente curricular 'HACA40 - Campo da Saúde: Saberes e Práticas' que, por ser obrigatório, concentra o maior número de alunas/os. 0 respectivo componente curricular tem como proposta compreender e analisar a história e a organização do campo da saúde no Brasil, os sistemas de saúde, os modelos de atenção e a situação de saúde da população brasileira, assim como propor reflexões sobre as novas propostas de práticas de saúde. No respectivo semestre, foram disponibilizadas 335 vagas, das quais 257 foram preenchidas. Do total de estudantes, 243 aceitaram participar, 11 não participaram por terem idade inferior a 18 anos e três não manifestaram interesse em participar da pesquisa.

Os dados foram coletados de modo coletivo, em sala de aula, a partir da combinação prévia com as/os docentes responsáveis pelo respectivo componente curricular, por meio da aplicação da técnica projetiva denominada Teste de Associação Livre de Palavras (TALP), com duração média de 20 minutos entre a leitura do Termo de Consentimento Livre e Esclarecido (TCLE); preenchimento do formulário para os dados sociodemográficos; exercício demonstrativo com o TALP e a orientação para que as respostas fossem palavras (adjetivos, substantivos, verbos), palavras-compostas, expressões e/ou frases curtas. Com base nessa técnica, foi solicitado às/aos estudantes que, a partir da expressão indutora "pessoa travesti", enunciassem até cinco palavras que rapidamente lhes ocorressem à mente. Em seguida, que classificassem as palavras evocadas por ordem de importância, de 1 a 5 . Por último, que explicassem por que determinada palavra foi considerada a mais importante. De acordo com essa técnica, quanto mais rápida for a resposta, maior seu efeito, validade e fidedignidade (Nóbrega; Coutinho, 2011).

Os dados foram processados pelo software Ensemblè de Programmes Permettant l'Analyse des Évocations (EVOC), com base em uma análise lexicográfica, que revelou a estrutura das representações sociais a partir da frequência de evocação (Freq) e da ordem média dos termos evocados (OME). A frequência está relacionada ao número de vezes que o termo foi evocado pelas/os participantes e a OME evidencia a ordem ou posição de cada evocação. A partir do processamento dos dados no EVOC, foram revelados elementos estruturais alocados em quatro quadrantes, assim denominados: núcleo central, primeira periferia, zona de contraste e segunda periferia. Os termos do núcleo central estão fortemente relacionados às condições socioculturais, normativas e aos valores sociais, e sofrem influência desses elementos, além de prescreverem atitudes, comportamentos e condutas do grupo de pertença, pois determinam seu significado e pertinência. Em função de sua capacidade de ligação à memória coletiva do grupo, resistem a mudanças e são pouco acessíveis ao contexto imediato, estruturando as representações sociais do grupo. 0 sistema periférico, por sua vez, em função de seu caráter flexível, possibilita a transformação da representação e a primeira periferia contempla os elementos considerados relevantes pela frequência de evocação, que, entretanto, apresentam menor relevância pela ordem média de evocação (Abric, 1997).

A partir da aplicação do TALP, foram identificadas 1.215 palavras evocadas pelas/os 243 participantes para o estímulo 'pessoa travesti', dentre as quais 249 eram diferentes. Os termos "homossexual", "mulher", "diferente", "opção", "transformação", "alegria", "identidade", "pessoa" e "homem" apresentaram elevada frequência e baixa OME, o que os configuram como provável núcleo central da representação do grupo investigado.

Neste trabalho, para o delineamento das representações sociais, os 243 termos considerados mais importantes e suas respectivas justificativas foram processados pelo software Iramuteq (Interface de $\mathrm{R}$ pour les Analyses Multidimensionnelles de Textes et de Questionnaires) (Ratinaud; Marchand, 2012), que resultou na nuvem de palavras e na classificação hierárquica descendente (CHD). Os elementos dessa classificação foram definidos a partir de um corpus composto por 244 segmentos de texto, 1.186 formas diferentes e 185 segmentos dimensionados pelo programa, e conformaram quatro classes, que se mostraram estáveis, com aproveitamento de $75,82 \%$ do material analisado.

O corpus constituído foi segmentado em quatro partições, assim denominadas: Classe 1 - "Fazer o corpo": possibilidade(s) para "ser/estar" travesti; Classe 2 - Travestilidades: vivências marcadas por preconceitos; Classe 3 - Liberdade como possibilidade de escolha no "tornar-se' travesti"; e Classe 4 - Travesti: pelo direito a "escolher" o que se é. 
No que concerne aos aspectos éticos, o projeto de pesquisa foi aprovado sob o protocolo de $\mathrm{n}$ 은 684.219/2014, em atendimento ao que preconiza a Resolução 466/2012 (Brasil, 2012). As/Os participantes da pesquisa assinaram o Termo de Consentimento Livre e Esclarecido (TCLE), sendo assegurado o direito de livre participação, bem como total liberdade em retirar seu consentimento em qualquer etapa da pesquisa. Para resguardar o anonimato da(o)s participantes, as respostas do questionário sociodemográfico e do TALP estão identificadas no texto alfanumericamente, configuradas no seguinte termo: $\left(\mathrm{E}_{\mathrm{xxx}}\right)$.

\section{RESULTADOS}

Dentre as/os participantes, a maioria se autodeclarou mulheres (167), na faixa etária de 18 a 29 anos (201), solteiras (207), soteropolitanas (160), de raça/cor preta/parda (201), adeptas do cristianismo (católica, 74 e protestante, 57) e sem religião (72). No que se refere a semestralidade em curso, 207 estavam matriculadas/os entre o primeiro e terceiro semestres, sendo a maioria oriunda de escola pública (199). Em relação ao trabalho e renda, exerciam atividade remunerada (82), enquanto que a maioria possuía renda mensal familiar até cinco salários mínimos (180). Quanto à orientação sexual: lésbicas (23), gays (37) e bissexuais (13), ao passo em que a maioria se declarou heterossexual (170). É importante assinalar que mais da metade (127) das/os estudantes relatou ter sido discriminada/o em algum momento da vida.

Como resposta à expressão indutora "pessoa travesti", elaborou-se o a nuvem de palavras (Figura 1) que permite representar a informação de maneira condensada. Essa construção se deu a partir das evocações classificadas como mais importantes, após lematização e aproximação semântica, resultando em 19 termos.

Figura 1. Nuvem de palavras elaborada pelo software Iramuteq a partir dos 243 termos evocados e classificados como mais importantes - frequência igual e/ou superior a 10 - por estudantes do

Bacharelado Interdisciplinar em Saúde (BIS) da Universidade Federal da Bahia (UFBA), sobre a pessoa travesti. Salvador, Bahia, 2016.

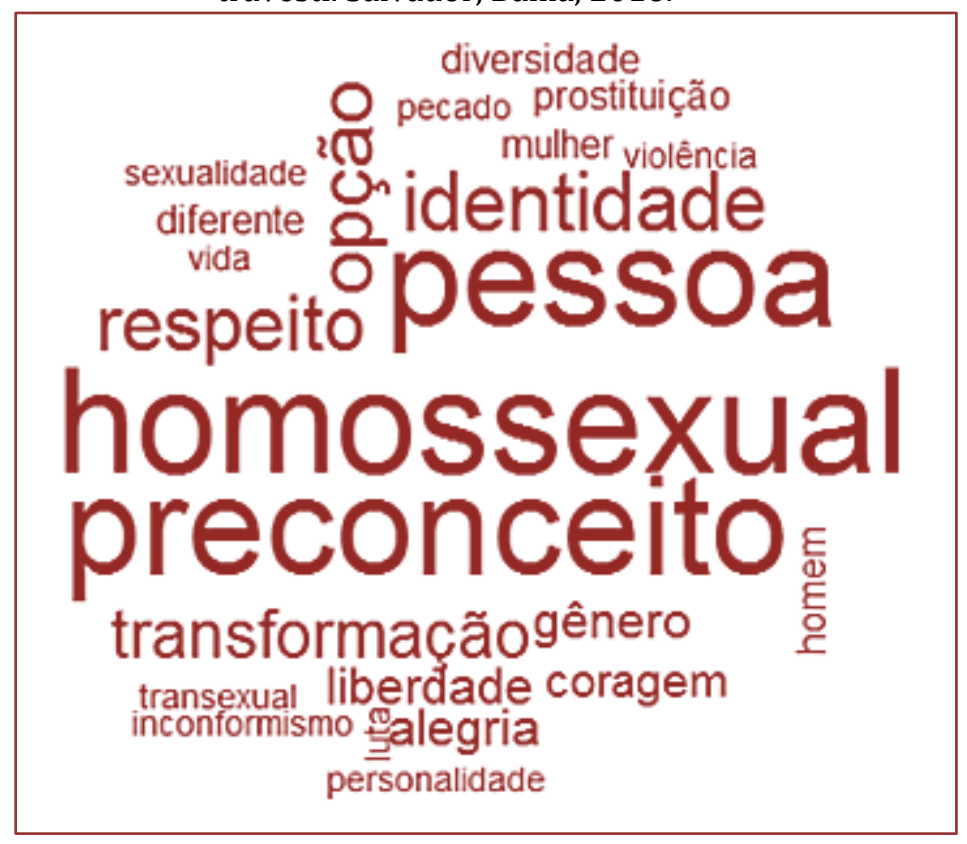

Na busca para aprimorar os resultados obtidos pela nuvem de palavras, as justificativas atribuídas às evocações consideradas mais importantes foram processadas pelo software Iramuteq, que a partir da CHD gerou quatro classes ou categorias semânticas, as quais estão representadas na Figura 2. Observa-se em sua partição estatística que a classe 2 (29,82\%) abrange as demais, seguindo-se das classes 1 (24,90\%), classe $3(22,2 \%)$ e da classe $4(23,5 \%)$. 
Figura 2. Dendograma das classes indicativas de representações sociais de estudantes do Bacharelado Interdisciplinar em Saúde (BIS) da Universidade Federal da Bahia (UFBA), sobre a pessoa travesti Classificação Hierárquica Descendente.Salvador, Bahia, 2016.

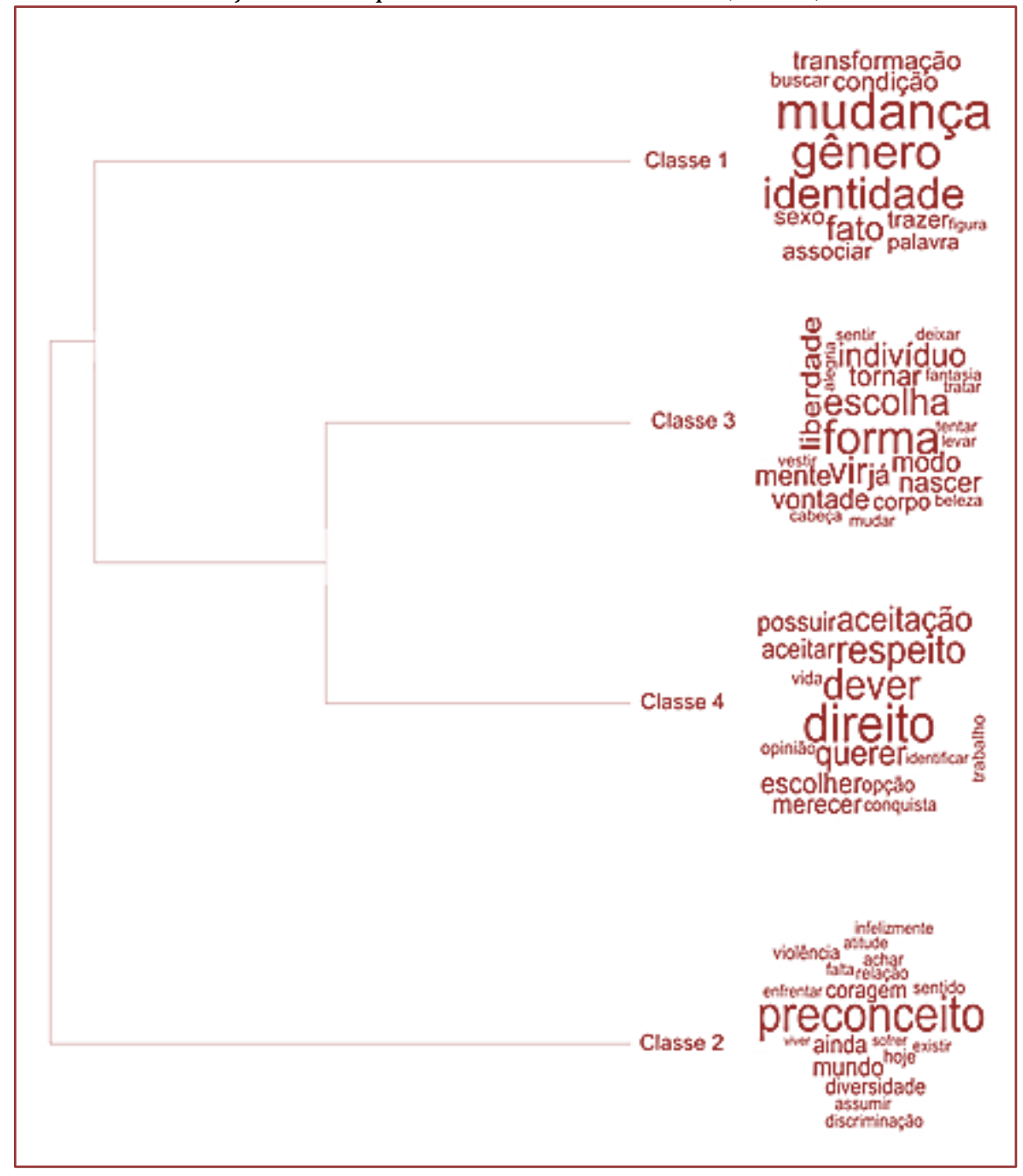

\section{DISCUSSÃO}

Entre os termos evocados classificados pelas/os participantes como mais importantes dispostos na Figura 1, a palavra "homossexual" ocupa a primeira posição, sugerindo que para o grupo investigado o termo 'travesti' está ligado à orientação sexual. Vale ressaltar que concebê-la dessa forma conota a atribuição do conceito "homossexual" à identidade de gênero travesti, porém esses termos não são sinônimos, tendo em vista que mobiliza dimensões diferenciadas nas vidas das pessoas.

As/os discentes reconhecem a travesti como uma 'pessoa' que, em função de sua identidade de gênero, vivencia preconceitos e a sua condição merece respeito. Os elementos "preconceito" e "pessoa", respectivamente, apresentam frequências semelhantes e evidenciam que, para as/os estudantes, a vivência travesti é marcada por preconceitos e exclusão em virtude de não se "enquadrarem" nas normas de sexo-gênero.

A priori, essas são questões que não devem ser negligenciadas, tendo em vista que indivíduos ou grupos não são receptores passivos. Ao contrário, pensam e estabelecem comunicações, ao tempo em que, constantemente, (re)produzem representações (Moscovici, 2013). Nesse sentido, as representações sociais sobre a travesti têm implicações diretas sobre suas vidas, na medida em que comportamentos adotados por profissionais de saúde resultam de representações e estereótipos socialmente compartilhados, que podem não corresponder ao modo como elas se expressam e/ou ao gênero a que sentem pertencer. 
A partir da CHD (Figura 2), a principal classe, ou seja, a primeira partição é a classe 2 - Travestilidades: vivências marcadas por preconceitos. Os termos mais frequentes que a compõe são: preconceito, mundo, coragem, diversidade, discriminação, violência e hoje. 'Preconceito', 'discriminação' e 'violência' revelam que as representações construídas pelas/os estudantes sobre o preconceito enfrentado por travestis, em função de estas não se enquadrarem nos padrões que regulam e normatizam o gênero, objetivam-se no enfrentamento cotidiano ('hoje') das normas estabelecidas e/ou impostas pelo 'mundo'.

Para as/os estudantes, de maneira geral, as pessoas que se autoafirmam travestis, cotidianamente, enfrentam atitudes preconceituosas, por divergirem da norma social que pauta o binarismo entre os sexos/gêneros e a heterossexualidade compulsória. Ressaltam ainda que, quando se pensa em travestis, estas são/estão muito mais expostas a atitudes preconceituosas, discriminatórias e violentas que as demais pessoas que compõem o acrônimo LGBTI+. Nesse aspecto, as travestis acabam sendo colocadas à margem, cada vez mais devido aos processos de normatização organizados pela/na sociedade, conforme se verifica nos seguintes segmentos de textos:

[...] na sociedade em que vivemos são praticados muitos atos de intolerância perante a estas pessoas [...] o preconceito tem afetado grande parte da população LGBT. Referente ao [a] travesti é bem pior, infelizmente esse é o quadro do país em que vivemos [...] o preconceito com esse grupo estigmatizado é muito presente na nossa sociedade, reconhecer o outro e aceitar o diferente precisa se estabelecer na sociedade [...] tudo que ronda o universo dos [de] travestis e transexuais hoje é a violência, principalmente pela discriminação e falta de uma rede de apoio. ( $\left.\mathrm{E}_{108} ; \mathrm{E}_{216} ; \mathrm{E}_{213} ; \mathrm{E}_{124}\right)$

Para o grupo investigado, as pessoas travestis enfrentam cotidianamente situações de preconceito e estas, consequentemente, restringem as possibilidades de inserção social. Nesse sentido, as normas e ideais regulatórios dos gêneros e das sexualidades produzem efeitos nocivos para as vidas das pessoas gênerodivergentes, na medida em que facultam e designam os destinos. 0 preconceito se constitui como um padrão de hostilidade de alguém, dirigido contra um grupo inteiro e/ou a seus componentes individualmente (Allport, 1972). Essas reações se ancoram em representações que restringem as diferenças individuais e cumprem uma função irracional específica para quem delas se utilizam. À vista disso, por ser o preconceito um constructo teórico, na prática o que as pessoas vivenciam é a discriminação, pois ao contrário do que costumeiramente se imagina, a discriminação independe das características pessoais, visto que nem sempre a discriminação produz os mesmos resultados e nem opera da mesma forma (Moreira, 2017).

Na perspectiva da/os estudantes, romper com as convenções sociais de gênero e sexualidade, de modo particular, é se expor a situações de discriminação e violência. Em muitos casos, "assumir" sua condição perante a família não é uma tarefa fácil, pois, quando se é expulsa de casa, as dificuldades se intensificam. Nesse caso, para (sobre)viver como travesti em uma sociedade preconceituosa e que não respeita as diferenças, é necessário "ser forte" e dispor de muita "coragem". Os segmentos a seguir ilustram parte dessa afirmação:

[...] não são todas as pessoas que têm coragem de assumir devido aos preconceitos muitas vezes até mesmo da família [...] a coragem é primordial para se afirmar em uma sociedade tão complexa e cheia de preconceitos [...] porque, apesar de eles[elas] lutarem para ser quem e como eles[elas] desejam, ainda tem todo preconceito, discriminação e violência existente na sociedade. ( $\left.\mathrm{E}_{044 ;} ; \mathrm{E}_{090} ; \mathrm{E}_{103}\right)$

Essa objetivação feita pelas/os participantes do estudo está em consonância com o que preconiza o movimento social organizado ao afirmar que, entre as parcelas populacionais vulneráveis e excluídas, "a que mais causa estranheza é, sem dúvida, a das travestis, pois como a identidade é visível, fica difícil ocultar-se ou misturar-se na multidão, passar despercebidas" (Simpson, 2011, p. 113). Esse ponto de vista também é compartilhado por outras pessoas trans à medida que pontuam: "ser travesti é aguentar o preconceito, porque a maior parte que a travesti vive todo dia é a discriminação, a falta de oportunidade de trabalho" (Lee, 2013, p. 77). No universo existencial da travesti, "podemos perceber a presença de exclusões de toda ordem, de desigualdades que enfraquecem suas potencialidades e marginalizam suas práticas" (Peres, 2015, p. 77). 
Dados da pesquisa nacional "Diversidade Sexual e Homofobia no Brasil", desenvolvida pela Fundação Perseu Abramo, em 2008, retrata que 73\% das pessoas acreditam que existe forte preconceito contra as travestis (Venturi, 2011). No acrônimo LGTBI+, o segmento de pessoas travestis e transexuais é o que mais sofre preconceito e ocupa o topo da pirâmide em decorrência de terem suas vidas dizimadas. A esse respeito, o levantamento feito pelo Observatório Trans (Nogueira; Cabral, 2018) constatou que 181 pessoas transexuais e travestis foram assassinadas em 2017.

Nesse aspecto, os termos e ideias comportadas nesta classe, pela especificidade do grupo estudado, em sua maioria de raça/cor preta/parda e com relato de discriminação em algum momento de suas vidas, podem apontar para a sensibilidade da parte das/os estudantes, ancorada em afeto e respeito pelas minorias, nesse caso para com as pessoas que se autorreferem como travesti. Destarte, os afetos não são entidades que se encapsulam, tampouco produções solitárias e/ou individuais. Ao contrário, acontecem no cotidiano, mediados nas/pelas relações que se estabelecem com o mundo e com o outro (Arruda, 2014).

A classe 1 - "Fazer o corpo": possibilidade(s) para "ser/estar" travesti -, apresenta-se como a segunda mais importante e é constituída pelos vocábulos mudança, gênero, identidade, condição e transformação. Essa classe permitiu a inferência de que os conteúdos nela se agruparam em torno do que a(o)s estudantes pensam sobre as possíveis modificações empreendidas pelas travestis no sentido de adequarem o seu corpo ao modo como se autopercebem.

Nesse caso, para as/os estudantes, modificar/alterar o corpo se torna o passo inicial com vistas à superação da 'insatisfação' com a conformação corporal frente a sua 'condição'. Isso foi considerado como muito relevante no processo de autoafirmação da travesti, por proporcionar a concretização de desejos no que tange ao modo de "ser/estar" de cada pessoa, correspondendo às singularidades individuais. Tal afirmação pode estar embasada nos seguintes segmentos de textos:

[...] a identidade é a mais importante, pois corresponde à individualidade de cada um [...] a escolha da palavra insatisfação como a mais importante é pelo fato de ser o passo inicial para uma mudança futura o sujeito em virtude de se sentir insatisfeito com aquela identidade [...] transformação, pois representa a busca de uma mudança de identidade quando não se está feliz da maneira que é. Importante é estar bem consigo mesmo [...] transformação, pois é um processo que envolve muito autoconhecimento, coragem e autoestima para que tenha o desfecho de mudança de gênero efetivamente [...] mudança, porque o[a] travesti se veste como o gênero oposto, há uma mudança quanto à característica física. ( $\left.\mathrm{E}_{242} ; \mathrm{E}_{164} ; \mathrm{E}_{133} ; \mathrm{E}_{093} ; \mathrm{E}_{072}\right)$

O conteúdo dessa classe indica que as/os estudantes fundamentam-se, parcialmente, no pensamento reificado sobre a identidade travesti. Teórica/os do campo das Ciências Sociais e da Antropologia investigaram acerca do modo como travestis se autopercebem, bem como sobre o uso de técnicas com vista às modificações corporais tendo em vista a conformação corporal com a autodeterminação de gênero. Dentre esses, destacam-se aqueles que buscaram, por intermédio de relatos e convivências com travestis, informações sobre esses aspectos, incluindo as facilidades e dificuldades no processo de "fabricação do corpo", a partir do uso de contraceptivos orais e injetáveis e da utilização do silicone líquido industrial (Benedetti, 2005; Peres, 2015; Pelúcio, 2009). Dessa maneira, "as travestilidades não podem ser sem um corpo transformado, marcado por um feminino que procura borrar, nesses corpos, sem apagá-lo de todo" (Pelúcio, 2009, p. 27). Nessa trajetória, as travestis podem recorrer a vários recursos, produtos e investimentos com a finalidade de produção do corpo e de uma expressão pautada no feminino: "embora seja possível estabelecer e visualizar regularidades nesse processo de transformação, cada travesti o vivencia de forma singular, com tempos e 'fases' específicas”' (Benedetti, 2005, p. 73).

Assim, a classe 1 destaca a importância desses artifícios no processo de autoafirmação da identidade de gênero, presente no pensamento das/os estudantes. Ela se refere à necessidade de utilização de tecnologias pelas travestis, nos processos de "(re)construções" corporais.

A classe 3 - Liberdade como possibilidade de escolha no 'tornar-se' travesti - apresenta-se na figura 2 organizada em torno dos elementos forma, escolha, indivíduo, tornar, nascer, vontade e liberdade. Ela revela conteúdos que perpassam as possibilidades que transcendem o 'nascer' para 'tornar-se' travesti. 0 conjunto de palavras que compõe essa classe retrata a inter-relação entre a liberdade, escolhas, motivações pessoais e a forma de 'ser/estar' travesti. 
Convém ressaltar que a liberdade possibilita o '(re)inventar-se' e a "con(forma)ção”, com vistas à superação da determinação biológica, conforme apontam os segmentos a seguir:

[...] a liberdade é importante para o ser humano expressar seus direitos e vontades [...] resistir em uma sociedade machista, engessada [...] a pessoa nasce de uma maneira biológica e a sexualidade lhe impõe uma vivência padrão. Porém, as travestis transcendem essa barreira modificando seus corpos [...] já que cada um[a] é dono[a] de si e tem a liberdade de fazer o que quer com seu corpo. (E230; E169; E002; E050)

Fica evidente que, para o grupo investigado, a vontade e a escolha são elementos fundamentais na tomada de decisão individual. Se, por um lado, a vontade, subentendida como motivação, se torna o passo inicial, por outro, 'dar forma' relaciona-se à autoimagem e ao modo como se deseja ser vista/notada, conforme exemplificam os segmentos abaixo:

A vontade é o que iniciaria o processo de se tornar um[a] travesti [...] o corpo do outro só deve razão a ele, o que a levou a ter determinada orientação de se vestir ou se arrumar dessa forma só deve respeito à ela [...] ninguém nasce travesti, como é uma escolha a partir dos sentimentos da pessoa se tornar um[a], já que dessa forma iria se sentir melhor. (E071; E082; E005)

Deve-se considerar que a formação da identidade social da travesti dar-se-á a partir de seu entendimento enquanto cidadã (Simpson, 2011). Nesse percurso, o apoio familiar é primordial, embora essa não seja a realidade da maior parte das pessoas: "[...] depois que eu me transformei, eles mostraram que eram preconceituosos, que eles não queriam uma travesti [...] à época que eu mais precisei deles eles não me ajudaram" (LEE, 2013, p. 31); “[...] desde os meus treze anos eu já sabia que ia ser uma travesti [...] minha transformação não foi da noite para o dia, muito menos tranqüila” (Nikaratty, 2013, p. 39-40).

Na contramão desse ponto de vista, em que cada pessoa tem a liberdade para "melhor" adequar as conformações corporais em consonância ao modo como se identifica e ao gênero a que sente pertencer, os segmentos a seguir ilustram conteúdos centrados no determinismo biológico, em estreita ligação com a religiosidade.

Pecado, porque acredito que se nascemos com determinada opção sexual não devemos tentar brincar de Deus e mudar [...] tenho uma formação evangélica e entendo que cada ser humano nasceu segundo o desejo do Senhor, não devendo esta interferir de qualquer forma na criação [...] pecado, pois julgando no contexto religioso o qual eu pertenço considero mais como pecado já que no padrão bíblico Deus criou homem e mulher, entretanto respeito a decisão de cada um [...] tenho a Bíblia que é a palavra de Deus como meu objeto de fé e ela me ensina que tal prática vai de encontro aos ensinamentos do Deus vivo. (E173; E201; E098; E068).

Tais ideias encontram-se ancoradas na dimensão psicológica centrada na religiosidade. Na medida em que essas/es estudantes concebem a travesti como pecado, isto permite inferir uma crença no determinismo. Ou seja, nasceu com pênis/vagina é homem/mulher e, compulsoriamente, sua orientação sexual deve ser pautada na/pela heterossexualidade. Acrescente-se que, por um lado, essa concepção parece não ser consensual. Entre a(o)s cinquenta e sete estudantes que se autorreferiram como protestantes, quatro compartilham desse entendimento. Para as/os demais, a pessoa travesti é considerada um "ser humano" como qualquer outra pessoa e deve ter a sua expressão e identidade de gênero respeitada pela sociedade. Entretanto, para as travestis, na medida em que se contrapõem ao determinismo, a anatomia deixa de ser o destino. Nesse processo, o que importa é a luta com vistas à superação, pois "uma vez demarcada, o futuro do corpo é a prótese. Isso os[as] travestis compreenderam bem. Há muito tempo" (Denizart, 1997, p. 8). Convém ressaltar a importância para que os sexos sejam tomados como "uma invenção" e não como uma determinação biológica (Lima, 2014, p. 27). Sendo assim, se existem várias possibilidades de se expressar/vivenciar as possíveis feminilidades e masculinidades, é admissível que existam também várias formas de se vivenciar as travestilidades, pois a não-linearidade entre corpo, sexo, gênero e desejo (Butler, 2005), que influenciou as concepções de gênero, aponta para as múltiplas configurações possíveis de existência a partir de diversos (re)arranjos entre essas categorias. 
Nesse sentido, se por um lado é possível observar avanços em relação à discussão sobre a religiosidadesexualidade, por parte de algumas instituições religiosas denominadas 'igrejas inclusivas', por outro constata-se ataques a temas relacionados à diversidade sexual e aos direitos sexuais e reprodutivos por grupos e algumas instituições religiosas (Musskopf, 2012). Assim, as mencionadas objetivações das/dos estudantes com viés religioso são um fato que nos chama a atenção. Diante de tais colocações, reafirma-se o entendimento e a evidência de representações hegemônicas que ainda permanecem cristalizadas e são acionadas à medida que se discorre sobre as identidades de gênero divergentes das normas regulatórias dos gêneros e das sexualidades.

A classe 4 - Travesti: pelo direito a 'escolher' o que se é - organiza-se em torno dos elementos direito, dever, respeito, aceitar, querer, escolher e opção. Ela denota estar pautada pelo direito individual, que faculta à pessoa escolher o modo de 'ser/estar'. Essa classe, pela sua localização no dendograma, pode apontar o discurso de um grupo com maior semelhança.

As/os participantes sinalizam para a importância do respeito às diferenças e de 'aceitar' que "ser travesti" é um direito da pessoa. Por esse ângulo, a pessoa possui a autonomia para escolher o que entende que é melhor para si e que lhe faz bem, e poderá utilizar-se das biotecnologias e empreender as alterações/modificações corporais, por sentir/perceber que o corpo, do modo como está, não a satisfaz. Os segmentos abaixo revelam esses sentimentos:

[...] todos possuem o direito de escolher como se portar, o que vestir entre outros e devem escolher aquilo que lhe faz bem [...] travesti é um ser humano e por isso merece respeito, possuem direitos e deveres [...] independente de orientação ou opção todos são pessoas devem ter esse direito reconhecido e respeitado de ser o que é [...] ser travesti é o direito da pessoa que não se identifica com o corpo que possui e tem o direito de escolher o que quiser fazer com ele ( $\left.\mathrm{E}_{070} ; \mathrm{E}_{236} ; \mathrm{E}_{217} ; \mathrm{E}_{237}\right)$.

o conjunto de palavras que compõe a classe 4 revela que o grupo investigado expressou respeito e sensibilidade para com as pessoas cujas identidades de gênero divergem das demais. Assim, como todas as pessoas, as travestis possuem direitos para fazer suas escolhas. Com isso, a partir do momento em que se compreendem as questões que envolvem o processo de/para "tornar-se" travesti, os futuros profissionais de saúde poderão orientar e melhorar suas práticas, especialmente no que concerne ao planejamento de ações e prestação de cuidados, ajudando-as nessa fase de transição, na minimização de riscos e na redução dos possíveis danos e agravos à sua saúde.

Portanto, as significativas relações entre o preconceito, estigma, violência, discriminação e os agravos à saúde exigem um aprofundamento teórico-conceitual que priorize a sensibilização para com o sofrimento do outro e contribua para que programas de enfrentamento a esses processos sejam bem-sucedidos. No campo da saúde, por exemplo, podemos citar a Política Nacional de Humanização (PNH) (Brasil, 2004b) e a Política Nacional de Saúde Integral LGBT, instituída pelo MS, por meio da Portaria no 2.836, de 1o de dezembro de 2011, que garante às travestis o direito à saúde integral, humanizada e de qualidade no âmbito do SUS (Brasil, 2012).

A PNH define que a humanização se pauta pela oferta de atendimento de qualidade em estreita relação com acolhimento e avanços tecnológicos, primando pela ambiência de cuidados e melhoria das condições de trabalho para profissionais (Brasil, 2004). A humanização das práticas e cuidado em saúde tem sido um tema debatido intensamente no âmbito da saúde coletiva (Ayres 2006). Desse modo, à medida que se fala de cuidado e humanização, devemos considerar os princípios e estratégias que guiam e/ou permeiam/norteiam a dinâmica das relações entre usuárias/os desses serviços e as/os profissionais de saúde que as/os atendem. Por isso, é importante que reflexões sejam feitas sobre a origem e a dimensão social das condições de adoecimento, bem como das tecnologias disponíveis que respondam a essas condições, pois se os serviços de saúde não estiverem preparados para "[...] responder aos projetos de vida (e seus obstáculos) dos diversos segmentos populacionais [...] de seus serviços, a possibilidade de cuidar de cada indivíduo não passará de utopia" (Ayres, 2006, p. 79).

Assim, a leitura das representações acerca da travesti se processa em estreita relação com as interlocuções imaginárias, simbólicas e conceituais, inter-relacionadas ao saber comum e hegemônico. Enquanto o senso comum, socialmente integrado, se inscreve na vida cotidiana e ancora-se nas vivências intersubjetivas, o saber científico, além de sua suscetibilidade a diversos modos de funcionamento, mostra-se resistente e se constitui institucionalmente. 


\section{CONCLUSÕES}

Esta pesquisa procurou compreender os sentidos das representações sociais de estudantes do BIS da UFBA sobre a pessoa travesti. Para o grupo investigado, não se "nasce" travesti. As alterações e/ou modificações corporais constituem o passo inicial do processo de autoafirmação, que pode ser acompanhado de mudanças corporais mais acentuadas e outras vestimentas, em função do processo de transição. 0 "tornar-se" travesti faz parte de um processo que perpassa a tomada de decisão individual, de acordo com a vontade, desejo e motivações próprias, na perspectiva do 'direito' como bem social.

Apesar dos resultados apontarem sensibilidade e respeito para com as travestilidades, as evocações atribuídas como mais importantes conotam a orientação sexual como sinônima da identidade de gênero travesti. Outra evidência que merece destaque é a concepção da travesti como 'pecado'. No entanto, se observa que, apesar do caráter religioso dessa representação, ela não é consensual entre as/os estudantes que se autorreferiram como protestantes, o que permite inferir que, em que pese a crença religiosa, o respeito à autonomia da pessoa prevalece como regra essencial.

A pesquisa sinaliza a necessidade da inserção de temas relacionados às demandas e necessidades das travestis - considerando as especificidades das travestilidades -, no âmbito da formação técnica (nível médio) e superior em saúde, enquanto ferramenta de potencialização do cuidado a outrem. A observação desses aspectos permite atentar, singularmente, ao modo como a comunicação circula nesse contexto, tendo em vista que o não respeito ao nome social e ao reconhecimento da expressão e identidades de gênero, considerando as posições não binárias, por exemplo, podem culminar em desconforto e/ou desencadear situações de tensão entre as/os que demandam cuidado e aquelas/es que cuidam, especialmente para as pessoas que ainda não tiveram seus nomes retificados junto ao Poder Judiciário ${ }^{71}$.

Ainda que o objetivo geral deste estudo tenha sido cumprido, é pertinente mencionar algumas limitações passíveis de serem desenvolvidas em futuras pesquisas. As principais estiveram vinculadas à amostra circunscrita unicamente a estudantes do BIS, bem como à não utilização do TALP com o uso de um termo e/ou expressão em substituição, em função de a temática ser carreada de preconceitos. Em relação a esse segundo aspecto, a resposta dada pela/o participante poderia ser atribuída a outrem nos seguintes termos: "o que você imagina que outras pessoas pensam sobre a pessoa travesti?". Ao imaginar falar no lugar de outrem, é possível que outras respostas surgissem e que as que aqui foram apresentadas pudessem estar associadas ao considerado politicamente correto (ou não). Ao mesmo tempo, sendo esta uma realidade transversal ao campo da saúde, parece pertinente a realização de estudos de cunho multidisciplinar em conjunto com estudantes de outros cursos da área de saúde e profissionais que interagem com esse segmento populacional.

Destarte, as representações sociais, de maneira geral, considerando o modo como esse objeto é concebido e definido, podem possibilitar a composição de um marco teórico que contribua para desmitificar, explicar e fomentar discussões atuais no que se refere aos processos identitários enquanto modos de "ser/estar" travesti. Enfatiza-se ainda que os resultados desta pesquisa demonstraram a importância da utilização da teoria das representações sociais, uma vez que as produções empíricas se complementaram para a explicação e compreensão do respectivo objeto que, em nossa investigação, é a pessoa travesti.

\footnotetext{
${ }^{71}$ O Supremo Tribunal Federal (STF), em 1 de março de 2018, por meio da Ação Direta de Inconstitucionalidade (ADI) 4275, entendeu ser possível a alteração de nome e sexo/gênero no registro civil, independentemente da cirurgia de transgenitalização ou da realização de tratamentos hormonais ou patologizantes (STF, 2018). Antes dessa decisão, o processo de retificação de nome era uma verdadeira via crucis, pois era necessário ajuizar uma ação junto ao Tribunal de Justiça e apresentar documentos (inclusive laudo psicológico e/ou psiquiátrico) que pudessem convencer a/o magistrada/o, pois a autonomia e autodeterminação nem sempre eram levadas em consideração. A conclusão desse pleito não acontecia antes de dois anos e, na maioria das vezes, era concedido somente a retificação do nome, sendo o sexo/gênero condicionado à realização da cirurgia de transgenitalização.
} 


\section{REFERÊNCIAS}

[1] Abric, J.-C. Les représentations sociales: espects théoriques. In: Abric, J.-C. (Org.). Pratiques sociales et représentations. 2. ed. Paris: PUF, 1997. p. 11-36.

[2] Almeida Filho, N. O modelo universidade nova. In: Santos, B. S.; Almeida Filho, N. A universidade no século XXI: para uma universidade nova. Coimbra: Edições Almedina, 2008. p. 139-57.

[3] Alport, G. W. La naturaleza del prejuicio. 4. ed. Buenos Aires: Editorial Universitária de Buenos Aires, 1971.

[4] Arruda, A. Meandros da teoria: a dimensão afetiva das representações sociais. In: Sousa, C. P. et al. (org.). Angela Arruda e as representações sociais: estudos selecionados. Curitiba: Champagnat; São Paulo: Fundação Carlos Chagas, 2014. p. 65-85.

[5] Ayres, J. R. C. M. Cuidado e humanização das práticas de saúde. In: Deslandes, S. F. (Org.). Humanização dos cuidados em saúde: conceitos, dilemas e práticas. Rio de Janeiro: Fiocruz, 2006. p. 49-83.

[6] Batista, K. B. C.; Gonçalves, O. S. J. Formação dos profissionais de saúde para o SUS: significado e cuidado. Saude soc. [Internet]. 2011. 20(4):884-99. Disponível em: http://dx.doi.org/10.1590/S0104-12902011000400007. Acesso em: 10 abr. 2016.

[7] Benedetti, M. Toda feita: o corpo e o gênero das travestis. Rio de Janeiro: Garamond, 2005.

[8] Bento, B. A reinvenção do corpo: sexualidade e gênero na experiência transexual. 2. ed. Natal: Edufrn, 2014.

[9] Biscarde, D. G. S.; Pereira-SANTOS, M.; Silva, L. B. Formação em saúde, extensão universitária e Sistema Único de Saúde (SUS): conexões necessárias entre conhecimento e intervenção centradas na realidade e repercussões no processo formativo. Interface (Botucatu). [Internet]. 2014. 18(48):177-86. Disponível em: http://dx.doi.org/10.590/1807-57622013.0586. Acesso em: 10 abr. 2016.

[10] Brasil. Ministério da Saúde. Travestis ganham campanha contra aids e preconceito. Brasília, DF, 2004a.

[11] Brasil. Ministério da Saúde. Secretaria-Executiva. Núcleo Técnico da Política Nacional de Humanização. Humaniza SUS: Política Nacional de Humanização: a humanização como eixo norteador das práticas de atenção e gestão em todas as instâncias do SUS. Brasília, DF: MS, 2004b.

[12] Brasil. Ministério da Saúde. Campanha: Sou travesti. Tenho direito de ser quem eu sou. Brasília, DF, 2010.

[13] Brasil. Ministério da Saúde. Carta dos direitos dos usuários da saúde. 3. ed. Brasília, DF: Ministério da Saúde, 2011. Disponível: http://bvsms.saude.gov.br/bvs/publicacoes/cartas_direitos_usuarios_saude_3ed.pdf. Acesso em: 11 jan. 2019.

[14] Brasil. Ministério da Saúde. Secretaria de Gestão Estratégica e Participativa. Departamento de Apoio à Gestão Participativa. Política Nacional de Saúde Integral de Lésbicas, Gays, Bissexuais, Travestis e Transexuais. Brasília, DF: MS, 2012.

[15] Brasil. Conselho Nacional de Saúde. Resolução n o 466, de 12 de dezembro de 2012. Brasília, 2012. Diário

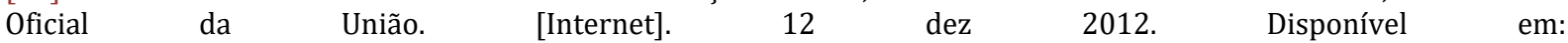
http://bvsms.saude.gov.br/bvs/saudelegis/cns/2013/res0466_12_12_2012.html. Acesso em: 10 abr. 2016.

[16] Butler, J. Cuerpos que importan. Ciudad Autónoma de Buenos Aires: Paidós, 2018.

[17] Cianciarrulo T. I. Instrumentos básicos no desenvolvimento do processo cuidativo: aprendizagem e aplicação. In:. Cianciarrulo, T. I. (Org.). Instrumentos básicos para o cuidar: um desafio para a qualidade de assistência. São Paulo: Atheneu, 2007. p.151-54.

[18] Coelho, M. T. À. D.; Teixeira, C. F. A prática educativa no Bacharelado Interdisciplinar em Saúde da UFBA. In: Coelho, M. T. Á. D.; Teixeira, C. F. (org.). Interdisciplinaridade na educação superior: o bacharelado em saúde. Salvador: Edufba, 2016. p. 43-75.

[19] Conselho Federal de Psicologia (CFP). Resolução no 1, de 29 de janeiro de 2018. Estabelece normas de atuação para as psicólogas e os psicólogos em relação às pessoas transexuais e travestis. Disponível em: https://site.cfp.org.br/wp-content/uploads/2018/01/resolucao_cfp_01_2018.pdf. Acesso em: 01 fev. 2018.

[20] Denizart, H. Engenharia erótica: travestis no Rio de Janeiro. Rio de Janeiro: Jorge Zahar, 1997.

[21] Feuerwerker, L. C. M. Educação dos profissionais de saúde hoje problemas, desafios, perspectivas e as propostas do Ministério da Saúde. Rev Abeno. 2003; 3: 24-7.

[22] Jodelet, D. Recentes desenvolvimentos da noção de representações nas ciências sociais. In: Almeida, A. M. O.; Jodelet, D. (org.). Representações sociais: interdisciplinaridade e diversidade de paradigmas. 1ạ ed. Brasília, DF: Thesaurus, 2009. p. 105-22. 
[24] Lee, D. A geografia de uma travesti é uma barra, é matar um leão a cada dia. In: Silva, J. M.; Ornat, M. J.; Chimin Junior, A. B. (org.). Geografias malditas: corpos, sexualidades e espaços. Ponta Grossa, PR: Todapalavra, 2013. p. 27-38.

[25] Lima, F. Corpos, gêneros, sexualidades: políticas de subjetivação - textos reunidos. 2. ed. Porto Alegre: Rede UNIDA, 2014.

[26] Moreira, J. A. O que é discriminação?. Belo Horizonte: Letramento; Casa do Direito; Justificando, 2017.

[27] Moreira, M. A. S. P. et. al. A saúde no olhar de imigrantes brasileiros. In: Silva, A. O.; Costa, I. C. C.; ALVES, M. S. C. F. (org.). Investigação em saúde: múltiplos enfoques. Natal: Edufrn, 2011. p. 127-43.

[28] Moscovici, S. Representações sociais: investigações em psicologia social. 13. ed. Petrópolis: Vozes, 2013.

[29] Mota, V. L. V.; Teixeira, C. F. A percepção dos graduandos do BI em Saúde sobre a trajetória acadêmica no curso no período de 2009-2011. In: Coelho, M. T. Á. D.; Teixeira, C. F. (org.). Interdisciplinaridade na educação superior: o bacharelado em saúde. Salvador: Edufba, 2016. p. 223-244.

[30] Musskopf, A. S. Via(da)gens teológicas: itinerários de uma teologia queer no Brasil. São Paulo: Fonte Editorial, 2012.

[31] Nikaratty, L. O que me marcou na vida é ser barrada e não poder entrar nos lugares: esta é a geografia de uma travesti. In: Silva, J. M.; Ornat, M. J.; Chimin Junior, A. B. (org.). Geografias malditas: corpos, sexualidades e espaços. Ponta Grossa, PR: Todapalavra. 2013. p. 39-54.

[32] Nóbrega, S. M.; Coutinho, M. P. L. A técnica de associação livre de palavras. In: Coutinho, M. P. L.; Saraiva, E. R. A. (org.). Métodos de pesquisa em psicologia social: perspectivas qualitativas e quantitativas. João Pessoa: Editora Universitária, 2011. p. 205-250.

[33] Nogueira, S. N. B.; Cabral, E. A. (org.). Dossiê: a carne mais barata do mercado. Uberlândia: Observatório Trans, 2018.

[34] Pelúcio, L. Abjeção e desejo: uma etnografia travesti sobre o modelo preventivo de aids. São Paulo: Ananblume, Fapesp, 2009.

[35] Pereira, S. C. L.; et al. Percepção de monitores do PET-Saúde sobre sua formação e trabalho em equipe interdisciplinar. Interface (Botucatu) [Internet]. 2015. 19(1): 869-78. Disponível em: http://dx.doi.org/10.1590/1807-57622014.0840. Acesso em: 10 abr. 2016.

[36] Peres, W. S. Travestis brasileiras: dos estigmas à cidadania. Curitiba: Juruá, 2015.

[37] Porcino, C.A.; Coelho, M.T.A.D.; Oliveira, J. F. "Sem direito a viver de dia": representações sociais de estudantes universitários sobre travestis [Internet]. In: Anais do 8o Colóquio Internacional: "Educação e Contemporaneidade"; 2014; São Cristóvão, SE, Brasil. São Cristóvão, SE; 2014. 1-12 [acesso 12 Mar 2016]. Disponível em: http://educonse.com.br/viiicoloquio/cdanais.asp?id=387. Acesso em: 11 set. 2015.

[38] Ratinaud, P.; Marchand, P. Application de laméthode ALCESTE à de "gros" corpus et stabilitédes "mondes lexicaux": Analysedu "Cable Gate" avec IraMuTeQ. In: Actesdes 11 eme Journées Internationales d'Analyse Statistiquedes Données Textuelles, Liège: JADT; 2012: 835- 44.

[39] Romano, V. F. As travestis no Programa Saúde da Família da Lapa. Saude soc. [Internet]. 2008. June. 17(2): 211-19. Disponível em: http://dx.doi.org/10.1590/S0104-12902008000200019. Acesso em: 27 abr. 2016.

[40] Simpson, K. Travestis: entre a atração e a aversão. In: Venturi, G.; Bokany, V. (Org.). Diversidade sexual e homofobia no Brasil. São Paulo: Fundação Perseu Abramo, 2011. p. 109-117.

[41] STF - Superior Tribunal Federal. Ação Direta de Inconstitucionalidade no. 4275, de 1 de março de 2018. Brasília. 2018. Disponível em: http://portal.stf.jus.br/processos/detalhe.asp?incidente=2691371. Acesso em: 13 jan. 2019.

[42] Venturi, G. Da construção dos dados à cultura da intolerância às diferenças. In: G. Venturi V. Bokany (Org.). Diversidade sexual e homofobia no Brasil. São Paulo: Fundação Perseu Abramo, 2011. p. 175-188. 


\section{Capítulo 26}

Lgbtfobia: Análise da posição político-jurídico dos ministros do STF

\section{Witalo Brenno Martins Acioli \\ Elba Ravane Alves Amorim}

Resumo: A presente pesquisa discute o posicionamento dos ministros do Supremo Tribunal Federal - STF sobre o tema LGBTfobia, especificamente com relação a Ação Direta de Inconstitucionalidade por Omissão (ADO) 26, e do Mandado de Injunção (MI) 47334. Nesse prisma, o foco central da pesquisa, é averiguar as mudanças e evoluções que podem vir a surgir após a decisão do STF, que interpreta a norma de racismo de forma extensiva, assim, até que o Congresso Nacional legisle sobre o tema LGBTfobia, a norma supracitada, abrangerá o crime de LGBTfóbicos. No que tange a decisão do SFT, é possível averiguar que é uma importante conquista, que pode contribuir para mudanças na seara social, e representando uma postura pedagógica, também, espera-se que contribua com a diminuição da violência contra lésbicas, gays, travestis e transexuais.

Palavras-chave: LGBTfobia, Movimento LGBT, STF, Poder Legislativo. 


\section{INTRODUÇÃO}

Analisando a história brasileira, pode-se observar que ainda é culturalmente enraizado a imagem da família tradicional patriarcal (homem, mulher e seus filhos). Desmistificar algo estabelecido pelos antepassados e que se perpetuou até os dias atuais, é obvio que enfrentaria barreiras e uma difícil aceitação. No Brasil, ser diferente ao que a população em sua maioria considera "padrão", é, para muitos, uma doença, um pecado, uma anomalia social que deve ser extinta. Tais concepções, manifestadas no campo individual ou institucional são violadoras de direito, razão pela qual precisam ser superadas para que a democracia e os direitos fundamentais e sociais preconizados na Carta Magna sejam acessíveis a todas as pessoas, sem excluir a população LGBT do direito de viver, ir e vir, ter acesso à educação, à saúde, ao trabalho, à família, etc.

Segundo o relatório da GGB (Grupo Gay da Bahia), realizado em 2018, a cada 20 horas um LGBT morre vítima de suicídio em razão da LGBTfobia, ou é assassinado de forma barbara. Havendo um aumento gritante na quantidade homicídios no Brasil, onde em 2010 ocorreram 130 homicídios de pessoas LGBTs, e em um lapso temporal de 8 anos, em 2018, essa quantidade subiu para 420 mortos, sendo, 320 por homicídios e 100 por suicídio.

Entre as formas utilizadas para cometer essas atrocidades, foram registadas o uso de 124 armas de fogo, 99 armas brancas, perfuro-cortantes e 97 mortes advindas de agressões físicas como espancamento, apedrejamento, pauladas, asfixias, corpo carbonizado, entre outras. (GGB, 2018).

Apesar de haver vários questionamentos em relação ao termo LGBTfobia, tímidas são as atitudes para mudar o atual cenário que diante do fenômeno viola o direito de brasileiros e brasileiras diariamente, para exemplificar quão assustadora é a realidade das pessoas LGBTs que vivem no Brasil, trazemos o triste dado que em Caruaru-PE, nos primeiros dias de isolamento social devido a pandemia do COVID-19, a violência não cessou, duas travestias foram assassinadas ${ }^{72} \mathrm{em} 48 \mathrm{~h}$.

Essa pesquisa tem o intuito de contribuir para que as pessoas possam refletir sobre a necessidade de novas medidas serem tomadas para mudar essa vivência violenta em que lésbicas, gays, travestis, bissexuais e transexuais, vem sofrendo diariamente, seja pelos meios tecnológicos (redes socais e pela mídia), seja por agressões físicas que acaba levando algumas pessoas a morte.

0 presente artigo tem como objetivo geral analisar a posição político-jurídica dos ministros do STF sobre o tema da LGBTfobia, e como esses posicionamentos podem, ou não, interferir positivamente no combate ao preconceito e discriminação social que a população LGBTs vêm sendo submetida. Foram Objetivos Específicos: 1. Desmistificar o termo LGBTfobia, refletindo o surgimento e a propagação no meio social; 2. Avaliar o atual cenário brasileiro com relação a população LGBT; 3. Discutir o voto dos ministros no julgamento da Ação Direta de Inconstitucionalidade por Omissão (ADO) 26, e do Mandado de Injunção (MI) 4733; 3 4. Refletir as contribuições da decisão no STF para o enfrentamento a violência contra população LGBT.

\section{METODOLOGIA}

A metodologia utilizada na presente pesquisa é natureza de qualitativa e de base descritiva e exploratória. Para as técnicas de procedimento metodológico o estudo optou pela pesquisa bibliográfica e documental. Por meio de autores como Daniel Borrilo e Cleyton Feitosa, foi possível debater a origem e a conceituação do termo LGBTfobia, assim como suas controvérsias. Nesse sentido, através do site do STF, foi possível averiguar, o voto dos ministros, na integra. E através de arquivos do Ministério dos Direitos Humanos, e do GGB (Grupo Gay da Bahia), foi analisado as porcentagens de violência cometidas contra lésbicas, gays, travestis, bissexuais e transexuais.

72Vítima 01: Paloma, assassinada na Rua Guararapes, área comercial da cidade no dia 21/03, tinha 22 anos de idade. Disponível em https://g1.globo.com/pe/caruaru-regiao/noticia/2020/03/21/travesti-e-morta-a-tiros-emcaruaru.ghtml. Vítima 02: Kelly, assassinada no Bairro Demóstenes Veras da cidade no dia 22/03, tinha 35 anos de idade. Disponível em https://www.espiaqui.com.br/artigo/travesti-e-assassinada-a-tiros-no-bairro-demostenesveras-em-caruaru. 


\section{A LUTA PELO RECONHECIMENTO DO TERMO LGBTFOBIA: ENTRE OS ESTUDOS TEÓRICOS E A MILITÂNCIA POLÍTICA}

Dentre muitos movimentos existentes no Brasil, o movimento pelo reconhecimento dos direitos da população LGBTs tem ganhado bastante visibilidade social, e vem sendo discutido dentre os meios políticos-jurídicos. O movimento na sua trajetória tem uma historicidade de luta, violência e enfrentamento ao preconceito. Diante disso, não se pode falar sobre avanços sociais atuais com relação a população LGBTs, sem antes debater o contexto histórico do termo LGBTfobia.

No século XX a homossexualidade era considerada por uma parte dos/as profissionais da área da psicologia e psiquiatrias como um transtorno de personalidade ou transtorno sexual, uma patologia que fazia com que os indivíduos não tivessem noção da realidade e agissem de forma diferente (diferente daquela estabelecida para seu corpo pelas normas sociais vigentes). Era para muitos, uma amostra falha. Apenas após acontecimentos que marcaram violentamente a história da população LGBTs, surge o ativismo político, a formação de grupos que começaram a lutar para desmistificar a imagem dos homossexuais, não mais como uma falta de discernimento mental, e sim, para uma afirmação política das sexualidades não heterossexuais no espaço público. (COSTA; NARDI, 2015).

As teorias hegemônicas no campo da psicologia e psiquiatria em torno do tema, apenas colaborava para aumentar esse estigma. Com a formação de grupos para lutar pelos direitos LGBTs começou-se a questionar essas teorias, e demostrar o sofrimento causado pelas mesmas, na população LGBT. Diante desse embate entre ativismo político e posicionamentos psiquiátricos e psicológicos norte-americano, à APA (American Psychological Association) deixou de considerar a homossexualidade como doença mental em 1973, através da observância de como esse estereótipo estava enfraquecendo o movimento LGBTs. (COSTA; NARDI, 2015).

Ao parar de interpretar a homossexualidade como uma patologia, surgiram vários posicionamentos doutrinários em torno do tema, surgindo a partir desse acontecimento, o termo homofobia. Como preleciona George Weinberg: "Homofobia é o pavor de estar próximo a homossexuais - e no caso dos próprios homossexuais, autoaversão" (Costa; Nardi, 2015, p. 717 apud Weinberg, 1972, p. 8). Seguindo o raciocínio do autor supracitado, o termo homofobia foi criado como uma forma da população LGBT se proteger e rebater as críticas sociais. Nesse prisma, alguns autores passaram a defender o posicionamento de que pessoas que tinham preconceito contra os homossexuais, são na verdade, as que precisam de tratamento psicológico. Nesse contexto George Weinberg novamente defende seu posicionamento ao afirmar: "Eu nunca consideraria um paciente curado caso não superasse seu preconceito contra homossexuais" (Costa; Nardi, 2015, p. 717 apud Weinberg, 1972, p. 1).

Diante das controvérsias sobre a homossexualidade e o preconceito enraizado na sociedade, surgem os termos heterossexismo e heteronormatividade. Para Harek (2004), o heterossexismo significa o preconceito com que as instituições tratam as pessoas não heterossexuais. Sob seu prisma, a justiça, educação e trabalho, idealiza que tudo que não é heterossexual, tem legitimidade ínfima. A heteronormatividade, criada por Michael Warner na década de 1990, significa dizer que o preconceito se manifesta através da construção de identidades, comportamentos e comunidades não heterossexuais, levando em consideração critérios biológicos (macho, fêmea), e expressões usadas (masculino, feminino). (HAREK, 2004).

Partindo dessa premissa, Herek (2004), preleciona que é a partir dos conceitos supracitados, que as pessoas têm suas formações. 0 que enaltece mais um problema, o preconceito contra diversidade sexual. Esse terceiro problema conceitua a homofobia, que passa a ser a discriminação contra a diversidade sexual, ou seja, o fato da pessoa ser gay, lésbica, bissexual, travesti ou transexual, faz com que ela tenha seu ser, existir e apresentar-se para o mundo contestado pela sociedade. 
Nas palavras de Daniel Borrillo, ele conceitua a homofobia como:

Do mesmo modo que a xenofobia, o racismo ou o antissemitismo, a homofobia é uma manifestação arbitrária que consiste em designar o outro como contrário, inferior ou anormal; por sua diferença irredutível, ele é posicionado a distância, fora do universo comum dos humanos. Crime abominável, amor vergonhoso, gosto de depravado, costume infame, paixão ignominiosa, pecado contra a natureza, vício de Sodoma - outras tantas designações que, durante vários séculos, serviram para qualificar o desejo e as relações sexuais ou afetivas entre pessoas do mesmo sexo. Confinado no papel do marginal ou excêntrico, o homossexual é apontado pela norma social como bizarro, estranho ou extravagante. (BORRILLO. 2010, p. 13/14).

0 preconceito, discriminação, exclusão e violência (física ou verbal), são atos que põem em prática a homofobia. A desigualdade social vem aumentando, as pessoas estão se tornando menos toleráveis, menos empáticas e mais inquestionáveis. Tudo que for contrário a seus princípios, não é mais respeitado.

Apesar do termo homofobia ser usado por algumas pessoas ainda, como Daniel Borrillo, para caracterizar o ódio e a aversão dirigidos a lésbicas, gays, bissexuais, travestis e transexuais, o termo vem sendo questionado por estudiosos da área. Como exposto, tal termo deu início a conceituação da violência contra a população LGBT. Todavia, vem sendo questionado pelo fato de não abarcar todas as identidades desse movimento. Para os ativistas, ao utilizar o termo homofobia, está se referindo as violações praticadas contra homossexuais, apenas, neste caso, (gays e lésbicas). 0 termo que vem sendo utilizado atualmente é, LGBTfobia, que significa o ódio proliferado contra toda e qualquer pessoa que não se adeque aos padrões heterossexuais impostos pela sociedade marxista e patriarcal. Com relação a nomenclatura, Cleyton Feitosa (2016, p. 119) afirma:

0 uso do verbo "nomear" no passado ocorre porque há uma tendência, cada vez mais assimilada pela militância brasileira, em adotar o termo "LGBTfobia" para expressar as violências dirigidas contra a população LGBT. Isso porque a palavra "homofobia" não abarcaria todas as identidades que compõem esse movimento social, reclamação feita em especial pelas lésbicas, travestis, transexuais e homens trans.

Não se aprofundando na conceituação ou diferenciação dos termos, há controvérsias entre os ativistas sobre qual o mais adequado. 0 importante é saber que ambos estão relacionados a violência contra pessoas não heterossexuais, mas, também, pode vir a atingir pessoas heterossexuais cujos comportamentos não segue o que prescreve a heteronormatividade. A única diferença questionada, é com relação a abrangência da palavra.

Outro questionamento importante de ser debatido, é com relação as políticas criadas para garantir direitos da população LGBT. Por muito ao menos no plano formal o Brasil empenhou esforço institucional para superar as desigualdades raciais, sociais e também sexuais. Novas legislações são criadas para garantir essa igualdade. Há legislações que envolvem mulheres, negros e pobres. Porém, ao observar o ordenamento jurídico, é possível visualizar o quão precário são as leis e iniciativas legislativas que busquem garantir diversidade sexual. Mesmo com a Constituição de 1988 que tem como um dos pilares a busca pelo pluralismo e a inclusão, além dos tratados nos quais o Brasil se obriga a respeitar e pôr em prática, é notório que há resistência para reconhecimento e garantia dos direitos da população LGBTs.

Os movimentos sociais, como o feminismo e o LGBT, buscam igualdade de direitos, reconhecimento social e acima de tudo, respeito. Algumas iniciativas foram criadas nessa trajetória de luta do movimento, podese citar a criação do Brasil Sem Homofobia (BSH) - Programa de Combate à Violência e à Discriminação contra LGBT e de Promoção da Cidadania Homossexual, em 2004; Publicação do decreto que cria o Programa Nacional de Direitos Humanos 3 - PNDH 3, 2009; criação da Coordenadoria Nacional de Promoção dos Direitos de LGBT, no âmbito da Secretaria de Direitos Humanos, 2010. Não são os únicos programas criados para a defesa dos direitos LGBT. Todavia, é importante ressaltar o quão recente é esses programas, e a quão antiga é a luta da população LGBT. (MELLO; BRITO; MAROJA, 2012) e o quão perigoso é interromper esse processo de institucionalização de iniciativas que tenham por objetivo democratizar o acesso de direitos para essa população.

Esses programas foram criados pelo poder executivo, e, embora exerçam o papel fundamental na luta pela conquista de direitos iguais, deixa explícito outro ponto que vem se mostrando ter uma evolução lenta, o poder legislativo. Sabe-se o Congresso Nacional exerce o papel de criar e pôr em prática, legislações que 
garantam a igualdade para todos e todas, esse é um dever imposto ao Congresso Nacional pela Constituição Federal de 1988. Como se pode dizer que vive em uma democracia representativa, se os representantes do povo não têm atuado de forma efetiva para garantir os direitos das minorias sociais?

Através dos meios midiáticos e da internet, é exposto cotidianamente, vários gays, lésbicas, bissexuais, transexuais e travestis, que são violentados, mortos, submetidos aos padrões sociais hegemônicos vigentes no Brasil. A violação de direito ocorre virtualmente ou presencialmente. Mesmo após a promulgação democrática da atual Constituição, onde tem em seu texto que todos têm liberdade de expressão, que devem ser respeitados, o princípio da dignidade da pessoa humana é constantemente violado.

E possível visualizar esse cenário de violência através de dados do disque 100, um dos únicos meios de proteção para população LGBTs, do ano de 2016, publicados pelo Ministério dos Direitos Humanos:

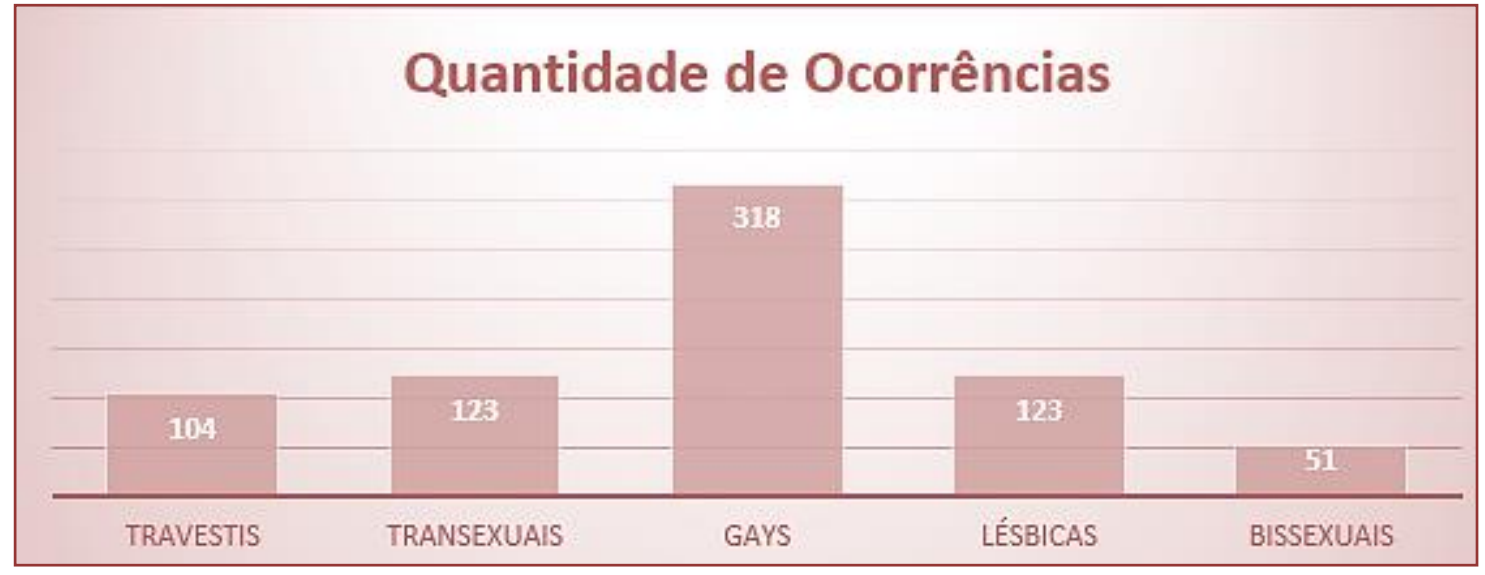

Fonte: Ministério dos Direitos Humanos, 2016. Organizado pelo autor.

Pode-se observar no gráfico acima, que os gays são os que mais têm suas vidas violadas. Pelo fato do machismo ainda ser exacerbado, e o homem ainda ser visto por muitos, como uma figura de alta moralidade, de força e respeito, a existência de gays é uma afronta à masculinidade frágil de muitos, por esse fato, são os mais violentados e mortos.

Um importante grupo que luta pelos direitos dos LGBTs é o GGB (Grupo Gay da Bahia), a mais antiga associação de defesa dos direitos humanos dos homossexuais no Brasil. Em 1988 foi nomeado membro da Comissão Nacional de Aids do Ministério da Saúde do Brasil e, desde 1995, faz parte do comitê da Comissão Internacional de Direitos Humanos de Gays e Lésbicas (IGLHRC), em 2016, a GGB divulgou que ocorreram 343 violações LGBTfóbicas, exposta em meios midiáticos. Também foi divulgado o aumento exacerbado da violência contra LGBTs:

Durante os governos de FHC mataram-se em média 127 LGBT por ano; na presidência de Lula 163 e no governo Dilma 296, sendo que nos dois anos e 4 meses de Temer, foram documentadas em média 407 mortes por ano. Enquanto nos Estados Unidos, com 330 milhões, mataram-se no ano passado 28 transexuais, no Brasil, com 208 milhões de habitantes, registraram-se 164 mortes: o risco de uma trans brasileira ser assassinada é 9 vezes maior do que as americanas. (GGB, 2018, p. 1).

Segundo a GGB, em 2018, dos 420 LGBTs mortos, foram vítimas de mortes violentas: “76\% homicídios e $24 \%$ suicídios, $45 \%$ gays, $77 \%$ com até 40 anos, $58 \%$ brancos, predominam profissionais do setor terciário e prestação de serviços, 29\% mortos com armas de fogo, 49\% na rua, apenas 6\% dos criminosos identificados". (GGB, 2018. P. 2). Com relação as taxas de suicídios: “60\% gays, $66 \%$ brancos, $84 \%$ com até de 30 anos, 15\% enforcamento". (GGB, 2018. P. 2). Vale destacar que com relação as pessoas transexuais, a vulnerabilidade é ainda maior, pois, como visto no gráfico acima, houve 123 mortes, de um total de um milhão de pessoas trans que existem no Brasil, até 2018, com isso, as chances de um transsexual ser morto é 17 vezes maior que a de um gay.

Entre os locais que ocorreram os assassinatos, observa-se o quão a crueldade e o ódio estar desenfreado, pois, 179 (49,4\%) são cometidos em vias públicas, 28 (7,7\%) em estabelecimentos privados e 155 (42,8\%) 
em residências. Muitas travestis que tiram seu sustento da prostituição acabam sendo mortas na "pista", seja por tiros, espancamento, atropelamentos, entre outros. (GGB, 2018).

Mesmo com a criação de programas, o número só aumenta. 0 cenário é preocupante, onde a intolerância e ignorância estão desenfreadas. Existem pessoas matando homossexuais por prazer, o sentimento de humanidade de algumas pessoas, vem se perdendo, e por isso, como já foram citados nessa pesquisa, os governantes precisam agir para sanar essas atrocidades. Seja por parte de poder legislativo, executivo ou judiciário, é coletiva a obrigação de resguardar os direitos individuais e fundamentais.

\section{ANALISE DOS VOTOS DOS MINISTROS DO STF NO JULGAMENTO DE AÇÃO DIRETA DE INCONSTITUCIONALIDADE POR OMISSÃO (ODS) 26, E DO MANDADO DE INJUNÇÃO (MI) 4377.}

Como dito no decorrer dessa pesquisa, o Congresso Nacional tem sido omisso ao se tratar das violações efetuadas contra LGBTs. Com base nesse panorama, o Partido Popular Socialista (PPS), propôs ao Supremo Tribunal Federal, Ação Direta de Inconstitucionalidade por Omissão. Afirmou:

[Temos aqui] pura e simples má vontade institucional do Parlamento Brasileiro em referida criminalização específica, de sorte a tornar evidente a mora inconstitucional do Legislativo neste caso concreto e tornar igualmente evidente, ainda, que é necessária a atuação desta Corte em sua função contramajoritária, impondo ao Congresso Nacional a criminalização específica das ofensas (individuais e coletivas), agressões e discriminações motivadas pela orientação sexual e/ou identidade de gênero, real ou suposta, da vítima para garantir que não seja inviabilizada materialmente a cidadania e/ou não sejam inviabilizados os direitos fundamentais à segurança (proteção eficiente) e à livre orientação sexual e à livre identidade de gênero, pois temos aqui típica opressão da minoria pelo despotismo da maioria parlamentar que se recusa a efetivar está absolutamente necessária e obrigatória criminalização específica, decorrente de imposição constitucional [pela ordem: art. 5o, XLI, XLII ou LIV proibição de proteção deficiente]. (PPS, 2013, p. 1).

Pela observância de que além de ser ínfima a quantidade de legislações que abrangem o tema, há muitos municípios e estados que não conseguem sanar o aumento da violência. Com legitimidade para tal, o PPS, afirmou que o crime de homofobia e transfobia, se enquadravam no crime de racismo, pois este não trata apenas de preconceitos biológicos, também abrange toda ideologia que pregue a superioridade/ inferioridade de um grupo sobre outro. E com isso, se torna obrigação do legislador sair do conformismo, e impor a sociedade legislações que venham a ter eficácia significativa. (PPS, 2013).

Com base nos princípios da dignidade da pessoa humana, liberdade de expressão e da proporcionalidade na vertente da proibição de proteção insuficiente, foi proposto ao STF que tenha a iniciativa de impor ao Congresso Nacional, a criminalização e a punição mais severas de todas as formas de homofobia e transfobia. E, sob essa ótica, o STF estabelecesse um prazo para que o Congresso Nacional formule essa legislação incriminadora. (PPS, 2013).

0 principal pedido feito ao Supremo Tribunal Federal foi que pressionasse o Congresso Nacional, para que legitimasse princípios que já são resguardos pela atual Constituição. Segundo o princípio da reserva legal, “[...] não há crime sem lei anterior que o defina”, seguindo essa lógica, atualmente não há legislações que defina e puna todos os atos violentos praticados contra lésbicas, gays, travestis e transexuais. Também foi pedido, que, em caso de mora do Congresso Nacional, houvesse indenização das vítimas de homofobia e transfobia enquanto tais condutas não forem criminalizadas. Assim foi o discurso:

Excelências, uma ordem constitucional de legislar, como norma jurídica que é, não pode ser considerada um mero conselho despido de imperatividade jurídica também relativamente à imposição (positiva) que consagra, donde esta Suprema Corte deve impor consequências jurídicas oriundas do descumprimento de tal ordem constitucional, ou seja, impor consequências jurídicas oriundas do menosprezo à supremacia constitucional inerente ao não cumprimento das ordens constitucionais de legislar. (PPS, 2013, p. 90). 
Como já dito anteriormente, o Congresso Nacional tem o dever de legitimar os direitos fundamentais de toda a população brasileira. Consequentemente o STF, tem como função, resguardar a constituição, e seguindo esse raciocínio, medidas necessariamente, precisavam ser tomadas para mudar o atual cenário.

Após o julgamento do pedido supracitado, vários posicionamentos foram levantados. Posicionamento nos quais a presente pesquisa propôs analisar. Seguindo essa ótica, antes de analisar o voto dos ministros é importante ressaltar que apesar te ter havido posicionamentos contrários a essa ação de inconstitucionalidade, todos os ministram demostraram em sua fala, que repudiavam a homofobia e a transfobia:

Os ministros Celso de Mello, Edson Fachin, Alexandre de Moraes, Luís Roberto Barroso, Rosa Weber, Luiz Fux, Cármen Lúcia e Gilmar Mendes votaram pelo enquadramento da homofobia e da transfobia como tipo penal definido na Lei do Racismo (Lei 7.716/1989) até que o Congresso Nacional edite lei sobre a matéria. Ministros Ricardo Lewandowski e Dias Toffoli, por entenderem que a conduta só pode ser punida mediante lei aprovada pelo Legislativo. 0 ministro Marco Aurélio não reconhecia a mora. (STF, 2019).

A Ministra Cármen Lúcia, julgou procedente a omissão do legislativo. Segundo ela, as especificidades de cada pessoa não podem ser interpretadas de forma que esta seja excluída do meio social. E principalmente, não é justificativa para que uma pessoa tenha sua dignidade e sua liberdade violada. Em sua fala ela afirma: "A reiteração de atentados decorrentes da homotransfobia revela situação de verdadeira barbárie. Quer-se eliminar o que se parece diferente física, psíquica e sexualmente". (STF, 2019).

De acordo com a Ministra, é possível observar que, a situação atual do país é de extrema violência, onde algumas pessoas tem o intuito de exterminar cidadã/os apenas por diferenças que só atingem o corpo e a mente da pessoa que não se adequa aos padrões da família tradicional.

O Ministro Gilmar Mendes, concordou com a procedência da ação de inconstitucionalidade. Ele entendeu que além de haver mora por parte do Congresso Nacional, a lei que resguarda o crime de racismo, é compatível com a proteção da população LGBT. Assim como a Ministra Cármen Lúcia, ele afirmou que há a necessidade de serem tomadas medidas plausíveis para sanar homicídios, agressões e ameaças praticados contra LGBTs. Em seu posicionamento, também esclareceu que esse tema é de proteção constitucional, e deve ser resguardado conforme os princípios e direitos fundamentais.

Assim como os Ministros supracitados, os demais que votaram a favor, tiveram o mesmo posicionamento. Ambos averiguaram que estaria de fato, havendo mora do Congresso Nacional em solucionar atos de brutalidades que vinham sendo cometidos contra uma parcela das minorias sociais. Nesse mesmo sentido, o Ministro Celso de Mello afirma também, que o Supremo tribunal Federal, em sua função primordial de resguardar os princípios constitucionais, também estaria sendo omisso, caso não tomasse as providências cabíveis para regulamentar os atos da vida civil que estão indo de encontro as normas supralegais presentes na atual Constituição.

Em contraposição, os Ministros Ricardo Lewandowski e Dias Toffoli, concordaram parcialmente com o pedido do PPS. Afirmam que realmente há um descaso do Congresso para com a população LGBT, e que, medidas precisam ser tomadas. Assim como os ministros que concordaram plenamente com o pedido, Lewandowski e Toffoli, afirmaram está havendo altos índices de discriminação e violência que precisavam ser sanados. Porém, se opuseram em relação a norma que envolve o racismo também abranger a população LGBT. Para eles, a lei de racismo não abrange a homofobia e a tranfobia. Nas palavras do Ministro Ricardo Lewandowski, ele afirma:

A extensão do tipo penal para abarcar situações não especificamente tipificadas pela norma incriminadora parece-me atentar contra o princípio da reserva legal, que constitui uma garantia fundamental dos cidadãos que promove a segurança jurídica de todos. (STF, 2019)

Por fim, o voto do Ministro Marco Aurélio, que foi vencido pelo da maioria. Em seu entendimento, o mandado de injunção é inadequado para solucionar esse caso especifico. Admitiu parcialmente a ADO, no que relatava o aumento desenfreado da violência contra lésbicas, gays, travestis e transexuais. Todavia, discordou em ralação a omissão do Congresso. Para ele, a lei de racismo não poderia ser ampliada para incidir sobre esse caso, e que deveria ser preservado os limites da separação dos Poderes e da reserva legal em termos penais. 
Após ressaltar o voto dos Ministros, e importante especificar o entendimento deles em torno do tema, pode-se observar que além de todos concordarem que os casos de homofobia e transfobia vem aumentando e o Brasil precisa enfrentar essa questão para garantir a população LGBT vida e vida digna, concordaram de forma mutua, que precisa haver legislações que versem sobre o tema que resguarde os direitos das minorias

\section{CONCLUSÃO}

Por conseguinte, foi decidido da seguinte forma:

Até que sobrevenha lei emanada do Congresso Nacional destinada a implementar os mandados de criminalização definidos nos incisos XLI e XLII do art. 5ํ da Constituição da República, as condutas homofóbicas e transfóbicas, reais ou supostas, que envolvem aversão odiosa à orientação sexual ou à identidade de gênero de alguém, por traduzirem expressões de racismo, compreendido este em sua dimensão social, ajustam-se, por identidade de razão e mediante adequação típica, aos preceitos primários de incriminação definidos na Lei no 7.716, de 08/01/1989, constituindo, também, na hipótese de homicídio doloso, circunstância que o qualifica, por configurar motivo torpe (Código Penal, art. 121, § 2º, I, "in fine”). (STF, 2019).

Vários atos homofóbicos e tranfóbicos são praticados anualmente, vários LGBTs são mortos sem repúdio, e principalmente, as legislações que protegem esse grupo são escassas. Além da omissão do Congresso Nacional pela busca pela resolução desse caso específico, essa omissão vem contribuindo para deixar a população LGBT mais vulnerável havendo continuidade das violações físicas e morais.

É visível que o Congresso agindo de tal forma, desrespeita o mandamento constitucional que impõe ao Estado o dever de proteção à dignidade das pessoas. 0 fato do STF ter ampliado a aplicabilidade da lei de racismo é uma estratégia paliativa para que a população LGBTs tenha um mecanismo jurídico para exigir que o Estado responsabilize os autores de violência LGBTfóbica. Nesse caso, a homofobia e a transfobia caracterizariam comportamentos subsumíveis à noção de racismo.

Outro ponto que faz com que o Congresso Nacional tenha a obrigação de formular legislações que abrangem o tema, é o fato que a norma constitucional preconiza a punição de "[...] qualquer discriminação atentatória dos direitos e liberdades fundamentais" (CF, art. 5o , XLI). É visível a necessidade de legislações que protejam a populações LGBT de todas as atrocidades cometidas contra os mesmos. É dever primordial dos três poderes zelar pelos direitos das minorias. Partindo dessas premissas, o principal achado dessa pesquisa é demostrar o quão importante e urgente, é, essa decisão do SFT, pois o Brasil sendo um país democrático, que preza pela igualdade para todos, não é admissível que ainda haja conformismo dos governantes perante as violações que vem sendo cometidas contra lésbicas, gays, bissexuais, travestis e transexuais.

\section{REFERÊNCIAS:}

[1] Borrilo, Daniel. Homofobia: História e crítica de um preconceito. Belo Horizonte: Autêntica, 2010.

[2] Brasil. Constituição da República Federativa do Brasil de 1988. Disponível em: http://www.planalto.gov.br/ccivil_03/Constituicao/Constituicao.htm. Acessado em 28/07/2019.

[3] Costa, Â. B. Nardi, H. C. Homofobia e Preconceito contra Diversidade Sexual: Debate Conceitual. Temas em Psicologia. Vol. 23, no 3. 2015, p. 715-726.

[4] Ggb. Mortes Violentas de LGBT+ no Brasil Relatório 2018. Grupo Gay da Bahia, 2018.

[5] Feitosa, Cleyton. As diversas faces da homofobia: diagnóstico dos desafios da promoção de direitos humanos LGBT. Periódicus, Salvador, n. 5, v. 1.2016, p. 300-320.

[6] Herek, G. M. Beyond "homophobia": Thinking about sexual prejudice and stigma in the twenty-fi rst century. Sexuality Research \& Social Policy, 1, 2004, p. 6-24.

[7] Ministério dos Direitos Humanos. Violência Lgbtfóbicas no Brasil: dados da violência/ elaboração de Marcos Vinícius Moura Silva - Documento eletrônico - Brasília: Ministério dos Direitos Humanos, 2018.

[8] Mello, L. Brito, W. Maroja, D. Políticas públicas para a população LGBT no Brasil: notas sobre alcances e possibilidades. Cadernos Pagu (39), julho-dezembro de 2012:403-429. 
[9] Stf. Voto do senhor Ministro Celso de Mello. Disponível em: http://www.stf.jus.br/arquivo/cms/noticiaNoticiaStf/anexo/AD026votoMCM.pdf. Acessado em 30/07/2019.

[10] Stf. Stf enquadra homofobia e transfobia como crimes de racismo ao reconhecer omissão legislativa. Disponível em: http://www.stf.jus.br/portal/cms/verNoticiaDetalhe.asp?idConteudo=414010. Acessado em 29/07/2019.

[11] Stf. Ado 26/Df. Disponível em: http://www.stf.jus.br/arquivo/cms/noticiaNoticiaStf/anexo/tesesAD026.pdf. Acessado em 30/07/2019.

[12] Vecchiatti, P. R. I. Ação Direta de Inconstitucionalidade por Omissão (distribuição). Vecchiatti Sociedade de Advogados. São Paulo, 2013. 


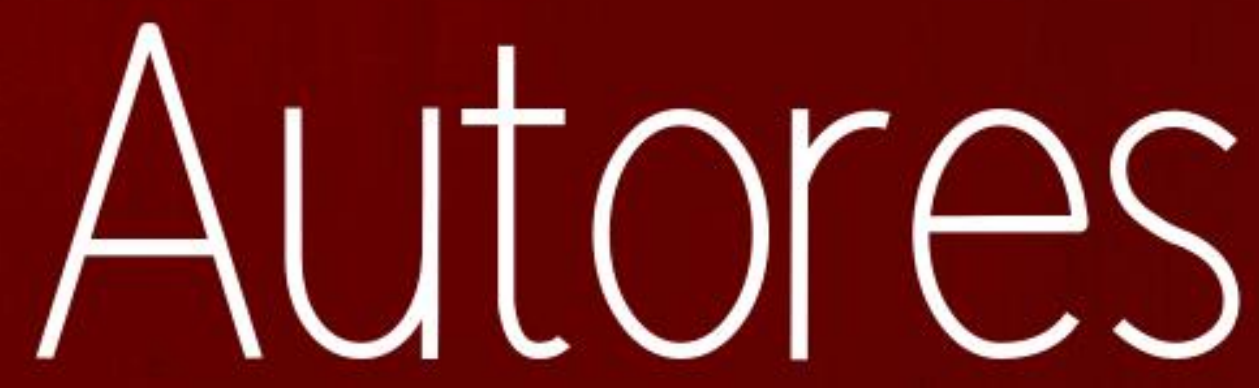




\section{ADÉLIA AUGUSTA SOUTO DE OLIVEIRA}

Profa Dra associada 4 dos cursos de graduação e pós-graduação em psicologia na Universidade Federal de Alagoas. Desenvolve pesquisas e publicações nas temáticas da infância e adolescência em contextos comunitários; nos estudos de metassinteses da produção teórica de conceitos psicológicos e de métodos na psicologia, em especial uso de imagens.

\section{ALLA SOÜB D'NADAH (Mariana Brites)}

Doutoranda na linha de Poéticas Transversais sob orientação de Maria Beatriz de Medeiros na Universidade de Brasília. Atualmente pesquisa performances, composições urbanas e registros das mesmas, focando no encontro e produção de arte gorda. Durante o percurso trabalhou com o Grupo de Pesquisa Corpos Informáticos, Coletiva tete-a-teta e Culto das Malditas.

\section{AMANDA OLIVEIRA BERNARDINO CAVALCANTI DE ALBUQUERQUE}

Enfermeira. Doutoranda em Enfermagem do Programa de Pós-graduação da UPE/UEPB. Mestre em enfermagem do Programa de Pós-graduação da UFPE. Especialista em Saúde Pública e no Programa de Saúde da Família pela FACISA. Atualmente trabalha como Professora Adjunto 1 das IES: FITs; UNIT e UNIBRA nos cursos de Enfermagem, Medicina, Radiologia e Psicologia.

\section{ANA BEATRIZ MEDEIROS FERREIRA}

Graduado em pedagogia, especialista em psicopedagogia e arte educação, mestranda em ciências da educação na Universidad Del Sol, PY. Paraguai.

\section{ANDERSON ALEXANDRE DE ARAÚJO SÁ}

Graduando do Curso de Bacharelado em Psicologia da Faculdade Santa Maria - PB; Membro do núcleo de extensão e pesquisa em gênero e sexualidade Anayde Beiriz

\section{ANGELA DE FARIAS}

Advogada, doutoranda PPGNEIM/UFBA, professora de Direito Penal.

\section{ANNA KARINA GONÇALVES XAVIER}

Possui graduação em Psicologia pela Universidade Federal de Pernambuco (1997). Mestra em Psicologia pelo Programa de Pós-graduação em Psicologia pela Universidade Federal de Pernambuco (2011) e Doutora em Psicologia pelo mesmo Programa (2018). Campos de atuação: gênero, sexualidade, direitos sexuais e reprodutivos, mulheres e juventude. Docente na Universidade Estácio de Sá, campus Recife.

\section{ARTHUR SILVA DE ANDRADE}

Graduando em Psicologia, pelo Centro Universitário Estácio do Recife. Representante discente do colegiado do mesmo curso e instituição de ensino. Participante do Programa Institucional de Bolsas de Iniciação Científica (PIBIC) com tema: "GÊNERO E ESCOLA: O QUE PROFESSORAS(ES) APRONTARAM NOS ENSINOS FUNDAMENTAIS E MÉDIO ENTRE 2003 A 2014". Suas pesquisas focam-se na área de Gênero e Sexualidade, Psicanálise e Semiótica.

\section{BEATRIZ COELHO FERREIRA}

Graduanda de psicologia pelo centro universitário Estácio de Sá. Participante do PIBIC na área de gênero. 


\section{BENÍCIA BRENDA BARBOSA DA SILVA}

Graduanda do Curso de Bacharelado em Psicologia da Faculdade Santa Maria - PB; Membro do núcleo de extensão e pesquisa em gênero e sexualidade Anayde Beiriz.

\section{CARLE PORCINO}

Psicóloga. Doutoranda no Programa de Pós-Graduação em Enfermagem e Saúde (PPGNEF), Universidade Federal da Bahia (UFBA). Atua voluntariamente no Grupo Gay da Bahia (GGB), Salvador, Bahia, Brasil.

\section{CARLOS ABERTO GOMES DE BRITO}

Licenciatura e Bacharelado em Psicologia pela FACHO;

Formação em PSICOLOGIA pela FACHO E UNICAP;

Bacharelado em Fonoaudiologia pela UNICAP;

Especialização em metodologia do ensino superior pela UNICAP ;

Mestrado em distúrbios da comunicação pela PUC-SP;

Especialista em Literatura Infanto juvenil;

Psicólogo clínico e Fonoaudiólogo atuando desde 1981;

Professor Adjunto e pesquisador em Psicologia da UNICAP, CCBS;

Escritor.

\section{CLEIDE DA CONCEIÇÃO SOLANO}

Graduada em Pedagogia pela UEMG, Especialista em Gestão Pública, Mestranda em Educação Tecnológica pelo CEFET/MG. Gestora Governamental da Ouvidoria Geral do Estado, atuando na Ouvidoria da educação. Professora da pós-graduação em Gestão Pedagógica/PUC Minas. Já atuou como professora da Polícia Militar (Colégio Tiradentes) e na rede municipal da Prefeitura de Belo Horizonte, foi Inspetora escolar da Secretaria Estadual de Educação e diretora pedagógica da Secretaria de Estado de Administração Prisional de Minas Gerais (SEAP/MG).

\section{CLEUMA SUELI SANTOS SUTO}

Enfermeira. Doutora em Enfermagem e Saúde pela Universidade Federal da Bahia (UFBA). Professora Assistente da Universidade do Estado da Bahia (UNEB), Campus VII, Senhor do Bonfim, Bahia, Brasil.

\section{DEJEANE DE OLIVEIRA SILVA}

Enfermeira. Doutora em Enfermagem e Saúde pela Universidade Federal da Bahia (UFBA). Professora Adjunto da Universidade Estadual de Santa Cruz (UESC), Ilhéus, Bahia.

\section{EDUARDO BARBUIO}

Graduado em Licenciatura Plena em Letras pela Fundação Educacional de Fernandópolis (2005), Mestre em Linguística pela Universidade de Franca (2010) e Doutor em Linguística pela Universidade Federal da Paraíba - UFPB (2016). Atualmente é Professor Adjunto II e ministra disciplinas da Área de Língua Inglesa e Língua Portuguesa na Universidade Federal Rural de Pernambuco, lotado na Unidade Acadêmica de Educação a Distância e Tecnologia EADTEC/ UFRPE. 


\section{ELBA RAVANE ALVES AMORIM}

Possui graduação em Direito pela Associação Caruaruense de Ensino Superior (2009), Especialização em Segurança Pública e Cidadania (ASCES 2010) e mestrado em Direitos Humanos pela Universidade Federal de Pernambuco (2015). Atualmente é advogada habilitada - Ordem dos Advogados do Brasil, compõe a Comissão de Direitos Humanos da OAB Caruaru. É professora Assistente 1 da Associação Caruaruense de Ensino Superior. Tem experiência na área de Políticas Públicas, foi Secretária da Mulher e Direitos Humanos de Caruaru (2012/2014), foi advogada do ProRural/Secretaria De Agricultura de Pernambuco (2015/2016). Desenvolve pesquisa com ênfase em Direitos Humanos, atuando principalmente nos seguintes temas: Igualdade, Gênero, Direitos da População LGBTs, Democracia e Feminismos, Violência Contra Mulher na Arena Política, Violência Doméstica, Direito de Família, Função Social da Propriedade. Integra a Coordenação Colegiada do Núcleo de Estudo de Gênero Elma Novaes, Coordena o Projeto de Extensão Administração Viva e compõe o NDE dos Cursos de Direito e Administração Pública na ASCES UNITA. Co-Autora do Manual Jurídico Feminista.

\section{ELLEN BORGES TENORIO GALDINO}

Psicóloga pela Universidade Federal de Alagoas (UFAL, 2018). Especialização em Terapias Cognitivo-Comportamentais na Infância e Adolescência (InTCC Recife, em andamento). Atualmente é psicóloga em um Centro de Referência de Assistência Social (CRAS) vinculado à prefeitura de Arapiraca-AL. Foi bolsista do Programa Institucional de Bolsas de Iniciação Científica (PIBIC).

\section{EMANUELLE CAMILA MORAES DE MELO ALBUQUERQUE}

Possui graduação em Letras pela Universidade Federal de Alagoas (2008), mestrado em Letras e Linguística pela Universidade Federal de Alagoas (2010). Atualmente cursa doutorado em Linguística no PPGLL-UFAL e é professora e coordenadora geral dos cursos de graduação da Universidade Federal do Agreste de Pernambuco. Tem experiência na área de Língua Portuguesa e Linguística, atuando principalmente nos seguintes temas: Aquisição da linguagem, Linguística Histórica e Sociolinguística.

\section{FÁBIO PERIANDRO DE ALMEIDA HIRSCH}

Doutor e Mestre em Direito Público, ambos com ênfase em Direito Constitucional, pela Universidade Federal da Bahia (PPGD-UFBA). Líder do Grupo de Pesquisa Constitucionalismo da Bahia, Direitos Fundamentais e Efetividade (Faculdade de Direito - UFBA). Professor Adjunto de Direito Constitucional da Universidade Federal da Bahia (UFBA), Adjunto de Direito Constitucional e Administrativo da Universidade do Estado da Bahia (UNEB) e de Jurisdição Constitucional da Universidade Jorge Amado (UNIJORGE). Advogado e Árbitro. Tem experiência em Direito Público, com ênfase em Direito Constitucional, Direitos Fundamentais (Segurança Jurídica e Direito Adquirido em particular) e Controle de Constitucionalidade (Jurisdição Constitucional e Controle Difuso em particular).

\section{FERNANDA DE CARVALHO AZEVEDO MELLO}

Mestranda pela Universidade Federal de Pernambuco no Programa de Pós-Graduação em Antropologia, desenvolvendo pesquisa com ênfase em gêneros, sexualidades, lesbianidades e festas. Graduada em Relações Internacionais (2011) e em Ciências Sociais (a concluir - 2020).

\section{GIORGE ANDRE LANDO}

Pós-Doutor em Direito pela Università degli Studi di Messina - Itália. Doutor em Direito pela Faculdade Autônoma de Direito de São Paulo - FADISP. Professor Adjunto do curso de Direito da Universidade de Pernambuco - UPE. Professor Permanente do Programa de Pós-graduação Stricto Sensu em Direitos Humanos da Universidade Federal de Pernambuco - UPFE. Professor-Pesquisador Visitante Sênior da Fiocruz/Piauí. 


\section{GLAUCE MICHELLE ARAUJO PENHA}

Graduaçao em Engenharia Civil pela Universidade Catolica de Pernambuco ( 1993)

Bachare l em Psicologia pela Universidade Catolica de Pernambuco ( 2020)

Pos graduaçao em Neurociencias e Comportamento PUC-RS (2021)

\section{IARA LUZIA HENRIQUES PESSOA}

Bacharel em Psicologia pela Universidade Católica de Pernambuco (2020), fluente em inglês. Formação em Psicanálise pelo GESCLIP (2021).

\section{IARLIS NEVES BRANDÃO}

Possui pós-graduação em Gestão de Pessoas com Ênfase em Comportamento Organizacional pela Faculdade Ruy Barbosa (2009), e graduação em psicologia pela Faculdade Ruy Brabosa e Direito pela Universidade Jorge Amado (UNIJORGE).

\section{JAQUELINE MOREIRA DE SOUZA}

Graduanda do Curso de Bacharelado em Psicologia da Faculdade Santa Maria - PB; Membro do núcleo de extensão e pesquisa em gênero e sexualidade Anayde Beiriz.

\section{JAQUELINE PAULINO GOMES}

Técnica em Enfermagem e Graduanda do sétimo período de enfermagem pelo Centro Universitário Tiradentes.

\section{JEANE FREITAS DE OLIVEIRA}

Enfermeira. Doutora em Saúde Pública pelo Instituto de Saúde Coletiva, Universidade Federal da Bahia (UFBA). Docente na Escola de Enfermagem da UFBA, onde atua na graduação e pós-graduação, Salvador, Bahia, Brasil.

\section{JEFERSON REIS SANTOS}

Graduado em História pela Universidade Federal da Bahia e Mestrando no Programa de PósGraduação em Educação: Conhecimento e Inclusão Social da Faculdade de Educação da Universidade Federal de Minas Gerais na linha de pesquisa Educação, Cultura, Movimentos Sociais e Ações Coletivas. Membro do grupo de pesquisa "Gênero, sexualidades, socialidades e subjetivações" da FAE/UFMG.

\section{JÉSSICA GABRIELE BURITY DA COSTA}

Graduanda do decimo período de Enfermagem pelo Centro Universitário Tiradentes - UNIT PE. Atualmente integrante do Projeto de Iniciação Cientifica intitulado " Programa Saúde na Escola: Desafios e Possibilidades na Implantação". Formação em curso de Suporte Básico de Vida em Cardiologia Para Profissionais de Saúde da American Heart Association pelo Laboratório de Treinamentos Em Emergências Cardiovasculares do Hospital Agamenon Magalhães SES RECIFE/PE. Experiência em Estágio Extracurricular no Núcleo de Epidemiologia- NEP do Real Hospital Português - Recife PE.

\section{JESSICA YOLANDA FIGUEIREDO DE BARROS}

Graduada em Serviço Social pela Universidade Federal de Alagoas, Especialista em Gestão Social: Políticas Públicas, Redes e Defesa de Direitos pela Universidade Anhanguera-Uniderp e Pósgraduanda em Saúde Pública: Política, Planejamento e Gestão pela Universidade AnhangueraUniderp. 


\section{JOSEVAL DOS REIS MIRANDA}

Doutor em Educação pela Universidade de Brasília (UnB). Professor da Universidade Federal da Paraíba, Centro de Educação, Departamento de Metodologia da Educação e Docente do Programa de Mestrado Profissional em Letras - PROFLETRAS da Universidade Federal da Paraíba.

\section{JULIANA DE ÁVILA FERREIRA}

Graduada em Administração pelo Centro Universitário Newton Paiva, graduanda em Administração Pública pela Universidade Federal de São João Del Rei (UFSJ), Especialista em Gestão do Sistema Prisional pela UCAM e Mestranda em Educação Tecnológica pelo CEFET/MG. Agente de Segurança Penitenciária na Secretaria de Estado de Justiça e Segurança Pública de Minas Gerais (SEJUSP/MG). Atualmente atua na gestão logística do Sistema Prisional, além de ser docente em cursos de formação destinados aos servidores do Sistema Prisional. Já ocupou o cargo de diretora em uma unidade prisional masculina na região metropolitana de Belo Horizonte/MG.

\section{KARINE DA SILVA SANTOS}

Graduada em Serviço Social pelo Centro Universitário Cesmac. Tem experiência na área de Serviço Social com ênfase na área de Educação para o Trânsito e Saúde Pública, desenvolvendo pesquisas e trabalho em comunidade. Foi monitora na disciplina de Fundamentos Teóricos e Metodológicos em Serviço Social III no Cesmac,

\section{KASANDRA CAMPOS DE OLIVEIRA}

Graduanda do Curso de Bacharelado em Psicologia da Faculdade Santa Maria - PB; Membro do núcleo de extensão e pesquisa em gênero e sexualidade Anayde Beiriz.

\section{KÁTIA LUCIANA GONÇALVES XAVIER}

Possui graduação em Pedagogia pela Fundação Educacional do Vale do Jequitinhonha (2003). Atualmente é Analista Educacional na Secretaria de Estado de Educação de Minas Gerais. Tem ampla experiência na área de Educação. Pós Graduada em Psicopedagogia e Inspeção Escolar e também Pós Graduanda em Orientação Educacional, atualmente cursando disciplina isolada no Mestrado em Educação Tecnológica no CEFETMG. Atua na área Educacional desde 2003, principalmente na análise de documentação escolar, tendo no início da carreira atuado com supervisão escolar em escolas de primeiro e segundo grau na Rede Municipal e Estadual de Minas Gerais. Atuou com capacitação de professores no PACTO pela Alfabetização do governo federal.

\section{LAYSA MARIA BARAUNA LIMA}

Graduanda do Curso de Bacharelado em Psicologia da Faculdade Santa Maria - PB; Membro do núcleo de extensão e pesquisa em gênero e sexualidade Anayde Beiriz.

\section{LINA MARIA BRANDÃO ARAS}

Doutorado em História pela USP, professora do PPGH e PPGNEIM/UFBA.

\section{LÚCIA MARIA TEMÓTEO}

Mestre em Educação pela Universidade Federal da Paraíba, Professora de Psicologia e Coordenadora de Pesquisa em Gênero e Sexualidade na Faculdade Santa Maria - FSM, Membro da Sociedade Psicanalítica da Paraíba 


\section{LÚCIA TALITA SANTOS DE LIMA}

Graduanda em Psicologia pelo Centro Universitário Estácio do Recife. Cursando inglês pelo Prolinfo. Participante do projeto de extensão com tema Programa de Resiliência e Prevenção ao Suicídio. Participa do Programa Institucional de Bolsas de Iniciação Científica (PIBIC) com tema: Feminismo e educação: Uma análise das produções acadêmicas sobre igualdade de gênero nas escolas, entre 2003 a 2014. Participou como auxiliar de Pesquisa do PIBIC intitulado de: "O Bullying homofóbico nas escolas: um estudo a partir das representações sociais". Participou do Curso de Extensão "Reconstruindo Diálogos: pesquisa-intervenção em psicologia e metodologias participativas com jovens"

\section{LÚCIA TEMÓTEO}

Docente do curso de bacharelado em Psicologia da Faculdade Santa Maria - PB;

Possui Licenciatura em Psicologia pela Universidade Estadual da Paraíba - UEPB;

Possui Mestrado em Educação pela universidade Federal da paraíba - UFPB;

Coordenadora do núcleo de extensão e pesquisa em gênero e sexualidade Anayde Beiriz.

\section{LUCIANA DE ARAÚJO VIEIRA}

Mestra em Psicologia pela Universidade Federal de Alagoas (2019), graduada em Psicologia pelo CESMAC (2006). Atualmente é psicóloga e coordenadora geral do serviço institucional de acolhimento para crianças e adolescentes vinculado à Prefeitura Municipal de Maceió. Psicóloga Clínica com formação em Gestalt Terapia, especialista em gerontologia social (UFAL) e especialista em gestão em saúde (UFAL).

\section{LUCIANA DE LIMA LOPES LEITE}

ARTEvista, Feminista e Educadora. Graduada em Ciências Sociais (UFPI) e Arte Visuais (UFPI), Mestre em Antropologia, Doutoranda em Educação, é professora no departamento de Artes Visuais da Universidade Federal do Piauí. Realiza pesquisas relacionadas a Arte como tática de resistência, questões de gênero, urbanidade e juventudes.

\section{LUCÍOLA CARLA CORREIA DA SILVA}

Docente do Centro Universitário do Vale do Ipojuca (UNIFAVIP), do Centro Universitário Maurício de Nassau (Uninassau) e da Faculdade de Olinda (FOCCA), Mestra em Comunicação (UFPE 2016). Pesquisa sobre Instagram e comunidades fotográficas virtuais desde 2014, atualmente aprofundando-se na investigação acerca das manifestações identitárias dos corpos através de imagens on-line.

\section{LUDMILLA CARVALHO FONSECA}

Doutoranda em Literatura e Vida Social, pela Universidade Estadual Paulista (UNESP), bolsista da Fundação de Amparo à Pesquisa do Estado de São Paulo (FAPESP), vinculada à Literatura e outras áreas do conhecimento, estabelecendo relação entre literatura e filosofia. Recentemente, desenvolve pesquisa de doutorado na área de literatura de autoria feminina e crítica feminista, atuando, principalmente, nos seguintes temas: Simone de Beauvoir, Clarice Lispector, feminismo, personagem feminina e existencialismo.

\section{LUIZ OTAVIO FERREIRA DA LUZ}

Doutorando em Educação pela Universidade Federal Rural do Rio de Janeiro (UFRRJ), possui Graduação em Arte / Educação Artística (UERJ) e em Psicologia (UFRJ); Mestrado em Educação pela UERJ; Especialização em Psicopedagogia (UNESA-RJ), Gênero e Sexualidade (IMS - UERJ), Educação de Jovens e Adultos (IFRJ). Servidor da Secretaria Municipal de Educação de Mesquita e da Secretaria Estadual de Educação do Rio de Janeiro. Psicologo Clínico em Consultório particular. Academicamente atua como pesquisador nos grupos de pesquisa: COTIDIANO ESCOLAR E 
CURRÍCULO (UERJ) atuando na linha de pesquisa Práticas curriculares cotidianas, Grupo de Estudos e Pesquisa Os Impactos do Conservadorismo na Educação Brasileira (UFF), atuando na linha de pesquisa Currículos, Gêneros, Sexualidades: Diversidades, diferenças, subjetividades e processos formativos, Grupo de Pesquisa Diálogos Escolas-Universidade: Processos Formativos, Currículos e Cotidianos (UERJ), atuando na linha de pesquisa Currículos, Gêneros, Sexualidades: Diversidades, diferenças, subjetividades e processos formativos e Grupo de Estudo e Pesquisa "Gêneros, Sexualidades e Diferenças nos Vários EspaçosTempos da História e dos Cotidianos" - GESDI (UERJ), atuando nas linhas de pesquisa Gêneros, Sexualidades, História das Mulheres e Diferenças e Currículos, gêneros, sexualidades: diferenças, subjetividades e processos formativos

\section{MARIA DE FÁTIMA ARAÚJO. DI GREGORIO}

Doutora em Família na Sociedade Contemporânea pela Universidade Católica do Salvador/UCSal, Mestre em Memória Social pela Universidade Federal do Estado do Rio de Janeiro/UNIRIO, Especialista em: Planejamento pela Faculdade de Educação da Bahia/FEEBA, Análise do Discurso pela Universidade Estadual do Sudoeste da Bahia/UESB e Recursos Tecnológicos aplicados à Educação pelo IPAE/RJ. Formação em Pedagogia e História. Participa do grupo de pesquisa de El Consejo Europeo de Investigaciones Sociales de América Latina /CEISAL, é professora permanente da linha 2 do Mestrado em Relações Étnicas e Contemporaneidade da UESB, - cujos estudos abrem espaços para diálogos entre etnias, família, gênero e memórias, buscando compreender como se dão os processos de produção e (re)formulação das identidades, - especialmente de mulheres que na dinâmica das relações, se reconhecem e auto definem impulsionando movimentos e formas de luta individuais ou coletivas. É Professora Titular da disciplina Práticas Pedagógicas pela Universidade do Estado da Bahia/UNEB - Campus V e de História da Educação Brasileira pela Universidade Estadual do Sudoeste da Bahia/UESB ? Campus de Jequié - onde coordena o GEHFTIM (Grupo de Estudos e Pesquisas Hermenêuticas sobre Famílias, Territórios, Identidades e Memórias) e o NEPE (Núcleo de Pesquisas do Curso de Pedagogia). Participa de encontros científicos nas Universidades de Sevilha, Salamanca e Santiago de Chile com investigações acerca das estampas familiares e dos processos de identidade em redes sociais. Diretora Acadêmica do IFDG (Instituto Fátima Di Gregorio) e a UNINTA pólo de Itiruçu.Consultora para avaliação de cursos superiores e Guia do Estudante MEC. Estuda Direito na Faculdade de Ciências e Tecnologia/FTC Campus Jequié/BA.

\section{MARIA JOSÉ S. PINHO}

Pós doutoranda em Modelagem Científica (2019) pela Universidad de Cádiz-ES. Doutorado e Mestrado em Educação (2013-2009) pela Universidade Federal da Bahia. Licenciada em Ciências Biológicas pela Universidade Católica do Salvador(1991). Professora Adjunta da Universidade do Estado da Bahia. Professora permanente do Mestrado Profissional em Educação. Delegada Regional Secção Bahia da SBRASH. Coord. do Grupo de Pesquisa em Educação Cientifica-CNPq. Representante do Grupo INOVAGOGIA/ES em Brasil.

\section{MARIA THEREZA ÁVILA DANTAS COELHO}

Psicóloga. Doutora em Saúde Coletiva com ênfase em Ciências Sociais em Saúde pelo Instituto de Saúde Coletiva (ISC), Universidade Federal da Bahia (UFBA). Professora Associada do Instituto de Humanidades, Artes e Ciências professor Milton Santos (IHAC), docente permanente do Programa de Pós-Graduação Estudos Interdisciplinares sobre a Universidade (PPGEISU) e professora colaboradora do Programa de Pós-Graduação em Saúde Coletiva (ISC/UFBA), Salvador, Bahia, Brasil.

\section{MARIA VIRGINIA ALMEIDA DE OLIVEIRA TELES}

Psicóloga. Mestranda em Estudos sobre as mulheres - as mulheres na sociedade e na cultura. Universidade Nova de Lisboa, Lisboa, Portugal. 


\section{MARIANA DE BARROS E SILVA PINHEIRO}

Graduanda do curso de Direito da Faculdade de Administração e Direito da Universidade de Pernambuco - FCAP/UPE. Voluntária do Programa Institucional de Iniciação Científica da UPEPFA/2019.

\section{MATHEUS DOS SANTOS CARVALHO}

Graduando de enfermagem pelo Centro Universitário Tiradentes.

\section{MYLLA MAGGI VIEIRA DA COSTA}

Licenciada em Letras na modalidade de Língua Portuguesa pela Universidade Federal da Paraíba. Feminista, artista e amante da literatura.

\section{PALOMA PEREIRA BORBA PEDROSA}

Doutora em Letras (2013) pela Universidade Federal de Pernambuco, instituição onde cursou também sua graduação (2002) e mestrado (2007). É Professora Adjunta da Universidade Federal Rural de Pernambuco, onde atua nas unidades acadêmicas do Cabo de Santo Agostinho (UACSA) e de Educação à Distância (UAEADTec). Atua como pesquisadora principalmente nas áreas de Estudos dos Gêneros Textuais, Retórica e Multimodalidade.

\section{PÂMELA TAYS DE HOLANDA SILVA}

Graduanda no curso de Bacharelado em Enfermagem pelo Centro Universitário Tiradentes UNITPE, Atualmente participa do projeto de pesquisa "Programa Saúde na Escola: Desafios e Possibilidades na Implantação" e do Núcleo de Estudos em Neurociências da Universidade Federal de Pernambuco UFPE, além de realizar atividades de estágio extracurricular na Fundação de Hematologia e Hemoterapia de Pernambuco, HEMOPE, Brasil.

\section{PATRÍCIA MARIA DE BRITO FRANÇA}

Graduanda em Enfermagem pelo Centro Universitário Tiradentes UNIT-PE. Possui: Monitorias em: Anatomofisiologia, Semiologia e Semiotécnica de Enfermagem e Saúde da Criança. Realizou Projetos de Extensão em: Educação em Saúde da População Masculina, em USF; Promoção do Aleitamento Materno em Primigestas, em USF; Sustentabilidade na Reutilização das Mantas de Materiais Cirúrgicos Estéreis; Saúde e Bem estar na Universidade; Educação em Saúde: Uma Nova Abordagem de Prevenção ao Câncer de Mama em Homens e Mulheres; APH Solidário, realizando minicursos de Atendimento Pré Hospitalar para estudantes de cursos da saúde em várias cidades do Estado de Pernambuco e Projeto Babado Gritaria e Confusão: Focus para a Saúde da População LGBT, em ambulatórios. Possui premiações de Honra ao Mérito em Congresso Nacional de Urgência e Emergência e pesquisas apresentadas em Simpósios e Semanas de Extensão. Com publicações de artigos e capítulos de livros sobre Práticas das Ciências da Saúde e Neurologia.

\section{PAULA ORCHIUCCI MIURA}

Profa. Dra. Adjunto 2 dos cursos de graduação e pós-graduação em psicologia na Universidade Federal de Alagoas. Desenvolve pesquisas e publicações em gravidez na adolescência, maternidade, paternidade, violência intrafamiliar contra criança e adolescente, adoção, instituição de acolhimento e infâncias. 


\section{RAQUEL QUIRINO}

Pós-doutorado e Doutorado em Educação pela UFMG; Mestrado em Educação Tecnológica pelo CEFET-MG. Professora do Programa Especial de Formação Docente e do Programa em PósGraduação em Educação Tecnológica; Líder do Grupo de Pesquisa em Formação e Qualificação Profissional - FORQUAP no CEFET-MG. Pesquisadora e Docente nas áreas: Divisão Sexual do Trabalho; Trabalho-Educação; Relações de Gênero na Ciência \& Tecnologia e na Educação Tecnológica; Didática e Formação Docente. Atua também como Consultora e Palestrante Educacional e Organizacional.

\section{RENATO MACIEL DOS SANTOS}

Graduando em Psicologia pelo Centro Universitário Estácio do Recife. Participa do Programa Institucional de Bolsas de Iniciação Científica (PIBIC) com tema: Feminismo e educação: Uma análise das produções acadêmicas sobre igualdade de gênero nas escolas, entre 2003 a 2014. Participou como auxiliar de Pesquisa do PIBIC intitulado de: "O Bullying homofóbico nas escolas: um estudo a partir das representações sociais". Participou do Projeto de extensão: (RE) Pensando sexualidade e gênero na adolescência. ". Participou do Curso de Extensão "Reconstruindo Diálogos: pesquisaintervenção em psicologia e metodologias participativas com jovens". Participante do Projeto Escola do Futuro pela Prefeitura do Recife. Atua nas áreas de Direitos Humanos, gênero, sexualidade e juventude.

\section{RITA DE CÁSSIA COSTA MOREIRA}

Graduada em Sociologia, Mestra e Doutora em Educação pela UFBA; Especialista em Literatura Infantil pela UNEB; formadora em Direitos Humanos e Diversidade e Contadora de Histórias.

\section{ROSE CLÁUDIA OLIVEIRA DE ANDRADE}

Mestranda em Relações Étnicas e Contemporaneidade, com área de concentração em Relações Étnicas, Gênero e Sociedade - UESB. Especialista em Gestão Educacional pela Faculdade de Educação Superior do Piemonte da Chapada/ FESPC e Metodologia do Ensino Superior pela Faculdades Intregadas de Jequié/FIJ. Pós graduanda em Psicopedagogia Institucional pela Faculdade de Tecnologia e Ciências/FTC (Faltando concluir) Graduada em pedagogia pela Universidade Estadual do Sudoeste da Bahia/UESB - Campus/Jequié. Professora efetiva da Rede Municipal de Ensino de Jaguaquara/BA desde 1996. Atuou como Professora da Faculdade de Ciências Educacionais/FACE Polo /Jaguaquara, Tutora do Programa de Capacitação para Gestores Escolares da Rede Estadual de Ensino- PROGESTÃO do Estado da Bahia nos municípios da DIREC 13 /Polo Jequié (2010/2011) . Tutora do Programa de Capacitação para Gestores Escolares da Rede Municipal de Ensino/ Jaguaquara/BA (2012/2013). Atuou como tutora e coordenadora no curso de Pedagogia na Faculdade de Tecnologia e Ciências/FTC- EAD /UP Jaguaquara 2007/2012. Mediadora do Projeto Regularização do Fluxo Escolar nos municípios de Jaguaquara, Itiruçu e Maracás nas Escolas Municipais e Estaduais. Tem experiência como Coordenadora Pedagógica e Diretora no município de Jaguaquara/Ba. Atuou como Diretora do Departamento Pedagógico na Secretaria Municipal de Educação de Jaguaquara/BA nos anos de 2013, 2014 e 2015 coordenando o ensino Público das Escolas Municipais. Técnica local do PME no município de Jaguaquara/Ba (2015). Coordenadora Multiplicadora do PACTO Estadual / Jaguaquara/BA (2015). Atuou como gestora eleita nas Escolas Municipais: Irmã Dulce (2009) Diana Jussiene (2016/2017). Atuou como Professora do Instituto Valdice Cruz; Instituto de Educação Social Tecnológico; Faculdade do Maciço de Baturité nos cursos de pedagogia. Professora do Curso de Pedagogia UESB Parfor/Itiruçu Bahia. Pesquisadora do grupo GEHFTIM .

\section{TUANY LORENA FERREIRA}

Graduanda de Psicologia pelo Centro Universitário Estácio do Recife. Formada em curso básico de secretariado. Participante do Projeto de Extensão Programa de Resiliência e Prevenção ao Suicídio. Participante do Projeto Escola do Futuro pela Prefeitura do Recife. 


\section{WITALO BRENNO MARTINS ACIOLI}

Graduando em Direito pelo Centro Universitário Tabosa de Almeida- ASCES UNITA. Integrante do projeto de pesquisa Gênero, Cultura e Administração Pública, do Laboratório de Políticas Públicas Municipais-LPPM da ASCES UNITA. Membro Acadêmico Ouvinte da Comissão de Direito Constitucional da OAB Caruaru. Pesquisador do Programa de Iniciação Científica da ASCES UNITA.

\section{ZULEIDE PAIVA DA SILVA}

Professora Adjunta da Universidade do Estado da Bahia, professora permanente do Mestrado Profissional em Educação e Diversidade-MPED. Tem doutorado Multi- Institucional e Multidisciplinar em Difusão do Conhecimento (UFBA, IFBA, UNEB et al), mestrado em Estudos Interdisciplinares sobre Mulheres, Gênero e Feminismo (UFBA). Pesquisadora vinculada ao DIADORIM - Centro de Estudos em Gênero, Raça/Etnia e Sexualidade, ao Grupo de pesquisa Formação, Experiência e Linguagens (FEL/CNPq) e Grupo de Leitura e Estudos Interdisciplinares de Gênero e Sexualidade (GLEIGS) lotados no Departamento de Educação, Campus XIV, da Universidade do Estado da Bahia (UNEB). Ativista da Liga Brasileira de Lésbicas-LBL e da Rede LESBI- Brasil. 


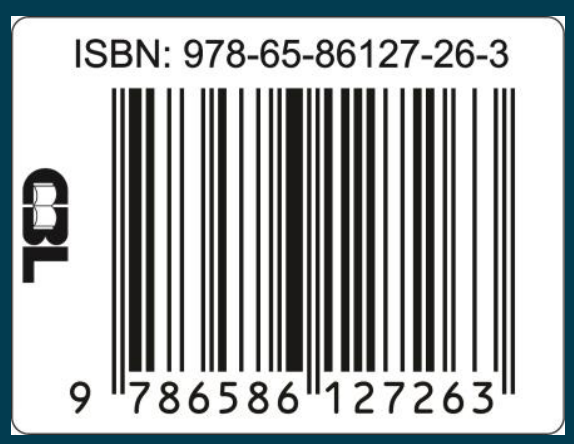

